\title{
Het nerveuze tijdperk en zijn historici : de opkomst van de mentaliteitsgeschiedenis in Duitsland, 1889- 1915
}

Citation for published version (APA):

Stoffers, E. P. M. (2007). Het nerveuze tijdperk en zijn historici : de opkomst van de mentaliteitsgeschiedenis in Duitsland, 1889-1915. [Doctoral Thesis, Maastricht University]. Universiteit Maastricht. https://doi.org/10.26481/dis.20071102es

Document status and date:

Published: 01/01/2007

DOI:

10.26481/dis.20071102es

Document Version:

Publisher's PDF, also known as Version of record

Please check the document version of this publication:

- A submitted manuscript is the version of the article upon submission and before peer-review. There can be important differences between the submitted version and the official published version of record.

People interested in the research are advised to contact the author for the final version of the publication, or visit the DOI to the publisher's website.

- The final author version and the galley proof are versions of the publication after peer review.

- The final published version features the final layout of the paper including the volume, issue and page numbers.

Link to publication

\footnotetext{
General rights rights.

- You may freely distribute the URL identifying the publication in the public portal. please follow below link for the End User Agreement:

www.umlib.nl/taverne-license

Take down policy

If you believe that this document breaches copyright please contact us at:

repository@maastrichtuniversity.nl

providing details and we will investigate your claim.
}

Copyright and moral rights for the publications made accessible in the public portal are retained by the authors and/or other copyright owners and it is a condition of accessing publications that users recognise and abide by the legal requirements associated with these

- Users may download and print one copy of any publication from the public portal for the purpose of private study or research.

- You may not further distribute the material or use it for any profit-making activity or commercial gain

If the publication is distributed under the terms of Article $25 \mathrm{fa}$ of the Dutch Copyright Act, indicated by the "Taverne" license above, 
HET NERVEUZE TIJDPERK EN ZIJN HISTORICI 
Op het omslag:

Prentbriefkaart uit Wuppertal (1912) en een illustratie uit A. von SchweigerLerchenfeld, Das eiserne Jahrhundert (Wenen, 1884). 


\section{HET NERVEUZE TIJDPERK EN ZIJN HISTORICI}

De opkomst van de mentaliteitsgeschiedenis in Duitsland 1889-1915

\section{PROEFSCHRIFT}

ter verkrijging van de graad van doctor aan de Universiteit Maastricht, op gezag van de Rector Magnificus, prof. mr. G.P.M.F. Mols volgens het besluit van het College van Decanen, in het openbaar te verdedigen

op vrijdag 2 november 2007 om 14.00 uur

door

Emmanuel Peter Marie Stoffers 
Promotores:

Prof. dr. A. Labrie

Prof. dr. A.J.J. Nijhuis (Universiteit van Amsterdam)

\section{Beoordelingscommissie:}

Prof. dr. T. Blom (voorzitter)

Prof. dr. F.W. Boterman (Universiteit van Amsterdam)

Dr. P.A.J. Caljé

Prof. dr. A. Knotter

Prof. dr. L.H.M. Wessels (Open Universiteit Nederland)

Dit proefschrift is mede tot stand gekomen dankzij steun van de Nederlandse Organisatie voor Wetenschappelijk Onderzoek (NWO). 
'Wij liepen verder over de stille paden van het kerkhof en verschillende beelden uit de tijd dat ik als jongen graag op deze plek vertoefde, kwamen in mij op. [...]

Toen ik hier eens zat - ik zal ongeveer negen of tien jaar oud zijn geweest overkwam mij iets merkwaardigs. Op de graven begonnen plotseling zonnen te dansen. Tegenwoordig weet ik natuurlijk dat het daarbij gaat om reflectiebeelden die ontstaan na een intense blik op de ondergaande vuurbal. Indertijd geloofde ik echter dat de dansende zonnen de zielen waren van de mensen die hier begraven lagen en ik dacht er meteen al die eerste keer lang over na met wie ik eigenlijk via deze zielebeelden, terugreikend naar het verleden, in contact zou willen komen.

Ik beschouwde deze verschijnselen als het grootste geheim dat ik bezat [...] en ik ben al deze gedachten eigenlijk pas na mijn definitieve vertrek uit Jessen kwijtgeraakt. Of zou zelfs tegenwoordig nog iets ervan zijn blijven hangen? Wat is een historicus anders dan een Seelenkünder langer Vergangenheiten [...]?' 



\section{Dankwoord}

De veelzijdige Britse historicus Geoffrey Barraclough heeft het historisch werk eens met aangename nuchterheid als volgt omschreven:

'Anyone who is going to make anything out of history will, sooner or later, have to do most of the work himself or herself. He will have to read, and consider, and re-consider, and then read some more.'

Het is een uitspraak die voor de geschiedwetenschap ongetwijfeld sterker geldt dan voor wetenschappen waarin het onderzoek een minder persoonlijk karakter draagt. Dat neemt niet weg dat ook de voorliggende historische studie veel te danken heeft gehad aan de directe betrokkenheid van een aantal mensen.

Het idee voor het onderzoek werd eind jaren tachtig geboren aan het Utrechtse Instituut voor Geschiedenis, tijdens een doctoraal werkcollege dat Pim den Boer, kenner van de Franse historiografie, wijdde aan de mentaliteitsgeschiedenis. In die context rees bij ondergetekende de vraag hoe de Duitse bijdragen uit de periode rond 1900 aan dit (op)nieuw ontdekte domein van de geschiedwetenschap begrepen moesten worden: publicaties die wel in de catalogus van de universiteitsbibliotheek te vinden waren, maar niet of nauwelijks in de recente literatuur over dit onderwerp.

Op dat moment was eigenlijk al te voorzien dat Hendrik Spiering en Joost Vijselaar, twee andere deelnemers aan dat levendige werkcollege, jaren later waardevol commentaar zouden gaan leveren op de binnendruppelende onderzoeksresultaten. Dezelfde vriendendienst bewees Guido Goossens, die even nauwgezet als kritisch de wording van het boek van dichtbij heeft gevolgd en consequent is blijven meedenken over de lijn van het onderzoek. Het zou me veel deugd doen als iets van de common sense, de breed ontwikkelde blik en de onafhankelijke geest van deze drie vrienden in dit boek is terug te vinden.

Zonder Arnold Labrie zou dit boek er niet alleen anders hebben uitgezien, maar misschien wel niet tot stand zijn gekomen. Ik dank hem voor het grote vertrouwen dat hij in het onderzoek is blijven stellen, sinds in 1993 een hem onbekende jonge medewerker van de Open Universiteit op de fiets bij hem thuis aankwam om een gezamenlijke subsidie-aanvraag voor het project bij NWO te bespreken. Dankzij hem werd de Maastrichtse Faculteit der Cultuur- en Maatschappijwetenschappen de bedrijvige thuishaven van dit project, waar het onderzoek uiteindelijk - en inderdaad vaak tussen de bedrijven door - ook voltooid kon worden. Aan het eind van het traject heeft de scherpe blik van Ton Nijhuis op het bijna afgeronde manuscript mij ertoe weten te brengen de premissen van het onderzoek ook voor mijzelf nog eens te verduidelijken.

Ik draag deze studie op aan de herinnering van Harry Johannes Stoffers (1925-2000), die het zaad van de verwondering zaaide en bij zijn grote waardering voor het woord en de wetenschap hun beperkingen niet uit het oog verloor.

Manuel Stoffers

Maastricht, maart 2007 



\section{INHOUD}

Dankwoord $\quad \mathrm{V}$

Lijst van tabellen en grafieken $\quad$ IX

Lijst van gebruikte afkortingen $\quad X$

1 Inleiding 3

1 'The French connection' 4

2 Het debat over de nieuwe Duitse cultuurgeschiedenis $\quad 7$

3 De geschiedenis en politiek van een idee: de veranderlijke psyche 13

4 Opbouw en afbakening van het onderzoek 17

2 Opkomst en doorbraak 23

1 Opkomst (1889-1896) 24

2 Het uur van Lamprecht 32

3 Terugslag en doorbraak (1896-1915 en verder) 37

3 De nieuwe cultuurgeschiedenis in vijf portretten 45

1 Eberhard Gothein 46

1.1 'Adieu Geschichte, aber doch auch auf wiedersehen' 46

1.2 Cultuurgeschiedenis als ideeëngeschiedenis en sociale geschiedenis $\quad 49$

1.3 Historische psychologie $\quad 55$

2 Georg Steinhausen $\quad 60$

2.1 Cultuurgeschiedenis als 'Geschichte des inneren Menschen' 62

2.2 Cultuurgeschiedenis als 'Lebensgeschichte eines Volkes' 66

3 Karl Lamprecht $\quad 73$

3.1 Lamprecht en de cultuurgeschiedenis $\quad 73$

$\begin{array}{ll}\text { 3.2 De sociaal-psychische factoren } & 76\end{array}$

$\begin{array}{lr}\text { 3.3 Regionale, nationale en universele geschiedenis } & 84\end{array}$

3.4 Psychische distantie $\quad 86$

3.5 Geschiedenis en psychologie $\quad 91$

4 Kurt Breysig $\quad 94$

4.1 Sociale geschiedenis, cultuurgeschiedenis, algemene geschiedenis 95

4.2 Cultuurgeschiedenis als onderzoek van de menselijke ziel 98

4.3 'Gevoelsstromingen als dragers van heel het historische gebeuren' 100

4.4 Breysigs Geschichte der Seele 103

5 Walter Goetz 108

$\begin{array}{ll}5.1 \text { Van politieke geschiedenis naar cultuurgeschiedenis } & 108\end{array}$

5.2 Cultuurgeschiedenis als Gesamtgeschichte... 110

5.3 ...en als Geistesgeschichte 112

$\begin{array}{ll}5.4 \text { Goetz' werk } & 115\end{array}$

6 De panoramische blik en de psychologische ontwikkeling 123

$\begin{array}{ll}\text { 6.1 De panoramische blik } & 124\end{array}$

$\begin{array}{ll}\text { 6.2 De toegang tot het verleden: kunst, statistiek, egodocumenten } & 126\end{array}$

$\begin{array}{ll}\text { 6.3 Cultuurgeschiedenis als geschiedenis van de menselijke natuur } & 128\end{array}$ 
1 Familieachtergrond en vroege scholing

2 Universitaire geschiedenisopleiding

3 Vroege academische carrière

4 Blijvende activiteiten binnen de discipline

5 De rol van de economen

\section{Verlicht historisme}

1 Het primaat van de politiek

2 De stille zuiverheid van de historische zin 171

3 De oorsprong van de moderne geschiedwetenschap 178

4 Engagement en het belang van de levensbeschouwing 182

5 Individu en collectief

6 Idealisme, Verstehen en psychologie 193

7 De menselijke natuur, cultuur en ontwikkeling 202

6 De plooibare psyche in de Duitse geesteswetenschappen 209

1 In het spoor van Burckhardt, Freytag en Riehl 210

2 De nieuwe cultuurhistorici en het West-Europese positivisme 216

3 De herbartiaanse psychologie en haar critici 221

4 De Historische School in de Nationalökonomie 234

$\begin{array}{lll}7 & \text { Cultuurhistorici van 'het nerveuze tijdperk' } & 247\end{array}$

1 'De ademende werkelijkheid van de natie' $\quad 247$

2 'Wij zijn kinderen van een andere tijd' 250

3 'Een nieuw kosmopolitisme' 251

4 'Voorwaarts zonder rust' 253

5 'Zenuwen in onze zin hebben onze voorouders niet gehad' 258

6 'Wij zijn geen eenheid meer' 264

7 'Sociaal idealisme' versus 'persoonlijkheidspolitiek' 268

8 De Duitse toekomst 276

9 De politiek van de nieuwe cultuurgeschiedenis $\quad 281$

8 Conclusie $\quad 285$

$\begin{array}{ll}\text { Aangehaalde bronnen en literatuur } & 293\end{array}$

$\begin{array}{ll}\text { Register } & 325\end{array}$

$\begin{array}{ll}\text { Summary } & 335\end{array}$

$\begin{array}{ll}\text { Over de auteur } & 341\end{array}$ 


\section{Lijst van tabellen en grafieken}

Tabel 2.1 Bernheims indeling van de geschiedwetenschap (1889) 29

Tabel 2.2 Organiserend bestuur van de Historikertage respectievelijk van 36

$\begin{array}{lll}\text { Tabel } 2.3 & \text { Indicatieve titelanalyse van artikelen verschenen in de } & 41\end{array}$

Historische Zeitschrift, 1859-1943

Tabel 2.4 Aantal artikelen gepubliceerd door Duitse (inclusief Zwitserse en Oostenrijkse) ordinarii voor geschiedenis in de ZfK en het AfK 1894-1943

Tabel 2.5 De ontwikkeling van het aantal auteurs dat in de periode 18941943 zowel in Zeitschrift en Archiv für Kulturgeschichte als in de Historische Zeitschrift publiceerde

Tabel 3.1 Steinhausens indeling van de cultuurgeschiedenis

Tabel 3.2 Lamprechts analyse van de individuele psyche en de collectieve psychische habitus

Tabel 3.3 De culturele ontwikkeling in de loop van de (Duitse) geschiedenis volgens Lamprecht

Tabel 3.4 Aanbod van werkcolleges (Übungen) aan het Königlich Sächsisches Institut für Kultur- und Universalgeschichte bij de Universiteit van Leipzig, zomersemester 1910

Grafiek 4.1 De ontwikkeling van het aantal leerstoelen geschiedenis in de Duitse landen die vanaf 1871 tot het Keizerrijk behoorden, 18401915

Tabel 4.1 Aantal, verdeling en ontwikkeling van de leerstoelen voor geschiedenis aan universiteiten en hogescholen in het Keizerrijk, 1889-1914 


\section{Lijst van gebruikte afkortingen}

AfK Archiv für Kulturgeschichte. 1(1903)-. Hoofdredactie: Georg Steinhausen (1903-1933) en Walter Goetz (1912-1958).

AS Lamprecht, Karl, Ausgewählte Schriften zur Wirtschafts- und Kulturgeschichte und zur Theorie der Geschichtswissenschaft, red. H. Schönebaum. Aalen: Scientia-Verlag, 1974.

BHK Badische Historische Kommission

DG Lamprecht, Karl, Deutsche Geschichte. Berlijn: Weidmannsche Buchhandlung, XII + 2 dln., 1891-1909.

DZGW Deutsche Zeitschrift für Geschichtswissenschaft. 1(1889)-8(1898). Hoofdredactie: L. Quidde (1889-1895), Karl Lamprecht e.a. (1896-1898) Freiburg: Mohr.

HV Historische Vierteljahrschrift.1(1898)-31(1937/38). Hoofdredactie: Gerhard Seeliger.

HZ Historische Zeitschrift. 1(1859)-. Hoofdredactie: Heinrich von Sybel (1859-1895); Heinrich von Treitschke (1895-1896); Friedrich Meinecke (1895-1935). München: Oldenbourg.

IKU Königlich Sächsisches Institut für Kultur- und Universalgeschichte bei der Universität Leipzig (1909)

PJb Preußische Jahrbücher. 1 (1858) - 240 (1935).

PW Goetz, Walter, red. Propyläen-Weltgeschichte: der Werdegang der Menschheit in Gesellschaft und Staat, Wirtschaft und Geistesleben. Berlin: Propyläen-Verlag, 10 dln., 1929-1933.

VDH Verband Deutscher Historiker

ZfK Zeitschrift für Kulturgeschichte. 1(1894)-9(1902). Hoofdredactie: Georg Steinhausen. Berlijn: Felber.

ZfVS Zeitschrift für Völkerpsychologie und Sprachwissenschaft. 1(1860)-20(1890). Hoofdredactie: Moritz Lazarus en Hajim Steinthal. 
In tijden van langzame verandering bestaat de neiging om de menselijke natuur als wezenlijk constant te beschouwen, omdat iedereen onwillekeurig de historische gedaante van de menselijke natuur die gangbaar is in zijn eigen tijd als eeuwig beschouwt. In revolutionaire tijden verschijnt het probleem van de variabiliteit van de menselijke natuur derhalve altijd in een nieuw licht.

Karl Mannheim, Man and society in an age of reconstruction (1940). 



\section{Inleiding}

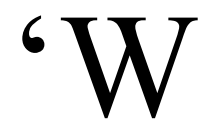

ij leven sneller dan onze voorouders.' De constatering stamt uit 1895. Aan het woord is een jonge Duitse historicus in een studie over 'de verandering van het Duitse gevoelsleven sinds de Middeleeuwen'. ${ }^{1}$ De auteur, Georg Steinhausen, was de initiatiefnemer en hoofdredacteur van het een jaar eerder opgerichte Zeitschrift für Kulturgeschichte. In zijn korte studie beschreef hij de verschillende 'ontwikkelingsfasen' in de geschiedenis van het Duitse voelen en waarnemen. Het was een onderwerp dat, zoals hij opmerkte, niet alleen bij het geletterde publiek, maar ook onder historici te weinig aandacht had gekregen. Het gevolg was dat zij vaak ten onrechte tijdgebonden kenmerken van het innerlijk leven van historische figuren beschouwden als individuele karaktereigenschappen.

Neem zijn eigen tijd, de vier decennia na 1850, waarmee Steinhausen zijn historische schets afsloot. De 'nervositeit' die veel van zijn tijdgenoten kenmerkte, was geen individueel verschijnsel, aldus de historicus, maar een collectief en tijdgebonden fenomeen dat bovendien niet per se als een ziekelijke toestand uitgelegd diende te worden. In navolging van de vooraanstaande zenuwarts Wilhelm Erb noemde Steinhausen het 'nieuwe nerveuze tijdperk' een gevolg van de komst van de moderne tijd. De belangrijkste factoren waren de 'onmetelijke toename en snelheid van de communicatie', 'de moderne grootsteedse bedrijvigheid', 'de kolossaal toegenomen eisen die aan de prestatievermogen van het individu worden gesteld', 'de politieke en sociale conflicten', 'de economische strijd om het bestaan'. Het mentale gevolg van deze tijdsverschijnselen was, aldus Steinhausen, een sterke verfijning van de gevoelens: 'wij zijn voor de verscheidenheid van de impressies ontvankelijker, wij nuanceren onze gevoelens buitengewoon'.

Voor de historicus die toegang tot deze geschiedenis van de gevoelens wilde krijgen, vormden egodocumenten uit het verleden (brieven, dagboeken, enzovoort), een bijzonder waardevolle bron, meende Steinhausen. Vooral als zij niet geschreven waren door uitzonderlijke individuen, maar door 'doorsneemensen'. In de inleiding van een bundel met dergelijke historische documenten, die hij in 1899 met steun van de Pruisische Academie van Wetenschappen uitgaf, merkte hij op dat in archieven deze documenten door archivarissen niet zelden waren voorzien van de aantekening 'Zonder betekenis!', 'Niet van belang!'. Daaruit sprak hun gebrek aan inzicht in de ware betekenis van deze bronnen, aldus Steinhausen. Die was gelegen in de kennis die zij konden opleveren over 'de mensen in het verleden', of preciezer: over 'het psychisch leven [Seelenleben] van een tijd'. Het was immers zaak voor de historicus om greep te krijgen op de veranderlijkheid van de psyche in de loop van de geschiedenis:

\footnotetext{
${ }^{1}$ Steinhausen (1895b), 41
} 
'Wie gelooft, dat het voelen en willen van mensen te allen tijde hetzelfde is geweest, wie de mensen uit het verleden slechts meet met de psychologische maatstaf van de tegenwoordige mens, die is geen echte historicus'.

Het was Steinhausens overtuiging dat de geschiedwetenschappers in zijn tijd op dit punt nog veel te leren hadden. Zij hadden in de regel te weinig aandacht voor 'cultuurgeschiedenis', een vorm van historisch onderzoek die volgens Steinhausen opgevat moest worden als 'historische psychologie in de breedste zin van het woord'.2

Bijna honderd jaar later, in 1986, werd een van de bronnenuitgaven van Steinhausen een internationaal verkoopsucces in de becommentarieerde vertaling van de Harvard historicus Steven Ozment. ${ }^{3}$ Het waren de hoogtijdagen van wat inmiddels, naar Frans gebruik, 'mentaliteitsgeschiedenis' was gaan heten.

\section{1 'The French connection'}

Ozments bestseller leidde niet tot veel aandacht voor de oorspronkelijke Duitse bezorger van deze bronnen en de Duitse context waarin zijn opvattingen over cultuurgeschiedenis als een vorm van historische psychologie hun oorsprong vonden. 'Mentaliteitsgeschiedenis' werd (en wordt nog steeds) als een Franse vondst beschouwd. Niet verwonderlijk, want de doorbraak van deze richting in het historisch onderzoek aan de universiteiten van de jaren tachtig in Nederland en elders in Europa en de VS was in hoge mate een Frans exportsucces - een verschijnsel dat op zichzelf een studie waard is.

Zoals aan het eind van de negentiende eeuw historici-in-opleiding uit de hele wereld naar Duitse universiteiten trokken, zo staken in de tweede helft van de twintigste eeuw veel buitenlandse historici hun licht op in Frankrijk. Nederlandse historici die het begrip 'mentaliteitsgeschiedenis' hier te lande op de kaart zetten, zoals Harry Peeters, Willem Frijhoff en Pim den Boer, hadden in Frankrijk gestudeerd of gewerkt en daar in de jaren zestig en zeventig kennisgemaakt met de opkomst van de histoire des mentalités onder historici rond het tijdschrift Annales: Économies, Sociétés, Civilisations. ${ }^{4}$

In Nederland onderwezen deze en andere historici de nieuwe lichtingen geschiedenisstudenten over 'het Franse wonder' en de grote betekenis van de Annales voor de vernieuwing van de geschiedwetenschap. Hoorcolleges over de geschiedenis van de geschiedwetenschap eindigden in de jaren zeventig en tachtig typisch met een uitgebreide bespreking van de Annales-historiografie, als het voorbeeld van de disciplinaire state of the art. ${ }^{5} \mathrm{De}$ 'mentaliteitsgeschiedenis' werd gepresenteerd als de meest recente vrucht van de bloeiende Franse historische school. De eerdere Franse

\footnotetext{
${ }^{2}$ Steinhausen (1899-1907), I, 1, vi.

${ }^{3}$ Ozment publiceerde zijn van toelichtingen voorziene vertaling onder de titel Magdalena and Balthasar: an intimate portrait of life in $16^{\text {th }}$-century Europe. Oorspronkelijke uitgave: Steinhausen (1895a). Er verscheen behalve een Engelse in ieder geval een Nederlandse, Zweedse en Duitse (!) uitgave van Ozments boek.

${ }^{4}$ Zie Peeters (1967), Peeters en Kruithof (1973), Peeters (1975), Peeters (1988), Den Boer (1981), Den Boer (1983), Frijhoff (1982), Frijhoff (1984). Over Peeters zie: Hutschemaekers en Winter (1996). De 'French connection' gold ook voor de Belgische historicus Raoul van Caenegem die in het Tijdschrift voor Geschiedenis al in 1965 een artikel over 'Psychologische geschiedenis' publiceerde: Caenegem (1965).

${ }_{5}$ Zie bijv. C. Offringa, 'Hoorcollege historiografie voor eerste- en tweedejaars studenten in de geschiedenis', Instituut voor Geschiedenis, RU Utrecht, 1982 (1976).
} 
structuralistische analyses van de samenleving in het verleden werden nu op een aantrekkelijke manier aangevuld met studies waarin de 'belevingswereld' van mensen in het verleden centraal stond.

Volgens een uitspraak uit 1968 van een bekende Franse mentaliteitshistoricus ging het bij 'mentaliteitsgeschiedenis' om een vorm van historisch onderzoek die 'nauwelijks buiten Frankrijk wordt bedreven'. 6 De mentaliteitshistorici hielden zich bezig met onderwerpen als de houdingen tegenover de dood (Ariès, Vovelle), het kind-zijn en de privé-sfeer (Ariès, Duby), de reukzin en andere aspecten van de 'mentale uitrusting' (Corbin, Febvre), de lichaamshouding (J.C. Schmitt), de ervaring van tijd en ruimte (Mandrou, Le Goff). Het ging om onderwerpen die voordien werden beschouwd als iets natuurlijks of individueels (en derhalve zonder geschiedenis), terwijl ze nu als een product van cultuur en samenleving en derhalve als historische fenomenen werden opgevat. 'Langzamerhand ontstaat zo een volledig gehistoriseerd beeld van het menselijk lichaam en de menselijke psyche in hun betrokkenheid op de samenleving', vatte Frijhoff in 1992 de gemeenschappelijke strekking van het groeiend aantal mentaliteitshistorische studies samen. ${ }^{7}$ Pim den Boer omschreef 'mentaliteitsgeschiedenis' in een begripsbepaling wat minder pregnant als de 'reconstructie van [de] collectieve geestesgesteldheid van samenlevingen en sociale groeperingen die in tijd en ruimte afgebakend zijn'. ${ }^{\text {. }}$

De beide Annales-oprichters Marc Bloch (1886-1944) en vooral Lucien Febvre (1878-1956) golden als de baanbrekers van deze vorm van geschiedschrijving. ${ }^{9} \mathrm{Zij}$ hadden zich in hun geschiedschrijving uitdrukkelijk gekeerd tegen het 'psychologisch anachronisme', de interpretatie van gedrag van mensen in het verleden met behulp van eigentijdse psychologische aannamen. Ze hadden ook herhaald gewezen op de noodzaak voor historici om de 'psychologische interval' tussen heden en verleden te onderkennen. ${ }^{10}$ Febvre werkte dergelijke opvattingen uit in enkele programmatische artikelen uit de jaren dertig en veertig. Daarin hield hij een enthousiast pleidooi voor een toenadering tussen geschiedenis en psychologie en voor een historische analyse van la vie affective, de outillage mentale en de sensibilités in het verleden. ${ }^{11}$ Febvre's studie uit 1942 over het geloof van Rabelais mondde uit in een analyse van zestiende-eeuwse manieren van waarnemen en denken die het boek de status van een mentaliteitshistorische klassieker gaven.

Voor de Franse historici Mandrou en Duby die in de jaren zestig de mentaliteitsgeschiedenis opnieuw onder de aandacht brachten, stond het vast: Febvre had niet alleen hen de ogen geopend voor deze thematiek, hij had 'werkelijk de historische psychologie gesticht' (waarbij 'historische psychologie' op dat moment als synoniem voor 'mentaliteitsgeschiedenis gold). ${ }^{12}$ Ook voor wetenschappers met een grotere persoonlijke afstand tot Febvre gold hij als ' $d e$ pionier van de historische psychologie', zoals een van de eerste analytici van zijn werk schreef. ${ }^{13}$ In Nederland suggereerde Pim den Boer in zijn begripsbepaling dat er weliswaar 'tal van oudere

\footnotetext{
${ }^{6}$ Mandrou (1968), 436.

${ }^{7}$ Zie Frijhoff in Te Boekhorst, Burke en Frijhoff (1992), 17.

${ }^{8}$ Den Boer (1983), 329.

${ }^{9}$ Daarbij wordt soms geprobeerd verschillende opvattingen van mentaliteitsgeschiedenis terug te voeren tot een van beide Annales-grondleggers: Bruguière (1989).

${ }^{10}$ Zie bijv. Febvre (1992), 218, en Bloch (1989), [1e dr. 1949], 64, 67-68, 79, 96, 114.

${ }^{11}$ Het gaat m.n. om Febvre (1938) en Febvre (1941).

${ }^{12}$ Mandrou (1961), xxiv. Met twee programmatische verhandelingen uit de jaren zestig verbreidden Duby en Mandrou zowel de uitdrukking als het project van de 'histoire des mentalités': zie Duby (1961) en Mandrou (1968).

${ }^{13}$ Mann (1971), 114.
} 
werken' waren die mentaliteitshistorische elementen bevatten, maar dat het in het algemeen bij de Annales-historici toch om iets nieuws ging. ${ }^{14}$ Minder aarzelend was Peter Burke, een van de bekendste 'fellow-travellers' van de Annales. Hij sprak van een 'Franse historische revolutie', een door de Franse geschiedwetenschap teweeggebrachte omwenteling in het denken over geschiedenis. ${ }^{15}$

Vanuit mentaliteitshistorische hoek was er zodoende minder aandacht voor het feit dat de Annales-geschiedschrijving niet op zichzelf stond, maar deel uitmaakte van zowel een langere traditie als van een internationale heroriëntatie in de geschiedwetenschappen, die al vanaf omstreeks 1890 in verschillende landen tot vergelijkbare ideeën en benaderingen had geleid. Studies waarin werd gewezen op de overeenkomsten tussen de Franse histoire des mentalités en de rond 1900 opkomende Duitse Geistesgeschichte en de Amerikaanse 'intellectual history', golden al snel als niet diepgaand genoeg in de behandeling van de Franse ontwikkelingen. ${ }^{16}$ Men kon zich daarbij gesteund voelen door een waarschuwing van de gezaghebbende DuitsAmerikaanse historiograaf Georg Iggers om de 'moderniteit' van de historische vernieuwers van 1890 vooral niet te overdrijven: er was volgens hem sprake van een 'kwalitatieve verandering' tussen de historiografie van de generatie van 1890 en die van Febvre en Bloch, een verandering waaruit volgens Iggers bleek dat de vroege vernieuwers nog niet 'the full impact of the social and cultural transformation of the twentieth century' hadden ervaren. ${ }^{17}$

Toch refereerde Febvre zelf aan het slot van zijn eerste programmatische mentaliteitshistorische publicatie uit 1938 uitdrukkelijk aan de 'grandes thèses doctrinales' van de in 1915 overleden Leipzigse historicus Karl Lamprecht (ook al deed hij dat om zijn eigen opvattingen te onderscheiden van het verwante project van zijn voorganger). ${ }^{18}$ En omgekeerd hanteerde deze bekendste Duitse historicus van zijn tijd al het Franse begrip mentalité in zijn geschiedenisonderwijs: studenten aan Lamprechts radicaal innovatieve, in 1909 opgerichte Institut für Kultur- und Universalgeschichte dienden niet slechts de uiterlijke feiten van een nationale geschiedenis te bestuderen, maar ook 'de "mentalité" van de betreffende natie'. ${ }^{19}$

Deze details zijn niet zonder betekenis. Ze leiden naar de kern van het voorliggende onderzoek. Zoals deze studie zal laten zien was het historisch onderzoek naar de ontwikkeling van collectieve 'geestesgesteldheden' en 'mentale uitrustingen' en de daarmee verbonden gedachte van de veranderlijkheid van de mens, geen exclusieve preoccupatie van de Franse historiografie. Zij vormde een belangrijk aspect van de pogingen in het Duitse Keizerrijk na 1890 om een nieuwe, academische vorm van cultuurgeschiedenis te ontwikkelen.

\footnotetext{
${ }^{14}$ Den Boer (1983), 334-335.

${ }^{15}$ Burke (1990). De omschrijving 'fellow-traveller van de Annales' is van Burke zelf.

${ }^{16}$ Zie bijv. Den Boer (1983), 318n4 over Schulin (1979). Opvallend is ook het ontbreken van de naam van Lamprecht in de omvangrijke, bijna 5000 titels tellende bibliografie op dit terrein die Harry Peeters in 1985 het licht deed zien: Peeters, Gielis en Caspers (1985). Febvre duikt daarin acht keer op, Bloch drie keer.

${ }^{17}$ Iggers (1984), 29-30. Meer over Iggers, hierna in paragraaf 2.

${ }^{18}$ Febvre (1938), 8*12-7.

${ }^{19}$ Zie Lamprecht (1988), 426 [1914] en hierna, Hoofdstuk 3, paragraaf 3.3. Voor de vroege geschiedenis van het begrip 'mentalité', dat rond 1900 in Frankrijk en vogue raakte, zie het uitstekende artikel van Raulff (1989).
} 
Aan deze pogingen is dit boek gewijd, niet om te laten zien dat de Franse mentaliteitsgeschiedenis een directe 'voorloper' zou hebben in de Duitse cultuurgeschiedenis, maar om duidelijk te maken dat ook buiten Frankrijk en onafhankelijk van de Annales-historiografie dergelijke ideeën in de geschiedwetenschap opkwamen.

De vraag is: waarom?

\section{Het debat over de nieuwe Duitse cultuurgeschiedenis}

In 1934 schreef de gerenommeerde Duitse geesteswetenschapper Eduard Spranger: 'Niemand begrijpt iets van geschiedenis die zichzelf niet heeft overtuigd van de enorme veranderlijkheid van het psychologisch type van de mens'. En hij vervolgde: 'De Duitse historicus Karl Lamprecht heeft de belangrijke gedachte gehad in die zin geschiedenis te schrijven als een psychologische geschiedenis' ${ }^{20}$ Eerder was de 'onaanvechtbare verdienste' van de Leipzigse historicus al door de hoogleraar economie Franz Eulenburg op vergelijkbare wijze aangeduid: hij zou 'het historisch veranderlijke gedrag van de ziel [historisch wandelbare Verhalten der Psyche] in het concrete leven van de volkeren' hebben aangetoond. ${ }^{21}$

Deze uitspraken over Karl Lamprecht (1856-1915) geven diens streven zonder meer juist weer. Maar zij dienen te worden aangevuld. Ondanks zijn reputatie als Außenseiter stond Lamprecht met de gedachte van een dergelijke 'psychologische geschiedenis' bepaald niet alleen in Duitsland. Binnen de Duitse geschiedwetenschap was hij de belangrijkste vertegenwoordiger van een groep historici die aan het einde van de negentiende eeuw oog kregen voor de historiciteit van de menselijke psyche. Een andere historicus uit deze groep is al geïntroduceerd: de oprichter van de Zeitschrift für Kulturgeschichte, Georg Steinhausen (1866-1933). De belangrijkste overige exponenten van deze stroming waren de hoogleraren Eberhard Gothein (1853-1923), Kurt Breysig (1866-1940) en Walter Goetz (1867-1958).

Deze vijf historici zijn de hoofdpersonen van deze studie. Zij wierpen zich in het Keizerrijk van Wilhelm II op als woordvoerders van een nieuwe, academische vorm van cultuurgeschiedschrijving, waarin het psychologisch perpectief een opvallende rol speelde. Net als de Franse mentaliteitshistorici enkele decennia later, rechtvaardigden deze Duitse cultuurhistorici hun historisch-psychologische interesse door te wijzen op de 'psychische distantie' tussen heden en verleden. Net als hun Franse collega's geloofden zij in het bestaan van collectieve psychische kenmerken en reflecteerden zij over nieuwe bronnen en methoden om deze kenmerken in het verleden op te kunnen sporen. En net als de vroege Annales-historici verbonden zij de overtuiging van de 'malleability of man' aan een hodiecentristische taakopvatting waarin juist het heden door de historicus gediend moest worden. ${ }^{22}$

Van deze vijf historici gelden Lamprecht, Gothein en Breysig sinds lang als de (overigens weinig succesvol geachte) aanjagers van de historiografische vernieuwing in

\footnotetext{
${ }^{20}$ Spranger (1974), 57; zie ook Spranger (1965), 349-350. Spranger had al in zijn proefschrift uit 1905 veel aandacht gegeven aan de opvattingen van Lamprecht: Spranger (1905).

${ }^{21}$ Eulenburg (1907), 336; vgl. ook de psycholoog Pflaum (1906), III, 12-14, over de verdienste van Lamprecht.

${ }^{22}$ Dosse (1994), 42-50, noemt het een wezenlijke innovatie van de Annales om te breken met de exclusieve aandacht voor het verleden dat 'de traditionele geschiedschrijving' kenmerkte, en in plaats daarvan zoveel mogelijk de studie van het heden en het verleden met elkaar te verbinden. De eigentijdse betrokkenheid kwam tot uiting in het relatief groot aantal artikelen over eigentijdse onderwerpen dat in de vroege Annales van de jaren dertig werd gepubliceerd, zie Raphael (1994), 79-88 en Wesseling (1995).
} 
de Duitse geschiedwetenschap van het fin-de-siècle. In een uitvoerig en invloedrijk artikel van Gerhard Oestreich uit 1969, een van de eerste uitgebreidere studies naar de vernieuwingsbeweging in de Duitse geschiedwetenschap, kwamen deze drie historici als hoofdpersonen naar voren. ${ }^{23}$ Het was de bedoeling van Oestreich (1910-1978), zelf vóór de oorlog opgeleid in de traditie van een sociaalhistorisch georiënteerde Verfassungsgeschichte ${ }^{24}$ om daarmee 'het begin van het sociaalhistorisch onderzoek in Duitsland' bloot te leggen. Sindsdien zijn er een of meer publicaties gewijd aan elk van de door hem besproken historici afzonderlijk. ${ }^{25}$ In het geval van Lamprecht betrof het daarbij de voortzetting van een reeks dissertaties en andere studies die ten dele al tijdens zijn leven aan zijn opvattingen werden gewijd. ${ }^{26}$

Sinds het artikel van Oestreich hebben de Duitse historiografische vernieuwers bovendien een plek gekregen in een reeks artikelen over de internationale vernieuwingen in de geschiedwetenschap rond 1900, die opvallend vaak door Duitse historiografen werden geschreven. ${ }^{27}$ Een van de meest uitgebreide en grondige van deze internationale vergelijkingen was van de hand van de Trierer historicus Lutz Raphael uit $1997 .^{28}$ Op grond van bestaand onderzoek naar de historiografische ontwikkelingen in diverse landen van Europa en in de VS in de jaren 1880-1940, stelde hij vast dat er internationaal sprake was van een hele reeks aan nieuwe historische benaderingen. Daartoe rekende hij onder andere de sociaal-economische geschiedenis, de mentaliteitsgeschiedenis, de politieke ideeëngeschiedenis en de (psychoanalytisch georiënteerde) psychohistory.

De opname van de Duitse vernieuwers in internationale vergelijkingen betekende meestal (maar niet altijd) een rehabilitatie van de betekenis van deze historici, wier reputatie nogal te lijden had gehad van de negatieve oordelen die contemporaine vakgenoten over hun werk hadden uitgesproken. Typerend is het veranderde oordeel over Lamprecht in de afgelopen decennia. Terwijl Oestreich in zijn artikel nog suggereerde dat het optreden van Lamprecht de gehele Duitse vernieuwingsbeweging in discrediet had gebracht, werd in 1991 door Leipzigse historici de ambitieuze KarlLamprecht-Gesellschaft opgericht die zich uitdrukkelijk in de traditie van de opvattingen van hun naamgever plaatste. ${ }^{29}$ Het motto van deze KLG was Karl Lamprecht weiterdenken, zoals de titel luidde van een bundel die zij in 1993 over zijn werk en erfenis publiceerde.

${ }^{23}$ Oestreich (1969).

${ }^{24}$ Zie over Oestreich: Miller (2002).

${ }^{25}$ Over Gothein verschenen: Alter (1982) en Maurer (1999), en eerder al de gedegen studie van Zorn (1968); een monografie door Maurer, die in 2006 ook de correspondentie van Gothein en zijn vrouw uitgaf, is in wording. Over Breysig: Brocke (1971) en Brocke (1972). De belangrijkste studies die over Lamprecht verschenen zijn: Viikari (1977), Metz (1979); Schorn-Schütte (1984); Griss (1987), Chickering (1993) en Diesener (1993).

${ }^{26} \mathrm{Zie}$, behalve een lange reeks biografische artikelen van zijn laatste assistent Herbert Schönebaum, vooral: Kuhnert (1906), Rothacker (1912), Doren (1916), Spieß (1921), Seifert (1925) en Hoffmeister (1956).

${ }^{27}$ Zie daarover wel: Schulin (1979), Schorn-Schütte (1984), 287-337; Schorn -Schütte (1985), Schorn-Schütte (1993), Schorn-Schütte (1994), Raphael (1990), Raphael (1997), Hübinger (1997), Iggers (1986); Iggers (1984),

${ }_{28}$ Raphael (1997).

29 'Es wird an die weltweit beachteten Arbeiten Karl Lamprechts insbesondere unter Betonung seines Einsatzes für die universitas litterarum, für die disziplinübergreifende Zusammenarbeit in akademischer Forschung und Lehre, für die universalgeschichtliche Orientierung einer vergleichenden Gesellschaftsforschung einschließlich ihrer Fundierung in mikroregionalen Studien und der Einbeziehung der Kulturgeschichte, für die theorie- und wissenschaftsgeschichtliche Arbeit und gegen jede willküliche Trennung von National- und Universalgeschichte angeknüpft.' Tekst ontleend aan de website van de KLG: www.uni-leipzig.de/ zhs/KLG/klsatzung.htm (mijn cursivering MS). 
Typerend voor de rehabilitatie van de vernieuwingstendensen in de Duitse historische wetenschap rond 1900 was ook het verschijnen van een uitgebreide studie van de Münsterse historicus Stefan Haas in 1994. Zijn Historische Kulturforschung in Deutschland, 1880-1930 was uitdrukkelijk gemotiveerd door het oordeel dat het door hem bestudeerde historisch onderzoek punten van inspiratie en oriëntatie voor huidige onderzoekers bevat. Hoewel er wel iets valt aan te merken op zijn aanpak, komt Haas de eer toe als eerste een studie te hebben geschreven waarin een groot aantal Duitse vernieuwers, zowel van binnen als van buiten de historische discipline, gezamenlijk en tegelijk meer in detail dan in eerdere collectieve studies, werd besproken. ${ }^{30}$ Uit zijn onderzoek kwamen naast Gothein, Lamprecht en Breysig onder anderen de historici Steinhausen en Goetz naar voren als belangrijkste cultuurhistorici in het Keizerrijk. Inmiddels zijn ook over deze historici verschillende afzonderlijke publicaties verschenen. Een grote geschiedenis van de Duitse cultuurgeschiedschrijving sinds de achttiende eeuw van de hand van de voormalige DDR-historiograaf Hans Schleier is, na een lange reeks voorstudies, in statu nascendi. ${ }^{31}$

Al met al is er inmiddels een aanmerkelijk aantal studies over de nieuwe Duitse geschiedschrijving rond 1900 gepubliceerd. De vragen die in het voorliggende onderzoek centraal staan, zijn in deze studies echter niet of slechts zijdelings aan de orde gekomen. Het betreft vragen naar de herkomst en de betekenis van de de idee van een historische psychologie en de daarmee verbonden gedachte van de plooibare psyche, die in deze jaren door een aantal vernieuwingsgezinde Duitse historici op de agenda van de historische vakwetenschap wordt geplaatst.

Zo valt het op dat, hoewel er in een deel van de literatuur gewezen wordt op fundamentele overeenkomsten tussen de historiografische vernieuwingsbewegingen in de verschillende landen, de historisch-psychologische aspecten grotendeels aan dit vergelijkende moment worden onttrokken (op incidentele opmerkingen over Lamprecht als 'een soort van mentaliteitshistoricus' na). ${ }^{32}$ Opmerkelijk is bijvoorbeeld dat Raphael in zijn uitgebreide internationale vergelijking van de nieuwe geschiedenis rond 1900 de Franse mentaliteitsgeschiedenis niet met een bredere psychologiserende tendens in verband brengt, maar samen met onder andere de politieke ideeëngeschiedenis in de categorie van 'kennissociologische' tendensen plaatst. ${ }^{33}$ Lamprecht en Steinhausen horen volgens hem thuis in een andere categorie, gewijd aan 'nationale ontwikkelingsgeschiedenissen', terwijl hij de Freudiaanse 'psychohistory' weer in een derde categorie onderbrengt. In het algemeen, meent Raphael, moet de betekenis van de psychologie voor de nieuwe tendenties in de geschiedwetenschap rond 1900 niet worden overdreven. Deze 'nieuwe wetenschap' was volgens hem nog te weinig ontwikkeld was om van groot belang te kunnen zijn voor de heroriëntatie van de geschiedwetenschap. ${ }^{34}$

Niet dat er helemaal geen aandacht is voor een 'psychologische wending' in de geesteswetenschappen rond 1900. De Amerikaanse historicus Henry Stuart Hughes wees al in 1958 in zijn klassieke studie Consciousness and society. The reorientation of European social thought 1890-1930 op de grote betekenis van de nieuwe belangstelling

\footnotetext{
${ }^{30}$ Zie voor enkele kritiekpunten: Stoffers (1996b). Het harde oordeel van Hübinger (1997), 139, dat Haas' studie 'stringent am Thema vorbeigeschrieben' is, lijkt mij echter meer dan onbillijk.

${ }^{31}$ Over Goetz was in 1992 al de voornamelijk biografisch en politiek georiënteerde monografie van Weigand (1992) verschenen. Over Steinhausen, zie Haas (1994), Herold (2003) en bovendien: Schleier (2003-), I, 943-980, 1032-1037.

${ }^{32}$ Zie bijv. Breisach (1983), 341-342.

${ }^{33}$ Raphael (1997), 70.

${ }^{34}$ Raphael (1990), 353-354; vgl. Raphael (1997), 58-60.
} 
voor de rol van het 'niet-logische', het 'onbeschaafde', het 'irrationele' en 'onbewuste' onder Europese intellectuelen in de jaren 1890: 'Psychologische processen hadden de externe realiteit vervangen als het meest dringende onderwerp van onderzoek'. ${ }^{35}$

Voor die constatering valt wel iets te zeggen, maar opvallend is dat Stuart Hughes, wanneer hij binnen dit kader de geschiedwetenschap bespreekt, uitsluitend ingaat op het 'neo-idealisme' en daarbij Meinecke als de belangrijkste Duitse representant opvoert. Maar net als Benedetto Croce, de voornaamste andere idealistische historicus die Hughes bespreekt, was Meinecke juist een tegenstander van de psychologisch georiënteerde Duitse cultuurhistorici uit de jaren 1890, die zich op hun beurt tegen het extreme idealisme van veel collega-historici afzetten. ${ }^{36}$ Hughes' aandacht voor (neo)idealistische denkers past in zijn stelling dat de 'revolte tegen het positivisme' de drijvende motivatie was in de belangstelling voor het irrationele. ${ }^{37}$ Maar zoals het geval van Freud zelf duidelijk maakt, werd de belangstelling voor onbewuste drijfveren onder 'de generatie van 1890' niet per definitie door idealistische en anti-positivistische opvattingen gestimuleerd. Eerder is het tegendeel het geval, zoals ook door de analyse van de nieuwe cultuurgeschiedschrijving duidelijk zal worden.

Het gebrek aan aandacht voor de psychologische ideeën van de Duitse historiografische vernieuwers van 1900 heeft ongetwijfeld te maken met de manier waarop hun historisch werk sinds de studie van Oestreich veelal werd opgevat: als pogingen om een sociale geschiedschrijving van de grond te krijgen, waarin het vooral erom ging 'sociaal-economische vraagstukken in het verleden sterker te onderzoeken' (zoals Oestreich meende). ${ }^{38}$ Vanuit dit perspectief trokken de psychologische opvattingen van de vernieuwers weinig belangstelling. En voor zover deze opvattingen aandacht kregen, werden ze vaak beschouwd als merkwaardige irrationele aspecten van een voor het overige niet onredelijk alternatief voor de traditionele politieke geschiedschrijving. ${ }^{39}$

Dergelijke opvattingen werden vooral verdedigd door marxisten en voorstanders van een kritische historische Sozialwissenschaft, die lange tijd het beeld van de Duitse historiografie rond 1900 hebben weten te domineren. Net als Oestreich zagen deze historici de opkomst van de nieuwe geschiedenis als een direct uitvloeisel van de maatschappelijke veranderingen in het kielzog van de industrialisering. ${ }^{40}$ Daarbij paarden zij sympathie voor de vernieuwingsgezinde historici aan een kritische beoordeling van wat zij uiteindelijk tot stand brachten.

Marxistische historici beschouwden de nieuwe geschiedenis als een uitvloeisel van een onontkoombare 'crisis' in de bestaande politieke geschiedschrijving: de ontwikkeling naar een industriële massasamenleving vereiste 'nu eenmaal' een vorm van geschiedschrijving, waaraan de oude historistische geschiedbeoefening, daterend uit een

${ }^{35}$ Hughes (1977), 66, zie ook 35, 63-64. Er is mij verder één (ouder en beperkt) onderzoek bekend waarin de psychologische opvattingen van een aantal Duitse geschiedtheoretici worden beschreven: Hitz (1950). Het artikel van Manuel (1971) bevat een schetsmatig overzicht van wetenschappers die geschiedenis en psychologie probeerden te combineren, van Vico tot Mandrou en Erikson. Uit het Keizerrijk wordt alleen Dilthey besproken.

${ }^{36}$ Voor Croce en Meinecke, zie hierna, Hoofdstuk 5.

${ }^{37}$ Dezelfde redenering is bijv. bij Romein (1967), II, 157 aan te treffen als hij over Lamprecht schrijft: 'Begonnen als positivist, eindigt hij als psychologist'. In feite was Lamprecht juist als positivist een psychologist.

${ }_{38}$ Oestreich (1969), 323. Zie ook hierna, Hoofdstuk 3.

${ }^{39}$ Zo o.a. bij veel marxistisch georiënteerde historici, die daarin een betreurenswaardige afwending van zijn materialistische opvattingen zagen. '[S] eine Anschauungen [wurden] allmählich immer irrationaler', vatte Viikari (1977), 454, dit oordeel samen. Zie ook Schleier (1983), 119.

${ }^{40}$ Oestreich (1969), 323. 
ouder tijdperk, niet langer beantwoordde. ${ }^{41}$ In Nederland viel een dergelijke visie al in Jan Romeins studie Op het breukvlak van twee eeuwen (1967) te bespeuren. Hij schreef de 'omslag in het historisch denken van die tijd' toe 'aan die tijd zelf, waarin massale bewegingen en onpersoonlijke machten klaarblijkelijk een zo overweldigende rol begonnen te spelen'. ${ }^{42}$ Vanuit orthodox marxistisch zicht was de nieuwe cultuurgeschiedschrijving een burgerlijke - en daarmee halfslachtige - poging tot aanpassing aan de veranderde sociaal-economische werkelijkheid. Het mislukken van deze poging was inherent aan het onvermogen van elke burgerlijke geschiedschrijving, zowel in Duitsland als elders, om de nieuwe realiteit van het industriële kapitalisme en de massale opkomst van het proletariaat op waarde te schatten. ${ }^{43}$

Vanuit de kritische Historische Sozialwissenschaft die in de jaren zeventig in Duitsland doorzette, lagen de accenten iets (maar niet helemaal) anders. Terwijl orthodoxe marxisten de nieuwe geschiedschrijving als een internationaal verschijnsel beschouwden, lag voor de kritische historici de nadruk op de Duitse Sonderweg, ook in dit historiografische opzicht. Invloedrijk was in dit opzicht vooral de interpretatie van Georg Iggers in zijn studie Deutsche Geschichtswissenschaft (1971, oorspronkelijke Amerikaanse uitgave 1968). Iggers sprak uitdrukkelijk van een 'scheiding van het Duitse historische denken van de hoofdstromingen van het Europese denken', die pas na de Tweede Wereldoorlog langzaam werd opgeheven. Toen pas, aldus Iggers, was er voor het eerst een groter aantal historici bezig met de problemen van de technische massasamenleving, die probeerden de historische methoden in overeenstemming met die van politicologen en sociologen te brengen. ${ }^{44}$

Kritische historici hadden de neiging de 'niet-moderne' kenmerken van de mainstream Duitse geschiedwetenschap te overdrijven en tegelijk de betekenis van de vernieuwers te minimaliseren. De veronderstelde geïsoleerdheid en ondergang van de nieuwe geschiedschrijving pasten in een visie op het Keizerrijk waarin de 'westerse' moderniteit zich niet had weten door te zetten. ${ }^{45}$ Enerzijds trokken de historiografische vernieuwers aandacht als de progressieve uitzonderingen die de regel van de achterlijke Duitse politiek en cultuur rond 1900 bevestigden. ${ }^{46}$ Anderzijds lag de nadruk uiteindelijk op het falen van deze vernieuwers, zowel door de mate waarin hun eigen opvattingen beïnvloed waren door 'typisch Duitse' manieren van denken, als door het uitzonderlijke verzet dat zij binnen de Duitse historische discipline ontmoetten. Dit verzet werd geduid als een teken van de kracht van de autoritaire, 'half-feodale' maatschappijstructuren in het Keizerrijk.

In een disciplinehistorische variant van deze interpretatie werd de relatief vroege vorming van de Duitse historische universitaire discipline rond het midden van de

\footnotetext{
${ }^{41}$ Bijv. Viikari (1977), 454: 'Lamprechts Aufstieg beruht darauf, dass die Wirtschafts- und Sozialgeschichte mit der Entwicklung des Kapitalismus und der neuen Gesellschaftsklassen [...] fast eine Naturnotwendigkeit wurde.' Andere marxistische interpretaties zijn o.a. te vinden bij de DDR-historici Engelberg (1959) en Schleier (1983).

${ }^{42}$ Romein (1967), II, 158.

${ }^{43}$ Zo bijv. Schleier (1983), 78.

${ }^{44}$ Iggers (1971), 41-42. Opmerkelijk is dat Iggers in dit beeldbepalende boek, in de beide uitvoerige hoofdstukken over de discussies rond 1900 (163-294) vrijwel geen vakhistorici bespreekt: zijn hoofdpersonen zijn Cohen, Dilthey, Windelband, Rickert, Weber, Troeltsch - en uiteindelijk dan toch nog een historicus: Meinecke.

${ }^{45}$ Vgl. daarentegen de aandacht voor de 'Bedeutung der vielen Gegentendenzen' in de geschiedwetenschap in het werk van de belangrijkste tegenhanger van de kritische Gesellschaftsgeschichte: Nipperdey (1990-1992), I, 641 e.v.

${ }^{46}$ Niet toevallig nam Hans-Ulrich Wehler, de voorman van de kritische geschiedschrijving, studies over Lamprecht, Gothein en Breysig op in de reeks Deutsche Historiker die in de jaren zeventig en tachtig verscheen.
} 
negentiende eeuw als verklaring aangedragen voor het verzet dat de latere vernieuwers ontmoetten. In Duitsland was de professionalisering van de geschiedwetenschap volgens deze visie rond 1865 afgesloten, dit wil zeggen op een moment dat datzelfde proces in Frankrijk en de VS nog moest beginnen. Als gevolg daarvan speelden in de vakhistorische normen de 'vorindustriellen Prägungen ihrer sozialen Trägergruppen und konservativ-romantische Erbschaften' een belangrijke rol. ${ }^{47}$ De vakhistorische tegenstanders van de nieuwe geschiedenis waren voorstanders van 'überkommene Traditionen' die werden getekend door een 'Bedrohungssyndrom' tegenover actuele ontwikkelingen in wetenschap en cultuur.

Gepaard met zowel de marxistische als de kritische interpretatie ging vaak een politieke positionering van de nieuwe historici als (relatief) 'progressief' ${ }^{48}$ Zoals Lutz Raphael heeft opgemerkt: 'De jongere kritische historiografiegeschiedschrijving veronderstelde [...] graag overeenkomsten tussen politiek correcte, dat wil zeggen liberale, democratische, of tenminste gematigde posities en professionele innovatieve prestaties'. ${ }^{49}$ Voor een deel gingen deze oordelen overigens terug op de tijd van de vernieuwers zelf, toen zij door tegenstanders werden geassocieerd met democratische of sociaaldemocratische tendensen. ${ }^{50}$ En ook later werden met name de opvattingen van Lamprecht vaak getypeerd als representatief voor het 'liberale' verzet tegen Bismarck van de kleine of juist de gegoede burgerij. ${ }^{51}$

Al met al wordt de studie van de Duitse geschiedwetenschap, inclusief de vernieuwingsbewegingen daarbinnen, gedomineerd door een sterke contextualistische interpretatie, waarin een (dikwijls vooropgestelde) visie op de Duitse politieke en maatschappelijke ontwikkeling de beslissende verklaring levert voor ontwikkelingen in de geschiedwetenschap.

Uit een begrijpelijke onvrede over de dwingende interpretatiekaders en het reductionisme van de Sonderweg-historiografie zijn er de laatste jaren door Lutz Raphael en Stefan Haas alternatieve verklaringen voor de opkomst van de nieuwe geschiedenis gepresenteerd. ${ }^{52}$ Beide auteurs merken op dat in de literatuur weliswaar vaak een directe relatie tussen historiografische en maatschappelijke veranderingen werd gelegd, maar dat niet werd aangetoond hoe de veranderingen in de leefwereld hun weerslag zouden hebben gevonden in het werk van de historici. ${ }^{53}$ Volgens Raphael valt er bovendien helemaal geen eenduidige samenhang tussen politieke en vakweten-

${ }^{47}$ Aldus Raphael (1990), 343; vgl. ook Iggers (1984), 22. Een van de elementairste impulsen van de Lamprechtstrijd noemt Raphael 'die Sicherung einer rückwärtsgewandten kulturellen und sozialen Identität der historischen Gelehrten’ (a.w., 360).

${ }^{48}$ Van de weeromstuit kwamen sommige onderzoekers tot de ontdekking dat het hier wel degelijk om (bijvoorbeeld) nationalistisch of zelfs imperialistisch denkende wetenschappers ging, zie bijv. Steinle (1995) en al veel eerder Hoffmeister (1956).

${ }^{49}$ Raphael (1997), 75.

${ }^{50}$ Zie hierna Hoofdstuk 2.

${ }^{51}$ In het Interbellum typeerde een rechtse vertegenwoordiger van de Sonderweg-these, Westphal (1930), 193, Lamprecht als een 'tegenstander van Bismarck' en als de 'Geschichtsphilosoph und Massenpsychologe des sozial optimistischen, wissenschaftlich fortschrittlichen, seelisch exakten Unternehmertums westlicher Prägung'. Deze ideologische duiding van de nieuwe geschiedenis - maar dan met een positief voorteken - werd in 1959 vrijwel exact gereproduceerd door de DDR-historicus Ernst Engelberg. Hij meende dat de cultuurgeschiedenis ten diepste voortkwam uit de oppositie van de (kleine) bürgerij tegen de (economische) politiek van Bismarck, zie Engelberg (1959), 25 e.v. Ook Metz (1984), 11 en Metz (1982), 99 ten slotte meende dat Lamprechts geschiedvisie vooral de belangen van een 'progressief, industrieel liberalisme' zou hebben aangesproken.

${ }_{52}$ Raphael (1997) lijkt daarmee enigszins afstand te nemen van Raphael (1990).

${ }^{53}$ Raphael (1997), 81n6; Haas (1994), 11. 
schappelijke posities vast te stellen. ${ }^{54}$ Volgens hem moet de opkomst van de nieuwe cultuurgeschiedenis niet zozeer als een cultureel bepaalde paradigmawisseling worden gezien, maar als een uiting van de verdergaande specialisering, diversificatie en pluralisering van het wetenschappelijk onderzoek in de loop van het moderniseringsproces. Ook Haas ziet meer in een internalistische wetenschapshistorische benadering, waarbij hij de opkomst van de nieuwe cultuurgeschiedenis in de eerste plaats interpreteert als een intellectueel antwoord op een intellectueel probleem: de overbrugging van de kloof tussen materialisme en idealisme. Vanuit dat standpunt besteedde hij overigens meer dan enig ander auteur aandacht aan het psychologische aspect van de historische Kulturforschung tussen 1880 en 1930.

De voorliggende studie is niet voortgekomen uit een preoccupatie met de Duitse Sonderweg, noch uit een behoefte aan een 'herbronning' van de eigentijdse geschiedbeoefening, zoals die bij Haas valt te bespeuren. De drijfveer achter dit onderzoek is de interesse in de herkomst en de verbreiding van mentaliteitshistorische benaderingen in de geschiedwetenschap. Het startpunt is hier niet de politiek en samenleving van het wilhelminische Keizerrijk, maar het historisch-psychologisch gedachtegoed van de belangrijkste cultuurhistorici in deze periode.

Dat wil overigens niet zeggen dat de politieke en maatschappelijke context van het Keizerrijk ontbreekt in deze historiografische studie. Anders dan Raphael en Haas suggereren, zullen politieke en algemene sociaal-culturele factoren wel degelijk relevant blijken om de opkomst van de nieuwe cultuurgeschiedenis in Duitsland te begrijpen. Het uitgesproken hodiecentrisme van de nieuwe cultuurhistorici zelf en hun uitgebreide historische analyses van de eigen tijd laten weinig twijfel over de vraag of een dergelijke politieke en cultuurhistorische interpretatie gerechtigd is. Alleen staat zij niet aan het begin, maar aan het eind van dit onderzoek - letterlijk: aan het eind van dit boek, en figuurlijk: als sluitstuk van de gepresenteerde historische analyse.

Om het anders te zeggen: in deze studie is de blik op de Duitse geschiedwetenschap rond 1900 niet 'van buiten naar binnen' gericht, maar 'van binnen naar buiten'. Het begin ligt bij een intellectuele conceptie, een idee dat zelf opvallend vaak een politieke connotatie heeft gekregen: de idee van de veranderlijkheid van de menselijke psyche.

\section{De geschiedenis en politiek van een idee: de veranderlijke psyche}

Het is een kerngedachte in deze studie dat de opkomst van de nieuwe Duitse cultuurgeschiedschrijving na 1890, net als de opkomst van de Franse mentaliteitsgeschiedenis, gezien kan worden als een onderdeel van de sinds de achttiende eeuw door steeds meer intellectuelen gedeelde overtuiging dat individuen beslissend gevormd worden door hun omgeving, dat wil zeggen dat zij over een plooibare psyche beschikken en dat hun waarneming, gevoelens en gedrag 'maakbaar' of althans veranderlijk zijn onder druk van buitenaf. Vanaf het moment dat deze overtuiging post vatte, drong zich al snel de gedachte op dat de psychologie niet alleen een sociale, maar ook een historische dimensie diende te hebben.

Er zijn aanwijzingen dat juist rond 1900 steeds meer wetenschappers deze historische dimensie bij de bestudering van de menselijke psyche probeerden aan te brengen. Neem bijvoorbeeld de getuigenis van de vooraanstaande Duits-Amerikaanse

${ }^{54}$ Raphael (1997), 75. 
experimenteel-psycholoog Hugo Münsterberg uit 1898. Hij bespeurde in de wetenschap van zijn tijd een (door hem betreurde) neiging tot 'onderschikking van de psychologie aan de historische visie op de mens', een tendens die onvermijdelijk zou leiden tot een 'ondermijning van de psychologie door middel van de geschiedenis' en uiteindelijk tot de 'ondergang van de ware psychologie'. Hij vond deze tendens zo bedreigend dat hij zijn voorzitterschap van de jaarvergadering van de American Psychological Association in 1898 aangreep om de verzamelde collega's uitvoerig te waarschuwen tegen deze 'gevaarlijke' ontwikkeling, die van Europa naar Amerika dreigde over te slaan. ${ }^{55}$

En inderdaad, Münsterberg lijkt rond 1900 een wetenschappelijke trend op het spoor te zijn gekomen die sindsdien niet meer is verdwenen van het academische toneel. In de loop van de twintigste eeuw zijn zowel in Europa als in de Verenigde Staten vele varianten van de door hem zo verfoeide 'geesteswetenschappelijke' en 'historische psychologie' tot ontwikkeling gekomen (al is zijn 'ware', experimentele psychologie daardoor geenszins ten onder gegaan).

We kunnen bijvoorbeeld voor de jaren dertig denken aan Sprangers 'geesteswetenschappelijke psychologie' (waarin hij aandacht vroeg voor 'historische Menschentypen') en aan de Sovjet-Russische psychologische 'cultuurhistorische school' (Vygotskij, Lurija), voor de jaren vijftig aan de historische analyse van psychologische functies door de Franse psycholoog Ignace Meyerson en aan J.H. van den Bergs fenomenologisch georiënteerde 'metabletica', voor de jaren tachtig aan het sociaal-constructivisme van de Amerikaanse psycholoog Kenneth Gergen ('social psychology as history'). Ook de 'kritische psychologie' van de jaren zeventig en later werd gedragen door de gedachte dat 'het psychische' een maatschappelijke en historische constructie is en dus als zodanig bestudeerd moet worden.

Historisch-psychologische theorieën werden niet alleen vanuit de universitaire psychologie ontwikkeld, maar ook vanuit de (andere) sociale wetenschappen en de filosofie. In de culturele antropologie verkondigde de invloedrijke Amerikaanse 'culture and personality' school vanaf de jaren dertig de grote invloed van de heersende cultuur op bepaalde persoonlijkheidskenmerken. ${ }^{56}$ In sociologische kring is de 'sociogenetische en psychogenetische' civilisatietheorie van Norbert Elias bekend geworden, terwijl Foucaults thesen over het historische karakter van (de discoursen over) waanzin en seksualiteit op een gegeven moment onder westerse academici brede bekendheid verwierven.

In vrijwel alle gevallen werden deze opvattingen ook gerecipieerd door historici, zoals omgekeerd het werk van historici met een belangstelling voor de plooibare psyche weerklank vond bij psychologen met een historische belangstelling: van een gescheiden ontwikkeling van de vakgebieden is juist hier geen sprake. Om slechts het voorbeeld van Lucien Febvre te noemen: hij verdedigde samen met de filosoof Henri Berr in 1932 de stelling dat 'beslissende vooruitgang van de geschiedwetenschap' alleen mogelijk was door vorderingen in de 'collectieve psychologie'. En hij legitimeerde zijn eerste programmatische mentaliteitshistorische stellingname meer concreet met verwijzingen naar de opvattingen van de collectief-psycholoog Charles Blondel. ${ }^{57}$ Omgekeerd waren

\footnotetext{
${ }^{55}$ Zie Münsterberg (1899) en over deze rede: Stoffers (2003).

${ }^{56}$ De veelal psychoanalytisch georiënteerde 'culture and personality' school, zou men als de collectieve en culturele variant van de freudiaanse psychohistory kunnen beschouwen, waarin de psychoanalyse van historische figuren centraal staat.

${ }^{57}$ Zie Febvre en Berr (1932), 365 en Febvre (1992), 213-214. Febvre haalde zijn Straatsburgse collega Charles Blondel aan over het eigen 'mentale systeem' van elke in tijd en ruimte afgebakende groep mensen en over de 'mentaliteitsverschillen' tussen groepen die in ruimte of tijd van elkaar verwijderd zijn. Blondel schreef behalve de vaak herdrukte Introduction à la psychologie collective (1928), waaruit Febvre citeerde, ook La mentalité primitive (Parijs 1926), dat vrijwel geheel op het werk
} 
bijvoorbeeld de uitgewerkte ideeën uit 1960 van de Roemeens-Britse socioloog Zevedei Barbu over de mogelijkheden van een 'historical psychology' weer (mede) geïnspireerd door het werk van Febvre. ${ }^{58}$

Wanneer we vanaf de wending van de negentiende naar de twintigste eeuw de toekomst 'inkijken' dan kan het lijken of Lamprecht en andere Duitse cultuurhistorici rond 1900 aan de wieg stonden van dergelijke twintigste-eeuwse initiatieven om een historische psychologie te ontwikkelen. Dat is echter net zo weinig terecht als dat aan Febvre en Bloch deze positie toekomt. In feite stond de idee van de 'malleability of man' op dat moment immers al meer dan honderd jaar ter discussie binnen een divers gezelschap van filosofen, biologen, antropologen, historici, taalkundigen, economen, sociologen, geografen, pedagogen en al wie zich nog meer op het terrein van de wetenschap van de mens bewoog. Zoals in deze studie nog aan de orde zal komen, was het een van de grote ideeën die de negentiende eeuw ontleende aan Verlichtingsdenkers en die valt aan te treffen in het gedachtegoed van onder anderen Comte, Mill, Marx, Spencer en Wundt. ${ }^{59}$

Het debat over dit vraagstuk werd dringend sinds de gedachte van een van God gegeven, persoonlijk verantwoordelijke 'ziel' in de zeventiende en achttiende eeuw zijn overtuigingskracht voor steeds meer intellectuelen begon te verliezen. De verschillen in gedragingen tussen mensen werden niet langer afdoende verklaard door de veronderstelling van een meer of minder rijkelijke bedeling met de goddelijke genade. Naarmate het gelijkheidsbeginsel terrein won, verloren bovendien juridisch afgedwongen (en gelegitimeerde) verschillen in gedrag aan betekenis. Tegelijk riepen de steeds intenser wordende koloniale confrontaties met 'vreemde' collectieve gedragingen in andere werelddelen om een wetenschappelijke verklaring.

Sindsdien wordt een reeks lastige vragen bij herhaling door wetenschappers gesteld. Kunnen verschillen tussen menselijke gedragingen worden herleid tot variërende erfelijkheidsfactoren en aangeboren fysieke constituties? Zo nee, wat is dan de rol van invloeden 'van buitenaf', zowel van fysische aard (klimaat en voeding bijvoorbeeld), als van sociale aard (opvoeding, onderwijs, sociaal milieu)? En vooral: hoe 'diep' reiken deze externe invloeden? Gaat het daarbij alleen om 'bewustzijnsinhouden' (bijvoorbeeld opinies, overtuigingen, moraal) of worden ook onbewuste manieren van waarnemen, denken, voelen en willen bepaald door omgevingsfactoren? Om het abstracter te zeggen: waar ligt bij een individu uiteindelijk de grens tussen natuur en cultuur?

Het is niet voor niets precies op deze grens dat het begrip 'mentaliteit' zijn specifieke inhoud en afbakening heeft gekregen. Volgens een vaak aangehaalde omschrijving uit 1932, afkomstig van de Duitse socioloog Theodor Geiger, ontleende het begrip 'mentaliteit' zijn scherpte aan het contrast met 'ideologie'. Bij 'ideologie' ging het om ideeën en opvattingen. 'Mentaliteit' daarentegen was een begrip uit de 'sociale karakterologie' dat duidde op de geistig-seelische Disposition: de 'directe vorming van de mens door zijn sociale leefwereld'. 'Mentaliteit is huid - ideologie kleding', zoals Geiger het verschil typeerde. ${ }^{60}$ Een hedendaags psycholoog heeft

\footnotetext{
van Lévy-Bruhl was gebaseerd. Andere directe connecties tussen (historisch) psychologen en (mentaliteits)historici zijn bijv. die van de Russische mentaliteitshistoricus A. J. Gurevic met de school van Vygotskij (zie: Métraux (1993)), en tussen Ignace Meyerson en de oud-historicus J.-P. Vernant.

${ }^{58}$ Zie Barbu (1960), o.a. 8. Over Barbu, zie de bijdrage van Castedello in: Jüttemann (1988), 174179.

${ }^{59}$ Zie hierna hoofdstuk 5, paragraaf 7 en hoofdstuk 6, m.n. paragraaf 2.

${ }^{60}$ Zie Geiger (1932), 77-78. Vgl. voor Frankrijk: Raulff (1989), 65.
} 
'mentaliteit' in andere woorden met dezelfde strekking aangeduid als culture interiorisée: een tot tweede natuur geworden cultuur. ${ }^{61}$

Het wetenschappelijke debat over de grens van natuur en cultuur 'in' het individu, gaf (en geeft) aanleiding tot een tweede reeks vragen van meer levensbeschouwelijke aard. Zijn gedragsverschillen tussen mensen überhaupt een kwestie van onderscheiden determinanten? Zijn verschillen niet veeleer terug te voeren tot individuele keuzes voor bepaalde normen en waarden, keuzes voor bepaalde idealen die inderdaad tot een specifieke manier van kijken en waarderen leiden, maar die op elk moment ook weer heroverwogen kunnen worden? Is het niet in strijd met een besef van persoonlijke vrijheid en individuele verantwoordelijkheid om de verschillen tussen menselijke gedragingen terug te voeren tot gegevenheden van fysieke of sociale aard? Kan de menselijke individualiteit en persoonlijkheid eigenlijk wel tot op de bodem wetenschappelijk geanalyseerd worden?

Het debat over deze vragen, die ook een rol speelden in de strijd over de nieuwe Duitse cultuurgeschiedenis, is nog lang niet uitgewoed. Dat komt omdat zij, ook in tijden van gentechnologie en DNA-analyses, nog niet eenduidig zijn beantwoord en ten dele ook niet eenduidig te beantwoorden zijn. Dat heeft de verspreiding van het debat over de veranderlijkheid van de mens echter niet in de weg gestaan. Zoals blijkt uit de bestaande literatuur over dit debat, is er sinds de achttiende eeuw een groot aantal auteurs geweest, uit een breed spectrum aan wetenschappelijke disciplines, dat zich met het vraagstuk van de veranderlijke psyche heeft beziggehouden. ${ }^{62}$ Deze literatuur maakt overigens ook duidelijk dat de geschiedenis van dit vraagstuk nog veel onontgonnen of half ontgonnen terreinen en weinig algemeen aanvaarde hoofdlijnen kent. Dat heeft ongetwijfeld te maken met de 'verdunning' van het debat over veel verschillende disciplines en wetenschappers. ${ }^{63}$ Vaak lastig te handhaven algemene indelingen, bijvoorbeeld in positivistische en idealistische denktradities (Jahoda), of in 'geneticistische', 'organicistische' en 'progressivistische' varianten (Mandelbaum) hebben vooralsnog weinig helderheid geschapen, maar maken wel duidelijk dat er in de negentiende eeuw een grote variatie aan standpunten over dit onderwerp bestond.

Ook bij deze onvolkomen stand van onderzoek springt bovendien één aspect van de geschiedenis van de idee van de veranderlijke mens in het oog: de opvallende aanwezigheid van uitgesproken politieke opvattingen bij wetenschappers die zich met dit thema hebben beziggehouden. ${ }^{64}$ Zonder twijfel behoren bijvoorbeeld progressieve ideologieën als het liberalisme, het marxisme en het feminisme tot de krachtigste inspiratiebronnen van het onderzoek naar het historisch karakter van psychische kenmerken. ${ }^{65}$ Zo spelen een aantal (proto)liberale denkers, van Locke tot John Stuart

${ }^{61}$ Zie Mucchielli (1985), 7.

${ }^{62}$ De voornaamste overzichtsliteratuur over dit thema: Passmore (1965), Mandelbaum (1974), m.n. 141-269, Jüttemann (1988) en Jahoda (1992). Meer recente historisch-psychologische theorieën worden besproken bij Fortmann (1979), Peeters (1978) en Peeters (1994).

${ }^{63}$ Zie Stoffers (1996a). Daar komt nog bij dat veel van de auteurs die zich met de geschiedenis van deze opvattingen hebben beziggehouden geen historici maar psychologen zijn, die meer bezig met een zoektocht naar een historische legitimatie of inspiratiebronnen in het verleden voor hun eigentijdse standpunten, dan met een historische analyse.

${ }^{64}$ Dit verband is voor het nature-nurture debat in het algemeen al eens empirisch onderzocht: bij een onderzoek uit 1949 onder vierentwintig Amerikaanse en Engelse psychologen, biologen, genetici en sociologen uit de periode 1900-1940 werd geconstateerd dat de wetenschappers met uitgesproken liberale of radicaal hervormingsgezinde politieke opvattingen vrijwel zonder uitzondering omgevingsfactoren benadrukten boven genetische factoren, terwijl dat voor de meeste politiek conservatieve wetenschappers precies omgekeerd lag. Zie Pastore (1949).

${ }^{65}$ In dit verband lijkt het meer dan toevallig dat de Nederlandse hoogleraar historische psychologie Harry Peeters zijn bijnaam 'Meneer Toekomst' met ere draagt, zie Hutschemaekers en Winter (1996). 
Mill en Herbert Spencer, met hun sterke nadruk op de opvoeding van individuen een belangrijke rol in de vroege geschiedenis van deze conceptie. Het marxisme is, nog los van allerlei indirecte invloeden, van fundamentele betekenis geweest bij de vorming van minstens twee twintigste-eeuwse psychologische scholen die het historisch karakter van psychische functies tot uitgangspunt namen. Zowel voor de gerenommeerde SovjetRussische cultuurhistorische school van Leontjev, Vygotskij en Lurija en de 'kritische psychologie' uit de jaren zeventig en later behoorde een belangrijk deel van onze psychische huishouding tot de 'bovenbouw' die door de maatschappelijke 'onderbouw' werd gedetermineerd. ${ }^{66}$ Het feminisme, tenslotte, heeft onder andere met historische argumenten de strijd aangebonden tegen de veronderstelde 'natuurlijkheid' van de (psychische) man-vrouw verschillen, om te laten zien dat het hier om culturele en daarmee veranderlijke en maakbare kenmerken ging.

Er dient echter een aantal kanttekeningen geplaatst te worden bij deze observatie. Dat bepaalde politieke standpunten het aantrekkelijk maken te denken in termen van de 'maakbare' mens, betekent niet dat een wetenschapper die overtuigd is van de historiciteit van de menselijke psyche ook noodzakelijkerwijs diezelfde politieke opvattingen koestert. Bovendien blijkt het feitelijk niet terecht historisch-psychologisch denken uitsluitend met progressieve politieke opvattingen te verbinden. Zo dient bijvoorbeeld de bekende historische psychologie van 'metableticus' J.H. van den Berg een uitgesproken maatschappijkritische boodschap, die eerder als anti-modern en 'reactionair' dan als progressief geduid kan worden. ${ }^{67}$ En terwijl, om een ander voorbeeld te noemen, de beide Annales-oprichters meer of minder radicale linksrepublikeinse opvattingen koesterden, konden latere mentaliteitshistorici, zoals Frijhoff heeft opgemerkt, even goed marxistisch georiënteerd zijn (Mandrou), als conservatief (Ariès). ${ }^{68}$

De geschiedenis van de idee van de veranderlijke psyche nodigt hoe dan ook uit tot nader onderzoek, zowel om beter zicht te krijgen op de verschillende ontwikkelingslijnen als om de manier waarop deze gedachte politieke relevantie heeft gekregen, beter in kaart te brengen. Het zijn kwesties die in deze studie aan de orde gesteld zullen worden voor de historisch-psychologische opvattingen van de Duitse cultuurhistorici rond 1900.

\section{Opbouw en afbakening van het onderzoek}

In de voorgaande paragrafen zijn de aanzetten tot het voorliggende onderzoek geschetst: de geringe aandacht in de literatuur voor de langere en internationale, intellectuele voorgeschiedenis van de histoire des mentalités, het weinige onderzoek naar de herkomst, verspreiding en betekenis van historisch-psychologische opvattingen binnen de Duitse historiografische vernieuwingsbeweging rond 1900, daarmee verbonden de behoefte aan een nuancering van de stereotype beeldvorming over de Duitse (cultuur)-

\footnotetext{
${ }^{66}$ Volgens de belangrijkste vertegenwoordiger van de cultuurhistorische school, Lurija (1971), 269, was 'het slechts nodig [...] dat de sociaalhistorische voorwaarden veranderen om [de cognitieve processen van mensen in minder complexe sociaalhistorische omstandigheden] te veranderen en te laten verdwijnen'. Dit inzicht werd door Lurija c.s. getoetst en juist bevonden tijdens de gedwongen collectivisatie in de jaren dertig. De belangrijkste theoreticus van de 'kritische psychologie', Klaus Holzkamp schreef o.a. een studie over de geschiedenis van de waarneming. Zie de bijdrage van Morus Markard in Jüttemann (1988), 430-439.

${ }^{67}$ Zie over Van den Berg: Zwart (2002), m.n. 24-25, 29, en 182-192.

${ }^{68}$ Zie Frijhoff (1982), 35, 41-42, en voor de vroege Annales: Raphael (1990) en Raphael (1992).
} 
geschiedschrijving, en tenslotte de behoefte aan een beter inzicht in de geschiedenis en politiek van de idee van de veranderlijke psyche.

Om op deze punten een bijdrage te leveren aan de literatuur worden in deze studie de intellectuele tradities en de historische context onderzocht die maakten dat het thema van de plooibare psyche na 1890 op de agenda van de Duitse geschiedwetenschap verscheen. Waaraan ontleende de thematiek van de plooibare psyche juist rond 1900 zijn actuele relevantie voor een aantal Duitse historici? En op welke intellectuele tradities grepen zij daarbij aanwijsbaar terug? Dat zijn de beide vragen die dit onderzoek hebben geleid.

Het onderzoek concentreert zich, als gezegd, op de historisch-psychologische opvattingen van vijf cultuurhistorici uit het Duitse Keizerrijk in de periode 1889-1915: Eberhard Gothein, Karl Lamprecht, Georg Steinhausen, Kurt Breysig en Walter Goetz. Kulturgeschichte bleek in de loop van het voorliggende onderzoek het contemporaine en lokale signaalwoord te zijn waaronder historisch onderzoek naar de veranderlijkheid van de mens in deze periode schuilging, zoals elders en later 'mentaliteitsgeschiedenis' of 'historische antropologie' dergelijke signaalwoorden werden.

De keuze voor de genoemde vijf cultuurhistorici rond 1900 betekent niet dat er geen andere Duitse historici met verwante opvattingen te noemen zouden zijn. Een aantal daarvan zal overigens ook ter sprake komen in dit onderzoek. Zoals de methodoloog Ernst Bernheim, die weerklank vond bij de cultuurhistorici met zijn uitgesproken waardering voor de Völkerpsychologie, of de Jenaer hoogleraar Ottokar Lorenz, die met zijn voorstellen voor een 'wetenschappelijke genealogie' een eigen vorm van historische psychologie formuleerde. Maar de vijf hoofdpersonen van deze studie onderscheidden zich in de decennia na 1890 van hun collega's doordat zij hun historisch-psychologische opvattingen inbedden in programmatisch uitgewerkte opvattingen over (en hun activisme ten gunste van) de cultuurgeschiedschrijving. Zij wierpen zich in de decennia rond 1900 uitdrukkelijk op als voorstanders van een hervorming van de geschiedwetenschap tot een nieuwe, academische vorm van cultuurgeschiedschrijving.

$\mathrm{Zij}$ deden dat overigens nooit als groep. Onderlinge meningsverschillen tussen de cultuurhistorici zullen in deze studie regelmatig de aandacht opeisen. Maar tegelijk zal duidelijk worden dat zij niet alleen fundamentele opvattingen over historisch onderzoek deelden, maar ook belangrijke contacten, docenten en inspiratiebronnen. Naast onmiskenbare verschillen, bestonden er soms veel overeenkomsten, zelfs tussen op het eerste gezicht zulke verschillende figuren als de anti-rankeaan Karl Lamprecht en de wel voor 'neorankeaan' versleten Walter Goetz.

De periode 1889-1915 was de tijd waarin de vijf hoofdpersonen hun activiteiten als professionele historici ten volle ontplooiden en de door hen aangezwengelde strijd over de cultuurgeschiedenis intensief werd gevoerd. 1889 is daarbij een onontkoombaar beginpunt, vooral vanwege de publicatie in dat jaar van Gotheins pleidooi voor de cultuurgeschiedenis: het was het startsein voor een meer dan twee decennia durende felle discussie binnen de historische discipline over het arbeidsterrein van de geschiedwetenschap. Voortgezet werd de discussie in eerste instantie vooral door Steinhausen, die in 1893 de Zeitschrift für Kulturgeschichte oprichtte, bedoeld als forum voor de nieuwe richting. Opnieuw tot grote intensiteit opgestookt werd de controverse vervolgens door het optreden van Lamprecht, die vanaf 1896 talloze theoretische beschouwingen over de cultuurgeschiedenis het licht liet zien. In 1900 volgde de publicatie van Breysigs Kulturgeschichte der Neuzeit, waarvan het eerste deel een uitgebreide uiteenzetting van zijn geschiedtheorie bevatte. En in 1910 leverde Walter Goetz, na zijn toetreding tot de redactie van Steinhausens inmiddels omgedoopte Archiv 
für Kulturgeschichte een voorlopig laatste bijdrage aan het debat, met een theoretische stellingname waarin hij de 'oude' en de 'nieuwe' richting met elkaar probeerde te verzoenen.

De keuze voor 1915 als eindgrens van het onderzoek is ten dele ingegeven door het overlijden in dat jaar van de belangrijkste van de vijf hoofdpersonen, Karl Lamprecht. Belangrijker is dat na de Eerste Wereldoorlog niet alleen een nieuwe generatie historici aantrad, maar ook de context waarin Duitse geschiedschrijvers zich bewogen sterk veranderde ten opzichte van de periode voor de Wereldoorlog. Derhalve zal maar in beperkte mate over de grens van 1915 'heengekeken' worden en dan vooral wanneer het werk van de cultuurhistorici van na die datum licht kan werpen op hun eerder geformuleerde opvattingen. Aan het begin van de onderzoeksperiode wordt de grens minder hard gehanteerd. Regelmatig zal worden teruggegrepen op het tijdvak vóór 1889 , vooral om duidelijk te maken in welke tradities de cultuurhistorici waren opgeleid en door welke oudere opvattingen zij waren gevormd.

Het is misschien goed om op te merken dat in deze studie geen poging wordt gedaan om de verspreiding van de gedachte van de veranderlijke psyche binnen de Duitse geesteswetenschappen, laat staan binnen de Duitse cultuur rond 1900, in kaart te brengen. Het boek is uitdrukkelijk geconcentreerd op de discussies binnen Duitse geschiedwetenschap. ${ }^{69}$ Aan niet-wetenschappers, niet-Duitse of niet als historicus opgeleide wetenschappers - psychologen, economen, artsen bijvoorbeeld - wordt slechts dan aandacht gegeven als zij het werk van de genoemde vijf historici direct of indirect blijken te hebben beïnvloed.

Voor de geschiedenis van de idee van de veranderlijke psyche is dat een serieuze, maar praktisch noodzakelijke beperking. Want er zijn genoeg aanwijzingen dat het om een in intellectuele kringen rond 1900 wijder verspreide gedachte ging. Ze speelde bijvoorbeeld een belangrijke rol in het historisch werk van de Weense journalist, acteur èn gepromoveerd filosoof Egon Friedell (1878-1938). In 1912 schreef hij 'eine Art Naturgeschichte des Menschen nach 1900', waarin hij theses over de 'geschiedenis van de blik' formuleerde, die hij later in zijn Kulturgeschichte der Neuzeit zou uitwerken. ${ }^{70}$ Friedells opvattingen zullen hier echter net zo goed buiten beschouwing moeten blijven als de historisch-psychologische aspecten van het werk van generatiegenoten van de nieuwe cultuurhistorici als Aby Warburg of Max Weber. ${ }^{71}$ Dat is jammer, maar te rechtvaardigen vanuit de doelstelling van deze studie: daarin gaat het immers om de opkomst en herkomst van deze gedachte binnen de geschiedwetenschap. De opvattingen van psychologen, artsen, filosofen en economen zullen wel besproken worden als het spoor van leermeesters, literatuurreferenties en inspiratiebronnen van de nieuwe cultuurhistorici inderdaad naar hen leidt. Dat geldt bijvoorbeeld voor verschillende oudere economen, voor de filosoof Dilthey en de Völkerpsychologen Lazarus en Steinthal, voor de Amerikaanse arts Beard en de journalist Freytag. Opnieuw geldt hier dat 'van binnen naar buiten' wordt gewerkt.

De opzet van dit onderzoek is geweest om de context waarin de nieuwe Duitse cultuurgeschiedenis rond 1900 (en daarmee de gedachte van de plooibare psyche binnen de Duitse geschiedwetenschap) opkwam, als de schillen van een ui, laag voor laag, af te pellen. Of misschien is het juister om te zeggen: laag voor laag aan te brengen.

\footnotetext{
${ }^{69}$ Bovendien blijven bijdragen uit de oude geschiedenis, die een enigszins aparte ontwikkeling kende, grotendeels buiten beschouwing.

${ }^{70}$ Zie Friedell (1912), 90 en Friedell (1960) 26-27.

${ }^{71} \mathrm{Bij}$ Warburg (en verschillende andere kunsthistorici) was er sprake van invloed van Lamprecht, zie Brush (1996) en Brush (2001). Over Max Weber zie hierna Hoofdstuk 5, noot 66.
} 
Drie verschillende lagen worden in deze studie achtereenvolgens onderzocht. De eerste relevante context waarin de gedachte van de plooibare psyche bezien moet worden, is het geheel van het wetenschappelijke werk van de bestudeerde cultuurhistorici. Aan de analyse daarvan is het uitvoerige hoofdstuk 3 gewijd. Het streven is geweest de historisch-psychologische opvattingen van de nieuwe cultuurhistorici te analyseren binnen de ontwikkeling van zowel hun geschiedtheorie als hun geschiedschrijving. Bovendien worden hier de geschiedtheoretische verschillen en overeenkomsten tussen de cultuurhistorici met de nodige precisie vastgesteld.

De tweede laag betreft de wetenschappelijke vorming van de cultuurhistorici. Deze laag wordt in drie hoofdstukken uitgediept (hoofdstukken 4 tot en met 6). Allereerst worden de afkomst, secundaire en universitaire opleiding en vroege carrière van de nieuwe cultuurhistorici onder de loep genomen en vergeleken met die van collegahistorici (hoofdstuk 4). Ook worden de institutionele kaders van de historische discipline onderzocht waarbinnen de cultuurhistorici werden onderwezen en waarbinnen zij carrière maakten. Dit hoofdstuk laat enerzijds de stevige geworteldheid van de nieuwe cultuurhistorici binnen de historische discipline zien, maar wijst anderzijds ook op hun sterke relaties met een andere discipline: de Nationalökonomie.

De intellectuele invloeden waaraan de cultuurhistorici tijdens hun opleiding werden blootgesteld, worden vervolgens in twee hoofdstukken geanalyseerd. In hoofdstuk 5 wordt onderzocht hoe de geschiedtheoretische en historisch-psychologische opvattingen van de cultuurhistorici zich verhielden tot dominante en minder dominante opvattingen binnen de historische discipline waarin zij waren opgeleid. De conclusie is tweeledig. Enerzijds wordt duidelijk dat de cultuurhistorici veel van de heersende vaknormen binnen de historische discipline deelden. Anderzijds zal ook blijken dat juist waar het de wenselijkheid en mogelijkheid van een historische psychologie betrof veel historistische collega's principiële, levenbeschouwelijke bezwaren koesterden. Het verschil in oriëntatie kwam onder andere tot uiting in de verschillende opvattingen over de oorsprong van de moderne historische wetenschap: volgens de cultuurhistorici lag die niet bij Ranke en de nationalistische opleving na de Bevrijdingsoorlogen, maar in de Verlichting.

In hoofdstuk 6 wordt onderzocht welke intellectuele invloeden buiten de historische discipline een rol hebben gespeeld in de vorming van de historischpsychologische opvattingen van de nieuwe cultuurhistorici. Van belang blijken daarbij een aantal wetenschappers uit de oudere Duitse cultuurhistorische traditie, de Herbartiaanse traditie in de Duitse psychologie en haar critici, en de Historische School in de Nationalökonomie. Zowel in hoofdstuk 5 als 6 worden intellectuele relaties gereconstrueerd op basis van wetenschappelijke referenties, uitdrukkelijk vermelde inspiratiebronnen en belangrijke docenten. Uit deze gegevens laten zich met enige precisie de wetenschappelijke tradities construeren, zowel binnen als buiten de eigen discipline, waardoor de cultuurhistorici al tijdens hun studie in hun opvattingen over de plooibare psyche waren gevormd.

De derde laag die in deze studie wordt onderzocht, betreft de positie van de cultuurhistorici in het culturele en politieke landschap van hun tijd. Zijzelf presenteerden hun geschiedopvattingen uitdrukkelijk als een onvermijdelijk onderdeel van de komst van de moderne tijd. Bovendien onderwierpen zij hun eigen tijd, die zij typeerden als een 'prikkelbaar' of 'nerveus tijdperk', aan soms zeer uitvoerige historische analyses. En zij verkondigden uitdrukkelijk dat de geschiedwetenschap een functie diende te hebben voor het heden. De vraag is dan welke maatschappelijke en politieke betekenis aan hun historisch-psychologische beschouwing van het verleden gehecht kan worden. Deze vraag is het onderwerp van hoofdstuk 7. Daarin wordt de 
manier waarop zij hun eigen tijd als historici percipieerden, verbonden met hun politieke activiteiten en opvattingen.

De nieuwe Duitse cultuurgeschiedschrijving ontstond, zoals een contemporaine observator in 1911 scherp opmerkte, als een onderdeel van 'een nieuw systeem, mens te zijn': zij diende als het intellectuele 'huisgewaad' van de eigentijdse mens, dat hem als het ware omringde met kennis over de historische en maatschappelijke differentiatie van de menselijke psyche. ${ }^{72}$ Maar dit 'huisgewaad' was niet politiek neutraal. In de woorden van Geiger: het was 'ideologie', geen 'mentaliteit'. Een ideologie die bij deze cultuurhistorici blijkt terug te voeren op een (links)liberale confrontatie met de moderniteit en die in veel opzichten geworteld was in Verlichte denkbeelden over de mens en de geschiedenis.

Die conclusie wordt aan het eind van deze studie uitgewerkt. Om te beginnen wordt nu eerst, in hoofdstuk 2 , bij wijze van nadere introductie van de hoofdpersonen en als kort chronologisch overzicht van de voornaamste gebeurtenissen, de opkomst van de nieuwe cultuurgeschiedenis in Duitsland in het behandelde tijdvak geschetst, aangevuld met een korte vooruitblik op het Interbellum.

${ }^{72}$ Naumann (1911), 1342-1343, 1339. Over de verwantschap tussen de nieuwe cultuurhistorici en Naumann, zie Hoofdstuk 7. 



\section{hoofdstuk 2}

\section{Opkomst en doorbraak}

$\mathrm{I}$

$\mathrm{n}$ de jaren dertig van de twintigste eeuw memoreerde de Leipzigse hoogleraar Walter Goetz eens wat er met historici gebeurde die rond 1900 als volgelingen van zijn voorganger Karl Lamprecht werden bestempeld: 'Wie de debatten van die jaren rond Lamprecht heeft meegemaakt, weet wat dat [...] betekende: het betekende toetreden tot een, in Duitsland in ieder geval, min of meer uitgestoten groep'. 'Degenen die zich op dit gebied wagen', schreef Lamprecht zelf in 1902, 'zijn voorlopig strijders zonder rust of respijt; ze staan elke ochtend opnieuw op het slagveld'. ${ }^{2}$

Lamprecht had in 1896 een frontale aanval geopend op de fundamenten van de Duitse geschiedschrijving. Hij was op dat moment, kort voor zijn veertigste verjaardag, al een van de meest productieve historici van zijn tijd en vooral bekend door zijn economisch-historische studies en de eerste delen van zijn Deutsche Geschichte (1891-1909), bij voltooing de omvangrijkste Duitse geschiedenis van de hand van één auteur. Tegenover de 'oude' politieke Personengeschichte, gericht op unieke daden van historische persoonlijkheden, verdedigde Lamprecht een 'nieuwe richting' die hij 'cultuurgeschiedenis' noemde en waarin het 'oneindig uitgestrekte gebied van gewoontegetrouw en collectief handelen' het onderwerp van onderzoek zou moeten zijn. ${ }^{3}$ Haar terrein reikte van kunst en wetenschap tot politiek, samenleving en economie. De politieke geschiedens 'die het historische gebeuren in wezen slechts beschouwt als een kaleidoskopische afwisseling van altijd dezelfde psychische krachten' diende te worden hervormd tot een 'wetenschap van de psychische veranderingen van menselijke gemeenschappen'.

Lamprecht schokte het historisch gilde in 1896 door zonder aarzeling de grootmeester van Duitse geschiedwetenschap, Leopold von Ranke, van zijn voetstuk te halen en diens geschiedopvattingen af te doen als een vorm van 'historisch mysticisme'. ${ }^{5}$ Dit radicale antwoord op de incidentele kritiek die Lamprecht al eerder van vakgenoten had gekregen, vormde het begin van een harde en publiekelijk gevoerde 'methodenstrijd', waarvan nog niet zo lang geleden algemeen werd aangenomen dat zij in een algehele nederlaag van Lamprecht eindigde. ${ }^{6}$

Lamprechts tegenstanders verzetten zich bijzonder heftig tegen de 'materialistische' mensopvatting die zij ontwaarden in zijn visie op de geschiedenis. ${ }^{7}$ De

\footnotetext{
${ }^{1}$ Goetz (1957), 313.

${ }^{2}$ Lamprecht (1974), 572 [1902] - zowel Goetz als Lamprecht refereerden hier overigens aan Breysig.

${ }^{3}$ Lamprecht (1896), 6.

${ }^{4}$ Resp. Lamprecht (1901), 12 en Lamprecht (1900), 15.

${ }^{5}$ Lamprecht (1896), 47. Zie ook Hoofdstuk 4, paragraaf 3.

${ }^{6}$ Zie bijv. Iggers (1971), 260 en Viikari (1977), 454.

${ }^{7}$ Zie verder Hoofdstuk 5, paragraaf 4.
} 
tegenstelling die Lamprecht had geschetst was in hun ogen uitdrukkelijk te herleiden tot een verschil in wereldbeschouwing. In Lamprechts werk werd het individu ten gunste van de massa 'geëlimineerd' en de menselijke vrijheid uitgebannen, zoals de Kielse Privatdozent Rachfahl verontrust opmerkte. ${ }^{8}$ De suggestie van Lamprecht dat de Duitse eenwording te danken was aan economische ontwikkelingen, was voor Rachfahl niets minder dan ungeheuerlich. ${ }^{9}$ Naar zijn mening mondde Lamprechts geschiedschrijving uit in 'historisch materialisme' en dat oordeel leek alleen maar bevestigd te worden door de lof die Lamprecht ontving van de marxistische historicus Franz Mehring. ${ }^{10}$ In de Historische Zeitschrift was Lamprecht door de jonge Münsterse hoogleraar Von Below al eerder politiek verdacht gemaakt als 'aanhanger van de nu bloeiende materialistische en fysiologische geschiedopvatting [...] waarvan de Genossen zich zullen verheugen dat zij een veelgeprezen historicus gewonnen hebben als een vurig voorop lopende vaandeldrager voor hun overtuigingen'. ${ }^{11}$ Zowel de Preußische Jahrbücher als de Historische Zeitschrift, sinds de jaren zestig de twee voornaamste opinievormende tijdschriften onder Duitse historici, werden onder leiding van de Berlijnse historici Delbrück, Sybel en Meinecke tot vehikels van het verzet tegen de 'materialistisch doordesemde oerbrij van Lamprecht'. ${ }^{12}$ De Leipzigse historicus was midden jaren negentig, zoals Rachfahl zich later in een terugblik op de 'Lamprechtstrijd' herinnerde, 'de meest populaire naam in de geschiedenis en het was nodig hem zijn aureool te ontnemen'. ${ }^{13}$ 'Men moet de bijl gebruiken', had Below met karakteristieke bruutheid al ten tijde van de strijd zelf verklaard. ${ }^{14}$

\section{Opkomst (1889-1896)}

Daarmee barstte in 1896 de bom die al enkele jaren onder de Duitse geschiedwetenschap lag te smeulen. Op zijn laatst in 1889 was duidelijk geworden dat zich een diepgaand verschil van mening onder de Duitse vakhistorici verbreidde. En dit verschil van mening concentreerde zich vanaf het begin op de status van wat 'cultuurgeschiedenis' werd genoemd.

Toen de geschiedwetenschap vanaf de jaren zestig van de negentiende eeuw een gevestigde, geïnstitutionaliseerde en bloeiende discipline werd aan de Duitse universiteiten was deze onderzoeksvariant hooguit een marginaal onderdeel van de professionele opvatting van geschiedenis. ${ }^{15}$ De voorstanders van de cultuurgeschiedschrijving behoorden in de decennia voorafgaand aan 1889 voor het merendeel niet tot

${ }^{8}$ Rachfahl (1897), 663, 667.

${ }^{9}$ Rachfahl (1896), 554; ook Meinecke (in HZ 77 (1896), 266) veroordeelde 'hoofdschuddend' de economische verklaring van de Duitse eenwording. Lamprecht herhaalde zijn opvatting overigens nog in 1904: Lamprecht (1891-1909), ErgBd. II.2, blz. 12.

${ }^{10}$ Mehring (1893/94); vgl. Chickering (1993), 175.

${ }^{11}$ Below (1893), 466.

12 '[M]aterialistisch durchsäuerten Urbrei Lamprechts' was Meinecke's verwoording van Sybels oordeel over Lamprecht in een brief aan de uitgever van de HZ, geciteerd in Schieder (1959), 88. Delbrück en Meinecke, hoofdredacteuren van resp. de PJb en de HZ keerden zich niet alleen persoonlijk tegen Lamprecht, maar bovendien verschenen de felste en meest uitgebreide kritieken in de PJb (Oncken 1897; Rachfahl 1896 (2x)) en de HZ (Below 1893, 1898; Lenz 1896). Sybel persoonlijk had de eerste kritiek van Below op Lamprechts DG aangescherpt, zie Chickering (1993), 159.

${ }^{13}$ Rachfahl (1926), 211.

${ }^{14}$ Below (1898), 195.

${ }^{15}$ Zie voor een meer gedetailleerde bespreking van de ontwikkeling van geschiedenis als een academische discipline Hoofdstuk 4, en van de vroegere ontwikkeling van de Duitse cultuurgeschiedenis, Hoofdstuk 6, paragraaf 1. 
de groep van aan de universiteit werkzame historici. Omgekeerd waren de kritieken die universitaire historici in deze decennia formuleerden tegen beoefenaren van de cultuurgeschiedenis, gericht tot outsiders, wetenschappers die niet behoorden tot de kleine gemeenschap van nog geen zestig hoogleraren geschiedenis. ${ }^{16}$ En dat was ook nog het geval toen in oktober 1888 de zojuist aangetreden hoogleraar voor nieuwe geschiedenis aan de universiteit van Tübingen, Dietrich Schäfer, zijn oratie Das eigentliche Arbeitsgebiet der Geschichte publiceerde, een diatribe gericht tegen de groeiende populariteit van cultuurgeschiedenis in Duitsland.

Hoewel Schäfer nauwelijks namen of titels noemde in zijn rede, is duidelijk dat hij daarin aan populaire en niet aan academische vormen van cultuurgeschiedenis refereerde. Schäfer bevestigde uitdrukkelijk het contrast tussen de populaire trend en de Historiker der Zunft en waarschuwde slechts zeer terloops tegen mogelijke invloeden van deze mode op de academische geschiedschrijving. ${ }^{17}$ In een aansluitende publicatie, waarin hij zijn visie nog eens verdedigde, keerde hij zich met name tegen cultuurhistorici als Hellwald, Henne am Rhyn en Lippert, van wie er geen hoogleraar geschiedenis was of zelfs maar aan een universiteit werkte. ${ }^{18}$ Schäfer bekritiseerde deze populaire vormen van cultuurgeschiedschrijving met morele en politiek geladen verwijten zoals die enkele jaren later in verhevigde mate ook tegen Lamprechts geschiedopvattingen zouden worden gelanceerd. Zo verwierp Schäfer de veronderstelde alles overheersende belangstelling van cultuurhistorici voor 'de alledaagse gewoonten en praktijken' van volkeren. Hij bekritiseerde de verwaarlozing van 'die geestelijke en morele beweegredenen die in mensen leven als een goddelijke erfenis' en verafschuwde de preoccupatie met 'de wijzen om die lage behoeften te bevredigen die voortkomen uit de dierlijke kant van het menselijk bestaan'. Als zodanig beschouwde Schäfer deze 'brede, gemakzuchtige trend' als een betreurenswaardig product van commerciële belangen en van 'onze zo democratisch georiënteerde tijden', gekenmerkt door een 'neiging tot nivelleren', een preoccupatie met de massa's en gebrek aan inzicht in de betekenis van buitengewone individuen. ${ }^{19}$

Schäfers opvattingen over geschiedenis verschilden in essentie niet van de uitgangspunten die historici als Treitschke, Droysen en Lorenz al eerder hadden verdedigd tegen vertegenwoordigers van de cultuurgeschiedenis - en die critici van Lamprecht later opnieuw naar voren zouden brengen. Volgens Schäfer had de staat altijd al en met recht het belangrijkste onderwerp van historisch onderzoek en historisch denken gevormd. ${ }^{20}$ Politieke vraagstellingen boden immers zowel vanuit ethisch als vanuit methodologisch oogpunt het beste perspectief op het verleden. Toewijding aan de staat, als de belichaming van het algemeen goed, was immers de hoogste maatstaf voor ethisch gedrag en tegelijkertijd moesten de ethische krachten beschouwd worden als de krachten die uiteindelijk de wereld regeerden, aldus Schäfer. Door aandacht te geven aan de staat en de politiek vervulde de historicus derhalve niet alleen een ethische plicht, hij concentreerde zich tegelijk op die krachten die de loop van de geschiedenis bepaalden. Op een letterlijk meer prozaïsch niveau was de historicus bovendien alleen vanuit een politieke vraagstelling in staat

${ }^{16}$ Treitschke (1859) en Ottokar Lorenz (1886) fulmineerden tegen Staatswissenschaftler Riehl; Droysen viel in 1863 de Engelse privé-geleerde Buckle aan en in 1878 bekritiseerde opnieuw Lorenz de fysioloog Dubois-Reymond - allen vanwege hun pleidooi voor de cultuurgeschiedenis. In geen van deze gevallen bekritiseerden de universitaire historici een collega.

${ }^{17}$ Schäfer (1888) 8, 28.

${ }^{18}$ Zie Schäfer (1891), 51, 54, 59.

${ }^{19}$ Zie Schäfer (1888), 6, 8, 28 en Schäfer (1891), 54-55.

${ }^{20}$ Schäfer (1888), 23, 25. Vgl. ook over staatsopvattingen van de historisten in het algemeen: Simon (1988), m.n. 67-68 
een perspectief te vinden dat alle historisch relevante feiten kon verenigen in één samenhangende voorstelling: alleen de invloedrijke ideeën, besluiten, wetten en maatregelen van degenen die de naties leidden konden de historicus van een oorzakelijk (of beter gezegd: intentioneel en teleologisch) samenhangend interpretatieschema voorzien. Politieke geschiedenis was zodoende niet alleen ethisch hoogstaand, methodisch vruchtbaar en politiek nuttig, het was ook de enige overtuigende manier om algemene geschiedenis te schrijven.

Schäfers rede trok pas de aandacht van de vakgenoten toen in 1889 een uitvoerige repliek van de hand van de Karlsruher hoogleraar Eberhard Gothein verscheen. Gothein pleitte hartstochtelijk voor een academische beoefening van de cultuurgeschiedenis. Hij hield staande dat geschiedenis in zijn tijd alleen cultuurgeschiedenis kon zijn en dat de politieke geschiedenis daaraan ondergeschikt gemaakt diende te worden. Tot haar belangrijkste opgaven rekende Gothein de taak om vast te stellen 'hoe de verandering van het gemoedsleven in hele generaties tot stand komt en zich uit'. ${ }^{21}$

Zowel uit Gotheins repliek als uit de aan het debat gewijde artikelen bleek eigenlijk voor het eerst duidelijk dat de vakhistorici zich niet langer unaniem achter het vertrouwde politiek-historische programma schaarden zoals dat door Schäfer was verwoord. De hoogleraren Bernheim in de Deutsche Litteraturzeitung (1889) en Pöhlmann in de Deutsche Zeitschrift für Geschichtswissenschaft (1890), ${ }^{22}$ de universitair docenten Buchholz in de Jahresberichte der Geschichtswissenschaft (1889) ${ }^{23}$ Hinneberg in de Historische Zeitschrift (1890) en Breysig in het Litterarische Centralblatt (1892), de historicus en archivaris Georg Winter in de Vierteljahrsschrift für Volkswirtschaft, Politik und Kulturgeschichte (1889), ${ }^{24}$ alsmede de ambitieuze historicus en bibliothecaris Steinhausen in Die Gegenwart (1891 en 1892), lieten hun oordeel allemaal in meer of mindere mate ten gunste van Gothein uitvallen. Pas in 1892, na een dupliek van Schäfer, verscheen in de Göttingische gelehrte Anzeigen een hartgrondige steunbetuiging met diens positie van de hand van Georg von Below, een jaar later op meer gematigde wijze gevolgd door Belows Doktorvater en Bonner collega Moriz Ritter in een Münchens dagblad. ${ }^{25}$

Uit de reacties op Schäfers oratie kwam voor het eerst ondubbelzinnig naar voren dat de eensgezindheid van de universitaire historici over het politieke domein van de geschiedenis barsten begon te vertonen. En verder bleek dat het debat gevoerd zou worden in termen van de tegenstelling 'politieke geschiedenis' versus 'cultuurgeschiedenis'. ${ }^{26}$ Terwijl die strijd eerder grotendeels was uitgevochten tussen universitaire historici en niet-vakhistorici ging het $\mathrm{nu}$ om een conflict binnen de historische discipline.

Het toegenomen belang dat binnen de historische vakwetenschap werd gehecht aan cultuurgeschiedenis bleek ook uit verschillende andere gebeurtenissen in 1889 en de jaren erna. Zo verscheen in 1889 een nieuw historisch tijdschrift, dat met zijn nadruk op de publicatie van Spezialuntersuchungen uitdrukkelijk gericht was op een

${ }^{21}$ Gothein (1889), 62.

${ }^{22}$ Zie over Pöhlmann: Christ (1979), 201-247.

${ }^{23}$ Buchholz (1889).

${ }^{24}$ Zie Zorn (1985), 464.

${ }^{25}$ Below (1892); voor Ritter (1893), heb ik het referaat over dit stuk geraadpleegd in ZfK 1(1894) 244-245. Een lijst van reacties op het Schäfer-Gothein debat is te vinden bij Steinhausen (1891, (1892b). Overigens lijkt de repliek van Schäfer (1891) zelf ook typisch voor het gebrek aan steun dat hij aanvankelijk kreeg: hij legt daarin in eerste instantie sterk de nadruk op de eigenlijke overeenkomsten tussen zijn positie en die van Gothein.

${ }^{26}$ Zie Hoofdstuk 6, paragraaf. 1. 
vakpubliek: de Deutsche Zeitschrift für Geschichtswissenschaft (vanaf 1898-1938: Historische Vierteljahrschrift). Het mag als de belangrijkste concurrent van de Historische Zeitschrift als algemeen disciplinair forum gezien worden. ${ }^{27}$ In dit expliciet op politiek historisch onderzoek georiënteerde blad waren uitgebreide bibliografische overzichten opgenomen. ${ }^{28}$ Opmerkelijk is nu dat vanaf de eerste jaargang 1889 in deze bibliografische overzichten een plek werd ingeruimd voor Culturgeschichte, en wel als enige thematische, niet-geografische en niet-chronologische rubriek naast 'hulpwetenschappen'. ${ }^{29}$ Onder de noemer 'cultuurgeschiedenis' werden studies vermeld over het 'juridisch, bestuurlijk en economisch leven', over kerk en religie, Bildung, letterkunde en kunst, en ten slotte over het 'huiselijk en gezelschapsleven, zeden en gebruiken'. 'Cultuurgeschiedenis' had met deze invulling klaarblijkelijk voldoende gewicht bij althans een gedeelte van de Duitse vakhistorici om er een deel van het historisch domein mee aan te duiden.

Het nieuwe belang van de cultuurgeschiedenis binnen de historische discipline kwam nog sterker naar voren toen eveneens in 1889 Ernst Bernheims gerenommeerde Lehrbuch der historischen Methode verscheen, de eerste Duitse introductie tot het historisch ambacht sinds Droysens syllabus Grundriß der Historik (1858). ${ }^{30} \mathrm{In}$ zijn voorwoord verwees Bernheim uitdrukkelijk, maar zonder namen te noemen, naar de vele meningsverschillen die de historische discipline teisterden ${ }^{31}$ Uit latere edities werd duidelijk dat Bernheim net als Schäfer en andere historici zich zorgen maakte over het oprukken van 'socialistisch-natuurwetenschappelijke opvattingen in samenhang met de machtige materialistische stromingen van onze tijd', maar tevens dat hij het antwoord daarop niet zocht in Schäfers eenzijdige idealisme of een hernieuwd benadrukken van de politieke geschiedenis. ${ }^{32}$ Bernheim probeerde een middenweg te bewandelen en het goede uit beide richtingen te combineren. Zijn werk maakte ongetwijfeld in verband daarmee een minder samenhangende indruk dan de Historik van Droysen. In plaats van diens idealistische geschiedbeschouwing en

${ }^{27}$ Zie Wolf (1910), 302; zie ook hierna, Hoofdstuk 4, paragraaf 1.4.

${ }^{28}$ Zie Quidde (1889), 3.

${ }^{29}$ Anders dan de HZ reageerde de DZGW (X (1893), 360) bovendien positief op de oprichting van de Zeitschrift für Kulturgeschichte, vgl. Steinhausen (1895), 192-193 en Steinhausen en Bernheim (1896), 323-324.

${ }^{30}$ De betekenis van Bernheim in dit opzicht is bij mijn weten nog niet eerder in de literatuur duidelijk gemaakt. Overigens zijn de cijfermatige verschillen tussen Droysens publicatie en die van Bernheim typerend voor de ontwikkeling die de historische discipline in Duitsland in de dertig jaar na Droysens Historik had doorgemaakt: tussen 1889 en 1908 verschenen zes oplagen van het magnum opus van Bernheim, waarbij de omvang gestaag toenam van ruim 500 tot 800 bladzijden. Droysens Grundriß der Historik, niet meer dan een gedrukte syllabus, werd daarentegen eerst als manuscript gedrukt in 1858, pas in 1868 (en opnieuw in 1875 en 1882) voor de handel. De laatste druk beslaat in de wetenschappelijke editie ca. 70 blz. In 1925 volgde nog een herdruk van de syllabus en in 1937 de eerste volledige uitgave van Droysens college op grond van zijn collegemanuscripten. Zie Droysen (1977), XIV-XV.

${ }^{31}$ Bernheim (1889a), V-VI. Ook in de Jahresberichte der Geschichtswissenschaft waarin in 1889 voor het eerst sinds jaren weer een rubriek geschiedtheorie werd opgenomen, werd opgemerkt dat er pas sinds kort meer over geschiedtheoretische kwesties werd gedebatteerd, zie Buchholz (1889).

${ }^{32}$ Citaat uit Bernheim (1908), III. Zie ook de voorwoorden bij de tweede en derde druk (1894, 1903). Vgl. het volgend citaat van Bernheim uit 1893 (in Schorn-Schütte (1994), 65): 'Jedenfalls müssen wir Dozenten uns gegen die neuen Strömungen nicht unwirsch abschließen, wie es wohl vielfach von der alten Richtung geschieht, sondern uns kräftig hineinbegeben und das Brauchbare, Lebenskräftige daraus herausholen, wie Sie und ich und manche andere es thun und auch ich es durch mein Lehrbuch zu bewirken suche. Verfehlt [...] scheint mir das bestreben [...] die Geschichte ich möchte sagen zu verstaatlichen [...]. Die Begünstigung der einseitig 'politischen' Richtung, die von oben her bei uns jetzt zu herrschen scheint, dünkt mich für die ganze Entwicklung unserer Wissenschaft recht nachteilig.' 
inspirerende en bevlogen woorden presenteerde Bernheim in de eerste plaats een gedisciplineerd, technisch en bibliografisch uitputtend, maar ook enigszins gefragmenteerd overzicht van de taken en werkwijzen van de geschiedwetenschap.

Het meest opvallend was dat in Bernheims domeinbepaling van de geschiedwetenschap de eenheid was verdwenen: met zijn werk deed de splitsing tussen politieke en cultuurgeschiedenis zijn intrede in een leer- en handboek voor historici. Weliswaar had ook Droysen in zijn collegereeks uit 1857 mit schwerem Herzen een passage gewijd aan de cultuurgeschiedenis, maar de toon was zeer gereserveerd en in de gepubliceerde korte syllabus van 1858 werd zij niet genoemd. ${ }^{33}$ Voor Bernheim was de plaats van de cultuurgeschiedenis een geheel andere. Kennelijk nog zonder kennisname van Schäfers oratie of Gotheins reactie daarop, ${ }^{36}$ gaf hij in zijn leerboek een omschrijving van geschiedenis en een indeling van de historische stof die zich laten schematiseren zoals in tabel 2.1 is weergegeven.

Bernheim verdeelde het hele historische domein inhoudelijk in twee grote en zoals hij expliciet erbij vermelde - 'gelijkwaardige' onderdelen: in cultuurgeschiedenis en politieke geschiedenis. ${ }^{37}$ Het criterium voor het onderscheid tussen beide was overigens zelf van politieke aard, zo blijkt uit zijn omschrijvingen; ten grondslag aan zijn onderscheid tussen politieke en cultuurgeschiedenis lag de klassieke liberale onderscheiding van het publieke en het private domein. En geheel in overeenstemming met liberale staatsopvattingen vormde niet het publieke, maar het private domein het overgrote deel van de menselijke activiteiten. Uitdrukkelijk wees Bernheim de beperking van de geschiedenis tot politieke daden af met het argument dat 'de culturele ontwikkeling van de mensen' niet (uitsluitend) afhankelijk was van de staat en toch evident tot het historisch domein behoorde. ${ }^{38}$ Ook in een gelijktijdig met zijn leerboek verschenen recensie van het Gothein-Schäfer debat verdedigde Bernheim expliciet het standpunt dat het cultuurhistorisch onderzoek een zelfstandige betekenis naast de staatkundige geschiedenis moest worden toegekend, overigens zonder dat cultuurgeschiedenis daarom als een afzonderlijke discipline kon worden beschouwd. ${ }^{39}$

${ }^{33}$ Droysen (1977), 379-382 (collegedictaat 1857).

${ }^{36}$ In de eerste druk ontbreken nog de verwijzingen naar Schäfer of Gothein, die wel zijn toegevoegd aan de tweede druk (1894).

${ }^{37}$ Bernheim (1889a), 44.

${ }^{38}$ Bernheim (1889a), 10-11. In de tweede druk van 1894 verwees Bernheim hier ook naar Schäfer als een Duitse vertegenwoordiger van de politiek-historische opvatting, naast de ook al in de eerste druk genoemde Ottokar Lorenz, een eerdere criticus van Riehls en Du Bois Reymonds varianten van cultuurgeschiedschrijving.

${ }^{39}$ Zie Bernheim (1889b) en nog eens in Bernheims bijdrage in Steinhausen en Bernheim (1896). 
Tabel 2.1

Bernheims indeling van de geschiedwetenschap (1889)

Geschiedenis: de wetenschap van de ontwikkeling van mensen in hun activiteit [Bethätigung] als sociale wezens

A. Algemene geschiedenis

\section{Algemene} geschiedenis van staten: een encyclopedieachtige aaneenrijging [kompendiumartige Aneinanderreihung] van de geschiedenis van alle bekende volkeren

B. Geschiedenis gespecialiseerd naar...

$$
\text { 2. ...omvang }
$$

a. Geschiedenis van de afzonderlijke culturele verschijnselen en activiteiten, zoals godsdienst-, kerk-, rechts-, standen-, kunstgeschiedenis, geschiedenis van de wetenschappen, van zeden [Sitten], nijverheid [Gewerbe], handel, gebruiken, spelen enz.

voortkomen b. Geschiedenis van de afzonderlijke politieke verschijnselen en geschiedenis van bepaalde groepen staten, van afzonderlijke staten enz. c.

d.

Geschiedenis van afzonderlijke gebieden zonder gesloten politieke eenheid nis van bepaalde groepen van mensen resp. van afzonderlijke mensen f. Geschiedenis van afzonderlijke gebeurtenissen

Bron: Bernheim (1889a), 4 (definitie van geschiedenis) en 38-39. De nummering is van Bernheim overgenomen, de tekst binnen het schema is vertaald naar Bernheims tekst, de schematische weergave en de Nederlandse tekst links van de tabel zijn van mij, MS. Bernheims nummering loopt 'van boven naar beneden': de geschiedenis van afzonderlijke gebeurtenissen is B.2.f. 


\section{Opkomst en doorbraak}

Voor Bernheim besloeg de politiek derhalve hooguit nog de helft van het domein van de geschiedwetenschap en wat misschien nog belangrijker was: zij kreeg van hem geen voorkeurspositie meer. Hij ontkende weliswaar niet dat de staat de cultuur beïnvloedde, maar hij wees erop dat het omgekeerde net zo goed gebeurde; het ene deel van het historisch domein kon derhalve niet als een bijproduct van het andere worden beschouwd. De eenheid en samenhang die Bernheim desalniettemin in het in tweeën gesplitste domein van de historicus bespeurde, was 'sociaal' (gesellschaftlich) van aard: alles draaide in de geschiedenis om de betrekkingen van de mensen tot elkaar. Zowel de politieke geschiedenis als de cultuurgeschiedenis waren in gelijke mate 'producten van de menselijke socialisering' (Vergesellschaftung). Qua object was de geschiedwetenschap dan ook geen Staatswissenschaft, maar veeleer, zoals Bernheim in weerwil van gevestigde historistische opvattingen schreef: een 'Gesellschaftswissenschaft'. ${ }^{40}$ Het verbaast vanuit dit perspectief niet dat Bernheim jaren later tot de ondertekenaars hoorde van de oprichtingsstatuten van de Deutsche Gesellschaft für Soziologie (1910). ${ }^{41}$

De reacties op Bernheims leerboek toonden net als de reacties op het SchäferGothein debat een verdeelde discipline. ${ }^{42}$ De Deutsche Zeitschrift für Geschichtswissenschaft vond dat Bernheim nog wel wat verder had mogen gaan in zijn waardering voor alternatieve benaderingen. ${ }^{43}$ Ook Lamprecht, Steinhausen en Breysig - de eerste twee waren oud-studenten van Bernheim - betoonden hun instemming met de zienswijze van Bernheim. ${ }^{44}$ Volgens Steinhausen hield Bernheim in zijn boek terecht rekening met de nieuwe eisen die 'in de afgelopen tijd' aan de geschiedwetenschap waren gesteld. ${ }^{45}$ Breysig op zijn beurt schreef een jaar later in een anoniem verschenen bespreking van de tweede druk: ${ }^{46}$

'Dat in het eerste handboek van de geschiedwetenschap aan hen [nl. 'de jonge, fris opkomende disciplines van de cultuurgeschiedenis'] binnen de gehele [geschied]wetenschap een gelijkwaardige plaats wordt toegekend naast de reactionaire opvattingen van anderen, zal B[ernheim] altijd tot eer strekken.'

\footnotetext{
${ }^{40}$ Bernheim (1889a), 11. Zie voor de historistische kritiek op de gedachte van een Gesellschaftswissenschaft: Fischer (1966), en hierna Hoofdstuk 5.

${ }^{41}$ Zie Verhandlungen (1910), [V] (Statut).

${ }^{42}$ De algemene uitspraak van Schorn-Schütte (1984a), 32, dat Bernheims collega's 'uitgesproken koel' reageerden op zijn boek, moet in deze zin gerelativeerd worden, zeker als we bovendien de herhaalde oplagen van zijn werk erbij betrekken. Zie ook de waarderende verwijzingen naar Bernheim door de Grazer hoogleraar Von Zwiedineck-Südenhorst op de Historikertag van 1895: Bericht, (1895),

${ }^{43}$ DZGW 10 (1893), 362-363.

${ }^{44}$ Lamprecht presenteerde zijn zes jaar oudere collega Bernheim in 1896 als een vertegenwoordiger van een jongere generatie vernieuwingsgezinde historici (Bernheim was op dat moment 46), die reeds ten dele op de goede weg was, zie Lamprecht (1896/97), 83.

${ }^{45}$ Zie Steinhausen (1894b), 349; en verder: Steinhausen (1892a), 256-257; Steinhausen (1894a); Steinhausen (1895).

${ }^{46}$ Breysig (1895), 1158; toeschrijving aan Breysig volgens Schilling (1928), nr. 202. Anonimiteit was overigens eerder regel dan uitzondering bij recensies voor het Literarische Centralblatt, zie Wolf (1910), 304n3.

${ }^{57}$ Geciteerd in Schorn-Schütte (1984a), 33.
} $5-9$. 
Dat was overigens een al te hoog gestemde verwachting, zoals Breysig zich waarschijnlijk ook wel realiseerde: Bernheim moest juist vanwege dit standpunt de kritiek van andere vakgenoten verduren. De Berlijnse hoogleraar Max Lenz beklaagde zich in 1890 bij Althoff, de machtige Pruisische functionaris voor het universiteitswezen, over Bernheims 'getheoretiseer' en pleitte voor een voortzetting van de geschiedschrijving volgens Rankes 'onomstotelijke doelstellingen'. ${ }^{57}$ En Georg von Below, korte tijd later net als Lenz een opponent van Lamprechts cultuurhistorische methode, wijdde in 1892 een gezamenlijke recensie aan het Gothein-Schäfer debat èn aan Bernheims leerboek, waarin hij Gothein en Bernheim in één adem veroordeelde. ${ }^{58}$

Het leek er in de eerste helft van de jaren negentig desondanks sterk op dat de academische beoefening van de cultuurgeschiedenis steeds meer de wind in de zeilen kreeg. Toen de Duitse wetenschap zich in 1893 op de wereldtentoonstelling in Chicago presenteerde en daartoe een overzicht van de stand van zaken in de diverse wetenschappen werd gepubliceerd, kon de hooggeleerde referent voor geschiedenis alleen maar constateren dat er 'een nieuwe richting in de geschiedwetenschap' was ontstaan, die enerzijds grote belangstelling koesterde voor de economische geschiedenis en anderzijds de opvatting huldigde dat geschiedenis uitsluitend cultuurgeschiedenis kon zijn. ${ }^{59}$ In de officieuse jaarbibliografie van de Duitse geschiedwetenschap, de Jahresberichte der Geschichtswissenschaft, verscheen in 1892 voor het eerst sinds 1881 weer een apart referaat over 'cultuurgeschiedenis' waarin maar liefst 495 cultuurhistorisch relevante publicaties werden opgesomd, een aantal dat in 1896 zelfs was opgelopen tot 748 .

De samensteller van deze cultuurhistorische referaten was de gepromoveerde historicus en Jenaer universiteitsbibliothecaris Georg Steinhausen, die al eerder was opgevallen door zijn Geschichte des deutschen Briefes (1889-1891). In 1894 richtte hij bovendien de Zeitschrift für Kulturgeschichte op. ${ }^{61}$ Steinhausen bepleitte al vanaf het Gothein-Schäfer debat in vak- en opiniebladen een sterkere academische positie van de cultuurgeschiedenis en wilde dat pleidooi nu met zijn tijdschrift kracht bijzetten. Cultuurgeschiedenis draaide voor hem om de vraag: 'Hoe zijn de mensen [in het verleden] eigenlijk geweest en hoe hebben ze geleefd?'. ${ }^{2}$ En zeker aanvankelijk waren zijn pleidooien succesvol: voor de eerste nummers van zijn tijdschrift wist hij onder andere bijdragen van de hoogleraren Gothein, Lamprecht, Caro en Bezold te winnen.

Niet alleen de receptie van het Schäfer-Gothein debat, de verschijning van Bernheims leerboek (dat al in 1894 aan een herdruk toe was) en de gesignaleerde ontwikkelingen in de vakbibliografie en de vaktijdschriften maken duidelijk dat cul-

\footnotetext{
${ }^{58}$ Below (1892), zie m.n. 291; ook Schäfer (1891), 56-57, bekritiseerde Bernheim in zijn repliek aan Gothein.

${ }^{59}$ Theodor Lindner in Lexis (1893), m.n. 553. De historicus Lindner (*1843, vanaf 1876 ordinarius in Münster, vanaf 1888 in Halle) toonde later overigens affiniteit met het streven van Lamprecht en Breysig. Zijn eigen Geschichtsphilosophie (1901) noemde hij een 'historische Psychophysik', zie Mütter (1980), 419-420. Hij schreef een omvangrijke Weltgeschichte en publiceerde in Steinhausens AfK een opstel over 'Reaktion und Kontrast in der Geschichte' (1906).

${ }^{61} \mathrm{Al}$ in 1891 was een Zeitschrift für Deutsche Kulturgeschichte (her)opgericht, maar dit blad, dat in 1893 weer ter ziele ging, had geen programma en geen expliciete academische pretenties. Verder verscheen in Wenen vanaf 1893 de Zeitschrift für Sozial- und Wirtschaftsgeschichte, onder redactie van de Weense historici Ludo M. Hartmann en Stephan Bauer.

${ }^{62}$ Steinhausen (1895), 195.
} 
tuurhistorische belangstelling onder vakhistorici in de eerste helft van de jaren negentig groeiende was. Terwijl Gothein halverwege de jaren tachtig nog had moeten uitwijken naar een economische leerstoel, ontstond er tussen 1889 en 1895 klaarblijkelijk ruimte voor de benoeming van vernieuwers. ${ }^{63}$ Zowel Bernheim als Lamprecht werden in deze jaren aangesteld als hoogleraar voor geschiedenis. Lamprecht stootte bovendien snel door naar een leerstoel aan een van de drie grootste universiteiten van het Keizerrijk, de bloeiende universiteit van Leipzig. ${ }^{64} \mathrm{Hij}$ zou in de komende jaren op verschillende manieren een grote rol gaan spelen in de Duitse geschiedwetenschap.

\section{Het uur van Lamprecht}

De jaren negentig vormden voor de Duitse historische discipline een periode van institutionele vernieuwingen, waarin verschillende cultuurhistorici, en onder hen vooral Lamprecht, een opvallende rol speelden.

Tot die institutionele vernieuwingen behoorde in de eerste plaats een opmerkelijke versnelling in het proces van formalisering en academisering van het regionaalhistorisch onderzoek. ${ }^{65}$ Van de elf met overheidsgelden gefinancierde historische commissies voor regionalhistorisch onderzoek die vóór 1914 in het Keizerrijk werden ingesteld, kwam een groot deel rond 1895 tot stand. Lamprecht was niet alleen de drijvende kracht achter een van deze Neubildungen, ${ }^{67}$ hij nam in 1894 bovendien het initiatief om nationale conferenties van deze en andere regionaalhistorische Publikationsinstitute te organiseren. ${ }^{68}$ En met succes: aan de eerste bijeenkomst die in 1895 onder voorzitterschap van Lamprecht bijeenkwam, namen maar liefst zestien historische commissies en particuliere verenigingen deel. Onder algemene bijval verklaarde Lamprecht bij de opening van de vergadering dat het bij regionale geschiedenis voornamelijk ging om de bestuurlijke, juridische en economische ontwikkeling, alsmede om de ontwikkeling van kunst, literatuur en wetenschap - kortom, zoals Lamprecht het formuleerde, om 'cultuurgeschiedenis in de breedste zin van het woord' ${ }^{69}$ In dezelfde vergadering werd, op verzoek van Georg Steinhausen, de hoofdredacteur van de Zeitschrift für Kulturgeschichte, de inventarisatie van de belangrijkste 'specifiek cultuurhistorische bronnen' waarvan een

${ }^{63}$ Het aantal historische leerstoelen in het Keizerrijk nam uitzonderlijk sterk toe tussen 1889 en 1895: van zevenenvijftig in 1889 tot vijfenzestig in 1895. In deze periode werden zeventien nieuwe historische hoogleraren op bestaande en nieuwe leerstoelen benoemd. Gegevens gebaseerd op Weber (1987). Zie voor meer cijfers over de ontwikkeling van de historische discipline hierna, hoofdstuk 4.

${ }^{64}$ Chickering (1993), 114. De universiteit van Leipzig kende een jaar na Lamprechts aantreden (zomersemester 1892) 314 studenten filosofie, filologie en geschiedenis, voor München was dit aantal 325 en voor Berlijn 627; na Leipzig was Heidelberg in het zomersemester van dat jaar de vierde universiteit (in aantallen van deze studenten) met 158 studenten, daarna volgde Bonn met 149 studenten; zie Lexis (1893), 618.

${ }^{65}$ Met 'regio's' worden in deze context Duitse 'landen' van vaak aanzienlijke omvang en een lange zelfstandige geschiedenis bedoeld.

${ }^{67}$ N1. de Koninklijke Saksische Commissie voor Geschiedenis (1896). Zie Wiemers (1996), 13-43, vgl. ook 148 .

${ }^{68}$ Strikt genomen ging het overigens om internationale bijeenkomsten: ook Oostenrijkse, Zwitserse, en soms Nederlandse en Belgische genootschappen namen deel aan deze conferenties. Zie verder Winter (1898), 314; Bericht (1894), 27 en Schorn-Schütte (1984b), 402-403.

${ }^{69}$ Bericht (1895), 63; vgl. Schorn-Schütte (1984b), 394-396, 402-403. 
wetenschappelijke uitgave wenselijk moest worden geacht, voor een volgende bijeenkomst op de agenda geplaatst. ${ }^{70}$

De regionaalhistorische conferenties die vanaf 1895 bijeenkwamen, vormden niet de enige nieuwe vakinstitutie waarin Lamprecht rond het midden van de jaren negentig de gelegenheid kreeg nieuwe historische benaderingen en thema's naar voren te schuiven. Twee jaar eerder was in München al een eerste algemeen congres van historici uit Duitsland, Oostenrijk en Zwitserland bijeengeroepen. De directe aanleiding daarvoor waren de onderwijshervormingen die Keizer Wilhelm II had voorgesteld. $^{71}$ In het voor ons thema toch al schicksalsreiche jaar 1889 had Wilhelm het Pruisische Staatsministerium verzocht plannen te ontwikkelen om in het lager en middelbaar onderwijs meer aandacht te besteden aan de vaderlandse geschiedenis en met name aan de meer en meest recente sociale en economische ontwikkeling. Het ministerie reageerde prompt met concrete voorstellen om deze uitbreiding van de schoolkennis met de moderne vaderlandse geschiedenis 'met name ook wat de cultuurontwikkeling betreft', tot stand te brengen. ${ }^{72}$ Het eerste nationale congres van Duitse historici in 1893 kwam in eerste instantie bijeen uit verontrusting over deze plannen.

Dat verzet gold vooral de politieke boodschap die Wilhelm II uitdrukkelijk aan zijn hervorming van het historisch onderwijs wilde verbinden. Geheel passend binnen de Neue Kurs, het nieuwe beleid dat de Keizer wilde voeren ten aanzien van het opkomend massasocialisme, probeerde Wilhelm met zijn onderwijspolitiek de socialisten eerder de wind uit de zeilen te nemen dan te knevelen. Zo zou het onderwijs over de sociale en economische geschiedenis van het vaderland volgens Wilhelm de leraar de gelegenheid bieden de scholieren duidelijk te maken 'hoe de Pruisische koningen zich hebben ingespannen de levensvoorwaarden van de arbeiders in een voortdurende ontwikkeling te verbeteren'; tegelijk zouden de leraren ook kunnen uitleggen dat de sociaaldemocratische opvattingen niet alleen 'onchristelijk', maar ook 'onuitvoerbaar' en 'schadelijk' voor individu en gemeenschap waren, zoals Wilhelm het formuleerde. ${ }^{73}$ De in München verzamelde historici keerden zich tegen de keizerlijke plannen voor zover het historisch onderwijs daarmee een uitdrukkelijke politieke Gesinnung kreeg opgelegd, maar stemden overigens in meerderheid wel in met de gedachte dat het historisch onderwijs tot vaderlandsliefde diende op te wekken. ${ }^{74}$

Het door de Keizer en zijn adviseurs gepropageerde onderwijs in de cultuurgeschiedenis kwam op het congres niet uitvoerig ter sprake. De vertegenwoordiger van de keizerlijke plannen, gymnasiumdirecteur Martens, pleitte in zijn stellingen vóór dergelijk cultuurhistorisch onderwijs, twee hooggeleerde referenten (Dove en Kaufmann) pleitten in geschrifte tegen en hielden uitdrukkelijk vast aan de prioriteit van de politieke geschiedenis. Maar over de kwestie werd niet gedebatteerd en ze

\footnotetext{
${ }^{70}$ Bericht, (1895), 64. Zie voor dit voorstel hierna, hoofdstuk 3, paragraaf 2.

${ }^{71}$ De geschiedenis van de Historikertage is beschreven door Schumann (1975); zie bovendien Erdmann (1968).

${ }^{72}$ Wilhelm II (1891), 6. Als gevolg van de grotere nadruk die de Keizer in het geschiedenisonderwijs op het heden wilde leggen, ontstond er in 1891 een uitgebreide discussie over de wenselijkheid van een 'regressieve methode', die de leerling vanuit het heden zou terugvoeren naar het verleden; zie Buchholz (1891), IV, 44-45; Bernheim (1899), 50-54; Goebel (1974), 711. Er kwam daadwerkelijk zo'n methode tot stand: Stenzler, Lindner en Landwehr (1891). Hoewel het bij Marc Blochs beroemd geworden 'regressieve methode' enkele decennia later veeleer ging om een methode van historisch onderzoek, is de parallel te opmerkelijk om niet te vermelden.

${ }^{73}$ Wilhelm II (1891), 4.

${ }^{74}$ Zie Bericht (1893), 13-14.
} 
kwam niet in stemming op de meer dan honderdhoofdige vergadering. Het enige congreslid dat zich geroepen voelde om terug te komen op de zaak was Lamprecht. Opvallend genoeg steunde hij de invoering van cultuurgeschiedenis in het middelbaar onderwijs niet, maar het kon de oplettende toehoorder niet ontgaan dat zijn argumentatie eerder praktisch was dan principieel: het 'economisch- en ander cultuurhistorisch onderzoek is nog te zeer in ontwikkeling en daarom geen kost voor gymnasiasten'. ${ }^{\text {' }}$

Toch betekende Lamprechts optreden tijdens deze eerste Historikertag een belangrijke stap voorwaarts voor de Duitse cultuurgeschiedschrijving: door de rol die hij in dit nieuwe vakorgaan wist te verkrijgen kon het als forum gaan dienen voor de nieuwe richting in de historische vakwetenschap. Lamprecht wierp zich tijdens de conferentie niet alleen op als organisator van een tweede Historikertag in Leipzig (1894), maar was als zodanig bovendien een van de initiatiefnemers van het plan om een beroepsvereniging van historici op te richten. Het bestuur van deze Verband deutscher Historiker (VDH) die tijdens de derde Historikertag in Frankfurt (1895) daadwerkelijk werd opgericht, zou zorg moeten dragen voor de continuïteit van de conferenties en als organiserend comité van komende bijeenkomsten dienen op te treden. ${ }^{76}$ Daarmee werd het voortbestaan van deze congressen, waarop zowel inhoudelijke bijdragen als organisatorische kwesties (bijvoorbeeld over de ontsluiting van het archiefwezen) werden besproken, pas verzekerd. ${ }^{77}$ Lamprecht had al de leiding gehad over de bijeenkomsten van 1894 en 1895 en nam nu ook zitting in het eerste vijftienhoofdige bestuur van de VDH dat door de vergadering in 1895 werd aangesteld. $^{78}$

Gezien Lamprechts rol in de organisatie verbaast het niet dat de vernieuwing ook inhoudelijk voet aan de grond kreeg tijdens de eerste Historikertage. Al op de allereerste bijeenkomst van 1893 had hij de vergadering uitdrukkelijk om toestemming gevraagd om de volgende keer ook kerk-, kunst-, rechts- en literatuurhistorici uit te mogen nodigen. ${ }^{79}$ Op de Historikertage van 1894 en 1895 traden daadwerkelijk naast historici ook een kunsthistoricus en twee economen op. Op de bijeenkomst van 1895 waren zelfs twee van de drie inhoudelijke voordrachten van economisch-historische aard. In een lezing over de inrichting van het historisch onderwijs aan de universiteit onderstreepte de Grazer hoogleraar Von Zwiedineck-Südenhorst in dat jaar bovendien het belang van de cultuurgeschiedenis en sloot hij zich aan bij de verdeling van het historisch domein die Bernheim in zijn leerboek had gegeven. ${ }^{80}$ Bij de opening van deze Historikertag had Lamprecht al de onvermijdelijk naderende Umwälzung van de geschiedwetenschap aangekondigd in deze tijden van verandering. ${ }^{81}$

Aan het begin van 1896 had Lamprecht derhalve goede redenen om de toekomst met vertrouwen tegemoet te zien. Hij was hoogleraar aan een van de grootste universiteiten van het land en had een vooraanstaande positie verworven in het

${ }^{75}$ Bericht (1893), 8; in de pers die deze en volgende Historikertage aandachtig volgde, werd aan deze uitspraak van 'der berühmte Wirtschaftshistoriker Lamprecht' veel waarde gehecht, zie Schumann (1975), 29n1.

${ }^{76}$ Zie Bericht (1895), 30-35.

${ }^{77}$ Tussen 1893 en 1914 werden er uiteindelijk dertien georganiseerd. In het Interbellum volgden er nog zes.

${ }^{78}$ Zie Tabel 2.2

${ }^{79}$ Bericht (1893), 24.

${ }^{80}$ Bericht (1895), 5-9. Von Zwiedineck (1845-1908) was degene die als Privatdozent in Graz in 1878-1880 de eerste referaten over cultuurgeschiedenis had verzorgd voor de Jahresberichte der Geschichtswissenschaft.

${ }^{81}$ Bericht (1895), 2. 
regionaalhistorisch onderzoek, op de nieuwe Historikertage en in de nieuwe vakorganisatie, de VDH. De eerste vijf delen van zijn Deutsche Geschichte (eerste druk: 1891-1895) waren al toe aan een tweede oplage; van het eerste deel waren binnen drie jaar 2000 exemplaren verkocht. ${ }^{82}$ Ongetwijfeld in verband met de ondersteuning die het cultuurhistorisch onderwijs van keizerlijke wege had gekregen, was zijn werk onder andere populair bij leraren. ${ }^{83}$ Met ingang van de jaargang 1896 werd hij ook nog eens een van de hoofdredacteuren van de meest directe concurrent van de Historische Zeitschrift, de in 1889 opgerichte Deutsche Zeitschrift für Geschichtswissenschaft. ${ }^{84}$

De tijd leek rijp voor zijn frontale aanval op de 'oude richtingen' in de geschiedwetenschap en voor het uitvoerige pleidooi voor een alternatieve, cultuurhistorische benadering van het verleden dat Lamprecht tijdens de vierde Historikertag in september van dat jaar aan de vakgenoten wilde voorleggen. ${ }^{85}$

${ }^{82}$ Aldus Chickering (1993), 178.

${ }^{83}$ Aldus Bernheim (1908), 716, die als geschieddidacticus extra goed op de hoogte geweest zal zijn van de stemming onder leraren: 'Wie man auch über das Werk [Lamprechts DG] urteilen mag, es hieße den offenbarsten Tatsachen widersprechen, wenn man leugnen wollte das es in den weitesten Kreisen Einfluß ausübt [...] namentlich auch der Lehrer, da hier zu der allgemeinen Vorliebe für das Kulturgeschichtliche bei uns hinzukommt, daß durch die Verordnungen von 1890 bis 1894 [m.b.t. het lager en middelbaar onderwijs] die Behandlung der socialen und wirtschaftlichen Elemente in allen Schulgattungen geboten worden ist und sich das am bequemsten in Lamprechts Deutscher Geschichte findet: man beachte nur, wie z. B. in der Skizze des demgemäß zu bietenden Lehrstoffes für Intersekundaner in den Verhandlungen der Direktorenversammlungen in Preußen 1893 [...] Lamprecht benutzt ist.'

${ }^{84}$ Zie daarover Chickering (1993), 165-166.

${ }^{85}$ In een brief aan Meinecke (!) schreef Lamprecht op 11 februari 1896: 'Mir scheint, es wäre wirklich nutzbringend, kämen wir zu einer Diskussion der erkenntnistheoretischen Grundlagen unseres Faches ganz im allgemeinen. [...] Dann habe ich für den Historikertag das Referat über kulturgeschichte übernommen und möchte mir dort erneut [...] systematisch äußern.' Brief opgenomen in Schieder (1959), 101. Lamprecht was ten tijde van de Historikertag ziek en kon zijn voordracht niet houden, hij publiceerde echter in dezelfde maand wel het resultaat van zijn eerste 'systematische' bespiegelingen over cultuurgeschiedenis: Lamprecht (1896/97).

${ }^{88}$ Aly (1895), 213. 
Tabel 2.2

\section{Organiserend bestuur van de Historikertage respectievelijk van het bestuur van de Verband} Deutscher Historiker, 1893-1913

* $\quad$ 1893: initiatiefnemers van de eerste Historikertag

$\mathrm{O}=\quad$ in 1893 gekozen Ortsausschuß (lokaal comité) ter voorbereiding van de tweede Historikertag

$\dagger=\quad$ in 1894 door de vergadering gekozen comité ter organisatie van de volgende Historikertag

$\mathrm{G}=\quad$ (op voordracht van het bestuur) nieuw door de vergadering gekozen VDH-bestuur

$\mathrm{H}=\quad$ opnieuw gekozen na afloop zittingstermijn

$\mathrm{C}=$ gecoöpteerd door het bestuur

$+=\quad$ lid bestuur op grond van verkiezing in een eerder jaar

$(v)=$ de nieuwe voorzitter, in de loop van de bijeenkomst gekozen op voordracht van het bestuur door de vergadering; hij leidde de $\mathrm{VDH} \mathrm{t} / \mathrm{m}$ de volgende bijeenkomst.

\begin{tabular}{|c|c|c|c|c|c|c|c|c|c|c|c|c|c|}
\hline & 1893 & $1894^{\dagger}$ & 1895 & 1896 & 1898 & 1900 & 1903 & 1904 & 1906 & 1907 & 1909 & 1911 & 1913 \\
\hline Lossen & $*$ & & & & & & & & & & & & \\
\hline Quidde & $*$ & & & & & & & & & & & & \\
\hline Stieve & $*$ & G & G & $\mathrm{G}(\mathrm{v})$ & + & & & & & & & & \\
\hline Zwiedineck-Südenhorst & $*$ & G & $\mathrm{G}(\mathrm{v})$ & $\mathrm{G}$ & + & + & $\mathrm{H}$ & + & + & & & & \\
\hline Heigel & $*$ & & $\mathrm{G}(\mathrm{v})$ & G & + & $\mathrm{C}$ & $\mathrm{C}$ & $\mathrm{C}$ & G & + & + & $\mathrm{H}$ & + \\
\hline Wachsmuth & & G & & & & & & & & & & & \\
\hline Arndt & $\mathrm{O}$ & G & & & & & & & & & & & \\
\hline Hansen & & $\mathrm{G}$ & $\mathrm{G}$ & $\mathrm{G}$ & $\mathrm{H}$ & + & + & $\mathrm{G}$ & + & + & $\mathrm{H}$ & + & $+(\mathrm{v})$ \\
\hline Lamprecht & $\mathrm{O}(\mathrm{v})$ & $\mathrm{G}(\mathrm{v})$ & $\mathrm{G}$ & $\mathrm{G}$ & + & + & $\mathrm{H}$ & + & + & $\mathrm{H}$ & + & + & $\mathrm{H}$ \\
\hline Weech & & G & G & G & $\mathrm{H}$ & + & + & G & & & & & \\
\hline Marcks & & G & G & & & $?(\mathrm{v})$ & G & + & & & & & \\
\hline Prutz & & G & G & G & + & $\mathrm{H}$ & + & + & & & & & \\
\hline Baldamus & $\mathrm{O}$ & G & & & & & & & $\mathrm{C}$ & & & & \\
\hline Meyer, Eduard & & & G & G & + & + & $\mathrm{H}$ & + & + & $\mathrm{H}$ & + & + & $\mathrm{H}$ \\
\hline Ulmann & & & G & G & $\mathrm{H}$ & + & + & G & + & + & $\mathrm{H}$ & + & \\
\hline Bachmann & & & G & & $\mathrm{C}$ & $\mathrm{C}$ & $\mathrm{C}$ & $\mathrm{C}$ & G & & & & \\
\hline Stä(h)lin & & & G & G & $\mathrm{H}$ & + & + & G & & & & & \\
\hline Kaltenbrunner & & & G & G & + & & & & & & & & \\
\hline Köcher & & & G & G & + & + & & & & & & & \\
\hline Hartwig & & & G & & & & & & & & & & \\
\hline Meyer von Knonau & & & & G & + & $\mathrm{H}$ & + & + & $\mathrm{H}$ & + & + & $\mathrm{H}$ & + \\
\hline Vogt & & & & G & + & + & & & & & & & \\
\hline Weber & & & & G & & & & & & & & & \\
\hline Huber & (v1) & & & $\mathrm{G}$ & + & & & & & & & & \\
\hline Gothein & & & & $\mathrm{G}$ & + & & & & & & & & \\
\hline Kaufmann, G. & & & & & $\mathrm{G}(\mathrm{v})$ & + & + & G & + & + & $\mathrm{H}$ & + & + \\
\hline Below & & & & & $\mathrm{C}$ & G & + & + & $\mathrm{H}$ & + & + & $\mathrm{H}$ & + \\
\hline Meinecke & & & & & $\mathrm{C}$ & $\mathrm{C}$ & G & + & + & $\mathrm{H}$ & + & + & $\mathrm{H}$ \\
\hline Redlich & & & & & $\mathrm{C}$ & G & $+(\mathrm{v})$ & + & G & + & + & + & + \\
\hline Egelhaaf & & & & & & $\mathrm{C}$ & $\mathrm{C}$ & $\mathrm{C}$ & $\mathrm{C}$ & G & + & + & \\
\hline Seeliger & & & & & & $\mathrm{C}$ & $\mathrm{C}$ & $\mathrm{C}$ & $\mathrm{G}(\mathrm{v})$ & + & + & $\mathrm{H}$ & + \\
\hline Schäfer, Dietrich & & & & & & G & & & & & & & \\
\hline Mühlbacher & & & & & & & G & & & & & & \\
\hline Scala & & & & & & & $\mathrm{C}$ & $\mathrm{C}(\mathrm{v})$ & & & & & \\
\hline Gelzer & & & & & & & & $\mathrm{G}$ & + & & & & \\
\hline Busch & & & & & & & & $\mathrm{C}$ & G & + & + & $\mathrm{H}$ & + \\
\hline Rietschel & & & & & & & & $\mathrm{C}$ & & & & & \\
\hline Ermisch & & & & & & & & & $\mathrm{C}$ & G & + & + & $\mathrm{H}$ \\
\hline $\mathrm{Ge} ß$ & & & & & & & & & $\mathrm{C}$ & & & & \\
\hline Lindner & & & & & & & & & $\mathrm{C}$ & & & & \\
\hline Breßlau & & & & & & & & & & $\mathrm{G}(\mathrm{v})$ & + & + & $\mathrm{H}$ \\
\hline Dopsch & & & & & & & & & & $\mathrm{C}$ & $\mathrm{C}$ & $\mathrm{C}$ & $\mathrm{C}$ \\
\hline Rachfahl & & & & & & & & & & $\mathrm{C}$ & $\mathrm{C}$ & $\mathrm{C}$ & $\mathrm{C}$ \\
\hline Werunsly & & & & & & & & & & $\mathrm{C}$ & $\mathrm{C}$ & $\mathrm{C}$ & $\mathrm{C}$ \\
\hline Brandi & & & & & & & & & & & $\mathrm{G}(\mathrm{v})$ & + & + \\
\hline Neumann & & & & & & & & & & & $\mathrm{C}$ & $\mathrm{C}$ & $\mathrm{C}$ \\
\hline Ottenthal & & & & & & & & & & & & $\mathrm{G}(\mathrm{v})$ & + \\
\hline Schulte, Aloys & & & & & & & & & & & & & G \\
\hline Ilgen & & & & & & & & & & & & & $\mathrm{C}$ \\
\hline & 1893 & 1894 & 1895 & 1896 & 1898 & 1900 & 1903 & 1904 & 1906 & 1907 & 1909 & 1911 & 1913 \\
\hline
\end{tabular}




\section{Terugslag en doorbraak (1896-1915 en verder)}

Om exact dezelfde redenen achtten degenen die eerder hadden ingestemd met Schäfers geschiedopvattingen dat het hoog tijd werd voor een tegenoffensief. Toen in 1895 de klassiek filoloog Friedrich Aly in de Preußische Jahrbücher de historische discipline opriep eindelijk eens 'tegen de banale vervlakking van de geschiedschrijving' in het geweer te komen en 'het indringen van het materialisme in de historische wetenschappen' tot staan te brengen, werd hij op zijn wenken bediend ${ }^{88}$ Hadden tot dan toe uitsluitend Schäfer, Ritter en Below zich publiekelijk tegen de nieuwe richting uitgesproken, nu meldden zich in korte tijd behalve opnieuw Below (1896, 1898, 1899), ook Rachfahl (1895, 1896, 1897), Treitschke (1896), Finke (1896, 1897), Lenz, (1896, 1898), Meinecke (1896, 1897), Hermann Oncken (1897; 1898), Schnürer $(1897,1900)$ en Delbrück $(1897,1898)$ als woordvoerders van de gevestigde opvattingen.

Hun wapen was de kritische bespreking, waarin behalve de levensbeschouwelijke correctheid ook het vakmanschap van Lamprecht in twijfel werden getrokken. ${ }^{89}$ Meer verborgen voor het publiek werden academische bevorderingen en benoemingen nu met extra aandacht en zorg bewaakt. Om te beginnen werd Lamprechts overname van de Historische Zeitschrift na het overlijden van de oprichter Sybel in 1895 verhinderd, evenals zijn mogelijke benoeming op Treitschkes leerstoel in Berlijn een jaar later. ${ }^{90}$ Lamprecht vertrok met ruzie uit de redactie van de Deutsche Zeitschrift für Geschichtswissenschaft, die prompt werd omgedoopt tot Historische Vierteljahrsschrift en die evenmin als de Historische Zeitschrift nog bijdragen van zijn hand zou publiceren. ${ }^{91}$ Ook de belangrijkste andere nieuwe cultuurhistorici hadden nauwelijks nog toegang tot deze twee algemene vaktijdschriften en hun werk werd er kritisch in besproken. ${ }^{92}$

Veel hele of halve medestanders van Lamprecht werden in hun loopbaan gehinderd. ${ }^{94}$ Onder de laatsten was binnen de discipline het meest prominente lid de jonge en veelbelovende Berlijnse extraordinarius voor Pruisische geschiedenis, Kurt Breysig, die zich vanaf 1896 uitdrukkelijk aan de kant van de vernieuwers schaarde. In 1900 publiceerde hij een omvangrijke Kulturgeschichte der Neuzeit waarin hij 'gevoelsstromingen' de dragers van alle historische processen noemde en verklaarde dat de psychologische duiding het einddoel van de historische analyse moest zijn. ${ }^{95}$ Breysigs poging om in 1908 een Seminar für vergleichende Geschichtsforschung op te richten, liep door het verzet van de overige historici van de faculteit op niets uit.

\footnotetext{
${ }^{89}$ Zie hierover Hoofdstuk 5.

${ }^{90}$ Zie hierover Schieder (1959).

${ }^{91}$ Zie Chickering (1993), 272-273.

${ }^{92}$ Lamprecht en Gothein publiceerden elk slechts twee vroege artikelen in de HZ, Steinhausen en
} Breysig geen enkele bijdrage. In de Historische Vierteljahrschrift verscheen geen enkele zelfstandige studie van een van de cultuurhistorici meer; alleen Goetz schreef nog een enkel in memoriam en een reeks recensies voor het blad

${ }^{94}$ Te denken valt aan de moeizame carrières van de met Lamprecht verbonden jongere wetenschappers Buchholz, Goldfriedrich, Kötzschke, Rein, Tille, Menke-Glückert; zie voor hun wederwaardigheden: Chickering (1993) en Blanke (1994), 145-151.

${ }^{95}$ Breysig (1900), XI, XXVI, 31-32, 286-291. 
Ernstiger was dat hij tot 1923 moest wachten voor hij een ordinariaat wist te bemachtigen. Ook Gothein - die in 1896 nog was toegetreden tot het bestuur van de Verband Deutscher Historiker - slaagde er niet meer in om van zijn economische leerstoel over te stappen naar een historische leerstoel. Daarentegen werden verschillende uitgesproken tegenstanders van Lamprecht (Finke, Meinecke, Rachfahl, Oncken) wel 'beloond' met een historisch ordinariaat (respectievelijk in 1897, 1901, 1903, 1906).

Toch was de overwinning van de 'oude richting' (in Lamprechts termen) volledig noch blijvend. De strijd rond Lamprechts geschiedopvattingen bracht een tijdelijke terugslag voor de vernieuwing van de Duitse geschiedschrijving, maar geen genadeklap. De meeste schade werd toegebracht aan de reputatie van Lamprecht en zijn medestanders. Aan het eind van zijn leven behoorde Lamprecht tot de Klasse der Gutverleumdeten zoals hij zelf publiekelijk en met de nodige spot kon vaststellen. ${ }^{97}$ Slechts een enkele historicus durfde na 1896 nog publiekelijk te verkondigen dat hij het eens was met Lamprecht. Zoals Otto Hintze die in 1897 verklaarde in te stemmen met althans een 'hoofdzaak' van Lamprecht, namelijk: 'dat de historische wetenschap gestoeld dient te worden op de brede basis van vèr reikend sociaalpsychisch onderzoek'. ${ }^{98}$

Buiten historische vakkringen en in het buitenland (met name onder historici in Amerika en Frankrijk) bleef het oordeel over de Leipzigse historicus en andere nieuwe cultuurhistorici beduidend positiever dan onder Duitse historici. ${ }^{99}$ Economen als Schmoller, Eulenburg en Oppenheimer, de filosoof, socioloog en pedagoog Paul Barth, psychologen als Spranger, Hellpach en Pflaum, alsmede veel kunsthistorici recipieerden vooral Lamprechts en Breysigs werk met waardering. ${ }^{100}$ Binnen de Leipzigse academische gemeenschap - waar Lamprecht goede contacten onderhield met Ostwald, Ratzel, Wundt en andere vooraanstaande wetenschappers - was zijn aanzien zo hoog dat hij in 1910 nog tot rector van de universiteit werd gekozen.

Op institutioneel vlak werd Lamprechts invloed slechts ten dele teruggedrongen. Tot 1903 bleef hij de nationale bijeenkomsten van regionaalhistorische instellingen leiden; daarna nam zijn medestander Kötzschke als permanent secretaris de feitelijke organisatie van deze bijeenkomsten over. ${ }^{101}$ Tot zijn dood werd Lamprecht ook telkens opnieuw gekozen in het bestuur van de Verband deutscher Historiker, al kreeg hij daarbinnen steeds meer te maken met tegenstanders van zijn benadering van de geschiedenis. In 1896 en in 1898 hadden verschillende sprekers op de Historikertage gepleit voor de vernieuwing van de geschiedwetenschap; in 1898 hielden zowel Lamprecht als Steinhausen nog een lezing waarin de betekenis van de cultuurgeschiedenis werd verdedigd. Daarna eisten steeds vaker tegenstanders van de vernieuwing het woord op, maar ook in 1903 (Gothein) en in 1907 (Lamprecht), kregen vernieuwers nog de gelegenheid het woord te richten tot de verzamelde vakgenoten. Ook traden zowel Lamprecht als Breysig op als sprekers tijdens het internationale congres van historici dat in 1908 in Berlijn werd georganiseerd.

Belangrijker was dat niet alleen Lamprecht maar ook Gothein en Breysig bestuurslid bleven van vooraanstaande regionaal-historische instellingen. Bovendien wist Lamprecht zijn historische leerstoel in Leipzig uit te bouwen tot een zelfstandig

\footnotetext{
${ }^{97}$ Lamprecht (1913), 428.

${ }^{98}$ Hintze (1982), 320-321 (verschenen in de HZ (!) van 1897).

${ }^{99}$ Zie daarover: Schorn-Schütte (1993), Sammler (1993), en genuanceerd: Becher (1994).

${ }^{100}$ Zie Stoffers (2003), 175-178.

${ }^{101}$ Zie Bericht (1896), 55-56, 62 en 64, Bericht (1898), 58, Bericht (1903), 43.

${ }^{103} \mathrm{Zie}$ voor de geschiedenis van het IKU de uitvoerige studie van Middell (2005).
} 
en innovatief Institut für Kultur- und Universalgeschichte (1909), waaraan na 1914 bovendien nog een apart onderzoeksinstituut werd toegevoegd. ${ }^{103}$ Daardoor slaagde hij erin een centrum voor universitair onderwijs en onderzoek op het terrein van de cultuurgeschiedenis te scheppen dat zijn dood overleefde en in het Interbellum opnieuw van betekenis kon worden. Dat gold overigens ook voor de regionaalhistorische instituties, waarbinnen de cultuurgeschiedenis vaak veel aandacht kreeg.

De strijd die binnen de discipline geleverd werd over de richting die het geschiedwetenschappelijk onderwijs en onderzoek diende in te slaan, droeg feitelijk bij aan de institutionele uitbouw van de discipline: de nieuwe cultuurhistorici stimuleerden de vorming van nieuwe disciplinaire instellingen waarin zij hun geschiedbenadering konden laten gelden. Dat was ook het geval bij de vaktijdschriften. De Zeitschrift für Kulturgeschichte had weliswaar te lijden onder de Lamprechtstrijd, zoals onder andere bleek uit de afname van het aantal hooggeleerde auteurs. ${ }^{104}$ Maar het tijdschrift verdween niet van het toneel, zoals haar kortstondige voorgangers, en dat gebeurde evenmin met de in 1893 opgerichte Zeitschrift für Sozial- und Wirtschaftsgeschichte. Op initiatief van Lamprecht en met medewerking van Breysig werd in 1899 nog een nieuw vakblad opgericht, de Deutsche Geschichtsblätter die onder leiding van Lamprechts medestanders Armin Tille en Rudolf Kötzschke tot 1920 zouden blijven bestaan. ${ }^{105}$ Hoewel expliciet opgericht als forum voor de landesgeschichtliche Forschung, publiceerde het blad veel algemene cultuurhistorisch georiënteerde bijdragen, bijvoorbeeld over 'medizinische Kulturgeschichte', 'verkeersgeschiedenis' of 'bevolkingsstatistiek'. Verder riep Lamprecht voor zijn promovendi ook nog een aantal publicatiereeksen (mede) onder zijn redactie in het leven. ${ }^{106}$

In het algemeen kan worden opgemerkt dat noch het aantal cultuurhistorische, noch economisch- of sociaal-historische publicaties afnam. In de Jahresberichte der Geschichtswissenschaft groeide het aantal titels in de rubriek 'cultuurgeschiedenis' tot 1700 voor het jaar 1899, waarna men besloot de rubriek verder op te delen. Zelfs in de Historische Zeitschrift nam het aantal cultuurhistorisch geaarde bijdragen vanaf 1900 gestaag toe. ${ }^{12}$ In het door Lamprechts tegenstanders Below en Meinecke uitgegeven meerdelige Handbuch der mittelalterlichen und neueren Geschichte (1903-) werden afzonderlijke delen gewijd aan historische geografie (1904), aan economische geschiedenis (1906), en zelfs aan een onderwerp als 'het huiselijk leven van de Europese cultuurvolkeren' (1903).

$\mathrm{Na}$ verloop van tijd waagde ten slotte opnieuw een hoogleraar het om zich expliciet voor de cultuurgeschiedenis te engageren: in 1910 trad de Tübingse mediëvist Walter Goetz toe tot de redactie van Steinhausens inmiddels tot Archiv für Kulturgeschichte omgedoopte tijdschrift en publiceerde daarin een hernieuwd pleidooi voor de cultuurgeschiedenis. Goetz stelde vast dat ondanks de Lamprechtstrijd de

${ }^{104}$ Zie Tabel 2.4.

${ }^{105}$ Zie Chickering (1993), 293, en Schorn-Schütte (1984b), 402 e.v. Ook Breysig was betrokken bij de oprichting van het blad en maakte deel uit van de redactieraad.

${ }^{106}$ Het gind om zesendertig Leipziger Studien aus dem Gebiet der Geschichte (1894-1902), circa twintig Geschichtliche Untersuchungen (1902-1909) en veertig Beiträge zur Kultur- und

Universalgeschichte (1906-1917); voor een titellijst van de laatste reeks, zie Middell (2005), 1123 e.v.

${ }^{112}$ Zie Tabel 2.3. Vgl. ook Schieder (1959), 51.

${ }^{114}$ Goetz (1910), 5. 
belangstelling voor de cultuurgeschiedenis onder een jongere generatie historici alleen maar was toegenomen. ${ }^{114}$ Goetz verdedigde het goede recht van deze belangstelling, maar deed tegelijk erg zijn best om de 'oude' en 'nieuwe' richtingen met elkaar te verzoenen. Dat deed hij onder andere door zich in zijn omschrijving van cultuurgeschiedenis expliciet rekenschap te geven van het belang van de staat. De kern van de cultuurgeschiedenis vormde voor hem echter de Geistesgeschichte. ${ }^{115}$

Goetz' verzoeningspoging had succes. Hij wist onder andere Dilthey en Troeltsch te winnen voor het Archiv en het tijdschrift voor het overgrote deel te vullen met bijdragen van universitaire wetenschappers, onder wie kunsthistorici, literatuurhistorici, sociologen, een enkele econoom en veel historici. Het aantal hoogleraren geschiedenis dat in het blad schreef nam direct na Goetz' bemoeienis sterk toe. ${ }^{116}$ Een indicatie voor het gestegen aanzien van het cultuurhistorische vakblad binnen de historische discipline was ook de toename van het aantal auteurs dat zowel bijdragen leverde aan de Historische Zeitschrift als aan het Archiv für Kulturgeschichte: ook hier kwam het Goetz-effect duidelijk tot uitdrukking. ${ }^{117}$ Toen Goetz na het overlijden van Lamprecht in 1915 bovendien de leiding over diens Leipzigse Institut für Kultur- und Universalgeschichte overnam en het voortbestaan ervan verzekerde, werd zijn betekenis voor de stimulering van de cultuurgeschiedenis binnen de historische discipline alleen maar groter. Hij moet zonder de twijfel gelden als de centrale figuur van de Duitse cultuurgeschiedschrijving in het Interbellum, die de doorbraak van deze richting binnen de Duitse historische vakwetenschap zonder meer heeft bespoedigd.

Dat van een doorbraak gesproken mag worden, blijkt uit een blik op de jaren twintig en dertig. Onder de nieuwe lichting geschiedwetenschappers waren meer hoogleraren dan ooit die de cultuurgeschiedenis als een belangrijk werkterrein beschouwden. De voornaamste voorbeelden zijn, behalve Goetz zelf: Karl Hampe (ordinarius vanaf 1903), Alfons Dopsch (ordinarius vanaf 1900), Fritz Kern (ordinarius vanaf 1914), Justus Hashagen (ordinarius vanaf 1920, leerling van Lamprecht), Bernhard Schmeidler (ordinarius vanaf 1927), Percy Ernst Schramm (ordinarius vanaf 1929), Wilhelm Bauer (ordinarius vanaf 1930) en Herbert Grundmann (ordinarius vanaf 1939, leerling van Goetz). Als we deze lijst uitbreiden met hoogleraren die zich vooral op het meer specialistische economisch-historische terrein bewogen dan kunnen we nog een reeks andere namen noemen, onder wie een aantal vroege leer- of beschermelingen van Lamprecht: Ernst Daenell (ordinarius vanaf 1913), Fritz Curschmann (ordinarius vanaf 1928), Rudolph Kötzschke (ordinarius vanaf 1930).

\footnotetext{
115 Goetz (1910), 13-15.

${ }^{116}$ Zie Tabel 2.4

${ }^{117}$ Zie Tabel 2.5
} 
Tabel 2.3

Indicatieve titelanalyse van artikelen verschenen in de Historische Zeitschrift 1859-1943

\begin{tabular}{|c|c|c|c|c|c|c|c|c|c|c|c|c|c|c|c|c|c|}
\hline $\begin{array}{l}\text { totaal aantal } \\
\text { artikelen }\end{array}$ & 95 & 83 & 106 & 102 & 103 & 93 & 125 & 107 & 92 & 110 & 125 & 95 & 106 & 122 & 127 & 139 & 126 \\
\hline $\begin{array}{l}\text { aantal artikelen } \\
\text { met in de titel: }\end{array}$ & 4 & 2 & 4 & 4 & 4 & 4 & 3 & 4 & 6 & 7 & 9 & 3 & 16 & 12 & 18 & 5 & 6 \\
\hline $\begin{array}{l}\text { *kirch", *geistl" } \\
{ }^{*} \text { relig }^{*}\end{array}$ & $\bullet$ & •• & ... & $\cdots$ & $\cdots$ & • & - & & •• & $\cdots$ & $\cdots$ & & • & $\ldots$ & - & - & \\
\hline *ku/ünst" & - & & & & & & & & • & .• & - & • & $\ldots$ & & .• & & \\
\hline $\begin{array}{l}{ }^{*} \text { soz/cial* } \\
{ }^{*} \text { soz/ciol* }\end{array}$ & & & & & & •• & - & $\cdots$ & & & & - & - & & - & & • \\
\hline $\begin{array}{l}\text { *wirtschaft" } \\
\text { *ökon* }\end{array}$ & & & & & & & - & & & & & & & - & $\cdots$ & & • \\
\hline *c/kultur* & - & & - & & & & & . & ... & & .• & & .• & ..... & ..... & .• & • \\
\hline $\begin{array}{l}{ }^{*} \text { geist }^{*} \\
{ }^{*} \text { psych }^{*},{ }^{*} \text { seel }\end{array}$ & & & & & & - & & & & & $\ddot{\bullet}$ & • & $\cdots$ & .• & $\cdots$ & .• & $\ddot{\bullet}$ \\
\hline $\begin{array}{l}\text { vijfjaarlijkse } \\
\text { perioden 1859- } \\
1943\end{array}$ & $\left|\begin{array}{c}18 . . \\
59- \\
63\end{array}\right|$ & $\mid \begin{array}{r}64- \\
68\end{array}$ & $\left|\begin{array}{r}69- \\
73\end{array}\right|$ & $\begin{array}{r}74- \\
78\end{array}$ & $\left|\begin{array}{r}79- \\
83\end{array}\right|$ & \begin{tabular}{|r|}
$84-$ \\
88
\end{tabular} \mid & $\begin{array}{r}89- \\
93\end{array}$ & $\begin{array}{r}94- \\
98\end{array}$ & $\left|\begin{array}{c}19 \\
99- \\
03\end{array}\right|$ & $\mid \begin{array}{c}. \\
04- \\
08\end{array}$ & $\left|\begin{array}{c}09- \\
13\end{array}\right|$ & $\left|\begin{array}{c}14- \\
19^{\circ}\end{array}\right|$ & $\left|\begin{array}{c}20- \\
24\end{array}\right|$ & $25-$ & $\begin{array}{r}30- \\
34\end{array}$ & $\left|\begin{array}{r}35- \\
39\end{array}\right|$ & $40-$ \\
\hline
\end{tabular}

• In 1918 en 1944 verscheen de HZ niet.

Toelichting: Elke stip staat voor één bijdrage waarvan de titel de linksgenoemde woorddelen bevat. Sommige titels bevatten overigens meer dan een van de genoemde woorddelen. In de tabel is de relatief sterke toename van het aantal cultuurhistorisch getinte titels in de jaren 1920-1934 af te lezen (waarbij 'cultuur' conform de opvatting van de nieuwe cultuurhistorici in de brede betekenis van het woord wordt opgevat, dit wil zeggen inclusief economie, samenleving, religie). In het totaal gaat het over de hele periode om 103 van dergelijke titels. Ter vergelijking: de woorddelen ${ }^{*}$ polit $^{*}$, ${ }^{*}$ staat $^{*}$, ${ }^{*}$ krieg $^{*}$ en ${ }^{*}$ diplomat $^{*}$ komen meer dan tweemaal zo vaak voor: in 271 titels van de in totaal $1856 \mathrm{HZ}$-bijdragen uit de periode 1859-1943.

De getoonde cijfers geven natuurlijk slechts een indicatie van de conjunctuur van cultuurhistorische titels in de HZ: niet alle cultuurhistorisch relevante bijdragen zijn aan de getraceerde woorddelen te herkennen. Omgekeerd zijn niet alle gevonden titels cultuurhistorisch relevant. Van de drieëndertig titels over kerk en religie gaat bijvoorbeeld een aanmerkelijk deel over de verhouding van kerk en staat; alleen al tien van deze titels bevatten ook de woorddelen *staat* of *polit*. De belangstelling voor deze thematiek in de jaren zeventig die uit de tabel naar voren komt, is ongetwijfeld terug te voeren op de Kulturkampf die Bismarck voerde tegen de katholieke kerk.

De analyse is uitgevoerd op grond van de elektronische inhoudsopgave van de $H Z$ zoals te vinden in het Zeitschriftenfreihandmagazin van de Erlanger Historikerseite (http://www.phil.unierlangen.de/ p1ges/home.html). 
Tabel 2.4

Aantal artikelen gepubliceerd door Duitse (inclusief Zwitserse en Oostenrijkse) ordinarii voor geschiedenis in de ZfK en Afk 1894-1943

\begin{tabular}{|c|c|c|c|c|}
\hline $\begin{array}{l}\text { perioden van vijf } \\
\text { opeenvolgende } \\
\text { jaargangen }\end{array}$ & $\begin{array}{l}\text { totaal aantal } \\
\text { gepubliceer- } \\
\text { de artikelen }\end{array}$ & $\begin{array}{l}\text { aantal artikel- } \\
\text { en geschreven } \\
\text { door PO (en } \\
\% \text { ) }\end{array}$ & $\begin{array}{l}\text { aantal artikelen } \\
\text { geschreven door PO }\end{array}$ & namen van $\mathrm{PO}$ in de $\mathrm{Z} / \mathrm{AfK}$ \\
\hline 1894-1898 & 95 & $8(8,4 \%)$ & $\bullet \bullet \bullet \bullet \bullet \bullet$ & $\begin{array}{l}\text { Caro, Bezold, Gelzer }(H) \text {, Krones } \\
(2 x) \text {, Lamprecht }(2 x) \text {, Wegele, }\end{array}$ \\
\hline 1899-1903 & 81 & $4(4,9 \%)$ & $\bullet \bullet \bullet$ & $\begin{array}{l}\text { Gelzer }(\mathrm{H}) \text {, Lamprecht }(2 \mathrm{x}) \text {, Pflugk } \\
\text { Harttung }\end{array}$ \\
\hline 1904-1908 & 92 & $2(2,2 \%)$ & $\bullet$ & Lindner, Meister \\
\hline 1909-1914* & 107 & $15(14,0 \%)$ & ••••••••••••• & $\begin{array}{l}\text { Below (4x), Bezold, Finke, Goetz } \\
(2 x) \text {, Hampe }(2 x) \text {, Heigel, Kaindl, } \\
\text { Pflugk Harttung }(3 x)\end{array}$ \\
\hline $1915-1926^{*}$ & 88 & $7(8,0 \%)$ & $\bullet \bullet \bullet \bullet \bullet$ & $\begin{array}{l}\text { Dopsch, Goetz }(3 x) \text {, Holtzmann, } \\
\text { Kern, Laqueur }\end{array}$ \\
\hline $1927-1931$ & 99 & $13(13,1 \%)$ & $\bullet \bullet \bullet \bullet \bullet \bullet \cdots \bullet \bullet$ & $\begin{array}{l}\text { Dopsch, Finke, Goetz }(4 x) \text {, Hampe } \\
(2 x) \text {, Hashagen, Kern }(3 x) \text {, } \\
\text { Münzer, }\end{array}$ \\
\hline $1932-1936$ & 107 & $22(20,6 \%)$ & 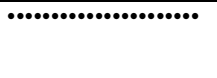 & $\begin{array}{l}\text { Berve (2x), Dopsch, Gelzer (M), } \\
\text { Goetz }(11 x) \text {, Hashagen, Heimpel, } \\
\text { Kern }(3 x) \text {, Ritter }(G) \text {, Schulte }(A)\end{array}$ \\
\hline 1937-1943* & 71 & $12(16,9 \%)$ & $\bullet \bullet \bullet \bullet \bullet \bullet \bullet \bullet \bullet$ & $\begin{array}{l}\text { Andreas }(2 x) \text {, Baethgen, Goetz } \\
(7 x) \text {, Hashagen }(2 x)\end{array}$ \\
\hline
\end{tabular}

* In de periode 1909-1914 verscheen de AfK niet in 1913.

In de periode 1915-1926 verscheen de AfK slechts in de jaren 1916, 1917, 1919, $1923,1926$.

In de periode 1937-1943 verscheen de AfK niet in 1940 en 1942.

Toelichting: Van de 740 artikelen uit de jaargangen 1894-1943 van de Zeitschrift en het Archiv für Kulturgeschichte, werden er drieëntachtig $(11,2 \%)$ geschreven door een gewoon hoogleraar (ordinarius, $\mathrm{PO}$ ) voor geschiedenis. Bovendien werden in ieder geval negen artikelen geschreven door historische extraordinarii (Breysig, Kötzschke, Hashagen, Mentz, Franz). Tenslotte werden nog eens vijfentwintig bijdragen geschreven door wetenschappers die later, maar in ieder geval voor 1943, (extra)ordinarius zouden worden. Dat betekent dat $15,8 \%$ van de artikelen werd geschreven door onderzoekers die vóór 1943 een (extra)ordinariaat voor geschiedenis aan een Duitstalige universiteit zouden bekleden. Ter vergelijking: voor de $H Z$ lag dat percentage in dezelfde periode $10 \%$ hoger $(25,5 \%$ of 293 van de in totaal 1149 artikelen in 1894-1943). Het is overigens opvallend dat dit percentage voor de $\mathrm{HZ}$ in de eerste decennia van haar bestaan (1859-1893) veel hoger lag: niet slechts een kwart, maar bijna de helft van de artikelen werd toen door (aanstaande) hoogleraren geschreven (44,8\% of 317 van de 707 artikelen).

Aan de cijfers in de tabel is af te lezen hoe Steinhausens Zeitschrift für Kulturgeschichte na 1899 de toch al niet overweldigende belangstelling van de kant van historische ordinarii verliest. Vanaf de betrokkenheid van Goetz bij het blad (1909/1910) neemt het aantal ordinarii plotseling sterk toe. In de jaren 1915-1926, wanneer het blad zeer onregelmatig verschijnt, zakt hun aantal weer in, om in het daaropvolgend decennium een hoogtepunt te bereiken. 
Tabel 2.5

De ontwikkeling van het aantal auteurs dat in de periode 1894-1943 zowel in Zeitschrift en Archiv für Kulturgeschichte als in de Historische Zeitschrift publiceerde

\begin{tabular}{|c|c|c|c|}
\hline $\begin{array}{l}\text { Periode van vijf } \\
\text { opeenvolgende } \\
\text { gezamenlijke } \\
\text { jaargangen }\end{array}$ & \multicolumn{2}{|c|}{$\begin{array}{l}\text { Aantal auteurs dat } \\
\text { in deze periode in } \\
\text { beide tijdschriften } \\
\text { publiceerde. }\end{array}$} & namen \\
\hline 1894-1898 & 2 & $\bullet$ & Bezold, Lamprecht \\
\hline $1899-1903$ & 3 & $\cdots$ & Binz, Friedenburg, Gelzer $(\mathrm{H})$ \\
\hline 1904-1908 & 3 & $\cdots$ & Geiger, Müller $(\mathrm{J})$, Werminghoff \\
\hline 1909-1914* & 13 & ............. & $\begin{array}{l}\text { Andreas, Below, Bezold, Brinkmann, Finke, Goetz, Hampe (K), } \\
\text { Heigel, Kern, Von Müller (K.A.), Rapp, Rosenstock, Spranger }\end{array}$ \\
\hline $1915-1926^{*}$ & 9 & $\bullet \bullet \bullet \bullet \bullet$ & $\begin{array}{l}\text { Bergsträßer, Dehio, Goetz, Hashagen, Hessel, Kähler, Kern, Rein, } \\
\text { Stimming }\end{array}$ \\
\hline $1927-1931$ & 9 & $\cdots \cdots \cdots$ & $\begin{array}{l}\text { Bauer (C), Goetz, Hampe (K), Hennig, Körner, Von Martin, } \\
\text { Neumann (C), Rosenberg, Steinberg }\end{array}$ \\
\hline $1932-1936$ & 6 & $\cdots \cdots$ & Baron, Berney, Goetz, Hashagen, Hennig, Ritter (G) \\
\hline $1937-1943^{*}$ & 6 & $\bullet \cdots \cdots$ & Andreas, Hashagen, Hennig, Hochholzer, Sander, Scharff \\
\hline
\end{tabular}

* In de periode 1909-1914 verscheen de AfK niet in 1913.

In de periode 1915-1926 verscheen de AFK slechts in de volgende vijf jaren: 1916, 1917, 1919,

1923, 1926; de $H Z$ verscheen niet in 1918.

In de periode 1937-1943 verscheen de AfK niet in 1940 en 1942.

De 'bijl' van Below en het Lamprecht ontnomen 'aureool' (Rachfahl) ten spijt: er kan geen twijfel over bestaan dat zich in het Interbellum aan de Duitse universiteiten een tot dan toe ongekende bloei van de cultuurgeschiedenis in de brede betekenis van het woord manifesteerde. In de Historische Zeitschrift nam het aantal cultuurhistorische bijdragen in de periode 1920-1935 opmerkelijk toe, terwijl in dezelfde periode in het Archiv für Kulturgeschichte het aantal artikelen dat door hoogleraren werd geschreven naar een hoogtepunt steeg. ${ }^{123}$

Het is de tijd dat ook buiten de historische discipline en buiten de universiteit de cultuurgeschiedenis veel waardering krijgt, de tijd van Spenglers Untergang des Abendlandes (1918-1922), van Warburgs 'Kulturwissenschaftliche Bibliothek' in Hamburg (1919-1933), van Groethuysens Entstehung der bürgerlichen Welt- und Lebensanschauung (1927-1930), Friedells Kulturgeschichte der Neuzeit (1927-1931), Frobenius' Kulturgeschichte Afrikas (1933), Alfred Webers Kulturgeschichte als Kultursoziologie (1935), en niet in de laatste plaats Elias' Über den Prozess der Zivilisation (1939). Net als in het geval van de cultuurgeschiedenis van de jaren negentig ging het hier telkens om wetenschappelijke projecten die gepresenteerd werden als een geschiedenis van de 'ziel', als 'psychogenetische Untersuchungen', als 'historische Gestaltlehre' - historisch onderzoek derhalve waarin de 'andere' of veranderlijke geestesgesteldheid van mensen in het verleden centraal stond.

De cultuurhistorici van het eerste uur werden in de jaren twintig en dertig min of meer gerehabiliteerd. De oprichter van de Zeitschrift für Kulturgeschichte, Georg Steinhausen, verwierf in deze tijd in Heidelberg als ordentlicher Honorarprofessor met een onderwijsbevoegdheid voor cultuurgeschiedenis de lang gewenste functie aan een universiteit - wellicht op voorspraak van de daar docerende historicus Karl

\footnotetext{
${ }^{123}$ Zie Tabel 2.3 en 2.4
} 
Hampe, een redactielid van het Archiv für Kulturgeschichte en een goede kennis van zowel Goetz als Gothein. ${ }^{124}$ Kurt Breysig werd nu eindelijk verheven tot ordinarius. ${ }^{125}$ En de Historische Zeitschrift publiceerde naar aanleiding van het overlijden van Gothein in 1924 een uitgebreide en positieve bespreking van diens historisch werk. ${ }^{126}$

Eén observator meende in 1930 zelfs alweer de oproep: 'Zurück zu Lamprecht' te beluisteren. ${ }^{127}$ Wetenschappers van naam, zoals de filosoof, pedagoog en psycholoog Eduard Spranger, de vooraanstaande sociaal-psycholoog Willy Hellpach, en de socioloog Hans Freyer, alle drie tijdens hun studie door Lamprecht beïnvloed, betuigden in deze jaren hun kritische waardering voor de Leipzigse historicus. ${ }^{128}$ Hellpach stelde in 1927 in een Festschrift-bijdrage voor Walter Goetz met recht vast dat Lamprecht 'anoniem veel sterker doorwerkt dan meestal erkend en (helaas) vaak toegegeven wordt'. ${ }^{129}$ De opvattingen van de man die tijdens zijn leven door sommige vakgenoten was betiteld als 'ignorant', 'geen serieuze wetenschapper' en zelfs als 'charlatan', werden door de filosoof Ernst Cassirer in de jaren dertig serieus genoeg genomen om er een (overigens niet onkritisch) hoofdstuk van zijn grote studie Das Erkenntnisproblem in de Philosophie und Wissenschaft der neueren Zeit aan te wijden. Zelfs in de Preußische Jahrbücher waarin Lamprecht na 1896 was verketterd, verscheen een decennium na zijn overlijden een lang herdenkingsartikel van de hand van zijn voormalige student Franz Arens, waarin 'het rijke levenswerk van de geniale inspirator' met sympathie werd besproken. ${ }^{131}$

Het is zoals Lamprecht's biograaf Chickering eens terzijde heeft opgemerkt: 'The Methodenstreit did not destroy cultural history in the German historical profession; it brought instead its final diffusion'. ${ }^{132}$ 'And defusion', voegde Chickering daar tussen haakjes nog aan toe: de cultuurgeschiedenis werd in het proces van verbreiding ook 'onschadelijk gemaakt'. Deze vaststelling brengt ons bij de vragen die in de volgende hoofdstukken centraal zullen staan. Wat was de aard van de Duitse cultuurgeschiedschrijving die na 1889 opkwam? En in welke opzichten vormde zij een bedreiging van de gevestigde opvattingen binnen de discipline?

${ }^{124}$ Zie Drüll (1986), 261; Goetz (1934), 35. De gegevens in Haas (1994), 260 zijn niet correct. In het enige artikel over Steinhausen, Herold (2003), wordt niet vermeld wie de hand heeft gehad in Steinhausens benoeming tot honorair hoogleraar. Hampe was op dat moment naast Eugen Täubler en Willy Andreas een van de drie ordinarii voor geschiedenis aan de universiteit van Heidelberg. Hij had als medewerker aan Steinhausens AfK en als goede kennis van zowel Gothein als Goetz zeker affiniteit met de cultuurgeschiedenis. Ook Willy Andreas publiceerde overigens in het AfK. Steinhausens genoegdoening was overigens slechts van korte duur: nadat hij een semester lang gedoceerd had, maakte een ernstige ziekte een einde aan zijn korte en late universitaire carrière.

${ }^{125}$ De Berlijnse historici (Ed. Meyer, Meinecke, Marcks, Vogel, Andreas) keerden zich overigens ook nu nog tegen de benoeming van Breysig, zie Brocke (1971), 109-112.

${ }^{126}$ Hampe (1924).

${ }^{127}$ Westphal (1930), 246.

${ }^{128}$ Voor Spranger, zie Hoofdstuk 1, paragraaf 2. Voor Freyer: Freyer (1926)

${ }^{129}$ Hellpach (1927), 517; zie ook Hellpach (1902).

${ }^{131}$ Zie Arens (1926a), 327; vgl. ook Arens (1926b). Vgl. ook Bruch (1993) en Bruch (1988), 127, over de doorwerking van de vraagstellingen van Lamprecht e.a.

${ }^{132}$ Chickering (1993), 263. 


\title{
De nieuwe cultuurgeschiedenis in vijf
}

\author{
portretten
}

I

n 1902 schreef Kurt Breysig aan Maximilian Harden, de uitgever van het spraakmakende opinieblad Die Zukunft, waaraan Karl Lamprecht en hij veel historische bijdragen leverden: 'In de geschiedenissen van de geschiedwetenschap tegen het jaar 2000 zal zeker staan dat de dingen, die Lamprecht en ik nu ondernemen, een volledige omwenteling van het historisch onderzoek betekenen'. 'Zijn persoon', schreef de econoom Carl Brinkmann in 1927 over Eberhard Gothein, een van de andere hoofdpersonen in dit boek, 'zal in de toekomst ooit vooral gedenkwaardig zijn als die van een strijder voor een nieuw begrip van de geschiedwetenschap'.

Wat wilden de vijf historici die zich in de decennia voor de Eerste Wereldoorlog opwierpen als voorstanders van een academische cultuurgeschiedenis? En in hoeverre wilden zij hetzelfde? Zij vormden in ieder geval geen hechte groep. Hoewel er allerlei onderlinge contacten bestonden tussen Gothein, Steinhausen, Lamprecht, Breysig en Goetz, traden zij geen enkele keer gezamenlijk als vijftal op de voorgrond. Een belangrijke reden daarvoor moet worden gezocht in de strijd die rond Lamprechts geschiedopvattingen losbarstte. Terwijl het Schäfer-Gotheindebat tot veel steunbetuigingen aan de laatste had geleid, onder andere van Steinhausen en Breysig, veroorzaakte de Lamprechtstrijd juist een sterke polarisatie, niet alleen binnen de groep van vakhistorici als geheel, maar ook binnen het kleine aantal historici dat zich uitdrukkelijk voor de cultuurgeschiedenis inzette. ${ }^{3}$

Was het in de eerste jaargang van Steinhausens Zeitschrift für Kulturgeschichte (1894) bijvoorbeeld nog mogelijk dat zowel Gothein als Lamprecht als de oudere Erlanger hoogleraar Von Bezold gebroederlijk naast elkaar publiceerden, na het uitbreken van de Lamprechtstrijd in 1896 werden snel breuklijnen zichtbaar. Al op de Historikertag in september 1896 voelde Gothein zich geroepen om afstand van Lamprecht te nemen, die kort daarvoor in twee publicaties zijn aanval op Ranke en de politieke geschiedschrijving had gelanceerd. Diezelfde publicaties werden op dat moment nog wel met instemming begroet door Steinhausen en stimuleerden Breysig om zelf met zijn kritiek op gevestigde geschiedopvattingen naar buiten te treden. Zowel Lamprecht als Breysig publiceerden in de tweede helft van de jaren negentig nog verschillende malen in Steinhausens Zeitschrift für Kulturgeschichte. Maar na verloop van de tijd - rond 1903 - raakten ook Steinhausen en Lamprecht gebrouilleerd. En zelfs Breysig, met wie Lamprechts relaties tot het eind toe respectvol en

\footnotetext{
${ }^{1}$ Geciteerd in: Brocke (1971), 55.

${ }^{2}$ Brinkmann (1927), 313.

${ }^{3}$ Hier kunnen we ook opmerken dat Bernheim, die vóór 1895 nog voor de cultuurgeschiedenis in het krijt was getreden, daarna vooral duidelijk probeerde te maken dat hij het niet met zijn oud-student Lamprecht eens was.
} 
vriendschappelijk bleven, voelde zich bij verschillende gelegenheden geroepen om zich te distantiëren van de opvattingen van Lamprecht. Goetz, ten slotte, verbond zich wel met Steinhausens Archiv für Kulturgeschichte, maar profileerde zich bij zijn eerste optreden als cultuurhistoricus uitdrukkelijk als een criticus van Lamprecht, om pas later met meer waardering over zijn voorganger te spreken.

Vanwege het individuele optreden van de Duitse cultuurhistorici in de periode 1889-1915 en hun onderlinge meningsverschillen heb ik ervoor gekozen om hun werk te presenteren in vijf zelfstandige intellectuele portretten. De portretten volgen elkaar min of meer chronologisch op, waarbij de volgorde wordt bepaald door het moment waarop de geportretteerde historicus voor het eerst expliciet in de publiciteit trad als verdediger van de cultuurgeschiedenis: 1889 in het geval van Gothein, 1891 in het geval van Steinhausen, 1896 in het geval van Lamprecht en Breysig en 1910 in het geval van Goetz. In elk portret zal ik aandacht besteden aan de receptie van het werk van de ene cultuurhistoricus door de overige cultuurhistorici. Op deze manier is het niet alleen goed mogelijk de onderlinge wisselwerking tussen de verschillende cultuurhistorici te laten zien, maar ook eventuele verschuivingen die in de loop van twee decennia binnen de Duitse cultuurgeschiedschrijving plaatsvonden. Zoals gaandeweg duidelijk zal worden, vormden de Duitse cultuurhistorici uit de periode 1889-1915 weliswaar geen hecht samenwerkende groep maar wel degelijk een samenhangende historiografische stroming. Hun aandacht voor het belang van een vorm van historische psychologie voor de historicus was daarbij een van de gemeenschappelijke kenmerken.

\section{Eberhard Gothein}

\section{1 'Adieu Geschichte, aber doch auch auf wiedersehen'}

Gotheins biografe en echtgenote heeft diens Aufgaben der Kulturgeschichte (1889) ooit gekwalificeerd als einzige polemische Schrift in zijn oeuvre. ${ }^{4}$ Gotheins antwoord op Dietrich Schäfers veroordeling van de cultuurgeschiedenis waarmee we in het vorige hoofdstuk hebben kennisgemaakt, opende met de uitspraak dat opkomende wetenschappen (zoals de cultuurgeschiedenis) niet bang moesten zijn om aloude domeinafbakeningen te vernietigen: 'ihre Aufgabe ist es, althergebrachte Abgrenzungen zu zerstören'.5 Zo expliciet had Gothein zich inderdaad nog niet eerder uitgelaten. Niettemin was de historicus al vanaf zijn promotie, twaalf jaar eerder, herhaaldelijk met gevestigde opvattingen in aanvaring gekomen. Van nature geen polemist, kende hij wel een gezonde weerstand tegen de druk van academisch conformisme. $^{6}$

Al meteen in zijn dissertatie uit 1877, over de pogingen van keizer Maximiliaan I om een Rijksbelasting in te voeren, keerde Gothein zich tegen de heersende vakopinie: het verzet tegen de Rijksbelasting had naar zijn mening weinig met politieke, in casu nationalistische motieven van doen, zoals Ranke had beweerd, maar kende een 'zuiver financiële' achtergrond. ${ }^{7}$ Een dergelijke afwending van de strikt politieke interpretatie van de geschiedenis bleef ook de rest van Gotheins historiografische oeuvre ken-

\footnotetext{
${ }^{4}$ Gothein (1931), 74.

${ }^{5}$ Gothein (1889a), 1. Zie voor Schäfers aanval hoofdstuk 2.

${ }^{6}$ Gothein liet zich in privé-kring in deze periode voorstaan op zijn 'zelfstandige karakter' in de wetenschap en voelde redenen om zich uit te spreken tegen gedienstigheid aan welke clique dan ook. Zie correspondentie van Gothein uit de periode 1883-84, geciteerd in: Gothein (1931), 52 en Maurer (1999), 162.

${ }^{7}$ Zie de brief van Gothein van maart 1876 aan Erdmannsdörffer, geciteerd in: Gothein (1931), 23.
} 
merken - al zou hij al snel evenmin een voorstander blijken te zijn van een al te eenzijdige nadruk op economische factoren. In zijn onderzoek naar volksopstanden in Zuid-Duitsland onder keizer Maximiliaan I, dat hij als Habilitationschrift (1878) indiende om zich als docent voor geschiedenis aan de universiteit van Breslau te kwalificeren, besteedde hij veel aandacht aan de betekenis van de volksreligiositeit en aan de collectieve geestesgesteldheid die bepalend was voor het verloop van deze opstanden. En in een vervolgartikel over hetzelfde onderwerp belichtte hij vooral de slechte sociale en economische toestand van de landbevolking rond 1500. Economische factoren, brede maatschappelijke bewegingen, religieuze opvattingen en zelfs collectieve waanideeën waren minstens zulke belangrijke historische factoren als de opvattingen en beslissingen in de hoogste regionen van de politiek.

De felle afwijzing van politieke historici als Ulmann, Baumgarten en Delbrück, die onder andere bleek uit negatieve besprekingen en uit de weigering van de laatste om een artikel van Gothein in de Preußische Jahrbücher op te nemen, was onder meer gebaseerd op het verwijt dat Gothein zich te zeer door de eigen tijd zou hebben laten leiden in zijn beoordeling van het verleden. ${ }^{8}$ En inderdaad laat Gotheins historische analyse zich ook lezen als een commentaar op de eigen tijd: de toenemende kloof tussen elite en volk wat betreft welvaart en scholing en de toenemende 'nivellering' van het volk (dat hij als 'het eerste slachtoffer' van een nieuwe, als materialistisch en rationalistisch gekenschetste tijd typeerde) - al deze fenomenen die Gothein in zijn historische studies vaststelde voor de periode rond 1500, konden met weinig fantasie ook op zijn eigen tijd van toepassing worden geacht. ${ }^{9}$ Dat de jonge Gothein de ontwikkelingen in zijn eigen tijd kritisch volgde, weten we in ieder geval zeker: de in het jaar van zijn Habilitation door Bismarck afgekondigde anti-socialistenwetgeving keurde hij niet alleen af, zij bracht hem er bovendien toe zich persoonlijk in te zetten als Volksbildner om een bijdrage te leveren aan het overbruggen van de door hem ervaren kloof tussen volk en elite. ${ }^{10}$

Gothein liet zich ook in religieus opzicht weinig gelegen liggen aan de gevoeligheden van zijn tijd, waarin de strijd tegen verschillende veronderstelde potentiële Reichsfeinde - socialisten, katholieken, joden - opflakkerde. In een toespraak op een grote Lutherherdenking in Breslau (1883) presenteerde hij de godsdiensthervormer vooral als revolutionair die de geesten had bevrijd uit de banden van de dogmatiek. Deze heterodoxe zienswijze lag klaarblijkelijk gevoelig: het schijnt de aanleiding te zijn geweest om het voor hem reeds aangevraagde historische extraordinariaat aan de universiteit van Breslau uiteindelijk toch niet te vergeven. ${ }^{11}$

${ }^{8}$ Zie Gothein (1931), 50-52. Ook Droysen en Maurenbrecher schijnen zich kritisch uitgelaten te hebben. Op verschillende actuele connecties van Gotheins historisch werk wordt gewezen in het nog altijd meest uitvoerige en precieze werkoverzicht door Brinkmann (1927). De 'enthusiastische Akzente' die de historicus Dove in 1890 in Gotheins (vroegere) werk bespeurde en betreurde, zijn misschien ook met diens eigentijdse betrokkenheid in verband te brengen, zie Dove (1925), 144.

${ }^{9}$ Gothein (1878), 1-2. Opvallend is dat ook Lamprecht in 1890 expliciet op de schrijnende analogieën tussen de Duitse 16de eeuw en zijn eigen tijd wijst (m.n. de toenemende sociale en economische tegenstellingen) - met als verschil de grote positieve rol van de staat in zijn eigen tijd, Lamprecht (1974), 172.

${ }^{10} \mathrm{Zie}$ voor Gotheins houding tegenover de socialistenwet zijn terugblik uit 1911, geciteerd in Gothein (1931), 27-28. Ook de Kulturkampf keurde Gothein af, zie Gothein (1931), 245.

${ }^{11}$ Aldus zijn echtgenote, zie Gothein (1931), 64; overgenomen door Alter (1982) en Maurer (1999). Opgemerkt moet worden dat de typering van Luther als revolutionair niet ongebruikelijk was. P.W. Jonas publiceerde in hetzelfde jaar Revolutionär oder Reformator: was war Luther? En W. Walther karakteriseerde Luther een jaar later in een uitgave van de 'Verein für Reformationsgeschichte' eveneens als 'Der politische Revolutionär' (Luther im neuesten römischen Gericht, I, 1884). Gotheins toespraak verhinderde bovendien niet dat Gothein in dezelfde tijd het verzoek kreeg van de net 
Dat Gothein tenslotte in 1885 een economische leeropdracht aan de TH van Karlsruhe aanvaardde moet hoe dan ook minder als een vrije keuze worden beschouwd dan als bittere noodzaak. Bij economen en andere geesteswetenschappers had hij erkenning voor zijn werk verworven, schreef hij in 1883 aan zijn verloofde, maar niet bij zijn eigenlijke vakgenoten: 'de historici bekijken me overal met argwaan'. ${ }^{12}$ De keuze voor een economische leerstoel was een noodsprong uit dit door hem zelf ervaren professionele isolement. 'Ik geloof dat ik in mijn hart toch altijd historicus blijven zal', schreef hij na de benoeming. ${ }^{13}$ En in een andere brief: 'Adieu Geschichte, aber doch auch auf wiedersehen'. ${ }^{14}$ Wie Gotheins wetenschappelijke oeuvre overziet kan alleen maar vaststellen dat hij zijn voornemen om historicus te blijven bijzonder voortvarend heeft uitgevoerd; aan het eind van zijn leven kon hij zichzelf nog altijd met recht typeren 'als historicus, die ik nu eenmaal ben'. 15

Binnen tien jaar na zijn benoeming tot hoogleraar economie waren zijn drie belangrijkste, omvangrijke en op archiefstudie gebaseerde historische werken verschenen. Geen daarvan viel binnen het traditionele domein van de politieke geschiedenis en twee evenmin binnen het domein van de economische geschiedenis. Als eerste verscheen Die Culturentwicklung Süd-Italiens (1886, 600 blz.), een omvangrijke bundel met studies over middeleeuwse volksreligiositeit en Renaissancecultuur in Zuid-Italië, waarvoor Gothein lovende woorden ontving van zijn grote voorbeeld Burckhardt. ${ }^{16}$ Het was, zoals hij in het voorwoord uitdrukkelijk schreef, een poging om 'een cultuurgeschiedenis te schrijven'. In 1892 volgde een 900 bladzijden tellende stads- en nijverheidsgeschiedenis van het Zwarte Woud (Wirtschaftsgeschichte des Schwarzwaldes), die door hem zelf oorspronkelijk als deel van een 'cultuurgeschiedenis van de Schwabische stam' was gedacht. ${ }^{17}$ En in 1895 publiceerde hij tenslotte een rond de figuur van Ignatius van Loyola opgebouwde 'cultuurgeschiedenis van de contrareformatie' (Ignatius von Loyola und die Gegenreformation, 800 blz.). ${ }^{18}$

Uit deze werken bleek Gotheins uitdrukkelijke wens zich als historicus te blijven profileren; en niet als historicus zonder meer, maar als 'cultuurhistoricus' - een uitdrukking die hij ook in zijn privé-correspondentie in de jaren tachtig herhaald gebruikte om zichzelf mee te omschrijven. ${ }^{19}$ Zijn profilering als cultuurhistoricus kwam het sterkst naar voren in de historische beginselverklaring die hij midden in deze historiografisch zeer vruchtbare periode publiceerde: het al meer dan eens genoemde Die Aufgaben der Kulturgeschichte (1889). Toen hij een jaar na de

opgerichte 'Verein für Reformationsgeschichte' om een studie over Ignatius en de SJ te schrijven, die in 1885 ook werd gepubliceerd onder auspiciën van deze vereniging.

${ }^{12}$ Geciteerd in Maurer (1999), 162

${ }^{13}$ Geciteerd in Gothein (1931), 66-67 (cursivering MS).

${ }^{14}$ Brief van 26.2.1885, geciteerd in Maurer (1999), 165, en volledig in Maurer (2006), 97.

${ }^{15}$ Gothein (1923), 198.

${ }^{16}$ Burckhardt stuurde Gothein naar aanleiding van dit werk een brief die hij als zijn Meisterbrief beschouwde. Het origineel is verloren gegaan; Burckhardts concept noemt Gotheins bundel een 'reichhaltiges und originales Werk', zie Burckhardt (1949-1986), IX, 28. Dat Burckhardt in Gothein zijn 'Erben und Nachfolger' begroette, zoals Gotheins leerling Salin (1924), XIV, als eerste vermeldde, kan op grond van diens conceptbrief niet worden beweerd; het was veeleer Gothein zelf die in zijn aanbiedingsbrief aan Burckhardt had opgemerkt dat hij met zijn werk 'in Ihre Fußstapfen' trad, zie Burckhardt (1949-1986), IX, 357. Na deze briefwisseling bracht Gothein een bezoek aan Burckhardt in Bazel, zie Gothein (1931), 71-72.

${ }^{17}$ Maurer (1999), 163.

${ }^{18}$ De typering 'cultuurgeschiedenis van de contrareformatie' is van Gothein zelf, Gothein (1895), III, 1 .

${ }^{19}$ Zie Maurer (1999), 161. 
publicatie van zijn Aufgaben benoemd werd tot hoogleraar Nationalökonomie aan de universiteit van Bonn deed Gothein ook nog eens alle moeite - en tot zijn grote voldoening met succes - om 'cultuurgeschiedenis' aan zijn leeropdracht te mogen toevoegen; voortaan gaf hij naast zijn economische colleges bijvoorbeeld ook colleges over Italiaanse cultuurgeschiedenis. ${ }^{20}$ Pogingen om in Leipzig (1890/91), Freiburg (1897) en München (1897/98) een eigenlijk historische leeropdracht te verwerven, mislukten echter; Gothein bleef voor de rest van zijn leven verbonden aan een economische leerstoel, eerst in Bonn, vanaf 1904 in Heidelberg. ${ }^{21}$ Ook zijn wens op latere leeftijd om nog een 'cultuurgeschiedenis van de middeleeuwen' te voltooien, bleef onvervuld. $^{22}$

\subsection{Cultuurgeschiedenis als ideeëngeschiedenis en sociale geschiedenis}

Overzien we Gotheins historiografische oeuvre dan domineert daarin, ongetwijfeld mede in verband met zijn hoofdleeropdracht als econoom, het thema van zijn Schwarzwald-boek. Hij werd een in zijn tijd nauwelijks geëvenaarde kenner van de economische en bestuurlijke geschiedenis van het Rijnland van Bazel tot Keulen, vooral van de periode na de middeleeuwen. Naast zijn nog door de gerespecteerde laat twintigste-eeuwse economisch-historicus Wolfram Fischer geprezen hoofdwerk, ${ }^{23}$ publiceerde hij tussen 1886 en 1917 een reeks van meer dan twintig soms zeer uitvoerige artikelen en korte monografieën op dit terrein, voornamelijk over de vroegmoderne tijd, alsmede twee omvangrijke studies over respectievelijk de Rijnscheepvaart (1903) en over Keulen (1915) in de negentiende eeuw. ${ }^{24}$ Deze en dergelijke economisch-historische studies vormden naar zijn mening een noodzakelijke en waardevolle uitbreiding van het traditionele historische domein, die in zijn tijd nog te weinig algemeen geaccepteerd was. In een 'state of the art' artikel dat hij in 1893 schreef als bijdrage aan de presentatie van de Duitse wetenschap op de wereldtentoonstelling in Chicago, beschreef hij de economische geschiedenis als 'de jongste' en tegelijk 'een van de krachtigste' takken van de geschiedwetenschap in zijn tijd, die ten onrechte 'nog vaak om de erkenning van zijn gelijkwaardigheid moet strijden'. ${ }^{25}$

Economische geschiedenis en cultuurgeschiedenis waren voor Gothein direct aan elkaar gerelateerd: economische geschiedenis werd door hem beschouwd als een onderdeel of subdiscipline van de cultuurgeschiedenis. Op grond van één van zijn vroege artikelen, gewijd aan 'de natuurlijke voorwaarden van de cultuurhistorische ontwikkeling in de Rijnvlakte en het Zwarte Woud' (1887), zou men zelfs de indruk kunnen krijgen dat Gothein onder 'cultuurhistorische ontwikkeling' vooral zaken als nederzettingspatronen, infrastructuur en middelen van bestaan begreep. Toch is deze indruk niet juist. De vernieuwing van de geschiedwetenschap draaide voor Gothein

${ }^{20}$ Zie de brief van Gothein, geciteerd in Gothein (1931), 79; vgl. Zorn (1968), 262-263. Overigens had al tot het leerstofgebied van Lamprechts economisch-historische extraordinariaat in Bonn (de voorloper van Gotheins leerstoel) op diens verzoek de 'cultuurhistorsche ontwikkeling' behoord, zie Lewald (1968), 242-244.

${ }^{21}$ Zie Zorn (1968), 263-267.

${ }^{22}$ Gothein (1931), 329-330.

${ }^{23}$ Zie Zorn (1968), 263. Fischer (*1928), was sinds 1964 ordinarius voor sociale en economische geschiedenis, FU Berlijn; in 1927 noemde de econoom Carl Brinkmann Gotheins Schwarzwaldboek al een 'klassisches Muster landschaftlicher Wirtschaftshistoriographie überhaupt' (320).

${ }^{24}$ Gothein (1903); Gothein en Neuhaus (1915-1916). Zie voor de andere titels de overigens niet geheel foutloze bibliografie in Gothein (1931).

${ }^{25}$ Zie Gothein (1893b), 583-584. 
niet uitsluitend of zelfs in de eerste plaats om de uitbreiding van het domein van de geschiedenis met economische vraagstukken, zoals hij in zijn Aufgaben der Kulturgeschichte duidelijk maakte. De economie presenteerde hij daarin als een 'bestanddeel van het historisch cultuurleven [...], dat met alle overige [bestanddelen] organisch verbonden is', als een 'integraal bestanddeel van de algemene cultuurgeschiedenis'. ${ }^{26}$ En dat was niet het enige. Economische toestanden waren naar zijn mening vaak sterker afhankelijk van 'cultuurfactoren' als staat, kerk, recht en religie dan omgekeerd. ${ }^{27}$ Het economisch moment was op zichzelf nooit bepalend. ${ }^{28}$ Typerend voor deze visie was dat hij de economie in de Aufgaben en elders als 'grondstof', 'zonder ideeën' kwalificeerde: een terrein dat pas historisch leven ingeblazen werd onder invloed van andere cultuurfactoren. ${ }^{29}$ Deze opvatting leidde ertoe dat in Gotheins economisch-historische studies vaak niet-economische factoren een aanmerkelijke rol speelden. Een technisch-financieel thema als de Duitse kredietverhoudingen aan de vooravond van de Dertigjarige Oorlog, werd in zijn behandeling bijvoorbeeld gekenmerkt door een ongewone 'vereniging van cultuurhistorische, economische en juridische vraagstellingen'. ${ }^{30}$ Karakteristiek is dat Max Weber voor zijn thesen over de relatie tussen protestantisme en kapitalisme kon verwijzen naar eerdere economisch-historische studies van Gothein, waarin hij aandacht had besteed aan de betekenis van het calvinisme voor de bloei van handel en nijverheid. ${ }^{31}$ Ook de bestuurlijke en politieke aspecten en problemen van de economische ontwikkeling kregen in zijn economisch-historische studies opmerkelijk veel aandacht. ${ }^{32}$

Dat laatste betekende overigens niet dat Gothein de bestuurlijke en politieke aspecten boven alles liet prevaleren: ook de staat werd door hem, net als de economie, in de eerste plaats als 'cultuurfactor', 'cultuursysteem' of als bedeutsames Kulturmoment beschouwd, zoals hij het in de Aufgaben formuleerde. ${ }^{33}$ De politieke geschiedenis kon wel een aspect worden genoemd van de cultuurgeschiedenis, maar het omgekeerde gold niet. ${ }^{34}$ Zo schreef hij dat de politieke geschiedenis weliswaar 'in haar noodzakelijkheid en haar eigen waarde' zou blijven bestaan, maar ook dat 'de algemene, de cultuurgeschiedenis van haar [de politieke geschiedenis] verlangt, dat zij zich aan haar [de cultuurgeschiedenis] aanpast en ondergeschikt maakt [ein- und unterordne],. ${ }^{35}$ Met nadruk keerde Gothein zich tegen Schäfers redenering dat toewijding aan de staat - bijvoorbeeld van de historicus - als zodanig morele

${ }^{26}$ Gothein (1889a), 45-46; ook nog Gothein (1918), 286.

${ }^{27}$ Gothein (1889a), 45, 62.

${ }^{28}$ Aldus Gothein (1914), 4.

${ }^{29}$ Gothein (1889a), 62; en opnieuw in 1896: Bericht (1896), 42.

${ }^{30}$ Aldus Brinkmann (1927), 323, over Gothein (1893a).

${ }^{31}$ Zie Dassen (1999), 399 en Voigt (2005), 158-161; Gothein wijdde in zijn Schwarzwaldboek (1892) verschillende pagina's $(673-674,689-697)$ aan de stimulerende economische invloed van Franse en Hollandse calvinistische vluchtelingen in Baden en Württemberg. Omgekeerd noemde Gothein Webers Protestantische Ethik later een Musterbeispiel van de sociologische en psychologische benadering (van economisch-historische vraagstukken?) die hij zelf altijd had nagestreefd, zie Gothein (1931), 234 en Maurer e.a. (2006).

${ }^{32}$ Vgl. Brinkmann (1927), die in dit verband zelfs spreekt over Gotheins 'gewisse Einseitigkeit der Betrachtung von den herrschaftlichen und merkantilistischen Elementen her' (320).

${ }^{33}$ Gothein (1889a), 6 en 14.

${ }^{34}$ Hoewel Gothein in zijn pleidooi voor de cultuurgeschiedenis soms differentieerde tussen politieke en cultuurgeschiedenis als twee, niet-overlappende, complementaire varianten van historisch onderzoek (zie bijv. Gothein (1889a), 11-13, 34), waren zijn uitspraken waarin de cultuurgeschiedenis de rol van een nieuwe, overkoepelende historische benadering toegewezen kreeg veel krachtiger. Zie Gothein (1889a), 34 en Gothein (1897a), 11, waar hij zich uitspreekt tegen de scheiding van politieke en cultuurgeschiedenis. Vgl. ook Hübinger (1989), 41.

${ }^{35}$ Gothein (1889a), 3 (mijn cursivering, MS). 
superioriteit kon claimen. ${ }^{36}$ In een encyclopedielemma gewijd aan Gesellschaft und Gesellschaftswissenschaft (1892) herformuleerde hij zijn kritiek op de eenzijdig politieke geschiedschrijving nog eens door op te merken dat 'juist de staatswetenschappen de sociale benadering het meest nodig hebben, dit wil zeggen elk fenomeen van het staatsleven dienen te begrijpen in haar samenhang met de andere verschijnselen van het Kulturleben' ${ }^{37}$

Waar het Gothein in zijn Aufgaben der Kulturgeschichte uiteindelijk om te doen was, was de omvorming van de algemene geschiedbeschouwing van een politiekhistorisch naar een cultuurhistorisch perspectief. 'Wil de geschiedenis in het huidige ontwikkelingsstadium van de menselijke geest deze [vooraanstaande] plaats innemen, dan kan zij slechts cultuurgeschiedenis zijn', schreef hij daar. ${ }^{38}$ Het schrijven van cultuurgeschiedenis beschouwde hij als een opgave van de tijd. In een tijd waarin, zoals hij vaststelde, andere geesteswetenschappen - zoals literatuurgeschiedenis, kunstgeschiedenis, religiegeschiedenis, filosofiegeschiedenis, geografie, economie, rechten, taalkunde - allemaal gekenmerkt werden door een cultuurhistorische benadering, diende ook de geschiedwetenschap zelf een cultuurhistorisch karakter aan te nemen. ${ }^{39}$ Pas dan kon zij aanspraak maken op een vooraanstaande plaats binnen de geesteswetenschappen als geheel: 'Er is slechts een wetenschap van de menselijke geest. Vatten we haar op naar haar onveranderlijke fundamenten, dan noemen we haar filosofie; proberen we de verandering en ontwikkeling van haar object [de menselijk geest dus, MS] te onderzoeken, dan spreken we over cultuurgeschiedenis. Tertium non datur, ${ }^{40}$

Het eigen object van de cultuurgeschiedenis bestond volgens Gothein derhalve niet, zoals Schäfer meende, uit 'de uiterlijke vormen en de hulpmiddelen van het alledaagse leven', en ook niet, zoals Gotheins oude opponent Baumgarten ooit had beweerd, uit een noodzakelijkerwijs onsamenhangende optelsom van een grote hoeveelheid details. ${ }^{41}$ Het ging bij cultuurgeschiedenis veel meer om het analyseren van de samenhang tussen de verschillende 'cultuursystemen' waarin een individu zich bewoog. Daartoe rekende Gothein min of meer in navolging van zijn voormalige docent Dilthey naast economie en staat bijvoorbeeld ook religie, kunst en recht. ${ }^{42}$ Dit was de 'idee van een cultuurgeschiedenis als hogere eenheid', als een geschiedenis van de onderling samenhangende cultuursystemen. ${ }^{43}$ Het object van de cultuurgeschiedschrijving bestond uit 'het culturele leven [Kulturleben] van het volk' (bijvoorbeeld 'die deutsche Gesamtkultur') of ook wel 'de algemene cultuur van een tijdperk' - aanduidingen die door Gothein nergens werden gepreciseerd, maar nu eens werden omschreven als 'de inhoud en vormen van de menselijke Gesittung' - dit wil zeggen het geheel van gewoonten - dan weer als 'de gemeenschappelijke, onderling weer verdeelde en conflicterende richtingen van het geestesleven' of kortweg als het 'gemeenschappelijke punt' waar de literatuur-, kunst-, staats- en andere geschiede-

${ }^{36}$ Gothein (1889a), 54.

${ }^{37}$ Gothein (1892b), 844 (mijn cursivering, MS).

${ }^{38}$ Gothein (1889a), 2-3.

${ }^{39}$ Gothein (1889a), 2, 6; ook nog Gothein (1918), 290.

${ }^{40}$ Gothein (1889a), 49.

${ }^{41}$ Gothein (1889a), 5, 15, 49.

${ }^{42}$ Gothein (1889a), 6. Dilthey had zes jaar eerder, in de door Gothein in zijn Aufgaben zeer geprezen Einleitung in die Geisteswissenschaften de geesteswetenschappen ingedeeld in 'wetenschappen van de cultuursystemen' en 'wetenschappen van de uiterlijke organisatie van de samenleving'. Gothein maakte dit onderscheid niet. De eigen stof van de geesteswetenschappen omschreef Dilthey als 'de historisch-sociale werkelijkheid'. Zie Dilthey (1914-2006), I, hfdst. 11 en 12.

${ }^{43}$ Gothein (1889a), 35, 6. 
nissen van een tijd samenkomen: der Mensch, die Gesellschaft. ${ }^{44}$ 'Het culturele leven van een volk bestaat er nu eenmaal uit, dat bepaalde processen zich in het algemeen of zeer vaak herhalen: de cultuurgeschiedenis heeft het voor het grootste deel met massaverschijnselen van doen'. ${ }^{45}$

Tegelijk schreef Gothein in zijn Aufgaben: 'cultuurgeschiedenis in haar zuiverste vorm is ideeëngeschiedenis' - en hij herhaalde deze stelling later nog enkele malen. ${ }^{46}$ Verschillende cultuurhistorische studies van Gothein - met name enkele kortere verhandelingen over de renaissance en de contrareformatie - vertonen inderdaad een sterk ideeënhistorisch karakter met een nadruk op het gedachtengoed van belangrijke intellectuele, religieuze en artistieke persoonlijkheden. ${ }^{47}$ Toch ging het Gothein, bij alle waardering voor creatieve individuen, uiteindelijk niet om hen. In een brief uit 1911 beschouwde hij het als zijn 'levenstaak' om 'de geheime betrekkingen, de voortdurende uitwisseling tussen individuen en de massa te begrijpen en te verklaren'. ${ }^{48}$ Het was een opgave waarmee hij uitdrukkelijk verder wilde gaan dan Ranke en Burckhardt hadden gedaan. In de cultuurgeschiedenis draaide het vooral om het ontstaan, de verandering en de invloed van ideeën in de 'werkelijke wereld'. Bij zijn analyse van de zeventiende-eeuwse Paraguayaanse Jezuïetenstaat wees hij bijvoorbeeld op de mogelijke invloed van Campanella's Zonnenstaat-utopie. ${ }^{49}$ En in de reeds genoemde studie over de kredietverhoudingen in de zeventiende eeuw ging hij uitgebreid in op de theoretische discussies op dit terrein. De 'ideeën' moesten ook niet te intellectualistisch worden opgevat: het ging om de manieren om de wereld te zien en die daarmee een 'wezenlijk' deel van een cultuur uitmaakten. ${ }^{50}$ 'Wie aanstoot neemt aan het woord "ideeën”, verduidelijkte hij in 1897, 'zegge: de doorgaande tijdstromingen, gedachtenrichtingen, levensdoelen, wereldbeschouwingen'. ${ }^{1}$ Voor Gothein bestond cultuurgeschiedenis uit het analyseren van de reikwijdte van maatschappelijk invloedrijke 'ideeën' of algemeen aanvaarde voorstellingen, die bijvoorbeeld in sociale verschijnselen als het gezin, het feodalisme en de geld- en kredietwezen tot uitdrukking kwamen.

Kenmerkend voor het karakter van Gotheins cultuurgeschiedenis was de typologische benadering die hij vanaf de jaren tachtig verdedigde. Juist omdat het naar zijn idee in de cultuurgeschiedenis niet om unieke gebeurtenissen ging, maar om telkens herhaalde 'massaverschijnselen', kon aan de hand van één typisch geval een wijder verbreid historisch fenomeen worden onderzocht, zoals hij in de Aufgaben uiteenzette. ${ }^{52}$ Het onderzoek van deze typen was het historisch equivalent van de experimentele methode in de natuurwetenschappen: door een typisch geval te isoleren en te analyseren kon de cultuurhistoricus de werkzame historische krachten op het spoor komen. 'Deze experimentele methode is het beste bezit van de cultuurgeschiedenis. Dankzij haar verhoudt zij zich tot de politieke geschiedenis als de chemie en de fysica tot de natuurbeschrijving, ${ }^{53}$ De zeventiende-eeuwse Para-

${ }^{44}$ Gothein (1889a), resp. 20, 2, 50, 52.

${ }^{45}$ Gothein (1889a), 15-16.

${ }^{46}$ Gothein (1889a), 50, ook 53. Ook Gothein in Bericht (1896), 42 en Gothein (1918), 292.

${ }^{47}$ Zie m.n. Gotheins studies over de renaissancedichter en -filosoof Thomas Campanella, over de wereldbeschouwing van de renaissance en de contrareformatie: Gothein (1908, (1904, (1907, (1894).

${ }^{48}$ Brief van 22.8.1911, in Maurer (2006), 386-387.

${ }^{49}$ Zie Gothein (1883).

${ }^{50}$ Gothein (1918), 277.

${ }^{51}$ Gothein (1897a), 6. Gothein verwijst hier waarschijnlijk naar Lamprecht, die kort daarvoor de aanval op Ranke's ideeënleer had geopend.

${ }^{52}$ Gothein (1889a), 15-16; zo ook nog eens: Gothein (1918), 282.

${ }^{53}$ Gothein (1889a), 11-17, m.n. 13. 
guayaanse Jezuïetenstaat was door Gothein bijvoorbeeld al eerder als een bepaald staatkundige 'type' geanalyseerd, als een historisch experiment waarvan het verloop kenmerkend was voor het wezen van het jezuïtische staatssysteem. ${ }^{54}$ Deze benadering van de geschiedenis vormde een van de redenen voor de kritiek van de kant van vakhistorici, die meenden er een aantasting van het singuliere karakter van historische verschijnselen in te bespeuren. ${ }^{55}$ Gothein bleef echter zijn leven lang vasthouden aan het nut van het type-begrip; aan het einde van zijn leven ontwikkelde hij zelfs een 'typologie van typen', waarin hij ook het gebruik van het begrip Stufe (stadium, fase) verdedigde als een chronologische variant van het type-begrip die zicht kon bieden op de regelmatigheid van historische ontwikkelingen. ${ }^{56}$ In zijn economisch-historische studies behandelde Gothein vaak regio's of steden als om hun meer of minder algemene eigenschappen onderzochte individuele gevallen. ${ }^{57}$ In andere studies kwam het tot uiting in het classificeren van sociale verschijnselen - minderheden, collectieve paniek, revoluties, psychische reacties op een oorlogssituatie - in een aantal typische, ook historische, varianten.

Het belang dat Gothein aan de maatschappelijke context en betekenis van ideeën hechtte, kwam duidelijk naar voren in zijn eerste grote cultuurhistorische werk, Die Culturentwicklung Süd-Italiens (1886). In de voorrede daarvan schreef hij uitdrukkelijk: 'Ik wil geen geleerdengeschiedenis schrijven, maar een cultuurgeschiedenis' en dat betekende naar eigen zeggen onder andere 'weergave van de sociale verhoudingen'. ${ }^{58}$ Terwijl zijn grote voorbeeld Burckhardt in diens Kultur der Renaissance zich weinig om economische aspecten had bekommerd en zich nauwelijks rekenschap had gegeven van de sociale gelaagdheid van de Italiaanse samenleving, ging Gothein in zijn Zuid-Italiaanse pendant uitvoerig in op de relaties tussen de humanisten en de verschillende sociale groepen. Achtereenvolgens beschreef hij de feodale verhoudingen en de landadel, de stadsadel - die hij typeerde als het milieu bij uitstek van de humanisten - de lagere stads- en plattelandsbevolking, de invloed van 'vreemde elementen' in deze samenleving (waarbij hij onder andere de handelsbetrekkingen naging en de immigratie door Grieken en Spanjaarden behandelde), en tenslotte de rol van geestelijkheid en vorsten. Op deze wijze schetste Gothein op een verhelderende en gedifferentieerde manier de sociale context waarin het Zuiditaliaanse humanisme kon gedijen.

Aandacht voor de maatschappelijke context van 'ideeën' betekende ook aandacht voor de lokale context. 'Men kan nu eenmaal geen cultuurgeschiedenis schrijven, als men niet voortdurend voeling houdt met alle lagen van de bevolking, en de drijvende krachten van de geschiedenis an der Stätte ihrer Wirksamkeit selber belauscht' merkte Gothein in een brief uit 1882 op. ${ }^{59}$ De twee voornaamste regio's waarover hij historische studies schreef, (Zuid-) Italië en het Rijnland, kende hij uit eigen studiereizen en omzwervingen op zijn duimpje. De plastische beschrijving van zuidelijk Italië vanaf de Gran Sasso, de hoogste top van het Italiaanse schiereiland, waarmee Gothein zijn Culturentwicklung Süd-Italiens opende, was gebaseerd op zijn eigen beklimming van de berg. ${ }^{60}$ In hetzelfde werk vinden we ook een eigentijdse beschrijving van het landleven in de Abruzzen, die teruggaat op zijn observaties

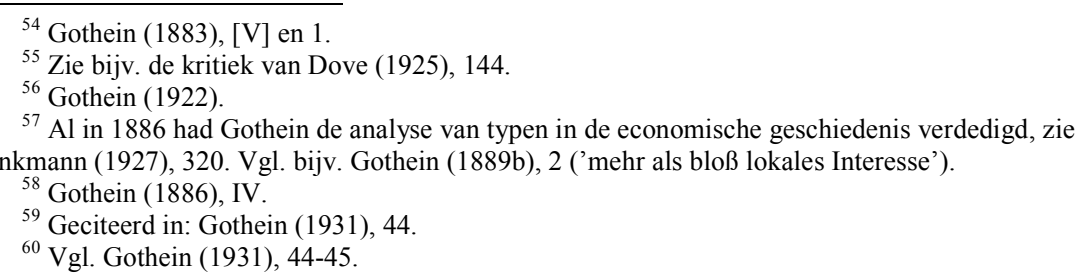


tijdens lokale wandeltochten. Een overkoepelend nationaal kader ontbrak in zijn regionale studies veelal. In zijn Culturentwicklung Süd-Italiens gaat de aandacht bijvoorbeeld vooral uit naar de verschillende lokale contexten (Napels en omgeving, Aquila en de Abruzzen) en de diverse nationaliteiten en groepen.

Het nationale perspectief speelde alleen een voorname rol in zijn grote studie over Ignatius von Loyola und die Gegenreformation (1895). Hier presenteerde Gothein de contrareformatie vooral als product van de Spaanse 'religieuze cultuur' (de uitdrukking is van Gothein) die Ignatius als een soort culturele makelaar over de rest van katholiek Europa had weten te verspreiden. In een uitgebreid eerste hoofdstuk analyseerde Gothein de aard en ontwikkeling van de Spaanse volksreligiositeit, met haar nadruk op strijdbaarheid, die hij als belangrijkste bestanddeel van de Spaanse nationaliteit presenteerde. De tweede grote nationale invloed op de contrareformatie, de Italiaanse religieuze cultuur, behandelde Gothein eveneens in een groot hoofdstuk maar opvallend is dat hij hier al weer snel differentieerde naar de verschillende sociale groepen en nauwelijks tot een samenvattende duiding van de Italiaanse religiositeit of nationaliteit kwam.

Dat de Spaanse nationaliteit een dergelijke speciale plaats in Gotheins oeuvre kreeg, had ongetwijfeld te maken met het feit dat hij haar geheel en al identificeerde met de volksreligiositeit - een thema dat vanaf zijn Habilitationsschrift een hoofdelement in zijn cultuurgeschiedschrijving vormde. ${ }^{61}$ Meer dan eens noemde hij de religieuze geschiedenis de schönste Frucht van de cultuurgeschiedschrijving. ${ }^{62}$ In zijn Heidelbergse tijd werd hij een actief lid van de Eranos-kring rond Max Weber, waarin voornamelijk godsdiensthistorische kwesties werden besproken. ${ }^{63}$ Gothein wilde in zijn godsdiensthistorische studies duidelijk maken dat het bij de religiositeit om een historische kracht van betekenis ging, of het nu om de Spaanse religieuze cultuur ging, om religieuze massabewegingen rond 1500, of om de 'christelijk-sociale' Jezuïetenstaat in Paraguay. Ook in zijn grote Culturentwicklung Süd-Italiens besteedde hij behalve aan het opkomend humanisme uitgebreid aandacht aan de volksreligiositeit: in studies over de verering van de Napolitaanse stadsheilige Januarius en de Longobardische cultus van de aartsengel Michael toonde Gothein de nauwe samenhang tussen de religieuze cultus en het politieke leven en wees hij op de invloed van de volksreligiositeit op de officiële kerkelijke leer. ${ }^{64}$

In de religieuze geschiedenis kon Gothein zijn favoriete ideeënhistorische benadering goed combineren met zijn belangstelling voor 'massaverschijnselen'. Maar zijn belangstelling voor de religie was dieper gefundeerd. Zoals hij aan het slot van zijn Aufgaben der Kulturgeschichte opmerkte, ging het in de godsdienstgeschiedenis om een 'geschiedenis van het gemoed en de verbeelding', een terrein dat hij tot de kern van de cultuurgeschiedenis rekende. ${ }^{65}$ En dat lijkt ook de reden dat Gothein als historicus zoveel meer belangstelling had voor middeleeuwse volksreligiositeit en voor het katholicisme, dan voor het hem eigen protestantisme. Verschijnselen als het collectieve wondergeloof en de heiligenverering leken hem vooral te interesseren als voorbeelden van de irrationele geestesgesteldheid van het volk, dat bijgevolg

${ }^{61}$ Gothein publiceerde behalve zijn hoofdwerk over Ignatius en de contrareformatie, nog kleinere studies over Ignatius $(1885,1922)$ en over de Jezuïeten $(1883,1912)$ en verschillende verhandelingen over de contrareformatie (1900, 1907, 1908). Overigens publiceerde Gothein ook nog enkele artikelen over Bismarcks houding tegenover religie $(1913,1915)$.

${ }^{62}$ Gothein (1895), VI; ook nog Gothein (1918), 289.

${ }^{63}$ Gothein (1931), 148 etc.; Dassen (1999), 55. Zie over de Eranos-kring: Treiber (2005).

${ }^{64}$ Gothein (1886), III.

${ }^{65}$ Gothein (1889a), 62; vgl. idem zijn opmerking in Maurer e.a. (2006), 269 en 237: 'die Kulturgeschichte [lehrt] die Macht der Irrtümer und der Leidenschaften' (brief 26.8.1908). 
bijzonder gevoelig was voor psychische Reflexbewegungen en geistige Epidemien. ${ }^{66}$ De getuigenissen van pre-modern bijgeloof waren naar zijn mening alleen interessant voor 'degenen die de samenhang van de hartstochten in de ziel van grote massa's willen doorgronden', zoals hij in zijn studie over Napels' stadsheilige schreef. ${ }^{67}$ In zijn boek over Ignatius van Loyola beschreef hij hoe de Spaanse religieuze cultuur bepaalde collectieve karaktereigenschappen 'in vlees en bloed' van de Spanjaarden had doen overgegaan. Zo was de Spaanse waardering voor 'de reinheid van het bloed' 'een onuitroeibaar volksinstinct' geworden, een 'waan', 'ontoegankelijk voor disciplinering door de rede'. De langdurige religieuze en ethnische strijd had in de Spanjaarden eigenschappen als strijdvaardigheid, trouweloosheid en wreedheid gestimuleerd. ${ }^{68}$ De religieuze geschiedenis was derhalve bij uitstek het terrein van wat Gothein in de Aufgaben der Kulturgeschichte een 'historische psychologie' noemde, die de diepste wortels van historische ontwikkelingen kon blootleggen.

\subsection{Historische psychologie}

Het Ignatius-boek (1895) was het laatste grote werk dat Gothein uitdrukkelijk als een cultuurgeschiedenis presenteerde. Na het uitbreken van de Lamprechtstrijd in 1896 bleef hij met zijn ijveren voor de cultuurgeschiedenis op de achtergrond. Alleen in twee herdenkingsartikelen over Burckhardt en Riehl die hij in 1897/98 in de Preußische Jahrbücher kon publiceren, kwam zijn eigen voorkeur voor de cultuurgeschiedenis weer met zoveel woorden naar voren. Zonder Lamprechts naam te noemen, maakte Gothein in deze artikelen echter ook duidelijk dat hij diens opvattingen over cultuurgeschiedenis niet zonder meer deelde. Al eerder, op de Innsbrucker Historikertag in september 1896, had hij zich voor een beperkt maar relevant publiek van vakhistorici wel rechtstreeks uitgelaten over de Lamprechtstrijd en daarbij expliciet afstand genomen van Lamprecht. Hij bekritiseerde de Leipzigse historicus toen niet alleen vanwege diens vermeende eenzijdige nadruk op de economische verhoudingen, ${ }^{69}$ maar ook vanwege zijn harde kritiek op Ranke's ideeënleer - volgens Gothein juist een gunstige uitzondering onder de politieke historici - en vanwege wat Gothein blijkbaar beschouwde als Lamprechts aanname van een (nationale) Gesammtpersönlichkeit. ${ }^{70}$ Toen hij een jaar later in zijn Burckhardtnecrologie 'met nadruk' vaststelde dat Burckhardt tegelijk de grootste Duitse cultuurhistoricus was geweest èn een Rankeaans historicus, die 'met recht' tegen de voorstelling van de wereldgeschiedenis als economisch proces geprotesteerd zou hebben, die als geen ander de invloed van 'fundamentele ideeën' had laten zien en die niet geloofde in 'formules' en 'ogenschijnlijk zekere economische en psycho-fysische

${ }^{66}$ Gothein (1878), bijv. 2, 20, 82 .

${ }^{67}$ Gothein (1886), 135.

${ }^{68}$ Gothein (1895), 17-21.

${ }^{69}$ Gothein verschilde specifieker ook van mening met Lamprecht over de Hofrechtstheorie, die hij in zijn Schwarzwaldboek bestreed. Zie in dit verband ook de expliciet tegen Lamprecht gerichte voetnoot in Gothein (1896), 246n, waarin Gothein Lamprecht een afkeer van de rechtsgeschiedenis verwijt. Overigens werd de veronderstelde veronachtzaming van het juridische aspect ook al door anderen (die Gothein in dit opzicht prezen) tegen Lamprecht ingebracht; vgl. Lamprecht (1888), waar hij zich tegen dit verwijt verdedigt. Omgekeerd bekritiseerde Lamprecht in 1891 Gotheins economische geschiedenis van het Zwarte Woud vanwege de eenzijdige nadruk op de bestuurlijke krachten, zie Lamprecht (1891), 440; vgl. Brinkmann (1927), 320.

${ }^{70}$ Gothein in Bericht (1896), 41-42. 
doctrines' om het verleden mee 'vast te spijkeren', waren dit ongetwijfeld stilzwijgende verwijten aan het adres van Lamprecht. ${ }^{71}$

Zoals we nog zullen zien, valt het te betwijfelen of Gothein met deze (ten dele verhulde) kritieken Lamprecht helemaal recht deed. Maar hij maakte in ieder geval wel duidelijk wat hij zelf van belang vond in de cultuurgeschiedschrijving. En daarbij hoorde ook de 'historische psychologie' die hij in zijn Aufgaben der Kulturgeschichte al een bijzondere plaats had toegekend als een 'geschiedenis van het gemoed en de verbeelding' en die hij vooral in zijn godsdiensthistorische studies had gepraktiseerd. In de Burckhardt-necrologie dook deze 'historische psychologie' opnieuw op. Het hoofdstuk in Burckhardts Kultur der Renaissance over de bevrijding van het individu werd door Gothein een exemplarisch eerste voorbeeld genoemd van een mogelijke 'historische psychologie', waarin een 'specifiek mensentype, namelijk: de moderne mens' werd geanalyseerd. En hij voegde eraan toe dat het de eigenlijke opgave van de cultuurgeschiedenis zou moeten zijn om te onderzoeken hoe deze 'moderne mens' zich verder had ontwikkeld. ${ }^{72}$ Ook in de Riehl-necrologie (1898) klonk zijn pleidooi voor een 'historische psychologie' door, toen hij de betekenis onderstreepte van diens pogingen 'de beide zintuigen [...] oog en oor historisch te analyseren'. ${ }^{73} \mathrm{Al}$ eerder had Gothein eens opgemerkt dat maatschappelijke verschijnselen niet uit 'vermeend vaststaande psychologische feiten' konden worden verklaard. ${ }^{74}$

Het is opvallend dat pas toen de Lamprechtstrijd enigszins geluwd was en een historicus als Goetz weer voor de cultuurgeschiedenis ging pleiten, Gothein zijn gedachten over 'historische psychologie' meer ruimte gaf. ${ }^{75}$ Alleen deed hij dit nu niet meer in het kader van beschouwingen over geschiedenis, maar in verhandelingen waarmee hij zich op het domein van de opkomende Duitse sociologie begaf. Zo behandelde hij het thema onder andere in een 'sociologie van de paniek' die hij op de eerste Duitse sociologendag (1910) presenteerde, in een 'sociologische beschouwing' over minderheden (1919) en in de bijdrage 'Über einige soziologische Grundfragen' (1923) die hij in de herdenkingsbundel voor Max Weber publiceerde. Over Historische Psychologie nach ihrer Möglichkeit sprak hij begin januari 1909 ook in Max Webers Eranos-kring, maar de tekst van deze rede is niet bewaard gebleven. ${ }^{76}$

Er is echter geen sprake van een breuk tussen Gotheins vroege cultuurhistorische en zijn latere sociologische beschouwingen. Niet alleen knoopte zijn sociologische studie over groepspaniek aan bij de thematiek van de geistige Epidemien in zijn Habilitationsschrift, ${ }^{77}$ ook de opmerkingen over historische psychologie en de analyse van maatschappelijke verschijnselen sloten direct aan bij hetgeen Gothein daarover al in zijn Aufgaben der Kulturgeschichte en andere vroege geschriften had beweerd. Omgekeerd had hij al in het begin van de jaren negentig over 'Gesellschaft und Gesellschaftswissenschaft' geschreven en meer dan eens een sociologisch thema als

${ }^{71}$ Gothein (1897a): 5-6. Ook contra Belochs historische bevolkingsstatistiek (8). Overigens werd deze passage opgemerkt en geciteerd door Below in een van zijn kritieken tegen Lamprecht, Below (1898), 263n.

72 Gothein (1897a), 9, 12.

${ }^{73}$ Gothein (1898), 8 .

${ }^{74}$ Vgl. Gothein (1896), 234.

${ }^{75}$ In de volgende publicaties speelt het concept van een 'historische psychologie' een rol: Gothein (1911), (1914), (1918), (1922), (1923).

${ }_{76}$ Zie Gothein (1931), 218; vgl. Dassen (1999), 55. In Treiber (2005), 84n35 wordt vermeld dat er anders dan bij andere voordrachten slechts een kort verslag van deze voordracht bestaat; in navolging van F.W. Graf neemt Treiber aan dat deze voordracht naar aanleiding van Simmels Soziologie (1908) werd gehouden.

${ }^{77}$ Zie Gothein (1911), 220n1. 
het gezin behandeld. ${ }^{78}$ Ook het woordgebruik van Gothein maakt duidelijk dat hij 'Geisteswissenschaften', 'Gesellschaftswissenschaften' en 'Kulturwissenschaften' niet strikt onderscheidde. ${ }^{79}$ De sociologie was in zijn optiek de eigentijdse, empirische variant van de geschiedfilosofie: in beide gevallen ging het om de reflectie over de algemene kenmerken van historische processen. ${ }^{80}$

Deze reflectie kon volgens Gothein niet anders dan naar de psychologie leiden. ${ }^{81}$ 'Afgeleide psychologie, dat is im Grunde alle cultuurwetenschap', meende hij, maar dan wel een historisch en sociaal gefundeerde psychologie. ${ }^{82}$

'Nooit kunnen we ons bij de grote vragen van de sociologische psychologie beperken tot de vaststelling van de afzonderlijke [eigentijdse] verschijnselen, altijd moeten we haar baseren op de vragen van de historische ontwikkeling, op de modificatie van het gevoelsleven onder invloed van de wisselende omstandigheden in de loop van de tijd. ${ }^{, 83}$

De gedachte dat de mensen overal en altijd in wezen hetzelfde zijn en blijven, vond Gothein 'twijfelachtig'. ${ }^{84}$ Weliswaar veranderde de menselijke natuur als zodanig niet, maar wel veranderden onder invloed van de omstandigheden de onderlinge krachtsverhouding van de psychische eigenschappen en de uiting ervan. ${ }^{85}$ In een historische en psychologische studie over de invloeden van de oorlogstoestand op de economie, analyseerde Gothein bijvoorbeeld uitgebreid de psychologische eigenschappen die door de speciale omstandigheden werden gestimuleerd en van waaruit verschillende kenmerken van de oorlogseconomie pas begrepen konden worden. ${ }^{86}$ In zijn studie over groepspaniek probeerde hij aannemelijk te maken dat de diverse historische culturen in verschillende mate gevoelig moesten zijn geweest voor de diverse vormen van groepspaniek, onder andere afhankelijk van de mate van 'disciplinering van de wil', de politieke organisatie en de 'nerveuze aanleg, ${ }^{87}$ Historische kennis moest op deze wijze de basis vormen voor een beschrijvende en analytische psychologische typologie - niet om aan het verleden illustraties van een psychologische theorie te ontlenen, maar eerder omgekeerd:

'om de ontwikkeling van de psychische eigenschappen van zowel de afzonderlijke individuen als van de massa's juist te beoordelen. Want deze [psychische] eigenschappen verschijnen in telkens nieuwe samenstellingen, en zij bepalen niet alleen het historische leven, maar worden zelf daardoor bepaald. De psyche, dat tere ding met zijn vleugelpaar, is zelf het veranderlijkste in de loop der tijden. 88

${ }^{78}$ Gothein (1892b, a), Gothein (1897b).

${ }^{79}$ Zie bijv. Gothein (1918), 281.

${ }^{80}$ Gothein (1918), 291; zie ook een uitspraak in zijn briefwisseling, Maurer e.a. (2006), 546: 'Ich halte ja sehr viel von Soziologie [...] ich glaube nun auch, daß sie grade durch die psychologischen Grundlegung, die ich ihr geben möchte, im Stande sein wird, die alte Geschichtsphilosophie zu ersetzen' (brief van 2-11-1920).

${ }^{81} \mathrm{Vgl}$. Gothein (1918), 292-293.

${ }^{82}$ Gothein (1911), 247 en Gothein (1931), 233-234. Het meest uitvoerig sprak Gothein over een dergelijke psychologie op de eerste Duitse sociologendag in 1910. Ook later verklaarde Gothein nog verschillende keren dat de sociologie, de geestes- of cultuurwetenschappen op een historische psychologie gegrondvest moesten worden; zie Gothein (1911), 247; Gothein (1914), 8; Gothein (1918), 292; Gothein (1923), 234. Vgl. ook Gothein (1931), 233 en Maurer e.a. (2006), 286, 332 en 340 [1909].

${ }^{83}$ Gothein (1911), 237.

${ }^{84}$ Gothein (1904), 106.

${ }^{85}$ Gothein (1914), 7.

${ }^{86}$ Gothein (1914), 3-31.

${ }^{87}$ Zie Gothein (1911), 237-244; vgl. ook Gothein (1931), 217-218.

${ }^{88}$ Gothein (1911), 247 (mijn cursivering MS) 
In een collegereeks over sociologie die Gothein rond 1910 verzorgde, behandelde hij 'de ontwikkelingsgeschiedenis van de menselijke psyche en toch ook weer haar vaste bestanddelen, die alleen telkens in nieuwe vormen omgemunt verschijnen' ${ }^{89} \mathrm{Hij}$ presenteerde daarin, zoals we uit de door zijn echtgenote aangehaalde correspondentie weten, onder meer een historische sociologie en psychologie van ruimte- en tijdvoorstellingen en een overzicht van de ontwikkeling van de opvattingen over maat en getal, 'cultuurhistorisch en psychologisch tegelijk', zoals hij opmerkte. ${ }^{90}$ Aan de orde kwamen in deze colleges onder andere de geschiedenis van de mobilisering en 'fixering' van volkeren en bevolkinsggroepen, en de 'ruimtedispositie' van woning en werkplaats in de verschillende tijden, volkeren en sociale lagen.

We zouden precieser willen weten hoe Gotheins 'ontwikkelingsgeschiedenis van de menselijke psyche' er uit heeft gezien. Zijn publicaties geven daar echter weinig duidelijkheid over. In het algemeen accepteerde hij ontwikkelingstheorieën voor zover het om afzonderlijke, welomschreven maatschappelijke verschijnselen ging: maatschappelijke verschijnselen kenden een eigen logica en daarmee een eigen ontwikkelingsdynamiek $^{91}$ Maar een alomvattende ontwikkelingsschema van de menselijke geest zoals Hegel dat bijvoorbeeld had gegeven, vond hij veel 'te beperkt' om de veelheid aan historische verschijnselen onder te vangen. ${ }^{92}$ Als er al iets wetenschappelijks over de Menschheitsentwicklung als geheel te zeggen viel, dan alleen door de studie van 'het psychisch leven en zijn talloze affecten'. ${ }^{93}$ Verspreid door zijn oeuvre deed Gothein uitspraken waarin iets als een psychisch ontwikkelingsmechanisme naar voren komt. Zo geloofde hij in een psychologische variant van de hegeliaanse ontwikkelingsdialectiek, die Hegel zelf zou hebben afgewezen: sociale ontwikkelingen werden, behalve door 'andere psychische krachten' als het 'psychische traagheidbeginsel', sterk bepaald door een psychologisch te begrijpen proces van maatschappelijke acceptatie, reactie en verzoening. ${ }^{94}$ Veel meer schreef Gothein er niet over, maar zijn eigen psychologische analyse van het ontstaan van (groeps)paniek kan misschien de tweede fase van dit mechanisme verduidelijken. Het ging daarbij volgens hem om 'een reactie van het onderbewustzijn, dat plotseling door de dam heenbreekt', om een 'plotselinge omslag na een voorafgaande spanning', die was ontstaan door de 'opeenhoping van onbewuste of halfbewuste psychologische indrukken'. (Groeps)paniek was derhalve een soort 'psychisch veiligheidsventiel'. ${ }^{95}$ Uit Gotheins historisch-psychologische studies blijkt verder dat hij dacht aan een toenemende beheersing en disciplinering van de psychische vermogens als een doorgaande ontwikkelingstendens; een verschijnsel als de paniek, waarin irrationele, minder bewuste krachten het roer overnamen, kwam naar zijn mening minder voor naarmate de cultuur minder primitief was en de individuen beter geschoold. Misschien had hij deze ontwikkeling op het oog toen hij aan het slot van zijn Aufgaben schreef

${ }^{89}$ Gothein (1931), 221-234, geeft lange citaten uit Gotheins brieven over zijn sociologiecollege in 1909; hier 223.

${ }^{90}$ Gothein (1931), 226. Direct na de Eerste Wereldoorlog verzorgde hij ook nog een college over de 'vergelijkende psychologie, morfologie en ontwikkelingsleer' van revoluties. In deze 'psychologie van de revoluties' was een gedeelte gewijd aan de 'Typenwandel', de opkomst van bepaalde typen persoonlijkheden in een revolutie (idem, 319 e.v.).

${ }_{91}$ Zie Gothein $(1923,(1911,(1922)$.

${ }^{92}$ Gothein (1923), 229.

${ }^{93}$ Gothein (1918), 292-293.

${ }^{94}$ Gothein (1923), 234.

${ }^{95}$ Zie Gothein (1923), 217; Gothein (1911), 220-221. 
dat voor de cultuurhistoricus de wereldgeschiedenis verschijnt als 'de gemeenschappelijke arbeid van het mensengeslacht aan zijn vervolmaking, ${ }^{96}$

De polarisatie die binnen de historische discipline optrad na Lamprechts aanvallen op de Rankeaanse, individualiserende, politieke geschiedschrijving, alsmede de mate waarin de Leipzigse historicus de discussie over de cultuurgeschiedenis ging domineren, maakten het voor Gothein steeds onaantrekkelijker zich in de methodenstrijd te mengen. Gothein had zelf kritiek geleverd op de eenzijdige politieke geschiedschrijving, maar was het op belangrijke punten oneens met de inhoud die Lamprecht aan de cultuurgeschiedschrijving gaf: zijn beoordeling van de Rankeaanse ideeënleer was veel positiever dan die van zijn Leipzigse collega, zijn oordeel over het belang van economische factoren daarentegen juist minder gunstig. Om dezelfde redenen kunnen we begrijpen dat Lamprecht vrijwel nooit aan Gothein als medestander of voorloper refereerde. Als hij al naar het Gothein-Schäfer debat verwees, dan eigenlijk alleen naar Schäfer als de stereotypische tegenstander van zijn eigen visie op het verleden. ${ }^{97}$

Toch werden Gothein en Lamprecht in de loop van hun carrière door andere historici geregeld met elkaar in verband gebracht. Beiden kwamen in 1883 in aanmerking voor de opdracht om een economische geschiedenis van het Zwarte Woud te schrijven, en de opdracht ging pas naar de drie jaar oudere Gothein nadat Lamprecht had afgezegd. ${ }^{98}$ In 1890 was Gothein min of meer Lamprechts (tot ordinarius verheven) opvolger in Bonn en hij werd nog in hetzelfde jaar, bij de opvolging van Georg Voigt als historisch ordinarius in Leipzig, ook diens directe concurrent, waarbij hij uiteindelijk aan het kortste eind trok. ${ }^{99}$ En toen Lamprecht in 1915 plotseling overleed, noemde Walter Goetz Gothein 'gewiß der rechte Mann' voor de opvolging, die tot zijn verbazing echter niet eens voor de positie in aanmerking werd genomen. ${ }^{100}$

Zo vreemd was Goetz' verwondering niet: bij alle meningsverschillen tussen Gothein en Lamprecht waren de overeenkomsten tussen beide historici vanuit later perspectief minstens zo opvallend. Beiden pleitten voor een uitbreiding van het historisch domein tot een alomvattende cultuurgeschiedenis waarin niet langer de politiek maar de cultuur van doorslaggevende betekenis was. Beiden gaven veel aandacht aan de collectieve psychologische kenmerken van groepen en waren overtuigd van de veranderlijkheid van die kenmerken in de loop van de geschiedenis. En hoewel Gothein het belang van de individuele persoonlijkheid meer benadrukte dan Lamprecht, ging ook zijn eigen aandacht minder uit naar individuen dan naar Massenerscheinungen en 'typen'. De betekenis van Gothein was vooral dat hij als eerste dit nieuwe perspectief onder woorden bracht en daarmee een onder historici breder levend ongenoegen over het traditionele politieke domein van de geschiedenis bleek te verwoorden. En misschien niet Lamprecht, maar in ieder geval wel jongere

${ }^{96}$ Gothein (1889a), 62.

${ }^{97}$ Overigens had Lamprecht in 1885 Gothein nog wel gesteund in diens eigen meningsverschillen met de politieke historici: een door de Preußische Jahrbücher geweigerde sociaal-economisch historische studie van Gothein plaatste hij in een vakblad onder zijn eigen redactie en voerde het vervolgens in een zeldzame eigen bijdrage aan de Preußische Jahrbücher als enige referentie op! Zie: Gothein (1885); Lamprecht (1885), 190.

${ }^{98}$ Zie Schönebaum (1959), 117.

${ }^{99}$ Zie Lewald (1968), 242-244.

${ }^{100}$ Brief van Goetz aan Karl Brandi, 23-6-1915, geciteerd in Weigand (1992), 151. 
historici als Georg Steinhausen en Kurt Breysig - beiden op het moment van Gotheins publicatie begin twintig en net gepromoveerd - werden op directe wijze door zijn repliek tegen Schäfer in hun afwijkende visie op geschiedwetenschap versterkt en gestimuleerd. $^{101}$

\section{Georg Steinhausen}

Georg Steinhausen duikt pas de laatste jaren nu en dan op in de literatuur over de Duitse geschiedwetenschap rond $1900 .{ }^{102}$ Hoewel deze als historicus opgeleide en gepromoveerde bibliothecaris pas helemaal aan het eind van zijn leven werd benoemd tot (honorair) hoogleraar cultuurgeschiedenis aan de universiteit van Heidelberg (1932), zouden we er verkeerd aan doen zijn werk geheel buiten de academische gemeenschap te plaatsen. Niet Gothein of Lamprecht, maar Steinhausen was in de eerste helft van de jaren negentig in woord en daad de meest gedreven activist voor een academische beoefening van de cultuurgeschiedenis in het Duitse taalgebied. Op grond van een hele reeks cultuurhistorische studies en bronnenuitgaven werd hij in 1913 door een contemporaine buitenlandse waarnemer als George Peabody Gooch in een gezaghebbend historiografisch overzichtswerk naast Lamprecht beschouwd als een van de 'most capable workers in the field [of Kulturgeschichte]'. ${ }^{103}$ Toen Steinhausen in 1925 werd verzocht zijn autobiografie te schrijven als bijdrage aan een collectief portret van de eigentijdse geschiedwetenschap, verscheen zijn levensbeschrijving temidden van die van louter hoogleraren. ${ }^{104}$

Gooch roemde speciaal Steinhausens originele Geschichte des deutschen Briefes (2 delen, 1889-1891), die de tweeëntwintigjarige doctor had voorzien van de naar eigen zeggen programmatisch bedoelde ondertitel Zur Kulturgeschichte des deutschen Volkes. ${ }^{105}$ Vanaf deze publicatie, waarmee Steinhausen ten tijde van het GotheinSchäfer debat in de publiciteit trad, was zijn lot verbonden met dat van de nieuwe cultuurgeschiedenis. Op energieke en praktische wijze probeerde hij de positie van de cultuurgeschiedenis binnen de wetenschappelijke gemeenschap te versterken, onder andere door in de jaren 1892-1896 de nieuw verschijnende cultuurhistorische publicaties te verzamelen en voor vakgenoten zichtbaar te maken in de Jahresberichte

${ }^{101}$ Overigens werd ook Gotheins latere werk door Steinhausen gevolgd en gewaardeerd, zie Steinhausen (1892d), I,4: 34 en 418-419. Er zijn geen aanwijzingen voor een nadere persoonlijke of intellectuele relatie tussen Goetz en Gothein. Goetz noemt hem niet in zijn autobiografie; ook in Weigands biografie van Goetz komt Gothein niet voor, behalve in de reeds geciteerde passage van Goetz over Lamprechts opvolging. Alleen in een historiografisch overzichtsartikel van Goetz uit 1932 (p. 380) wordt Gothein genoemd in het obligate rijtje Duitse cultuurhistorici: Burckhardt, Riehl, Gothein, Lamprecht. Het ontbreken van nadere contacten is opmerkelijk omdat Gothein in veel opzichten dicht bij Goetz' historiografische opvattingen stond.

${ }^{102}$ Een van de eersten die aandacht gaf aan Steinhausen was Haas (1994); hij wordt ook genoemd in Böhme, Matussek en Müller (2002), 47-48 en besproken in Patzel-Mattern (2002), 188-194 en Schleier (2003-), I, 943-980, 1032-1037. In 2003 verscheen naar aanleiding van het honderdjarige bestaan van het $A f K$ de eerste publicatie die geheel aan Steinhausen was gewijd: Herold (2003).

${ }^{103}$ Gooch (1952), 541. Overigens maakt Gooch t.a.p. de fout Steinhausen als pupil van Lamprecht te beschouwen.

${ }^{104}$ Namelijk: Below, Dopsch, Finke, Goetz, Kaindl, Lehmann. Ook het tweede deel van de serie uit 1926 was (grotendeels) gevuld met bijdragen van ordinarii.

${ }^{105}$ Zie Steinhausen (1925), 10; zie voor recensies van dit werk: Steinhausen (1891), nr. I, 5: 13. Inmiddels wordt de geschiedenis van de brief geregeld aan Duitse universiteiten gedoceerd, waarbij het werk van Steinhausen standaard tot de opgevoerde literatuur behoort. O.a. aan de universiteiten van Berlijn, Kiel, Münster Tübingen, Wenen werden in 2002 of eerder projecten, hoor- en werkcolleges over de geschiedenis van de brief gehouden met verwijzingen naar Steinhausen. 
der Geschichtswissenschaft, de officieuze jaarbibliografie van de Duitse geschiedwetenschap. In een tijd waarin het aantal historische vakpublicaties sterk groeide was deze activiteit ten behoeve van de cultuurgeschiedenis extra van belang. Ook voor de omvangrijke en veel gebruikte handbibliografie van de Duitse geschiedwetenschap, de Dahlmann-Waitz, verzorgde Steinhausen in de editie van 1912 de cultuurhistorische secties.

Nog duidelijker zette Steinhausen de academische cultuurgeschiedschrijving op de kaart door zijn initiatief eind 1893 tot de oprichting van de nog altijd bestaande Zeitschrift (inmiddels: Archiv) für Kulturgeschichte, die expliciet in het leven was geroepen om een forum te verschaffen aan de academische cultuurgeschiedschrijving. Onder de titel Zeitschrift für deutsche Kulturgeschichte was al in de jaren vijftig, opnieuw in de jaren zeventig en tenslotte nog eens tussen 1891 en 1893 een algemeen cultuurhistorisch tijdschrift verschenen, maar deze tijdschriften haalden nooit hun eerste lustrum, kenden nauwelijks universitaire medewerkers en hadden geen duidelijke academische pretenties. Dat was anders bij Steinhausens Zeitschrift für Kulturgeschichte met haar uitgesproken doelstelling om de beoefening van de cultuurgeschiedenis als academische discipline te stimuleren. Steinhausen wist zowel Gothein als Lamprecht te winnen voor een bijdrage aan het eerste nummer - en probeerde vervolgens met wisselend succes ook andere universitaire wetenschappers aan het tijdschrift te binden. Lamprecht zou nog enkele malen in zijn tijdschrift publiceren, net als Breysig en nog later Goetz. Met Goetz, vanaf 1909 medewerker van het blad en zijn uiteindelijke opvolger als hoofdredacteur, zou Steinhausen een nauwe samenwerking aangaan die het academische karakter van het blad verder zou verstevigen en de toekomst ervan wist te verzekeren.

Vanuit wetenschappelijk oogpunt even belangrijk en aanvankelijk ook even veelbelovend was Steinhausens aanhoudende initiatief op de Historikertage in Frankfurt (1895), Innsbruck (1896) en Neurenberg (1898) om de Duitse cultuurgeschiedenis van een eigen reeks wetenschappelijke bronnenuitgaven te voorzien. ${ }^{106}$ Op de Neurenbergse Historikertag presenteerde hij uiteindelijk zes verschillende bronnencategorieën die naar zijn mening vanuit cultuurhistorisch perspectief wetenschappelijke edities verdienden, maar geen plaats hadden gekregen in reguliere bronnenreeksen als de Monumenta Germaniae Historica: 1. privé-brieven, 2. reglementen en verordeningen uit de diverse sociale lagen en kringen (bijvoorbeeld hof, stad, politie), 3. dagboeken en huis(houd)boeken, 4. reisverslagen, 5. inscripties en 6. inventarissen. Het waren deze bronnen die naar zijn mening beter dan de vaak door cultuurhistorici gebruikte artistieke of literaire bronnen geschikt waren als bron voor de cultuurgeschiedenis. ${ }^{107}$ Hoewel Steinhausen met zijn plan de bijval oogstte van de bijna 150-koppige vergadering van historici in Neurenberg en hij de financiële steun verwierf van de Berlijnse Academie van Wetenschappen, bleef het project in de beginfase steken: als Denkmäler der deutschen Kulturgeschichte verschenen slechts twee delen met middeleeuwse privé-brieven en twee delen met Duitse hofreglementen uit de zestiende en zeventiende eeuw - belangrijke bronnen voor de gedragsregels die golden aan de Duitse hoven van het ancien régime. ${ }^{108}$

${ }^{106}$ Zie Bericht (1896), 64; Bericht (1898), 47-50.

${ }^{107}$ Zie Steinhausen (1899-1907), I, VI.

${ }^{108}$ Steinhausen (1899-1907) en Kern (1905-1907). Overigens trad Below ook hier weer als criticus op, zie Steinhausen (1899-1907), II, XI. 
Tabel 3.1

Steinhausens indeling van de cultuurgeschiedenis. In de rechterkolom een verdeling van Steinhausens belangrijkste monografieën volgens zijn eigen rubricering van de cultuurgeschiedenis. Opvallend is het verschil met de andere nieuwe cultuurhistorici: de rubrieken die bij Steinhausen zelf (vrijwel) leeg bleven - juridische, religieuze en artistieke aspecten - zouden wel onderzocht worden door de andere nieuwe cultuurhistorici. Ook het economisch en bestuurlijk leven zou bij de andere nieuwe cultuurhistorici een grotere plaats innemen.

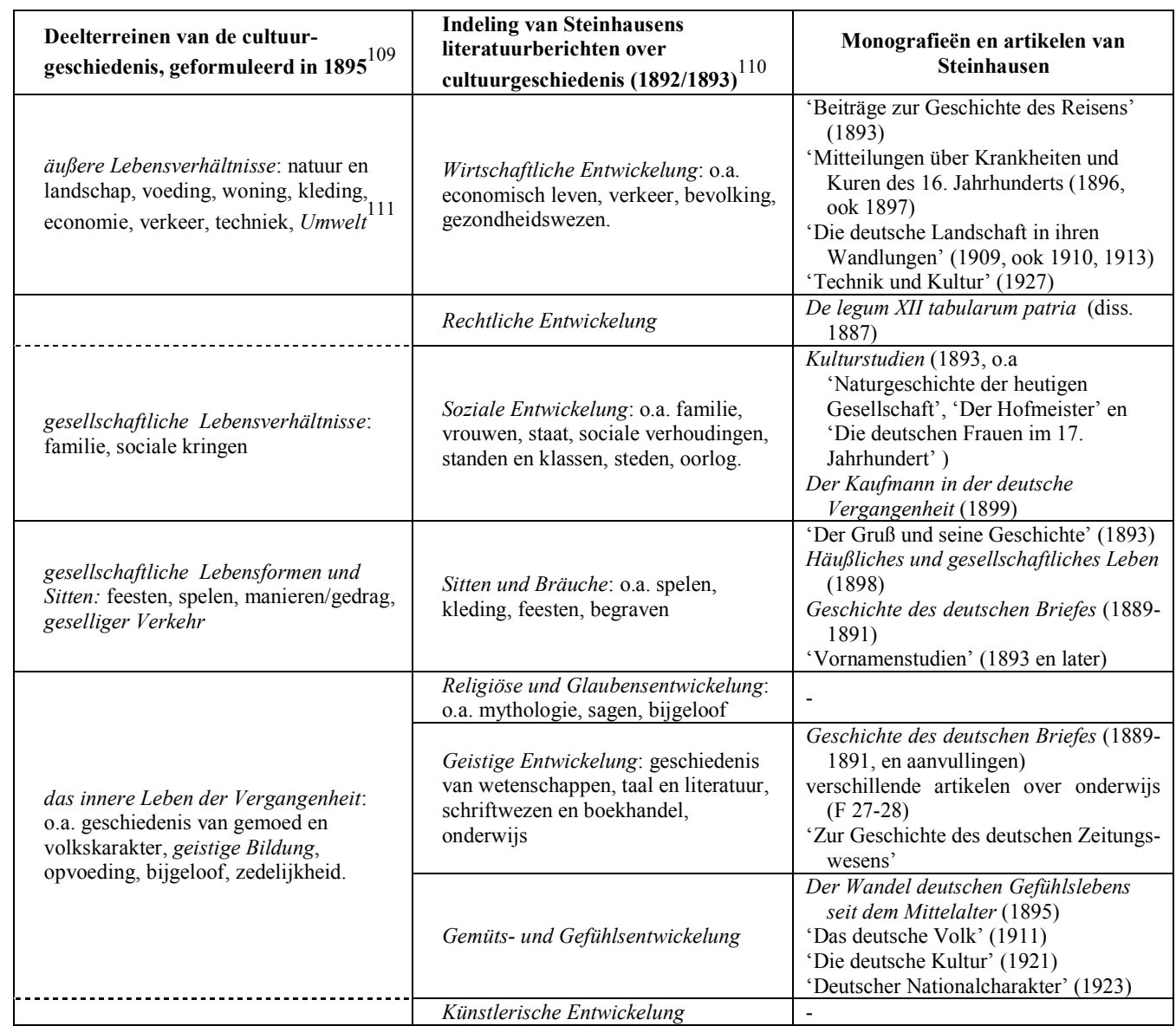

\subsection{Cultuurgeschiedenis als 'Geschichte des inneren Menschen'}

Het was Steinhausen die met al deze activiteiten de zaak van een academische cultuurgeschiedschrijving in praktisch opzicht het krachtigst behartigde tussen het SchäferGothein debat (1888-1891) en het optreden van Lamprecht en Breysig in 1896. Bovendien publiceerde hij in de eerste helft van de jaren negentig een reeks program-

${ }^{109}$ Steinhausen (1895c), 195. Deze opsomming komt grotendeels overeen met de vergelijkbare opsomming van cultuurhistorische deelterreinen in Steinhausen (1925), 243-248.

${ }^{110}$ Bijv. Steinhausen (1892a) en Steinhausen (1893a).

${ }^{111}$ Steinhausen (1925), 245. 
matische artikelen waarin hij, onder verwijzing naar Bernheim, Gothein en later Lamprecht, voortdurend de beoefening van de cultuurgeschiedenis aan de Duitse universiteiten bepleitte. ${ }^{112}$

In deze artikelen verdedigde Steinhausen onvermoeibaar de gedachte van een zelfstandige cultuurgeschiedenis 'in engere zin' naast de politieke geschiedenis. Het domein van de cultuurgeschiedenis typeerde hij incidenteel wel als het 'nietpolitieke'. ${ }^{113}$ Naar zijn opvatting werd de cultuurgeschiedschrijving vooral gekenmerkt door een andere invalshoek dan de politieke geschiedenis, zodat zelfs bij overlappende onderwerpen het historisch materiaal in beide gevallen heel anders behandeld werd. In deze zin sprak hij over cultuurgeschiedenis als een Spezialgeschichte of zelfs als een historische Sonderdisziplin. En geheel in lijn met dit standpunt pleitte hij vanaf 1891 voortdurend voor de inrichting van aparte leerstoelen voor cultuurgeschiedenis, om te beginnen in Berlijn - een pleidooi dat hij kracht bij zette met een inventarisatie van het academisch onderwijs in de cultuurgeschiedenis in de periode 1888-1891. Uit die inventarisatie bleek dat, behalve een hele reeks universitaire kunst- en literatuurhistorici en Staatswissenschaftler ook een aantal historische universitair docenten, extraordinarii en ordinarii in hun colleges in deze jaren naar eigen zeggen aandacht gaven aan cultuurgeschiedenis. Ook Gothein en Lamprecht werden door Steinhausen in dit verband genoemd. ${ }^{114}$ Steinhausens inventarisatie maakte duidelijk dat cultuurgeschiedenis inmiddels in het universitaire onderwijs een eigen, zij het nog bescheiden plaats had verworven. Dat betekende volgens hem ook dat het domein van de cultuurgeschiedenis aanspraak kon maken op academische institutionalisering in de vorm van leerstoelen. ${ }^{115}$

Bij nadere beschouwing wordt duidelijk dat ook Steinhausen uiteindelijk cultuurgeschiedenis meer beschouwde als overkoepelende, algemene geschiedenis dan uitsluitend als aparte variant van historisch onderzoek naast de politieke geschiedenis. ${ }^{116}$ Zijn opsommingen van de deeldomeinen van de cultuurgeschiedenis roepen vanwege hun alomvattendheid deze suggestie al meteen op. ${ }^{117}$ In een artikel uit 1892 schreef hij bovendien expliciet: 'Naar mijn mening kan de geschiedenis van alle perioden slechts vanuit één optiek, namelijk de cultuurhistorische, geschreven worden'. En nog duidelijker: 'Als de geschiedenis haar ware opgaven vervult, dan zal het begrip 'cultuurgeschiedenis' vanzelf verdwijnen. [...] Wie in onze zin over cultuurgeschiedenis spreekt, bedoelt daarmee: juist opgevatte geschiedenis'. ${ }^{118}$

In 1895 liet hij, in een reactie op kritiek van de Historische Zeitschrift, bovendien doorschemeren dat zijn pleidooi voor nieuwe, aparte leerstoelen voor cultuurgeschiedenis niet zozeer uit een principiële als wel uit een strategische keuze voortvloeide. Steinhausen had op andere plekken meermaals verklaard dat hij een

${ }^{112}$ Zie Steinhausen (1892c), voor het eerst verschenen in 1891; Steinhausen (1892b); Steinhausen (1894), verschenen 1893; Steinhausen (1895c); Steinhausen (1896a); Steinhausen en Bernheim (1896).

${ }^{113}$ Steinhausen (1925), 243.

${ }^{114}$ Steinhausen noemt verder de kunst- en literatuurhistorici Hermann Grimm, Friedländer en Biedermann, de Staatswissenschaftler Riehl, onder de historische universitair docenten o.a. Ranke's laatste assistent Ignaz Jastrow, onder de extraordinarii o.a. Von Zwiedineck-Südenhorst en onder de historische ordinarii o.a. Grauert, Pöhlmann en Lenz.

${ }^{115}$ Zie Steinhausen (1892c), vgl. bovendien Steinhausen en Bernheim (1896), 321.

${ }^{116}$ Ook Goetz (1916a), 274, meende dat het verschil tussen Steinhausen en bijv. Lamprecht in dit opzicht niet zo groot was.

${ }^{117}$ Zie Tabel 3.1

${ }^{118}$ Steinhausen (1892b), 54 en 55 (mijn cursivering, MS); vgl. ten slotte ook nog Steinhausen (1892a), IV, 6: 'So wenig ich die Trennung politischer und Kulturgeschichte billige [sic!] [...] man wird so lange von einer Kulturgeschichte sprechen müssen als man Geschichte nur als politische Geschichte faßt'. 
goede verstandverhouding met de politieke historici wilde bewaren; in dat voornemen paste het niet om de cultuurgeschiedenis als de rechtmatige opvolger van de politieke geschiedenis als vertegenwoordiger van de algemene geschiedenis presenteren. Het zou eenvoudig op te veel verzet stuiten om cultuurhistorici op bestaande leerstoelen voor geschiedenis te benoemen, ook al zou daarmee, aldus Steinhausen, recht gedaan worden aan de 'wending [...] die zich tegenwoordig in de geschiedwetenschap voltrekt'. 119

Ook voor Steinhausen was cultuurgeschiedenis derhalve in laatste instantie de eigentijdse of moderne vorm van algemene geschiedenis. Dat bleek ook toen hij in zijn tweede boekpublicatie, de essaybundel Kulturstudien (1893), de belangrijkste taak van de cultuurgeschiedenis formuleerde: 'Als de eigenlijke opgave van de cultuurgeschiedenis of beter gezegd van de geschiedenis überhaupt beschouw ik de beantwoording van de vraag die Carlyle heeft geformuleerd: "hoe en wat waren de mensen vroeger?" 120 Een van zijn eigen monografieën, gewijd aan de geschiedenis van de Duitse koopman, introduceerde hij als 'niet een technische geschiedenis van de handel, maar een stuk mensengeschiedenis [ein Stück Menschengeschichte]' ${ }^{121}$ Zelfs wanneer hij zich met meer uiterlijke kanten van de cultuurgeschiedenis bezighield techniek, communicatiemiddelen, landschap - dan was het zijn uitgesproken doelstelling niet te blijven staan bij uiterlijkheden, maar van daaruit door te dringen tot 'hoe de mensen toentertijd dachten, voelden, handelden'. ${ }^{122}$ Dit terrein noemde hij bij herhaling de 'mooiste', 'bijzonder waardevolle' of 'wezenlijke' opgave van de cultuurgeschiedenis. ${ }^{123} \mathrm{Zij}$ werd door hem betiteld als een 'Geschichte des inneren Menschen' en als haar eigenlijke gebied noemde hij 'het innerlijke wezen van de mensen, hun voelen en Empfinden', 'het gemoeds- en gevoelsleven van het collectief of van bepaalde lagen'. ${ }^{124}$ In een van zijn laatste werken uit 1931 gebruikte Steinhausen hiervoor ook enkele keren de aanduiding Mentalität. ${ }^{125}$

En hij spreekt dan over 'Mentalitätsgruppen'. Net als Gothein legde Steinhausen er de nadruk op dat in de historische benadering 'de mens altijd als een sociaal wezen' diende te worden beschouwd - als een deelgenoot van zijn volk en als een kind van zijn tijd. ${ }^{126}$ Het belangrijkste object van de cultuurhistoricus bestond uit 'de werkelijke mensen' en dat wilde zeggen: 'de massa', de 'doorsneemens', het ging hem om de mens als collectivum, 'als Gattungswesen [...] als type, als een vertegenwoordier van zijn tijd, van zijn generatie'. ${ }^{127}$ Het verbaast niet dat Steinhausen in recensies van werk van Gothein de nadruk legde op diens gave om het typische weer te geven. ${ }^{128}$ Ware cultuurgeschiedenis was 'waarachtige mensenschildering', niet de beschrijving van

${ }^{119}$ Steinhausen (1895c), 197. Elders schreef Steinhausen dat de cultuurgeschiedenis een recente, 'aufstrebende' wetenschap was, 'erst ein Product des neueren Zeitgeistes', die als 'de wetenschap van de toekomst' beschouwd moest worden, Steinhausen (1892b), 54 en Steinhausen (1894), 2.

${ }^{120}$ Zie Steinhausen (1893b), VII (mijn cursivering, MS); vgl. idem Steinhausen (1892b), 55 en 56, Steinhausen (1892d), I,4; Steinhausen (1894), 195 en Steinhausen (1925), 248.

${ }^{121}$ Steinhausen (1899), 6.

${ }^{122}$ Steinhausen (1892b), 55.

${ }^{123}$ Steinhausen (1894), 3; Steinhausen (1895c), 195; Steinhausen (1896b), 14; Steinhausen (1905a), 59.

${ }^{124}$ Steinhausen (1925), 245, 247.

${ }^{125}$ Steinhausen (1931), 92, 96, 329n. Dit was nog vóór Theodor Geigers (1932) klassiek geworden omschrijving van het mentaliteitsbegrip.

${ }^{126}$ Steinhausen (1892b), 55.

${ }^{127}$ Steinhausen (1892b), 55; Steinhausen (1893b), VII; Steinhausen (1894), 3 (mijn cusivering). 'Doorsneemens': Steinhausen (1895a), VI; Steinhausen en [Goetz?] (1910), 2; Steinhausen (1925), 243, Steinhausen (1898a), 450, 453.

${ }^{128}$ Zie Steinhausen (1892d), I, 4: 418. 
individuele helden, maar 'typische Menschenschilderung' waarbij aan de hand van 'typische voorbeelden de aard van de betreffende generatie' getoond kon worden. ${ }^{129}$ De brieveneditie van het echtpaar Paumgartner die Steinhausen verzorgde, had bijvoorbeeld naar zijn eigen zeggen geen enkel politiek-historisch of literair belang: 'het zijn pure doorsneemensen, maar juist daarom cultuurhistorisch interessant'. ${ }^{130}$

Door egodocumenten als privébrieven, dagboeken en reisverslagen te gebruiken als voornaamste bron kon Steinhausen de aandacht richten op 'de Empfindungs- en denkwijzen, op het gevoelsleven en de opvattingen van doorsneemensen'. ${ }^{131}$ Met name de (privé-)brief diende hem als 'getuigenis van het heersende geestes- en gemoedsleven van het Duitse volk, als spiegel van zijn karakter, van zijn gevoelens, van zijn voorliefdes en interesses'. ${ }^{332}$ Elders verklaarde hij zijn belangstelling voor de brief met de opmerking dat juist brieven 'ons de mensen zelf in hun wezen nader kunnen leren kennen'. ${ }^{133}$ In zijn Geschichte des deutschen Briefes behandelde Steinhausen deze thematiek zo dat hij historische schetsen over de frequentie en gebruik van de brief en de organisatie van het briefverkeer in de verschillende perioden combineerde met analyses over vorm en vormelijkheid, thematiek en stijl van de brieven in de verschillende sociale lagen. Deze analyses illustreerde hij met vele door hem als 'typisch' gepresenteerde citaten uit brieven, die vervolgens zijn conclusies over het 'innerlijke leven' van de mensen in het verleden moesten staven.

Steinhausen sprak (net als Gothein) over 'historische psychologie' of (net als Lamprecht) over 'sociaal-psychologische geschiedschrijving' om zijn benadering van de cultuurgeschiedenis te benoemen. ${ }^{134}$ Hij was ervan overtuigd dat mensen uit het verleden niet met de huidige psychologische maatstaf gemeten mochten worden en dat het voelen, willen en waarnemen van mensen in de loop van de tijd was veranderd. ${ }^{135}$ Maar hoe was de mens veranderd? Uit Steinhausens cultuurgeschiedenissen kunnen we opmaken dat het karakter van mensen naar zijn mening vooral gevormd werd door de - natuurlijke en culturele - omgeving. In de eerste plaats moesten landschap, klimaat en bodem invloedrijker worden geacht dan rassenkenmerken. ${ }^{136}$ Zo meldde Steinhausen bijvoorbeeld in een cultuurhistorische studie over de Germanen dat hun oorspronkelijke leefomgeving van 'zee en woud' een grote invloed had uitgeoefend: onmetelijk, eentonig, wild en oorspronkelijk, verdiepten ze het gemoed en het innerlijk leven van de Germanen, werkten bevrijdend en verfrissend, maar remden ook de ontwikkeling van een meer verfijnde cultuur. ${ }^{137}$ Het gure klimaat had de Germaan zijn 'huiselijkheid' gebracht. ${ }^{138}$ Maar ook de menselijke levenswijze - de cultuur - liet zijn sporen na in het karakter en gedrag van de mensen. 'Cultuur' betekende nu eenmaal 'Bildung, Umbildung' van de mens. ${ }^{139}$ Een studie over 'het huiselijk en sociaal leven in de negentiende eeuw' leidde Steinhausen bijvoorbeeld in met de 'geweldige omslag' die zich gedurende die eeuw had voltrokken: de grote technische en economische veranderingen hadden niet alleen een fundamentele verandering van de levensvoorwaarden en de levenswijzen teweeggebracht, maar ook 'de innerlijke mens'

\footnotetext{
${ }^{129}$ Steinhausen (1896b), 11-13.

${ }^{130}$ Steinhausen (1895a), VI.

${ }^{131}$ Steinhausen in Bericht (1898), 47.

${ }^{132}$ Steinhausen (1892b), 55.

133 Steinhausen (1898c), 443.

${ }^{134}$ Steinhausen (1905b), 236; Steinhausen (1925), 243, 262.

${ }^{135}$ Steinhausen (1899-1907), I, VI.

${ }^{136}$ Steinhausen (1910), m.n. 143, Steinhausen (1911), 21

${ }^{137}$ Zie Steinhausen (1905a), 2-3, 16-17.

${ }^{138}$ Steinhausen (1905a), 68.

${ }^{139}$ Steinhausen (1910), 132.
} 
'een ongehoorde schok' bezorgd; daardoor waren de mensen in dit tijdvak 'buitengewoon' veranderd: zij waren 'energieker, praktischer, maar ook nerveuzer' geworden. ${ }^{140}$ En onder verwijzing naar werk van de zenuwarts Erb wees hij elders op de invloed van de ongekende groei en snelheid van de communicatie, de enorm toegenomen eisen aan het prestatievermogen van het individu, de politieke en sociale tegenstellingen, het moderne grotestadsleven, de economische strijd om het bestaan. De resulterende 'nervositeit' droeg echter niet per se een ziekelijk karakter, maar betekende eenvoudig dat het gevoel 'verfijnder' was geworden. ${ }^{141}$

Die laatste bewering - over de fijngevoelige moderne mens - vindt een pendant in contrasterende uitspraken van Steinhausen over de minder fijnbesnaarde mens in het verleden, speciaal uit de middeleeuwen. In zijn boek over de brief bijvoorbeeld werden middeleeuwers op grond van hun schrijfstijl afgeschilderd als kinderlijk, naïef, niet in staat logisch of oorspronkelijk te denken, conventioneel, zonder individualiteit. ${ }^{142}$ En elders sprak hij over de 'van natuurlijke driften vervulde Duitse mensen' uit de middeleeuwen, ongedisciplineerd, gedreven door 'natuurlijke hartstochten' die open tot uitdrukking kwamen: 'Zoals men zich bijvoorbeeld in het seksuele leven onbevangen en natuurlijk gaf, zo heerste ook elders krachtige ruwheid. Een rauwe, bijna wrede trek ging door het bestaan'. ${ }^{143}$ Hoewel Steinhausen weinig expliciete uitspraken deed over de menselijke cultuurontwikkeling als geheel - en zich meer dan eens uitsprak tegen de gedachte van ontwikkelingswetten - ${ }^{144}$ blijkt uit dergelijke verspreide opmerkingen dat hij in termen van een algemene historische vooruitgang dacht. Zonder dat hij die gedachte uitwerkte, komen we in zijn werk bij herhaling uitdrukkingen tegen als (Kultur)stufe, Entwicklungsgrad, 'hogere' en 'lagere' culturen. ${ }^{145}$ Zoals Gothein in de Aufgaben der Kulturgeschichte de cultuurgeschiedenis typeerde als het werk van de mensheid aan haar vervolmaking, zo ging het ook in Steinhausens 'mensengeschiedenis' uiteindelijk om 'de ontwikkeling en vervolmaking van de menselijke levensvormen en levensuitingen', zoals hij het in zijn eerste geschiedtheoretische bijdrage formuleerde. ${ }^{146}$

\subsection{Cultuurgeschiedenis als 'Lebensgeschichte eines Volkes'}

Steinhausens Menschengeschichte resulteerde in historisch onderzoek 'van een collectief psychisch leven in nationaal kader'. ${ }^{147}$ Anders dan Gothein legde hij de meeste nadruk op de volkeren of naties als de eenheden van de cultuurgeschiedenis. Naast de door hem telkens herhaalde en geparafraseerde Carlylese vraagstelling ("hoe en wat waren de mensen vroeger?") duikt in zijn programmatische geschriften vanaf het begin een andere formulering op waarin dat tot uitdrukking komt: zijn omschrijving van de cultuurgeschiedenis als 'de levensgeschiedenis allereerst van een bepaald volk, in laatste instantie van de mensheid'. ${ }^{148}$ Cultuurgeschiedenis was inderdaad geen geschiedenis van de staat, maar de geschiedenis van 'de natie' oftewel Volksgeschichte. De ware historische samenhang werd niet door een staatkundig

${ }^{140}$ Zie Steinhausen (1898b), 1-8.

${ }^{141}$ Steinhausen (1895b), 40-41.

${ }^{142}$ Steinhausen (1889-1891), I, 39-62.

143 Steinhausen (1921), 27-28.

${ }^{144}$ Zie bijv. Steinhausen (1898a), 458; Steinhausen (1925), 32.

${ }^{145}$ Zie bijv. passim in Steinhausen (1905a).

${ }^{146}$ Steinhausen (1892c), [oorspronkelijk 1891], 256.

${ }^{147}$ Steinhausen (1925), 243; Steinhausen (1898a), 454.

${ }^{148}$ Steinhausen (1894), 3, ook al in zijn eerste theoretische stellingname: Steinhausen (1892c), [oorspronkelijk 1891], 256. 
perspectief gewaarborgd, zoals Steinhausen met een verwijzing naar het staatkundig gefragmenteerde Duitse verleden opmerkte, maar door het nationale perspectief, door het begrip van het Volkstum (in de zin van 'nationaliteit'). ${ }^{149}$ 'Cultuur' en cultuurgeschiedenis waren naar Steinhausens mening nauw verbonden met dit historisch gegroeid Volkstum, dat weliswaar veranderlijk geacht moest worden, maar desalniettemin 'ein starker Faktor des Beharrens' vormde, zoals hij het in zijn grote overzicht van de Duitse cultuurgeschiedenis formuleerde. ${ }^{150} \mathrm{Er}$ bestond geen tegenstelling tussen Volkstum en cultuur, het Volkstum was de stam waarop de cultuur geënt was, cultuur was altijd in hoge mate nationale cultuur. Cultuurgeschiedenis à la Steinhausen was de geschiedenis van de volksziel, een symbiose van Volksgeschichte en Menschengeschichte.

Steinhausen kende wel degelijk de bezwaren tegen een dergelijk nationaal perspectief. Hij waarschuwde herhaald voor het gevaar van al te gemakkelijke generalisaties als het ging om de bepaling van de nationale aard en wees op de grote invloed van nationalistische voorkeuren en afkeren. ${ }^{151}$ Hij merkte bij herhaling op dat niet de vergissing moest worden begaan het Volkstum als een mystieke, romantische constructie op te vatten en er iets oorspronkelijks en onveranderlijks, al dan niet bepaald door 'rassenkenmerken', van te maken. ${ }^{152}$ Niet alleen waren de Duitsers van oudsher al een Mischvolk, het volkskarakter was bovendien 'niet onveranderlijk, maar iets dat historisch geworden is'. ${ }^{153}$ Belangrijker dan rassenkenmerken waren, zoals al opgemerkt, landschap, klimaat, bodem, maar bovenal de ten dele van deze natuurlijke factoren afhangende historische factoren, met name de langdurende economische en sociale verhoudingen in de primitiefste ontwikkelingsstadia van de nationale geschiedenis. Vervolgens waren ook de gemeenschappelijke wederwaardigheden die een bevolkingsgroep meemaakte en het proces van historisch 'samensmelten', met name door het samenleven onder gemeenschappelijke overheden, van invloed op het volkskarakter. ${ }^{154}$ De politieke en culturele geschiedenis van een volk vormden èn hervormden zodoende voortdurend het nationale karakter, dat vervolgens overigens ook weer de loop van de nationale geschiedenis beïnvloedde. ${ }^{155}$ Veel nationale karaktertrekken die men wel aan de vroegste fasen van de ontwikkeling meende te kunnen ontlenen, waren in feite inherent aan het betreffende ontwikkelingsstadium en in datzelfde stadium bij alle volkeren aan te treffen.

Steinhausen noemde verder het begrip 'volk' zelf meer dan eens een 'onduidelijk en ietwat chaotisch begrip', dat met voorzichtigheid gehanteerd moest worden. 'Volk en volk is niet hetzelfde', merkte hij op in een bespreking van de cultuurhistorische opvattingen van de door hem gewaardeerde voorgangers Riehl, Freytag en Burckhardt: voor de een bestond 'het volk' in wezen uit de landelijke bevolking, bij de ander ging het vooral om de (kleine) burgerij, bij de derde draaide alles in feite om de

${ }^{149} \mathrm{Al}$ in Steinhausen (1892b), 54-55, maar vooral Steinhausen $(1910,(1922)$.

${ }^{150}$ Steinhausen (1904), VI. Behalve dit grote overzichtswerk publiceerde Steinhausen ook nog drie losse, meer populaire deeltjes waarin afzonderlijke periodes in de Duitse cultuur werden beschreven: Germanische Kultur in der Urzeit (1905), Kulturgeschichte der Deutschen im Mittelalter (1910) en Kulturgeschichte der Deutschen in der Neuzeit (1912). Aan het eind van zijn leven volgde nog het omvangrijkere Deutsche Geistes- und Kulturgeschichte von 1870 bis zur Gegenwart (1931).

${ }^{151}$ Zie bijv. Steinhausen (1910), 138-140; Steinhausen (1911), 21; Steinhausen (1923), 392: 'Im ganzen behält der Begriff des N[ationalcharakter]s etwas unbestimmtes, Gefühlsmäßiges; seine wissenschaftliche Feststellung bleibt schwierig'.

${ }^{152}$ Steinhausen (1910), m.n. 133 en 140 e.v.; ook Steinhausen (1925), 263-264.

${ }^{153}$ Steinhausen (1923), 392.

${ }^{154}$ Steinhausen (1910), m.n. 143, Steinhausen (1911), 21

${ }^{155}$ Steinhausen (1923), 392; Steinhausen (1910), 144 
geschoolde elite - zonder dat een van deze cultuurhistorici zich rekenschap gaf van deze beperkte selectie. ${ }^{156}$

'Het volk' als zodanig kon moeilijk een eenheid genoemd worden: de cultuurhistoricus diende naar Steinhausens herhaald uitgesproken mening voortdurend te differentiëren tussen de verschillende regio's enerzijds en de verschillende sociale groepen anderzijds. Bovendien moest de historicus ook altijd rekening houden met het 'cultuurstadium' waarin een volk verkeerde en dat zijn eigen kernmerken met zich mee bracht. ${ }^{157}$ In zijn grote overzicht over de Duitse cultuurgeschiedenis, Geschichte der Deutschen Kultur (1904) waren daarom naar Steinhausens eigen zeggen 'de interne en externe toestanden [...] in elk stadium anders geschilderd naar de afzonderlijke sociale lagen, en niet minder zijn de uitzonderlijk belangrijke regionale [landschaftlichen] verschillen zoveel mogelijk in acht genomen'. ${ }^{158}$

In Steinhausens geschiedschrijving komen deze overwegingen vooral tot uiting in zijn expliciete aandacht voor de verschillende sociale lagen. In zijn grote Geschichte der Deutschen Kultur werd bijvoorbeeld voortdurend onderscheiden tussen boeren, burgers, geestelijkheid, adel, vorsten - en kwam ook de positie van de vrouw geregeld expliciet aan bod. Typerend was ook de reeks van twaalf rijk geïllustreerde Monographien zur deutschen Kulturgeschichte die Steinhausen tussen 1899 en 1905 uitgaf en die nog eens in 1924 werden gepubliceerd met de toepasselijker titel Die deutschen Stände in Einzeldarstellungen. Onder die noemer liet Steinhausen de geschiedenis schrijven van de verschillende beroepen: de arts, de jurist, de leraar, de wetenschapper, de protestantse geestelijke, de koopman (Steinhausens eigen bijdrage aan de reeks), de ambachtsman, de boer en de soldaat, maar ook de geschiedenis van zwervers, joden en kinderen. ${ }^{159}$ Behalve aan de koopman wijdde Steinhausen zelf bovendien nog een of meer artikelen aan respectievelijk de hofmeester, de 'betere kringen' en de vrouw in het verleden. ${ }^{160}$

Toch moeten we Steinhausens nuanceringen van het volksbegrip en zijn pogingen tot differentiatie van 'het volk' met de nodige korrels zout nemen. Ondanks zijn eigen reserves over de eenheid van het Duitse volk kwam hij telkens weer tot uitgewerkte algemene typeringen van de Duitse aard: ' ...door alle verschillen heen komen de grote, tot op heden gemeenschappelijke trekken naar voren', meende hij. ${ }^{161}$ Skepsis tegenover het begrip van een Germaans volkskarakter noemde hij in 1905 zelfs 'misplaatst'. ${ }^{162}$ 'Tussen de Germanen van de oertijd en ons bestaat in waarheid nog altijd een diepe, onuitroeibare samenhang'. ${ }^{163}$ Het Duitse nationale karakter was weliswaar historisch ontstaan en 'iets gewordens', maar dan wel iets 'zeer vroeg gewordens'. Daardoor had het in de loop van de historische ontwikkeling het karakter van iets oorspronkelijks en natuurlijks had gekregen. ${ }^{164}$ De in het vroegste ontwikkelingsstadium gevormde collectieve seelischer Typus veranderde nog maar ten dele: het was een basiskarakter dat de 'vloed van vreemde cultuurinvloeden' weer-

${ }^{156}$ Steinhausen (1898a), 455.

${ }^{157}$ Steinhausen (1905a), passim (bijv. 60, 63).

${ }^{158}$ Steinhausen (1904), VI; vgl. ook Steinhausen (1910), 139; Steinhausen (1911), 21; Steinhausen (1923), 392.

${ }^{159}$ De auteurs waren, naast Steinhausen zelf, Georg Liebe (2x), Hermann Peters, Franz

Heinemann, Hans Boesch (dir. van het GNM), Adolf Bartels, Emil Reicke (2x), Ernst Mummenhoff, Theodor Hampe (ex-dir. GNM) en Paul Drews.

${ }^{160}$ Zie Steinhausens bibliografie in Steinhausen (1925): F.1, 9, 21, 23, $28,42$.

${ }^{161}$ Steinhausen (1911), 21.

${ }^{162}$ Steinhausen (1905a), 59.

${ }^{163}$ Steinhausen (1905a), 22.

${ }^{164}$ Steinhausen (1910), 144. 
stond en ondanks alle latere cultivering wezenlijk hetzelfde was gebleven. ${ }^{165}$ Weliswaar was de Lehrgang die de Duitsers hadden doorgemaakt - Romeinse cultuur, christendom, Renaissance, Verlichting - vergelijkbaar met die van de andere Europese volkeren, maar de eigen aard van de Duitsers maakte dat de 'nationale cultuurontwikkeling' daar tot andere uitkomsten had geleid dan elders. ${ }^{166}$ En Steinhausen schrok er niet voor terug de eigen aard van de Duitsers herhaalde malen te beschrijven, waarbij hij ondanks zichzelf uitkwam bij stereotypes als 'individualisme', 'innerlijkheid', 'realisme' en - tevens de verklaring voor de elkaar in sommige opzichten tegensprekende kenmerken - 'innerlijke gespletenheid'.

Uiteindelijk werd de hele nationale geschiedenis volgens Steinhausen bepaald door twee factoren: 'enerzijds de nationale aard, het bodenständige Volkstum met zijn begaafdheden, driften en oude tradities van leven en cultuur en anderzijds de wereldcultuur'. ${ }^{167}$ De verhouding en wisselwerking tussen deze twee factoren, het Duitse volkskarakter en 'vreemde cultuurinvloeden', was cruciaal in zijn visie op het Duitse verleden. Aangezien die wisselwerking op haar beurt sterk bepaald werd door de beschikbare communicatievormen en -technieken, kregen deze in zijn cultuurgeschiedschrijving eveneens veel aandacht; in een zeldzame uiting van aforistisch taalgebruik schreef hij zelfs: 'Der Verkehr macht die Kulturgeschichte'. ${ }^{168}$ Hij beschouwde het als een van de onderscheidende kwaliteiten van zijn geschiedschrijving dat hij de Duitse cultuurgeschiedenis niet in isolement bekeek en consequent aandacht gaf aan de invloeden van andere (nationale) culturen. Met de noodzaak van een dergelijke internationale blik op de nationale cultuurgeschiedenis verdedigde hij ook de weglating van het beperkende 'deutsche' in de titel van zijn Zeitschrift für Kulturgeschichte. ${ }^{169}$

In Steinhausens cultuurgeschiedenis speelden de 'wereldcultuur' en het nationale karakter elk een eigen rol. Vormde het nationale karakter 'ein starker Faktor des Beharrens, ${ }^{170}$ de wereldcultuur zorgde juist voor de historische veranderingen. 'Vreemde cultuurinvloeden' leidden echter alleen tot een 'hogere cultuur' en een volgend 'ontwikkelingsstadium' indien ze in overeenstemming werden gebracht met het nationale karakter. Dat gebeurde alleen als bij de verbinding van het hogere vreemde cultuurgoed een krachtig Volkstum overwoog. ${ }^{171}$ Uiteindelijk speelde een overkoepelend Volkstum in Steinhausens geschiedschrijving zodoende toch een bepalende en nauwelijks genuanceerde rol. Steinhausens verklaringen over de veranderlijkheid van het volkskarakter ten spijt - ook große Bildsamkeit beschouwde hij als een kenmerk van het Duitse volkskarakter - ${ }^{172}$ werd het Volkstum in zijn voorstelling van zaken toch de bepalende factor in de historische ontwikkeling, waaraan andere krachten als de politiek en de economie ondergeschikt waren. ${ }^{173}$ Terwijl hij zich meer dan eens uitdrukkelijk distantieerde van de rassenleer en van een 'politiek-völkische opvatting' van het Volkstum, typeerde hij 'de leidende gedachte' van zijn historisch hoofdwerk tegelijkertijd als 'het duidelijk maken van de eigen aard van de Duitsers als

\footnotetext{
${ }^{165}$ Steinhausen (1911), 22.

${ }^{166}$ Steinhausen (1922), 7-8.

${ }^{167}$ Steinhausen (1921), [1e dr. 1910] 2.

${ }^{168}$ Steinhausen (1905a), 21.

169 Aldus Steinhausen (1893a), IV, 9.

${ }^{170}$ Steinhausen (1904), VI.

${ }^{171}$ Zie Steinhausen (1921) [1e dr. 1910], 1-2.

${ }^{172}$ Steinhausen (1923), 392.

${ }^{173}$ Steinhausen (1910), 136.
} 
bepalende cultuurfactor. [...] Die deutsche Kultur ist Leistung des deutschen Volkes und Ausfluß seiner Art'. ${ }^{174}$

Waar Steinhausens perspectief op de Duitse geschiedenis in de praktijk op neerkwam kwam al duidelijk naar voren in de verhandeling van de negenentwintigjarige over Der Wandel deutschen Gefühlslebens seit dem Mittelalter (1895). Tot na de veertiende eeuw vormden de Duitsers nog een jugendliches Volk, dat een weinig gedifferentieerd maar gesund-natürliches gevoelsleven kende dat zich al snel in aufsteigender Kraft ontwikkelde. De wijze van denken en voelen was nog voor alle lagen van de bevolking hetzelfde en volkstümlich. De Volkstümlichkeit des Gefühlsausdruck demonstreerde Steinhausen aan de hand van voorbeelden van reine naturfreude en van nuchterheid en directheid bij het uiten van gevoelens van liefde en leed. Vanaf de zestiende eeuw was er naar zijn mening echter sprake van achteruitgang. Als gevolg van 'nieuwe vreemde invloeden' (namelijk de Renaissance en de Franse hofcultuur) verleerden de elites 'natuurlijk te voelen', zij leden aan Verbildung en vielen ten prooi aan Unnatur: er was een gebrek aan eenvoud en waarheid en de uitdrukking van gevoelens van liefde en leed was stijfjes. Ook het natuurgevoel was verpest, zoals Steinhausen demonstreerde met de populariteit van de 'smakeloze' Franse tuinen. Als reactie op de vreemde, verfijnde zeden van de geschoolden werd het volk in deze periode juist ongevoeliger en groffer en vatbaarder voor bijgeloof als de heksenwaan. Zo ontstond er een kloof tussen volk en geschoolden en kon Steinhausen als geheel spreken van een 'zinkend volk'. De 'goede Duitser' wende er steeds meer aan anders te leven, anders te spreken en anders te voelen dan in zijn eigenlijke aard lag. 'Daarmee gaf hij echter een goed deel van zichzelf weg'. ${ }^{175}$ Vanuit het piëtisme kwam er in de achttiende eeuw vervolgens langzaam weer een wending ten goede - naar het innerlijke en het natuurlijke - al schoot men aanvankelijk in de periode van de Empfindsamkeit te ver door en had men uitsluitend nog oog voor het innerlijke leven. Kort voor 1850 tekende zich in het Duitse gevoelsleven weer een nieuwe wending af en werd het materialistischer, mannelijker en tegelijk verfijnder en genuanceerder, tot in het nerveuze toe.

Dezelfde nadruk op de tegenstelling Volkstum-vreemde culturen, hetzelfde ontwikkelingsperspectief in opeenvolgende sequenties van actie en reactie, en tenslotte dezelfde onverbloemde oordelen over de kwaliteit van de nationale culturele toestand (verpakt in gezond-ongezond en natuurlijk-onnatuurlijk metaforen) zijn terug te vinden in Steinhausens grote overzichtswerk Die Geschichte der Deutschen Kultur (1904, herdrukt 1913, 1929 en, postuum, 1936). Het verrast niet dat dit werk in de jaren dertig geschikt werd bevonden voor een nationaalsocialistische bewerking, ondanks Steinhausen verklaarde afkeer van völkische opvattingen. ${ }^{176}$ Het in de loop van de historische ontwikkeling nu eens naar voren komen en dan weer juist terugdringen van het Volkstum speelde ook daarin een grote rol. Hoewel Steinhausen meende dat een echte nationale Duitse cultuur pas in de achttiende eeuw via de scholing van de middenstand tot stand kwam, bespeurde hij toch al in het tweede hoofdstuk, gewijd aan de periode na Karel de Grote, de 'Bildung eines nationalen Kulturkreises' en 'das Hervortreten des deutschen Menschen'. De bloeitijden van de nationale Duitse cultuur waren de dertiende tot vijftiende eeuw (met nadruk op realisme, natuurlijkheid, spontaniteit) en vooral de periode van het Duitse idealisme in

\footnotetext{
${ }^{174}$ Steinhausen (1925), 263-264; vgl. Steinhausen (1910), 141.

${ }^{175}$ Steinhausen (1895b), 19.

${ }^{176}$ Eugen Diesel verzorgde in 1936 een bewerking van het boek. Hij meldde in het voorwoord dat juist in deze tijd van 'nationaalsocialistische revolutie' de 'duizendjarige' geschiedenis van de Duitse cultuur aan het Duitse volk verteld moest worden.
} 
1750-1850 (met grote nadruk op de innerlijkheid) - en in beide gevallen ging het vooral om successen van stedelijke bevolking en de geschoolde burgerij, zij vormt voor Steinhausen het hart van de Duitse natie. ${ }^{177}$ Tussen deze twee bloeiperiodes, en ervóór, lagen tijdvakken waarin 'vreemde invloeden' overheersten. En in de periode na 1850 dreigde opnieuw de snelle materiële ontwikkeling de van nature innerlijke Duitser van zichzelf te vervreemden. Meer dan in het eerste werk wees Steinhausen in dit omvangrijke overzicht van de Duitse cultuurgeschiedenis er op dat vreemde cultuurinvloeden als zodanig niet ongunstig waren (integendeel: zij waren verantwoordelijk voor de veranderingen), maar wel dat zij verkeerd konden uitpakken als zij niet in overeenstemming werden gebracht met het nationale karakter. In dit werk integreerde Steinhausen (sociaal-)economische en technische ontwikkelingen in zijn beschouwingen en presenteerde hij belangwekkende overzichten over de ontwikkeling van het Duitse landschap als achtergrond bij zijn cultuurgeschiedenis. Ook andere beschrijvingen van de uiterlijke cultuurgeschiedenis (wonen, eten, kleden) vonden een plaats, maar Steinhausens aandacht ging toch vooral uit naar de 'sociale levensvormen' en de zeden, die hij het meest direct in verband kon brengen met de nationale aard en daarmee met het 'innerlijke leven in het verleden'.

Met zijn nadruk op het Volkstum, zijn aandacht voor de 'zedengeschiedenis' en ook met zijn onverbloemde kwaliteitsoordelen over historische ontwikkelingen stond Steinhausen van alle nieuwe cultuurhistorici het dichtst bij een oudere, uit het midden van de eeuw daterende cultuurhistorische benadering. ${ }^{178}$ In een laat literatuurreferaat over de geschiedenis van de 'sociale cultuur en zedengeschiedenis' (1917), merkt hij op dat het hier om een terrein ging dat van oudsher als eerste in gedachten kwam bij 'cultuurgeschiedenis': de geschiedenis van het huiselijke en gezelschapsleven, van het privé-leven en de zeden. Het leverde hem bij alle waardering voor zijn tijdschrift, zijn bibliografische overzichten, zijn bronnenpublicaties en zijn pleidooien voor een academische cultuurgeschiedschrijving, veel kritiek op, ook van de kant van de andere nieuwe cultuurhistorici, die overigens allen vroeg of laat en meer of minder bij zijn tijdschrift betrokken waren. Vooral Lamprecht oordeelde uiteindelijk bijzonder streng over Steinhausens werk.

Aanvankelijk waren de verhoudingen tussen Lamprecht en Steinhausen overigens niet slecht. Beide cultuurhistorici correspondeerden met elkaar; Steinhausen beweerde dozijnen vriendschappelijke brieven en kaarten van Lamprecht ontvangen te hebben. Lamprecht publiceerde in het allereerste nummer en in verschillende latere jaargangen van Steinhausens tijdschrift en al in de eerste jaargang daarvan verscheen bovendien een artikel over Lamprecht waarin hij als grondlegger van de 'sociaalstatistische methode' in de geschiedwetenschap werd bejubeld. Toen Lamprecht zich in 1896 met 'Was ist Kulturgeschichte?' voor het eerst uitdrukkelijk opwierp als verdediger en theoreticus van de cultuurgeschiedenis, berichtte Steinhausen daar uitgebreid en enthousiast over. ${ }^{179}$ En nog in 1900 planden beiden gezamenlijk de vorming van een cultuurhistorische vereniging en noemde Lamprecht Steinhausens werk in een reeks van nieuwe en gewaardeerde ontwikkelingen op het terrein van de geschiedwetenschap. ${ }^{180}$

\footnotetext{
${ }^{177}$ Vgl. Steinhausen (1893b), 116.

${ }^{178}$ Zie hierna Hoofdstuk 6, paragraaf 1.

${ }^{179}$ Steinhausen (1896a).

${ }^{180}$ Zie Lamprecht (1900b), 1972.
} 
Deze aanvankelijke toenadering was ook niet vreemd. Beide cultuurhistorici deelden de voorkeur voor de niet-politieke kanten van de geschiedenis, de opvatting dat cultuurgeschiedenis een volwaardige academische discipline diende te zijn, de nadruk op het typische, het collectieve en de doorsneemens in plaats van het singuliere, op de massa in plaats van het individu, en not least de (sociaal-) psychologische focus. Zelfs in de latere verwijdering tussen beide cultuurhistorici speelden, althans vanuit Steinhausens perspectief, juist de overeenkomsten in hun beider werk een belangrijke rol: volgens Steinhausen had Lamprecht zijn werk ausgeslachtet en bijvoorbeeld de karakteristiek van de eigen tijd als 'nerveus' aan Steinhausen ontleend. ${ }^{181}$ Uiterlijk vanaf circa 1903 bekoelde de verhouding snel. ${ }^{182}$ Aan Steinhausens kant speelde daarin miskenning mee: hij voelde zich door het optreden van Lamprecht na 1896 begrijpelijkerwijs steeds meer van de positie als bekendste Duitse activist voor de cultuurgeschiedenis verdreven. Bovendien moest Steinhausen wel merken dat Lamprecht de toch al kwetsbare naam van de cultuurgeschiedenis - die Steinhausen juist van een stevige academische status wilde voorzien - uiteindelijk alleen maar verder in diskrediet had gebracht. We kunnen ons voorstellen dat hij zijn eigen project probeerde te redden door het van Lamprecht te dissociëren en diens betekenis als cultuurhistoricus te bagatelliseren - dat was ook de strategie die Goetz tien jaar later zou volgen.

De inhoudelijke verschillen mogen bij alle overeenkomsten echter niet worden onderschat. Lamprecht en alle andere nieuwe cultuurhistorici waren het in de eerste plaats niet eens met de door Steinhausen voorgestelde scheiding van politieke en cultuurgeschiedenis. Zoals we hebben gezien, was dat ook voor Steinhausen zelf echter geen hard standpunt. Een belangrijker struikelblok was Steinhausens Volkstumconcept. In een recensie uit 1905 kwalificeerde Lamprecht het werk van Steinhausen als achterhaald. Door alle nadruk van Steinhausen op de afzonderlijke sociale standen kreeg de sociale samenhang en de voortdurende ontwikkeling te weinig aandacht of hooguit de vorm van een verouderd 'romantisches Volkstumsbegriff'. ${ }^{183}$ Ook Goetz, die nauw met Steinhausen ging samenwerken als mederedacteur van het Archiv für Kulturgeschichte, oordeelde later dat Steinhausen in verouderde, met name volkskundige termen dacht over cultuur. ${ }^{184}$ En Breysig die hem in 1905 prees om zijn verdiensten voor de cultuurgeschiedenis en de 'geschiedenis van de Duitse ziel', ${ }^{185}$ legde tegelijk de vinger op de zere wond door op te merken dat Steinhausen enerzijds weliswaar meer aandacht voor vreemde invloeden bepleitte, maar anderzijds toch vaak de onafhankelijkheid en eigenheid van het eigen Volkstum overschatte en ook anderszins meer als iemand uit 1860 dan als een historicus uit 1900 schreef. $^{186}$

In een recensie van Steinhausens Der Wandel deutschen Gefühlslebens had Breysig al vastgesteld dat Steinhausen wel heel makkelijk een enkel gegeven typerend noemde voor een algemene toestand. En dat was inderdaad het grootste probleem in Steinhausens cultuurgeschiedenis: wellicht juist vanwege zijn uitgesproken besef van de betekenis van de sociale en regionale differentatie en van de internationale context, slaagde hij er niet in om de door hem veronderstelde sociaal-psychische samenhang overtuigend weer te geven en sprong hij uiteindelijk al te gemakkelijk van Mensen-

\footnotetext{
(1904)

${ }^{182}$ Vgl. daarover Steinhausen zelf in Steinhausen (1925), 265-266; zie ook Lamprecht (1905b),

257 en Chickering (1993), 257-258.

${ }^{183}$ Goetz (1934a), 331-332.

${ }^{184}$ Goetz (1934a), 383.

${ }^{185}$ Zie Breysig (1905b), 1674.

${ }^{186}$ Breysig (1905c), 1644; Breysig (1905b), 1674.
}

${ }^{181}$ Zie Steinhausen (1925), 265-266n; Steinhausen (1903), 362-363; vgl. de reactie van Lamprecht 
geschichte - via afzonderlijke groepen en regio's - naar Volksgeschichte, van afzonderlijke details over het psychisch leven van 'doorsneemensen' naar algemene uitspraken over het Duitse nationale karakter. In een antwoord op Lamprecht's kritiek gaf hij aan dat de erkenning van de regionale en sociale verschillen hem ertoe had gebracht telkens aan te geven dat de culturele leiding van de ene regio en sociale laag, naar de andere overging. ${ }^{187}$ Het probleem was dat Steinhausen niet goed kon aangeven hoe 'de leiding' van de ene naar de andere groep of regio overging en hoe die 'leiding' in de praktijk werkte en gestalte kreeg. De historische samenhang kreeg daardoor in zijn cultuurgeschiedenissen alleen vorm door het problematische Volkstum-begrip. Typerend genoeg liet hij, vergeleken met de andere nieuwe cultuurhistorici, relatief weinig aandacht uitgaan naar die culturele verschijnselen waarvan de collectief vormende invloed veel aannemelijker was te maken: economie, religie, bestuur en recht. Zoals we later zullen zien, had deze uitzonderingspositie van Steinhausen onder de nieuwe cultuurhistorici veel te maken met zijn van de anderen afwijkende opleiding.

\section{Karl Lamprecht}

\subsection{Lamprecht en de cultuurgeschiedenis}

Een van de kritiekpunten die de andere nieuwe cultuurhistorici tegen Steinhausen aanvoerden, betrof zijn verdediging van de cultuurgeschiedenis als historische $s u b$ discipline. Lamprecht, Breysig en Goetz sloten zich vroeger of later aan bij Gotheins verdediging van cultuurgeschiedenis als algemene geschiedenis. Zowel bij Lamprecht als Breysig waren daarbij aanvankelijk aarzelingen te bespeuren over de uitdrukking Kulturgeschichte (of over het type geschiedschrijving dat daar normaliter onder werd verstaan). Moest de nieuwe richting niet veeleer als 'sociale geschiedenis' worden aangeduid - zoals ook latere commentatoren hebben gesuggereerd?

Wat Lamprecht betreft was het bepaald niet zo dat hij het begrip 'cultuurgeschiedenis' ter benoeming van de nieuwe tendensen in de Duitse geschiedwetenschap na 1889 introduceerde en dat het vervolgens door anderen werd overgenomen. Het was veeleer andersom. Terwijl namelijk zowel Gothein als Steinhausen de term al vanaf 1889 uitdrukkelijk gebruikten om een alternatieve visie op de geschiedenis mee aan te duiden, ging Lamprecht zich pas vanaf 1894 publiekelijk met het begrip 'cultuurgeschiedenis' associëren - en dan in eerste instantie nogal aarzelend. ${ }^{188}$ Nog in datzelfde jaar plaatste Lamprecht zich bijvoorbeeld mèt de

${ }^{187}$ Steinhausen (1905c), 369-370.

${ }^{188}$ De gelijkstelling (of ten minste associatie) van cultuurgeschiedenis en moderne geschiedwetenschap komt in Lamprechts publicaties pas voor het eerst voor in 1894, in het voorwoord bij de tweede oplage van DG I (ook afgedrukt in Lamprecht (1988), 125-131) en in een passage uit DG IV (boek 11.3.2); in dat jaar publiceerde Lamprecht ook in de nieuw verschijnende ZfK. Opvallend is echter dat Lamprecht in verschillende programmatische opstellen tussen 1894 en 1896, zelfs nog in Alte und neue Richtungen (begin 1896) het woord Kulturgeschichte niet of slechts aarzelend gebruikt (vgl. bijv. Lamprecht (1896), 17), terwijl het begrip vanaf 'Was ist Kulturgeschichte?' (zomer/najaar 1896) een centrale rol speelt in zijn geschiedtheoretische vocabulaire. Opmerkelijk is bovendien, zoals al vermeld, dat Lamprecht zich ten tijde van het Gothein-Schäfer debat (1888-1891) niet expliciet en publiekelijk uitsprak over de kwestie. Dit is des te opvallender omdat voor iedereen in de historische professie al rond 1890 duidelijk was dat Lamprecht geen voorstander kon zijn van een eenzijdige politieke geschiedschrijving à la Schäfer. Lamprecht had zijn historisch ordinariaat in 1890 immers verdiend met een indrukwekkende reeks niet-politieke, overigens niet uitsluitend economischhistorische studies. Een advertentietekst voor het eerste deel van zijn Deutsche Geschichte (1891), dat 
Nederlandse historicus P.J. Blok op het standpunt dat politieke geschiedenis noch cultuurgeschiedenis eenzijdig moesten worden bedreven en dat beiden dienden op te gaan in een sociale geschiedenis. ${ }^{189}$ Deze aarzeling ten aanzien van de cultuurgeschiedenis kan het beste begrepen worden door er op te wijzen dat Lamprecht onder cultuurgeschiedenis uiteindelijk iets anders bleek te verstaan dan de meeste van zijn voorgangers. Allereerst zag hij niet veel in datgene wat in de jaren zeventig en tachtig meestal onder 'cultuurgeschiedenis' werd verstaan. Hij verafschuwde oudere en populaire beschavingsgeschiedenissen, die hij herhaaldelijk als Archeologie des Bric$\grave{a}$-brac afdeed en waarvan ook Blok zich in zijn door Lamprecht geprezen Leidse oratie uitdrukkelijk had gedistantieerd. Evenmin zag Lamprecht veel in de sociaaldarwinistisch geïnspireerde cultuurgeschiedenissen uit deze periode. ${ }^{190}$ Maar ook verschilde hij, zoals in de voorgaande paragrafen duidelijk is geworden, in sommige opzichten van mening met de nieuwe cultuurhistorici die vanaf 1889 naar voren waren getreden. Steinhausens tweedeling van het historisch domein in een cultuurhistorisch en een politiek-historisch deel was fundamenteel in strijd met zijn eigen opvattingen. En weliswaar verdedigde Lamprecht net als Gothein een radicaal andere opvatting van geschiedenis dan Schäfer, met Gotheins pleidooi voor de cultuurgeschiedenis kon hij om andere redenen niet instemmen; vooral was voor hem de door Gothein geprezen Ranke en diens ideeënleer onlosmakelijk verbonden met de individualiserende, teleologische, politiek georiënteerde wijze van geschiedschrijving die hij wilde hervormen. ${ }^{191}$

Er waren overigens ook overeenkomsten met de beide eerdere verdedigers van de cultuurgeschiedenis. Net als voor Steinhausen was cultuurgeschiedenis voor Lamprecht een vorm van sociale psychologie van doorsneemensen uit een bepaalde historische periode. En net als voor Gothein was cultuurgeschiedenis voor hem uiteindelijk niets anders dan een wetenschappelijk verantwoorde, moderne vorm van algemene geschiedenis, waarvan de politieke geschiedenis noodzakelijkerwijs slechts een onderdeel uitmaakte. Weliswaar onderscheidde hij politieke en cultuurgeschiedenis methodologisch als twee aparte benaderingen van het verleden - de een 'individualistisch' (op individuen gericht), de ander 'collectivistisch' (op collectieven gericht) hij liet er weinig twijfel over bestaan dat ook de politieke 'personengeschiedenis' uiteindelijk zoveel mogelijk zou moeten opgaan in een cultuurhistorische Zustands- of Lebenshaltungsgeschichte. ${ }^{192}$ Ook de politieke geschiedenis kon en moest op cultuur-

verscheen zonder elke programmatische verklaring, kon zonder nadere toelichting opmerken: 'Die geschichtliche Richtung des Verfassers ist bekannt'.

${ }^{189}$ Lamprecht (1894), 1455. Later keerde Lamprecht zich overigens expliciet tegen sociale geschiedenis (begrepen als groeps- of standsgeschiedenis) als basis voor de cultuurgeschiedenis, zie Lamprecht (1905b), 327 en Lamprecht (1974), 469-470 [1898/1899]. Bloks oratie was zelf ongetwijfeld geïnspireerd door de Schäfer-Gothein controverse; zie Blok (1894), 6, waar Blok refereert aan heftige debatten 'ook in de laatste jaren weder' over het 'eigenlijke arbeidsveld der geschiedenis'. Bloks standpunt lijkt in zijn benadrukking van de geschiedenis als een sociale wetenschap die zowel politieke als cultuurgeschiedenis omvat, geënt op Bernheims Lehrbuch. Vreemd genoeg noemt Blok echter wel allerlei oudere auteurs, maar noch Schäfer, noch Gothein of Bernheim bij naam. Wel prijst Blok Lamprecht verschillende keren in zijn oratie (o.a. diens DG, zie pp. 15, 23). Vgl. over Bloks rede: Tollebeek (1990), 78-86, en over de latere verwijdering tussen Lamprecht en Blok: Blaas (1982), m.n. 285-287.

${ }^{190}$ Zie Lamprecht (1896/97), 145 en hoofdstuk 6, paragraaf 1.

${ }^{191}$ Zie Lamprecht (1896). In latere verwijzingen naar het debat noemde Lamprecht meestal slechts Schäfer (in kritische zin), terwijl hij maar een enkele keer ook Gotheins repliek vermeldde (Lamprecht (1896/97), 107n).

${ }^{192}$ Zie uitdrukkelijk in Lamprechts bijdrage aan het Handbuch der Politik (Berlijn 1912): 'Staatsform und Politik im Lichte der Geschichte', afgedrukt in Lamprecht (1974), 747-760. Zie ook Lamprecht (1896/97), 145. In het huidige Duits verstaat men onder Lebenshaltung meestal 
historische wijze als een 'collectivistische staatsgeschiedenis' worden geschreven. ${ }^{193}$ De geschiedenis van de binnenlandse en buitenlandse politiek werd, zoals hij het in zijn Deutsche Geschichte voor de eigen tijd formuleerde, 'door de economische ontwikkelingen en de daaruit volgende sociale ontwikkelingen in haar hele wezen beslissend bepaald'. ${ }^{194}$ In het algemeen diende de traditionele aandacht voor individuele, intentionele handelingen die de politieke geschiedenis kenmerkte, te worden geïntegreerd in de historische studie van gewoontegetrouw, onbewust collectief gedrag: 'Een geschiedenis van de daad [..] en zeker van de politieke daad kan niet worden gedacht zonder dat die grondig gefundeerd wordt in de onbewuste levensprocessen van de menselijke gemeenschap waartoe ze behoort'. ${ }^{195}$ In grote delen van de geschiedenis, zoals de geschiedenis van de zeden, van mythen, taal, recht en economie was volgens Lamprecht immers niet de daadkrachtige persoonlijkheid van doorslaggevend belang, maar die psychische Haltung der Gesamtheit. ${ }^{196}$

Het is aannemelijk dat Lamprecht nog in het begin van de jaren negentig vreesde dat een uitdrukkelijk als 'cultuurgeschiedenis' gepresenteerde geschiedenis hetzij niet serieus genomen zou worden, hetzij teveel als een specialistisch onderdeel van de geschiedenis zou worden opgevat. Zoals we in het vorige hoofdstuk hebben gezien was zijn positie in 1896 zodanig versterkt dat hij de hoop kon koesteren het eigentijds begrip van 'cultuurgeschiedenis' zijn eigen stempel op te drukken. ${ }^{197}$ Minder aannemelijk is de alternatieve verklaring voor Lamprechts aanvankelijke aarzeling over de cultuurgeschiedenis, die al door tijdgenoten, onder wie Steinhausen en Schmoller, werd aangevoerd: namelijk, dat zijn geschiedopvattingen pas in de jaren negentig in plaats van een economisch-historisch karakter een cultuurhistorische oriëntatie kregen. ${ }^{198}$ Weliswaar publiceerde Lamprecht in de eerste tien jaar na zijn dissertatie uit 1878 een aantal uitgesproken economisch-historische studies, maar naar eigen zeggen waren ook deze studies 'altijd slechts als een onderdeel van de cultuurgeschiedenis' geconcipieerd. ${ }^{199}$ En inderdaad had Lamprecht al in zijn dissertatie over de middeleeuwse agrarische geschiedenis uitdrukkelijk te kennen gegeven dat het hem daarin in ieder geval niet om een studie van de middeleeuwse landbouw in technische zin ging, maar om 'de levenswijze van het volk', waarbij hij bijvoorbeeld ook aandacht schonk aan de opvattingen van de bevolking over handel, nijverheid en handwerk. ${ }^{200}$ Ook zijn omvangrijkste economisch-historische studie, Deutsches Wirtschaftsleben im Mittelalter (1885-1886), was naar eigen zeggen oorspronkelijk opgezet als een onderdeel van een nooit voltooide 'Rijnlandse cultuurgeschiedenis' waarin een beeld van de Gesamtkultur zou worden gegeven - een voorstelling van zaken die in ieder

\footnotetext{
'levensonderhoud'; in de context waarin Lamprecht het woord gebruikt, dient algemener 'levenswijze' te worden begrepen.

${ }^{193}$ Lamprecht (1896/97), 142.

${ }^{194}$ Lamprecht (1891-1909), ErgBd. II.2, 11.

${ }^{195}$ Lamprecht (1891-1909), ErgBd. II.2, 4; zie ook al Lamprecht (1896), 6; Lamprecht (1896/97), 145.

${ }^{196}$ Lamprecht (1896/97), 107.

${ }^{197}$ Zie Hoofdstuk 2, paragraaf 2

${ }^{198}$ Lamprecht zou op de Historikertag van 1893 naar een getuigenis van Steinhausen zelfs tot 'terughoudendheid' tegenover de cultuurgeschiedenis hebben gemaand (aldus Steinhausen (1925), 33). Bij nader toezien blijkt Steinhausens uitspraak niet correct: op de Historikertag van 1893 meende Lamprecht volgens het officiële verslag slechts dat 'economisch- en ander [sic!] cultuurhistorisch onderzoek [...] geen kost voor gymnasiasten' was - maar dit betekende evident niet dat hij dit soort historisch onderzoek zelf afkeurde (zie Bericht (1893), 8). Vgl. ook Lamprecht (1974), 597-603 ['Biopsychologische Probleme', 1904].

${ }_{199}$ Zie Lamprecht (1974), 599 [1904].

${ }^{200}$ Zie Lamprecht (1878), 3 (mijn cursivering, MS).
} 
geval strookt met het feit dat Lamprecht het onderwerp van dit boek in de ondertitel omschreef als de 'materiële cultuur' (en in de tekst onderscheidde van de 'ideële cultuur') en derhalve kennelijk 'cultuur' als de overkoepelende term beschouwde. ${ }^{201}$ Tegen een eenzijdige economische oriëntatie van de vroege Lamprecht pleiten verder de niet te verwaarlozen reeks studies op het terrein van de 'ideële cultuur', vooral kunsthistorische studies over middeleeuwse manuscriptilluminatie en een enkele rechtshistorische of ideeënhistorische analyse, die hij al vóór 1890, gelijktijdig met zijn economisch-historische studies publiceerde. ${ }^{202}$ In een manuscript uit 1888 benoemde Lamprecht verder een inhoudelijk overzicht van de door hem geplande Deutsche Geschichte expliciet als 'Kulturgeschichtliche Gesamtdisposition'. ${ }^{203}$ En toen hij in 1889 een nieuwe buitengewone leerstoel in Bonn ging bekleden, werd op zijn initiatief het leerstofgebied gewijzigd van 'economisch-historische ontwikkeling' in 'cultuurhistorische ontwikkeling'. ${ }^{204}$

\subsection{De sociaal-psychische factoren}

Om geen misverstand over zijn algemene geschiedenis van het Duitse volk te laten ontstaan noemde Lamprecht zijn magnum opus in 1891 eenvoudig Deutsche Geschichte en niet 'Deutsche Kulturgeschichte' - ook al beschouwde hij het werk wel degelijk als exemplarisch voor wat hij vanaf 1896, toen de tijd daarvoor rijp leek, uitdrukkelijk als zijn cultuurhistorische benadering zou typeren. Dit omvangrijke, uiteindelijk negentien boekdelen tellende werk, waaraan Lamprecht minstens zovele jaren werkte, werd vanaf het begin gekenmerkt door een zo mogelijk allesomvattende behandeling van het maatschappelijke leven, van zowel Gesellschafts- und Geistesleben als Wirtschaft, Politik en Verfassung. Het eerste deel, gewijd aan de Germanen tot en met de Merovingen, gaf niet alleen overzichten van politieke en militaire gebeurtenissen, maar behandelde ook de kunstuitingen, de juridische ontwikkeling, de ontwikkeling van de sociale en politieke orde en organisatie, de opvattingen over recht en zedelijkheid, en over de verhouding van 'godheid, mens, natuur'. Of nemen we de drie uitvoerige Ergänzungsbände over de eigen tijd, die

${ }^{201}$ Zie Lamprecht (1974), 599 en 68. Ook elders gebruikt Lamprecht in deze vroege periode het begrip 'Cultur' als basiscategorie, bijvoorbeeld in Lamprecht (1887), in samenstellingen als 'Stätte alter Cultur' (1), 'hohe Cultur' (8), 'die hohe Cultur des antiken Weltstaates' (17), 'Römische Cultur' (18), 'das Mittelalter seine Cultur' tegenover de 'moderne Cultur' (13), 'Cultur der Gegenwart' (20), 'Culturmitteln' (8), 'menschliche Culturzwecke' (6), 'Culturschichten' (i.v.m. sporen uit diverse perioden, 15), 'ländliche Cultur' (185). Volgens Lamprecht (1896/97), 127 had hij het begrip 'materiële cultuur' ontleend aan de econoom Roscher.

${ }^{202}$ Het gaat om negen publicaties, waaronder één zelfstandige monografie, tussen 1881 en 1889 ; zie Schönebaum (1955/56), nrs. 17, 22, 28, 29, 33, 39, 43, 44, 63.

${ }^{203}$ Zie voor een weergave van dit ms: Schönebaum (1961), 223-229, hier 224.

${ }^{204}$ Lewald (1968), 242. Dat Lamprecht in 1894 nog instemde met P.J. Bloks oordeel dat de sociale geschiedenis als de eigenlijke geschiedenis moest worden beschouwd, terwijl hij twee jaar later aan de cultuurgeschiedenis dezelfde betekenis toekende, maakt vooral duidelijk dat Bloks opvatting van 'sociale geschiedenis' en Lamprechts opvatting van 'cultuurgeschiedenis' dicht bij elkaar lagen. Te meer aangezien ook voor Blok beide aanduidingen nauw verwant waren: hij typeerde de sociale geschiedenis in zijn oratie immers als een 'breeder' opgevatte Culturgeschichte (het Duits is van Blok) en 'in zekeren zin hare dochter en de erfgenaam harer traditiën'. Sociale geschiedenis was voor Blok een 'geschiedenis der maatschappij in haar geheel', die zich van de economische geschiedenis ('waarmede zij dikwijls verward wordt'), onderscheidde door de aandacht voor de 'psychische elementen' in de samenleving - een aspect waaraan Lamprecht in zijn recensie van Bloks oratie refereerde en dat, zoals we nog zullen zien, bepalend zou blijken te zijn voor zijn eigen opvatting van cultuurgeschiedenis. Zie Blok (1894), 14-15; vgl. Lamprecht (1894), 1455, alsmede de gelijktijdige opmerking in DG IV (1894): 'Für das kulturgeschichtliche Gebiet [...] ließe sich eine Zukunft vorstellen, die auf dem Wege psychologisch induktiver Durcharbeitung [...] zu vollkommeneren wissenschaftlichen Wahrheiten führen würde' (4e ed., p. 134). 
gezamenlijk de beste indruk geven van Lamprechts cultuurgeschiedschrijving. In het eerste deel daarvan behandelde Lamprecht in bijna 500 pagina's de ontwikkeling van het geestesleven: muziek, beeldende kunst, letterkunde, wereldbeschouwing (inclusief wetenschap). Het volgende, even omvangrijke deel was gewijd aan de economische geschiedenis (met aandacht voor techniek, verkeer, productiewijzen, ondernemingsvormen) en de sociale ontwikkeling (met aandacht voor 'de psychologie van de vrije onderneming' en de verspreiding daarvan, voor nieuwe sociale groepen en sociale veranderingen, voor reacties tegen de vrije onderneming). Tenslotte werd in het derde deel in bijna 800 bladzijden de binnenlandse en buitenlandse politiek behandeld: de rijksconstitutie, het partijwezen, het binnenlands beleid; emigratie, de Duitse belangen in buitenland, expansie, koloniale en wereldpolitiek. De 'grote mannen' Bismarck en Wilhelm II werden in de inleiding van dit deel geportretteerd als 'persoonlijkheidstypen', typische vertegenwoordigers van de verschillende fasen in de moderne cultuurontwikkeling.

Lamprechts cultuurgeschiedschrijving bestreek in de praktijk een nog breder terrein dan het werk van Gothein en Steinhausen. Terwijl Gothein zich bij voorkeur concentreerde op de religieuze, ideeënhistorische en bestuurlijk-economische geschiedenis, en Steinhausen vooral keek naar sociale 'levensvormen', verdeelde Lamprecht zijn aandacht gelijkmatig over economie en samenleving, kunst en wetenschap, politiek en bestuur. In de publicatiereeksen die hij opzette en in de talloze, ten dele daarin gepubliceerde dissertaties die hij begeleidde, komt hetzelfde brede scala aan onderwerpen aan bod: naast veel economisch-historisch onderzoek en historiografiegeschiedenis vallen daarin zulke uiteenlopende thema's op als Duitse reizigers in de zestiende eeuw (Hantzsch, 1895), de clanorganisatie in de Schotse hooglanden (Conrady, 1898), de bloedwraak bij de Arabieren (Procksch, 1899), het causale denken in de middeleeuwse geschiedschrijving en letterkunde (Schneider, 1905), de ontwikkeling van de oudchinese ornamentiek (Hoerschelmann, 1907), de geschiedenis van het vertalen in de achttiende eeuw (Fraenzel, 1913) en de mentale ontwikkeling van negerkinderen (Franke, 1915).

Ondanks de gevarieerdheid van Lamprechts thematiek vertoonde zijn oeuvre een opmerkelijke eenheid. Hier komt tot uiting dat hij van alle nieuwe cultuurhistorici, naast Breysig, de meest theoretisch georiënteerde was en naar een systematische doordenking van zijn historische inzichten streefde. Van alle nieuwe cultuurhistorici leverde hij ook het grootste aantal theoretische bijdragen; tussen 1896 en 1901 publiceerde hij zelfs vrijwel uitsluitend theoretische, programmatische, polemische of historiografische geschriften, in totaal meer dan veertig. ${ }^{205} \mathrm{Al}$ in 'Was ist Kulturgeschichte?' (1896), het eerste theoretische opstel dat hij expliciet wijdde aan de cultuurgeschiedenis, bracht hij onder woorden welke structurele samenhang hij in de cultuurhistorische ontwikkeling meende te ontwaren - een conceptie die hij zou bijstellen, maar niet wezenlijk zou veranderen. Hij analyseerde hier als het ware de schering en de inslag die naar zijn idee het weefsel van het historisch leven vormden.

Lamprecht onderscheidde in deze analyse drie soorten factoren die van invloed waren in de geschiedenis: 'individuele', 'natuurlijke' en 'culturele (sociaalpsychische) factoren'. ${ }^{206}$ Van deze drie werkzame krachten achtte hij de eerste het

${ }^{205}$ Lamprechts belangrijkste theoretische geschriften zijn in volgorde van verschijnen: Alte und neue Richtungen in der Geschichtswissenschaft (1896), 'Was ist Kulturgeschichte?' (1896), 'Individualität, Idee und sozialpsychische Kraft' (1897), Die kulturhistorische Methode (1900), 'Über den Begriff der Geschichte' (1903), Moderne Geschichtswissenschaft (1905), 'Zur universalgeschichtlichen Methodenbildung' (1909) en Einführung in das historische Denken (1912).

${ }^{206}$ Lamprecht (1896/97), 103, 111. 
minst belangrijk en de laatste van het allergrootste belang. Natuurlijke factoren - ras, klimaat, bodem - vormden de min of meer constante omstandigheden van het historisch leven, die daardoor onvoldoende de historische veranderingen konden verklaren. Lamprecht besteedde er niet veel aandacht aan in zijn werk, al achtte hij de 'natie' als 'natuurlijke gemeenschap' de meest geëigende eenheid van de geschiedenis en vond hij in verband daarmee dat 'genealogie' (inclusief erfelijkheidsleer) en familiegeschiedenis een onderdeel van de cultuurgeschiedschrijving en van het cultuurhistorisch onderwijs dienden te zijn. ${ }^{207}$

Voor de historische ontwikkeling waren de culturele factoren echter meer bepalend: niet alleen in 'primitieve ontwikkelingsfasen' maar ook in 'hoge culturen' reikte de macht van het individu op de meeste terreinen niet ver; bepalend was die psychische Haltung der Gesamtheit. Deze 'psychische houding van het collectief' werd door Lamprecht in dezelfde verhandeling ook aangeduid als 'psychisch totaalorganisme' [Gesamtorganismus], 'de collectieve geestelijke habitus [geistigen Gesamthabitus] van een tijd', 'de algemene psychische dispositie' of, met een term uit de muziektheorie, de 'geestelijke diapason' (grondstemming). ${ }^{208}$ Deze collectieve of algemene psychische dispositie was volgens Lamprecht de resultante van de wisselwerking tussen de 'sociaal-psychische factoren'. Daaronder verstond hij allereerst economie, taal en kunst, en verder zeden, mythe, godsdienst en moraal, recht en wetenschap: dit waren terreinen van het leven waar niet het individu, maar het collectief beslissend was.

De keuze van deze 'factoren' leidde Lamprecht af uit de wijd verbreide gedachte dat de psychische activiteiten in drie hoofdcategorieën te verdelen waren: willen, voorstellen (of denken) en voelen (Empfindung, bij Lamprecht speciaal in de betekenis van zintuiglijk waarnemen). Aan elk van deze psychische vermogens kende Lamprecht een basismotief toe dat het meest zuiver op specifieke maatschappelijke terreinen tot uiting kwam: de economie (dit wil zeggen, de zorg voor het levensonderhoud) zag hij als het domein bij uitstek van de wil, de taal vooral als het terrein van het voorstellen/denken, en kunst en ornament als het terrein van waarneming en gevoel (zie Tabel 3.2). ${ }^{209}$

${ }^{207}$ Zie Lamprecht (1913a); vgl. Devrient (1911), 'Vorwort' en Tabel 3.3, nr. 15.

${ }^{208}$ Zie Lamprecht (1896/97), 107, 110, 112, 127, 143. Hier en elders gebruikt Lamprecht 'psychisch' en 'geistig' door elkaar. Daarbij moet 'geistig' als de bredere term en 'psychisch' als de preciesere term worden beschouwd: 'geistig' (in de zin van niet-materieel, innerlijk, mentaal) sloot wel het psychische in, maar niet andersom.

${ }^{209}$ Daarbij moet in gedachten worden gehouden dat Lamprecht 'kunst' definieerde als 'het streven, het gevoel in kracht of intensiteit te versterken' of als 'de behoefte binnen het gevoelsleven om de indrukken te accentueren en te versterken'. Zie Lamprecht (1896/97), resp. 122 en 118. Later sprak hij ook kortweg over Anschauung(skraft), zie Lamprecht (1974), 526. 


\begin{tabular}{|l|l|l|l|l|}
\hline \multicolumn{2}{|c|}{ individuele psyche } & \multicolumn{1}{c|}{ collectieve psychische habitus (diapason) } \\
\hline $\begin{array}{l}\text { psychische } \\
\text { activiteit }\end{array}$ & basismotief & $\begin{array}{c}\text { primaire } \\
\text { sociaal-psychische } \\
\text { factoren }\end{array}$ & $\begin{array}{c}\text { secundaire } \\
\text { sociaal-psychische } \\
\text { factoren }\end{array}$ & $\begin{array}{c}\text { tertiaire } \\
\text { social-psychische } \\
\text { factoren }\end{array}$ \\
\hline willen & streven naar behoud soort & economie & zeden & recht \\
\hline voorstellen & gebruik denkvormen & taal & mythe & wetenschap \\
\hline $\begin{array}{l}\text { voelen/waar- } \\
\text { nemen }\end{array}$ & $\begin{array}{l}\text { streven naar versterking van } \\
\text { de indrukken }\end{array}$ & $\begin{array}{l}\text { primitieve kunst } \\
\text { (ornamentatie) }\end{array}$ & symboliek & kunst en literatuur \\
\hline
\end{tabular}

Tabel 3.2 Lamprechts analyse van de individuele psyche en de collectieve psychische habitus

De drie domeinen: economie, taal en (ornamentale) kunst, vormden in Lamprechts opvatting de drie oorspronkelijke sociaal-psychische factoren. In latere fasen van de menselijke ontwikkeling zou elk van deze drie terreinen zich verder ontwikkelen en worden uitgesplitst in nieuwe uitingsvormen. Binnen het domein van de wil kwamen eerst de zeden tot ontwikkeling, binnen het domein van het voorstellen de mythologie, op het terrein van de kunst de symboliek. Vervolgens ontwikkelde zich op het terrein van de wil het recht, op het terrein van het denken de wetenschap en kwamen kunst en literatuur tot een zelfstandige ontwikkeling. Opvallend is dat godsdienst noch moraal een reguliere basisplaats kregen in dit schema: Lamprecht typeerde ze als sociaalpsychische factoren die pas in de loop van de menselijke ontwikkeling waren ontstaan en waarin de verschillende psychische activiteiten tegelijk verenigd waren. Het wekt overigens wellicht bevreemding dat Lamprecht deze maatschappelijke domeinen als 'factoren' benoemde. Hij wilde zich daarmee onderscheiden van historici die deze maatschappelijke 'toestanden' slechts als 'omstandigheden' beschouwden, als het toneel waarop de historische gebeurtenissen plaatsvonden. Voor Lamprecht vormden de genoemde domeinen uitdrukkelijk meer dan dat: het waren de belangrijkste oorzaken van de historische gebeurtenissen, inderdaad werkzame historische factoren. ${ }^{211}$

Deze verschillende sociaal-psychische of culturele factoren stonden volgens Lamprecht in een voortdurende onderlinge wisselwerking - zoals ook de psychische activiteiten van een individu volgens heersende psychologische inzichten een elkaar voortdurend beïnvloedend geheel vormden. ${ }^{212}$ Lamprecht wees verschillende malen uitdrukkelijk de gedachte van de hand dat één enkele van de sociaal-psychische factoren een hoofdrol toekwam in de vormgeving van de geschiedenis. Hij bekritiseerde in dit verband het intellectualisme en sciëntisme van positivisten als Comte, Buckle en Du Bois Reymond die meenden dat de technische en wetenschappelijke ontwikkelingen en daarmee de 'zogenaamde geistige [hier te vertalen met: intellectuele] factoren' allesbepalend waren. Evenzeer wees hij de nadruk van de 'politieke historici' op slechts vaag gedefinieerde 'zedelijke machten' af, alsmede de 'socialistische school' (Marx) die de alleenheerschappij van de materiële factor, de economie, verkondigde. ${ }^{213}$ Naar Lamprechts opvatting was er sprake van een zeer gecompliceerde en historisch veranderlijke verhouding tussen de sociaal-psychische factoren ('eine höchst verwickelte Menge wandelbarer Wechselwirkungen') die niet

${ }^{210}$ Door Lamprecht omschreven als 'Komplex sozialpsychischer, allgemein gebrauchter

Reaktionsformen gegenüber den Einwirkungen gemeinsamer, gesellschaftlichter Lebensweise', Lamprecht (1896/97), 123.

${ }^{211}$ Lamprecht (1896/97), 112-113.

${ }^{212}$ Lamprecht (1896/97), 116, 126; Lamprecht baseerde zich hier en elders (bijv. Lamprecht (1913d), 65-66) expliciet op Wundts 'Gesetz der psychischen Relationen'.

${ }^{213}$ Lamprecht (1896/97), 137-138, ook 116. 
tot een algemene formule was te reduceren. Desalniettemin suggereerde hij dat meest oorspronkelijke van deze factoren - vooral de zorg voor het levensonderhoud (economie) en het verlangen naar versterking van het gevoelsleven (tot uiting komend in kunst) - ook de krachtigste en meest omvattende waren en dus relatief sterker dan 'latere' culturele fenomenen als moraal, recht of religie. ${ }^{214}$

Het belang dat Lamprecht aan economie en kunst hechtte, kwam sterk naar voren in de praktijk van zijn geschiedschrijving en in zijn bronnengebruik. Vanaf zijn eerste historische studies kregen economische en artistieke ontwikkelingen in zijn werk speciale aandacht. Op beide terreinen bewoog hij zich als een specialist: hij publiceerde in het begin van zijn carrière niet alleen een indrukwekkend aantal economischhistorische artikelen en boeken, maar ook een reeks kunsthistorische studies waarmee hij, volgens een recente studie van de kunsthistorica Brush 'een beslissende invloed' uitoefende op een aantal vooraanstaande Duitse kunsthistorici, onder wie Aby Warburg. ${ }^{215}$ Nog zijn laatste grote project, de organisatie van een omvangrijke tentoonstelling over de ontwikkeling van schrift en druk ter gelegenheid van de 'Internationale Ausstellung für Buchgewerbe und Graphik' in Leipzig (Bugra, 1914), richtte hij zo in dat economische en artistieke ontwikkelingen als parallelle fenomenen gelijke aandacht kregen. ${ }^{216}$

Kunstuitingen kregen in Lamprechts geschiedschrijving een voorkeursbehandeling als het er om ging de aard van een heersende psychische dispositie te analyseren. De uitgebreide analyse van de eigen tijd in zijn Deutsche Geschichte begon Lamprecht bijvoorbeeld met een beschrijving van ontwikkelingen op het terrein van de muziek, de beeldende kunst, de letteren en de wereldbeschouwing. Het was op deze terreinen dat 'nieuw psychische leven' eerst en vooral tot uitdrukking kwam. 'Ook nu weer', schreef hij over de recentste ontwikkelingen, 'zoals vrijwel altijd of tenminste in de regel, begon een nieuw stadium van de diepste, en dat wil zeggen: psychische ontwikkeling met een verandering van de esthetische mens' ${ }^{217}$ Lamprecht beschouwde elke kunstuiting niet in de eerste plaats als de uiting van een bewuste artistieke intentie, maar als de uitdrukking van een bepaalde collectieve psychische gesteldheid. De ontwikkeling van de portretkunst werd door hem bijvoorbeeld in verband gebracht met de positie van het individu en de ontwikkeling van de individualiteit in de diverse perioden. Zo achtte hij het typerend voor de ondergeschikte positie van het individu dat noch in de beeldende portretten, noch in autobiografieën en geschiedkundige portretten uit de veertiende eeuw veel persoonlijks was aan te treffen: het ging bij de portretten uit deze periode veelal om een 'weergave van het beroepsmatige, het familiale', zoals in de letterkunde van die

${ }^{214}$ Lamprecht (1896/97), 139. De geschiedenis van de taal en het denken kreeg minder aandacht van Lamprecht; alleen wetenschapsgeschiedenis behandelde hij in zijn DG systematisch. De geschiedenis van 'ervaringsbegrippen' die hij in een manuscript uit 1888 ontwierp ('Entwicklung der sprachlichen Ausdrucksmittel für die Erfahrung’, zie Schönebaum (1961), 224-226), komt in zijn publicaties slechts incidenteel terug. Overigens verscheen in een reeks onder zijn redactie in 1905 een interessante studie op dit terrein van zijn latere medewerker en hoogleraar aan het IKU, Hermann Schneider: Das kausale Denken in deutschen Quellen zur Geschichte und Literatur des zehnten, elften und zwölften Jahrhunderts. Aan de hand van literaire en historiografische werken traceerde de auteur veranderingen in denkvermogens (versterking geheugen, abstractie, rationalisering) tussen de tiende en twaalfde eeuw.

${ }^{215}$ Zie Brush (1996), 206; al in 1916 publiceerde de aan het IKU werkzame extraordinarius Alfred Doren een studie over Lamprecht en de kunstgeschiedenis: Doren (1916) - maar dit aspect van zijn oeuvre bleef lange tijd onderbelicht.

${ }^{216}$ Zie Lamprecht (1914c), m.n. 1-2. Over de Bugra zie Estermann (2005).

${ }^{217}$ Lamprecht (1891-1909), ErgBd. I [1902], 3. 
tijd sociale typetjes ('de sluwe boer', 'de vrolijke vagebond' etc.) de hoofdrol speelden. $^{218}$

Lamprechts aandacht ging meer uit naar de vorm dan naar de inhoud van kunstuitingen; de vorm, aldus Lamprecht, was de 'in de dingen hineingehauchte psyche', de geest die de stof bezielde. ${ }^{219}$ Om die reden was de historische ontwikkeling van de (primitieve) ornamentatie al vanaf de jaren tachtig een lievelingsonderwerp van Lamprecht. ${ }^{220}$ Bij de behandeling van beeldende kunst leidde zijn aandacht voor de artistieke vorm tot analyses van kleurgebruik, contour- en lichtweergave - door Lamprecht opgevat als directe uitingen van het gezichtsvermogen. ${ }^{221}$ Het eigentijdse impressionisme en post-impressionisme beschouwde hij op grond van een dergelijke analyse bijvoorbeeld als uitingen van de nerveuze fijngevoeligheid voor indrukken (Reizsamkeit) en de daaruit volgende verscherpte waarneming. ${ }^{222}$ Ook in zijn cultuurhistorische analyses van muziek, zelfs van de ideeënkunst van Wagner, besteedde hij meer aandacht aan vormaspecten van diens composities dan aan de opvattingen van de componist. Voor hem waren de 'rusteloze modulaties', het grote belang van de nevenstemmen en de antimetrische ritmes die de muziek van Wagner kenmerkten vooral een teken dat de 'zenuwen' van Wagner en zijn publiek fijner waren geworden en tot nieuwe waarnemingsnuancen in staat waren. ${ }^{223}$ Zelfs het wagneriaanse Gesamtkunstwerk als geheel werd door hem geïnterpreteerd als de uitdrukking van een eigentijdse psychische toestand: namelijk van het 'moderne' bewustzijn van de synesthesie van zintuiglijke ervaringen. ${ }^{224}$

Kreeg op deze wijze de kunst van Lamprecht de status van meest directe representatie van een bepaalde collectieve psychische gesteldheid, de economie leverde hem de belangrijkste verklaringen op voor die gesteldheid. Terwijl Lamprecht zich bovendien bij kunstuitingen grotendeels op bronnen met beperkte representativiteit baseerde, hadden zijn economische analyses een sterk collectief karakter dat door Lamprecht met veel statistisch materiaal werd onderbouwd. In die zin moet Lamprechts verzet tegen het materialismeverwijt gerelativeerd worden. De eigentijdse Reizsamkeit beschouwde hij bijvoorbeeld in hoge mate als een uitvloeisel van de maatschappelijke dominantie van de 'vrije onderneming', wij zouden tegenwoordig zeggen: van het overheersen van de markt en het marktdenken. Deze economische organisatievorm - waarbij de ondernemer niet alleen een producent maar ook een zelfstandig verkoper was die actief consumenten moest benaderen en afzetmarkten diende te veroveren en daarbij geplaagd werd door de vrije concurrentie van andere ondernemers - zorgde voor een grote bestaansonzekerheid en 'nervositeit' die tegelijk als een belangrijke stimulans fungeerde voor de verdere ontwikkeling van de intellectuele vermogens. Zowel de sterke groei van verkeer en communicatie, en daarmee weer de intensivering van de waarneming en beleving van tijd en ruimte, als de sterke ontwikkeling van het causale en inductieve denken in de moderne tijd, waren naar Lamprechts mening nauw verbonden met de door de vrije onderneming veranderde 'economische psyche'. ${ }^{225}$ 'Het mag niet ontkend worden,' schreef Lamprecht in 1903 in zijn Deutsche Geschichte, 'en dat is het juiste aan de tegenwoordig al te radicaal bestreden geschiedfilosofische leer van Karl Marx, dat aan deze

\footnotetext{
${ }^{218}$ Lamprecht (1891-1909), IV [1894], 258-260.

${ }^{219}$ Lamprecht (1891-1909), ErgBd. I [1902], 81. Vgl. Lamprecht (1974), 649 [1909].

${ }^{220}$ Zie m.n. Lamprecht (1882), ook nog Lamprecht (1913d), 76-87.

${ }^{221}$ Zie bijv. Lamprecht (1891-1909), IV [1894], 288-297 en ErgBd. I [1902], 69-85.

${ }^{222}$ Lamprecht (1891-1909), ErgBd. I [1902], 184.

${ }^{223}$ Lamprecht (1891-1909), ErgBd. I [1902], 24-35.

${ }^{224}$ Lamprecht (1891-1909), ErgBd. I [1902], 51-66.

${ }^{225}$ Zie Lamprecht (1891-1909), ErgBd. II.1 [1903], m.n. 11-175 en 241-262.
} 
ontwikkeling van het intellect toch op de eerste plaats weer, hoewel geenszins uitsluitend, economisch-historische processen ten grondslag liggen'. ${ }^{226}$

Hoewel Lamprecht zijn lezers op deze wijze graag herinnerde 'aan de materiële ondergrond van alles, zelfs van het hoogste historische leven', ${ }^{227}$ beschouwde hij het als 'volkomen eenzijdig om alle verhoudingen uit het economische te construeren', zoals hij op de Historikertag van 1898 verklaarde. ${ }^{228}$ Zijn geschiedopvatting was uiteindelijk niet materialistisch maar psychologistisch. Alle domeinen van het historisch leven - ook de economie - werden door hem in de eerste plaats opgevat als psychische of sociaal-psychische verschijnselen. ${ }^{22}$ De gebruikelijke economische ontwikkelingstheorieën dienden psychisiert of beseelt te worden om in verband gebracht te kunnen worden met de historische veranderingen van andere menselijke activiteiten. In het geval van zijn eigen tijd, bijvoorbeeld, was de collectieve psychische noemer van zowel ondernemer als kunstenaar de Reizsamkeit: bij de ondernemer tot uiting komend in onzekerheid over de markt en de pogingen om die te boven te komen, bij de kunstenaar blijkend uit een fijngevoeliger weergave van de wereld, in beide gevallen teken van een intensievere waarneming en beleving van de werkelijkheid. 'Het economisch leven is niets anders dan een deelontwikkeling van de algehele psychogenese', meende hij. Zoals hij op het stofomslag van zijn Deutsche Geschichte liet vermelden, wilde hij 'de wederzijdse invloed van materiële en geestelijke ontwikkelingsfactoren binnen de Duitse geschiedenis duidelijk [...] maken, alsmede de uniforme psychische fundamenten en ontwikkelingsstadia van het gehele historische proces bloot [...] leggen. ${ }^{230}$

${ }^{226}$ Lamprecht (1891-1909), ErgBd. II.1 [1903], 113. Vgl. bovendien over Marx: Lamprecht (1903), 266; Lamprecht (1905a), 106-108; Lamprecht (1914a), [8].

${ }^{227}$ Lamprecht (1974), 602 (1904); Lamprecht (1914a), [8].

${ }^{228}$ Bericht (1898), 44. Hij voegde daar overigens aan toe, dat dat eveneens voor alle andere eenzijdige verklaringsmodellen gold.

${ }^{229}$ Zie bijv. Lamprecht (1974), 600 [1904]; Lamprecht (1900b).

${ }^{230}$ Geciteerd in Lamprecht (1974), 600 [1904]. 


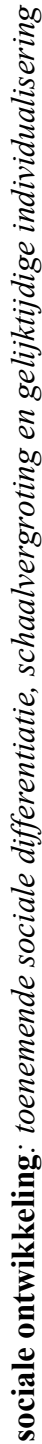

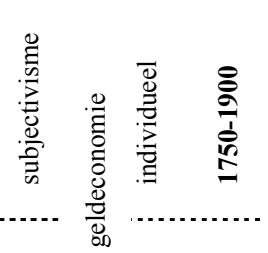

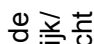

ฮ

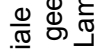

ठำ

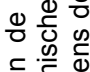

ก

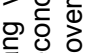

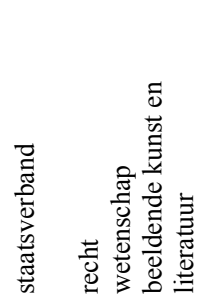

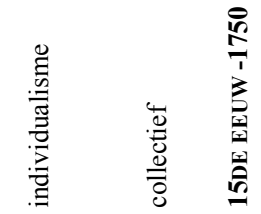

웜

ब

额

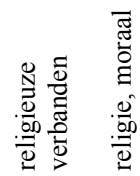

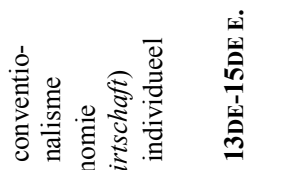

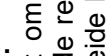

$\frac{\sqrt{2}}{\frac{2}{2}}$

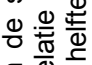

$\frac{5}{5}$

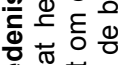

ฐิ

步 $\frac{4}{0}$

过员

os क

ब

อำㅇํㅇ

용.
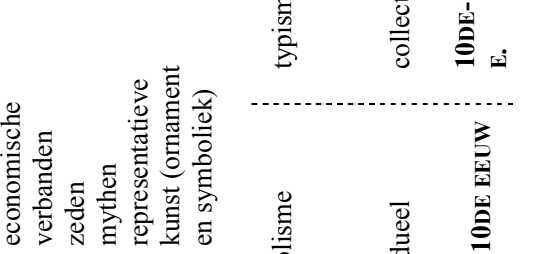

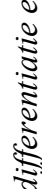

둥

으

产它它

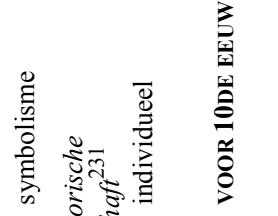

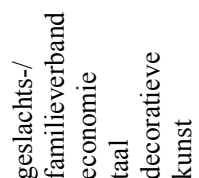

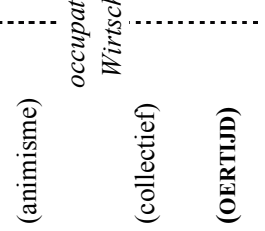

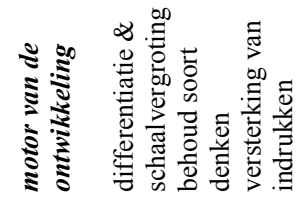

룰

空气。

○这

는 원

责

ป็

논웡

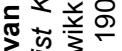

응 兵

ํ.

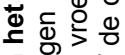

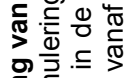

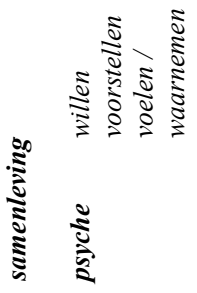

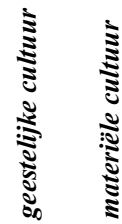

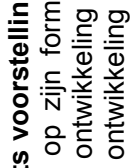




\subsection{Regionale, nationale en universele geschiedenis}

Het verloop van het historisch proces en de opeenvolging van de verschillende cultuurstadia kon volgens Lamprecht het best in nationale geschiedenissen worden onderzocht. Zijn keuze om een Deutsche Geschichte te schrijven, sprak wat dat betreft boekdelen. Toch verrichtte hij vooral in het begin van zijn carrière veel regionaalhistorisch onderzoek en eindigde hij als een ijveraar voor de beoefening van de Universalgeschichte.

Met name tussen 1880 en 1891 leverde Lamprecht een groot aantal bijdragen aan lokaal- of regionaalhistorische tijdschriften; van één van de belangrijkste daarvan werd hij in deze periode bovendien zelf mede-oprichter en een van de beide hoofdredacteuren. $^{232}$ Tot zijn voornaamste boekpublicaties vóór het verschijnen van zijn Deutsche Geschichte behoorden de regionaalhistorische bundel Skizzen zur rheinischen Geschichte (1887) en vooral zijn vierdelige Wirtschaftsleben im Mittelalter (1885/86), dat gebaseerd was op onderzoek in de Middenrijn- en Moezelstreek. En Lamprecht bleef gedurende zijn hele leven het lokaal- en regionaalhistorisch onderzoek stimuleren, onder andere door de vele dissertaties die hij op dit terrein begeleidde. ${ }^{233}$ Toch was voor Lamprecht uiteindelijk nooit de regio de basiseenheid van de cultuurgeschiedenis. Zoals in zijn grote middeleeuwenboek naar voren kwam, bestudeerde hij de regio voor zover zij exemplarisch was voor de nationale ontwikkeling. In het voorwoord van dat werk deelde Lamprecht uitdrukkelijk mee dat hij juist het 'universele' karakter van de bevindingen wilde bewaren en alles wat uitsluitend 'lokaal' was wilde uitscheiden; het ging hem expliciet om 'het algemene in het bijzondere'. ${ }^{234}$ Als treffende uitdrukking van deze gedachte presenteerde hij in een latere lokaalhistorische studie uit 1895 zijn studieobject als een paradigma. ${ }^{235}$

Niet de regio en evenmin de staat, maar de natie, aldus Lamprecht in 'Was ist Kulturgeschichte?' was de 'reguliere drager van de wereldhistorische ontwikkeling,. ${ }^{236}$ Het onderzoek naar de 'reguliere factoren' in de historische ontwikkeling zou zich derhalve altijd binnen een nationaal kader moeten voltrekken. Cultuur diende beschouwd te worden als 'een product van de menselijke socialisering [Vergesellschaftung], vooral van de natuurlijkste vorm daarvan, de nationale, ${ }^{237}$ Deze door Lamprecht niet nader toegelichte nadruk op het belang van de natie, moet worden beschouwd als de meest vèrstrekkende concessies die hij maakte in de erkenning van het belang van de 'natuurlijke factoren' in de geschiedenis: hij zag de natie immers als een natuurlijke gemeenschap, wat niet anders kon betekenen dan een gemeenschap gebaseerd op natuurlijke verwantschap en gemeenschappelijke afstamming. Typerend voor dit standpunt was het dat Lamprecht in zijn Deutsche Geschichte ook veel aandacht besteedde aan de Zwitserse, Nederlandse en Oostenrijkse geschiedenis. Maar

${ }^{232}$ Volgens de bibliografie van Schönebaum (1955/56) zijn het er vijftien: nr. A. 12, 13, 14, 15, $16,18,19,21,22,26,28,29,49,59,60$. Lamprecht was samen met F. Hettner de hoofdredacteur van de eerste tien jaargangen van de Westdeutsche Zeitschrift für Geschichte und Kunst (1882-1891).

${ }^{233}$ Zie Schönebaum (1955/56), B.I (lijst van begeleide dissertaties). Voor andere activiteiten van Lamprecht als promotor van regionaalhistorisch onderzoek, zie hoofdstuk 2, paragraaf 2 en SchornSchütte (1984b).

${ }^{234}$ Zie Lamprecht (1988), 48. Vgl. Schorn-Schütte (1984a), 395.

${ }^{235}$ Lamprecht (1895).

${ }^{236}$ Lamprecht (1974), 244.

${ }^{237}$ Lamprecht (1974), 281. 
ondanks dit uitgesproken nationale perspectief speelde het 'rassekarakter' geen dominante rol in Lamprechts geschiedopvattingen. ${ }^{238}$

Hoewel enige tijd een gewaardeerd lid van de Alldeutscher Verband kon de leiding daarvan uiteindelijk niet anders dan vaststellen dat Lamprecht 'cultuur' helaas belangrijker achtte dan 'ras' en bovendien al te 'kosmopolitisch' georiënteerd was. ${ }^{239}$ En niet ten onrechte. Anders dan bij Steinhausen, die eveneens een nationaal perspectief voor zijn cultuurgeschiedenis koos, mondde Lamprechts cultuurgeschiedenis niet uit in een analyse van het Duitse volkskarakter. Zelfs zijn geschiedenis van het Duitse nationale bewustzijn, die hij vanaf de vierde oplage (1906) bij wijze van inleiding aan zijn Deutsche Geschichte liet voorafgaan, sprak nergens over typisch nationale eigenschappen en mondde uit in de verwachting van een toenemende internationale oriëntering. ${ }^{240}$ De Duitse geschiedenis, waaraan hij het grootste deel van zijn onderzoek wijdde, beschouwde hij als 'paradigmatisch' voor de algemene ontwikkeling van naties. 'Het type van de nationale ontwikkeling [Völkerwerden] dient te worden vastgesteld', zoals hij meende. ${ }^{241}$ Daarvoor was de Duitse geschiedenis uitstekend geschikt: er bestonden geschreven (Romeinse) bronnen zelfs over de prehistorische fasen van de ontwikkeling, terwijl het land anderzijds inmiddels tot de hoogst ontwikkelde naties ter wereld behoorde. De afzonderlijke naties waren voor Lamprecht 'exemplaren van een algemeen nationaal type [...] met regulier terugkerende ontwikkelingsmomenten'. ${ }^{242}$

Om deze reguliere nationale ontwikkelingsmomenten op het spoor te komen, was het niet alleen nodig om de onderlinge invloeden tussen verschillende naties en periodes te verdisconteren, ${ }^{243}$ maar vooral ook om verschillende nationale ontwikkelingen onderling te vergelijken. Dit was de zin van de nauwe koppeling die Lamprecht maakte tussen cultuurgeschiedenis en universele geschiedenis, zoals die het meest duidelijk tot uitdrukking kwam in de naam en de opzet van het door hem opgezette en geleide universitaire Institut für Kultur- und Universalgeschichte (IKU, 1909). De Universalgeschichte die hij voorstond was niet zozeer een geschiedenis van de mensheid als geheel, als veeleer een vergelijkende geschiedenis van nationale ontwikkelingen. Het ging daarbij overigens zowel om overeenkomsten als verschillen; studenten aan het IKU moesten niet alleen de reguliere ontwikkeling van naties leren kennen, maar (zoals in de inleiding al is gezegd) ook 'de geest, het cultureel specifieke, de "mentalité" van de betreffende natie'. ${ }^{244}$ Tot het leerprogramma

${ }^{238} \mathrm{Na} 1900$ suggereerde hij wel dat verschillen in nationale ontwikkeling, bijvoorbeeld tussen Duitsland en China, teruggevoerd zouden kunen worden op een verschillend 'rassekarakter' (Lamprecht (1974), 617 [1907/8], 647 [1909]), maar elders achtte hij deze verklaring onbevredigend en noemde hij het rassekarakter zelf weer historisch van aard (Lamprecht (1974), 735 [1910]). Hetzelfde kan over de geografie gezegd worden, zie Lamprecht (1913d), 154-156 en Lamprecht (1900a), 44: 'die geographischen Grundlagen bilden wohl starken Verursachungen der einzelnen Völkergeschichten, nicht aber den Kern dieser selbst. Der Maßstab kann nur in den in jedem Völkerschicksal sich wiederholenden gemeinsamen Momenten aller Entwicklungen menschlicher Gemeinschaften gefunden werden.' In Krauses studie over Lamprecht en de Alldeutscher Verband komen alleen uit de oorlogstijd als racistisch aan te merken uitspraken voor, zie Krause (1993), 198.

${ }^{239}$ Krause (1993), 187.

${ }^{240}$ Lamprecht (1891-1909), I (5e opl. 1912, 44-56).

${ }^{241}$ Lamprecht (1900a), 44.

${ }^{242}$ Lamprecht (1974), 282.

${ }^{243}$ Lamprecht (1974), 282; deze invloeden werden door Lamprecht betiteld als 'renaissancen' (diachroon), 'recepties' (synchroon) en 'diosmosen' (wisselwerkingen).

${ }^{244}$ Zie Lamprecht (1988), 426 [1914]. In hetzelfde oorlogsjaar gebruikte Lamprecht de term mentalité nog een keer: Lamprecht (1914b), 9 ('das, was die Franzosen mentalité nennen - wie soll man das Wort übersetzen? - geistige Haltung des Augenblicks, in der alle anderen geistigen Betätigungen eingeschlossen und begründet sind?'). 
behoorden onder andere collegereeksen over de Franse, de Engelse, de Chinese cultuurgeschiedenis en cursussen waarin nationale ontwikkelingen - bijvoorbeeld de voorstelling van ruimte bij Franse en Italiaanse kinderen, of de Japanse en de Duitse kunstgeschiedenis - onderling werden vergeleken (zie Tabel 3.4). Een van Lamprechts redenen om op het IKU een grote (uiteindelijk meer dan honderdduizend exemplaren bevattende) verzameling kindertekeningen uit de hele wereld aan te leggen, was om na te gaan in hoeverre er verschillen waren te constateren in het 'psychische ontwikkelingsproces' van kinderen uit de diverse landen. ${ }^{245}$ Maar de nadruk lag voor Lamprecht ook hier meer op de universele overeenkomsten dan op nationale verschillen. 'Het hele materiaal', stelde hij tien jaar na aanvang van de collectie met tevredenheid vast, 'toont, hoezeer het jeugdige individu afhankelijk is van de cultuur van zijn omgeving, hoezeer echter desondanks ook bij alle culturen en rassen dezelfde psychische aanleg blijkt, en hoe als gevolg daarvan overal dezelfde richting van de geestelijke ontwikkeling in bepaalde wetmatige stadia aan de dag treedt'. ${ }^{246}$

\subsection{Psychische distantie}

Uit de wisselwerking van de sociaal-psychische factoren ontstond volgens Lamprecht een bepaalde collectieve psychische dispositie die de 'diapason' ('grondstemming') in een tijd bepaalde. Deze grondstemming veranderde in de loop van de geschiedenis, zoals ook de afzonderlijke sociaal-psychische factoren in de loop van de geschiedenis van aard veranderden. Deze verandering werd door Lamprecht beschreven als de opeenvolging van een aantal 'psychisch differente' Kulturzeitalter, tijdvakken met een eigen psychische gesteldheid die van elkaar werden gescheiden door een zekere 'psychische distantie'. ${ }^{247}$ Dit begrip van 'psychische distantie' lag aan de basis van Lamprechts opvatting van geschiedenis, die terugging op zijn historische sensatie van de vreemdheid van de geestesgesteldheden uit het verleden. Het is een ervaring die, vanwege haar belang voor Lamprechts werk, waard is in extenso aangehaald te worden: ${ }^{248}$

'Ik heb reeds vroeg tiende-eeuwse bronnen over de Duitse kerkgeschiedenis en vervolgens over de Duitse geschiedenis in het algemeen systematisch doorgewerkt. Daarbij vormde zich bij mij de ervaring van het bestaan van een in verhouding tot tegenwoordig absoluut ander geestesleven in deze tijd. Om deze aan de geschreven bronnen ontleende kennis te verdiepen, ging ik vervolgens voor hetzelfde tijdvak over naar de kunstgeschiedenis en vond mijn ervaring hier bevestigd; de geestelijke diapason, de algemene psychische dispositie van waaruit de kunst ontstond en waarin zij gedijde, was identiek aan de diapason van de zeden en de literatuur (want ook de letterkunde had ik inmiddels erbij gehaald). Ik probeerde nu de afstand van deze hele geestelijke houding van de tiende eeuw tot onze tegenwoordige tijd te meten. Ik zag al snel dat die [afstand] niet zonder meer te begrijpen was, maar slechts bepaald kon worden door kennis van de veranderingen in de eeuwen die tussen de tiende eeuw en tegenwoordig liggen. Zodoende verbreedde mijn opgave zich tot een overzichtelijke geschiedenis van de psychisch differente tijdperken van de laatste acht eeuwen Duitse geschiedenis.'

\footnotetext{
${ }^{245}$ Zie Lamprechts 'Anhang' (p. IV) in Levinstein (1905).

${ }^{246}$ Lamprecht (1914c), 3. Zie ook Lamprecht (1914a), [1].

${ }^{247}$ Aldus de titel van een hoofdstuk uit Lamprecht (1913d).

${ }^{248}$ Lamprecht (1896/97), 127; vgl. ook Lamprecht (1913d), 57. Zie overigens voor een kritiek van deze autobiografische passage, hierna Hoofdstuk 5, paragraaf 6.
} 
Tabel 3.4

Aanbod van werkcolleges (Übungen) aan het Königlich Sächsisches Institut für Kultur- und Universalgeschichte bij de Universiteit van Leipzig, zomersemester 1910. Naar: Lamprecht (1910), 13-16. Lamprecht verzorgde zelf de cursussen 1, 9 en (samen met o.a. Japanse docenten) 20. Voor de verschillende hoofdcursussen onder a werden gastdocenten uit het buitenland aangetrokken die in hun eigen taal college gaven (nrs. 10-12). Het werkcollege over ontwikkelingspsychologie (nr. 18) werd verzorgd door de psychologisch extraordinarius en latere ordinarius Felix Krüger.

\begin{tabular}{|c|c|}
\hline \multicolumn{2}{|r|}{ Inleidende cursussen } \\
\hline $\begin{array}{l}1 \\
2 \\
3 \\
4\end{array}$ & $\begin{array}{l}\text { Inleiding tot de historische studie als zodanig: introductie tot bronnenonderzoek, speciaal van de Duitse middeleeuwen } \\
\text { Inleiding tot Duitse cultuurgeschiedenis: introductie tot de cultuurgeschiedenis van de 18de en 19de eeuw en tot } \\
\text { cultuurhistorisch bronnenonderzoek } \\
\text { Inleiding tot de economische en sociale geschiedenis } \\
\text { Inleiding tot de Duitse rechtsgeschiedenis }\end{array}$ \\
\hline \multicolumn{2}{|r|}{ Hoofdcursussen } \\
\hline \multicolumn{2}{|r|}{ a cursussen gericht op cultuurhistorisch onderzoek van afzonderlijke naties } \\
\hline $\begin{array}{l}5 \\
6 \\
7 \\
8 \\
9 \\
10 \\
11 \\
12 \\
13 \\
14\end{array}$ & $\begin{array}{l}\text { Duitse volkszeden en -gebruiken bij de kringloop van het jaar } \\
\text { kritische Übungen over controverses m.b.t. de geschiedenis van de middeleeuwen } \\
\text { De geschiedenis van de onderdrukkings- en censuurpogingen van het Duitse intellectuele leven van de } 15 \mathrm{de} \text { t/m de } \\
18 \text { de eeuw (pauselijke Index, boekcensuur van overheidswege) } \\
\text { De sociale geschiedenis van de } 19 \text { de eeuw, speciaal van sociale theorieën en partijen } \\
\text { De Duitse cultuurgeschiedenis van de } 19 \text { de eeuw (invloed van hegelianisme en darwinisme op het historisch denken) } \\
\text { De ontwikkeling van het Belgische, m.n. Vlaamse stadswezen in de middeleeuwen (Belgische methode, volgens } \\
\text { Pirenne, in het Frans) } \\
\text { Franse cultuurgeschiedenis. De grote historici en de Franse opvatting van geschiedenis in de } 17 \mathrm{de} \text { en } 18 \mathrm{de} \text { eeuw } \\
\text { (Franse methode, in het Frans) } \\
\text { Engelse cultuurgeschiedenis van de } 18 \text { de en } 19 \text { de eeuw (Engelse methode, in het Engels) } \\
\text { Übungen in het lezen en verklaren van Byzantijnse historici m.b.t. Oosteuropese en Kleinaziatische culturen } \\
\text { Chinese geschiedenis in aansluiting bij de Schi-King }\end{array}$ \\
\hline \multicolumn{2}{|r|}{ b vergelijkende cursussen } \\
\hline $\begin{array}{l}15 \\
16 \\
17 \\
18 \\
19 \\
20\end{array}$ & $\begin{array}{l}\text { Vergelijkende familiegeschiedenis: het familiebegrip en overerving } \\
\text { Vergelijkende kinderpsychologie. De ontwikkeling van de voorstelling van ruimte bij Franse en Italiaanse kinderen } \\
\text { Ontwikkelingsgeschiedenis van primitieve kunst (ornamentiek) studentenkring } \\
\text { Ontwikkelingspsychologie. Oervormen van religie } \\
\text { Vergelijkende geschiedenis van Oudamerikaanse culturen } \\
\text { Ontwikkelingsgeschiedenis van de Japanse kunst in verhouding tot verwante Europese ontwikkelingen, met name in } \\
\text { Duitsland }\end{array}$ \\
\hline
\end{tabular}


'Historisch besef' betekende voor Lamprecht de ervaring van het verleden als een wezenlijk vreemd verleden, bevolkt door 'psychisch differente' (groepen) individuen. Geen enkele menselijke gebeurtenis uit het verleden kon derhalve zonder meer vanuit het heden worden begrepen. In zijn werk haalde hij talloze gevallen aan waaruit, bijvoorbeeld, 'het volledige onderscheid van de affecten en de gevoelsmatige dispositie' in het verleden en tegenwoordig moest blijken. ${ }^{249}$ Zoals het verhaal van de elfde-eeuwse Keizer Koenraad II die temidden van de hofhouding voor zijn zoon op de knieën viel en hem in tranen om hulp smeekte. Of hij wees op de talloze middeleeuwse wonderverhalen, die volgens hem duidelijk maakten dat het denken in termen van oorzaak en effect nog in hoge mate door het denken in analogieën werd verdrongen. Of hij duidde de specifieke betekenis van 'vriendschap' bij de Germanen, om te illustreren dat de 'zedelijke wereld' indertijd 'geheel andere waarden en een geheel andere structuur' bezat 'dan wij tegenwoordig kennen'. ${ }^{250}$

Veel aandacht gaf Lamprecht aan de veranderlijkheid van de waarnemende vermogens van de menselijke psyche. Van een zintuig als het oog achtte hij het 'waarschijnlijk' dat het in de loop van de geschiedenis onder invloed van de veranderde cultuur fysiek was verfijnd en verbeterd. ${ }^{251}$ En als er al geen directe fysiologische verandering had plaatsgevonden, dan was in ieder geval 'elk zien al een oordelen', zoals hij het in zijn Deutsche Geschichte kantiaans formuleerde: het innerlijke nabeeld van een waarneming was geen onveranderde afspiegeling van de werkelijkheid, maar altijd eenzijdig, want opgebouwd uit slechts bepaalde aspecten van de zintuiglijke Empfindung. ${ }^{252}$ Dat betekende in de praktijk dat de waarneming per cultuurtijdperk verschilde. 'In de ontwikkeling van de mensheid bestaat er niet slechts één manier om [...] door toepassing van een voorstelling van tijd en een idee van ruimte, waar te nemen', schreef hij. 'Duizenden vormen komen hier in aanmerking. De praktische ruimtebeleving en tijdsvoorstelling van lagere culturen is een totaal andere dan die van hogere culturen'. ${ }^{253}$

De verschillende 'algemene psychische disposities' die elk tijdvak kenmerkten werden door Lamprecht als een eenheid opgevat. Hij benoemde ze meestal met een enkele term. De vroegmoderne tijd typeerde hij - naar Burckhardt - als een 'individualistisch' tijdvak. De nieuwste tijd (vanaf circa 1750) karakteriseerde hij als een 'subjectivistische' verdieping daarvan. Het verdere verleden werd in drieën verdeeld, met aan de middeleeuwse kunstgeschiedenis ontleende termen die de geleidelijke ontwikkeling naar een individuele en naturalistische waarneming en weergave van de werkelijkheid tot uitdrukking dienden te brengen: symbolisme, typisme, conventionalisme. $^{254}$

De overgang van het ene naar het andere tijdperk werd normaliter veroorzaakt, zoals Lamprecht uiteindelijk in 1904 ontdekt meende te hebben, door een snelle

${ }^{249}$ Lamprecht beschouwde ook Breysigs cultuurgeschiedenis als te weinig psychisch 'ontwikkelend', zie Lamprecht (1901), 2062. Overigens hanteerde hij klaarblijkelijk een nergens verantwoorde grens tussen het constante en het variabele in de menselijke psyche: hij bekritiseerde tijdens de Historikertag van 1903 Sombart omdat die 'constante driften van de menselijke natuur als variabel beschouwt', zie Bericht (1903), 18.

${ }^{250}$ Alle genoemde voorbeelden in: Lamprecht (1913d), 54-65.

${ }^{251}$ Lamprecht (1913d), 79. Ook al Lamprecht (1896/97), 118-119.

${ }^{252}$ Lamprecht (1891-1909), IV, 288.

${ }^{253}$ Lamprecht (1914a), [4]; zie ook Lamprecht (1914c).

${ }^{254}$ Wel genoemd, maar niet nader toegelicht in Lamprecht (1896/97); een latere toelichting is te vinden in Lamprecht (1891-1909), ErgBd. I [1902], 69-79; Lamprecht (1913d), 76-95. Aan deze tijdperken ging in de 'oertijd' 'wellicht' nog een tijdperk van 'animisme' vooraf (Lamprecht (1896/97), 131). De geschiedenis van de beeldende kunst noemde Lamprecht ook wel een 'Geschichte der Anschauungskraft' (Lamprecht (1974) 524 [1901]. 
toename van indrukken of prikkels (Reize) van welke aard ook: dat konden ingrijpende natuurlijke gebeurtenissen, wetenschappelijke ontdekkingen, technische ontwikkelingen, economische veranderingen, maar bijvoorbeeld ook artistieke of intellectuele invloeden van elders zijn. Deze nieuwe indrukken zorgden voor een dissociatie van de oude diapason waarna een nieuwe psychische dispositie kon ontstaan. ${ }^{255}$ Door deze vertaling van de sociaal-psychische factoren naar 'prikkels' gaf Lamprecht opnieuw de principiële gelijkheid van de diverse sociaal-psychische factoren aan: de beslissende nieuwe prikkels konden immers van allerlei aard zijn. Maar hij gaf tegelijk toe dat het in de praktijk dikwijls juist de sociaal-economische ontwikkelingen waren die tot een tijdelijke periode van dissociatie en tot verandering van de diapason aanleiding gaven. ${ }^{256}$ De nadruk op de 'prikkels' die het individu bereikten, leidden ook tot een grote aandacht van Lamprecht voor de geschiedenis van verkeer en communicatie: door verbeteringen in de communicatie - het toenemend aantal verplaatsingen bijvoorbeeld, of de verbreiding van berichten via de drukpers - nam immers de uitwisseling van prikkels direct toe. In deze zin zou Lamprecht net als Steinhausen hebben kunnen beweren dat 'de communicatie de cultuurgeschiedenis bepaalt'. ${ }^{257}$

Wat was de motor (of logica) van deze veranderingen? In Lamprechts antwoord op deze vraag komt opnieuw naar voren dat hij een (bio)psychologisch en een meer sociaal-economisch verklaringsmodel probeerde te combineren. In ieder geval meende hij dat er twee algemene bewegingsprincipes uit de loop van de geschiedenis waren af te leiden. Op psychisch terrein was er in de loop van de geschiedenis sprake van een toenemende intensivering, differentiatie en verfijning van de psychische vermogens. Deze ontwikkeling kan als een uitvloeisel worden beschouwd van wat Lamprecht als een van de basismotieven van de menselijke psyche beschouwde: het 'kunstzinnige' streven naar versterking van de indrukken. Het was de ontwikkeling die hij in de kunst signaleerde van primitieve ornamentiek en symboliek tot eigentijds subjectivisme en impressionisme. "Van tijdperk tot tijdperk nam het geestesleven in intensiteit toe, werden de nuances fijner, de affecten evenwichtiger, de energie van zien en opvatten indringender'. ${ }^{258}$ Niet zoveel anders dan Steinhausen gaf Lamprecht bijvoorbeeld in zijn Deutsche Geschichte het volgende beeld van de veertiende-eeuwse burger, de tegenvoeter van zijn nerveuze, scherp waarnemende en fijngevoelige tijdgenoten: ${ }^{259}$

'De burger, vertegenwoordiger van de meest ontwikkelde beroepslaag in de veertiende eeuw, stond nog ver af van het geestelijke individualisme van het reformatietijdperk. Zijn driften en opvattingen waren nog zelden van persoonlijke aard: op jonge leeftijd gold hij al als volledig opgevoed, zijn mondigheid verwierf hij zelfs in steden als Bazel en Frankfurt al op zijn veertiende jaar en nooit vond hij zichzelf interessant als persoonlijke microkosmos: meestal wist hij zelfs niet zijn leeftijd met zekerheid te noemen. Des te meer heersten ongeregelde driften; de hartstochten waren nog grof en overheersend; wat betreft het verstandige maathouden in voornemen, gedrag en spreken was overal sinds de goede dagen van het ridderdom zelfs een terugval opgetreden. [...] Er was sprake van een directheid van de hartstochtelijke Empfindung, die, voortdurend aanwezig, maar al te makkelijk tot vreselijke uitspattingen kon leiden.'

Lamprechts Deutsche Geschichte was de geschiedenis van een continue menselijke vooruitgang en groei, die door Lamprecht om die reden ook wel als een 'sociale bio-

\footnotetext{
${ }^{255}$ Zie uitgebreid voor het eerst Lamprecht (1905a), hfdst. 3.

${ }^{256}$ Lamprecht (1905a), 107-108; Lamprecht (1913d), 144-145.

${ }^{257}$ Vgl. Lamprecht al in 1888, geciteerd in: Schönebaum (1961), 226; en Lamprecht (1905a), 110.

${ }^{258}$ Lamprecht (1896/97), 128, 132-133.

${ }^{259}$ Lamprecht (1891-1909), IV [1894], 260-261.
} 
psychologie' of - met een term die later opnieuw door Norbert Elias zou worden gebruikt - als 'menselijke psychogenese' werd aangeduid. ${ }^{260}$ Onder de economische en sociale ontwikkelingen die zo vaak tot een verandering van Kulturzeitalter leidden, moest een zelfstandige ontwikkelingspotentie van de menselijke ziel worden aangenomen. ${ }^{261}$ Daarop zal hij gedoeld hebben toen hij eens schreef dat geistige Strömungen 'uiteindelijk beslissend zijn in de voortgang van de geschiedenis'.262 Lamprecht vergeleek de psychische ontwikkelingsgang van de natie met de ontwikkeling van een eikenboom uit een eikel: onder normale omstandigheden vond altijd dezelfde ontwikkeling plaats. ${ }^{263}$ In deze opvatting paste ook Lamprechts waardering voor Haeckels biogenetische grondwet, ${ }^{264}$ volgens welke het individu in korte tijd dezelfde ontwikkeling doorliep als de hele soort. Een consequentie van deze gedachte was dat voor het begrijpen van vroege en duistere ontwikkelingsfasen van de mensheid gebruik kon worden gemaakt van de kinderpsychologie. Lamprecht nam deze mogelijkheid zeer serieus. Niet alleen kregen zijn studenten onderwijs van een psycholoog in de ontwikkelingspsychologie, ${ }^{265}$ ook diende zijn collectie kindertekeningen aan het IKU om een empirische basis voor onderzoek naar de cognitieve ontwikkeling van kinderen - en daarmee van primitieve culturen - te verwerven. ${ }^{266}$

Lamprechts nadruk op de principiële gelijkheid van de verschillende 'sociaalpsychische factoren' en zijn nadruk op de hoeveelheid 'prikkels' als oorzaak van cultuurovergangen, passen goed in deze opvatting van de psychische ontwikkeling van menselijke gemeenschappen als een autogeen, biologisch proces van 'stetiges Wachsen'. Behalve door de kracht van de analogie overtuigde dit principe echter weinig als het erom ging afzonderlijke historische fenomenen te verklaren: elke historische verandering kon daarmee immers simpelweg als een autonoom 'groeiproces' worden 'verklaard'. Dat is een van de redenen waarom Lamprechts gedachte van elkaar dwingend opvolgende Kulturzeitalter zoveel kritiek heeft moeten verduren, ook al beklemtoonde hij herhaaldelijk dat het bij deze Kulturzeitalter niet om absolute waarheden ging, maar slechts om 'statistische grootheden' en heuristische hulpmiddelen voor het vinden van causale samenhangen. ${ }^{267}$

Toch probeerde Lamprecht in zijn geschiedschrijving ook wel degelijk de sociale mechanismen achter (of eigenlijk: behorend bij) dit proces te analyseren. Daarbij speelde een tweede bewegingsprincipe dat hij in de geschiedenis bespeurde de hoofdrol: de continue ontwikkeling van een sterke gelijkheid van alle individuen naar een toenemende individuele differentiatie als gevolg van het uiteenvallen van de

${ }^{260}$ Zie Lamprecht (1974), 599 ['Biopsychologische Probleme', 1904]; Lamprecht (1974), 729 [1910]; Lamprecht (1913d), 68. Overigens tekende Lamprecht zelf aan dat in het begrip Fortschritt altijd een waardeoordeel schuil ging en derhalve beter vermeden kon worden, zie Lamprecht (1896), 78-79.

${ }^{261}$ Lamprecht (1891-1909), ErgBd. II.2, 24-25; vgl. Lamprecht (1901), 2062; Lamprecht (1902),

142-143; Lamprecht (1974), 704 [1910].

262 Lamprecht (1914b), 29.

${ }^{263}$ Lamprecht (1896/97), 136; overigens nam Lamprecht expliciet afstand van Darwins evolutieleer en mechanismen als 'aanpassing' en 'overerving', zie Lamprecht (1913d), 149-152.

${ }^{264}$ Al vermeld in Lamprecht (1896/97), 114; stelliger vanaf 1904/5, zie bijv. Lamprechts 'Anhang' in Levinstein (1905), V. Ook Lamprecht (1913d), 136.

${ }^{265}$ Zie Tabel 3.4, nr. 15 en 16; de psycholoog Felix Krüger doceerde aan het IKU ontwikkelingspsychologie.

${ }^{266}$ Zie voor Lamprechts oproep in binnen- en buitenlandse bladen om kindertekeningen in te zenden zijn bijdrage in Levinstein (1905), 'Anhang', III-XIV.

${ }^{267}$ Lamprecht (1896/97), 133-134; Lamprecht (1974), 332, 338 [1897]; 651, 661 [1908] en 721$722[1910]$. 
samenleving in steeds meer verschillende (beroeps)groepen. ${ }^{268}$ Dit proces van sociale differentiatie, dat Lamprecht in verband bracht met een gelijktijdig proces van schaalvergroting, werd door hem verklaard door de toenemende arbeidsdeling en de geleidelijke verbetering van communicatie- en organisatiemiddelen, die weer mogelijk waren geworden door de gestage toename van welvaart en kapitaalvorming. ${ }^{269}$ In het proces van toenemende sociale differentiatie en individualisering speelden derhalve economie en techniek - ondanks Lamprechts afzwakking van economische verklaringen - een beslissende rol. Zoals op psychisch vlak de scherp waarnemende en fijngevoelige mens het eindpunt van de ontwikkeling vormde, zo was op sociaal vlak het gedifferentieerde individu het eindpunt van de historische ontwikkeling. Beide ontwikkelingstendensen vormden een samenhangend geheel: de arbeidsdeling in de samenleving bracht enerzijds psychische differentiatie met zich mee en zorgde anderzijds voor de bemiddeling van psychische kenmerken naar andere groepen. Deze redenering volgend legde Lamprecht meer dan zeventig jaar vóór Alexander Murrays bekende Reason and Society in the Middle Ages (1978) al een verband tussen sociale differentiatie - met name als gevolg van de opkomst van de geldeconomie - en rationalisering in de middeleeuwen. ${ }^{270}$

\subsection{Geschiedenis en psychologie}

In de literatuur over Lamprecht is vaak beweerd dat hij aan een natuurwetenschappelijk georiënteerde psychologie à la Wundt de wetten ontleende waaruit zijn analyse van het verleden als het ware vanzelf voortvloeide. En inderdaad, in zijn belangrijkste vroege programmatische geschrift 'Was ist Kulturgeschichte?' is een buitenproportioneel deel van de referenties ontleend aan Wilhelm Wundt: tweeentwintig van de 109 referenties (20\%) verwijzen naar werk van zijn Leipzigse collega. De historicus en geschiedtheoreticus Ottokar Lorenz, tweede in deze citatieindex, moet het met slechts twaalf verwijzingen doen. En ja, de psychologie werd door Lamprecht wel het fundament en de mechanica van de geschiedwetenschap genoemd en geschiedenis niets anders dan 'toegepaste psychologie'. ${ }^{271}$

Toch is dit niet het hele verhaal. Lamprechts opvatting van geschiedenis als toegepaste psychologie was gebaseerd op de overweging dat zowel psychologie als geschiedenis de menselijke ervaring tot onderwerp hadden en dus direct relevant voor elkaar waren. ${ }^{272}$ Dat was overigens bepaald geen uitzonderlijk standpunt in zijn tijd, maar een oordeel dat in veel varianten bij veel wetenschappers valt aan te treffen. Zoals Georg Simmel, die in een door Lamprecht aangehaalde geschiedfilosofische verhandeling uit 1892 ook de nadruk had gelegd op het 'innerlijke karakter van historische processen' en had verklaard dat 'als de geschiedenis geen marionettenspel wil zijn, zij een geschiedenis van psychische voorvallen is' ${ }^{273}$ Duitse psychologen als Münsterberg en Wundt verkondigen in de jaren negentig eveneens dat geschiedenis toegepaste psychologie was. ${ }^{274}$ En zelfs Rachfahl, een van Lamprechts tegenstanders, citeerde met instemming Diltheys voorstel voor een nieuwe psychologie die 'de basis

${ }^{268}$ Lamprecht (1896/97), 143-144; Lamprecht (1900a), 28; Lamprecht (1905a), 3.

${ }^{269} \mathrm{Zie}$ voor deze theorie: Lamprecht (1891-1909), ErgBd. II.1 [1903], 3-114.

${ }^{270}$ Zie m.n. Lamprecht (1891-1909), ErgBd. II.1, 69-114 [1903].

${ }^{271}$ Lamprecht (1905a), 16-17.

${ }^{272}$ Zie Lamprecht (1896/97), 77.

${ }^{273}$ Simmel (1989), 303-304. Indien er een wettenstellende psychologie zou bestaan, dan zou derhalve de geschiedwetenschap een vorm van toegepaste psychologie zijn, meende ook Simmel in deze studie.

${ }^{274}$ Zie Stoffers (2003). 
voor de geesteswetenschappen zal worden, zoals de wiskunde dat voor de natuurwetenschappen is'. ${ }^{275}$

Maar wat was de psychologie waarop Lamprecht zijn geschiedenis baseerde? Hij sprak in 1903 uitdrukkelijk uit dat hij zich bij geen enkele bestaand psychologisch systeem aansloot; er kon dus ook geen sprake zijn van een onderwerpen van de geschiedenis aan één psychologisch systeem. ${ }^{276}$ De twee psychologische 'wetten' die hij expressis verbis aan Wundt ontleende, betroffen enkele van diens meest algemene psychologische inzichten, met name de 'wet van de psychische relaties' en de 'wet van de creatieve synthese'. ${ }^{277}$ In de eerste 'wet' ging het om het inzicht dat de psyche een samenhangend systeem is, dat als geheel verandert door veranderingen in een enkel deel. Naar Lamprechts opvatting gold dat ook voor een collectieve psychische dispositie. De tweede 'wet' gaf vorm aan de gedachte dat het geheel (de individuele of collectieve psyche) meer is dan de som van de delen: er ontstaan nieuwe eigenschappen in het geheel door de combinatie en wisselwerking van onderdelen, die deze eigenschappen op zichzelf niet kennen. Ook aan andere wetenschappers ontleende Lamprecht dergelijke algemene psychologische inzichten, aan Simmel bijvoorbeeld de opvatting dat het individu niet langer als een afgesloten eenheid gezien kon worden en ideeën over sociale differentiatie en het verband tussen groepsgrootte en individualisering. ${ }^{278}$ Later gebruikte Lamprecht ook nog het psychologisch werk van Lipps. ${ }^{279}$

Van een natuurkundige opvatting van wetmatigheid en een mechanische toepassing van psychologische inzichten kan echter in geen van deze gevallen worden gesproken. Het ging Lamprecht, die herhaald het onvermijdelijk artistieke karakter van de geschiedschrijving beklemtoonde, ${ }^{280}$ bij het gebruik van de psychologie van zijn dagen veel meer om de verrijking, verfijning en verbetering van het begrippenapparaat dat de historicus ter beschikking stond in de schildering van het verleden. ${ }^{281}$ Waar de wetenschap in het duister tastte en de complexiteit van het verleden ondoordringbaar was, diende de historicus gebruik te maken van de kunstzinnige verbeelding en een verhaal te vertellen. Maar zijn verhaal moest zoveel mogelijk gebruik maken van wetenschappelijk doordachte begrippen. Zulke begrippen waren bijvoorbeeld ook 'het leenstelsel' of 'de geldeconomie', in Lamprechts formulering: 'abstracties van het typische uit herhaald voorgekomen historische verschijnselen'. ${ }^{282}$

Gezien Lamprechts psychologische opvatting van de geschiedenis was het logisch dat hij voor de psychologische begripsvorming te rade ging bij de wetenschappelijke psychologie van zijn dagen. Maar dat betekende niet dat hij de geschiedenis als een historische invuloefening voor psychologen beschouwde. Integendeel. Het is weinig commentatoren opgevallen dat Lamprecht herhaald en uitdrukkelijk de geschiedenis boven de psychologie stelde en tot de meest fundamentele geesteswetenschap verhief. Dat Lamprecht geen keus maakte voor één bepaald eigentijds psychologisch systeem om het verleden te analyseren, hing samen met zijn overtuiging dat eigentijdse psychologische theorieën misschien van toepassing waren op eigentijdse psychische gesteldheden, maar dat zij niet zonder meer op het verleden toegepast konden worden.

${ }^{275}$ Zie Rachfahl (1896), 91.

${ }^{276}$ Lamprecht (1891-1909), ErgBd. I, 3n.

277 Zie Lamprecht (1903).

${ }^{278}$ Zie Lamprecht (1896/97), 80, 144.

${ }^{279}$ Zie Lamprecht (1905a). [1913]

${ }^{280}$ Zie Lamprecht (1896/97), 92-93; Lamprecht (1905a), 5, 22, 102; Lamprecht (1974), 841

${ }^{281}$ Zie o.a. Lamprecht (1896/97), 92; Lamprecht (1900a), 6-8, 30, 35, 44n1; Lamprecht (1905a), 5, 22, 102; Lamprecht (1974), 841 [1913].

${ }^{282}$ Lamprecht (1900a), 23. 
De geschiedwetenschap ging geenszins op in de psychologie als een 'mechanica van de psychische bewegingen'. ${ }^{283}$ De historische ontwikkeling domineerde de psychologische wetten - niet andersom; het geestelijk leven was eerder de schepper van 'de psychische organisatie' dan omgekeerd, zegt Lamprecht zelfs ergens. ${ }^{284}$ Er bestond een 'oneindige' kloof tussen denken en voelen in de eigen tijd en die in het verre verleden - en het laatste kon niet met een eigentijdse statische psychologie worden geanalyseerd. ${ }^{285}$ De geschiedenis van de psychologie (als vak) was niets anders dan een geschiedenis van de pogingen om 'het psychisch karakter' van de eigen tijd zoveel mogelijk recht te doen, zoals Lamprecht in de Zeitschrift für Kulturgeschichte opmerkte. $^{286}$

In principe moest worden aangenomen dat de psyche zich niet alleen in zijn geobjectiveerde verschijningsvormen wijzigde, maar dat het daarbij ook om constitutieve, 'biologische' veranderingen ging. ${ }^{287}$ 'Psychologie', schreef hij in 1900, 'is zonder twijfel deel van een [historische] ontwikkeling en daarom deel van de historische wetenschappen. [...] [D]e historische discipline (in zijn meest algemene zin: de studie van de psychologische veranderingen van menselijke gemeenschappen) [is] binnen de Geisteswissenschaften de leidende wetenschap'. ${ }^{288}$ En nog eens: als 'kerndiscipline' van de geesteswetenschappen, als eerste wetenschap onder de geesteswetenschappen, diende de geschiedenis begrepen te worden, althans 'die [moderne] geschiedwetenschap, die zich tot opgave stelt de verschillende ontwikkelingsstadia van de sociale psyche van menselijke samenlevingen zowel in verleden als heden op te helderen'. ${ }^{289} \mathrm{Zij}$ moest binnen de psychologie aanzetten tot 'een historische benaderingswijze': de psychologie moest 'variabel' worden, zij behoefde een 'concept van tijd als functie [zeitlicher Funktionsbegriff]' - en alleen de geschiedenis kon zorgdragen voor een dergelijk 'evolutionair' perspectief. ${ }^{290}$ Nog in 1913 waarschuwde hij tegen de onhistorische neiging tot 'statisch deductieve constructies' binnen de psychologie en prees hij onder andere de beschrijvende psychologie van Dilthey en Lipps vanwege het genetische ontwikkelingsperpectief dat hij daarin ontwaarde. De empirische psychologie werd steeds meer tot een ontwikkelingsgeschiedenis van het menselijke psychische leven en naderde zo dicht tot de cultuurgeschiedenis. ${ }^{291}$ Om deze reden verzette verzette Lamprecht zich in 1913 ook heftig tegen de actie van Duitse filosofen om psychologen van filosofische leerstoelen te verwijderen: Lamprecht vreesde een verschraling van de psychologie tot een natuurwetenschappelijke psychologie en pleitte voor een voortgezette opvatting van psychologie als onderdeel van de geesteswetenschappen. ${ }^{292}$

${ }^{283}$ Lamprecht (1903), 269.

${ }^{284}$ Lamprecht (1896/97), 119.

${ }^{285}$ Lamprecht (1903), 270-272.

${ }^{286}$ Lamprecht (1974), 475 [1899].

${ }^{287}$ Lamprecht (1905a), 86. Vgl. Lamprecht (1913d), 79: 'wahrscheinlich ist, daß sich der Apparat [nl. het fysieke oog] unter den psychischen Einwirkungen höherer Kulturstufen verfeinert und insofern verbessern kann oder muß.'

${ }^{288}$ Lamprecht (1900a), 14-15.

${ }^{289}$ Lamprecht (1891-1909), ErgBd. I, 455 [1902].

${ }^{290}$ Lamprecht (1905a), 19-20.

${ }^{291}$ Lamprecht (1974), 842-845 [1913].

${ }^{292}$ Zie Lamprecht (1913c, b); vgl. Rath (1994), 266-273. 
Lamprecht was zonder twijfel de meest productieve en actieve Duitse cultuurhistoricus uit de periode 1889-1915. Hij was in menig opzicht de centrale figuur van de nieuwe cultuurgeschiedenis: hij formuleerde de nieuwe sociaal-psychologische opvatting van cultuurgeschiedenis het meest consequent en het meest uitvoerig, hij had de grootste uitstraling in binnen- en buitenland, en stond op enig moment in contact met alle andere nieuwe cultuurhistorici. Anderzijds was Lamprecht ook het meest radicaal - in zijn collectivisme, in zijn nadruk op de economische factor, in zijn afwijzing van Ranke, in zijn geloof in een 'biologische' ontwikkeling van cultuurtijdperken - en wist hij uiteindelijk alleen met Breysig (die de laatste overtuiging met hem deelde) een blijvend vriendschappelijk contact te onderhouden. Hij fungeerde ten slotte als een splijtzwam onder de cultuurhistorici, vooral omdat zijn radicalisme de verhouding van de cultuurgeschiedenis tot de politieke geschiedenis opnieuw op scherp had gezet en de cultuurhistorici de aansluiting bij de Zunft dreigden te verliezen. Bij alle onderlinge verschillen die al genoemd zijn en nog genoemd zullen worden, moeten echter de fundamentele overeenkomsten van de overige nieuwe cultuurhistorici met Lamprecht niet over het hoofd worden gezien. Zijn aandacht voor het typische en collectieve, voor de doosneemens, zijn geloof in een universele, stapsgewijze ontwikkeling van de mens en, last but not least zijn overtuiging van de veranderlijkheid van de (collectieve) psychische dispositie van mensen, deelde hij met de meesten van hen.

\section{Kurt Breysig}

In Lamprecht's opvatting kende de cultuurgeschiedenis, als een geschiedenis van 'sociaal-psychische factoren', duidelijk een sociale component. Maar Lamprecht prefereerde uiteindelijk de term 'cultuurgeschiedenis' boven het begrip 'sociale geschiedenis' als aanduiding voor zijn opvatting van algemene geschiedenis. ${ }^{293}$ Voor de Berlijnse extraordinarius voor Pruisische geschiedenis en latere hoogleraar 'Gesellschaftslehre und allgemeine Geschichtswissenschaft' Kurt Breysig lagen de zaken enigszins anders. Hij had aanvankelijk een voorkeur voor de aanduiding 'sociale geschiedenis', maar toen hij vervolgens ook het alternatief 'cultuurgeschiedenis' ging gebruiken, deed hij geen afstand van de eerdere uitdrukking.

Dit dubbele woordgebruik van Breysig is wel geïnterpreteerd als een vorm van begripsverwarring. De belangrijkste kenner van zijn werk, Bernhard vom Brocke, meende bijvoorbeeld dat de titel die Breysig voor zijn Kulturgeschichte der Neuzeit (1900) had gekozen diens historische preoccupaties eigenlijk onvoldoende nauwkeurig weergaf: 'juister zou voor grote delen van het werk "sociale geschiedenis" zijn'. ${ }^{294} \mathrm{Nu}$ droegen delen van dit werk onmiskenbaar een sociaalhistorisch karakter; ook hield Breysig met name in de tweede helft van de jaren negentig regelmatig enthousiaste pleidooien voor 'sociale geschiedenis'. ${ }^{295}$ Niet voor niets vatte hij het onderwerp van de geschiedenis kortweg samen als 'de verhouding van mensen onder elkaar'. ${ }^{296}$ En net als Bernheim en Lamprecht behoorde hij in 1909 tot de oprichters van de 'Deutsche Gesellschaft für Soziologie', waarvan hij zelfs tot een van de eerste voor-

${ }^{293}$ Vgl. Lamprecht (1905b), 327-328.

${ }^{294}$ Zie Brocke (1971), 51. Vom Brocke oordeelde op vergelijkbare wijze dat Lamprechts DG 'im Gewand seiner Kulturgeschichte' eigenlijk een 'sociale geschiedenis' presenteerde (203). Brocke neemt zodoende hetzelfde standpunt t.a.v. de term 'cultuurgeschiedenis' in als zijn leermeester Oestreich (zie Hoofdstuk 1, paragraaf 2).

${ }^{295}$ Zie m.n. Breysig (1896a), Breysig (1899).

${ }^{296}$ Breysig (1897b), 338. 
zitters werd gekozen. ${ }^{297}$ Maar anderzijds herhaalde hij als zestigjarige nog eens uitdrukkelijk waarvoor hij zich naar eigen zeggen 'sinds een mensenleven' had ingezet: 'alle geschiedenis is cultuurgeschiedenis' ${ }^{298}$ In feite blijkt Breysig goede redenen te hebben gehad om in zijn Kulturgeschichte der Neuzeit (1900-1901) en latere publicaties zowel 'cultuurgeschiedenis' als 'sociale geschiedenis' te blijven gebruiken.

\subsection{Sociale geschiedenis, cultuurgeschiedenis, algemene geschiedenis}

Onmiskenbaar waren Breysigs geschiedtheoretische opvattingen geïnspireerd door de lopende discussies over cultuurgeschiedenis. Nadat hij zich als twintigjarige student in een referaat uit 1886 nog eens had verklaard met de kritiek van vakhistorische zijde op de cultuurgeschiedenis, ${ }^{299}$ veranderde hij in de loop van zijn studie radicaal van inzicht. In een schrijven aan zijn leermeester Gustav Schmoller uit 1889 koos de net gepromoveerde Breysig in het debat tussen Gothein en Schäfer de kant van de eerste en noemde hij Schäfers positie 'wetenschappelijk volstrekt reactionair'. ${ }^{300}$ Anders dan Lamprecht mengde Breysig zich ook publiekelijk in dit debat met een bespreking waarin hij tussen de regels door zijn kritiek op Schäfer liet blijken: zijn korte referaat over de controverse besloot de vijfentwintigjarige doctor met de vaststelling dat Schäfers standpunt 'toch niets anders betekende' dan dat 'de staat niet alleen zou domineren, maar alle andere [onderwerpen van de geschiedschrijving] op een zeer kleine ruimte zou moeten terugdringen'. ${ }^{301}$

Breysig formuleerde zijn geschiedtheoretische standpunten overigens pas expliciet in het publieke domein nadat hij begin 1896 tot Extraordinarius voor Pruisische geschiedenis in Berlijn was benoemd, een jaar nadat hij in een anonieme recensie al de uitgebreide behandeling van de cultuurgeschiedenis in Bernheims Lehrbuch had geprezen. ${ }^{302}$ Onder verwijzing naar het Schäfer-Gothein debat en in aansluiting bij 'Lamprechts ideenreiche uiteenzettingen' die eerder dat jaar waren verschenen, formuleerde Breysig toen in twee opstellen zijn eigen visie op de door hem noodzakelijk geachte vernieuwing van de geschiedwetenschap. ${ }^{303} \mathrm{Na}$ tien jaren van grote wetenschappelijke productiviteit waarin hij deze visie theoretisch verder uitwerkte en bovendien in zijn geschiedschrijving probeerde te realiseren, leidde het steeds duidelijker wordend gebrek aan vakhistorische waardering vanaf 1908 tot een langdurige onderbreking van zijn stroom wetenschappelijk publicaties. Pas na zijn bevordering tot ordinarius in 1923 kwam zijn wetenschappelijk werk met gedeeltelijk nieuwe accenten weer op gang. ${ }^{304}$

${ }^{297}$ Zie Bruch (1988), 136.

${ }^{298}$ Breysig (1926), 566 (mijn cursivering, MS)

${ }^{299}$ Zie Brocke (1971), 41n.

${ }^{300}$ Geciteerd in: Brocke (1971), 39. In een terugblik uit de jaren dertig schrijft Breysig over de periode 1889-1892: 'Ich hatte schon damals die lebhafteste und nahezu polemisch eingestellte Abneigung gegen die nur-politische Geschichte, die zu jener Zeit unbedingt vorherrschte', Breysig (1962), 32.

${ }^{301}$ Breysig (1892), 869. Deze recensie verscheen in juni 1892; in dezelfde zomer werd Breysig toegelaten als universitair docent.

${ }^{302}$ Zie hoofdstuk 2, paragraaf 1.

${ }^{303}$ Zie Breysig (1896c) en Breysig (1896a), m.n. 3-8. De daaropvolgende belangrijkste door mij bestudeerde theoretische geschriften van Breysig (tot aan WO I) zijn: Breysig (1898); Breysig (1897a); Breysig (1900a); Breysig (1902c); Breysig (1905a); Breysig (1907), 31-87: 'Einleitung'; Breysig (1908). Uit de periode na WO I is in mijn verband vooral relevant Breysig (1931), 1-31 en 326-526, alsmede Breysig (1930, (1929b, a).

${ }^{304}$ In de navolgende analyse zal ik mij grotendeels beperken tot Breysigs vooroorlogse werk. 
In zijn eerste programmatische artikelen uit 1896 keerde Breysig zich uitdrukkelijk tegen de beperking van de geschiedenis tot politieke geschiedenis èn tegen een scheiding van politieke en cultuurgeschiedenis, ten gunste van een 'waarlijk algemene geschiedschrijving'. ${ }^{305}$ Die werd nog niet uitdrukkelijk 'cultuurgeschiedenis' genoemd, maar wel beschreef Breysig alle mogelijke historische deelterreinen direct al als een vorm van 'cultuur': in de algemene geschiedenis ging het zowel om politiek als om alle niet-politieke vormen van 'sociale cultuur', alsmede om de 'materiële cultuur' en de 'innerlijke [geistige] cultuur'. In een dergelijke algemene geschiedenis zou de 'sociale geschiedenis' in de meest brede betekenis van het woord een belangrijke categorie vormen. Breysig omschreef haar thematiek in 1896 op een opmerkelijke manier:
'de verhouding van menselijke gemeenschappen tot elkaar en dat van de individuen tot deze gemeenschappen. Het onderzoek van wat Goethe de Geist der Zeiten noemt, is haar eigenlijke doel. Zij dient de intiemste uitingen van het volksleven na te gaan, de veranderingen van het familie-, het gemoedsleven op te sporen en die misschien wel moeilijkste en toch meest lonende opgave van de historicus te vervullen, de geschiedenis van de persoonlijkheid te doorgronden'. ${ }^{306}$

Het ging in Breysigs 'sociale geschiedenis' dus niet alleen om de geschiedenis van de uiterlijke sociale verhoudingen, maar ook om de geschiedenis van de 'tijdgeest', het gemoedsleven, de persoonlijkheid. Tegelijk maakte Breysig duidelijk dat ook een dergelijke breed gedefinieerde sociale geschiedenis nog niet samenviel met algemene geschiedenis; zij omvatte namelijk 'zeker niet alle manifestaties van de geestelijke en materiële cultuur'. ${ }^{307}$ Voor die algemene geschiedenis, die in zijn visie gekenmerkt werd door de verbinding van sociale en 'geestesgeschiedenis' gebruikte Breysig in zijn Kulturgeschichte der Neuzeit en elders de term 'cultuurgeschiedenis'. 'De cultuur die ik bedoel,' schreef hij in het voorwoord tot dat werk, 'omvat in de letterlijke zin van het woord zowel alle sociale instituties als alle geestelijke scheppingen'. ${ }^{308}$

Er bestond geen verschil tussen cultuurgeschiedenis en 'eigenlijke geschiedenis' - 'Geschiedenis is geschiedenis van de menselijke cultuur', schreef Breysig ${ }^{309}$ - en juist dat standpunt verklaart zijn aarzeling om het woord 'cultuurgeschiedenis' überhaupt te gebruiken: hij wilde niet de indruk wekken iets anders dan algemene geschiedenis te presenteren. ${ }^{310}$ Een uitspraak die Steinhausen zich eens liet ontvallen: 'men zal zo lang van cultuurgeschiedenis moeten spreken als men geschiedenis slechts als politieke geschiedenis opvat' - zou zonder meer door Breysig (en overigens door alle hier besproken cultuurhistorici) kunnen zijn overgenomen. ${ }^{311}$ Illustratief voor zijn gelijkstelling van algemene en cultuurgeschiedenis was dat Breysig het eerste (theoretische) deel van zijn Kulturgeschichte der Neuzeit de titel meegaf 'Opgaven en maatstaven van een algemene geschiedschrijving' en daarin de verbintenis van sociale en ideële geschiedenis vervolgens weer benoemde als Universalgeschichte. Breysig keerde zich in een apart gepubliceerde toelichting bij dit werk overigens ook met

${ }^{305}$ Breysig (1896c), 164-170.

${ }^{306}$ Breysig (1896a), 7 (mijn cursiveringen, MS). De laatste volzin bijna letterlijk herhaald in Breysig (1900a), 53 (ipv 'geschiedenis van de persoonlijkheid' staat hier 'geschiedenis van het persoonlijk leven').

${ }^{307}$ Breysig (1896c), 173-174, zo ook Breysig (1900-1901), dl. I, 28.

${ }^{308}$ Breysig (1900-1901), dl. I, VII; zie ook Breysig (1901), 723.

${ }^{309}$ Breysig (1905b), 1671.

${ }^{310}$ Zie Breysig (1900a), VII; vgl. Breysig (1926), 566.

${ }^{311}$ Steinhausen (1892a), IV, 6; vgl. hierboven paragraaf 2.1 . 
zoveel woorden tegen de opvatting dat cultuurgeschiedenis als een onderdeel van de algemene geschiedenis moest worden beschouwd (het standpunt van Bernheim en Steinhausen, dat Breysig overigens niet helemaal terecht ook toeschrijft aan Gothein) of de gedachte dat de cultuurgeschiedenis een eigen methode zou hebben - zoals Lamprecht had beweerd. ${ }^{312}$

In zijn Kulturgeschichte der Neuzeit bestreek Breysig in de praktijk een even veelomvattend terrein als Lamprecht in zijn Deutsche Geschichte: behalve de geschiedenis van kunst, religie en wetenschap, besprak hij daarin uitgebreid sociaal-economische, politieke en juridische ontwikkelingen en last but not least historische veranderingen in het familieleven en de persoonlijkheid. En kijken we naar Breysigs historiografisch oeuvre als geheel, dan vinden we daar een zelfde variatie aan onderwerpen, waarbij hij zijn blik van een beperkt chronologisch, geografisch en thematisch terrein in de loop der jaren steeds verder liet uitwaaieren. Uitgaande van de vroeg-moderne Pruisische bestuursgeschiedenis, waaraan hij zijn drie eerste boekpublicaties (1889-1895) wijdde, richtte hij zich in de tweede helft van de jaren negentig met enkele soms zeer uitvoerige artikelenreeksen op de sociale ontwikkeling van de verschillende Europese volkeren van middeleeuwen tot heden (1896-98, samen 366 blz.), en het gelijktijdig ontstaan van nationalisme en Völkergesellschaft in dezelfde periode (1899-1900, 115 blz.). In zijn daaropvolgende, vierde en omvangrijkste boekpublicatie, de onvoltooid gebleven driedelige Kulturgeschichte der Neuzeit (1900-1901) werd deze vergelijkende sociale geschiedenis allereerst chronologisch aangevuld met uitvoerige inleidingen over de oudheid en op de tweede plaats thematisch met de behandeling van het geistige Leben (kunst, wetenschap en religie). Aan het thema van de godsdienstgeschiedenis wijdde Breysig in 1905 ook nog een aparte monografie, die het ontstaan van de godsidee behandelde.

Op dat moment was Breysig - net als Lamprecht - ervan overtuigd geraakt dat de ontwikkeling van alle volkeren of volksgroepen volgens een vast traject van Kulturzeitalter of Entwicklungsstufen verliep - door de Berlijnse historicus aangeduid met de gebruikelijke periodebenamingen: oertijd, oudheid, middeleeuwen, nieuwe tijd, nieuwste tijd. De samenvatting en ordening van deze inzichten vormde het onderwerp van een boekje uit 1905, dat eindigde met de opstelling van vierentwintig door hem geconstateerde regelmatigheden of 'wetten' in de wereldgeschiedenis. Breysigs wending naar de wereldgeschiedenis kwam ook tot uiting in zijn poging in $1907 \mathrm{om}$ in Berlijn een expliciet met Lamprechts IKU vergelijkbaar 'Seminar für vergleichende Geschichtsforschung' op te richten, bedoeld om 'uit de vergelijking van de verschillende nationale ontwikkelingen tot voldoende kennis van de algemene, Europese samenhangen en van de afzonderlijke nationaliteiten' zowel binnen als buiten Europa te komen. ${ }^{313}$ In hetzelfde jaar verscheen het eerste deel van zijn Geschichte der Menschheit, gewijd aan de Amerikaanse en Groenlandse Völker ewiger Urzeit. Hierin behandelde Breysig systematisch economie, zeden, familie, klassen, bestuur, recht, oorlog, geloof, beeldende en andere kunsten, kennis en techniek. Onder de losse artikelen van Breysig uit deze periode vallen verder, behalve een lange reeks theoretische en historiografische bijdragen, twee studies op over 'de ontdekking van de liefde' in de middeleeuwen en de invloed van de vrouw op de middeleeuwse levensvormen (1903), een studie over recht en rechtspraak rond 1500 (1898-1900, 90 blz.) en een reeks kunsthistorische artikelen.

\footnotetext{
${ }^{312}$ Zie Breysig (1901), 723.

${ }^{313}$ Zie Breysigs Denkschrift uit 1907, opgenomen in Brocke (1971), 305-308. Lamprechts IKU was overigens op dat moment nog niet formeel opgericht.
} 
Een blik op zijn onderwijsactiviteiten geeft hetzelfde gevarieerde beeld. Behalve over meer gebruikelijke historische onderwerpen verzorgde Breysig onder andere een aantal hoorcolleges over de geschiedenis van de 'geestelijke cultuur' en (vanaf 1900) over sociologie (inclusief 'psychologie van de samenleving'), hij behandelde een enkele keer de geschiedenis van de familie en de vrouw (1908/1909), regelmatig sprak hij over de vergelijkende staats-, economische en klassengeschiedenis en in ieder geval gedurende één semester organiseerde hij Übungen waarin aandacht werd gegeven aan de geschiedenis van de persoonlijkheid (1914/15). Onder zijn begeleiding werden dissertaties geschreven die vaak de Pruisische bestuurs-, stands- en economische geschiedenis behandelden - zijn eigenlijke leerstofgebied - maar die ook onderwerpen betroffen als liefde en huwelijk in de Duitse roman ten tijde van Rousseau (Nowack, 1906), de geschiedenis van het landschapsgevoel in de vroege achttiende eeuw (Kammerer, 1909) en middeleeuwse huwelijksopvattingen (door de latere Israelische hoogleraar Richard Koebner, 1911). ${ }^{314}$

\subsection{Cultuurgeschiedenis als onderzoek van de menselijke ziel}

Net als bij de andere nieuwe cultuurhistorici werd dit omvangrijke historische domein door Breysig beschouwd en doorgelicht vanuit een sociaal-psychologisch perspectief. Naar zijn Kulturgeschichte der Neuzeit verwees hij dertig jaar later eens als zijn Gesellschaftsseelenkunde von $1900 .{ }^{315}$ Pas vanuit dit psychologisch perspectief kreeg het begrip 'cultuurgeschiedenis' dat Breysig hanteerde ook diepere zin. Want terwijl hij cultuurgeschiedenis in de meeste brede zin opvatte als Universalgeschichte, dit wil zeggen een overkoepelende, algemene geschiedenis van zowel sociale als 'geestelijke' en materiële geschiedenis, hanteerde hij ook een inhoudelijk meer specifieke definitie. 'Cultuurgeschiedenis', schreef hij, 'is geschiedenis van het ik, van de ziel', oftewel 'de geschiedenis van de veranderingen die de mens aan zich zelf, aan zijn ik, heeft voltrokken'. ${ }^{316}$ Niettegenstaande het belang van de sociale geschiedenis in zijn Kulturgeschichte der Neuzeit had dit werk uitdrukkelijk een 'psychologisch, geen sociologisch einddoel'. ${ }^{317}$ 'Ik wil nooit het laatste doel van elke geestes- en cultuurwetenschap uit het oog verliezen', schreef hij daar: 'het onderzoek van de menselijke ziel' ${ }^{318}$ En die uitspraak moet niet als een gratuite vertoon van diepzinnigheid worden beschouwd. Al vanaf 1895/96 dacht hij in dezelfde zin over zijn levensproject als een 'geschiedenis van de mens'. ${ }^{319}$ Hij pleitte vanaf zijn eerste programmatische verklaringen voor een 'geschiedenis van de persoonlijkheid' en een geschiedenis van de 'gevoels- en gemoedsontwikkeling van de volkeren'. Persoonlijkheid, gevoel en gemoed waren volgens hem immers geen individuele aangelegenheden. Zoals hij in 1896 schreef:

'de geschiedenis van het gevoelsleven [...] heeft getoond dat de innerlijkste bewegingen van ons hart en gemoed, die wij gewoon zijn te beschouwen als onze persoonlijkste zaak, voor een goed deel, indien niet voor het grootste deel producten zijn

${ }^{314}$ Zie voor een lijst van publicaties, colleges en begeleide dissertaties tot 1928: Schilling (1928), met aanvullingen in Schilling (1962).

${ }^{315}$ Breysig (1931), XI.

${ }^{316}$ Breysig (1905b), 1671; vgl. ook Breysig (1907), 41 ('...wer Geschichte als Kulturgeschichte, d.h. als Geschichte der Ichbildung erkennt...') en Breysig (1926), 566 ('Kultur kann tiefer und echter Auslegung nie etwas anderes bedeuten als Bildung, Umbildung, Pflege, Entfaltung der Seele'.)

${ }^{317}$ Zie Breysig (1900a), XXVI (inhoudsopgave)

${ }^{318}$ Breysig (1900a), XI.

${ }^{319}$ Breysig (1907), VIII. Vgl. Breysig (1962), 91 (dagboekaantekening 11.3.1896) en 103 (dagboek 31.12.1900). 
van de volksziel, manifestaties van de nationaliteit [Volkstum] en van de tijd waartoe wij behoren. De tijdvakken hebben hun sentiments, net zo goed als zij hun modes, hun filosofiëen en hun kunst hebben'. ${ }^{320}$

Werk van Steinhausen prees hij als (overigens onvolkomen) voorbeelden van een dergelijke 'geschiedenis van de ziel'. ${ }^{321}$ Deze zielsgeschiedenis leverde Breysig de belangrijkste verklaring op voor de Stufenbau der Weltgeschichte en vormde vanaf het begin het fundament van zijn opvattingen over het verleden. ${ }^{322}$ 'Dieper en tegelijk verder [dan andere verklaringen] reikt de sociaal-psychologische [gesellschaftseelische] duiding van de tijden', schreef hij in $1905 .{ }^{323}$ Uiteindelijk was geschiedenis immers niets anders dan de 'geschiedenis van het willen en voelen, van het voorstellen en denken' ${ }^{324}$ In 1931, toen Breysig met zijn omvangrijke Geschichte der Seele im Werdegang der Menschheit zijn eerdere ideeën over dit onderwerp samenvatte en aanvulde, presenteerde hij de 'psyche van de mens' daadwerkelijk 'als het eigenlijke onderwerp, als de drager, de held van de wereldgeschiedenis' waarvan hij de lange ontwikkeling wilde beschrijven en analyseren. ${ }^{325}$

In Breysigs Kultur- of Universalgeschichte vervulde het (sociaal-)psychologisch perspectief een aantal belangrijke en onderling samenhangende functies. Allereerst probeerde hij vanuit dit perspectief de 'innerlijke eenheid van de geschiedenis' te laten zien, het diende expliciet de 'Vereinheitlichung des Geschichtsbildes'. ${ }^{326}$ Om te voorkomen dat een algemene geschiedschrijving zou uitmonden in een onsamenhangende compilatie van verschillende aspecten van het verleden, was er een gemeenschappelijke noemer voor al die aspecten nodig. En die noemer was voor Breysig, net als voor Lamprecht, de psyche: de ziel was het brandpunt van het menselijk bestaan. Alleen in deze 'binnenste kern van de mens' kon een maatstaf gevonden worden die zowel van toepassing was op het 'handelende' als op het 'schouwende' leven, op de 'sociale geschiedenis' zowel als op de 'geestesgeschiedenis'. Als de historicus er in slaagde zowel denken als doen te vertalen naar een zelfde psychische noemer, dan kon hij de verschillende sociale, politieke en intellectuele en artistieke aspecten van het verleden ook in verband met elkaar brengen. Tegelijk konden alleen zo ook uniforme criteria Breysig zelf sprak van geschichtliche Maßstäbe - gevonden worden om hele cultuurtijdperken aan af te meten en van elkaar te onderscheiden. En ten slotte meende Breysig in de meest fundamentele menselijke motivaties ook de oorzakelijke factoren te vinden die de verklarende 'ontwikkelingsgeschiedenis' van de lange termijn die hij voorstond, nodig had. ${ }^{327}$ Het psychologisch perspectief vormde zodoende een panacee voor de bekende problemen van de cultuurgeschiedenis: zij leverde een gemeenschappelijke noemer voor het gevarieerde historisch gebeuren, een uniforme maatstaf

${ }^{320}$ Breysig (1896c), 205.
${ }^{322}$ Breysig (1905b), 1674.
Het is daarom niet terecht dat zij in Vom Brocke's werk over Breysig geen vooraanstaande plaats krijgt toebedeeld. Hier wreekt zich de eenzijdige aandacht voor het sociaalhistorisch perspectief ten koste van het cultuurhistorisch en psychologisch aspect.

${ }^{323}$ Breysig (1905a), 13.

${ }^{324}$ Breysig (1900-1901), I, 31. Hier overigens net als bij Lamprecht (en Goetz) wisseling van psychisch en geistig, want hij vervolgt '... also der geistigen Funktionen der Menschen'.

${ }^{325}$ Breysig (1931).

${ }^{326}$ Breysig (1905b), 1671; Breysig (1931), XII; Breysig (1901), 350.

${ }^{327}$ Over dat ideaal voor het eerst Breysig (1896c), m.n. 193-211; over basisdriften als als 'laatste bewegende oorzaken', zie o.a. Breysig (1902c), 1364. Onder 'ontwikkeling' verstond Breysig (1) een verandering, die (2) grotendeels oorzakelijk te verklaren was uit de voorafgaande toestand en (3) leidde tot een groei met behoud van de kern van de oude toestand, Breysig (1907), 52-54. 
om de onderscheiden tijdperken aan af te meten en de diepste oorzakelijke verklaring voor de historische ontwikkeling.

'Wellicht is het mogelijk', schreef hij in zijn Kulturgeschichte der Neuzeit, 'om te laten zien dat willen en denken, voelen en voorstellen in verschillende tijden ook in verschillende mate het geestelijke en sociale leven van de volkeren hebben bepaald. ${ }^{328}$ Deze suggestie zou Breysig daadwerkelijk in zijn omvangrijke Geschichte der Seele uit 1931 uitvoeren; daarvòòr ontwikkelde hij eerst nog een eenvoudiger historisch-psychologisch model van veranderende 'gevoelsstromingen' als fundament van alle historische veranderingen.

\section{3 'Gevoelsstromingen als dragers van heel het historische gebeuren'}

Breysigs eerste uitgewerkte gedachten over dit thema werden sterk bepaald door zijn intensieve kennismaking met het gedachtengoed van Nietzsche, kort na zijn habilitatie tot docent op zesentwintigjarige leeftijd in 1892. Vier jaar later, in hetzelfde jaar waarin hij werd benoemd tot extraordinarius en waarin zijn eerste pleidooien verschenen voor een alternatieve oriëntatie van de geschiedwetenschap (1896), publiceerde hij een positief gestemd artikel over Nietzsches 'ethische en sociologische opvattingen', zeker geen gebruikelijke daad voor een universitair historicus in zijn dagen. En in het jaar waarin zijn Kulturgeschichte der Neuzeit verscheen, dat overigens zijn schatplichtigheid aan Nietzsche vermeldde, ${ }^{329}$ sprak hij aan de lijkbaar van de filosoof een rede uit waarin hij hem als 'Newton van de mensheidswetenschap' vierde, als 'onderzoeker van de psychologie van de samenleving' die de 'wortels van het zedelijk-sociaal handelen' had blootgelegd. ${ }^{330}$

Met Nietzsche deelde Breysig de visie op 'de eeuwige mens' als im Grunde egoïstisch, alsmede de grote waardering voor de geest- en wilskracht van sterke individuen. Hij verschilde echter met Nietzsche van mening in twee belangrijke opzichten. Ten eerste in zijn acceptatie van de massamens, die weliswaar niet over de geest- en wilskracht van het grote individu beschikte, maar volgens Breysig desalniettemin diens werk pas mogelijk maakte. ${ }^{331}$ Er moest een tussenweg gekozen worden tussen het eenzijdige individualisme dat Nietzsche aanhing en het eenzijdige collectivisme dat hij bij socialisten, nationalisten, maar ook bij Lamprecht bespeurde

${ }^{328}$ Breysig (1900a), 32.

${ }^{329}$ Breysig (1900a), 96n.

${ }^{330}$ Breysig (1900c), 416, 412-413; vgl. Breysig (1896b). Overigens konden niet alle van de circa twintig aanwezigen Breysigs 'cultuurhistorische analyse van het fenomeen Nietzsche' (aldus architect Fritz Schumacher) waarderen, zie Das Nietzsche-Archiv in Weimar. München, Wenen: Carl Hanser Verlag, 2000, 47.

${ }^{331}$ Zie Breysig (1896b), 362-366 waar Breysig het o.a. heeft over Nietzsche's 'miskennen' van 'het gemoed' ten gunste van de wil en zijn 'bis zur Beschränktheit einseitiger Individualismus'. En Breysig (1900c), 415, waar hij als kritiek op Nietzsche formuleert dat het sterke individu slechts succesvol kan zijn indien gesteund door de vele 'kleinen en zwakken'. Vgl. ook Breysig (1902a), 1030 1031: 'Es ist ein Widersinn, anzunehmen, daß die Vielen, [...] die letzten Urheber der von ihren Führern ersonnenen Gedanken seien. Eine andere Erklärung aber ist möglich [...] Nicht die neuen scharfen Vorstellungen und klaren Bilder steigen von den größeren Gesammtheiten zu den Schöpferischen auf, wohl aber die dunklen, triebmäßigen Regungen, aus denen heraus oben auf den Gipfeln das Neue gezeugt wird.[...] Solche Neuerungen sind ganz und gar nicht die Erzeugniss einzelnere führender Köpfe, ja überhaupt nicht der Köpfe, sondern der Gemüther, der Stimmungen früher hätte man gesagt der Herzen. [.|.] Und so sind dann doch weitere, vielleicht kaum übersehbar weite Ketten von Menschen die Mithelfer, die Mitzeugenden am Werke des Genius.' Na WO I lijkt Breysigs anti-collectivisme meer uitgesproken te zijn geworden, vgl. Breysig (1925), 58-93. In zijn Geschichte der Seele (1931) beschrijft hij de grote individuen als leiders en voorlopers van de algemene gemoedsveranderingen (bijv. 30, 515-518). 
en waartoe hij naar eigen zeggen aanvankelijk ook zelf neigde. ${ }^{332}$ Ten tweede kende Nietzsche volgens Breysig te veel betekenis toe aan de wil; het - veelal onbewuste gemoedsleven was volgens de Berlijnse historicus veel bepalender voor het karakter en het gedrag van mensen. Verbeelding, verstand en wil vormden slechts hulpmiddelen, het gemoed bepaalde richting en doel: ${ }^{333}$

'Wij dwazen en narren nemen aan dat al ons denken en streven bepaald wordt door de zakelijke of persoonlijke motieven waarvan we ons bewust zijn. [...] ...en merken niet, dat wij in waarheid helemaal niet naar al deze richtsnoeren en regels handelen, maar naar de innerlijkste, geheel gevoelsmatige aandriften van ons wezen. [...] En in deze donkere, bijna geheel onder de oppervlakte van het bewustzijn liggende regionen krijgen al onze besluiten de beslissende richting [...] ${ }^{334}$

Aldus Breysig in zijn Kulturgeschichte der Neuzeit, dat hij afsloot met de conclusie dat 'gevoelsstromingen de dragers [zijn] van heel het historisch gebeuren'. ${ }^{335}$ Hier openbaarde zich een verschil met Lamprecht, die juist wil, verstand en Empfindung als de primaire psychische factoren beschouwde en Empfindung daarbij in de eerste plaats als 'waarneming' uitlegde. ${ }^{336}$ Terwijl Lamprecht in zijn werk herhaald kritiek gaf op de onder historici gebruikelijke 'Motivenforschung' - het ging in de geschiedenis vaak helemaal niet om intenties en motieven - presenteerde Breysig met zijn theorie over de basisdriften van het menselijk gevoelsleven juist een nieuwe variant daarvan. Tegelijk wordt hier ook een overeenkomst met Gothein duidelijk, die net als Breysig een sterke interesse aan de dag legde voor de (volks)religiositeit: in beide gevallen gebeurde dat uit de overtuiging dat in de godsdienst bij uitstek het irrationele 'gemoed' zich openbaarde. 'Religieuze neigingen', schreef Breysig daarover, 'als de op zichzelf meer onbewuste, onbestemde en gevoelsmatige, staan in deze onderwereld van stemmingen en ontstemmingen, immers, zo paradoxaal dat mag klinken, [...] dichter bij het lichamelijke'. ${ }^{33}$

Volgens Breysig werd het menselijk gemoed gedomineerd door twee fundamentele 'instincten van het hart', beide overigens uitvloeisel van een ten diepste egoïstische verlangen naar persoonlijk geluk: Ichliebe (ook Herrschafts-, Machttrieb of persoonlijkheidsdrang) en Nächstenliebe (ook Hingabetrieb of gemeenschapsdrang). ${ }^{338}$ In zijn Kulturgeschichte der Neuzeit en andere studies wilde hij vervolgens laten zien dat deze beide basisdriften afwisselend en in 'wisselende mengverhoudingen' hele tijdperken in de geschiedenis van een volk of groep volkeren bepaalden. ${ }^{339}$ Er waren met andere woorden tijdperken die gedomineerd werden door een ik-cultuur en tijdperken die gedomineerd werden door een wij-cultuur. Deze tijdperken wisselden elkaar keurig af: van oertijd (wij-cultuur), naar oudheid en vroege middeleeuwen (ik-cultuur), en vervolgens van de late middeleeuwen (wij-cultuur), naar de nieuwe tijd (ik-cultuur) en nieuwste tijd (wij-cultuur gecombineerd met sterke

${ }^{332}$ Zie Breysig (1896c), 205.

${ }^{333}$ Breysig (1900a), X; Breysig (1902c), 1364.

${ }^{334}$ Breysig (1900a), 288-289.

${ }^{335}$ Breysig (1900a), 286.

${ }^{336}$ Zie hierboven paragraaf 3.2 .

${ }^{337}$ Breysig (1902a), 1030; Breysig kende de religieuze geschiedenis een voorkeursplaats toe binnen de geschiedenis van het 'geestelijke leven', zie: Breysig (1907), I, 75.

${ }^{338}$ Deze 'antropologie' voor het eerst expliciet en uitgebreid in Breysig (1897b).

${ }^{339}$ Breysig (1902d), 20. 
ik-cultuur) was er sprake van een 'grote pendelslag', die Breysig als 'de ademtocht van de wereldgeschiedenis' betitelde. ${ }^{340}$

In de sociale geschiedenis (en Breysig rekende daartoe ook de behandeling van het staatsleven) kwamen de neiging tot samenwerken of tot overheersen het meest direct tot uiting en daarom was de sociale geschiedenis bij hem anders dan bij Lamprecht van fundamenteel belang: in zijn als geschiedenis van de Ichbildung opgevatte cultuurgeschiedenis stond de verhouding van individu tot groep immers centraal. Breysig traceerde deze verhouding in zijn historisch werk allereerst in een geschiedenis van het Europese staatsvormingsproces. De Verfassungsgeschichte bleef voor deze specialist in de Pruisische bestuursgeschiedenis de 'ruggegraat' van de geschiedenis. De 'grote pendelslag' in de geschiedenis toonde volgens hem een afwisseling van perioden van collectief bestuur (oertijd, late middeleeuwen) en alleenheerschappij (oudheid en vroege middeleeuwen, nieuwe tijd); de nieuwste tijd (na 1789) kende vervolgens met haar democratische, socialistische en nationalistische tendensen weer een sterk collectivisme in het staatsleven, maar bracht tegelijk met haar caesarisme en imperialisme een bijna even sterke neiging tot alleenheerschappij tot uiting.

Parallel aan deze staatsgeschiedenis beschreef Breysig de klassengeschiedenis van adel, burgerij en arbeiders eveneens in termen van Machttrieb (streven naar heerschappij) en Hingabetrieb (groepsvorming). Vervolgens herleidde de Berlijnse historicus ook bewegingen in kunst, wetenschap en religie tot de twee basismotieven. In de kunsten kwam de heersdrift tot uiting in idealistische, formele kunst, terwijl meer realistische, 'stofkunst' volgens hem beschouwd moest worden als uitvloeisel van een neiging tot overgave aan de werkelijkheid. In de wetenschap leidde heersdrift tot een meer deductieve benadering, overgave daarentegen tot sterker empirisme. In de religie ten slotte kwam de tegenstelling terug in de meer of minder sterke mate van onderwerping aan godheid of kerkgemeenschap. ${ }^{341}$ De grote betekenis van de beide basisdriften bleek volgens Breysig daaruit dat in het algemeen zowel de politiek als de sociale verhoudingen, en zowel wetenschap als kunst en religie gelijktijdig gedomineerd werden door dezelfde basisdrift.

Uit het gegeven dat Breysig de beide basisdriften het vermogen toedichtte om hele tijdperken te domineren valt af te leiden dat hij ze niet opvatte als individuele psychische kenmerken. Hij sprak van gesellschafts-seelische Triebkräfte: sociaalpsychische drijfkrachten. Hoewel Breysig zich vanaf het begin wilde onderscheiden van Lamprecht door aan te geven dat bij hem de geschiedenis niet totaal opging in collectieve krachten en hij ook ruimte wilde geven aan de sterke persoonlijkheid, kwamen zijn eigen uiteenzettingen op het fundamentele niveau van de sociaalpsychische drijfkrachten dicht in de buurt van een dergelijk collectivisme. Hij erkende dit ook met zoveel woorden: ${ }^{342}$

${ }^{340}$ Zie samenvattend over deze ontwikkeling: Breysig (1902c), citaten hier op blz. 78. Dezelfde gedachte is onuitgewerkt overigens al in zijn eerste programmatische verhandeling over 'sociale geschiedenis' (1896) te vinden: Breysig (1896a), 5-6. Binnen Europa onderscheidde Breysig twee verschillende Völkergesellschaften die dezelfde stadia hadden doorlopen: de oude Grieks-Romeinse en de nieuwe Germaans-Romaanse. Met 'oudheid' doelde Breysig in dit verband derhalve niet op de Grieks-Romeinse oudheid, maar op een tijdperk dat te vinden was in elke cultuur die de oertijd was ontstegen.

${ }^{341}$ Zie Breysig (1902b) 113 e.v.; Breysig (1902d); Breysig (1902c) en Breysig (1905a).

${ }^{342}$ Breysig (1902c), 1364; 'hier evenwel is het collectivisme op zijn plaats', voegde hij er zelfs expliciet aan toe. 
'[B]ij het volstrekt kuddeachtige gedrag van de mensen, die door traditie en gemeenschappen van allerlei aard gebonden zijn, achter en aan elkaar, is a priori aan te nemen, dat zij in deze minst bewuste en onbestemdste, driftmatigste besluiten het allersnelst als massa handelen zullen.'

Zijn geloof in de kracht van de sterke persoonlijkheid sloot volgens Breysig het geloof in de (sociale) gedetermineerdheid van het handelen niet uit: ook de sterke persoonlijkheid was gevormd tot wie hij was en deelde belangrijke eigenschappen met zijn tijd en volk - alleen in mindere mate dan anderen. ${ }^{343}$ Breysigs voorstel om geen geschiedenis van personen maar een 'persoonlijkheidsgeschiedenis' te schrijven, had uitdrukkelijk als doel aan te tonen dat ook de dominante persoonlijkheidsvormen bijvoorbeeld van de leidende individuen - veranderden naar gelang de tijd en de omstandigheden. ${ }^{344}$ In zijn eerste programmaverklaring uit 1896 schreef hij al dat een mens niet alleen gevormd werd door de aangeboren Anlage, maar ook door het ouderlijk, sociaal, regionaal en nationaal Milieu en door zijn eigen belevenissen. ${ }^{345} \mathrm{De}$ overeenstemming in het handelen van individuen binnen levensgemeenschappen was, zo schreef hij later, vooral het gevolg van Einübung, meer dan van aanleg. ${ }^{346}$ En voor de twee meest fundamentele motivaties van de mens gold de invloed van de samenleving bijzonder sterk. Dit 'schijnbaar persoonlijkste van onze innerlijke constitutie' was geenszins individueel bepaald: ${ }^{347}$

'[Z]o sterk is de solidariteit van alle menselijke lotgevallen, zo onzelfstandig is het individu, zo overheersend de drift tot imitatie in ons, dat ook deze elementairste, deze innerlijkste en schijnbaar oorspronkelijkste eigenschappen massaal en in grote aantallen optreden, dat hele tijdperken, hele volkeren en hele reeksen generaties door een van beide [psychische] grondtypen of door een van de vele mogelijke mengvormen van deze twee, worden gekenmerkt.'

\subsection{Breysigs Geschichte der Seele}

Breysig kreeg niet zonder reden van Lamprecht het verwijt te horen dat de mens in zijn geschiedopvatting toch eigenlijk onveranderlijk was. ${ }^{348}$ Breysig wees dit verwijt weliswaar van de hand, maar moest zelf toegeven dat zijn voorstelling van twee elkaar afwisselende gronddriften dicht in de buurt kwam van de gedachte van een 'eeuwige mens. ${ }^{349}$

Misschien dat hij daarom in zijn latere Geschichte der Seele (1931) een verfijndere historisch-psychologische analyse presenteerde waarin niet alleen de beide door hem onderscheiden Grundtriebe gehistoriseerd werden, maar daarnaast ook wat hij de psychische Grundkräfte noemde: voelen, willen, verbeelden en denken - die psychische vermogens derhalve die in Lamprechts geschiedopvatting vanaf het begin centraal stonden en gehistoriseerd werden. Het ging bij deze geschiedenis van de ziel overigens om een geschiedenis van het Gesamt-Ich, een geschiedenis van de 'lichaamziel combinatie': ook lichamelijke fenomenen als gezichtsuitdrukking, gebaren, houding, en manieren van lopen moesten typisch worden geacht voor bepaalde historische

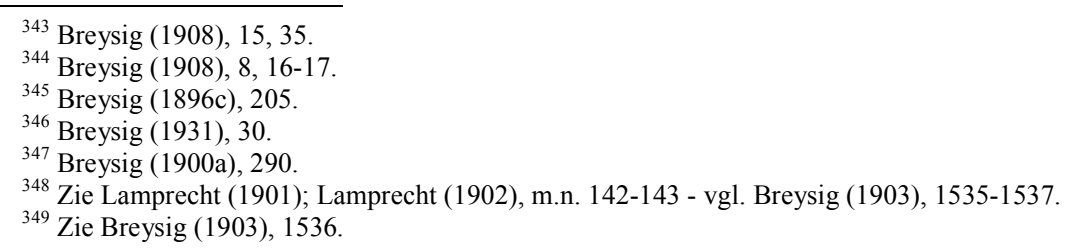


en sociale eenheden. ${ }^{350}$ Breysig meende opnieuw aan te kunnen tonen dat elk van de vier psychische vermogens in verschillende tijden een verschillende plaats toekwam, ja dat in onderscheiden tijdvakken meestal één van deze vermogens overheerste en dat de historische ontwikkeling als geheel door een regelmatige afwisseling tussen de verschillende vermogens werd beheerst. ${ }^{351}$ Zo waren volgens hem in de oertijd verbeelding en gevoel dominant, met een overheersende rol voor de verbeelding; in de oudheid kwam de wil op de eerste plaats, ondersteund door het verstand. In de middeleeuwen revancheerde het gevoel zich - nu als leidende kracht, met ondersteuning van de verbeelding. Vervolgens traden in de nieuwe tijd verstand en wil opnieuw op de voorgrond - maar nu met de ratio op de eerste plaats en de wil als secundaire kracht. De nieuwste tijd, ten slotte, was in deze reeks een uitzonderlijk tijdperk, zoals Breysig dat ook al voor beide gronddriften had vastgesteld: geen van de psychische vermogens was dominant, bijna alle vermogens wisten afwisselend het leven te bepalen. ${ }^{35}$

Net als bij Lamprecht kunnen we ons afvragen wat de motor achter deze historische en psychische veranderingen was. De regelmaat die Breysig in de geschiedenis ontdekte, had twee gezichten. Enerzijds was er de 'ademtocht van de wereldgeschiedenis', de grote pendelbeweging tussen tegengestelde psychische driften en krachten. De motor hierachter was niets anders dan 'verzadiging en oververzadiging': onder de individuen en generaties die lange tijd bijvoorbeeld in een ik-cultuur hadden geleefd, ontstond van lieverlede onvrede over de bestaande toestand - als eerste onder krachtige individuen - en langzaam verkeerde door een verandering van de algemene stemming de cultuur in haar tegendeel. ${ }^{353}$

Tegelijk constateerde Breysig ook doorgaande, 'Wachstumsähnliche' lijnen in zijn sociaal-psychologische geschiedenis. De afwisseling van de psychische krachten in de loop van de Kulturstufen werd namelijk in eerste instantie bepaald door hun onderlinge kwaliteitsverhouding: gevoel en verbeelding waren, als de meest primitieve krachten, in de vroegste cultuurstadia dominant en werden in de latere stadia teruggedrongen door de 'hogere' psychische vermogens wil en verstand. ${ }^{354}$ En uiteindelijk was er in de loop van de cultuurontwikkeling sprake was van een toenemende versterking van de rationele vermogens ten koste van de verbeelding. De toenemende betekenis van de rationaliteit moest daarbij volgens Breysig niet worden beschouwd als het doorgeven van 'gedragsregels' - als een kwestie van normen en waarden dus maar als een 'daadwerkelijke overerving van nieuw verworven eigenschappen'; het ging om 'veranderingen in de constitutie van de psyche: de werktuigen van het verstand, naar alle waarschijnlijkheid ook van de hersenen, moeten veranderd zijn, in de zin van uitsplitsing - differentiatie - verfijning, verscherping. De gewoonte om de logische juistheid van een verband te onderzoeken en te controleren moet versterkt

${ }^{350}$ Breysig (1931), 16-20; overigens al in Breysig (1908), 18-19. In deze opvatting voelde Breysig zich gesteund door recente psychologische typologieën van Kretschmer en Kräpelin, zie ook Breysig (1929a, b), (1930).

${ }_{351}^{351}$ Breysig (1931), 15.

${ }^{352}$ Zie voor een schematisch overzicht: Breysig (1931), 495.

${ }^{353}$ Breysig (1931), 338-339, 371-372, 401, 496.

${ }^{354}$ Breysig (1931), 372. Hier kan gememoreerd worden dat Breysig suggereerde dat er misschien sprake was van een parallel van fylo- en ontogenese, maar hij werkte deze gedachte, anders dan Lamprecht, niet verder uit. Zie Breysig (1905a), 121; in de 2e druk van Der Stufenbau (1927) wordt de biogenetische grondwet verworpen (p. 132), maar als analogie desalniettemin gehandhaafd. Vgl. ook Breysig (1931), 418. 
zijn en zich steeds bestendiger en nadrukkelijker hebben doorgezet'. ${ }^{355}$ Overigens constateerde Breysig in de loop van de cultuurontwikkeling naast de versterking van de ratio ook een continue 'stijgende curve' van het gevoel - in de zin van medeleven en Hingabetrieb - ten koste van de wil. ${ }^{356}$ Breysigs slotsom in de Geschichte der Seele was dat de vrije krachten van de mens, zijn wil en verbeelding, in de loop van de ontwikkeling relatief afnamen ten opzichte van de krachten die hem aan de wereld bonden, rationaliteit en gevoel.

Breysig bleef uiteindelijk bijzonder vaag over de verklaring van deze ontwikkeling. Anders dan Lamprecht greep hij niet terug op economische of sociale mechanismen - zoals de toenemende welvaartsoverschotten of de voortgaande arbeidsdeling - als verklaringen voor het verloop van zijn psychologische ontwikkelingsgeschiedenis. Hij sprak weliswaar over volks- en 'tijdszielen' die zowel product als agens waren: het product van de op elkaar in werkende individuen, dat tegelijk zelf bepaalde krachtvelden produceerde. ${ }^{357}$ Maar ondanks algemene uitspraken over het belang van het milieu en de betekenis van Einübung, analyseerde of demonstreerde hij deze mechanismen in zijn geschiedschrijving nergens; met name de invloeden van het milieu werden in latere geschriften weer sterk geminimaliseerd. Uiteindelijk bleef er één duidelijke constante in zijn werk als het om de verklaring van het geschiedverloop ging: de nadruk op de grote rol van de 'leiders', de creatieve persoonlijkheden gekoppeld aan het imiterende kuddegedrag van de massa. Maar dit was natuurlijk onvoldoende om de doorgaande ontwikkeling van de Kulturstufen te kunnen verklaren.

Het lijkt er sterk op dat Breysig de door hem geconstateerde psychologische ontwikkeling van culturen in laatste instantie beschouwde als een uiting van een autogene en bovendien universele ontwikkelingspotentie die elke menselijke gemeenschap in zich droeg. ${ }^{358}$ Dat wordt bevestigd door zijn opvattingen over de samenhang tussen de Kulturstufen enerzijds en Volkstum en ras anderzijds. Breysig minimaliseerde de betekenis van raciale en vooral van nationale verschillen verregaand. Hij claimde met enige nadruk dat uit zijn vergelijkende onderzoek naar cultuurstadia 'de eenheid van de mensheidsontwikkeling' volgde. ${ }^{359}$ Het belang dat sommige wetenschappers en niet-wetenschappers uit zijn tijd aan nationaliteit en ras hechtten, werd door hem herhaald bekritiseerd. Hij geloofde weliswaar dat er verschillen in nationale aard waren die in het gedrag van individuen tot uiting kwamen, ${ }^{360}$ maar stelde tegelijk vast dat de betekenis van deze verschillen vaak werd overdreven - zoals bijvoorbeeld duidelijk werd in zijn reeds aangehaalde kritiek op Steinhausen. ${ }^{361}$ 'Hoe stellig is men tegenwoordig niet doordrongen van de nationaliteit [Volkstum], van de

${ }^{355}$ Breysig (1931), resp. 443 en 434. Overigens noemde Breysig elders de 'verandering in het geheel van de ziel' 'wellicht slechts functioneel en niet constitutioneel' (ib. 395).

${ }^{356}$ Breysig (1931), 340, 417-423, 451-458.

${ }^{357}$ Breysig (1931), 22-24. Volksziel en 'tijdsziel' mochten beslist niet als een onafhankelijke entiteit worden beschouwd, maar slechts als 'de som van de individuele psyches waaruit ze samengesteld [zijn] en het geheel van de wederzijdse invloeden en wisselwerkingen waardoor deze individuele psyches tot een eenheid verbonden zijn', Breysig (1931), 22.

${ }^{358} \mathrm{Na}$ WO I formuleerde Breyisg expliciet een theorie van de Eigenbewegtheit van de menselijke geschiedenis, zie Brocke (1971), 242-246.

${ }^{359}$ Breysig (1905a), 15.

${ }^{360}$ Zie bijv. Breysig (1908), 18-19. De preoccupatie met het Volkstum werd bij Breysig, net als overigens bij veel andere Duitse intellectuelen, versterkt door de als een internationale cultuurstrijd opgevatte Eerste Wereldoorlog: toen begon Breysig aan een uiteindelijk in 1932 gepubliceerde historische studie over de eigen aard van de Duitsers: Vom deutschen Geist und seiner Wesensart. Het boek eindigt met een vergelijking tussen Engeland, Frankrijk en Duitsland die uitmondt in vertrouwde stereotypes; de Duitsers als volk van Geist en Genie, krijgen de rol van de oude Grieken toebedeeld.

${ }^{361}$ Zie hierboven, noot 184 . 
eigen aard van de volkeren!', riep hij op een andere plek uit. 'En toch denk ik dat in ieder geval in de sociale, staatkundige en economische ontwikkeling, maar oneindig vaak ook in de geschiedenis van de geestelijke cultuur, alle Europese volkeren overwegend overeenkomsten laten zien, en wel in tijdvakken, die nog niet zoals het onze, "in het teken van het verkeer" stonden'. ${ }^{362}$ Typerend voor deze opvatting was dat in Breysigs geschiedschrijving meestal niet een enkele natie, maar een Völkergesellschaft, een samenhangende groepen volkeren, centraal stond. ${ }^{363}$ In zijn Kulturgeschichte der Neuzeit en in verschillende artikelenreeksen was bijvoorbeeld Europa als geheel - de 'germanisch-romanische Völker' - de eenheid van onderzoek. Daarbinnen werden weliswaar nationale verschillen opgemerkt, maar de nadruk lag op de overeenkomsten. En in dezelfde trant wees Breysig claims van extreme racisten van de hand: 'onzegbaar veel dat tegenwoordig als een rassenverschil geldt, is slechts een verschil in stadium', schreef hij in $1905 .{ }^{364}$ Alle 'rassen' bezaten in principe dezelfde ontwikkelingspotentie. Dat nam niet weg dat er volgens hem sprake was van een opmerkelijke verdeling van de rassen over de ontwikkelingsstadia: het zwarte ras was nog grotendeels in de oertijd blijven steken, het roodbruine ras had slechts de fase van de oudheid bereikt, het gele ras bevond zich nog het stadium van de middeleeuwen en alleen het blanke ras had al de hele ontwikkeling tot aan de nieuwste tijd doorlopen. Deze onmiskenbare superioriteit van het blanke ras duidde niet op een verschil in ontwikkelingspotentie, maar op een verschil in ontwikkelingstempo. Het hoge ontwikkelingstempo van het blanke ras verklaarde Breysig vervolgens uit een combinatie van natuurlijke aanleg, geografische factoren en klimaat, waarbij de ('raciale') verschillen in aanleg zelf ten dele ook weer verklaard moesten worden door de differentiërende invloed van bodem en klimaat. ${ }^{365}$

Hoewel de Seelengeschichte volgens Breysig verder reikte dan welke andere verklaringspoging ook en hij de 'laatste, bewegende oorzaken' in de geschiedenis ermee op het spoor meende te zijn, bleef zijn 'historisch gefundeerde sociale psychologie' hardnekkig tussen hemel en aarde zweven. ${ }^{366}$ Veel minder dan Lamprecht slaagde Breysig erin zijn psychologische geschiedenis met concrete voorbeelden te verduidelijken en bleef zijn geschiedschrijving op een te abstract niveau om zelfs maar op deelterreinen overtuigend te zijn. Het verwijt dat Breysig Lamprecht maakte, dat deze 'in veel opzichten voornamelijk nog een schilderende, beschrijvende geschiedvorser' was, gaf minstens zozeer zijn eigen beperkingen aan als die van zijn 'naaste rivaal', zoals Breysig Lamprecht zelf ooit aanduidde. ${ }^{367}$ Breysig beschouwde

${ }^{362}$ Breysig (1902b), 112; vgl. ook in de praktijk de onderscheiden volkskarakters afzwakkend: Breysig (1900b), 131.

363 Onder Völkergesellschaft verstond Breysig een internationale gemeenschap van volkeren (zoals de Europese) gekenmerkt door Kulturgemeinschaft en politieke wisselwerking, zie Breysig (1899), m.n. 329-335; Breysig (1900a), XXVII, 78-79.

${ }^{364}$ Breysig (1905a), 10. In zijn bespreking van dit werk onderschreef Steinhausen (1906) overigens expliciet deze uitspraak.

${ }^{365}$ Breysig (1905a), 89-106; Breysig (1902b), 109-112; Breysig (1907), 64--65, 525-530; Breysig (1908), 13 (een vergelijking van rassen en volkeren zou aantonen 'wie ungerecht viele Rassenangriffe sind $\left.[\ldots]^{\prime}\right)$.

${ }^{366}$ Citaten ontleend aan Breysig (1931), 519; Breysig (1902c), 1364 ; Breysig (1929b), 16 ('geschichtlich begründete Gesellschaftseelenkunde' ).

${ }^{367}$ Laatste citaat in Brocke (1971), 55n98; verder Breysig (1902e), 509; vgl. Breysig (1902d), 24. 
zijn eigen werk als 'duidende geschiedenis', een geschiedschrijving die zich bezighield met de uitleg, beter gezegd 'diepteduiding' van de historische 'feitelijkheden':

'voor zover zij de geschiedenis van de psyche [Seelengeschichte] wil onderzoeken, is zij genoodzaakt, principieel en voortdurend binnen te dringen in een gebeuren dat zich onder de oppervlakte van de uiterlijke vormen van het handelen voltrekt, in de diepten van het binnen-ik, soms in de laag van de bewuste motieven, vaker in het rijk van het half-bewuste, meestal in dat van het onbewuste'. ${ }^{368}$

Met zijn 'duidende geschiedenis' probeerde Breysig een eis te vervullen die hij aan de geschiedwetenschap van zijn dagen had gesteld: namelijk om het verleden in al zijn variatie niet alleen te beschrijven, maar ook als een historische ontwikkelingsgang met al zijn regelmatigheden te verklaren. Uiteindelijk diende de geschiedwetenschap een 'bewegingsleer, een fysica van het menselijk gebeuren' te kunnen geven, die wellicht zelfs zou kunnen uitmonden in een gesamtgeschichtliche Formelgebung. ${ }^{369}$ "Ik vermoed,' schreef Breysig in 1900 in zijn Kulturgeschichte der Neuzeit,

'dat de geschiedschrijving binnen afzienbare tijd nog eens naar tabel- en cijfermatige, ja zelfs naar grafische presentatiemiddelen zal grijpen, en het is niet onmogelijk dat haar resultaten in de verre toekomst in de vorm zijn te gieten, die tegenwoordig de scheikunde gebruikt voor haar analysen. De voorwaarde daarvoor zou alleen zijn, dat de psychologische begrippen nog onvergelijkelijk veel scherper, specifieker en beter afgebakend zouden worden dan zij tegenwoordig zijn' ${ }^{370}$

Een geschiedwetenschap die haar naam waard was, diende dus in de eerste plaats haar begripsomschrijvingen te preciseren en dan zeker ook de psychologische begrippen waarmee immers de meest diepgaande duiding van de geschiedenis was te geven - een pleidooi dat sterke overeenkomsten met het streven van Lamprecht vertoonde. En evenmin als Lamprecht achtte Breysig een bestaande psychologische theorie zonder meer geschikt voor zijn historische 'duidingen'. De geschiedwetenschap diende uit de gang van de geschiedenis haar eigen psychologie af te leiden, zoals hij in zijn Geschichte der Seele ook had proberen te doen. ${ }^{371}$ Maar helaas scherpte Breysig zijn begrippen minder dan welke andere cultuurhistoricus aan de historische werkelijkheid en toonde hij zich, bewust van zijn creatieve Ich-Herrlichkeit, een vormende meester van het historisch proces.

Dat maakte zijn positie binnen de groep nieuwe cultuurhistorici des te opmerkelijker: ondanks zijn idiosyncratische en nietzscheaans angehauchte opvattingen was hij misschien wel het minst omstreden onder de andere nieuwe cultuurhistorici. ${ }^{372}$ Hoewel hij met Lamprecht van mening verschilde - met name over de aard van de psychologische basis van de geschiedenis, over de verhouding individucollectief en over de typering van de verschillende cultuurtijdperken - bleven beiden gedurende hun hele leven vriendschappelijk verkeer onderhouden. Lamprecht overwoog al in 1893 Breysig als docent naar Leipzig te halen, zij correspondeerden samen en hun wederzijdse recensies bleven bij alle geuite kritieken vriendelijk, welwillend en waarderend. Breysig werd door tijdgenoten wel als leerling of volgeling van Lamprecht beschouwd; ten onrechte, maar helemaal vreemd was dit niet. Breysig

\footnotetext{
${ }^{368}$ Breysig (1931), 3.

${ }^{369}$ Breysig (1908), 3, 30; hier ook samenvattend Breysigs geschiedtheorie.

${ }^{370}$ Breysig (1900-1901), I, 204.

${ }^{371}$ Breysig (1931), IX-X.

${ }^{372}$ Alleen van Gothein ken ik geen enkele reactie op werk van Breysig.
} 
zelf beschouwde Lamprecht als de enige historicus die net als hij een meer conceptuele, vergelijkende universele geschiedwetenschap voorstond; zijn eerste programmatische artikel verscheen in een algemeen vaktijdschrift dat mede onder Lamprechts redactie stond en zij vormden samen met vele artikelen het historische gezicht van Hardens spraakmakende opinieblad Die Zukunft. Breysig beschouwde zichzelf ook als een koppel met Lamprecht: aan Harden schreef hij in 1902 dat 'Lamprecht en ik' 'tegen het jaar 2000' zeker verantwoordelijk zouden worden gehouden voor 'een volledige revolutie van het geschiedonderzoek'. ${ }^{373}$ Bij het verschijnen van Breysigs Kulturgeschichte der Neuzeit legde omgekeerd Lamprecht de nadruk op de overeenkomsten van Breysigs werk met dat van andere vertegenwoordigers van 'de nieuwe richting' in de geschiedwetenschap, van wie hij verder ook Steinhausen met name noemde: 'Waar zij [...] de vergelijking terugvoeren tot de psychische basis van al het historische leven [....] wordt alle geschiedenis voor hen tot een geschiedenis van het psychisch leven van menselijke gemeenschappen'. ${ }^{374}$ En ook Steinhausen legde in overwegend positieve besprekingen de nadruk op de overeenkomsten tussen Breysig en hemzelf - in ieder geval wat de psychologische oriëntatie betrof. ${ }^{375}$ Walter Goetz, ten slotte, eerde de Berlijnse historicus naar aanleiding van zijn zeventigste verjaardag in 1936 publiekelijk als iemand 'die de grote erfenis van Herder erkend en vermeerderd heeft'. ${ }^{376}$ Goetz deelde, zoals nog zal blijken, belangrijke opvattingen met zijn Berlijnse collega.

\section{Walter Goetz}

\subsection{Van politieke geschiedenis naar cultuurgeschiedenis}

De Tübingse mediëvist Walter Goetz was de laatste Duitse vakhistoricus die het in het Keizerrijk uitdrukkelijk voor de cultuurgeschiedenis zou opnemen. Dat was overigens pas in 1910, een jaar of vijftien na het uitbreken van de Lamprechtstrijd. In de tweede helft van de jaren negentig had deze strijd bijzonder fel gewoed met een intensieve en sterk gepolariseerde uitwisseling van opvattingen, standpunten en meer of minder persoonlijk gerichte kritieken. ${ }^{377}$ Sinds de eeuwwisseling was de polemiek enigszins verstomd - in die zin dat de politieke historici niet meer direct en uitgebreid op Lamprechts nieuwste publicaties reageerden. Desondanks had de Lamprechtstrijd, aldus Goetz, bij een jongere generatie wetenschappers tot een 'sterke toename van de cultuurhistorische interesse geleid'. ${ }^{378}$

Tot die 'nieuwe generatie wetenschappers' rekende Goetz met zoveel woorden ook zichzelf, elf jaar jonger dan Lamprecht, maar ongeveer even oud als Steinhausen en Breysig (beiden op dat moment vierenveertig). Anders dan Steinhausen en Breysig had Goetz pas relatief laat in zijn carrière zijn belangstelling voor de cultuurgeschiedenis laten blijken en dat dat uiteindelijk gebeurde lijkt, ondanks of juist

${ }^{373}$ Geciteerd in Brocke (1971), 55.

${ }^{374}$ Lamprecht (1900b), 1972. Vgl. verder Lamprecht (1901) en Lamprecht (1902).

${ }^{375}$ Lamprecht wees overigens ook op bepaalde overeenkomsten tussen Steinhausens en Breysigs opvattingen waar de eerste het niet mee eens was, zie Lamprecht (1905b), 327. Steinhausen (1901); Steinhausen (1902); Steinhausen (1906).

${ }^{376}$ Goetz (1957b), 315. Goetz herkende zich al eerder in Breysigs verklaarde anti-collectivisme, zijn opkomen voor het grote individu en zijn streven naar een mensheidsgeschiedenis, zie Goetz (1918), 24, $28 \mathrm{n} 16$.

${ }^{377}$ Het beste overzicht is te vinden in de Lamprecht-biografie van Chickering (1992), m.n. dl. II: 'The destruction of the historian'.

${ }^{378}$ Goetz (1910a), 5. 
vanwege alle meningsverschillen, mede onder invloed van Lamprecht te zijn gebeurd, in wiens vakgroep hij vanaf 1895 docent werd. ${ }^{379}$ In ieder geval leidden de intensieve discussies op de door Lamprecht georganiseerde 'Historische Avonden' ertoe dat hij besloot zich in de individuele en sociale psychologie te verdiepen. ${ }^{380}$ Tegelijk ging Goetz, die zich als historicus en docent had gekwalificeerd met politiek-historische studies en bronnenedities, zich in Leipzig steeds meer bezighouden met de religieuze en intellectuele geschiedenis van de late middeleeuwen en de vroeg-moderne tijd, met name van Italië. Tot zijn meest geliefde historische thema's hoorden vanaf dat moment Franciscus van Assisi en Dante, het Italiaans humanisme en de Renaissance. Van zijn overigens niet zeer talrijke boekpublicaties zijn de belangrijkste een analyse van de historische bronnen over Franciscus van Assisi (1904) en twee verzamelbundels over respectievelijk Italië in de middeleeuwen (1942) en Dante (1958). Hieraan kunnen nog twee (kunst)historische stadsportretten van Ravenna (1901) en Assisi (1909) in de reeks Berühmte Kunststätten worden toegevoegd.

Het Reizwort 'Kulturgeschichte' gebruikte Goetz voor het eerst voor zijn eigen werk in 1897 toen hij als dertigjarige docent in Leipzig een hoorcollegereeks aankondigde onder de titel 'Kulturgeschichte der Renaissance', waarin hij de geschiedenis van de nieuwe tijd als een geschiedenis van het individualisme presenteerde. ${ }^{381}$ Maar pas na zijn benoeming tot ordinarius voor middeleeuwse geschiedenis in Tübingen (1905) duikt de term ook op in de titel van een van zijn publicaties, eerst nog als de algemene noemer van een publicatiereeks voor zijn promovendi (vanaf 1908) en dan in 1910 in zijn eerste geschiedtheoretische verhandeling en beginselverklaring 'Geschichte und Kulturgeschichte'. ${ }^{382}$ Een jaar eerder had Goetz al blijk gegeven van een serieuze betrokkenheid bij de cultuurgeschiedenis door zich achter de schermen verregaand te bemoeien met de succesvolle reanimatie van Steinhausens Archiv für Kulturgeschichte. ${ }^{383}$ En zes jaar later zou zijn hier begonnen persoonlijke verbintenis met een van de nieuwe instituties voor cultuurgeschiedenis leiden tot zijn tweede belangrijke institutionele succes als cultuurhistoricus: de overname van de leiding van het Leipzigse Institut für Kultur- und Universalgeschichte na de dood van Lamprecht in 1915. 'Het Leipzigse professoraat heb ik aanvaard in de overtuiging dat dit centrum van de cultuurgeschiedenis behouden diende te worden en de erfenis van Lamprecht solide belegd', schreef Goetz daar later zelf over. ${ }^{384}$ Goetz bleek in beide functies bij uitstek de man om de politieke historici met de cultuurgeschiedenis te verzoenen en zo de cultuurgeschiedenis uit de schootslijnen te halen. Hij slaagde daarin, waarbij hij opmerkelijk veel standpunten van van Lamprecht wist vast te houden.

${ }^{379}$ Zie de enthousiaste kennismaking met Lamprecht, geciteerd in Weigand (1992), 53-54; zie afstandelijker Goetz (1910a), 5 ('auch das [de Lamprechtstrijd] ist für diejeningen unter uns, die wir noch Lernende waren, eine fruchtbare Anregung [...] gewesen').

${ }^{380}$ Zie Weigand (1992), 53-54, 61 en Goetz (1957a), 36.

${ }^{381}$ ZieWeigand (1992), 61-62 en 405.

382 Goetz (1908-1939); Goetz (1910a).

${ }^{383}$ Aldus Chickering (1993), 258-259 - bevestigd noch gepreciseerd door Neuhaus (2003) of Herold (2003). Ook zelf noemde Goetz zich in zijn in memoriam voor Steinhausen al vanaf 1909 medehoofdredacteur van het tijdschrift, zie Goetz (1934b), 2 - zo staat hij dan echter nog niet vermeld in het tijdschrift; 'officieel' werd hij dit, aldus Steinhausen (1925), 254, pas in 1912.

${ }^{384}$ Goetz (1925), 163; in Goetz (1957a), 46, is de laatste zinsnede veranderd in: 'daß die Erbschaft Lamprechts zwar in veränderter Form, aber doch als geistesgeschichtliche Forschungsstätte bleiben müsse'. 


\subsection{Cultuurgeschiedenis als Gesamtgeschichte...}

Goetz' streven naar een verzoening van de politieke historici met de cultuurgeschiedenis werd meteen duidelijk uit zijn geschiedtheoretische beginselverklaring uit 1910. Die verscheen als eerste bijdrage in het eerste nummer van het mede onder zijn (bege)leiding vernieuwde Archiv für Kulturgeschichte en kon makkelijk opgevat worden als een programma voor het vernieuwde tijdschrift - te meer omdat, zoals we nog zullen zien, de erin verdedigde opvattingen overeen kwamen met de koers die werd uitgezet in het niet persoonlijk ondertekende korte voorwoord van de nieuwe uitgever en de redactie.

Wat Goetz' artikel extra interessant maakt is dat hij aan de ene kant zijn nek uitstak door de beoefening van de cultuurgeschiedenis voor het eerst sinds de Lamprechtstrijd opnieuw te propageren, maar zich aan de andere kant uitdrukkelijk wenste te dissociëren van de door zijn goede 'vrienden en relaties' - zoals Moriz Ritter, Meinecke, Below, Marcks - veroordeelde opvattingen van Lamprecht en Steinhausen. Aan het geval van Goetz kunnen we zien hoe sterk de aantrekkingskracht van de cultuurgeschiedenis blijkbaar was, zelfs voor een historicus die door goede persoonlijke relaties vooral verbonden was met critici van Lamprecht en tegenstanders van de cultuurgeschiedenis in het algemeen. ${ }^{385}$ Zijn pleidooi voor de beoefening en onderwijzing van de cultuurgeschiedenis aan de universiteiten was geen 'radicalisme', schreef hij uitdrukkelijk. 'Ook niets nieuws, in feite iets vanzelfsprekends', waarnaar 'een groot deel van de jongere generatie' verlangde. En hij wilde met zijn artikel laten zien 'hoe oud en nieuw' - Goetz noemde onder de eerste kwalificatie met name Ranke - 'zich laten verbinden en verbonden moeten worden'. ${ }^{386}$

Goetz' verzoeningsstrategie was er niet op gericht om uitersten te verenigen; zij gold welbeschouwd alleen de politieke historici, niet Lamprecht. Integendeel, het uitdrukkelijk afzetten tegen Lamprecht was een deel van Goetz' pacificatie van de politieke historici. Misschien moeten we, gezien de heftigheid van de reacties op Lamprecht, spreken van een overlevingsstrategie van de Tübingse cultuurhistoricus. Toen Lamprecht in een publieke reactie op Goetz' beginselverklaring de nadruk legde op de onderlinge overeenkomsten, reageerde Goetz in ieder geval als gebeten: hij sprak voortdurend over uns andern, de niet-lamprechtiaanse cultuurhistorici, die, zoals hij opmerkte in het geheel niet streefden naar het voortzetten van Lamprechts gedachtegoed, maar juist naar het 'uitschakelen' ervan. Voortdurend ook liet hij het (in werkelijkheid maar geringe) generatieverschil tussen Lamprecht en de 'jongere generatie' cultuurhistorici naar voren komen om daarmee aan te geven dat Lamprecht passé was, maar dat de cultuurgeschiedenis desalniettemin een toekomst had.

Volgens Goetz had het overgrote deel van de 'competente onderzoekers' wezenlijke onderdelen van Lamprechts geschiedopvattingen afgewezen: de biologische wetmatigheid van de geschiedenis, zijn omschrijving van specifieke cultuurtijdperken, het primaat van de sociaal-psychische factoren, de vergelijkende methode. En Goetz liet er geen twijfel over bestaan dat hij zich in deze punten achter 'de meerderheid' schaarde. Ook van Steinhausen onderscheidde hij zich overigens met enige nadruk in zijn beginselverklaring: ook deze cultuurhistoricus hechtte naar zijn mening teveel gewicht aan de sociaal-psychische factoren. Bovendien behoorden favoriete thema's van Steinhausen als het volksleven en de 'zedengeschiedenis' volgens Goetz niet tot de cultuurgeschiedenis maar tot de volkskunde. De aloude associatie met volks-

\footnotetext{
${ }^{385}$ In zijn autobiografie wijst Goetz bijv. op de onenigheid met zijn schoonvader Moriz Ritter op dit punt, Goetz (1925), 164.

${ }^{386}$ Goetz (1910a), 19.
} 
kundige curiosa, die de cultuurgeschiedenis nog altijd aankleefde, diende resoluut afgewezen te worden. ${ }^{387}$

Op nog een ander punt bekritiseerde Goetz in zijn artikel de hoofdredacteur van het Archiv für Kulturgeschichte en zocht hij toch nog aansluiting bij Lamprecht: hij pleitte voor een alomvattende definitie van cultuurgeschiedenis als algemene geschiedenis of Gesamtgeschichte 'vanuit een ontwikkelingsperspectief (echter zonder wetmatigheid!)', een 'samenvatting' van heel het historische gebeuren, waartoe uitdrukkelijk ook de politieke geschiedenis behoorde. ${ }^{388}$ Hadden Lamprecht en Breysig in de jaren negentig nog geaarzeld over het woord 'cultuurgeschiedenis' omdat het iets anders (en minder) dan algemene geschiedenis leek aan te duiden, in 1910 lagen de zaken inmiddels anders: wie een hoorcollege over de cultuurgeschiedenis van de middeleeuwen aankondigde, aldus Goetz, kon erop rekenen dat de studenten daaronder het geheel van geistige èn economische èn politieke geschiedenis van de middeleeuwen verstonden.

Ook de politiek diende onder de algemene noemer van de cultuurgeschiedenis beschreven te worden. De gerenommeerde renaissance-kenner Hans Baron, een voormalig student van Goetz, schreef later eens dat Goetz hem ervan had doordrongen 'that history should be a study of both politics and culture'. ${ }^{389}$ Goetz bestreed expliciet de opvatting van cultuurgeschiedenis als zelfstandige variant van historisch onderzoek naast de politieke geschiedenis. Ook het politieke leven was immers 'cultuurleven' de staat bevond zich niet buiten en niet onafhankelijk van de cultuur, er was sprake van een wisselwerking tussen beide fenomenen. Onder invloed van Goetz' opvatting kreeg de politiek nu voor het eerst expliciet een plaats toegewezen in het Archiv für Kulturgeschichte: in het redactionele voorwoord van het eerste vernieuwde nummer werden onder andere literatuurreferaten aangekondigd over de 'politiek-juridische cultuur en organisatie'. En inderdaad wijdde het blad in de loop van de jaren verschillende besprekingsartikelen aan 'de geschiedenis van de politieke cultuur' - een begrip dat hier voor het eerst opgang lijkt te hebben gemaakt vóór het in de jaren zeventig via de omweg van de Amerikaanse politicologie (Almond) opnieuw in Duitsland werd geïntroduceerd. ${ }^{390} \mathrm{De}$ aandacht voor de 'politieke cultuur', aldus het eerste literatuurbericht over dit thema, kwam voort uit de overtuiging dat de cultuur van een tijd ook in de vormen van het staatsleven, in de aard van de politieke handelingen en het politieke denken tot uitdrukking kwam. ${ }^{391}$ In zijn beginselverklaring van 1910 kwam Goetz de politieke historici overigens tegemoet door in zijn omschrijving van de geschiedwetenschap de staat, als de 'sterkste' onder de Kulturmächte, naar voren te schuiven; voor de juiste begripsbepaling verwees hij nota bene naar de twintig jaar oude reacties van de tegenstanders van Gothein: Schäfer, Below, Ritter. ${ }^{392}$ De staat moest voor grote delen van het cultuurleven 'het ordenende en voorwaardenscheppende principe' worden genoemd, stelde Goetz vast. Om slechts in een voetnoot

${ }^{387}$ Goetz (1910a), 6. Dat standpunt weerhield Goetz er later niet van te pleiten voor de bestudering van 'de ontwikkeling van alle menselijke levensvormen', waaronder je toch ook volkskundige onderwerpen zou verwachten, zie Goetz (1957a), 77. De zedengeschiedenis verdween overigens niet uit het Archiv für Kulturgeschichte: onder de thema's waarover het vernieuwde Archiv vanaf 1910

literatuurreferaten aankondigde, behoorden ook de 'sociale [gesellschaftliche] cultuur en de zeden'.

${ }^{388}$ Goetz (1910a), 7. Zo formuleert Goetz het ook later in 1912, 1916 en 1925, telkens expliciet in aansluiting bij Lamprecht. Vgl. Goetz (1934a) over Steinhausen, m.n. 383.

${ }^{389}$ Geciteerd in: Weigand (1992), 409 (mijn cursivering, MS)

${ }^{390} \mathrm{Zie}$ de literatuurberichten over dit thema in de jaargangen 1912, 1916, 1926 en 1934. Zie over de latere geschiedenis van het begrip: Iwand (1985).

${ }^{391}$ Rapp (1912), 118-119.

${ }^{392}$ Goetz (1910a), 12-13n2. 
daarbij aan te tekenen dat de staat toch weer niet anders dan als onderdeel van het 'cultuurleven', en in wisselwerking daarmee, gedacht kon worden.

Goetz' domeinafbakening bracht hem in zijn beginselverklaring tot de volgende definitie van geschiedenis èn cultuurgeschiedenis, een definitie die tot de komma ook voor Lamprechts rekening zou kunnen zijn gekomen, en na de komma de politieke historici tevreden moest stellen: ${ }^{393}$

'de uiteindelijke opgave van de geschiedwetenschap is een totale geschiedenis [Gesamtgeschichte] van de ontwikkeling van het mensengeslacht, voornamelijk binnen zijn staatkundige verbanden (= cultuurgeschiedenis)'.

Met het ontwikkelingsbegrip dat hij in deze omschrijving gebruikte, verwees Goetz naar het eigen (namelijk: dynamische, synthetische en causaal-georiënteerde) perspectief van de cultuurhistoricus: net als de andere nieuwe cultuurhistorici meende hij dat zij de speciale taak hadden om de samenhang en het verloop van het historisch proces tot op het bot te analyseren. In Goetz' eigen woorden diende de cultuurhistoricus 'de wederzijdse afhankelijkheid te laten zien van de afzonderlijke domeinen van het leven, hun respectievelijke betekenis vast te stellen voor het Gesamtleben en voor de verdere historische ontwikkeling en de samenhangende krachten te onderzoeken die dit veelvormige leven voortdrijven'. ${ }^{394}$

\section{3 ...en als Geistesgeschichte}

Aan deze algemene omschrijvingen voegde Goetz nog toe dat binnen het terrein van de 'algemene geschiedenis (oftewel cultuurgeschiedenis)' de Geistesgeschichte een vooraanstaande plaats toekwam. ${ }^{395}$ De invloed van Goetz op de koers van het vernieuwde Archiv bleek ook op dit punt uit het redactionele voorwoord van het eerste nieuwe nummer: daar werd de cultuurgeschiedenis als een 'algemeen-historische discipline' getypeerd die haar zwaartepunt uiteindelijk in de Geistesgeschichte had. ${ }^{396}$ Enkele jaren later, Goetz was inmiddels de overleden Lamprecht in Leipzig opgevolgd, rechtvaardigde hij de centrale positie van de Geistesgeschichte met de stelling dat 'de psychische geschiedenis [Seelengeschichte] van de mens toch meer dan welke andere historische factor de gehele historische ontwikkeling begeleidt. ${ }^{397}$ Net als de andere nieuwe cultuurhistorici meende Goetz in een dergelijke Seelengeschichte - maar meestal sprak hij van Geistesgeschichte - het verbindende element en de drijvende kracht in het gevarieerde historische gebeuren te hebben gevonden. ${ }^{398}$ Niet alleen de culturele verschijnselen in engere zin (wetenschap en kunst), maar ook de 'ondergrond' van politiek en economie was in wezen geistig. ${ }^{399}$ Het Leipzigse Institut für Kultur- und Universalgeschichte zou onder zijn leiding daarom, zoals Goetz in 1916 verklaarde, een centrum voor algemene geschiedenis blijven, dat uitging 'van het onderzoek van het geestelijke als het drijvende of tenminste wezenlijk drijvende in de hele geschiedenis'. 400

\footnotetext{
${ }^{393}$ Goetz (1910a), 13; terzijde zij opgemerkt dat Lamprecht met de hele definitie had kunnen instemmen als Goetz in plaats van 'staatkundige verbanden', 'nationale verbanden' had geschreven.

${ }^{394}$ Goetz (1910a), 11-12.

${ }^{395}$ Goetz (1910a), 15.

${ }^{396}$ Steinhausen en [Goetz?] (1910), 3.

${ }^{397}$ Goetz (1916a), 275n1.

${ }^{398}$ Vgl. Goetz (1934c), 296: ‘... von den treibenden geistigen Kräften auszugehen und so alles Geschehen aus einer relativ einheitlichen Wurzel abzuleiten...'

${ }^{399}$ Goetz (1926), 2; Goetz (1916a), 277.

${ }^{400}$ Goetz (1916a), 276.
} 
Goetz, anders dan Lamprecht of Breysig weinig geneigd tot theorievorming, heeft nergens uitvoerig verwoord wat hij onder Geistesgeschichte - of Seelengeschichte verstond. ${ }^{401}$ Het antwoord op die vraag is echter van belang om vast te stellen in hoeverre Goetz zich onderscheidde van de andere nieuwe cultuurhistorici en met name van Lamprecht, tegen wie hij zich onder andere vanwege diens nadruk op de 'sociaalpsychische factoren' uitdrukkelijk afzette. In hoeverre vond met Goetz een wending plaats van de Duitse cultuurgeschiedenis naar een meer intellectualistische Geistesgeschichte, zoals die bijvoorbeeld ook door zijn vriend Meinecke na 1900 werd bedreven? ${ }^{402}$

Opvallend is ten eerste dat Goetz tussen de cruciale termen geistig en seelisch of psychisch eerder associeert dan differentieert, zoals overigens ook bij Lamprecht en Breysig vaak het geval was. Goetz sprak bijvoorbeeld over de geistig-seelische Habitus van volkeren. ${ }^{403}$ Als hij op de ene pagina sprak van de geistige Untergrund van al het historisch leven, kon hij daar op de volgende pagina zonder probleem naar refereren als 'deze laatste seelische Untergrund'. ${ }^{404}$ Voor de verhouding tot Lamprecht is speciaal van belang dat hij ook Lamprechts sociaal-psychologische geschiedopvatting bij herhaling typeerde door te zeggen dat voor hem 'het geestelijke [geistige] leven de beheersende factor van al het historische leven' was. ${ }^{405}$ In zijn autobiografische terugblik uit 1925 wees Goetz expliciet op zijn overeenstemming met Lamprecht in dit opzicht. 'Eén fundamentele opvatting' van zijn voorganger had hij bij zijn overname van het IKU niet veranderd: namelijk dat de geschiedvorser de Gesamtgeschichte van het mensengeslacht diende te onderzoeken en daarbij het beste vanuit de 'ontwikkeling van het geestelijke leven' kon vertrekken. ${ }^{406}$

Dat wil niet zeggen dat Goetz het in alle opzichten eens was met Lamprecht. In een toelichting bij de door hem opgezette Propyläen-Weltgeschichte (1929-1933) schreef Goetz dat hij anders dan Lamprecht van mening was dat 'het aanwezige psychische ontwikkelingsstadium' nooit alleen bepalend was voor doen en laten van de mens - altijd moest daarnaast met een 'doelgerichte levenskracht' van het individu gerekend worden. ${ }^{407}$ Dit standpunt, dat Goetz eerder had uitgewerkt in een oorlogsverhandeling over 'de betekenis van persoonlijkheid en gemeenschap in de geschiedenis' (1918), bracht hem dicht in de buurt van Breysigs opvattingen, naar wiens werk over de verhouding van het individu tot de wereld hij ook verwees. ${ }^{408} \mathrm{Net}$ als Breysig wilde Goetz in deze verhandeling tegenover Lamprechts sociaal-

${ }^{401}$ Als zijn geschiedtheoretische bijdragen kunnen gelden: Goetz (1910a), (1918), (1932b), (1934c), (1935).

${ }^{402}$ Goetz zelf eerde Meinecke in 1952 juist vanwege zijn wending naar de Geistesgeschichte, zie Goetz (1957a), 348-349: 'Der Enge der politischen Geschichte war endgültig überwunden. [.|.] Die Zeit wird kommen, so hoffen wir, in der die Geschichte der Völker und die Geschichte der Menschheit als Geistesgeschichte geschrieben wird. Der Platz Meineckes in dieser Entwicklung ist damit bestimmt.'

${ }^{403}$ Goetz (1932b), 9. Vgl. ook Goetz (1929-1933), X, xxiii ('was für seelische und geistige Veränderungen gehen in den Völkern vor sich') en het eerdere citaat hierboven over Seelengeschichte (voetnoot 397).

${ }^{404}$ Zie Goetz (1929-1933), X, xxiii-xxiv.

${ }^{405}$ Goetz (1957c), 299 [1912]; idem, Goetz (1933a), 26; vgl. ook Goetz (1957b), [1936], 314: 'wie Lamprecht [...] zu einem seelengeschichtlichen [Standpunkt] kam, so ist auch bei Breysig das geistesgeschichtliche Moment immer mehr beherrschend [...] geworden.' Overigens betitelde ook een tijdgenoot en naaste collega als Gerhard Seeliger Lamprechts onderzoeksrichting als 'geistesgeschichtlich', zie Seeliger (1919), 137.

${ }^{406}$ Goetz (1925), 163.

${ }^{407}$ Goetz (1934c), 296; vgl. overigens in deze zin ook al Goetz' kritiek op de 'geistesgeschichtliche Untersuchungen' van een student van Lamprecht, Goetz (1904).

${ }^{408}$ Goetz (1918), 24, 28n16. 
psychologische collectivisme het belang van het individu en meer in het bijzonder van 'de grote persoonlijkheid' benadrukken. Het sterke individu had de wil en de daadkracht om een 'vrije keuze' te maken tussen de altijd gevarieerde en tegenstrijdige 'sociaal-psychische factoren' waaraan het was blootgesteld; dat was de individuele levenskracht waar hij over sprak. ${ }^{409}$ Een grote persoonlijkheid was geen willoos geketende in de kerker van de cultuur, hij kon, integendeel, beslissend richting geven aan het collectief en aan de geschiedenis. De massa an sich was handlungsunfähig en behoefde leiding. Bovendien kwam al het nieuwe voort uit een idee, en dat ontsproot altijd aan een individu en nooit aan de massa. 'Aangezien het individu iets zelfstandigs is en van hem de aansporing tot al het handelen van de gemeenschap moet uitgaan, daarom moet zijn handelen beschouwd worden als het creatieve element in de geschiedenis'. 410

Maar dit was ook voor Goetz niet het hele verhaal. Hij ontkende uitdrukkelijk 'persoonlijkheidscultus' te willen bedrijven. Waar het individu als 'het drijvende element in de geschiedenis' moest worden beschouwd, bleef de gemeenschap nog altijd 'het dragende' en 'pas in nauwe samenwerking scheppen zij [beide] het historische leven'. 411 'Het individuele en het typische zijn voor ons anderen even sterke historische krachten', had hij in zijn beginselverklaring van 1910 al verklaard tegenover Lamprecht. ${ }^{412}$ Een individu kon immers slechts als deel van een gemeenschap invloed uitoefenen. Individu en gemeenschap stonden feitelijk in een voortdurende wisselwerking met elkaar - en de historicus diende aandacht te besteden aan de verschillende vormen van deze wisselwerking en de historische variaties daarin, zoals bijvoorbeeld Breysig had gedaan. ${ }^{413}$ Hoe dan ook was 'de historische begrensdheid van het individu door sociaal-psychische factoren [...] een niet te loochenen feit'; zelfs een 'grote persoonlijkheid' was tot op zekere hoogte zeitlich bedingt. $^{414}$

Hoe ver Goetz' gedachten over de invloed van het collectief op het individu ondanks zijn verklaarde afkeer van Lamprechts collectivisme gingen, werd duidelijk toen hij zijn eigen opvattingen afzette tegen andere dan sociaal-psychologische varianten van het collectivisme: de eigentijdse rassenleer en Volksgeist-theorieën. Vooral na, maar ook al tijdens de Eerste Wereldoorlog keerde Goetz zich tegen al te makkelijke verklaringen over het Deutschtum, over rasse-eigenschappen of een 'aangeboren' Volksgeist. ${ }^{415}$ De meeste 'nationale karaktereigenschappen' waren naar zijn overtuiging van relatief recente datum en een gevolg van de historische ontwikkeling en van een veranderende omgeving. Met name de historische ontwikkeling speelde tegenover het 'schijnbaar voor eeuwig aangeborene' een beslissende rol. ${ }^{416} \mathrm{Er}$ bestonden geen 'zuivere rassen' en geen 'zuiver Volkstum' en evenmin zuiver nationale culturen.

${ }^{409}$ Goetz (1918), 22.

${ }^{410}$ Goetz (1918), 23.

${ }^{411}$ Goetz (1918), 24.

412 Goetz (1910b), 230 (mijn cursivering, MS).

413 Goetz (1918), 24.

${ }^{414}$ Goetz (1918), 12-13.

${ }^{415}$ Zie m.n. Goetz (1919), Goetz (1926) en vooral: Goetz (1932c). Maar ook al in 1916: Goetz (1916b), bijv. 42-43. Typerend was ook de kritische bijdrage van Friedrich Hertz over 'Rasse und Geschichte' die Goetz opnam in het eerste deel van de Propyläen-Weltgeschichte (1931).

${ }^{416}$ Goetz (1932c), 9. 
'De volkeren en de individuen worden gevormd door milieu [Umwelt] en geschiedenis en hierdoor transformeren ze ook voortdurend verder, ongeacht van wat voor ras ze oorspronkelijk ooit afstamden'. ${ }^{417}$

In een artikel over 'Die Rassenforschung' (1932) stelde Goetz dat mensen door een blijvende verandering van omgeving hun 'oorspronkelijke' kenmerken verloren: onderzoek had aangetoond, aldus Goetz, dat zelfs lichaamshouding en manier van lopen, ja ook de manier van lachen veranderden als mensen naar de grote stad verhuisden. Overal en voortdurend vond tussen individuen, maar ook tussen grotere groepen en volkeren een proces van Angleichung plaats, de aanpassing aan anderen in een veranderende constellatie. Voor Goetz stond de conclusie 'onomstotelijk' vast:

'de psychische structuur [seelische Struktur] van mensen die tot een ras, een volk, een stam, een familie behoren, verandert. En wel als gevolg van het uiterlijke en innerlijke milieu [Umwelt]: zowel de geografische omstandigheden als de invloeden van de overlevering, van de opvoeding, van het beleven zijn in staat de afzonderlijke mensen of groepen van mensen te veranderen. ${ }^{418}$

Als het ging om het belang van de 'innerlijke' factoren in de geschiedenis kunnen we voorlopig vaststellen dat Goetz zich aansloot bij Lamprecht. Net als Lamprecht en de andere nieuwe cultuurhistorici verwachtte Goetz alleen vanuit dit perspectief een eenheid in de geschiedenis tot stand te kunnen brengen, maar veel minder dan Lamprecht of Breysig theoretiseerde hij erover hoe dit precies zou moeten gebeuren. Wel is duidelijk dat het in zijn Geistesgeschichte om meer ging dan om een puur intellectuele geschiedenis; hij erkende het belang van de sociaal-psychische factoren, van de vormende invloed van geschiedenis en omgeving op de 'psychische structuur' en gedrag van de mens - tot in lichaamshouding en het lachen toe - en van het proces van Angleichung van individuen en groepen die met elkaar in contact staan. Anderzijds wilde Goetz zich meer dan Lamprecht rekenschap geven van het belang van het (grote) individu in de geschiedenis, dat alleen verantwoordelijk kon worden gehouden voor nieuwe, creatieve ideeën, voor het leiden van de massa en voor de historische vooruitgang in het algemeen. Goetz' ideeën kwamen in deze opzichten dicht in de buurt van de opvattingen van Breysig. ${ }^{419}$

\subsection{Goetz' werk}

Het analyseren van Goetz' eigen geistesgeschichtliche werk lijkt veel op het zoeken van illustraties bij deze constateringen. Allereerst valt op dat Goetz in zijn werk inderdaad de meeste aandacht gaf aan 'grote persoonlijkheden': Franciscus en Dante behoorden tot zijn meest geliefde historische onderwerpen. En terwijl bijvoorbeeld de cultuurhistorische bronnen die Steinhausen uitgaf bij voorkeur betrekking hadden op 'doorsneemensen' uit een bepaalde klasse, publiceerde Goetz in de Quellen zur Geistesgeschichte des Mittelalters und der Renaissance die hij vanaf 1928 redigeerde,

${ }^{417}$ Goetz (1932c), 15.

${ }^{418}$ Goetz (1932c), 11.

${ }^{419}$ Goetz (1957b), 315. Overigens toonde Goetz nergens zijn expliciete instemming met Breysigs overtuiging van de wisselende psychische basisdriften in de geschiedenis. Bij wijze van vraag leek hij daar in 1918 in een opstel waarin hij ook naar een relevante studie van Breysig (1902c) verwees, wel aan te refereren: een nog onbeantwoorde, belangrijke vraag was 'warum zu Zeiten das Individuum starker hervorttritt als die Gesamtheit, zu anderen die Gesamtheit mehr als das Individuum', Goetz (1918), 24. Brands (1965), 122, die overigens opmerkt dat Goetz 'beslist geen volgeling in engere zin' van Lamprecht was, wijst er op dat Below na WO I herhaaldelijk tegen Goetz' geschiedopvattingen polemiseerde. 
uitsluitend intellectuele tractaten van uitzonderlijke persoonlijkheden als Leonardo Bruni. Ook in de reeks Beiträge zur Kulturgeschichte die hij vanaf 1908 uitgaf, en waarin veel dissertaties van leerlingen werden gepubliceerd, duikt een opvallend groot aantal studies over individuen op: van de vijfenvijftig delen die tot 1939 verschenen, was meer dan een derde gewijd aan individuele historische persoonlijkheden. Een aantal daarvan had overigens een psychologische invalshoek en nam uitdrukkelijk 'de individualiteit' of 'persoonlijkheid' van deze historische actoren tot onderwerp.

Wanneer Goetz het 'geistige leven' aan een onderzoek onderwierp, domineerden de grote persoonlijkheden minder. Een oorlogsstudie over Deutschlands geistiges Leben im Weltkrieg (1916) concentreerde zich bijvoorbeeld op collectieve verschijnselen, zoals pers, wetenschap, onderwijs, lectuur, volksopvoeding en cultuurpolitiek waarvan de ontwikkelingen in veel gevallen met behulp van getallen en statistiek (in plaats van personen) werd verduidelijkt. ${ }^{420}$ Als hoofdredacteur van de PropyläenWeltgeschichte streefde Goetz naar eigen zeggen ernaar de geistige Untergrund alles geschichtlichen Lebens te laten zien. Hij publiceerde zelf twee korte introducerende en twee langere zelfstandige bijdragen die, met zoveel woorden, de geistige Struktur, Grundlagen, Bewegung of Entwicklung van een bepaalde tijdvak moesten duidelijk maken. ${ }^{421}$ In de beide langere van deze bijdragen kwamen dezelfde onderwerpen als in de oorlogsverhandeling over het geistige Leben aan de orde, maar kregen wetenschap, religieus leven, letterkunde, beeldende kunsten en muziek een grotere plaats - en steeg het aantal besproken 'belangrijke personen' navenant. Met paragrafen over de 'bürgerliche Gesellschaft' voegde Goetz in deze bijdragen echter ook een sociale en psychologische laag aan zijn analyse toe, waarin hij economische en sociale veranderingen beschreef en de psychische effecten daarvan. 'Het literaire leven weerspiegelt dit laatste psychische fundament van een tijd maar zeer onvolkomen', schreef hij in het slotdeel van de $P W$ zelf over de beperkingen van deze bronnen. 'Het geheel van de psychische veranderingen kan slechts uit politiek, economie en de gepubliceerde opinies duidelijker worden begrepen - het is het denken en handelen van de mensen, voortkomend uit onmeetbare stemmingen en raadselachtige massasuggesties, dat het verschil met het verleden kenmerkt'. ${ }^{422}$

De zoektocht naar het 'psychisch fundament van een tijd' werd door Goetz minder expliciet ondernomen dan door Lamprecht, Breysig of Steinhausen. Slechts enkele publicaties onderscheiden zich in dit opzicht. Een ervan was Goetz' literatuurreferaat over de geschiedenis van het landschapsgevoel uit $1936{ }^{423}$ Dit thema had al langer Goetz' belangstelling, zoals blijkt uit de drie studies over dit onderwerp die hij in de Beiträge zur Kulturgeschichte des Mittelalters und der Renaissance onder zijn redactie liet opnemen. ${ }^{424}$ In zijn literatuurreferaat gaf Goetz

${ }^{420}$ Overigens ontwierp Goetz nog in 1932 een voorstel t.b.v. de Historische Reichskommission voor het onderzoek naar het 'seelische und geistige Leben der Nation im Weltkrieg', waarin behalve veel aandacht voor de Duitse cultuurpolitiek in WO I ook veel aandacht voor de 'stemming' in leger en bevolking en met als slotstuk: 'Der Krieg als seelisches Erlebnis der Nation'. Zie Weigand (1992), $163 n 147$.

${ }^{421}$ Zie Goetz (1929-1933), VIII, XVII-XXVI; VII, XVII-XXIV; VIII, 457-540; X, 3-42.

${ }^{422}$ Goetz (1933b), xxiv.

${ }^{423}$ Goetz (1936). Overigens had ook Breysig in 1909 een dissertatie (door Kammerer) over de geschiedenis van het natuurgevoel begeleid. En Steinhausen voegde aan de tweede druk van zijn Geschichte der deustchen Kultur (1913) hoofdstukken toe waarin hij 'Die Geschichte der deutschen Landschaft' beschreef.

${ }^{424}$ Stockmayer (1910), Ganzenmüller (1914) en Böheim (1934). Het Nachleben van deze studies leidt o.a. naar de werk van de vooraanstaande Russische mediëvist en mentaliteitshistoricus A.J. Gurevic, die in zijn bekende studie over het middeleeuwse wereldbeeld (1972) opvallend veel gebruik maakte van Duits cultuurhistorisch onderzoek van vóór WO II, m.n. (maar niet alleen) uit de kring rond 
aan dat hij van de bestudering van de geschiedenis van het natuurgevoel 'belangrijke inzichten in de structuur en de ontwikkeling' van de westerse 'geest' verwachtte. Het onderwerp leidde volgens hem onvermijdelijk tot de vraag of 'de mensen in de loop der tijden uiteindelijk altijd hetzelfde waren? ${ }^{425}$

In zijn beantwoording van deze vraag beklemtoonde Goetz allereerst de noodzaak van zorgvuldig en uitgebreid empirisch onderzoek en ook van expliciete vergelijkingen tussen tijdperken (terwijl hij eerder Lamprechts vergelijkende methode had afgewezen). Een voorschot nemend op de uitkomst van een dergelijk onderzoek, meende hij vervolgens dat bij alle gelijkblijvende Hauptmotive in het natuurgevoel in de diverse tijdvakken, de verschillen opgemerkt moesten worden. Die verschillen betroffen de intensiteit van het natuurgevoel, de invloeden van de natuur op de mens, en de mate waarin de verschillende 'stemmingen' ontwikkeld waren. Hetzelfde motief dat in het ene tijdperk op de voorgrond trad, verdween in een ander tijdperk naar de achtergrond. Het natuurgevoel, zo concludeerde Goetz ten slotte, was afhankelijk van het 'stadium van ontwikkeling' waarin een Kulturkreis zich bevond:

'Men moet zich [...] realiseren dat het menselijke natuurgevoel zich in een zeer specifieke verhouding tot de Gesamtkultur ontwikkelt, dat het derhalve in de verschillende stadia van de opwaartse ontwikkeling van een Kulturkreis iets is dat zich ontwikkelt van een eenvoudig naar een hoger stadium. ${ }^{426}$

Waarop Goetz met deze Lamprechtiaanse (of Breysigiaanse) wendingen precies doelde werd niet erg duidelijk, behalve dat hij de veranderingen in het natuurgevoel verbond met veranderingen in de 'oriëntatie van de verbeelding', die op zichzelf weer niets anders waren dan 'versterkingen en uitbreidingen van het zien en het voelen'. In die veranderingen speelde 'het grote individu' in de gedaante van de kunstenaar waarschijnlijk een leidende rol, suggereerde hij aan het eind van zijn opstel, geheel in lijn met zijn algemene opvattingen over de rol van het individu: 'het zou niet voor het eerst in de geschiedenis van het zien zijn dat de kunstenaar de anderen de ogen had geopend'. 427

Opvallend aan Goetz' referaat over de geschiedenis van het natuurgevoel was dat hij - net als Lamprecht en Breysig - refereerde aan een door 'stadia' gekenmerkte cultuurontwikkeling die hij bovendien verbond met de historisch-psychologische ontwikkeling van 'het zien en voelen'. Deze zelfde kenmerken, die duidelijk maken dat Goetz in meer opzichten een erfgenaam van Lamprecht was dan hij zelf in eerste instantie wilde laten blijken, vinden we terug in zijn preoccupatie met de geschiedenis van het portret.

Dit thema had Goetz na het opstarten van de onderzoeksafdeling van het Leipzigse IKU tot een van de hoofdprojecten van het instituut gemaakt. ${ }^{428}$ Onder de overkoepelende titel Die Entwicklung des menschlichen Bildnisses plande Goetz een reeks van minstens tien studies, waarin behalve afbeeldingen van middeleeuwse vorsten, of de geschiedenis van de vroeg-christelijke portretten, uiteindelijk ook de

Goetz, het AfK en/of het IKU: behalve van Ganzenmüller en Stockmayer ook van Schramm, Kern, Doren, Lauffer, Hampe, Kemmerich (een leerling van Lamprecht) en Teuffel; en verder van Eicken (1887), Biese (1888), Zoepf (1908), Kantorowicz en Wührer (1930).

${ }_{425}$ Goetz (1936), 349 en 353.

${ }^{426}$ Goetz (1936), 347.

${ }^{427}$ Goetz (1936), 352.

${ }^{428}$ Zie Sch[önebaum] (1926), 272; Goetz (1925), 166; Goetz (1930a), 389. Niet besproken in Middell (2005). 
Japanse en Chinese portretkunst moesten worden behandeld. ${ }^{429}$ Goetz slaagde erin dit project een institutionele basis te geven, niet alleen binnen het IKU, maar ook binnen de Deutsche Ikonographische Ausschuß - een door de Verband Deutscher Historiker in 1930 ingestelde nationale afdeling van het Internationaal Iconografisch Comité waarvan Goetz samen met zijn leerling Sigfrid Steinberg, zijn goede vriend en Göttingse hoogleraar Karl Brandi en diens directe collega Percy E. Schramm deel uitmaakten. ${ }^{430}$ Goetz was in deze hoedanigheid ook verantwoordelijk voor de uitgave van een zevendelige Historische Bildkunde die in de jaren dertig verscheen en waarin onder andere een bibliografie over de geschiedenis van het Duitse portret gepubliceerd. $^{431}$

Maar hoe belangrijk Goetz' organisatorische initiatieven op dit terrein ook waren, het thema zelf had hij ontleend aan zijn voorganger: het was Lamprecht die voor Wereldoorlog I de geschiedenis van het (beeldende en literaire) portret als cultuurhistorisch fenomeen op de agenda van de historici had geplaatst. In feite stammen de eerste tekenen van Goetz' belangstelling voor dit onderwerp uit een (overigens kritische) bespreking van een studie van Lamprechts promovendus Max Kemmerich naar 'de geschiedenis van het literaire portret' uit $1904{ }^{432}$ In zijn Deutsche Geschichte had Lamprecht zelf het thema regelmatig behandeld, in 1898 publiceerde hij er een kort opstel over en hij begeleidde vanaf 1896 ook nog diverse andere dissertaties over de historische variaties in het weergeven van persoonlijkheden, met name in historiografische werken. ${ }^{433}$ Lamprecht had bovendien al in 1914 voor de 'cultuurhistorische afdeling' van de Internationale Ausstellung für Buchgewerbe und Graphik (Bugra, Leipzig, 1914) waarvoor hij verantwoordelijk was, een deeltentoonstelling ingericht over de ontwikkeling van het beeldende portret. ${ }^{434}$

Goetz zette deze studies voort, door in een reeks cultuurhistorische bijdragen onder zijn redactie onderzoek te publiceren over 'individuele persoonlijkheidsschildering' in middeleeuwse en renaissancistische geschiedwerken. ${ }^{435} \mathrm{Op}$ het Internationale Congres van Historische Wetenschappen te Oslo in 1928 presenteerde hij bovendien het IKU project over de geschiedenis van het portret met dezelfde vragen die ook al in Lamprechts werk en de dissertaties onder diens begeleiding centraal stonden:

'Het menselijk portret wordt hier niet als een kunsthistorisch, maar als een geistesgeschichtliches fenomeen onderzocht. Geprobeerd wordt uit de vormgeving ervan conclusies te trekken over de wil en het vermogen tot portretteren in vroegere

\footnotetext{
${ }^{429}$ Zie voor een overzicht van de drie uitgegeven en de overige geplande delen Steinberg en Steinberg-Von Pape (1931), I, na. blz. 160.

${ }^{430}$ Zie over de (voor)geschiedenis van dit Comité: Keyser (1935), 7-16, alsmede Bericht (1930), 51 en Bericht (1932), 51-53. Het IIC was in 1928 tijdens het Internationale Congres van Historische Wetenschappen in Oslo opgericht.

${ }^{431}$ Goetz (1934-1937).

432 Goetz (1904).

${ }^{433}$ Behalve de dissertatie van Kemmerich (1902), begeleidde Lamprecht al in 1896 een dissertatie over persoonlijkheidsschildering in 10de-eeuwse geschiedwerken, in 1905 een dissertatie over portretten van middeleeuwse vorsten, in 1910 een dissertatie over de weergave van het individu in Taines geschiedschrijving, en in 1912 een dissertatie over het portret bij vroegmiddeleeuwse Armeense historici; zie de lijst van dissertaties in Schönebaum (1955/56). Zie verder Lamprecht (1898) en voor relevante passages in de DG: d1. 12, Sachregister, 'Bildnismalerei'.

${ }^{434}$ Zie Lamprecht (1914c), 13-14; en Lamprecht (1914a).

${ }^{435}$ Het gaat om de studies van Teuffel (1914) en Gmelin (1927) uit de Beiträge zur
} Kulturgeschichte des Mittelalters und der Renaissance (55 dln., Leipzig, Berlin, 1908-1939), onder redactie van Goetz. 
cultuurstadia - op welke plaats in de cultuurontwikkeling ontstaat de wens naar weergave van het menselijke portret, op welke plaats ontstaat het van de werkelijkheid afgekeken portret, en wanneer lukt het de kunstenaar de totale inhoud van een persoonlijkheid in een portret te leggen? [...] - uit zijn werk [nl. dat van de portretkunstenaar] moet iets van de tijdgeest afgeleid worden. ${ }^{436}$

Wat opvalt is allereerst dat Goetz een directe relatie veronderstelde tussen het portret (als kunstuiting) en het karakter van een heel tijdperk; zoals hij elders schreef: 'de geestelijke toestand van een tijdperk laat zich in hoge mate uit de verhouding van de mens tot zijn portret afleiden'. ${ }^{437}$ Het onderzoek naar de geschiedenis van het menselijk portret zou een excellente toegang bieden tot de 'tijdgeest'. En ten tweede valt op dat de koppeling tussen portret en tijdperk via de kunstenaar door Goetz niet alleen werd gezocht in een bepaalde artistieke wil of intentie maar vooral in een vermogen tot portretteren, dat afhankelijk was van een bepaald 'stadium van de cultuur'. Ook in zijn tegen Lamprechts benadering gerichte recensie uit 1904 begreep hij de ontwikkeling van het portret als een 'geschiedenis van het vermogen van de verschillende tijdvakken om portretten te maken'. ${ }^{438}$ De geschiedenis van het portret toonde met andere woorden in de loop van de cultuurontwikkeling een opgaande lijn waarin 'oog en hand' van de kunstenaar en zijn tijdgenoten steeds beter in staat waren om 'de werkelijkheid van de menselijke figuur' te zien en weer te geven. ${ }^{439}$

Het fraaist onderbouwde Goetz deze visie in een essay dat hij in 1937 publiceerde en waarin zowel de geschiedenis van de persoonsweergave als de geschiedenis van het natuurgevoel een plaats kregen. Het algemene onderwerp van dit essay was de ontwikkeling van de Wirklichkeitssinn in de late middeleeuwen. Het thema - 'realisme, zin voor de werkelijkheid" - werd door Goetz zo breed mogelijk opgevat. Eerdere studies van bijvoorbeeld Haskins over de twaalfde-eeuwse wetenschap en zelfs van Burckhardt over de 'Entdeckung der Welt und des Menschen' in zijn Kultur der Renaissance waren naar Goetz' mening te beperkt van opzet. 'Hier', schreef Goetz over zijn eigen studie, 'dient de zin voor de werkelijkheid de gehele verhouding van de mens tot zichzelf en tot zijn omgeving te omvatten - een psychisch [seelisches] probleem dus, dat met de stand van de cultuur van het avondland zeer nauw samenhangt, 440

Goetz probeerde in zijn essay, zoals hij het formuleerde, de 'ontwikkeling van een nieuw zien' te beschrijven. Natuurlijk keek ook de middeleeuwer - maar hij zag veel niet van wat wij nu zien. De mens moest het zien eerst leren. ' $[\mathrm{H}]$ et zien van de primitieve mens is anders dan dat van de cultureel ontwikkelde mens' - en wat in de (vroege) middeleeuwen nog ontbrak was de wil tot observeren. ${ }^{441}$ Goetz beschreef vervolgens de veranderingen in de geschiedschrijving met een individuelere manier van persoonsbeschrijving, de opkomst van persoonlijker vormen van hagiografie, de opkomst van de autobiografie en de biografie van minder belangrijke individuen, en

${ }^{436}$ Goetz (1928a), 345 (mijn cursivering).

${ }^{437}$ Goetz (1930a), 389.

${ }^{438}$ Goetz (1904), 64, 65, 67. Vgl. : 'De kunstenaar leeft niet volgens eigen wetten; hij komt uit zijn tijd voort, hij neemt de opvatting van zijn milieu [Umwelt] en het geheel van haar tradities in zich op', Goetz (1928b), VIII.

${ }^{439}$ Goetz (1930a), 389. Overigens verklaarde ook Breysig (1931), 17, dat historische afbeeldingen van mensen onvervangbare bronnen vormden voor 'het psychische wezen' van een tijd of groep: 'Gebärde, Haltung, Gang, Mienenspiel und Gesichtsgepräge, Kleider- und Haartracht der Angehörigen einer solchen Geschichts- und Gesellschaftseinheit offenbaren von ihren innersten Seelenrichtung zwar zunächst sehr elementhaft-einfache, demnächst aber auch ganz zarte, ganz feine Eigenschaften [...]'.

${ }^{440}$ Goetz (1942), 4.

${ }^{441}$ Goetz (1942), 8 . 
tenslotte uitgebreid het sterkere empirisme in natuurwetenschap en het toegenomen realisme in de beeldende kunst.

Goetz verklaarde al deze veranderingen behalve door invloeden van buitenaf (met name van arabische en klassieke kennis) vooral door 'de vooruitgang van de westerse geest naar een hoger stadium van de cultuur, ondersteund door sociale verschuivingen en een toenemende uiterlijke horizonverbreding,. ${ }^{442}$ Met dat laatste doelde Goetz op de opkomst van geldeconomie en burgerij en het begin van een groter aantal verre reizen van Europeanen tijdens en na de Kruistochten. Florence - de stad waar 'aan het eind van de dertiende eeuw de bril uitgevonden werd' - was de ideale biotoop van de nieuwe Wirklichkeitssinn, 'ontstaan uit de reële machten van de stad, uit het lekendom en arbeidszaam koopmanschap, uit aangeboren nuchtere zin en een niets ontziende drang naar zelfbehoud'. ${ }^{443}$

Het grote individu speelde in deze alomvattende cultuurverandering een bemiddelende rol: een kunstenaar als Giotto, zelf gevormd door zijn tijd, opende de massa letterlijk de ogen voor een nieuwe manier van zien: zij 'zagen slechts die werkelijkheid, die Giotto en zijn tijdgenoten hen leerden te zien'. ${ }^{44}$

Zoals hier opnieuw duidelijk wordt, bestond er in de praktijk van Goetz' Geistesgeschichte een spanning tussen zijn verklaarde individualisme (dat hem van Lamprecht onderscheidde) en zijn geloof in een collectieve universele cultuurvooruitgang, die weer op een psychische fundament werd teruggevoerd - een overtuiging die hem met Lamprecht verbond. Ook al verwierp Goetz meer dan eens het rechtlijnige cultuurstadia-model dat Lamprecht had opgesteld, hijzelf bleek wel degelijk te geloven in een algemene cultuurontwikkeling die hij als een min of meer autonome factor in de geschiedenis aanmerkte. 'Het betreffende stadium van de cultuur is dwingend voor iedereen en zo ook voor de kunstenaar', schreef hij bijvoorbeeld terloops in zijn essay over de opkomst van het realisme. ${ }^{445}$

Goetz' opvatting over de betekenis van de cultuurontwikkeling kwam het duidelijkst naar voren in zijn bekendste en misschien wel belangrijkste project: de redactie over het tiendelige historische overzichtswerk, de Propyläen-Weltgeschichte (19291933). Goetz had op verzoek van uitgever Ullstein de leiding over een nieuwe uitgave van dit collectieve seriewerk op zich genomen - nadat eerder Breysig voor de eer bedankt had ${ }^{446}$ - en wel onder de voorwaarde dat de opzet ervan cultuurhistorisch zou zijn. ${ }^{447}$ In de nieuwe Propyläen-Weltgeschichte was ernaar gestreefd, aldus Goetz in het voorwoord van het eerste deel, 'de geistige ontwikkeling van de mensheid als kern van haar geschiedenis weer te geven - een geschiedenis van de menselijke cultuur is derhalve het doel van deze nieuwe onderneming'. ${ }^{448}$

Zoals de ondertitel aangaf, ging het in deze wereldgeschiedenis om 'de wording van de mensheid in maatschappij en staat, economie en geestesleven' - en dat waren inderdaad de thema's waar afzonderlijke hoofdstukken aan werden gewijd. ${ }^{449}$ De

${ }^{442}$ Goetz (1942), 39.

${ }^{443}$ Goetz (1942), 40.

444 Goetz (1942), 58.

${ }^{445}$ Goetz (1942), 11.

${ }^{446}$ Zie Brocke (1971), 191-192.

${ }^{447}$ Weigand (1992), 271.

${ }^{448}$ Goetz (1929-1933), I, [xvii].

${ }^{449}$ Van de 55 hoofdstukken kende het merendeel (35, waarvan 3 sterk religieus georiënteerde hoofdstukken over het (contra)reformatietijdperk) een geografische of chronologische afbakening; voor het overige waren er 9 gewijd aan sociaal-economische onderwerpen (incl. 3 over koloniale rijken en een over de ontdekkinsgreizen) en 7 aan de geistesgeschichte (ontstaan Christendom, kerk en pausdom, renaissance, Verlichting, classicisme en romantiek, geestesgeschiedenis 19de eeuw en rond 1900 - de 
meeste ruimte was daarbij gereserveerd voor de West-Europese ontwikkeling, maar daarnaast werden ook aparte hoofdstukken gewijd aan Oost-Europa, verschillende (pre-koloniale) Aziatische culturen (China, Japan, Indië, Nabije Oosten) en de islamitische wereld. Alleen aan Afrika (met uitzondering van Egypte) en precolumbiaans Amerika werd in deze wereldgeschiedenis weinig aandacht besteed. Ten opzichte van een vorige uitgave uit 1907-1910 had Goetz de ondertitel op een veelzeggende wijze veranderd. De oorspronkelijke volgorde 'staat en maatschappij' draaide hij om en hij verving 'Kultur und Geistesleben' door 'Wirtschaft und Geistesleben': 'cultuur' was in zijn ogen immers geen 'aspect' van het verleden, maar het alles overkoepelend begrip.

Uit de introducties die Goetz verzorgde voor elk deel en de slotbeschouwingen die hij in het laatste deel en na afsluiting van de reeks publiceerde, bleek opnieuw dat Goetz (in ieder geval op dat moment) dichter bij Lamprecht stond dan hij in 1910 publiekelijk had willen laten blijken. Goetz waagde zich nu zelfs aan algemene beschouwingen over het verloop van de historische ontwikkeling - ooit de grond voor de felste verwijten van veel vakhistorici tegen Lamprecht - en wees op 'wetmatigheden', 'herhaalde' en 'typische verschijnselen' in de geschiedenis. Al direct na zijn overname van het IKU had hij verklaard dat de historicus zich niet aan algemene geschiedfilosofische vragen kon onttrekken en dat de geschiedenis ook een begripswetenschap diende te zijn die zich niet door de sociologie en andere vakken de kaas van het brood moest laten eten. ${ }^{450} \mathrm{Nu}$ schreef Goetz: ${ }^{451}$

'Wereldgeschiedenis zonder geschiedfilosofie is onmogelijk, want zij is niet uitsluitend eeuwige ontwikkeling, maar ook de voortbrenging van typische verschijnselen, van herhaling van wat mensen teweegbrengen, ja van wetmatigheid, onder bepaalde voorwaarden die natuur of cultuur oproepen, nooit starre herhaling, maar ook nooit buiten de baan van een in het geheel genomen regelmatige ontwikkeling.'

De 'moderne gedachte van de ontwikkeling van de mensheid' moest geaccepteerd worden. Ongeacht of alle mensen van gemeenschappelijke voorouders afstamden of niet, 'in ieder geval doorloopt deze mensheid overal dezelfde of vergelijkbare cultuurstadia'. ${ }^{452}$ En voor deze ontwikkeling waren ongetwijfeld historische wetten vast te stellen, 'aangezien in de historische wereld altijd weer grote overeenkomsten optreden'. De creativiteit van de mens maakte het ondenkbaar dat dergelijke historische wetten ooit tot een simpele formule zouden zijn te reduceren,

'[m]aar een wetenschappelijke wereldgeschiedenis moet zich toch tot doel stellen vast te houden aan de regelmatigheden van de ontwikkeling van de mensheid en die wetten te vinden die ook de vrijheid van het individu bedwingen en die voor de ontwikkeling van de cultuur bepaalde stadia van vooruitgang en neergang betekenen'. ${ }^{453}$

Goetz was niet erg mededeelzaam over de aard van de cultuurontwikkeling, die hij uiteindelijk samenvatte als de Aufstieg van de wilde tot 'de cultuurmens van tegen-

beide laatste van de hand van Goetz zelf). De overige 4 behandelden geschiedfilosofische systemen, ras, geografie en de vroegste ontwikkeling van de mens.

${ }^{450}$ Zie Goetz (1916a), 277; Goetz vermeldde hier nog dat de 'geschiedfilosofie', waarvan hij het nut verdedigde, door Lamprecht 'Psychologie der Kulturentwicklung' was genoemd.

${ }^{451}$ Goetz (1934c), 285.

452 Goetz (1929-1933), I, [xxi]

${ }^{453}$ Goetz (1929-1933), I, xxiv. 
woordig' ${ }^{454}$ Duidelijk was wel dat hij overtuigd was van een vooruitgang van een 'lagere' naar een 'hogere' cultuur, zonder dat hij precies definieerde waarin dat 'hogere' en 'lagere' nu eigenlijk gelegen was. In zijn introducties tot de delen van de Propyläen-Weltgeschichte vinden we slechts verspreide opmerkingen daarover. Zoals dat hij 'de gang van elke opgaande cultuur' als een 'versterking van de krachten van het eenvoudigere naar het gecompliceerdere' beschouwde. ${ }^{45}$ En dit 'gecompliceerdere' betekende vooral een toegenomen pluraliteit; de negentiende eeuw, aan het einde van de Europese ontwikkeling, werd zodoende gekenmerkt door

'een vruchtbare verscheidenheid, die uit de voortgeschreden ontwikkeling van de Europese cultuur volgde. Uit de eenheid van de middeleeuwse cultuur bleek haar onderontwikkelde toestand; vanaf de dertiende eeuw betekende elke stap voorwaarts een vernietiging van deze eenvoudige eenheid en de opkomst van een verscheidenheid, die uit de toegenomen kennis van de natuur en de geschiedenis, uit de rijkere ontwikkeling van alle individuen en uit de verdieping van het Geistige in het algemeen ontstaan moest. Elke versterking [Steigerung] van cultuur betekent differentiatie [Verunterschiedlichung], toegenomen zelfstandigheid van het individu tegenover oude tradities en autoriteiten'. ${ }^{456}$

De late middeleeuwen vormden in deze ontwikkeling naar toegenomen pluraliteit een cruciale periode, en wel vanwege de opkomst van de steden en de geldeconomie: 'de stad was overal de basis van de vooruitgang [van de cultuur]'. Niet alleen was zij essentieel vanwege de daarvoor noodzakelijke welvaarststijging, zij alleen ook leverde de evenzeer nodige mogelijkheid tot 'geistige en artistieke uitwisseling en Umsatz'. Zo was 'uit sociale verschuivingen ook de culturele verandering voortgekomen'. ${ }^{457}$

De culturele differentiatie vond niet alleen plaats binnen de afzondelijke culturen, maar ook op het niveau van de mensheid als geheel: volgens Goetz was de mensheid vertrokken uit een 'primitieve eenheid' en had zich vervolgens 'versplinterd'. Daarmee doelde hij op het ontstaan van de diverse staten, naties en 'nationale culturen' in de loop van de geschiedenis. ${ }^{458}$ Hoewel Goetz nationale culturen als van elkaar onderscheiden 'individualiteiten' typeerde en het nationale element in een ontwikkeld Volkstum 'onvergankelijk, scheppend en richtingevend' noemde, legde hij de nadruk uiteindelijk bij het universele aspect in deze nationale culturen. Zuiver nationale culturen bestonden naar zijn overtuiging helemaal niet: voortdurend was er sprake van 'vreemde' invloeden - en zonder deze invloeden zou een nationale cultuur zich nooit verder ontwikkelen. De verheerlijking door sommige tijdgenoten van 'de gotische mens' - de Duitser van voor de 'on-Duitse invloed' van de renaissance - vond Goetz onverteerbaar. De enige uitspraak die hij over het wezen van de Duitse cultuur (en dan alleen vanaf de achttiende eeuw) durfde te doen, typeerde in feite Goetz' eigen houding: namelijk dat zij gekenmerkt werd door een drang naar het algemeen menselijke, en derhalve telkens boven al het nationale wilde uitstijgen, aus nationale Kultur Menschheitskultur. ${ }^{459}$ Uiteindelijk was het universele het bepalende en blijvende. En uiteindelijk keerde de mensheid weer terug naar zijn oorspronkelijke eenheid. Maar niet zonder ondertussen te zijn veranderd: de cultuur had zich al doende

\footnotetext{
${ }^{454}$ Goetz (1929-1933), I, xxii-xxiii.

${ }^{455}$ Zie Goetz (1929-1933), IV, [xxi].

${ }^{456}$ Goetz (1929-1933), VIII, [xix]-xx.

${ }^{457}$ Goetz (1929-1933), IV, xxiv-xxv.

${ }^{458}$ Goetz (1929-1933), I, [xxi], xxv; IV, xxiii; X, 525.

${ }^{459}$ Goetz (1919), 45, 51; vgl. ook al Goetz (1916b), 42-44.
} 
verder ontwikkeld en daarmee de 'krachten' en de verscheidenheid van de individuen versterkt.

Voor het slotdeel van de Propyläen Weltgeschichte schreef Goetz het laatste geistesgeschichtliche hoofdstuk in de hele reeks, waarin hij onder andere de wetenschappelijke ontwikkelingen direct vóór de wereldoorlog analyseerde. Slechts één historicus werd daarin met name genoemd (en afgebeeld) - en dat was Lamprecht. Bij alle kritiek die Goetz ook nu weer noemde - te schematisch, te natuurwetenschappelijk - werd Lamprecht door zijn opvolger geprezen vanwege zijn 'Bekenntnis zum Ganzen' en omdat hij de 'ontwikkelingsgedachte' in de geschiedschrijving opnieuw leven had ingeblazen. ${ }^{460}$ In een vrijwel gelijktijdig verschenen overzicht van de moderne historiografie dat Goetz voor de International Encyclopaedia of the Social Sciences schreef, stelde hij vast dat Lamprecht 'a source of stimulating suggestions for all historical research' werd. ${ }^{461}$ Zoals we hebben gezien, behoorde zeker ook Goetz zelf tot de geïnspireerde historici - en meer dan hij aanvankelijk in 1910, bij zijn eerste Bekenntnis tot de cultuurgeschiedenis, had willen toegeven. Het zouden derhalve zeer goed niet alleen strategische redenen kunnen zijn geweest waarom Lamprecht, die Goetz persoonlijk kende, vanaf het begin de nadruk legde op de overeenkomsten tussen diens opvattingen en zijn eigen ideeën en op een gegeven moment zelfs overwoog om zijn latere opvolger als medewerker naar het IKU te halen. ${ }^{462}$

\section{De panoramische blik en de psychologische ontwikkeling}

Toen de Duitse historicus Gerhard Oestreich in 1969 het eerste samenvattende artikel publiceerde over de nieuwe richtingen in de Duitse geschiedschrijving rond 1900, meende hij dat hun aard het best omschreven kon worden als 'sociale geschiedenis'. Oestreich verklaarde uitdrukkelijk dat het een 'semantische onnauwkeurigheid' was om het nieuwe historische onderzoek te typeren als 'cultuurgeschiedenis'. ${ }^{463}$ En hoewel er al direct kritiek kwam op deze voorstelling van zaken, hebben Duitse onderzoekers lange tijd de neiging getoond de nieuwe trends in de Duitse geschiedschrijving rond 1900 net als Oestreich te benoemen in de terminologie van de Historische Sozialwissenschaft die vanaf de jaren zeventig opbloeide. ${ }^{464}$ Historio-

${ }^{460}$ Goetz (1929-1933), X, 25.

${ }^{461}$ Goetz (1932a), 380. Vgl. in dit verband ook de milde typeringen van Lamprecht in Goetz (1957c) [1912]. Kritischer gestemd is een tot 1957 ongepubliceerde en ongedateerde (wellicht kort na Lamprechts dood geschreven) tekst: Goetz (1957d).

462 Goetz (1925), 162.

${ }^{463}$ Oestreich (1969), 326.

${ }^{464}$ Zie bijv. Iggers (1986), 235; Iggers meende t.a.p. zelfs dat Schäfers kritiek de 'sociale geschiedenis' (dus niet de cultuurgeschiedenis) gold. Ook Oestreichs leerling Vom Brocke (1971) verklaarde dat Lamprechts DG 'im Gewand seiner Kulturgeschichte' eigenlijk een 'sociale geschiedenis ' presenteerde (203); en de titel van Breysigs Kulturgeschichte der Neuzeit (1900) dekte naar Vom Brockes mening de inhoud evenmin: 'juister zou voor grote delen van het werk "sociale geschiedenis" zijn' (51). Met de vroege kritiek op Oestreichs rede doel ik op de (eerder gepubliceerde) treffende reactie van Nipperdey (1968). Nipperdey formuleerde hier o.a. een kritiek op de aard van de Duitse sociale geschiedenis in de jaren zestig: hij vroeg om een omvorming van de sociale geschiedenis in een historische antropologie en in die zin leek hem een sterkere aansluiting van de eigentijdse sociale geschiedenis bij onderdelen van de negentiende-eeuwse cultuurgeschiedenis aanbevelenswaardig, evenals de noodzaak van een sociaal-psychologische analyse. 
grafen als Rüsen en Jaeger verkondigden nog in de jaren negentig Oestreichs standpunt dat de uitdrukking 'cultuurgeschiedenis' voor de nieuwe historiografische ontwikkelingen misleidend was. ${ }^{465}$

Pas in het laatste decennium is er meer aandacht gekomen voor het specifiek cultuurhistorische karakter van de vernieuwingspogingen in de Duitse geschiedwetenschap rond $1900{ }^{466}$ En met recht, zoals uit het voorgaande duidelijk is geworden. Zoals Oestreich al had moeten toegeven, was Kulturgeschichte de term die tijdgenoten meestal gebruikten om de nieuwe richting in de geschiedwetenschap mee aan te duiden. En het was ook de naam die de voornaamste vertegenwoordigers van de nieuwe geschiedenis in Duitsland zelf gebruikten om hun benadering van de verleden mee te benoemen. De pogingen tot vernieuwing van de geschiedwetenschap in Duitsland in het tijdvak 1889-1915, van Gothein tot Goetz, werden zoals we hebben gezien, welbewust en met goede redenen onder de algemene noemer van 'cultuurgeschiedenis' ondernomen. Aan het eind van dit hoofdstuk, waarin de belangrijkste vertegenwoordigers van de nieuwe cultuurgeschiedenis de revue zijn gepasseeerd, is het mogelijk enkele algemene kenmerken van de nieuwe richting op te merken.

\subsection{De panoramische blik}

Misschien is het niet meer dan toeval dat een van de nieuwe Duitse cultuurhistorici een verre verwant was van de Duitse uitvinder van het panorama als kunstgenre, Johann Adam Breysig (1766-1831). ${ }^{467}$ In ieder geval werd de nieuwe Duitse cultuurgeschiedenis gekenmerkt door wat je met recht een 'panoramische blik' zou kunnen noemen. Typisch waren de alinea's waarmee Gothein zijn grote Culturentwicklung Süd-Italiens (1886) opende: in één rondgaande blik schilderde hij het uitzicht van de Gran Sasso over de zuidelijke helft van het Italiaanse schiereiland en introduceerde zo Land und Leuten. De panoramische blik was de uitdrukking van het verlangen naar een alomvattende visie op het verleden waaraan alleen een cultuurgeschiedenis kon voldoen. Zoals alleen al hun opsommingen van de deelaspecten van de cultuurgeschiedenis duidelijk maakten, was het de bedoeling van de Duitse cultuurhistorici om het historisch domein te verbreden tot een alles omvattende geschiedenis van de mens.

Het cultuurbegrip van de nieuwe Duitse cultuurhistorici behelsde derhalve aanmerkelijk meer dan 'Cultuur met hoofdletter $C$ ' en betrof in principe niet uitsluitend elitaire uitingen van kunst, wetenschap en literatuur (zelfs al beperkte met name Walter Goetz zich in de praktijk vaak wel tot deze cultuuruitingen). Van de economie tot de religie, van de kunsten tot zeden en gewoonten, van wetenschap tot demografie - er was geen levensterrein dat in hun visie op het verleden kon ontbreken. Zelfs de enkeling die, zoals Steinhausen in navolging van Bernheim, pleitte voor een 'cultuurgeschiedenis in engere zin' waarvan de politiek was uitgesloten, leek dit meer om taktische dan om principiële redenen te doen. Zoals het meest duidelijk naar voren kwam in de literatuurberichten van het vernieuwde Archiv für Kulturgeschichte (1910), was 'cultuur' voor de nieuwe cultuurhistorici een fenomeen dat op elk onder-

\footnotetext{
${ }^{465}$ Zie Jaeger en Rüsen (1992), 141: 'Der Begriff der "Kulturgeschichte" ist in diesem Zusamenhang mißverständlich, da es eher sozialhistorische Probleme und Fragestellungen waren' die Lamprecht aan de orde stelde.

${ }^{466}$ M.n. door werk van Schleier, Haas en Raphael, eerder al door Metz en Schorn-Schütte.

${ }^{467}$ Zie Oettermann (1980); J.A. Breysig was een broer van Kurt Breysigs overgrootvader (Brocke (1971), 19n). De verwantschap werd voor zover ik weet overigens niet door Breysig zelf opgemerkt. Maurer e.a. (2006), 592, signaleren naar aanleiding van een bezoek van Gothein aan een panorama de populariteit van deze kunststukken rond 1900.
} 
deel van het menselijk leven betrekking kon hebben: gesproken werd niet alleen van 'literaire en artistieke cultuur', maar ook van 'religieuze en ethische cultuur', van 'politieke cultuur' en 'sociale cultuur', en zelfs van 'economische cultuur' en 'technische cultuur'. Tot 'cultuur' rekenden de cultuurhistorici uitdrukkelijk ook 'materiële cultuur': techniek, economie, communicatiemiddelen. De tegenstelling tussen 'cultuur' als een innerlijke verworvenheid en 'civilisatie' als een uiterlijk fenomeen, die in Duitsland in bredere kring vooral na de Eerste Wereldoorlog weerklank vond, duikt ook dan pas - en slechts incidenteel - bij enkele cultuurhistorici op, met name bij Steinhausen en Goetz. ${ }^{468}$

Nadrukkelijk werd door de nieuwe cultuurhistorici opgemerkt dat zij met hun geschiedschrijving niet alleen zowel materiële als geestelijke cultuur wilden onderzoeken, maar ook de samenhang daarvan. Het streven was uitdrukkelijk gericht op, zoals Breysig het omschreef, de 'Vereinheitlichung des Geschichtsbildes' - niet alleen nodig om het gevarieerde cultuurhistorische materiaal met elkaar te verbinden, maar ook als reactie op het specialistisch detailonderzoek dat de historische wetenschap in haar algemeenheid steeds meer kenmerkte. Ook dat was kenmerkend voor de panoramische blik: niet alleen alle delen willen zien, maar het geheel. De nieuwe cultuurhistorici ging het niet louter om het onderzoeken van cultuurhistorische onderwerpen als aanvulling op het bestaand historisch onderzoek. De vernieuwers beschouwden cultuurgeschiedenis als een moderne, wetenschappelijk beter verantwoorde en meer bij de eigen tijd passende vorm van algemene geschiedenis. Daarmee keerden zij zich tegen de onder Duitse historici van hun tijd nog altijd wijd verbreide aanname dat 'de politiek' en in het bijzonder de beslissingen van staatslieden de belangrijkste dynamische factor in de geschiedenis vormden.

Voor het tekortschieten van de politieke geschiedenis als algemene geschiedenis voerden de cultuurhistorici expliciet of impliciet twee redenen aan: in de politieke geschiedenis bestond allereerst te weinig aandacht voor de sociale factor, voor de rol van de massa en de 'doorsneemens'. En verder werd in de politieke geschiedenis te weinig rekening gehouden met de invloed van andere 'cultuurfactoren': religie en kunsten, wetenschap en techniek, zeden en gewoonten, en niet in de laatste plaats: de economie. Steinhausen voelde goed aan dat het onttrekken van het primaat aan de politiek bij een belangrijke groep historici op onoverkomelijke weesrtand zou stuiten en bepleitte om die (strategische) reden een tweedeling van het historisch domein in politieke en cultuurgeschiedenis. En Goetz eerbiedigde het primaat van de politiek door de staat dan tenminste de belangrijkste cultuurfactor te noemen. De overige cultuurhistorici stelden onverbloemd dat de politieke geschiedenis slechts een onderdeel was van de cultuurgeschiedenis. Als pregnante uitdrukking daarvan werd het begrip 'politieke cultuur' in deze context geboren.

De panoramische blik van de cultuurhistorici kwam, zo paradoxaal als dat op het eerste gezicht mag lijken, zowel tot uitdrukking in een duidelijke belangstelling voor regionale geschiedenis als in een nieuwe nadruk op wereldgeschiedenis. In beide gevallen verloor de staat als historische eenheid aan betekenis. In de regionale geschiedenis kon de panoramische blik op het verleden de meest nauwkeurige invulling krijgen. In de programmatische introductie tot het nieuwe regionaal-

${ }^{468}$ Zie Fisch (1992); vgl. Labrie (1994). Het oprukken van de begrippentegenstelling is te demonstreren aan het laatste, eigentijdse hoofdstuk van Steinhausens Geschichte der Deutschen Kultur, waar ze pas in de tweede druk van 1913 (p. 487, 489) opduikt. In de eerste druk van 1904 ontbreekt 'Zivilisation' volgens het register nog en heeft S. het over 'ein ... Zeitalter äußerlich-materieller Kultur'. In de derde druk (1929) spreekt hij over '...Zivilisation im neuerdings oft betonten Gegensatz zur Kultur...' (656, mijn cursivering MS). Bij Goetz trof ik de tegenstelling aan in Goetz (1930b), xx. 
historische vakblad Deutsche Geschichtsblätter, waarbij zowel Lamprecht als Breysig betrokken waren, werd vastgesteld dat voor cultuurhistorisch onderzoek een 'verdieping in het lokale' wenselijk was. ${ }^{469}$ Tot de onderwerpen zonder uitdrukkelijke regionale component die hier aan de orde werden gesteld behoorden onder meer krijgsgeschiedenis, Verkehrsgeschichte, bevolkingsstatistiek, medizinische Kulturgeschichte, theatergeschiedenis, techniek- en wetenschapsgeschiedenis. Typisch was dat in dit tijdschrift een relatief groot aantal bijdragen dat specifiek aan diverse bronnencategorieën was gewijd: kerkelijke visitatierapporten, stadsplattegronden, kloosterrekeningen, reisbeschrijvingen bijvoorbeeld. Zo gauw niet alleen de politieke, maar ook de materiële en geestelijke ontwikkelingen onderwerp van de geschiedschrijving werden, kon alleen onderzoek van kleinere territoriale eenheden voor een stevig fundament zorgen, zoals Breysig ook al in 1892 had opgemerkt. ${ }^{470}$ De alomvattendheid van hun cultuurbegrip leidde derhalve samen met de wens deugdelijk historisch onderzoek af te leveren in eerste instantie tot een concentratie op kleinere territoriale eenheden. Het doel van dit regionaalhistorisch onderzoek was voor de meeste cultuurhistorici (de uitzondering is Steinhausen), echter uitdrukkelijk niet het lokaal of regionaal bijzondere. Het ging hen om het typische, het algemene of universele dat in de lokale geschiedenis tot uitdrukking kwam. Zoals Lamprecht het eens formuleerde: in het lokale kwam erst recht deutlich het universele te voorschijn. ${ }^{471}$ Het 'lokale' was slechts een middel om 'het universele' op het spoor te komen. Elders sprak Lamprecht over lokaal onderzoek als 'paradigmatisch'.

De panoramische blik van de cultuurhistorici, gericht op het overkoepelende en gemeenschappelijke, leidde hun belangstelling echter ook naar Weltgeschichte, Universalgeschichte, Menschheitsgeschichte. Zowel Lamprecht, Breysig als Goetz probeerden daadwerkelijk een dergelijke universele geschiedschrijving tot stand te brengen. Zowel bij Lamprecht als bij Breysig kreeg de Universalgeschichte het karakter van vergelijkend historisch onderzoek. Beiden onderzochten zowel westerse als niet-westerse culturen met de bedoeling om tot een vergelijking van nationale ontwikkelingen te komen. Een dergelijke internationale vergelijking noemde Lamprecht al in 1896 de 'nächste Aufgabe für eine Neubegründung weltgeschichtlichen Verständnisses,. ${ }^{472}$ Het doel was daarbij in eerste instantie om een algemeen type van nationale ontwikkelingen vast te stellen en vervolgens ook om een beter zicht te krijgen op nationale verschillen. Bij Goetz kreeg de wereldgeschiedenis een wat ander karakter: voor hem ging het erom de eenheid van de mensheidsgeschiedenis in zijn oorsprong en (nabije) toekomst te laten zien en de verschillende trajecten die de verschillende culturen en naties naar dat gemeenschappelijke einddoel hadden genomen.

\subsection{De toegang tot het verleden: kunst, statistiek, egodocumenten}

Zo breed als het cultuurbegrip van de nieuwe cultuurhistorici was, zo gevarieerd waren hun bronnen. Vooral kunstuitingen kregen veel aandacht van de cultuurhistorici. Zowel Lamprecht als Breysig en Goetz publiceerden kunsthistorische studies en baseerden hun cultuurgeschiedschrijving ten dele op de interpretatie van kunstwerken. Zoals Lamprecht opmerkte hadden beeldende bronnen als voordelen dat ze ook voor de oudste, schriftloze culturen beschikbaar waren, dat ze minder dan schriftuitingen aan het intellect en de logica gebonden waren en ook verbeelding en gemoed konden

\footnotetext{
${ }^{469}$ Geciteerd door Schorn-Schütte (1984b), 402

${ }^{470}$ Breysig (1900d), 5-6, Breysig citeert hier een eerdere publicatie uit 1892 .

${ }^{471}$ Geciteerd in Schorn-Schütte (1984b), 395.

${ }^{472}$ Lamprecht (1896/97), 100.
} 
weerspiegelen, en dat hun vormentaal makkelijker onderling was te vergelijken. ${ }^{473}$ Institutioneel het meest opvallende (maar overigens wel late) gevolg van de aandacht van de Duitse cultuurhistorici voor de kunst was de oprichting van het Duits Iconografisch Comité door historici binnen de Verband deutscher Historiker en de uitgave van het handboek Historische Bildkunde, beide onder invloed van Walter Goetz in het Interbellum.

Wat de interpretatie betreft, kan men zeggen dat de cultuurhistorici de kunsten in het algemeen niet bestudeerden als uiting van een bewuste artistieke intentie, maar als directe getuigen van psychisch onbewuste krachten: de zintuigen of driften. De beeldende kunst werd door hen beschouwd als een bron voor de geschiedenis van de blik, de muziek als een bron voor de geschiedenis van het oor, etc., zoals ze wetenschappelijke uitingen interpreteerden als getuigen van de ontwikkeling van het intellect. Dit perspectief leidde tot een grotere belangstelling voor de vorm dan voor de inhoud van de kunstwerken. Vooral bij Lamprecht was dit opvallend. Als mediëvist ging zijn aandacht al vroeg uit naar middeleeuwse decoratie en ornamentiek, de minst 'inhoudelijke' of ideeënrijke kunstuitingen. Maar ook als hij de muziek van een ideeënkunstenaar als Wagner analyseerde, trok Lamprecht meer conclusies uit diens muzikale vormentaal - ritme, harmonie, stemvoering - dan uit het verklankte verhaal of uit de opvattingen van de componist. Bijzonder was Lamprechts gebruik van kindertekeningen als historische bron: met de bedoeling zicht te krijgen op de vroegste ontwikkeling van de menselijke verbeelding èn op eventuele nationale variaties daarin, liet hij in de diverse landen volgens zijn voorschrift kindertekeningen maken en creëerde zodoende een nieuwe en eigentijdse, onderling goed vergelijkbare reeks bronnen ten behoeve van historisch onderzoek.

Lamprecht was verder de meest consequente gebruiker van een nieuwe categorie bronnen voor de cultuurgeschiedschrijving: de statistiek - een verdienste waarvoor hij in de eerste jaargang van Steinhausens Zeitschrift für Kulturgeschichte uitgebreid werd geprezen. Als het om economische fenomenen in engere zin ging (die immers ook tot de cultuurgeschiedenis gerekend werden), lag de betekenis van de statistiek voor de hand, maar Lamprecht gebruikte haar bijvoorbeeld ook om de mobiliteit van mensen in de eigen tijd te beschrijven (aantal gereisde kilometers per trein, aantal verhuizingen etc.). Bij andere cultuurhistorici, bijvoorbeeld bij Breysig, bleef het gebruik van statistische gegevens meer wens dan werkelijkheid, ${ }^{474}$ maar we treffen het bijvoorbeeld ook aan bij Goetz als hij het 'geestelijk leven' analyseerde door gebruik te maken van oplagecijfers van boeken en tijdschriften of als Steinhausen de groei van de stadsbevolking of de toename van het aantal kilometers Duits spoor met getallen documenteerde. ${ }^{475}$

Tenslotte valt op dat in de nieuwe cultuurgeschiedenis ook egodocumenten uitdrukkelijk aandacht kregen als bron voor de historicus. Hier was Steinhausen de belangrijkste initiator. Hij publiceerde niet alleen een geschiedenis van de brief, maar verzorgde en stimuleerde ook de uitgave van historische privé-brieven, dagboeken en reisverslagen. Daarbij richtte hij zich uitdrukkelijk op het in beeld brengen van (geletterde) doorsneemensen uit zoveel mogelijk lagen van de bevolking. In zijn tijdschrift verschenen naast talrijke bijdragen over historische reisverslagen en briefwisselingen ook enkele studies over de geschiedenis van de autobiografie, onder

\footnotetext{
${ }^{473}$ Lamprecht (1974), 648-449 [1909], Lamprecht (1913d), 125-130

${ }^{474}$ Zie hierboven paragraaf 4.4 , bij noot 369 .

${ }^{475}$ Zie o.a. Goetz (1916b), 31-39; Steinhausen (1931), 64.
} 
andere van de hand van een voormalige student van Lamprecht. ${ }^{476}$ Georg Misch, de Dilthey-leerling die in 1907 was begonnen met de publicatie van zijn grote Geschichte der Autobiographie, was in 1910 een van de door Steinhausen en Goetz aangezochte medewerkers van het vernieuwde Archiv om literatuurberichten over de geschiedenis van de persoonlijkheidsontwikkeling te gaan verzorgen. ${ }^{477}$

Voor het overige baseerden vooral Gothein en Goetz hun cultuurgeschiedschrijving in meer of mindere mate op literaire, filosofische, wetenschappelijke of artistieke producten van enkele uitzonderlijke individuen of groeperingen die zij niettemin representatief achtten voor een hele cultuur. Gothein had daarbij meer oog voor de betekenis en invloed van massabewegingen - bijvoorbeeld op het terrein van religie - en besteedde ook aandacht aan de receptie van 'hoge cultuur' in verschillende lagen van de bevolking. Bij Goetz was de sprong van de geanalyseerde hoge cultuur naar de algemene cultuur meestal het grootst - een sprong die hij verantwoordde door zijn nadruk op cultureel leiderschap - al besefte hij wel degelijk dat 'het literaire leven' op zichzelf te weinig inzicht bood in het ware karakter van een tijdperk en verbonden moest worden met kennis van politiek, economie en samenleving.

\subsection{Cultuurgeschiedenis als geschiedenis van de menselijke natuur}

Bij alle nieuwe cultuurhistorici kreeg het cultuurbegrip een psychologische invulling of een psychologisch fundament. Onder 'cultuur' werd een 'gezamenlijke psychische toestand' verstaan, een grondstemming 'die alle psychische verschijnselen van een tijd en daarmee alle historische gebeurtenissen doordringt', zoals Lamprecht het formuleerde. ${ }^{478}$ Cultuur betekende voor alle cultuurhistorici in wezen cultura animi, de cultivering van de ziel, zij het op een alles behalve klassieke wijze. Zij schreven cultuurgeschiedenis als een vorm van 'historische psychologie', als 'sociaalpsychologische geschiedschrijving', 'mensengeschiedenis', 'geschiedenis van de innerlijke mens', 'geschiedenis van de persoonlijkheidsvormen', 'geschiedenis van de Ichbildung'. Het ging in de nieuwe cultuurgeschiedenis niet om 'wie es eigentlich gewesen', maar 'wie die Menschen eigentlich gewesen', zoals Steinhausen het contrast met de rankeaanse geschiedschrijving puntig formuleerde. ${ }^{479}$ In de praktijk van hun geschiedschrijving ging de meeste aandacht uit naar de geschiedenis van het gemoed en het gevoelsleven enerzijds en de ontwikkeling van de perceptiewijzen anderzijds. Typische studies betroffen de volksreligiositeit (Gothein, Breysig), het natuurgevoel door de eeuwen heen (Goetz, Steinhausen, Breysig), de geschiedenis van het portretteren en waarnemen (Lamprecht, Goetz), van het individualisme en nervositeit (Lamprecht), van de familie en omgangsvormen (Gothein, Steinhausen, Breysig). Deze psychologische oriëntatie vormde het specifieke kenmerk van de Duitse cultuurgeschiedenis rond 1900 en onderscheidde haar van haar directe voorgangers. ${ }^{480}$

Er waren twee theoretische redenen die de cultuurhistorici zelf aanvoerden voor deze psychologische oriëntatie: ten eerste meenden zij zo in staat te zijn de veronderstelde eenheid van de geschiedenis te onderzoeken en te formuleren. De verschillende activiteiten van een individu als privé- en publiek persoon kwamen immers samen in zijn geest of psyche; zij stonden daar niet los van elkaar, maar werden er op een of

${ }^{476}$ Overigens was de dissertatie over dit onderwerp die de betreffende auteur, Adolf Rein, jaren daarvoor bij Lamprecht had geschreven door de andere historici van de Leipzigse faculteit afgewezen, zie Chickering (1993), 356.

${ }^{477}$ Steinhausen en [Goetz?] (1910), 2. Dit voornemen werd overigens niet gerealiseerd.

${ }^{478}$ Lamprecht (1900a), 26.

${ }^{479}$ Steinhausen (1895c), 195.

${ }^{480}$ Vgl. Hoofdstuk 6, paragraaf 1. 
andere manier gecoördineerd. Zoals het gedrag van een individu op verschillende terreinen in zijn samenhang begrepen kon worden door zijn karakter vast te stellen, zo kon ook in de geschiedenis de eenheid van een cultuur worden begrepen door het psychisch fundament ervan te analyseren. Daarmee hing een tweede overweging nauw samen: alleen de psychologische analyse kon een fundametele verklaring leveren voor historische gebeurtenissen. Aangezien alle handelen terug te voeren was op een psychisch proces kon alleen de psychologische analyse ook fundamenteel inzicht bieden in het historisch leven. Een geschiedschrijving die uitsluitend uiterlijke lotgevallen beschreef, verwisselde 'schil en kern' en bood de historisch geïnteresseerde tijdgenoot 'stenen voor brood', verkondigde Lamprecht. ${ }^{481}$

In het algemeen deelden de cultuurhistorici in dit opzicht de inzichten van hun generatiegenoot Simmel, naar wiens vroege geschiedfilosofisch werk verschillende onder hen ook verwezen. ${ }^{482}$ Net als de nieuwe cultuurhistorici legde Simmel de nadruk op het 'Charakter der Innerlichkeit der historischen Vorgänge': niet alleen het kennend subject (de historicus), maar ook de objecten waren 'zielen', de 'materie' van de geschiedwetenschap bestond uit het denken, willen en voelen van mensen. 'Soll die Geschichte nicht ein Marionettenspiel sein', schreef hij, 'so ist sie die Geschichte psychischer Vorgänge [...]'. Zoals Lamprecht meende dat het uiteindelijke object van de historicus nooit in uiterlijke lotgevallen ook niet van cultuurhistorische aard gelegen was, maar uitsluitend in de veranderingen van het collectieve Seelenleben, ${ }^{483}$ zo schreef Simmel dat de uiterlijke voorvallen van de geschiedenis slechts interesse en begrip opriepen voor zover ze verbonden waren met het innerlijk: ze kwamen uit 'Seelenbewegungen' voort en riepen 'Seelenbewegungen' op. Indien er een wettenstellende psychologie zou bestaan, dan zou de geschiedwetenschap een vorm van toegepaste psychologie zijn, meende Simmel, zoals op hun beurt Lamprecht en Gothein wel spraken over geschiedenis of de cultuurwetenschappen in het algemeen als 'angewandte' of 'abgeleitete Psychologie'. ${ }^{484}$

Bij veel van de nieuwe cultuurhistorici, niet alleen bij Lamprecht en Breysig, maar ook bij Steinhausen en Gothein, vinden we de uitgesproken verwachting dat de cultuurgeschiedenis wetenschappelijk dieper zou graven en beter verantwoord zou zijn dan de tot dan toe gebruikelijke geschiedschrijving. Steinhausen presenteerde de cultuurgeschiedenis in het eerste nummer van de Zeitschrift für Kulturgeschichte als een 'wetenschap van de toekomst' tegenover de 'altersschwache' concurrenten. ${ }^{485}$ Gothein verklaarde in zijn Aufgaben dat de cultuurgeschiedenis zich tot de politieke geschiedenis verhield als de fysica tot de natuurbeschrijving: alleen zij was analytisch van aard en drong pas werkelijk door tot de historische krachten achter de afzonderlijke historische gebeurtenissen. ${ }^{486}$ En ik memoreerde al Breysigs droom van een geschiedschrijving die met tabellen, getallen en afbeeldingen zou werken en scheikundige vormen zou aannemen. Typerend voor het sciëntisme van de nieuwe cultuurhistorici was dat zij zich allen uitdrukkelijk afkeerden van het in hun tijd

${ }^{481}$ Lamprecht (1903), 265.

${ }^{482}$ Breysig (1893); Lamprecht (1896/97), 80n1, 110n2, 136n2; Zowel Breysig als Gothein waren bevriend met Simmel. Over Gotheins vriendschap met Simmel schrijft Marie Luise Gothein: 'Was nun jetzt in diesen Jahren seines Lebens ihn so stark zur psychologisch-soziologischen Betrachtung hindrängte war [...] ein Mann [...]: Georg Simmel', Gothein (1931), 211-216, m.n. 211. Gothein maakte zich (tevergeefs) sterk om Simmel een hoogleraarspost in Heidelberg te bezorgen, zie Maurer (2006).

${ }^{483}$ Lamprecht (1974), 507 [1899].

${ }^{484}$ Simmel (1989), 303-304 [1892]; Lamprecht (1905a), 16; Gothein (1911), 247.

${ }^{485}$ Steinhausen (1894), 2.

${ }^{486} \mathrm{Zie}$ Gothein (1883), 1; Gothein (1889a), 11-17. 
opkomende anti-rationalisme en de estheticerende en individualiserende neo-romantische geschiedschrijving, onder andere in kringen rond de dichter Stefan George. ${ }^{487}$ Bij Breysig, die tot de bewonderaars van George behoorde, leidde dit meningsverschil uiteindelijk tot een pijnlijke breuk met de George-Kreis. ${ }^{488}$ En Gothein, wiens zoon Percy in George's ban was geraakt, schreef in 1918, nadat hij de recente hang van intellectuelen naar mystiek, 'beleving' en 'schouwen' als 'Rückfälle und Irrwege' had getypeerd: 'Het is wenselijk dat de strenge discipline van het natuurwetenschappelijke denken, dat feiten wil zien en voor elk van deze feiten het bewijs van zijn rechtstitel, niet $[\ldots]$ verloren gaat'. ${ }^{4} 9$

Erg veel verder ging 'de natuurwetenschappelijke benadering' van de nieuwe cultuurhistorici overigens niet. Ook Lamprecht erkende meer dan eens het onvermijdelijk artistieke aspect van de geschiedschrijving, dat naar zijn mening zelfs soms de historische complexiteit beter kon representeren dan met strikt wetenschappelijk middelen mogelijk was. ${ }^{490}$ Wel waren cultuurhistorici het er zonder uitzondering over eens dat geschiedwetenschappers ten behoeve van de geschiedschrijving moesten streven naar een wetenschappelijker begripsvorming - en dat wilde zeggen: ten eerste, een preciesere omschrijving en afbakening van de gebruikte begrippen en, ten tweede, de bewuste formulering van algemenere historische begrippen, die van toepassing konden worden geacht op een reeks historische voorvallen of personen. Zij allen pleitten in dit verband vooral voor een actievere onderzoek van 'het typische'; historische begrippen als 'het leenstelsel' of 'de geldeconomie' waren, in de woorden van Lamprecht, niets anders dan 'Abstraktionen des Typischen aus wiederholt vorgekommenen historische Erscheinungen'. ${ }^{491}$ De 'wetten' of beter 'regelmatigheden' die vooral Lamprecht en Breysig in de geschiedenis ontwaarden, presenteerden zij als uit de historische gegevens zelf afgeleide algemene hypothesen over delen of het geheel van het geschiedverloop. ${ }^{492}$

Ondanks de centrale betekenis die ze toekenden aan de psychologie, meende geen van hen - ook Lamprecht niet - dat de geschiedwetenschap niets anders behelsde dan het toepassen van 'psychologische wetmatigheden' op historisch materiaal. Hoogstens enkele zeer algemene psychologische inzichten (bijvoorbeeld over onderlinge wisselwerking van psychische vermogens of de verbanden tussen lichaam en psyche) werden met name door Lamprecht en Breysig in hun geschiedschrijving toegepast om historische processen te analyseren. Maar zowel Lamprecht als Breysig merkten

${ }^{487}$ Zie Lamprecht (1974), 509-522 [1900]; Goetz (1935). Voor Gothein, behalve het volgende citaat, de herinneringen van zijn zoon en George-volgeling Percy: Gothein (1952, (1956). Voor Breysig: Brocke (1971), 159-171, m.n. 166 ev. Voor Steinhausen: Steinhausen (1931), 432-436, 214-222.

${ }_{488}$ Zie Brocke (1971), 159-171; Breysig, Knoll en Landmann (1960), m.n. 65 e.v.

${ }^{489}$ Gothein (1918), 280; zie voor de gespannen verhouding tot George het getuigenis van Percy Gothein (1952), m.n. 7-11.

${ }^{490}$ Zie o.a. Lamprecht (1896/97), 92, Lamprecht (1900a), 30, 35, Lamprecht (1905a), $22,102$. Breysig neigde het meest naar het strikt scheiden van kunst en wetenschap, zie Breysig (1900a), o.a. 126-127, 176, 203 e.v., maar voegde in de praktijk wel weer uitgesproken artistieke elementen toe aan zijn geschiedschrijving, zie: Breysig (1907).

${ }^{491}$ Lamprecht (1900a), 23; Lamprecht legde meer dan eens de nadruk op het feit dat de geschiedschrijving altijd een artistiek element zou blijven houden, maar dat de wetenschappelijke vooruitgang in de preciesere formulering van (algemene) begrippen gelegen was, Lamprecht (1900a)30; Lamprecht (1974), 841 [1913].

${ }^{492}$ Vgl. bijv. Lamprecht (1988), 365, in zijn toespraak op het Internationale Congres van Historici in Berlijn (1908): ' ...Gesetze [over de psychologische ontwikkeling van de mensheid], die freilich nicht als metaphysisch gegebene starre Regeln dieser Entwicklung anzusehen seien. Vielmehr seien die geschichtswissenschaftlichen, wie alle wissenschaftlichten Gesetze nur als vorläufige Vermutungen einer hypothetischen Wahrheit zu verstehen [...]'. 
uitdrukkelijk op dat geen enkele bestaande psychologische theorie zonder meer overgenomen kon worden voor hun historische analyses. De reden hiervoor was duidelijk: gericht op de veranderingen in de collectieve psychologische kenmerken van mensen in het verleden en daarmee gefocust op de 'psychische distantie' tussen historische periodes en gemeenschappen, zou de toepassing van de statische en tijdloze wetenschappelijke psychologie uit hun eigen tijd onvermijdelijk tot anachronistische interpretaties leiden. Van alle nieuwe cultuurhistorici zijn in dit hoofdstuk uitspraken aangehaald waaruit blijkt dat ze ervan overtuigd waren de psychische dispositie of het psychisch functioneren van de mens in de loop van de tijd aan veranderingen onderhevig was. Zij verdedigden derhalve een historische psychologie waarbij de psychologie uiteindelijk ondergeschikt was aan en afgeleid werd uit historische kennis - en niet omgekeerd. De (cultuur)geschiedenis was de leidende discipline binnen de geestewetenschappen, meenden Gothein en Lamprecht expliciet. Het was een onhoudbare toestand, schreef Goetz na zijn overname van het IKU, dat terreinen die zonder twijfel tot de geschiedwetenschap behoorden (zoals het thema van de ontwikkeling van culturen) door buurwetenschappen als de Völkerpsychologie, de sociologie en de economie geheel aan haar waren onttrokken: het ging hier immers om vraagstukken die weliswaar van de historicus een sterkere begripsvorming vereisten dan hij gewoon was, maar 'die toch slechts met de onderzoeksmiddelen van de historicus tot hun laatste einde konden worden gevoerd' ${ }^{493}$

Aan de basis van de opvatting van geschiedenis als historische psychologie lagen twee verschillende en niet altijd met elkaar in overeenstemming gebrachte overtuigingen. Enerzijds legden alle cultuurhistorici, zelfs de verklaarde individualisten onder hen, veel nadruk op de cultuur als een sociaal product en de mens als een door of in wisselwerking met de omstandigheden gevormd wezen. Zoals Lamprecht deze sociologische aanname formuleerde: cultuur moest beschouwd worden als 'een product van de menselijke socialisering'. ${ }^{494}$ Anderzijds bleken de nieuwe cultuurhistorici zonder uitzondering gevoelig voor de gedachte van de mensheid als een zich zelfstandig tot volledige potentie ontwikkelend geheel. Volgens deze (quasi-) biologische aanname was 'cultuur' het cumulatieve en universele eindproduct van de ontwikkeling van de mensheid. Het fundamentele verschil tussen beide aannames betrof de uiteindelijke oorzaak van de gesignaleerde culturele en psychologische veranderingen: vormden sociale veranderingen (het meest genoemd werden welvaartsstijging en arbeidsdeling) de primaire oorzaken of was de psychologische ontwikkeling van de mensheid een autogeen proces van groei en verbetering? Beide overtuigingen komen we bij alle cultuurhistorici tegen, maar ze werden slechts zelden expliciet gecombineerd; een uitzondering was Lamprechts incidentele omschrijving van geschiedenis als 'een sociale biopsychologie'. ${ }^{495}$ En vrijwel nooit werden ze helder ten opzichte van elkaar afgebakend.

Wat de eerste, sociologische aanname betreft: de meeste nieuwe cultuurhistorici verhielden zich enigszins ambivalent ten opzichte van de gedachte dat de mens tot in zijn psychische dispositie door zijn (sociale en natuurlijke) omgeving werd gevormd. De overtuiging dat de aard van het individu sterk bepaald werd door de mensen met wie iemand verkeerde, door de activiteiten die iemand verrichtte, door de aard en de hoeveelheid van de boodschappen en prikkels die iemand bereikten werd het meest consequent uitgedragen en uitgewerkt door Lamprecht, die graag verwees naar de uitspraak van Dilthey dat de mens 'als door wanden' omgeven is door de historische

\footnotetext{
${ }^{493}$ Goetz (1916a), 277-278.

${ }^{494}$ Lamprecht (1896/97), 99.

${ }^{495}$ Lamprecht (1974), 599 [1904].
} 
omstandigheden, 'ook in zijn diepste betrekkingen'. ${ }^{496}$ Het heeft er alle schijn van dat dit niet alleen voor de tegenstanders van de cultuurgeschiedenis, maar ook voor de andere Duitse cultuurhistorici het meest omstreden punt was in Lamprechts opvattingen. Met name Breysig en Goetz waren anders dan Lamprecht niet bereid de vrije wil en creativiteit van het 'grote individu' als een sociaal product te beschouwen. Dat neemt echter niet weg dat ook zij voor de grote 'massa' van de bevolking uitgingen van een collectieve bepaaldheid en dat ook hun belangstelling vooral uitging naar collectieve verschijnselen. Niet toevallig behoorde niet alleen Lamprecht, maar ook Breysig tot de oprichters van de Deutsche Gesellschaft für Soziologie in 1909 en sprak Gothein op haar eerste congres in $1910 .^{497}$

Kenmerkend voor de sociologische aanname was de aandacht die de cultuurhistorici hadden voor de media, de geschiedenis van communicatiemiddelen en communicatiewijzen, van de groet en de brief (Steinhausen), tot boekhandel en perswezen (Lamprecht, Goetz), ${ }^{498}$ en - in de studies over de eigen tijd - trein en telefoon. De media beïnvloedden immers direct de onderlinge wisselwerkingen tussen individuen, die automatisch tot een gemiddeld mensentype leidden met eigenschappen die door velen gedeeld werden. De meningen over de precieze aard van de collectieve wisselwerkingen verschilden sterk per historicus. Volgens de verklaarde 'individualisten' Breysig en Goetz werd de grote massa van de mensen wezenlijk gevormd onder invloed van grote persoonlijkheden en door een fundamentele kuddegeest en imitatiedrift; Breysig legde daarbij in eerste instantie vooral de nadruk op het gemoedsleven, Goetz op de waarneming. Ook bij Lamprecht waren de 'prikkels' van buitenaf vooral van invloed op waarneming, bij Steinhausen ook op de zeden, terwijl bij Gothein de collectief gerecipieerde ideeën de beslissende historische krachten vormden. Dat de cultuurhistorici overtuigd waren van de sociale en historische aard van de mens wordt bevestigd door hun gemeenschappelijke reserves tegenover biologische rassentheorieën: het waren naar hun mening veelal geen biologische en aangeboren kenmerken die groepen mensen van elkaar onderscheidden, maar sociale en historische factoren. De vorming en hervorming van de menselijke vermogens onder invloed van historische en sociale factoren was wat de nieuwe cultuurhistorici verstonden onder 'cultuur' en de geschiedenis daarvan was 'cultuurgeschiedenis'.

Toch lieten de cultuurhistorici zich ook vaak door biologische of quasibiologische aannamen over de ontwikkeling van cultuur leiden: zij neigden ernaar de culturele ontwikkeling op te vatten als een autogeen groeiproces. De cultuurdrager was daarbij in principe de mensheid als geheel. Zelfs bij Steinhausen, voor wie de nationale aard uiteindelijk van doorslaggevende betekenis was in de cultuur-

${ }^{496}$ Zie Lamprecht (1974), 724 [1910].

${ }^{497}$ Zie Verhandlungen (1910), [V] (Statut) en 216-248.

${ }^{498}$ Lamprecht noemde de geschiedenis van de boekhandel 'recht eigentlich eine Materie, die in sich die Potenz zur kulturgeschichtlichen Darstellung birgt', Lamprecht (1974), 847 [1913].

Verschillende dissertaties onder zijn leiding betroffen de boekgeschiedenis, de geschiedenis van het vertalen, van de publieke opinie en de pers, zie Schönebaum (1955/56), B.I, nrs. 60, 111, 112, 113, 123, 124. Hij maakte deel uit van de commissie die aan zijn oud-student Johannes Goldfriedrich de opdracht gaf een Geschichte des deutschen Buchhandels (4 dln., 1886/1908-1913) (af) te schrijven. Volgens de hedendaagse boekhistoricus Mark Lehmstedt, de inleider van een recente digitale heruitgave (2000), 'eine fulminante Geschichte der Buchkultur im deutschen Sprachraum, ein Standardwerk, das als Ganzes bis heute durch nichts ersetzt worden ist und dem selbst weltweit nur die ein Jahrhundert später konzipierte und von Dutzenden Autoren verfaßte »Histoire de l'édition française« (1982/86) zur Seite gestellt werden kann.' [Einführung. Digitale Bibliothek Band 26: Geschichte des deutschen Buchwesens, S. 9] Zie ook Estermann (2005). Een Duitstalige cultuurhistoricus uit de jongere generatie met een duidelijke sociaalpsychologische belangstelling, de Weense ordinarius Wilhelm Bauer (18771953), zou bekend worden door grote studies over de geschiedenis van de publieke opinie $(1914,1930)$. 
ontwikkeling, zorgde de 'wereldcultuur' ten minste voor de dynamiek in de geschiedenis. Steinhausen gebruikte bovendien net als de andere cultuurhistorici formuleringen die de ontwikkeling van cultuur volgens een aantal vaste stadia, vooronderstelde. Bij Gothein en Steinhausen kreeg deze ontwikkeling overigens niet veel aandacht - al verdedigde Gothein uitdrukkelijk het gebruik van het Stufen-begrip. Maar bij Lamprecht, Breysig en zelfs bij Goetz bestonden meer uitgewerkte opvattingen over hoe de cultuur - en daarmee de psychische vermogens en attituden zich ontwikkelden. In het algemeen leken de nieuwe cultuurhistorici uit te gaan van een universele culturele ontwikkeling die leidde naar een grotere individualisering en naar een verdere differentiatie en verfijning van de psychische vermogens. Bij Breysig mondde de geschiedenis uit in een overwicht van de 'gebonden' krachten, gevoel en verstand (tegenover de 'vrije krachten' wil en verbeelding). Deze culturele ontwikkeling werd door de cultuurhistorici over het algemeen als een universele ontwikkeling beschouwd: de aandacht die naar nationale of regionale ontwikkelingen uitging was er doorgaans op gericht juist het universele element naar voren te halen. Verschillen in cultuur werden opgevat als verschillen in ontwikkelingstempo of ontwikkelingsstadium. In deze zin leidde hun opvatting van cultuurgeschiedenis hen als vanzelf naar 'universele geschiedenis', 'mensheidsgeschiedenis', 'wereldgeschiedenis'. Alleen Steinhausen benadrukte vooral de nationale betekenis van de verschillen in culturele ontwikkelingen.

In het algemeen kan worden vastgesteld dat de expliciete of impliciete duiding van de cultuurontwikkeling als een zelfstandig groeiproces van verbetering, verfijning en intensivering vaak de plaats innam van daadwerkelijk verklarende mechanismen. Daarmee is een belangrijke tekortkoming van deze cultuurgeschiedenis genoemd - ook volgens de maatstaven van de cultuurhistorici zelf. Want het zoeken naar diepgravende, oorzakelijke verklaringen in de geschiedenis was een expliciet doel geweest van de Duitse cultuurhistorici. Cultuurgeschiedenis diende volgens hen 'ontwikkelend' te zijn, en dat betekende dat een historische toestand daadwerkelijk als een productieve oorzaak voor de daaropvolgende toestand moest worden geanalyseerd (en niet slechts als de context van een bepaalde historische gebeurtenis). De overtuiging dat geen van de terreinen van het leven een voorrang boven een ander mocht worden toegekend en dat nu eenmaal alles met alles in verband stond en tot één geheel werd verbonden, verhinderde dat de cultuurhistorici zich op de analyse van specifieke deelterreinen concentreerden. De meest overtuigende delen van hun werk ontstonden echter als zij wel degelijk een analytische prioriteit toekenden aan een bepaald terrein zoals de economie en de rol daarvan voor arbeidsdeling en maatschappelijke orde maar deze opvatting werd zelfs door degenen die haar toepasten (en dat was met name Lamprecht) niet volmondig geaccepteerd.

Dat zijzelf dit probleem niet onderkenden, wijst er op dat we met een vooronderstelling van doen hebben die zij zelf voldoende verklarende kracht toekenden, maar die inmiddels aan het begin van de eenentwintigste eeuw veel van haar overtuigingskracht heeft verloren. Zij werd mooi verwoord door Gothein in de laatste regels van zijn Aufgaben der Kulturgeschichte: 'die Weltgeschichte erscheint ihr [nl. de cultuurgeschiedenis] als die gemeinsame Arbeit des Menschengeschlechts an seiner Vervollkommnung, ${ }^{499}$

${ }^{499}$ Gothein (1889a), 62. 


verzuchtte hij: ' $\mathrm{Nu}$ zal ik [...] deze oude politieke historici [...] laten zien dat ik historicus blijf, zij het ook onder een andere firma, die me slechts een grotere vrijheid van optreden garandeert'. ${ }^{1}$ Ook de andere cultuurhistorici, met uitzondering van Goetz, onderhielden een moeizame relatie met de historische discipline. Lamprecht kreeg bij herhaling van zijn critici te horen dat hij geen echte historicus (of zelfs helemaal geen serieuze wetenschapper) genoemd kon worden. Breysigs pogingen om in Berlijn tot ordinarius benoemd te worden, stuitten op het aanhoudende verzet van de historici in de faculteit. En Steinhausen verwierf pas helemaal aan het einde van zijn leven de universitaire functie, waartoe hij zich vanaf het begin geroepen voelde.

Toch zou het verkeerd zijn de cultuurhistorici eenzijdig als disciplinaire Außenseiter neer te zetten. ${ }^{2}$ De cultuurhistorici bevonden zich tegelijk binnen en buiten de historische discipline. Zij waren er in opgeleid, maar keerden zich ook tegen sommige heersende vaknormen; zij maakten deel uit van de historische discipline, maar werden tegelijk door vakgenoten voor niet-vakgenoten uitgemaakt. Om precieser te bepalen welke positie de cultuurhistorici binnen de historische discipline innamen en relevante verschillen met hun vakgenoten op het spoor te komen, zal ik in dit hoofdstuk onder andere een vergelijkend onderzoek uitvoeren naar de sociaal-culturele achtergrond, de 'onderwijscarrière' en de professionele carrière van de vijf leidende cultuurhistorici. De relevante gegevens over de vijf cultuurhistorici zullen daarbij worden afgezet tegen de gegevens over hoogleraren geschiedenis van hun generatie in het algemeen, zoals die zijn verzameld en geanalyseerd in het statistisch onderzoek van Wolfgang Weber. ${ }^{3}$ In een aantal gevallen zal ik bovendien een meer beperkte vergelijking maken met de belangrijkste critici van de nieuwe cultuurgeschiedenis, met name Georg von Below, Hans Delbrück, Heinrich Finke, Max Lenz, Friedrich Meinecke, Hermann Oncken, Felix Rachfahl, Dietrich Schäfer en Gustav Schnürer. ${ }^{4}$

In hoofdstuk 5 zal worden ingegaan op de verhouding van de nieuwe cultuurhistorici tot heersende opvattingen binnen de historische discipline. Hier gaat het eerder om de positie van de cultuurhistorici binnen de disciplinaire instituties. In het hoofdstuk zal blijken dat de nieuwe cultuurhistorici aanvankelijk, qua sociaal-culturele achtergrond en vroege intellectuele prestaties, tot die nieuwe leden van de discipline behoorden die het best toegerust leken om in de geschiedwetenschap een vooraanstaande rol te gaan spelen. Hoewel zij door latere tegenstanders met diskwalificaties als 'dilettant', 'ignorant' of 'onhistorisch' buiten de beroepsgroep werden geplaatst, blijkt uit de vroege carrière van de cultuurhistorici dat zij het historisch handwerk naar het

\footnotetext{
${ }^{1}$ Geciteerd in Gothein (1931), 66-67 (cursivering MS).

${ }^{2}$ In deze zin deel ik slechts gedeeltelijk de mening van Wolfgang Weber, op wiens onderzoeksgegevens ik mij hierna baseer. Zie voor Webers benadering: Weber (1984) en (gedeeltelijk identiek) Deutsch en Weber (1985).

${ }^{3}$ Weber $(1987 b)$.

${ }^{4}$ Zie het overzicht van de kritieken door Seifert (1925).
} 
aanvankelijke oordeel van de oudere vakgenoten snel en goed beheersten. Pas hun afwijkende meta-historische opvattingen - opvattingen over aard, onderwerp en benadering van de geschiedwetenschap - leidden tot het verwijt van onprofessionaliteit, dat opvallend vaak door jongere collega's met een minder exemplarische sociaalculturele achtergrond naar voren werd gebracht.

Ondanks de pogingen om de cultuurhistorici te marginaliseren en buiten de vakhistorie te plaatsen, bleven de nieuwe cultuurhistorici actief in de historische discipline. Om zich ten overstaan van het verzet van hun collega's te verzekeren van arbeids- en publicatieruimte waren de cultuurhistorici vaak betrokken bij de creatie van nieuwe disciplinaire instituties en organisatievormen en leverden daarmee, los van hun vakinhoudelijke vernieuwingsvoorstellen, substantiële en blijvende bijdragen aan de ontwikkeling van de historische discipline in Duitsland. Tegelijk zal duidelijk worden dat steun van buiten de historische discipline - met name van economen - daarbij een belangrijke rol speelde.

\section{Familieachtergrond en vroege scholing}

Hoe kwamen de cultuurhistorici tot hun vernieuwende opvatting van de geschiedenis? Het antwoord op die vraag moet beginnen bij het begin: bij de historische vorming die zij van huis uit of op school meekregen. Waren hun afwijkende manier om geschiedenis te schrijven en het verzet dat zij daarmee opriepen binnen de discipline, wellicht gerelateerd aan een (van andere historici) afwijkende sociaal-culturele achtergrond?

Duidelijk is in ieder geval dat de latere cultuurhistorici al vóór hun studietijd op een of andere manier met de geschiedwetenschap in aanraking waren gekomen. Eberhard Gothein groeide op als wees in het gezin van zijn oom, gymnasiumleraar Gustav Stenzel, zoon van een bekende collega en studievriend van Ranke, en getuigde zelf van de betekenis van deze omgeving voor zijn historische vorming. ${ }^{5}$ Karl Lamprecht, zoon van een in het Duitse idealisme geschoolde theoloog en predikant, werd in zijn studiekeuze sterk gestimuleerd door rector Wilhelm Herbst van de eliteschool van Schulpforta, die Lamprecht (net als eerder Ranke en Nietzsche) bezocht. ${ }^{6}$ Herbst was een historicus, leerling van Ranke en geen voorstander van een cultuurhistorische oriëntatie van het middelbaar geschiedenisonderwijs. ${ }^{7}$ De vader van Georg Steinhausen was zelf gymnasiumleraar en historicus, opgeleid door Ranke en Droysen, die bovendien Georgs peetoom was. ${ }^{8}$ Walter Goetz was de zoon van een politiek actieve arts, die al als scholier bevriend was geraakt met enkele in Verfassungsgeschichte geïnteresseerde geschiedenisstudenten en daardoor zijn studiekeuze liet bepalen. ${ }^{9}$ Ook Kurt Breysig,

\footnotetext{
${ }^{5}$ Zie Gothein (1931), 5-6. Gotheins vader stierf in 1861, zijn moeder in 1870.

${ }^{6}$ In zijn dissertatie, opgedragen aan zijn oude school, bedankt Lamprecht Herbst met de woorden dat deze 'zuerst den Sinn für geschichtliche Auffassung in ihm weckte', zie Lamprecht (1878), 'Vorwort'. Zie verder Schorn-Schütte (1984), 22; Chickering (1993), 15-17; over Herbst: Sproll (1978). Herbst steunde Lamprecht nog in het verwerven van zijn eerste betrekkingen, zie Schönebaum (1962), m.n. 385.

${ }^{7}$ Herbst keerde zich in een publicatie uit Lamprechts gymnasiumtijd (1869) expliciet tegen cultuurhistorisch onderwijs als 'die allerverfehlteste Methode', zie Bengel (1896), 34-35. Vgl. ook Erdmann (1978), 104. Lamprechts toenmalige waardering voor Herbst blijkt misschien uit het feit dat de afscheidsrede die hij bij het verlaten van het gymnasium schreef een lievelingsonderwerp van Herbst betrof: een episode uit Thucydides' Peloponnesische oorlog; zie Schönebaum (1955/56), 7 en Chickering (1993), 17.

${ }^{8}$ Steinhausen (1925), 235.

${ }^{9}$ Goetz (1957), 2; Weigand (1992), 19. Later zou Goetz overigens als schoonzoon van Moriz Ritter door nauwe persoonlijke relaties met diverse traditioneler georiënteerde geschiedwetenschappers worden verbonden
} 
wiens vader klassieke talen doceerde aan een gymnasium en verschillende wetenschappelijke edities op zijn naam had staan, was ongetwijfeld niet pas aan de universiteit met de geschiedwetenschap in aanraking zijn gekomen; in zijn herinneringen herleidt hij zijn liefde voor de geschiedenis tot zijn laatste schooljaren. ${ }^{10}$

Wat deze eerste gegevens al suggereren, wordt bevestigd door een nadere beschouwing: de latere cultuurhistorici waren qua maatschappelijke achtergrond typische Duitse Bildungsbürger. Dank zij het historisch-statistisch onderzoek van Wolfgang Weber naar de Duitse leerstoelhouders voor geschiedenis kunnen we dit oordeel verder preciseren: het sociaal-culturele profiel van de nieuwe cultuurhistorici kwam overeen met dat van een meerderheid van de Duitse hoogleraren geschiedenis van hun eigen generatie. ${ }^{11}$ Dat gold voor de regio en het stedelijk of landelijk milieu waarin ze opgroeiden, voor hun godsdienstige achtergrond, voor het beroep van hun vader en last but not least voor hun scholing.

Zo waren vier van de vijf cultuurhistorici afkomstig uit Pruisen, net als een kleine meerderheid $(56 \%)$ van de hoogleraren geschiedenis die tussen 1881 en 1910 in het Duitse Rijk werden benoemd; alleen Goetz was geboren in het koninkrijk Saksen. ${ }^{12}$ Alle cultuurhistorici groeiden op in noordelijk en oostelijk Duitsland, in een driehoek waarvan Berlijn het middelpunt was en die gemarkeerd werd door Erfurt in het zuidwesten, Breslau in zuidoosten en Greifswald in het noorden.

De cultuurhistorici brachten hun jeugd - of een substantieel deel daarvan - door in een urbaan milieu, dat wil zeggen in stadjes en steden van meer dan 10.000 inwoners net als een kleine meerderheid $(54 \%)$ van de latere hoogleraren geschiedenis die geboren werden tussen 1851 en $1880 .{ }^{13}$ Daarmee behoorden de cultuurhistorici tot een kleine minderheid van de Duitse bevolking: nog niet een op de zeven Duitsers leefde in 1871 in gemeenten van meer dan 10.000 inwoners. ${ }^{14}$ Van de cultuurhistorici had Lamprecht nog de meest landelijke achtergrond: hij werd geboren en groeide op in de Landstadt Jessen, voor hij in de Kleinstadt Wittenberg en later in Schulpforta bij Naumburg naar het gymnasium ging. In deze beide historische steden deed hij zijn eerste historische ervaringen op, zoals hij ten behoeve van een biografisch artikel eens aan Georg Winter vertelde: als gymnasiast raakte hij onder de indruk van de vele historische reminiscenties in de Lutherstad Wittenberg en de oude bisschopszetel

${ }^{10}$ Breysig (1962), 10.

${ }^{11}$ Zie Weber (1987b), m.n. 59-187.

${ }^{12}$ Gothein werd geboren in Silezië (hij noemt zich in Gothein (1889), 23-24 expliciet een Altpreuße, voor wie Preußens Größe van kindsbeen af een geloofsartikel was), Lamprecht in Pruisisch Saksen, Steinhausen in Brandenburg en Breysig in Westpruisen.

${ }^{13}$ In de Duitse statistieken werd vanaf 1871 een gemeente met meer dan 2000 inwoners als een stad aangeduid; bij minder dan 5000 inwoners sprak men van een Landstadt, bij meer dan 5000 inwoners van een Kleinstadt, bij meer dan 20.000 inwoners van een Mittelstadt en boven de 100.000 van een Großstadt. Gothein werd geboren in het kleine stadje Neumarkt (het huidige Środa Śląska bij Breslau), maar groeide op in het grote Breslau (1875: 239.050 inwoners); Goetz groeide op in Leipzig-Lindenau (Leipzig 1875: 127.387 inwoners). Breysig werd geboren in Posen (1875: 60.998 inwoners) en groeide op in Erfurt (1875: 48.030 inwoners), Steinhausen groeide op in Brandenburg aan de Havel (1875: 27.371 inwoners) en Greifswald (1875: 18.022 inwoners). Lamprechts geboorteplaats Jessen telde in 18612519 inwoners (bron: www.jessen.de); de steden waar hij zijn middelbare schooltijd doorbracht, Wittenberg en Naumburg, telden in 1875 respectievelijk 12.427 en 16.258 inwoners. Bron: Statistisches Jahrbuch für das Deutsche Reich. Berlijn, 1881, 3-5.

${ }^{14}$ Köllmann (1973), 245; Hohorst, Kocka en Ritter (1975-1978), II, 43; in 1871 leefde slechts 4,8\% van de Duitse bevolking (tegenover 30\% van de latere hoogleraren geschiedenis) in steden van meer dan 100.000 inwoners. Van de nieuwe cultuurhistorici groeiden Gothein en Goetz in dergelijke Großstädte op. 
Naumburg; de scholier kon het niet laten de eeuwenoude plaveisels van de Naumburger Dom aan een nadere inspectie te onderwerpen. ${ }^{15}$

Verder kwamen alle cultuurhistorici uit een protestants milieu, net als ongeveer $56 \%$ van de nieuw benoemde historici in 1890 (dat aandeel nam toe tot $68 \%$ in 1915). ${ }^{16}$ Gothein stamde uit een van oudsher joods geslacht, maar was zelf gedoopt. ${ }^{17}$ Ongeveer de helft van de vaders van de nieuw benoemde historici uit de periode 1890-1910 was academisch geschoold; voor de nieuwe cultuurhistorici gold dat voor alle vaders. Van de ouders van historici die tussen 1881 en 1910 benoemd werden tot hoogleraar, was de ene helft (afnemend van 55\% naar 37\%) werkzaam in industrie en handel (inclusief notarissen, advocaten en artsen), de andere helft (toenemend van 35\% naar 58\%) in dienst van kerk en staat (als ambtenaren, predikanten, (hoog-)leraren). Daarnaast was van dezelfde generatie historici een afnemend aandeel van 10 tot $5 \%$ van de vaders werkzaam in de landbouw. ${ }^{18}$ De ouders van de vijf cultuurhistori behoorden tot de eerste twee categorieën: twee vaders waren artsen en drie waren werkzaam als gymnasiumleraar of predikant. Daarmee waren alle cultuurhistorici afkomstig uit de bovenlaag van de Duitse samenleving, net als 67\% van de historici die tussen 18611920 tot ordinarius werden benoemd; daarvan was, net als bij de cultuurhistorici, 2/3 van de vaders in dienst van staat of kerk. ${ }^{19}$

Voor zover zij een Pruisische Volksschule hadden gevolgd, hadden de cultuurhistorici daar al geschiedenisonderwijs genoten. Bij dit lagere geschiedenisonderwijs lag de nadruk op de Duitse en vooral op de Pruisische geschiedenis. Het uitgesproken doel was om door middel van vertellingen over het volk en zijn heersers en Gods leidende hand de liefde voor God, koning en vaderland te stimuleren. Als methode werd aanbevolen om levens van epochemachende Männer centraal te stellen, anderzijds kon ook het kulturgeschichtliche aspect aan de orde komen. Nationale gedenkdagen - bijvoorbeeld Luthers geboorte- of sterfdag, de geboortedagen van Frederik Willem III en IV, de Völkerschlacht bij Leipzig - werden aangegrepen om het historisch onderwijs door het jaar te ordenen. ${ }^{20}$

De cultuurhistorici doorliepen net als vrijwel alle universitaire historici van hun generatie een humanistisch gymnasium, waarbij niet alleen Lamprecht, maar ook Goetz en Gothein een vooraanstaande instelling met een bovenregionale uitstraling bezochten. ${ }^{21}$ Het is wellicht overbodig te vermelden dat de cultuurhistorici door deze scholing tot een kleine en gepriviligieerde groep behoorden: terwijl in 1871 3,9 miljoen

${ }^{15}$ Aldus Winter (1898), m.n. 307-308.

${ }^{16}$ Het aantal joodse historici onder de nieuw benoemde hoogleraren nam eveneens toe: van $3 \%$ in 1894 tot $13 \%$ in 1915. Daarentegen daalde het aandeel van de katholieken onder de nieuw benoemde historici, dat sinds $1865(20 \%)$ was gestegen tot $41 \%$ in 1895 , vervolgens weer tot $19 \%$ in 1915 ; zie Weber (1987b), 85.

${ }^{17}$ Gotheins vrouw noemt hem in haar biografie 'der Protestante'. Bergsträsser (1964) duidt hem in de NDB aan als 'evangelisch'; hij vermeldt verder dat Gotheins vader zijn naam veranderde van Gottheiner in Gothein, hetgeen doet vermoeden dat Gothein's vader zich bekeerde tot het christendom; zo ook Maurer e.a. (2006), 1 en 582. In het naslagwerk Die Juden im deutschen Kulturbereich (Berlijn: Jüdischer Verlag, 1959) wordt Gothein overigens als een joodse wetenschapper beschouwd.

${ }^{18}$ Weber (1987b), 73.

${ }^{19}$ Weber (1987b), 76, volgens de indeling van D.K. Müller, Sozialstruktur und Schulsystem, Göttingen: 1977, 522-524.

${ }^{20}$ Zie Erdmann (1982), 78-84. In de periode 1854-1872 gold voor de Pruisische Volksschulen de zogenaamde Stiehlsche Regulative, daarna de nieuwe Allgemeine Bestimmungen. De genoemde kenmerken golden voor beide regelingen.

${ }^{21}$ Respectievelijk het Thomasgymnasium in Leipzig en het Magdalena-gymnasium in Breslau; net als Schulpforta telde het Leipzigse Thomasgymnasium een buitenproportioneel aantal latere hoogleraren geschiedenis onder zijn leerlingen, zie Weber (1987b), 95 en 100. 
Pruisische kinderen de lagere Volksschule bezochten (waarvan iets minder dan de helft meisjes), zaten er in hetzelfde jaar uitsluitend 120.000 jongens op hogere middelbare scholen, waarvan minder dan tweederde op het gymnasium. ${ }^{22}$ Met andere woorden: van een gemengde klas met 32 kinderen op de lagere school ging één jongen naar een hogere middelbare school; slechts twee jongens uit drie van dergelijke klassen gingen naar het gymnasium. ${ }^{23}$

De meeste cultuurhistorici herleidden hun historische belangstelling uitdrukkelijk tot hun middelbare schooltijd. De betekenis van het gymnasiaal historisch onderwijs werd door Lamprecht zelfs zo groot geacht dat hij de geistige Disposition van Ranke in essentie terugvoerde op het onderwijs dat deze, net als hijzelf, in Schulpforta had gevolgd. ${ }^{24}$ Op de hogere, middelbare scholen was de inzet van het historisch onderwijs, althans volgens de in Pruisen gepubliceerde leerplannen, nauwelijks anders dan op de Volksschule. Het aantal uren dat op humanistische gymnasia besteed werd aan geschiedenis was natuurlijk groter dan op de Volksschule en dat aantal nam nog toe in 1856 en opnieuw in 1882 . Verder ging aan de humanistische gymnasia begrijpelijkerwijs relatief meer aandacht uit naar de oude geschiedenis. Gedurende het hele gymnasium werd volgens de leerplannen de geschiedenis van de oudheid tot de eigen tijd tweemaal doorlopen, waarbij voor de middeleeuwse en nieuwe periode de Duitse geschiedenis centraal stond. Net als in de Volksschule was in het gymnasiaal historisch onderwijs de biografische methode favoriet, al werden cultuurhistorische elementen ook hier niet geheel uitgesloten. En tot in de jaren tachtig gold ook hier als uitdrukkelijk einddoel de opwekking tot de liefde voor vorst en vaderland en 'het geloof in een van hogerhand geleide ontwikkeling van de mensheid'. Daarnaast had het historisch onderwijs op het gymnasium tot doel het begrijpen van de eigen tijd en de ontwikkeling van het sittliche Gefühl en de Gesinnung, van moraal en overtuigingen van de scholier. ${ }^{25}$

$\mathrm{Al}$ met al kunnen we concluderen dat de latere cultuurhistorici door hun scholing en sociaal-culturele achtergrond deelden in de historische en culturele vorming die een meerderheid van de hoogleraren geschiedenis van hun generatie, en daarmee een kleine elite van het Duitse Bildungsbürgertum, eigen was. In deze vorming lag de nadruk, wat de Duitse geschiedenis betreft, op grote mannen en 'nationale' daden. De tijd dat cultuurgeschiedenis in het middelbaar onderwijs meer aandacht kreeg, was nog niet aangebroken.

Vergeleken met de ordinarii voor geschiedenis van hun generatie in het algemeen valt de homogeniteit van het sociaal-cultureel profiel van de cultuurhistorici op: zij waren allen protestants (zij het dat Gothein uit een joods geslacht stamde), geboren in Pruisen (op Goetz na), opgegroeid in voornamelijk middelgrote tot grote steden uit het noordoosten van het Duitse Keizerrijk, opgeleid aan ten dele gerenommeerde gymnasia, met academisch gevormde vaders, die als arts, gymnasiumleraar of predikant zonder uitzondering behoorden tot de maatschappelijke bovenlaag. De cultuurhistorici onderscheidden zich door hun familieachtergrond kortom niet van de meerderheid van hun collega-historici.

Dat gold opvallend genoeg wel voor een aantal belangrijke naar buiten tredende critici van de cultuurhistorici: onder hen vinden we meer afwijkingen van het ideaaltype

${ }^{22}$ Zie Hohorst, Kocka en Ritter (1975-1978),II, 157-159; in 1865 zaten van de ca. 1,9 miljoen 1120jarige jongens in Pruisen ca. 80.000 jongens (4,2\%) op hogere middelbare scholen, zie Hohorst, Kocka en Ritter (1975-1978), I, 31 en 226.

${ }^{23}$ Overigens was het onderwijs op de Volksschule alleen in dorpen en kleinere steden gemengd, zie Nipperdey (1990-1992), I, 561.

${ }^{24}$ Lamprecht (1896/97b), 49.

${ }^{25}$ Zie Erdmann (1982), 83. 
van de Duitse Bildungsbürger en van de meerderheid van de hoogleraren geschiedenis dan onder de uitgesproken cultuurhistorici. Zo waren Rachfahl, Schnürer en Finke katholiek, stamde zowel Finke als Dietrich Schäfer uit een voor Duitse historici uitzonderlijk armoedig milieu van keuterboeren respectievelijk arbeiders, en dreef Onckens vader een kunsthandel. Zelfs Below had als Junker een voor universitaire historici eerder atypische achtergrond. Dat juist historici met een afwijkende sociaalculturele achtergrond zich publiekelijk en uitdrukkelijk achter de professionele waarden van de gevestigde geschiedwetenschap plaatsten, zou voor deze groep toegeschreven kunnen worden aan de behoefte zich des te sterker als rechtgeaard lid van de discipline te willen profileren. ${ }^{26}$

Dat de persoonlijke achtergrond en met name de Gesinnung daadwerkelijk een rol speelde in de opname binnen de historische discipline, blijkt bijvoorbeeld uit het feit dat de net gepromoveerde Lamprecht in 1880 door zijn leermeester Von Noorden bij de directeur van het Pruisische staatsarchief Von Sybel niet alleen werd aanbevolen vanwege zijn intellectuele capaciteiten, maar ook als 'ganz protestantischer Preuße [...] zugleich mit braver monarchischer Gesinnung erfüllt'. ${ }^{27}$ Om bij dezelfde Sybel in aanmerking te kunnen komen voor een archiefbaantje werd de katholieke historicus Finke in 1882 eerst door een protestantse theoloog op eventuele ultramontaanse opvattingen onderzocht. ${ }^{28}$ En dat was dan na afloop van de Kulturkampf. Nog in 1896, in een reactie op een kritiek van Finke, voerde Lamprecht zelf de religieuze oriëntatie van zijn tegenstander aan als een bewijs van een onnationale houding en mankerend historisch bewustzijn. $^{29}$

Omgekeerd zouden we kunnen veronderstellen dat de cultuurhistorici door hun achtergrond weinig twijfels kenden over hun toekomst als lid van de historische Zunft en daardoor minder snel terugschrokken om af te wijken van de voor historici gebruikelijke paden. Tot die 'afwijkingen' kunnen we niet alleen hun dissidente geschiedopvattingen rekenen, maar bijvoorbeeld ook Gotheins interpretatie van Luther als 'revolutionair' (een interpretatie die hem naar verluidt een extraordinariaat in Breslau kostte) ${ }^{30}$ Breysigs publieke Nietzsche-verering en Goetz' vroege aansluiting bij de Nationalsoziale Verein rond Friedrich Naumann - een daad waarvoor de rector van de Leipzigse universiteit hem waarschuwde met de woorden: 'Tun Sie es nicht, bei uns werden Sie sonst nie etwas!' ${ }^{31}$ Duidelijk is in ieder geval dat er geen directe relatie is tussen de afwijkende vakhistorische opvattingen van de latere cultuurhistorici en hun

\footnotetext{
${ }^{26}$ Men kan zelfs vermoeden dat een dergelijk motief een rol heeft gespeeld in de nadruk waarmee de joodse historicus Ernst Bernheim $(* 1850)$ ondanks zijn affiniteit met de nieuwe cultuurgeschiedenis, voortdurend zijn disciplinaire (en morele) rechtgeaardheid naar voren bracht. Vgl. het 'Vorwort' van Bernheims Lehrbuch waarin hij zich distantieert van Lamprecht en expliciet waarschuwt tegen het gevaar van de 'sozialistisch-naturwissenschaftliche Auffassung im Zusammenhang mit den mächtigen materialistische Strömungen unserer Zeit' voor 'unsere Fachwissenschaft', Bernheim (1908), iii-iv. Door critici werden Bernheim en zijn voormalige leerling Lamprecht wel met elkaar geassocieerd, a.w., 717n2; voor een voorbeeld van een anti-semitische vakhistorische reactie tegen Bernheim, zie Chickering (1993), 99 n40.

${ }^{27}$ Geciteerd door Schönebaum (1962), 382.

${ }^{28}$ Zie Finke (1925), 99. Ook Goetz werd nog in 1886 als student nog door de historicus Maurenbrecher gewaarschuwd voor de 'ultramontaanse' opvattingen van een hoogleraar in München, zie Goetz (1957), 3.

${ }^{29}$ Zie Lamprecht (1896/97a), m.n. 269, 275. Ook een joodse geloofsovertuiging gold expliciet als argument tegen de benoeming tot ordinarius voor geschiedenis, zie bijv. Simon (1988), 92-96, over de carrière van Harry Bresslau in de jaren tachtig. Simon demonstreert t.a.p. aan de hand van veel benoemingszaken aan de Berlijnse faculteit dat de religieuze en politieke overtuiging niet zelden een rol speelden bij benoemingen en bevorderingen van historici.

${ }^{30}$ Zie hierboven, hoofdstuk 3, paragraaf 1 .

${ }^{31}$ Goetz (1957), 37.
} 
sociale en culturele achtergrond. Bij het begin van hun studie wees niets erop dat hun professionele integratie een probleem zou gaan worden. Op grond van hun familieachtergrond en schoolopleiding waren zij voorbeeldig toegerust om opgenomen te worden in de historische discipline.

\section{De universitaire geschiedenisopleiding}

Het sociaal-culturele milieu en de gymnasiale vorming van de latere cultuurhistorici stonden garant voor een vroeg contact met heersende opvattingen over het verleden. Een grondige kennismaking met de geschiedwetenschap volgde ná hun schooltijd aan een of meer van het twintigtal universitaire instellingen die het Keizerrijk aan het einde van de negentiende eeuw telde.

De keuze van de cultuurhistorici om geschiedenis te gaan studeren, paste in een algemene trend: het belang van geschiedenis als studie binnen de universiteiten nam in de tweede helft van de negentiende eeuw relatief en absoluut toe. Terwijl het totale aantal leerstoelen aan universiteiten in het Keizerrijk tussen 1864 en 1910 toenam van 723 naar 1236 (een toename van 70\%), lag de toename van het aantal historische ordi-

\section{Grafiek 4.1}

De ontwikkeling van het aantal leerstoelen geschiedenis in de Duitse landen die vanaf 1871 tot het Keizerrijk behoorden, 1840-1915.

Detail uit de grafiek opgenomen in Weber (1987b), 47. Horizontaal het jaar, verticaal het aantal leerstoelen. Rond 1970 (het eindpunt van Webers onderzoek) was het aantal hoogleraren in de BRD en DDR samen verder toegenomen tot zo'n 190.

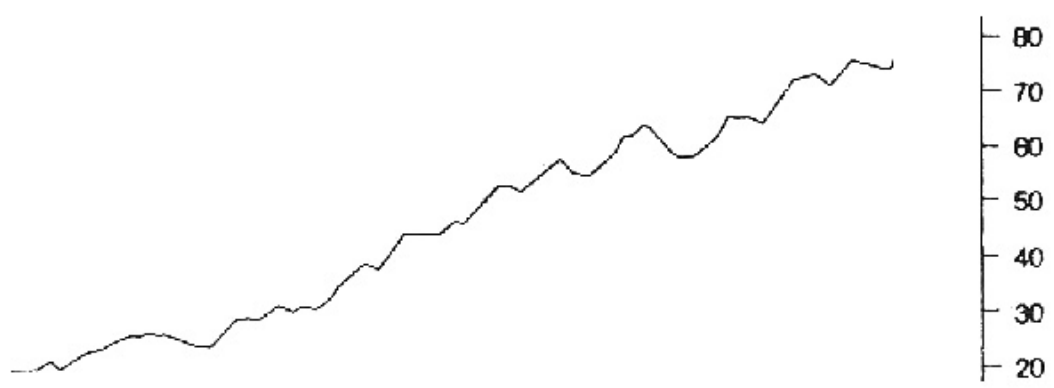

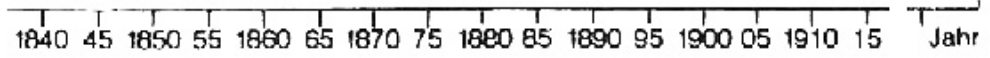


nariaten in dezelfde periode bijna tweemaal zo hoog, boven de $130 \%$ (van 32 naar 75 ). ${ }^{32}$ De directe reden daarvoor lag ongetwijfeld in de even sterke uitbreiding van het middelbaar onderwijs: de historische opleidingen aan de universiteiten leverden immers in de eerste plaats docenten geschiedenis voor de middelbare scholen af. ${ }^{33}$

Tabel 4.1

Aantal, verdeling en ontwikkeling van de leerstoelen voor geschiedenis aan universiteiten en hogescholen in het Keizerrijk, 1889-1914

Getallen afgeleid uit het overzicht van leerstoelen in Weber (1987b). Weber vermeldt overigens niet de in 1903 gestichte Königliche Akademie zu Posen (Poznan), waaraan sinds 1906 in ieder geval de (met Lamprecht gelieerde) historicus Gustav Buchholz als ordinarius doceerde.

\begin{tabular}{|c|c|c|c|c|c|}
\hline Bondsstaat & Instelling & \multicolumn{2}{|c|}{1889} & \multicolumn{2}{|c|}{$1914^{*}$} \\
\hline Baden & U Freiburg i.B. & 2 & \multirow{2}{*}{$\begin{array}{l}4 \\
(7 \%)\end{array}$} & 4 & \multirow{2}{*}{$\begin{array}{l}7 \\
(9 \%)\end{array}$} \\
\hline Baden & U Heidelberg & 2 & & 3 & \\
\hline Beieren & U Erlangen & 2 & \multirow{4}{*}{$\begin{array}{l}7 \\
(12 \%)\end{array}$} & 2 & \multirow{4}{*}{$\begin{array}{l}10 \\
(13 \%)\end{array}$} \\
\hline Beieren & U München & 2 & & 4 & \\
\hline Beieren & U Würzburg & 2 & & 3 & \\
\hline Beieren & TH München & 1 & & 1 & \\
\hline Hessen & U Gießen & 2 & 2 & 3 & 3 \\
\hline Mecklenburg-Schw. & U Rostock & 1 & 1 & 2 & 2 \\
\hline Pruisen & U Berlijn & 5 & \multirow{12}{*}{$\begin{array}{l}32 \\
(55 \%)\end{array}$} & 8 & \multirow{12}{*}{$\begin{array}{l}41 \\
(53 \%)\end{array}$} \\
\hline Pruisen & U Bonn & 4 & & 4 & \\
\hline Pruisen & U Breslau & 4 & & 4 & \\
\hline Pruisen & U Göttingen & 4 & & 3 & \\
\hline Pruisen & U Greifswald & 3 & & 3 & \\
\hline Pruisen & U Halle-Wittenberg & 3 & & 3 & \\
\hline Pruisen & U Kiel & 2 & & 3 & \\
\hline Pruisen & U Königsberg & 2 & & 3 & \\
\hline Pruisen & U Marburg & 3 & & 3 & \\
\hline Pruisen & U Münster** & 2 & & 4 & \\
\hline Pruisen & TH Danzig & 0 & & 1 & \\
\hline Pruisen & U Frankfurt a.M. & 0 & & 2 & \\
\hline Rijksland Elzas-Loth. & U Straatsburg & 2 & 2 & 3 & 3 \\
\hline Rijk? & $D U$ Dorpat*** & 2 & 2 & 0 & 0 \\
\hline Kon. Saksen & U Leipzig & 3 & \multirow{2}{*}{4} & 4 & \multirow{2}{*}{5} \\
\hline Kon. Saksen & TH Dresden & 1 & & 1 & \\
\hline Saksen-Weimar & U Jena & 2 & 2 & 2 & 2 \\
\hline Württemberg & U Tübingen & 2 & 2 & 3 & 3 \\
\hline \multirow[t]{2}{*}{ Hamburg } & U Hamburg & 0 & 0 & 2 & 2 \\
\hline & Totaal & & 58 & & 78 \\
\hline
\end{tabular}

*Ik heb 1914 (en niet 1915) als eindpunt gekozen, om eventuele oorlogsinvloeden op de leerstoelbezetting buiten beschouwing te laten.

${ }^{* *}$ Akademie met universitaire status en promotierecht, pas in 1902 formeel betiteld als universiteit. ${ }^{\star * \star}$ Aan de Deutsche Universität in Dorpat (tegenwoordig Tartu, Estland) werd volgens de gegevens van Weber na 1900 geen historische leerstoel meer bezet, met uitzondering van het jaar 1918.

${ }^{32}$ Algemene cijfers ontleend aan Nipperdey (1990-1992), I, 569. Voor de ontwikkeling van het aantal historische leerstoelen, zie Grafiek 4.1.

${ }^{33}$ Het aantal leerlingen op middelbare scholen in Pruisen nam van 1873 tot 1914 toe met 127\% (1873: 106.000 - 1914: 241.000). Zie Nipperdey (1990-1992), I, 554. Bovendien nam ook het aantal uren geschiedenis dat daar gegeven werd in deze periode nog enigszins toe. 
In de jaren zeventig en tachtig, de studiejaren van de cultuurhistorici, was er sprake van een getalsmatig sterk expanderende discipline: gemiddeld gesproken kwam er elk jaar één nieuwe historische leerstoel bij - tweemaal zoveel als gemiddeld in de eerste helft van de negentiende eeuw. In het decennium volgend op de Reichsgründung werden zelfs niet minder dan zestien nieuwe leerstoelen geschapen. De universiteit van Berlijn herbergde het grootste aantal hooggeleerde historici: in 1889 hielden zij vijf leerstoelen bezet. De universiteiten van Bonn, Göttingen en Breslau volgden in dat jaar met elk vier historische ordinariaten, de universiteiten van Marburg, Greifswald, HalleWittenberg en - als eerste niet-Pruisische universiteit - Leipzig met elk drie; veruit de meeste universiteiten hadden er in 1889 twee, een enkele instelling slechts een. ${ }^{34}$ Het aantal historische leerstoelen dat een universiteit onderhield, correspondeerde niet per se met de grootte van de universiteit: de universiteit van München had bijvoorbeeld in 1892 op ongeveer 325 studenten filosofie, filologie en geschiedenis slechts twee historische leerstoelen, terwijl de veel kleinere universiteit van Marburg met ongeveer 124 studenten in deze studierichtingen drie historische ordinariaten kende. ${ }^{35}$

De universiteiten waar de latere cultuurhistorici hun opleiding genoten, kunnen in vrijwel alle gevallen (en zeker waar het ging om Berlijn, Göttingen en Breslau) tot de grotere centra van het universitair historisch onderwijs in hun tijd worden gerekend: Breysig studeerde voornamelijk in Berlijn en korte tijd in Tübingen, Steinhausen korte tijd in Berlijn en hoofdzakelijk in Greifswald, Gothein in Breslau en Heidelberg, Lamprecht in Göttingen, Leipzig en (postdoctoraal) in München, Goetz eveneens in Leipzig en München, en bovendien korte tijd in Freiburg. ${ }^{36}$

Het sterk groeiend aantal historische hoogleraren in de jaren zeventig en tachtig ging gepaard met een opdeling van het leerstofgebied van de afzonderlijke historische leerstoelen. Rond 1890 was de geleidelijke opsplitsing van de oude leerstoelen voor algemene geschiedenis in afzonderlijke leerstoelen voor oude, middeleeuwse en nieuwe geschiedenis aan de meeste universiteiten een feit. ${ }^{37}$ Middeleeuwse en nieuwe geschiedenis werden nog wel eens gecombineerd in een enkele leerstoel, oude geschiedenis was duidelijk een vak apart.

Het universitair geschiedenisonderwijs expandeerde nier alleen getalsmatig in de jaren zeventig en tachtig, maar werd tegelijk ook intensiever: het was de periode dat aan alle historische opleidingen in het Keizerrijk historische Seminare werden ingericht. Het Seminar was een met een leerstoel verbonden universitaire institutie met een eigen begroting, waaruit een bibliotheek en aparte onderwijsruimten werden bekostigd. Op enkele uitzonderingen na (Königsberg, Greifswald, Breslau) werden dergelijke historische Seminare pas na 1848 aan de Duitse universiteiten ingericht. ${ }^{38}$ Net als dat het geval was met het aantal ordinariaten betekende ook hier de Reichsgründung een versnelling in de ontwikkeling van de discipline: tien van de achttien historische Seminare die in de tweede helft van de negentiende eeuw werden ingericht, ontstonden in de jaren zeventig. Alle latere cultuurhistorici waren opgeleid aan dergelijke historische seminaria: in Berlijn (Breysig), Breslau (Gothein), Greifswald (Steinhausen), Göttingen (Lamprecht), Leipzig (Lamprecht, Goetz) en München (Goetz). Met de inrichting van een historisch seminarium aan de universiteiten van Göttingen en Leipzig tijdens Lamprechts studie aldaar (in respectievelijk 1876 en 1877), behoorden deze

\footnotetext{
${ }^{34}$ Zie Tabel 4.1.

${ }^{35}$ Studentenaantallen volgens Lexis (1893), 618.

${ }^{36}$ Gothein, de oudste van de vijf, studeerde van 1872 tot 1877 , Lamprecht van 1874 tot 1878 , Steinhausen van 1883 tot 1887 , Breysig van 1884 tot 1888 en Goetz van 1886 tot 1890 .

${ }^{37}$ Zie Engel (1959), 340 e.v.

${ }^{38}$ Zie m.n. voor de vroegste geschiedenis van de historische seminaria: Pandel (1994).
} 
opleidingen in feite tot de latere Duitse instellingen waar een dergelijke voorziening werd getroffen. ${ }^{39}$

Het historische Seminar betekende vanuit disciplinair oogpunt een belangrijke vernieuwing van het universitair historisch onderwijs en zou later in andere landen naar Duits voorbeeld worden overgenomen. ${ }^{40}$ Vóór de instelling van de Seminare waren in het universitair historisch onderwijs uitsluitend hoorcolleges gebruikelijk, de Vorlesungen, met hun kenmerkende eenrichtingsverkeer tussen docent en student. Deze onderwijsvorm was beter geschikt voor het overbrengen van kennis en opinies dan voor het aanleren van vaardigheden. Juist dat laatste werd echter, vooral sinds Ranke zijn studenten ging opleiden in de 'historisch-kritische methode', een belangrijk onderdeel van de historische studie. Om deze vaardigheden te oefenen werden door Ranke kleinschalige werkcolleges, de zogenaamde Übungen, ingevoerd waarbij gezamenlijk werkstukken en bronnen werden besproken. Hier werden de studenten de rankeaanse waarden van Kritik, Präcision, Penetration ingeprent. ${ }^{41}$ 'Wij leerden op deze wijze het handwerk van onze wetenschap vanaf de basis', beschreef Breysig zijn ervaring met dergelijke Seminarübungen. ${ }^{42}$ Het ging daarbij om het opsporen, de kritische analyse en de interpretatie van historische bronnen. Hier was niet alleen de docent aan het woord maar moesten ook de studenten zelf optreden als historici-in-opleiding. Van deze werkgroepen ging uit de aard der zaak - door het nauwere contact met de docent, doordat er actief geoefend in plaats van passief gerecipieerd werd, en door het corrigerende optreden van de docent - een sterkere disciplinerende werking uit dan van de hoorcolleges. ${ }^{43}$ En dat was ook uitdrukkelijk de bedoeling, zoals de hooggeleerde vakreferent voor de Duitse geschiedwetenschap op de wereldtentoonstelling van 1893 duidelijk maakte toen hij het nut van de Seminarübungen aan de buitenwereld presenteerde: veel meer dan in de hoorcolleges was de docent hier in de gelegenheid 'op de wetenschappelijke en geestelijke Bildungsgang [van zijn studenten] invloed uit te oefenen'. ${ }^{44}$

Afgaande op een aantal algemene gegevens over hun opleiding moeten de latere cultuurhistorici hun vakhistorische opleiding met succes hebben gevolgd. ${ }^{45} \mathrm{Zij}$ waren bovengemiddelde studenten die zich qua studieresultaten niet, of slechts in positieve zin, onderscheidden van andere studenten die later ordinarius voor geschiedenis zouden

${ }^{39}$ Volgens de verspreide gegevens uit 1904 in Lexis (1904) zijn de oprichtingsdata van de Historische Seminare aan de Duitse universiteiten als volgt: Königsberg 1832, Greifswald <1839, Breslau 1843, München 1857, Würzburg 1857, Bonn 1861, Marburg <1865, Rostock 1865, Freiburg 1870, Erlangen, Kiel, Straatsburg, 1872, Gießen 1873, Tübingen 1875, Göttingen 1876, Leipzig 1877, Münster 1878, Jena 1879, Berlijn 1883 (!), Heidelberg 1890 (Halle-Wittenberg: niet vermeld, in ieder geval $<1893$, waarschijnlijk 1875, zie Blanke (1994), 157). Het gaat hier om met overheidsgelden gesteunde instellingen; Seminare georganiseerd op persoonlijk inititatief van ordinarii en meestal bij hun thuis gehouden, bestonden vaak lang voor de inrichting van een officieel Seminar. Het bekendste en meest invloedrijke voorbeeld van een dergelijk ongefinancierd Seminar zijn de onderwijsgroepen die Ranke vanaf 1825 in Berlijn organiseerde. Zie ook Heimpel (1959), 140-143 en Blanke (1994), 155-161.

${ }^{40}$ Vgl. Werner (1992).

${ }^{41}$ De woorden van Ranke, aangehaald door diens voormalige student en latere hoogleraar Arndt in Bericht (1893), 14-15.

${ }^{42}$ Breysig (1962), 14, naar aanleiding van de Seminarübungen van zijn docent Koser.

${ }^{43}$ De behoefte van de vakhistorici om meer zicht te krijgen op de houding van hun studenten blijkt op een aardige wijze uit de aanbeveling van Lamprecht aan de verzamelde historici op de eerste Duitse Historikertag (1893) om na de Seminarübung met de studenten het Bierhaus te bezoeken 'da sich die deutsche Zunge erst löst, wenn sie begossen wird.' Zie Bericht (1893), 8.

${ }^{44}$ Lindner (1893) in Lexis (1893), 560-561: doel van de Übungen was meestal 'Einführung in die Methode', hier lag het zwaartepunt van de 'strengwissenschaftliche Ausbildung'.

${ }^{45}$ In het volgende hoofdstuk zal nader worden ingegaan op de inhoud van het universitair historisch onderwijs dat de cultuurhistorici volgden. 
worden. Net als de meeste latere ordinarii van hun generatie promoveerden de cultuurhistorici 4 tot 5 jaar na het begin van hun studie. Breysig legde het doctorexamen 'cum laude' af, Gothein zelfs 'summa cum laude', Lamprechts examen en dissertatie kregen de beoordeling 'sehr gut'. ${ }^{46}$ De promotieleeftijd lag voor de latere ordinarii gemiddeld op 23 jaar; van de cultuurhistorici was alleen Gothein een jaar ouder bij zijn promotie, Breysig en Steinhausen waren respectievelijk één en twee jaar jonger. ${ }^{47}$

Overigens wijst de vergelijking met hun peer group in een ander opzicht wel op een veelbetekenende afwijking in de universitaire opleiding van de cultuurhistorici. Zij heeft niet met de snelheid of de resultaten maar met de inhoud van hun studie te maken. Uit gegevens van Wolfgang Weber blijkt dat van de hoogleraren geschiedenis die tussen 1851 en 1900 aantraden bijna tweederde filologie als bijvak of zelfs als hoofdstudie had gekozen. ${ }^{48}$ Van de vijf woordvoerders van de nieuwe cultuurgeschiedenis koos echter alleen Steinhausen filologie als bijvak. De vier andere cultuurhistorici studeerden, naast geschiedenis, Nationalökonomie (hoewel Gothein daarin uiteindelijk niet officieel afstudeerde), net als slechts 16\% van alle hoogleraren geschiedenis die tussen 1851 en 1900 werden benoemd. ${ }^{49}$ Ook onder de uitgesproken critici van de nieuwe cultuurgeschiedenis studeerde slechts een enkeling (Rachfahl) naast geschiedenis af in Nationalökonomie; Schäfer, Below, Meinecke, Oncken, Finke, Lenz, Schnürer en zelfs Hintze kozen officieel voor filologische of filosofische bijvakken. ${ }^{50}$ Zoals verderop in dit hoofdstuk en later in deze studie nog zal blijken moet deze studiekeuze van grote betekenis worden geacht voor zowel de carrière als de intellectuele ontwikkeling van de cultuurhistorici. $^{51}$

\section{Vroege academische carrière}

De vijf cultuurhistorici sloegen allemaal het pad in naar een academische carrière. Zij verwierven vroeg of laat ook allemaal een hoogleraarstitel en een leeropdracht aan een universiteit. In de meeste gevallen is er ook een duidelijk 'breekpunt' in hun loopbaan vast te stellen: na een in het algemeen voortvarend begin, leidde hun kritiek op

\footnotetext{
${ }^{46}$ Zie Gothein (1931), 26; Schorn-Schütte (1984), 33 en 39. Breysigs dissertatie werd als 'industriae et acuminis documentum eximium' beoordeeld en zijn Habilitationsschrift als 'ausgezeichnet' gekwalificeerd, zie Brocke (1971), 22-24. Goetz kreeg voor dissertatie en examen het cijfer 'IIa'; zijn habilitatie werd beoordeeld als 'im allgemeinen gut', zie Weigand (1992), 28 en 50. Over Steinhausen heb ik geen gegevens.

${ }^{47}$ Weber (1987b), 118.

${ }^{48}$ Weber (1987b), 110 en 113.

${ }^{49}$ Weber geeft geen preciezere gegevens dan voor alle hoogleraren geschiedenis die aantraden tussen 1851 en 1900, zodat niet duidelijk is of onder de hoogleraren geschiedenis van hun eigen generatie dit percentage misschien iets hoger ligt. Het gaat in totaal tussen 1851 en 1900 om 24 personen die Nationalökonomie of Staatswissenschaften als hoofd- of bijvak hadden gestudeerd. Weber wijst er bovendien op dat de gegevens over de studievakken niet altijd eenduidig of volledig zijn.

${ }^{50}$ Volgens de gegevens in Weber (1987a).

${ }^{51}$ Zie hierna paragraaf 5 en Hoofdstuk 6, paragraaf 4. Even opvallend, maar minder goed statistisch verwerkbaar en vergelijkbaar, is de (vroege) preoccupatie van veel nieuwe cultuurhistorici met de kunstgeschiedenis - een vak dat slechts door een enkele latere hoogleraar geschiedenis van hun generatie als bijvak werd gekozen. Zowel Lamprecht als Goetz studeerden bij de kunsthistoricus Anton Springer. Breysig bereidde zich voor om een bijvakexamen in kunstgeschiedenis af te leggen, maar voerde dit voornemen uiteindelijk niet uit. Ook Gothein hield zich met (vooral Italiaanse) kunstgeschiedenis bezig, zelfs in die mate dat Dilthey zich in 1882 inzette om hem een leerstoel in dat vak te bezorgen. Lamprecht (over middeleeuwse miniaturen en ornamentiek), Goetz (over Hans Thoma, over Ravenna en Assisi als Kunststätten) en Breysig (o.a. over impressionisme en expressionisme) publiceerden ook artikelen en monografieën op het terrein van de kunst(geschiedenis).
} 
heersende ideeën over geschiedenis vaak tot een stagnatie van hun carrière binnen de discipline.

Als we de vroege carrières van de cultuurhistorici eerst één voor één in ogenschouw nemen, springt die van Georg Steinhausen er enigszins uit. Hij was de enige cultuurhistoricus die zich na zijn promotie niet wist te kwalificeren als universitair docent en pas aan het einde van zijn carrière een academische functie verwierf als honorair hoogleraar cultuurgeschiedenis aan de Universiteit van Heidelberg. Aan een mogelijk gebrek aan intellectuele aspiraties lag dat niet: al kort na zijn promotie trok hij als drieëntwintigjarige de wetenschappelijke aandacht met het eerste deel van zijn omvangrijke Geschichte des deutschen Briefes (1889-1891), ${ }^{52}$ enkele jaren later publiceerde hij een bundel Kulturstudien en werd hij de hoofdredacteur van de Zeitschrift für Kulturgeschichte. Aan steun binnen de historische discipline ontbrak het hem, althans aanvankelijk, evenmin: zijn habilitatiepoging in de jaren negentig aan de Universiteit van Jena strandde niet door gebrek aan steun van de beide plaatselijke historici Gelzer en Lorenz, maar door het verzet van zijn werkgever, de directeur van de Universiteitsbibliotheek in Jena. ${ }^{53}$ Zijn positie als universitair bibliothecaris maakte het Steinhausen overigens wel mogelijk om de cultuurgeschiedens op een andere manier binnen de historische vakwetenschap een belangrijke plek te geven: hij herïntroduceerde in 1892 de cultuurhistorische rubriek in de officieuse vakbibliografie van de discipline, de Jahresberichte der Geschichtswissenschaft, en bleef die verzorgen tot $1896 .^{54}$

Eberhard Gothein's carrière als historicus begon te haperen na zijn vroege habilitatie tot docent geschiedenis in Breslau. Het lukte hem ondanks steun van onder andere de daar docerende historicus Alfred Dove niet om in Breslau na zijn habilitatie in 1878 verder te komen en een Umhabilitierung naar Straatsburg in 1884 (Dove vertrok dat jaar uit Breslau) bracht evenmin verbetering in zijn professionele vooruitzichten: daar domineerde een van de vroege critici van zijn werk, Hermann Baumgarten. Wel lukte het hem met steun van onder andere de Freiburgse historicus Erdmannsdörffer een

\footnotetext{
${ }^{52} \mathrm{Vgl}$. Roethe (1891).

${ }^{53}$ Steinhausens habilitatiepoging vond waarschijnlijk kort na 1892 plaats. Heinrich Gelzer, die later ook in Steinhausens Z/AfK zou publiceren, was een oudhistoricus en Burckhardt-leerling. Ottokar Lorenz, Ranke-leerling èn voorstander van een natuurwetenschappelijk georiënteerde generatieleer in de geschiedwetenschap, was een vriend van een oud-docent van Steinhausen, Wilhelm Scherer. Volgens het getuigenis van Steinhausen zelf wilde Lorenz stappen bij de lokale overheden ondernemen om zijn zaak tegenover de UB-directeur te bepleiten, maar keerde Steinhausen zich daartegen; zie Steinhausen (1925), 256-257.

${ }^{54}$ De Jahresberichte waren een uitgave van de door Droysen in het leven geroepen 'Historische Gesellschaft zu Berlin’ (1872). Volgens Theodor Lindner in Lexis (1893), 558, werden zij uitgegeven met steun van het Pruisische onderwijsministerie. Zie verder Hoppe en Lüdtke (1940), 16 en Simon (1988). Het betrof hier geen lijsten met louter titels, maar referaten waarvan de auteurs ordenend, selecterend en oordelend een overzicht gaven over de vakliteratuur. De cultuurhistorische rubriek van de Jahresberichte bestond vanaf de eerste jaargang (1878) tot 1881 en verdween vervolgens uit de bibliografie. tot Steinhausen haar in 1892 opnieuw invoerde (overigens zij hier nog opgemerkt dat Steinhausen ook voor de omvangrijke en veel gebruikte handbibliografie van de Duitse geschiedwetenschap, Dahlmann-Waitz' Quellenkunde der deutschen Geschichte, in 1912 de cultuurhistorische secties verzorgde). De Jahresberichte stonden van de jaargangen 1881 tot en met 1896 onder hoofdredactie van Ignaz Jastrow (1856-1937). Hij onderhield volgens Chickering (1994), 150, 'nauwe banden' met Lamprecht. Diens leerling Hans Helmolt nam de rubrieken ‘cultuurgeschiedenis' en 'wereldgeschiedenis' van Steinhausen over in 1897 tot resp. 1899 en 1900. De cultuurhistorische rubriek werd in 1900 gesplitst in een algemene en een Duitse afdeling, die beiden werden overgenomen door een andere beschermeling van Lamprecht, Rudolf Kötzschke. Hij schreef daadwerkelijk echter alleen het referaat over Duitse cultuurgeschiedenis in 1900. G. Buchholz, opnieuw een historicus uit de kring rond Lamprecht, verzorgde in 1889 en 1891 de overigens opvallend slecht onderhouden rubriek 'geschiedfilosofie' waarvoor eerder (in 1878) Droysen en later (in 1894) Windelband tekenden.

${ }^{56}$ Zie Zorn (1968); Gothein (1931), 50-53, 66-67.
} 
belangrijke onderzoeksopdracht te verwerven van de net opgerichte Badische Historische Kommission. Gothein voelde zich desalniettemin genoopt uit te wijken naar economische ordinariaten: hij werd eerst benoemd tot hoogleraar in de economie aan de TH van Karlsruhe (1885) en vervolgens met steun van de machtige universiteitsreferendaris Althoff in hetzelfde vak aan de universiteit van Bonn (1890). Het lukte hem uiteindelijk ondanks verschillende nieuwe kansen niet meer om een historisch professoraat te bemachtigen. ${ }^{56}$

Volgens Gothein zelf lag dat aan zijn afwijkende benadering van de geschiedenis. ${ }^{57}$ Hermann Baumgarten liet hem na zijn benoeming in Karlsruhe tevreden weten dat het met de geschiedenis toch niks zou zijn geworden'. ${ }^{58}$ Een reactie die door Gothein zelf werd geduid als typisch voor 'die politieke historici die iedereen die iets nieuws nastreeft als een schender van hun monopolie beschouwen'. ${ }^{59}$ Zelfs de hem overigens toegedane Dove noemde in 1890 Gotheins 'gebruik van universeel-cultuurhistorische typische categorieën' een van zijn 'vroeger naar buiten tredende gebreken' en toonde zich gereserveerd over Gotheins omvangrijkste publicatie tot dan toe, het in 1886 gepubliceerde Culturentwicklung Süd-Italiens. ${ }^{60}$

$\mathrm{Na}$ de habilitatie tot docent nog wel succesvol binnen de historische discipline was Kurt Breysig. Hij had zich na zijn promotie door middel van verschillende publicaties (waaronder een bekroonde verhandeling) laten kennen als een talentvolle onderzoeker van de Pruisische bestuursgeschiedenis. Op grond daarvan werd hij begin 1896 op voorspraak van zowel de econoom Schmoller als de historicus Treitschke - bij beiden was hij gepromoveerd en had hij zich ook gehabiliteerd - benoemd tot buitengewoon hoogleraar voor nieuwere, speciaal Pruisische geschiedenis. Eerder was hij al als kandidaat in overweging genomen voor de bezetting van gewone leerstoelen in Leipzig en Freiburg. Daarmee eindigde zijn snelle carrière voorlopig echter. Nadat hij nog in 1897 een aanbod van Althoff had afgeslagen om aan de 'afgelegen' Münsterse Akademie hoogleraar te worden, duurde het tot 1923 voor Breysig in Berlijn een (persoonlijk) ordinariaat kreeg aangeboden. ${ }^{61}$

Het scherpe breekpunt in Breysigs carrière was de publicatie van zijn vroegste theoretische beginselverklaring midden in de methodenstrijd, 'Ueber Entwicklungsgeschichte' (1896). Dat Breysig zich in deze en volgende verhandelingen ondubbelzinnig bekende tot de nieuwe richting in de Duitse geschiedwetenschap betekende, ondanks de steun van Althoff, het einde van zijn carrière als vakhistoricus. De Berlijnse historici - onder wie Lenz, Schäfer en Meinecke (zijn beschermheer Treitschke was in 1896 overleden) - keerden zich voortaan en tot het einde toe tegen pogingen om Breysig met een ordinariaat te bekleden. Het Berlijnse ordinariaat dat Breysig uiteindelijk verwierf, betrof in de eerste plaats 'Gesellschaftslehre' en vervolgens pas 'allgemeine Geschichtswissenschaft'. ${ }^{6}$

\footnotetext{
${ }^{57}$ Zie Gothein (1931), 49-50: 'Damals hat man sich nur soweit darum [nl. om zijn Habilitationsschrift] gekümmert, daß man es allseitig unerhört fand, wie ein so junger Kerl Ranke in seiner Auffassung [...] entgegenzutreten wagte'. Tot zijn toenmalige tegenstanders binnen de discipline rekende zijn echtgenote-biografe Droysen, Maurenbrecher, Ulmann, Delbrück, Baumgarten. Alleen Treitschke zou het voor hem hebben opgenomen.

${ }^{58}$ Gothein (1931), 67.

${ }^{59}$ Gothein (1931), 67.

${ }^{60}$ Dove (1925b), 144.

${ }^{61}$ Brocke (1971), 24-25; ironisch genoeg ging het in 1897 in Münster om de opvolging van de grootste criticus van de cultuurgeschiedenis, Georg von Below. Benoemd werd uiteindelijk Finke, die zich publiekelijk tegen Lamprecht had gekeerd.

${ }^{62}$ Brocke (1971), 26.
} 
Twee van de vijf woordvoerders van de academische cultuurgeschiedenis in de periode 1889-1915 wisten als dertiger een historisch ordinariaat te bemachtigen: Lamprecht en Goetz. Lamprecht had zijn eerste extraordinariaat (in Bonn) net als Breysig al op negenentwintigjarige leeftijd verworven. Daarvoor hadden zich onder andere zijn oud-docenten de hoogleraren Weizsäcker en Von Noorden ingezet en kreeg hij de steun van Treitschke en de net in Bonn benoemde ordinarius Dove. ${ }^{63}$ Lamprecht had zich onder andere verdienstelijk gemaakt als mede-oprichter van de Gesellschaft für rheinische Geschichtskunde (1881) en als een van de hoofdredacteuren van de Westdeutsche Zeitschrift für Geschichte und Kunst (1882). In Bonn werd Lamprecht ook aangeworven als medewerker van de Historische Kommission van de Beierse Academie van Wetenschappen, de oudste uit overheidsgelden gefinancierde historische onderzoeksinstelling met een nationaal werkterrein. ${ }^{64}$ Althoff benoemde Lamprecht vervolgens tegen de wensen van de faculteit in als ordinarius in Marburg (1890), waarmee hij een volwaardige historische leeropdracht verwierf. Al een jaar later werd hij door de Leipzigse filosofische faculteit en met instemming van de historici daarbinnen (onder wie Goetz' latere beschermheer Maurenbrecher), benoemd tot opvolger van de historicus Voigt. ${ }^{65}$

Opvallend aan die laatste benoeming was dat de Leipzigse historici de voorkeur gaven aan Lamprecht boven de eveneens genomineerde Gothein. ${ }^{66}$ Die voorkeur is vanuit later perspectief verrassend, omdat Gothein, zoals we in het vorige hoofdstuk hebben gezien, in verschillende opzichten dichter bij de traditionele idealistische geschiedbeschouwing stond dan Lamprecht. Misschien speelde in de keuze van de Leipzigse historici eenvoudig het meer ondernemende karakter of de grotere productiviteit van Lamprecht een rol, of wellicht ook zijn eigen opleiding aan de Leipzigse universiteit. ${ }^{67}$ Het waren in ieder geval niet economische studies als zodanig die in slechte aarde bij de vakhistorici vielen - want zowel Gothein als Lamprecht hadden zich laten kennen als economisch-historici. Het was niet voor niets dat de Lamprechtstrijd niet uitbrak over diens vroege economisch-historische studies. ${ }^{68}$ Lamprechts heftigste

${ }^{63}$ Zie Schönebaum (1962); Lewald (1968) en Chickering (1993), 84-87.

${ }^{64}$ Lamprecht verzorgde in 1887 eenmalig een uitgave van Duitse stadskronieken voor de Kommission. Deze was in 1858 op initiatief van de Beierse koning Maximiliaan II, en met medewerking van Ranke, haar eerste voorzitter, opgericht. Zie Heimpel (1959), 164 e.v. De uitgave van de ontzagwekkende bronnenreeks Monumenta Germaniae Historica dateerde al vanaf 1819, maar zij was in eerste instantie een initiatief van de private 'Gesellschaft für ältere deutsche Geschichtskunde'. Pas in 1875 kwam de uitgave van de MGH in handen van een semi-officiëel orgaan, de Zentraldirektion, geleid door vertegenwoordigers uit verschillende Duitse wetenschappelijke academies en onder de hoede van de Pruisische overheid; zie Bresslau (1921).

${ }^{65}$ Zie Chickering (1993), 113-114 en Czok (1984), 5-6.

${ }^{66}$ Dat gold overigens niet voor Alfred Dove, die hen beide persoonlijk kende en beiden bij een eerdere gelegenheid had gesteund. Hij steunde de Leipzigse kandidatuur van Gothein door middel van een brief aan een lid van de benoemingscommissie. Hij merkte in die brief overigens op dat hij beide historici 'wie sie denn in ihrer geistigen Physiognomie und ihrem Bildungsgang manche Ähnlichkeit haben, für würdig halte [...] vor allen übrigen - in Betracht gezogen zu werden [...] Eine stattliche Zukunft bringen beide mit.' Lamprecht had van beiden de grotere wils- en arbeidskracht, meende Dove, maar hij miste 'als Historiker' bij hem de 'stille Reinheit des geschichtlichen Sinnes', 'das Naive, die hingebende Anschauung', die hij bij Gothein wel bespeurde. Bovendien veroordeelde hij de 'souveräne Willkür soziologischer Abstraktion und Kombination' die hij in het eerste deel van Lamprechts DG bespeurde. Zie de brief van 19-11-1890 aan Otto Ribbeck in Dove (1925b), 142-145 en hierna Hoofdstuk 5. Later werd Dove bevriend met Gothein (zijn opvolger aan de BHK), terwijl zijn oordeel over Lamprecht sterk negatief eindigde, zie Dove (1925a), 313-316.

${ }^{67}$ In de benoemingscommissie zaten zowel de vertrekkende historicus Voigt als de kunsthistoricus Anton Springer, beiden oud-docenten van Lamprecht, zie Czok (1984), 5-6.

${ }^{68}$ Below kreeg in zijn polemiek daartegen weinig publieke steun, zie Chickering (1993), 146-151. 
criticus, Von Below, was zelf een vruchtbaar economisch historicus. Wat waarschijnlijk wel een rol speelde, was dat Gothein in zijn Aufgaben der Kulturgeschichte de cultuurgeschiedenis expliciet als een nieuwe vorm van algemene geschiedenis en derhalve als een concurrent van de politieke geschiedenis had gepresenteerd en verdedigd. In de Leipzigse benoemingscommissie keerde de historicus Maurenbrecher zich fel tegen Gothein, met het argument dat diens benoeming een 'gewagtes, akademisches Experiment' zou betekenen. ${ }^{69}$

Lamprecht daarentegen leek zich in eerste instantie beter bewust waar de disciplinaire gevoeligheden lagen. Zijn Deutsche Geschichte, waarin hij staatkundige ontwikkelingen als uiting van de heersende (economie en) cultuur behandelde, publiceerde hij niet vóórdat hij benoemd was tot ordinarius: het manuscript van het eerste deel hield hij als extraordinarius in Bonn willens en wetens onder zich. ${ }^{70}$ En bij de uiteindelijke publicatie van het eerste deel in 1890/1 liet hij een programmatisch voorwoord achterwege. Zijn voorzichtigheid had wellicht te maken met het feit dat hij al vroeg gewaarschuwd was voor het vakhistorisch oordeel in dezen: naar aanleiding van een verhandeling uit 1878 over de ontwikkeling van het individualisme in de middeleeuwen, die als de oerkern van zijn Deutsche Geschichte wordt beschouwd, kreeg de kersverse doctor van zijn leermeester Von Noorden te horen dat men als historicus op 'zulke dingen' geen academische loopbaan kon funderen. ${ }^{71}$ Lamprecht knoopte de opmerking in zijn oren en publiceerde de verhandeling uiteindelijk pas in 1909, als aanhangsel bij zijn Deutsche Geschichte. Pas nadat hij zich in zijn eerste jaren als ordinarius een stevige positie in de discipline leek te hebben verworven, associeerde hij zich met het begrip Kulturgeschichte als een nieuwe vorm van algemene geschiedenis en formuleerde hij expliciet en openlijk zijn kritiek op de bestaande geschiedschrijving.

Ook Walter Goetz trad pas expliciet in het krijt voor de cultuurgeschiedenis nadat hij tot ordinarius was benoemd en was ook toen nog, zoals we hebben gezien, erg bekommerd om de politieke historici niet voor het hoofd te stoten. Goetz onderhield anders dan de andere cultuurhistorici (in ieder geval tot 1933) blijvend goede betrekkingen met vooraanstaande politieke historici en had al zijn carrièrestappen aan collega-historici te danken. ${ }^{72}$ Zo kon hij als student en oud-promovendus van Maurenbrecher op grond van diens aanbeveling als medewerker terecht bij de Münchense Historische Kommission, waar hij zijn habilitatie voorbereidde (1892-1895). ${ }^{73}$ Die habilitatie vond plaats in Leipzig in 1895 - Maurenbrecher was inmiddels overleden onder de hoede van de historicus en neorankeaan Erich Marcks, die hem ook aan werk als wetenschappelijk redacteur hielp. ${ }^{74}$ Verschillende boekbesprekingen in de Historische Zeitschrift (1896) en de Historische Vierteljahrsschrift (1898), waarin Goetz zich resoluut tegen katholieke geschiedinterpretaties keerde, legden de basis voor contact met Georg von Below, die hem vervolgens uitnodigde om mee te werken aan diens meerdelige historische Handbuch. ${ }^{75}$ Een tweede aanstelling bij de Münchense Historische Kommission in 1900 verwierf Goetz doordat zijn schoonvader, de gerespecteerde Bonner historicus Moriz Ritter alleen zelf een betrekking bij de Commissie wenste te aanvaarden als zijn schoonzoon ook in dienst werd genomen. Goetz' benoeming tot

${ }^{69}$ Citaat bij Czok (1984), 5 en 25 n 18.

${ }^{70}$ Zie Winter (1898), 313; Chickering (1993), 122. En niet ten onrechte - zie de reactie van Dove in noot 67.

${ }^{71}$ Schönebaum (1951), m.n. 101; vgl. ook Schorn-Schütte (1984), 35-38.

${ }^{72}$ Zie behalve Weigand (1992), ook Weber (1987b), 232-234.

${ }^{73}$ Weigand (1992), 34, 41.

${ }^{74}$ Weigand (1992), 73

${ }^{75}$ Zie Weigand (1992), 65-66. 
ordinarius in Tübingen (1905) tenslotte was vooral het werk van de historicus Wilhelm Busch, daarbij gesteund door de vertrekkende Below. ${ }^{76}$ Met deze benoeming aan de kleine universiteit van Tübingen kwam er een einde aan Goetz' relatief lange periode van docentschap en werd een dreigende carièrreachterstand op zijn leeftijdgenoten in één klap goed gemaakt. ${ }^{77}$

Vergelijken we de vroege carrières van de nieuwe cultuurhistorici met die van hun peer group dan kunnen we vaststellen dat zij, geholpen door hun familieachtergrond, hun voortvarende studie en de actieve steun van hun oud-docenten geschiedenis, een relatief voorspoedige start van hun loopbaan kenden. ${ }^{78}$

Zo duurde het voor de meeste nieuwe hoogleraren geschiedenis die tussen 1885 en 1905 werden benoemd, na de promotie $3 \frac{1}{2}$ tot 6 jaar voor zij een onderwijsbevoegdheid aan een universiteit verwierven. Van de cultuurhistorici bleven Breysig en Goetz binnen deze marge (4-4 $\frac{1}{2}$ jaar), terwijl Lamprecht en Gothein zich aanmerkelijk sneller als docent aan een universiteit wisten te kwalificeren (al na 1-2 jaar). De vier cultuurhistorici die een universitaire loopbaan insloegen behoorden als 24- tot 27jarigen tot de jongste en gezien hun studieresultaten ook tot de meestbelovende Privatdozenten van hun lichting.

Zowel Breysig als Lamprecht verwierven vervolgens al op negenentwintigjarige leeftijd een extraordinariaat. En zowel Gothein als Lamprecht en Goetz aanvaardden ook hun eerste gewone leerstoel op relatief jonge leeftijd. ${ }^{80}$ Gothein was eenendertig en daarmee zes jaar jonger dan het jaargemiddelde van de nieuw benoemde historici. ${ }^{81}$ Lamprecht was drieëndertig bij de aanvaarding van zijn eerste ordinariaat (en daarmee de jongste hoogleraar geschiedenis van dat moment) en vijf jaar jonger dan gemiddeld, en zelfs Goetz was met zijn zevenendertig jaar nog altijd vier jaar jonger dan de gemiddelde ordinarius voor geschiedenis die in hetzelfde jaar voor het eerst werd benoemd. Overigens behoorden ook de meeste uitgesproken critici van de nieuwe cultuurgeschiedenis tot hoogleraren die jonger dan gemiddeld een leerstoel verwierven. ${ }^{82}$

${ }^{76}$ Weigand (1992), 100. Eerder was Goetz al in aanmerking gekomen voor leerstoelen in Rostock en Gießen via respectievelijk de historici Seeliger en (opnieuw) Ritter.

77 Tübingen kende bij Goetz' benoeming twee volwaardige historische leerstoelen; zijn voorganger Below (1925), 36-38, noemde Tübingen 'abgeschieden, fast einsam' en de universiteit een 'Durchgangsuniversität', vanwaar veel hoogleraren (net als Below zelf) graag naar bijvoorbeeld Freiburg i.B. vertrokken.

${ }^{78}$ Overigens kenden in ieder geval Gothein en Lamprecht ook buiten de historische discipline een succesvolle carrière aan de universiteit: beiden werden gekozen tot rector van hun universiteit.

${ }^{79}$ Lamprecht was 24 jaar bij zijn habilitatie, Gothein 25, Breysig 26 en Goetz 27. Vgl. daarmee de cijfers bij Weber (1987b), 142: van de historici die tussen 1885 (het jaar van Gotheins eerste professoraat) en 1905 (het jaar van Goetz' eerste hoogleraarschap) werden benoemd tot historisch ordinarius steeg de habilitatieleeftijd gemiddeld van 27 jaar in 1885 tot 30 jaar in 1905 .

${ }^{80}$ De gemiddelde leeftijd waarop Duitse historici in het algemeen hun eerste ordinariaat aanvaardden, steeg tussen 1875 en 1915 aanhoudend: in 1885, het jaar van Gotheins eerste leerstoel, lag het gemiddelde op zevenendertig jaar, in 1905, het jaar van Goetz' eerste professoraat, was de gemiddelde leeftijd van nieuwe hoogleraren geschiedenis gestegen tot eenenveertig jaar. Zie Weber (1987b), 165.

${ }^{81}$ Gothein werd op 31 janari 1885 benoemd tot gewoon hoogleraar (ordinarius) in Karlsruhe, zie Maurer (1999), 165-166. Salin en Bergsträßer geven ten onrechte 1884 als jaar van de benoeming van Gothein. Gotheins opvolger werd in 1890 Karl Bücher, die al ordinariaten in de economie had bekleed in Dorpat en Bazel voordat hij Gotheins positie aanvaardde.

${ }^{82}$ Below was 33 (5 jaar onder het jaargemiddelde) bij de aanvaarding van zijn (eerste) leerstoel aan de Münsterse Akademie (1891), Lenz 34/35 (1885, -2/3), Rachfahl 35/36 (1903, -5/6), Oncken 36/37 $(1906,-4 / 5)$ en Meinecke 38 (1901, -2). Alleen Finke was ouder dan gemiddeld: 41/42 (1897, +1/2). Lamprecht was overigens al in 1887 en 1888 aan verschillende universiteiten genomineerd, zie Chickering (1993), 96. 
Op een leeftijd van vijfendertig jaar hadden de cultuurhistorici bovendien elk, met uitzondering van Goetz, naast hun dissertatie en een soms aanzienlijke reeks kleinere studies en artikelen op zijn minst één belangwekkende historische monografie op hun naam staan: Gothein zijn vuistdikke Kulturentwicklung Süd-Italiens (1886), Lamprecht zijn nog altijd imposante statistische studie en bronnenuitgave Deutsches Wirtschaftsleben im Mittelalter (1885/6), Steinhausen zijn Geschichte des deutschen Briefes (18891891) en Breysig de drie delen van zijn ambitieuze Kulturgeschichte der Neuzeit (1900).

Bovendien vonden de cultuurhistorici ook hun weg naar de historische vakbladen. Gothein (1881), Lamprecht (1891) en Goetz (1896) publiceerden elk in het begin van hun carrière op zijn minst één bijdrage in de Historische Zeitschrift (HZ), het meest gerenommeerde historische vakorgaan. ${ }^{83}$ Ook in het voor een algemener publiek bestemde 'zusterblad' van de $H Z$, de Preußische Jahrbücher, verschenen in de jaren tachtig nog bijdragen van Lamprecht en Gothein. Lamprecht en Breysig publiceerde bovendien ook in de belangrijkste concurrent van de HZ, de Deutsche Zeitschrift für Geschichtswissenschaft, in 1889 opgericht door de jonge historicus en latere nobelprijswinnaar Ludwig Quidde, waarvan Lamprecht in 1896 mede-redacteur werd. Ook in vooraanstaande regionale vakhistorische bladen verschenen veel (vroege) bijdragen van de cultuurhistorici: Gothein schreef veruit de meeste van zijn historische artikelen voor het huisorgaan van de Badische Historische Kommission, de Zeitschrift für die Geschichte des Oberrheins en Breysig publiceerde in het begin van zijn carrière verschillende bijdragen in de Forschungen zur brandenburgischen und preußischen Geschichte.

In de weerstand die de nieuwe cultuurhistorici opriepen, speelde hun jeugdige voortvarendheid ongetwijfeld mee; het lijkt ten dele de verklaring voor de verwijten van haast, onrust en arrogantie die sommige cultuurhistorici (met name Lamprecht en Breysig) in het begin van hun carrière werden gemaakt. ${ }^{84} \mathrm{Zij}$ vormden daarmee vooral een directe bedreiging voor leeftijdgenoten, die immers met de cultuurhistorici moesten concurreren om een functie in de discipline te vinden.

Tegelijk bood de strijd die rond de nieuwe cultuurgeschiedenis in de jaren negentig ontbrandde aan jonge historici de gelegenheid zich ten gunste van de bestaande disciplinaire normen uit te spreken en zich daarmee publiekelijk als acceptabele Zunfthistoriker te profileren. Dat die gelegenheid werd aangegrepen blijkt uit het feit dat tot de woord-

\footnotetext{
${ }^{83}$ De Historische Zeitschrift, die in 1859 (met overheidssteun) werd opgericht, geldt als het vroegste historische vakorgaan in Duitsland en daarbuiten dat die naam verdient. Niet dat er daarvóór geen tijdschriften bestonden waarin historische studies van meer of minder specialistische aard werden gepubliceerd. Zo verscheen al sinds 1830 bijvoorbeeld het onder de hooggeleerde redactie van achtereenvolgens Friedrich von Raumer, W.H. Riehl en W. Maurenbrecher uitgegeven Historische Taschenbuch (1830-1892). Opvallend genoeg legde juist de HZ zich niet toe op het publiceren van 'specialistische' historische studies, maar had zij integendeel een uitgesproken voorkeur voor meer algemene, essayistische bijdragen. Wat de $\mathrm{HZ}$ tot vakorgaan maakte, waren niet de wetenschappelijke studies, maar andere onderdelen van het blad die haar onderscheidden van de oudere historische tijdschriften: de aanvankelijk opgenomen bibliografische overzichten, de mededelingen uit de discipline (aanvankelijk met name de verslagen van de Beierse Historische Commisie) en de uitvoerige recensierubriek. De tot een artikel uitgegroeide recensie, het besprekingsartikel, werd de meest kenmerkende soort bijdrage aan de HZ. Het waren vooral deze onderdelen waardoor juist de HZ het centrale forum van de Duitse geschiedwetenschap werd. Zie Schieder (1959), m.n. 5-8, Faulenbauch (1986) en Stieg (1986). Stieg meldt niets over de oudere vaktijdschriften, Historisches Taschenbuch en Forschungen zur deutschen Geschichte. Zie hiervoor Wolf (1910), 296-302. Daar ook informatie over andere tijdschriften die van belang waren voor negentiende-eeuwse Duitse historici.

${ }^{84}$ In beide gevallen viel het woord 'Streber'. Voor Lamprecht zie Chickering (1993), 83-84, voor Breysig: Brocke (1971), 35-36.
} 
voerders van de disciplinaire kritiek op Lamprecht voornamelijk niet-gevestigde historici behoorden, wetenschappers die op het moment van schrijven zelf nog maar aan het begin van hun carrière stonden. Terwijl het vanuit een later perspectief lijkt alsof leidende historici zich openlijk uitspraken tegen de nieuwe richting, werden Finke (*1855), Meinecke (*1862), Rachfahl (*1867) en Hermann Oncken $(* 1869)$ feitelijk pas ordinarius nadat ze zich in het publiek tegen Lamprecht hadden gekeerd. Finke was nog extraordinarius op het moment dat hij zijn eerste uitvoerige Lamprecht-kritiek schreef, Meinecke en Rachfahl waren Privatdozent en Oncken had zich zelfs nog niet gekwalificeerd als docent. Ook de vroegste aanvallen van Below (*1858) op zijn voormalige docent Lamprecht dateerden uit de tijd dat Below Privatdozent (en Lamprecht extraordinarius) was. Van de critici die omvangrijkere besprekingen aan de nieuwe richting wijdden, waren verder alleen Schäfer, Lenz en de gematigde Zwitser Schnürer ordinarius op het moment van schrijven. Vanuit dit perspectief zou men de genuanceerde bespreking van Lamprechts opvattingen door de Berlijnse Privatdozent Otto Hintze in de Historische Zeitschrift van 1897 - een bespreking die Lamprecht zelfs als een wending in de methodenstrijd te zijner gunste interpreteerde - bijna als een daad van moed gaan beschouwen.

Overigens dient er geen misverstand over te bestaan dat de kritiek die de nieuwe cultuurhistorici van generatiegenoten kregen, onderschreven werd door invloedrijke vertegenwoordigers van de zittende generatie hoogleraren. Zo was het Sybel die Belows aanval op Lamprecht in de Historische Zeitschrift aanscherpte en Lenz die Onckens kritiek aanmoedigde en waarschijnlijk ook Rachfahl tot zijn kritieken aanzette. ${ }^{86}$ Zonder de steun van de redactie van de Historische Zeitschrift (Sybel, Treitschke, Meinecke) en de Preußische Jahrbücher (Delbrück) hadden de heftigste kritieken niet op zo'n vooraanstaande plaats kunnen verschijnen.

Het mogelijke motief van een ostentatieve conformering aan de vakhistorische normen door jonge critici van de cultuurgeschiedenis kan des te sterker hebben gespeeld bij historici die door een afwijkende religieuze, politieke of sociale achtergrond een potentieel zwakkere professionele positie innamen en daarom de behoefte konden voelen hun disciplinaire rechtgeaardheid expliciet te laten blijken. Zoals we hebben gezien weken opvallend veel critici van de nieuwe richting af van de religieuze en maatschappelijke achtergrond die onder hoogleraren geschiedenis gebruikelijk was. ${ }^{87}$

Daarbij komt nog dat juist in de tweede helft van de jaren negentig de concurrentie onder de gegadigden voor historische leerstoelen heviger werd. Precies in de jaren waarin de vaknormen het hevigst ter discussie stonden, kwam er niet alleen een einde aan de gestage toename van het aantal te verdelen ordinariaten, maar was er zelfs sprake van een afname van het aantal historische hoogleraarsposten. Terwijl er in 1895 vijfenzestig bezette leerstoelen waren, daalde dat aantal in de daarop volgende jaren tot negenenvijftig (1898) en nam vervolgens weer toe, om pas in 1902 het niveau van 1895 te passeren. ${ }^{88}$

\footnotetext{
${ }^{86}$ Over Below en Sybel: zie Below (1925), 24. Voor de kritiek van Rachfahl en Oncken, leerlingen van Lenz, zie Chickering (1992), 235. Lenz' eigen kritiek (1896) was geschreven op herhaald aandringen van de HZ, zoals hij in de bespreking meldde. Een kritiek van Schnürer (1897) voor het katholieke Historische Jahrbuch werd geschreven op verzoek van de Münchense hoogleraar Grauert.

${ }^{87}$ Zie hierboven, Paragraaf 1.

${ }^{88}$ Gegevens gebaseerd op Weber (1987b); zie de 'dip' rond 1898 in Grafiek 4.1.
} 
De vraag in hoeverre de in 1896 uitgebroken Lamprechtstrijd in deze stagnatie een rol speelde valt moeilijk te beantwoorden; ${ }^{89}$ het was zeker een periode waarin historische benoemingen meer dan vroeger omstreden waren, maar financiële overwegingen kunnen even goed in elk van deze gevallen een doorslaggevende rol hebben gespeeld. Duidelijk is in ieder geval dat de strijd om de nieuwe cultuurgeschiedenis niet zonder meer een generatieconflict was, maar een strijd tussen twee groepen getalenteerde jonge historici die zowel streden voor hun positie binnen de historische discipline als voor de richting die de geschiedwetenschap diende in te slaan.

\section{Blijvende activiteiten binnen de discipline}

De stagnatie die in de carrière van de meeste de cultuurhistorici optrad in verband met hun afwijkende opvattingen over de geschiedenis, betekende geenszins het einde van hun betrokkenheid bij de historische discipline, zoals in hoofdstuk 2 al is vastgesteld. ${ }^{90}$

De cultuurhistorici vonden voor zover nodig ruimte voor hun ideeën in nieuwe disciplinaire instituties en media aan de totstandkoming waarvan zij belangrijke bijdragen leverden. Voor zover nodig, want met name voor Goetz gold deze noodzaak in ieder geval al niet: hij publiceerde evenzeer in het Archiv für Kulturgeschichte als in de Historische Zeitschrift; en hij werd zowel lid (in 1911) van de traditionele Münchense Historische Kommission, als de opvolger van Lamprecht (1915) aan diens innovatieve Institut für Kultur- und Universalgeschichte. Overigens was ook Breysig lid en vanaf 1899 zelfs bestuurslid van een eerbiedwaardige vakorganisatie (zij het een met een beduidend minder groot bereik dan de Historische Kommission): de uit 1836 daterende Verein für die Geschichte der Mark Brandenburg, waarvan bijvoorbeeld ook Hintze, Meinecke en Dietrich Schäfer lid waren. ${ }^{92}$

Voorbeelden van de blijvende rol die de cultuurhistorici in nieuwe disciplinaire instellingen en media bleven spelen nadat de strijd over hun geschiedopvattingen was uitgebroken, zijn er legio. Zij bleven actief in de nieuwe regionaal-historische instellingen, zoals de (mede) door Lamprecht opgerichte private Gesellschaft für rheinische Geschichtskunde (1881), waarvan Gothein in 1892 bestuurslid werd. ${ }^{93}$ Gothein werd in 1904 ook lid en later (1913) voorzitter van de Badische Historische

\footnotetext{
${ }^{89} \mathrm{Na} 1896$ werd Steindorffs Göttingse leerstoel niet langer door een ordinarius bezet. Dat gebeurde ook in 1897 met Von Bezolds Erlanger ordinariaat, terwijl Aloys Schultes Freiburgse RK leerstoel enkele jaren geheel onbezet bleef. In 1898 werd het ordinariaat van Wattenbach in Berlijn enkele jaren door een extraordinarius vervuld, terwijl de gewone leerstoelen van Menzel in Bonn, van Haussman in Dorpat en van Wegele in Würzburg (enige tijd) onbezet bleven. In 1899, tenslotte, werd ordinarius Felix Stieve aan de Münchense TH opgevolgd door een extraordinarius. Van deze acht leerstoelen die enige tijd geen (volwaardige) bezetting kenden in deze jaren, betroffen er twee de opvolging van hoogleraren met aanwijsbare affiniteit met de nieuwe richting (Bezold, Aloys Schulte). In het geval van Schulte was de met hem bevriende Gothein door de Faculteit voorgesteld, maar de regering weigerde, waarschijnlijk omdat de leerstoel voor een katholieke wetenschapper bestemd was. Dat neemt niet weg dat met de uiteindelijke benoeming van Finke, behalve een katholiek ook een uitgesproken criticus van de nieuwe richting werd benoemd in plaats van de cultuurhistoricus Gothein.

${ }^{90}$ Zie Hoofdstuk 2, paragraaf 3.

${ }^{92}$ Zie Brocke (1971), 34 en Schultze (1923), m.n. 12-18; de VGMB werd vernieuwd in 1887 en opnieuw in 1899 met een sterkere nadruk op wetenschappelijk onderzoek. In 1921 werd de vereniging tenslotte tot een formele historische commissie omgevormd.

${ }^{93}$ Zorn (1968), 265.
} 
Kommission. ${ }^{94}$ Lamprecht bleef tot aan zijn dood de leiding hebben over de door hem opgerichte Koninklijke Saksische Commissie voor Geschiedenis (1896). ${ }^{95}$ Hij bleef verder zijn hele leven bestuurslid van de Verband Deutscher Historiker, waarvan overigens ook Gothein in de tweede helft van de jaren negentig bestuurslid was. Zowel Lamprecht, Gothein, Steinhausen als Goetz traden als spreker op tijdens verschillende Historikertage of tijdens de nationale bijeenkomsten van regionaal-historische organisaties. En ook al publiceerden de meeste cultuurhistorici na 1896 nauwelijks nog in de $H Z$ of de Historische Vierteljahrschrift (de opvolger van de Deutsche Zeitschrift für Geschichtswissenschaft), zij leverden wel bijdragen aan nieuwe vakbladen als de Zeitschrift/Archiv für Kulturgeschichte, de Zeitschrift für Sozial- und Wirtschaftsgeschichte en de Deutsche Geschichtsblätter.

De disciplinaire weerstand tegen de nieuwe cultuurhistorici vormde onmiskenbaar een stimulans voor de disciplinaire vernieuwing door de cultuurhistorici. Door nieuwe organisaties en tijdschriften te vormen, creëerden de nieuwe cultuurhistorici vakwetenschappelijke fora waar zij met hun benadering wel terecht konden. Tot welke disciplinaire innovaties dat proces kon leiden wordt het meest spectaculair duidelijk gemaakt door Lamprechts Institut für Kultur- und Universalgeschichte (IKU, 1909). ${ }^{98}$

$\mathrm{Al}$ in 1905 hadden de geleidelijk toenemende spanningen tussen Lamprecht en zijn Leipzigse historische collega's een splitsing van het historisch seminarium tot gevolg in een algemeen deel en een cultuurhistorisch deel onder de exclusieve leiding van Lamprecht. ${ }^{108}$ Dat laatste vormde de kern van het latere IKU, dat Lamprecht geheel volgens zijn eigen geschiedopvattingen kon inrichten. In dit instituut volgden studenten net als in een traditioneel historisch seminarium hoor- en werkcolleges over historische bronnenstudie. Maar voor het overige week het curriculum sterk af van het gebruikelijke historische studieprogramma: naast colleges over sociale en economische geschiedenis en over de cultuurgeschiedenis van diverse westerse èn niet-westerse landen, kregen studenten onderwijs in rechtsgeschiedenis en kunstgeschiedenis, psychologie en volkskunde. ${ }^{109}$

De colleges werden normaliter verzorgd door specialisten op elk van deze gebieden: voor psychologie was bijvoorbeeld de psycholoog Felix Krüger verantwoordelijk, voor Chinese cultuurgeschiedenis werd de extraordinarius voor Oostazatische talen August Conrady ingezet, voor verschillende nationale cultuurgeschiedenissen werden gastdocenten uit de betreffende landen aangetrokken, en voor de volkskunde trad de

\footnotetext{
${ }^{94}$ Zie Bergsträsser (1964), 654; vgl. Gothein (1931), 247

${ }^{95}$ Zie Wiemers (1996), 13-43, vgl. ook 148.

${ }^{98} \mathrm{Zie}$ voor de geschiedenis van het IKU behalve de opstellen van Gibas, Behrendt, Diesener \& Kudrna, Hoyer en Zeuske in Diesener (1993), alsmede Diesener (1995), nu Middell (2005).

${ }^{108}$ Chickering (1993), 276.

${ }^{109}$ Zie het onderwijsplan voor 1910 in Lamprecht (1910), 13-16; ook: Lamprecht (1988), 405-414.
} 
Leipzigse extraordinarius voor noordse filologie, Mogk, op. Verder was niet alleen het Seminar für Landesgeschichte nauw met het IKU verbonden, maar na 1913 ook het uit het Instituut zelf voortgekomen 'Oostaziatische Seminarium' en het 'Seminarium voor vergelijkende godsdienstgeschiedenis'. ${ }^{110}$

Een dergelijk interdisciplinair georganiseerd historisch instituut was een novum binnen de historische discipline. Alleen voor de oude geschiedenis was al eerder een interdisciplinair historisch instituut ontstaan, namelijk het Berlijnse 'Institut für Altertumskunde' dat vanaf 1897 de studie van oude geschiedenis, klassieke archeologie en oude talen verenigde. ${ }^{111}$ Het IKU was echter veel breder van opzet, zeker nadat in 1925 ook nog het nieuwe Instituut voor Sociologie onder leiding van de latere IKUdirecteur Hans Freyer ermee werd verbonden.

Niet alleen de opzet, ook de uitrusting van het IKU was veel ruimer dan die van een gewoon historisch seminarium. Het IKU nam meer dan dertig ruimtes in beslag en had niet alleen een grote eigen bibliotheek, maar kende ook een omvangrijk dia-archief 'voor cultuurhistorische demonstraties', een verzameling primitieve beeldhouwwerken, een grote collectie door Lamprecht verzamelde kindertekeningen uit diverse landen ten behoeve van vergelijkende psychologische studies, een verzameling van cultuurhistorisch interessante brieven en een collectie afbeeldingen voor een geschiedenis van het portret. ${ }^{113}$ De kosten die deze rijke uitmonstering met zich bracht, wist Lamprecht te bestrijden door behalve de overheden ook de rijke burgerij te interesseren voor de financiering van het instituut. ${ }^{114}$ Overigens werd dit succes door vakcollega's als argument tegen zijn vakmanschap ingebracht: 'Geen serieuze geleerde zou dat hebben klaargespeeld', sneerde een van Lamprechts critici, de krijgshistoricus Delbrück in de Preußische Jahrbücher. ${ }^{115}$

Aan het IKU was de interdisciplinariteit geïnstitutionaliseerd. Dat ging volgens sommige commentatoren ten koste van de historische discipline. Typerend was een reactie die in 1914 onder andere in het historische tijdschrift Vergangenheit und Gegenwart werd gepubliceerd: als Lamprecht zonodig de wetten van sociale ontwikkeling wilde bestuderen, dan was dat durchaus berechtigt. Maar: 'hij moet zichzelf geen historicus noemen. Hier ligt de kern van het verzet tegen Lamprecht. Hij is naar het vijandelijke kamp overgelopen en weet het niet'. ${ }^{116}$

Maar er was ook een andere opvatting mogelijk. Zij werd helder geformuleerd door Goetz: de geschiedenis kon haar 'grote plaats' als 'leermeesteres van de natie' slechts behouden als zij haar belangstelling uitbreidde naar alle terreinen van het leven, schreef

${ }^{110}$ Zie Sch[önebaum] (1926).

${ }^{111}$ Zie Engel (1959), 364-365.

113 Zie voor een beschrijving van het IKU: Lamprecht (1910), 8-13.

${ }^{114}$ In de lijst van sponsoren van het IKU, gepubliceerd door Hoffmeister (1956), 265-266, treffen we o.a. de naam van verschillende uitgevers, van de Hamburg Amerik. Paketfahrt AG, en van de bekende Amerikaanse mecenas Andrew Carnegie aan. Overigens werden ook uit naam van Wilhelm II en de Chinese Keizer schenkingen gedaan, zie Chickering (1993), 351-353.

${ }^{115} \mathrm{PJb} 156$ (1914), 543; ook Gothein bezat goede contacten in de financiële wereld en wist die te benutten voor de wetenschap, zie Gothein (1931), 322; voor een hoogleraar in de economie lagen die contacten echter meer voor de hand dan voor een historisch ordinarius.

${ }^{116}$ Het ging hier om de vertaling van een opstel van de Amerikaanse historicus Show (1914); een waarderend referaat over dit voor Lamprecht zeer negatieve artikel door de hoofdredacteur van de Historische Vierteljahrsschrift verscheen zowel in dat vakblad als in de Preußische Jahrbücher: Seeliger (1914). Seeliger (p. 542) sloot zich in zijn slotregels aan bij Show's 'disciplinaire' invalshoek: '[...] die Geschichtswissenschaft muß ihr eigenes Gebiet hüten und maß dafür sorgen, daß ihre Aufgaben durch eine Ausdehnung ins Ungemessene nicht ins Schwanken geraten und daß bei dieser Gelegenheit ihre fest ausgebildeten Methoden nicht erschüttert werden'. 
hij al in zijn eerste verdediging van de cultuurgeschiedenis. ${ }^{117}$ 'Wij [historici]', meende hij na zijn overname van het IKU enkele jaren later, 'hebben de plicht ons de heerschappij over ons gebied niet door anderen afhandig te laten maken. [...] Het is geen houdbare toestand, dat gebieden die ongetwijfeld tot de geschiedwetenschap behoren, haar door buurwetenschappen zo goed als onttrokken worden'. ${ }^{118}$ Vragen over de ontwikkeling van de menselijke cultuur raakten weliswaar aan het terrein van de geschiedfilosofie, de Völkerpsychologie en de sociologie - en vanzelfsprekend was samenwerking met deze wetenschappen noodzakelijk - maar dergelijke vragen dienden uiteindelijk, aldus Goetz, met historische middelen te worden beantwoord. ${ }^{119}$

Wanneer we de institutionele ontwikkeling van de Duitse historische wetenschap tussen 1890 en 1914 overzien en de plaats van de cultuurhistorici daarin, dan komen we al met al tot het volgende beeld.

De periode waarin de cultuurhistorici actief werden als wetenschappers was er een van institutionele vernieuwing van de Duitse geschiedwetenschap, na een periode van vooral kwantitatieve groei van het vakgebied. ${ }^{120}$ In de decennia vóór 1890 was het aantal historische leerstoelen en het aantal officiële historische seminaria sterk toegenomen. Tegelijk bleef de interlokale organisatie van de historische discipline in deze periode beperkt: van nationale betekenis waren vooral de jaarbibliografie (de Jahresberichte der Geschichtswissenschaft), een algemeen vakorgaan (de Historische Zeitschrift) en twee onderzoeksinstellingen (de Beierse Historische Kommission en de Zentraldirektion van de $M G H)$.

$\mathrm{Na} 1895$ haperde de groei van het aantal leerstoelen tijdelijk, maar omstreeks dezelfde tijd vond er een opmerkelijke toename van het aantal nieuwe vaktijdschriften en vakinstellingen plaats. Allereerst kwam er een reeks nieuwe vaktijdschriften van de grond die, net als de $H Z$, door hun uitvoerige recensierubrieken en mededelingen uit de discipline dienst deden als vakorgaan. Bovendien ontstond er een aantal nieuwe instituties ten behoeve van het historisch onderwijs en onderzoek: naast het oudere disciplinair geoganiseerde historisch seminarium werd het interdisciplinair geoganiseerd historisch instituut gecreëerd; verder werd het regionaal-historisch onderzoek georganiseerd in nieuwe officiële instellingen; en ten slotte kwamen er in deze periode met de Historikertage, de Verband Deutscher Historiker en de nationale conferenties van regionaal-historische publicatie-instituten drie nieuwe nationale disciplinaire organisatievormen tot stand.

De positie van de cultuurhistorici in deze ontwikkeling is eenduidig: zij maakten een integraal deel uit van de fase van institutionele vernieuwing van de Duitse geschiedwetenschap. Terwijl de nieuwe cultuurhistorici vooral na 1896 minder sterk vertegenwoordigd waren in de oudere media en organisatievormen van de historische discipline (overigens met uitzondering van de Jahresberichte en met uitzondering van Goetz), was hun betrokkenheid bij de institutionele vernieuwingen na 1890 opvallend groot: zowel in de nieuwe regionaal-historische instellingen, als in de nieuwe nationale historische organisatievormen, in de nieuwe vaktijdschriften en in de oprichting van nieuwe interdisciplinaire historische instituten, waren zij duidelijk aanwezig en speelden zij niet zelden een initiërende en/of leidinggevende rol. Dat laatste gold in uitzonderlijke mate voor Lamprecht.

Terwijl de cultuurhistorici op grond van hun afwijkende geschiedopvattingen door hun tegenstanders als disciplinaire buitenstaanders werden afgeschilderd, kunnen zij op

\footnotetext{
${ }^{117}$ Goetz (1910), 9.

${ }^{118}$ Goetz (1916), 275.

${ }^{119}$ Goetz (1916), 277-278.

${ }^{120}$ Vgl. Middell (2005), 61-152.
} 
grond van hun werk voor en binnen de nieuwe disciplinaire media en instituties met meer recht als hervormers worden betiteld, die mede verantwoordelijk waren voor de uitbouw van de historische discipline.

\section{De rol van de Nationalökonomen}

Maar dit is niet het hele verhaal. Hoewel de cultuurhistorici een succesvolle vroege carrière kenden binnen de historische discipline, en daarbinnen ook actief bleven na het verzet van andere historici tegen hun opvattingen, moet erop gewezen worden dat zij daartoe mede in staat waren door steun van buiten de discipline. In het verloop van hun carrière blijkt vooral de steun van Nationalökonomen, speciaal van economen uit de zogenaamde 'Historische School', vaak een belangrijke rol te hebben gespeeld.

De basis voor de opmerkelijk intensieve betrekkingen tussen de nieuwe cultuurhistorici en de Nationalökonomen werd gelegd tijdens hun universitaire studie. Zoals in paragraaf 2 is opgemerkt onderscheidde de opleiding van vier van de vijf nieuwe cultuurhistorici zich in één opzicht opvallend van de overgrote meerderheid van hun collega-historici: door de keuze voor Nationalökonomie als bijvak. ${ }^{121}$ De vier nationalökonomisch geschoolde cultuurhistorici kregen allemaal een opleiding door voormannen van de zogenaamde Historische School die tussen 1870 en 1914 binnen de Nationalökonomie domineerde. ${ }^{122}$ Gothein en Lamprecht studeerden respectievelijk bij Karl Knies (1821-1898) en Wilhelm Roscher (1817-1894), die gerekend worden tot de oudere Historische School. Breysig en Goetz studeerden respectievelijk bij Gustav Schmoller (1838-1917) en Lujo Brentano (1844-1931), leidende representanten van de jongere Historische School. ${ }^{123}$ Bovendien studeerden drie van deze vier cultuurhistorici niet alleen bij deze economen, zij dankten aan hen ook belangrijke stappen in hun carrière. $^{124}$

Dat gold zeker voor Eberhard Gothein. Na het begin van zijn studietijd in Breslau kwam Gothein als student in Heidelberg (1874-1875) onder de indruk van de econoom Karl Knies, naast Wilhelm Roscher en Bruno Hildebrand (1812-1886) de voornaamste vertegenwoordiger van de eerste generatie historisch georiënteerde economen in Duitsland. Onder Knies' invloed werd Gothein in Heidelberg een actief en ambitieus deelnemer van het economisch seminar en aan discussieavonden van de plaatselijke Staatswissenschaftliche Verein. ${ }^{125}$ Teruggekeerd naar Breslau bleek de invloed van zijn economische studie in zijn dissertatie over de 'gemene penning' van 1495, waarin hij nadrukkelijk de financiële factor naar voren haalde ten opzichte van de onder historici meer geaccepteerde politieke interpretatie van Ranke. In Breslau behoorde Gothein ook tot de gefascineerde toehoorders van de econoom Brentano, met wie hij later bevriend raakte. $^{126}$

${ }^{121}$ Zie paragraaf 2.

${ }^{122}$ Zie voor de oudere Historische School: Eisermann (1956); voor de jongere Historische School, m.n. Schmoller: Schäfer (1971).

${ }^{123}$ Bovendien studeerde Breysig bij Gustav Schönberg en Meitzen, en Lamprecht bij Georg Hanssen. Zowel Schönberg als Meitzen en Hanssen, beiden gespecialiseerd in agrarische geschiedenis, worden tot de Historische School gerekend.

${ }^{124}$ Een van de voorwaarden daarvoor was de aanwezigheid van de economen in dezelfde (filosofische) faculteit als de historici, waardoor zij benoemingszaken konden beïnvloeden. Alleen in München en Tübingen, alsmede in Würzburg, Freiburg en Straatsburg behoorden de economen respectievelijk tot een afzonderlijke of een andere (juridische) faculteit. Zie Bruch (1988), 117.

${ }^{125}$ Vanwege zijn door Dilthey veranlasste terugkeer naar Breslau studeerde hij uiteindelijk niet af in Nationalökonomie als tweede studievak, zie Gothein (1931), 18, 12, 22.

${ }^{126} \mathrm{Zie}$ Gothein (1915), 4. 
Toen er als gevolg van de kritiek van historici op zijn dissertatie en Habilitationsschrift weinig schot zat in Gotheins carrière, bleken zijn contacten met economen in het westelijke Heidelberg van grote waarde. Het waren namelijk naast de historicus Bernhard Erdmannsdörffer, vooral de economen Knies en Lexis die hem de grote opdracht van de Badische Historische Kommission bezorgden, om een economische geschiedenis van het Zwarte Woud te schrijven. ${ }^{127}$ Het huisorgaan van de Badische Historische Kommission bood Gothein vervolgens ook de meeste publicatieruimte in de eerste jaren na zijn habilitatie, ${ }^{128}$ terwijl daarnaast in deze periode twee langere historische verhandelingen onder de hoede van een andere vooraanstaande econoom, Gustav Schmoller, werden uitgegeven. ${ }^{129}$

Op aandringen van Brentano liet Gothein zich umhabilitieren naar Straatsburg, waar hij opnieuw weinig aansluiting bij de historici vond, maar wel met economen op vriendschappelijke voet verkeerde. Juist in Straatsburg was het staatswetenschappelijke seminar, zoals Gothein zelf later schreef, door toedoen van Schmoller, Lexis en Knapp tot 'de belangrijkste broedplaats van de economische geschiedenis' geworden. ${ }^{130}$ Het is aannemelijk dat dezelfde economen die een rol speelden in zijn aanstelling bij de Badische Historische Kommission zich nog geen twee jaar later ook inzetten om Gothein, die inmiddels als onderzoeker in Baden zijn contacten had opgebouwd, een economisch professoraat te bezorgen aan de TH van Karlsruhe. ${ }^{131}$ Van deze contacten waren bovendien Lexis en vooral Schmoller belangrijk als goede vrienden en invloedrijke adviseurs van de machtige Pruisische universiteitsreferendaris Althoff. Van Knapp weten we dat hij in 1889 zowel met Schmoller als Althoff correspondeerde over

${ }^{127}$ Aldus Gothein (1931), 53. Opmerkelijk is overigens dat eerst Lamprecht door Lexis was benaderd voor deze opdracht, zie Schönebaum (1959). Zowel Lexis (tot 1886) als Knies (tot 1898) en Erdmannsdörffer (tot 1901) waren lid van de Badische Historische Kommission (BHK). In het voorwoord van zijn Schwarzwald-boek noemt Gothein zelf naast Lexis ook archivaris Baumann (Donaueschingen) als opdrachtgever. Zij waren als leden van de BHK belast mer de keus van een onderzoeker voor het project, dat terugging op een voorstel van Baumann, zie Fünfundzwanzig Jahre (1909), 23. Andere hoogleraar-leden bij de oprichting: de historici Ed. Winckelmann (Heidelberg; voorzitter BHK 18831896), Hermann von Holst (Freiburg) en Bernhard Simson (Freiburg); verder prof. F.X. Kraus (Freiburg, leeropdracht onbekend). Overigens werd in 1885 de staatsrechtsgeleerde Otto Gierke lid, in 1891, Gotheins opvolger in Karlsruhe Karl Bücher en in 1896 Max Weber. Gothein werd zelf lid na zijn benoeming in Heidelberg in 1904 en ten slotte voorzitter van de BHK in 1913.

${ }^{128}$ Er verschenen van 1886 tot 1890 negen artikelen van Gothein in de Zeitschrift für die Geschichte des Oberrheins, dat v.a. 1886 tot 1896 onder redactie stond van de Karlsruher archivaris en latere Bonner historicus Aloys Schulte, met wie Gothein in deze periode bevriend raakte.

${ }^{129}$ Schmoller nam in 1883 en nog eens in 1889 een historische studie van Gothein op in de reeks Staats- und socialwissenschaftliche Forschungen die onder zijn redactie verscheen.

${ }^{130}$ Gothein (1931), 65-66. Lujo Brentano (1844-1931) was v.a. 1871 docent in Berlijn, extraordinarius en ordinarius in Breslau, Straatsburg (1882), Wenen (1888), Leipzig (1889), München (1891). G.F. Knapp (1842-1926) was van 1874-1918 professor in Straatsburg. Lexis (1837-1914) was in 1872 extraordinarius voor Nationalökonomie in Straatsburg, in 1874 ordinarius in Dorpat, 1876: Freiburg, 1884: Breslau, 1887: Göttingen. Lexis, Schmoller, Brentano en Knapp waren allen vertegenwoordigers van de tweede generatie historisch georiënteerde economen. Brentano en Knapp waren weer leerlingen van Georg Hanssen, een docent van Lamprecht. Citaat van Gothein over Straatsburg afkomstig uit: Gothein (1893), 585.

${ }^{131}$ Gegevens daarover ontbreken in de literatuur. Tot Gotheins contacten behoorden in ieder geval de Karlsruher landsarchivaris Von Weech, secretaris van de BHK in 1883-1905, die zelf enkele jaren eerder een Duitse geschiedenis 'mit besonderer Berücksichtigung der Kulturgeschichte' (1879) had gepubliceerd. Volgens Gothein zelf speelde Weech een grote rol in de benoeming, zie Maurer e.a. (2006), 95. Gothein raakte in Karlsruhe ook bevriend met de latere historisch ordinarius Aloys Schulte - na 1910 redactielid van het Archiv für Kulturgeschichte, zie Gothein (1892), voorwoord. Schulte werkte vanaf 1883 als archivaris in Donaueschingen, vanaf eind 1885 als archivaris (onder Von Weech) in Karlsruhe, en vanaf 1892 als ordinarius in Freiburg, zie Braubach (1968), 301. Gotheins misgelopen historisch ordinariaat in 1897 betrof waarschijnlijk de opvolging van Schulte in Freiburg. 
een mogelijke positieverbetering van Gothein en daarop van beiden een instemmende reactie kreeg. ${ }^{132}$ Toen in 1890 in Bonn ruimte voor een Nationalökonom ontstond, werd Gothein op instigatie van Althoff als zodanig benoemd. ${ }^{133}$ Aan het eind van datzelfde jaar waren het opnieuw economen, dit keer met name Brentano en de oude Roscher, de promotor van Lamprecht, die zich voor de benoeming van Gothein inzetten toen in Leipzig - in het koninkrijk Saksen en dus buiten bereik van de Pruisische functionaris Althoff - een historische leerstoel vrijkwam. ${ }^{134}$ Benoemd werd toen echter niet Gothein maar, mèt steun van de historici in de faculteit, Karl Lamprecht. Gothein bleef, ondanks zijn eigen voorkeur voor een historische leerstoel, voor de rest van zijn leven hoogleraar in de Nationalökonomie, tot 1904 in Bonn en vervolgens in Heidelberg.

Uit Brentano's en Roschers keuze voor Gothein in plaats van Lamprecht in 1890 zouden we kunnen afleiden dat Lamprechts contacten met de Nationalökonomie minder goed waren dan die van Gothein. Toch is dat maar ten dele waar; het is eerder zo dat Lamprecht op dat moment daarnaast betere relaties met historici onderhield dan Gothein, die inmiddels al enkele jaren economie had gedoceerd en bovendien in het begin van zijn carrière explicieter was geweest in zijn kritiek op de gebruikelijke politieke geschiedschrijving. Maar ook Lamprecht had belangrijke sprongen in zijn carrière mede te danken aan de Nationalökonomen.

Net als Gothein was Lamprecht tijdens zijn studietijd in de ban geraakt van de Nationalökonomie, in zijn geval vooral door de Leipzigse colleges van de grondlegger van een historisch georiënteerde Nationalökonomie, Wilhelm Roscher. Al eerder had hij overigens in Göttingen colleges gevolgd bij de econoom en agrarisch historicus Georg Hanssen. ${ }^{135}$ Onder invloed van Roscher vormde Lamprecht zijn al eerder geconcipieerde dissertatie over Ivo van Chartres om tot een economisch-historische studie waarvoor Roscher, naast de historicus Von Noorden, als promotor optrad. ${ }^{136}$ Behalve Von Noorden, die het werk vanwege zijn nauwgezet bronnenonderzoek prees, was ook Roscher ingenomen met het proefschrift, hetgeen er ongetwijfeld toe bijdroeg dat de dissertatie door Schmoller werd opgenomen in de eerste jaargang van diens Staats- und socialwissenschaftliche Forschungen.

Toen Lamprecht vervolgens als Privatdozent in Bonn ging werken (1880-1885), leidde het hoofdredacteurschap van de door hem mede opgerichte Westdeutsche Zeitschrift für Geschichte und Kunst vanaf 1882 tot een geregeld schriftelijk contact met Schmoller, die hij benaderde met het verzoek om bijdragen aan zijn tijdschrift. In 1882 verscheen ook Lamprechts eerste eigen publicatie in een economisch vaktijdschrift, nadat hij al een hele reeks publicaties in regionale en algemene historische tijdschriften had gepubliceerd. Opvallend was dat het daarbij niet ging om een specialistisch economisch-historisch onderzoek, maar om een uitgebreid literatuuroverzicht op economisch-historisch terrein dat hij samenstelde voor de Jahrbücher für National-

\footnotetext{
${ }^{132}$ Gothein (1931), 78-79; Lewald (1968), 244; Zorn (1968), 262. Schmoller publiceerde ook een positieve reactie op Gotheins Aufgaben der Kulturgeschichte in zijn Jahrbuch (1889), 1483 e.v. Vgl. Schäfer (1891), 7.

${ }^{133}$ Zie Zorn (1968), 262.

${ }^{134}$ Zie Alter (1982), 46; Zorn (1968), 263; Schorn-Schütte (1984), 75; Chickering (1993), 113; Czok (1984), 5 .

${ }_{135}$ Georg Hanssen was de leermeester van Brentano en Knapp. Zie over hem: Fürstenberg (1933).

${ }^{136}$ Vgl. Lamprechts voorwoord tot de Franse vertaling uit 1889, zoals afgedrukt in Le Moyen Age 2 (1889), 133: ‘...je commençai à voir combien il est difficile de caractériser cette base changeante de l'état de la civilisation, sur laquelle on a l'habitude de camper les grandes figures du Moyen Age. A ce moment, je fus obligé de perdre quelque peu de vue mon héros et, à la place d'une dissertation d'histoire politique et religieuse, ce fut un travail d'histoire économique que je menai à terme.'
} 
ökonomie und Statistik. ${ }^{137}$ Met dit in volgende jaren nog enkele malen herhaalde kunststuk liet de jonge Bonner Privatdozent zien dat hij zelf niet alleen als specialist, maar ook als generalist goed thuis was op het terrein van de geschiedenis van de economie.

Het is dan ook niet vreemd dat toen Lamprecht in 1885 benoemd werd tot historisch extraordinarius en in 1890 tot ordinarius, dit mede te danken aan de steun die hij van de kant van Nationalökonomen kreeg. Deze benoemingen, die tegen de (gedeeltelijke) onwil van de plaatselijke faculteiten van regeringswege werden doorgedreven, konden namelijk alleen plaatsvinden door het ingrijpen van Althoff te zijner gunste. En Althoff op zijn beurt zette zich in voor Lamprecht mede op grond van aanbevelingen door de economen Schmoller en Meitzen (met wie Lamprecht studietochten door het Eifelgebied had gemaakt). ${ }^{138}$ Dat Lamprecht in deze jaren binnen de kring van Nationalökonomen gewaardeerd werd, blijkt verder niet alleen uit de zeer positieve besprekingen van zijn grote Deutsches Wirtschaftsleben im Mittelalter uit de kring van economen - terwijl de $H Z$ bij monde van Von Below eerder kritisch oordeelde - ${ }^{139}$ maar ook uit het feit dat hij als medewerker werd gevraagd voor de eerste en volgende uitgaven van het omvangrijke Handwörterbuch der Staatswissenschaften (eerste editie: 1890-1897), een belangrijk monument van de Duitse Nationalökonomie rond 1900. ${ }^{140}$ Het was derhalve beslist niet toevallig dat Lamprechts geschiedtheoretische coming out werd gepubliceerd in een economisch tijdschrift (1895): daar voelde hij de intellectuele ruimte om zijn kritiek op de geschiedwetenschap zonder omhaal van woorden te uiten en aan haar de economische wetenschap ten voorbeeld te stellen. ${ }^{141}$ Ook later bleef Lamprecht onder Nationalökonomen, bijvoorbeeld bij Karl Bücher en Franz Eulenburg, meer waardering ondervinden dan onder vakhistorici.

Breysig studeerde een decennium later dan Gothein en Lamprecht. Hij heeft van alle nieuwe cultuurhistorici qua opleiding en carrière waarschijnlijk het meest aan de Nationalökonomie te danken gehad. Breysig was een beschermeling en leerling van Gustav Schmoller. Nadat hij al in Tübingen (1885/86) een inleiding in de economie bij

\footnotetext{
${ }^{137}$ Zie Schönebaum (1955/56), nr 41; verder nr. 51: 1886; nr. 80: 1895 (rec.); nr. 95: 1897, nr. 100: 1897.

${ }^{138}$ Meitzen meldde Althoff in 1884 dat hij overtuigd was dat Lamprecht 'bijzonder gekwalificeerd was om Kulturgeschichte te doen', zie Chickering (1993), 104n164. Het schijnt overigens aanvankelijk Althoffs plan te zijn geweest Lamprecht in Bonn uiteindelijk als ordinarius voor Nationalökonomie te benoemen, in welk kader hij hem in 1889 verplichtte tot het verzorgen van ook het niet-historisch georiënteerde onderwijs in dat vak. Met Lamprechts vertrek naar Marburg, kreeg Gothein van Althoff de rol toebedeeld van historisch georiënteerde ordinarius voor Nationalökonomie, zie Chickering (1993), 85 en Lewald (1968), 237-240.

${ }^{139}$ Ook in de katholieke Historische Jahrbücher klonk kritiek; Schmoller daarentegen noemde die het een epochale stap voorwaarts in de wetenschap, zie Chickering (1993), 83, Schorn-Schütte (1984), 50. Overigens wordt de econoom Meitzen (die het boek lovend besprak) door Lamprecht in het voorwoord bedankt voor de betrokkenheid bij de totstandkoming van het werk. Ook later was er meer waardering uit deze hoek, bijv. van Eulenburg (1907) en Oppenheimer (1908). Bovendien is het niet toevallig dat een historicus die dicht bij Schmoller stond, Otto Hintze, ook Lamprechts werk beter kon waarderen dan menig collega.

${ }^{140}$ Uitgegeven door onder andere Lexis, zie Bruch (1980), 318-320. Overigens schreef ook Below enkele bijdragen voor deze encyclopedie.

${ }^{141}$ Lamprecht (1895); hierin m.n. de door historici gewraakte passage waarin Lamprecht schrijft dat het in het eigentijdse geschiedonderzoek niet meer om de Rankeaanse vraag 'wie es eigentlich gewesen, sondern um die Frage wie es eigentlich geworden handelt. Die Zeit deskriptiver Geschichtsschreibung wird durch eine Zeit evolutionistischer Geschichtsschreibung abgelöst [...] An stelle der juristischen Methode gelangt die morphologische Methode der Wirtschafts- und Sozialwissenschaften zur Herrschaft.' (295). Er waren overigens al wel eerder publieke meningsverschillen geweest tussen Lamprecht en andere historici, o.a. met Below (1887), met A. Bruder (1887/1888) en met Lehmann (in 1893).
} 
Gustav von Schönberg had gevolgd, ${ }^{142}$ liep hij vanaf eind 1886 in Berlijn colleges bij Schmoller, in wiens seminar hij vervolgens in 1887 toetrad. ${ }^{143}$ Daarnaast kwam hij ook onder de indruk van andere Berlijnse economen, met name van August Meitzen, die enkele jaren eerder nog met Lamprecht door de Eifel was getrokken. ${ }^{144}$ Breysig promoveerde bij Schmoller (en Treitschke) in 1888 en werd vervolgens Schmollers assistent in het staatswetenschappelijk seminarium. Hij werd al vroeg medewerker aan verschillende door Schmoller opgezette en/of geredigeerde reeksen van studies en bronnen op het gebied van de Pruisische geschiedenis en lid van de door Schmoller voorgezeten 'Verein für die Geschichte der Mark Brandenburg'. Hij habiliteerde zich bij Schmoller (en opnieuw Treitschke) in 1892 en beiden drongen er met succes bij Althoff op aan om Breysig in 1896 te benoemen als extraordinarius voor nieuwe, speciaal Pruisische geschiedenis - zoals de Berlijnse faculteit trouwens al in 1894 had gewenst. En het was opnieuw Schmoller die in 1907/9, dit keer tegen de meerderheid van de faculteit in, Breysigs verzoek tot de oprichting van een eigen seminar voor vergelijkend historisch onderzoek met een aparte stemverklaring namens de Nationalökonomen ondersteunde. ${ }^{145}$ Ten slotte was het ook Schmoller die Breysig de meeste publicatieruimte in de wetenschappelijke media bood. Niet alleen vinden we Breysigs naam (net als die van Gothein en Lamprecht) onder de auteurs van de door Schmoller uitgegeven Staats- und socialwissenschaftliche Forschungen ${ }^{146}$ bovendien verschenen bijzonder veel historische verhandelingen van Breysig, waaronder enkele van zijn belangrijkste publicaties, in Schmollers eigen Jahrbuch. ${ }^{147}$

Breysig had, kortom, net als Gothein en Lamprecht belangrijke stappen in zijn carrière te danken aan zijn contact met economen. Dat gold veel minder, of eigenlijk helemaal niet, voor Walter Goetz, die zoals we hebben gezien zijn carrièrstappen dankte aan zijn goede contacten in vakhistorische kring. Des te opvallender is de uitspraak in zijn memoires dat geen enkele docent bepalender was voor zijn ontwikkeling dan de econoom Brentano (zoals vermeld, ook een van Gotheins docenten en vrienden): 'Geen enkele van mijn academische docenten heeft zozeer de hele richting van mijn leven bepaald als hij'. ${ }^{148}$

Als student had Goetz in Leipzig met Brentano kennisgemaakt en op grond van die kennismaking voor Nationalökonomie als afstudeervak gekozen; in zijn Münchense periode tussen 1892 en 1895 zocht hij als jonge doctor opnieuw toegang tot Brentano's seminar. Deze kennismaking met Brentano bracht, zoals Goetz het zelf uitdrukte, een 'wetenschappelijke Umstellung' bij hem teweeg - een uitspraak die gezien Goetz' integratie in de historische discipline en zijn aanvankelijk weinig afwijkende geschiedtheoretische opvattingen opmerkelijk is te noemen. ${ }^{149}$ De uitspraak krijgt bovendien een bredere relevantie omdat ze uitdrukking lijkt te geven aan een algemene ervaring van de woordvoerders van de nieuwe cultuurgeschiedenis met betrekking tot

${ }^{142}$ Schönberg (1839-1908) wordt eveneens beschouwd als een vertegenwoordiger van de historische school, zie Schäfer (1971), 46.

${ }^{143}$ Brocke (1971), 21.

${ }^{144}$ Breysig (1962), 17 e.v.; Brocke (1971), 22.

${ }^{145}$ Dat dit plan, dat wellicht ook Breysigs verheffing tot ordinarius zou hebben bespoedigd, desondanks sneuvelde, had veel te maken met het plotselinge terugtreden van Althoff in 1907 en zijn dood in 1908, waardoor Schmoller zijn belangrijkste connectie in het Pruisische onderwijsministerie verloor. Overigens had Schmoller in 1905 ook nog een poging gedaan om Breysig over te halen de opvolger van Gothein te worden op diens economische leerstoel in Bonn, zie Brocke (1971), 152n103.

${ }^{146}$ In deze reeks verschenen ook een groot deel van de door Breysig begeleide dissertaties: Spahn (1896), Bergmann (1901), Wolters (1905), Rachel (1905), Huth (1907), zie Schilling (1928) en (1962).

${ }^{147}$ Zie Schilling (1928), nrs. 10, 19, 27, 28, 34, 73, 75, 78, 84, 89, 103, 104, 107, 223, 261, 303.

${ }^{148}$ Goetz (1957), 13.

${ }^{149}$ Goetz (1957), 29, mijn cursivering. 
hun economische studie. Zo typeerde Gothein de econoom Knies als de enige van zijn Heidelbergse docenten van wie hij iets had opgestoken. ${ }^{150}$ Breysig noemde bij al zijn waardering voor Ranke en Treitschke, toch Schmoller zijn 'eigentlicher Lehrer', een docent die een belangrijke wending in zijn historische oriëntatie te weeg had gebracht. ${ }^{151}$ En Steinhausen - de enige van de woordvoerders van de nieuwe cultuurgeschiedenis die geen economie studeerde - betreurde het later sehr dat hij in zijn Berlijnse studietijd niet alleen de colleges van Dilthey maar ook die van Schmoller had gemist, '[v]ermutlich hätten beide mir gerade in der Richtung meiner [nl. kulturgeschichtlichen] Neigungen etwas sein und geben können'. ${ }^{152}$ Tekenend voor de mate waarin de nieuwe cultuurhistorici zichzelf beschouwden als leerlingen van Nationalökonomen is ook dat zowel Lamprecht, Breysig als Gothein meewerkten aan Festschriften voor hun oud-docenten economie, respectievelijk Hanssen, Schmoller en Knies.

De goede contacten tussen economen en cultuurhistorici en hun wederzijdse waardering vormen een belangrijke verklaring voor de opvallende steun die de cultuurhistorici ondervonden van Althoff, de machtige Pruisische Ministerialdirektor voor universiteitszaken. Gedreven door dezelfde politieke opvattingen die ook tot uitdrukking kwamen in de keizerlijke voorstellen voor de hervorming van het geschiedenisonderwijs, had Althoff de hand gehad in de benoeming van veel voor 'kathedersocialisten' uitgemaakte economen van de Historische School. ${ }^{153}$ Op hun beurt bepleitten deze economen vaak met succes de kandidatuur van de cultuurhistorici bij Althoff. De benoemingen van Lamprecht in Bonn en Marburg en die van Gothein in Bonn waren immers mede dank zij Althoff tot stand gekomen en Althoff zette zich ook in voor Breysig in Berlijn. Als hij dat aanbod niet geweigerd had, was Breysig door Althoff al in 1897 benoemd tot historisch ordinarius in Münster. Althoff probeerde in 1896 zelfs Lamprecht als opvolger van Treitschke in Berlijn benoemd te krijgen. ${ }^{154}$ Tot de kring van zijn naaste adviseurs in universitaire benoemingszaken behoorde opvallend genoeg geen enkele universitaire historicus in functie (de oudhistoricus Theodor Mommsen die hem van advies diende, was al sinds 1884 met emeritaat), maar wel de economen Schmoller en Lexis. ${ }^{155}$ Zoals een kenner van 'het systeem Althoff' heeft opgemerkt, werd zonder het advies van met name Schmoller vrijwel geen economische of historische leerstoel bezet. ${ }^{156}$

Ook de relatief sterke positie van de cultuurhistorici in de nieuwe historische vakinstellingen komt door de goede relatie tussen economen en cultuurhistorici in een nieuw licht te staan. ${ }^{157}$ Zoals we al in het geval van de Badische Historische Kommission hebben kunnen zien, maakten niet alleen historici maar ook historische georiënteerde economen deel uit van de nieuwe instellingen voor regionaalhistorisch

${ }^{150}$ Gothein (1931), 18.

${ }^{151}$ Brocke (1971), 22n14; Breysig (1962), 50; Gezien de rol van Schmoller in Breysigs carrière is het niet meer zo verwonderlijk dat Geistesaristokrat en nietzscheaan Breysig zichzelf in zijn

herinneringen onderdanig typeert als Schmollers 'getreuer Schildknappe' (34).

${ }^{152}$ Steinhausen (1925), 238

${ }^{153}$ Zie Brocke (1980), 46.

${ }^{154}$ Brocke (1980), 83; Chickering (1992), 181.

${ }^{155}$ Brocke (1980), 69-70. Overigens verzette Mommsen zich tegen Lamprechts opvolging van Treitschke in Berlijn, zie Chickering (1992), 187.

${ }^{156}$ Brocke (1980), 82.

${ }^{157}$ Overigens dient ook de al gesignaleerde betrokkenheid van de cultuurhistorici bij de Jahresberichte der Geschichtswissenschaft in dit verband te worden gememoreerd: hoofdredacteur in de periode 1881-1896 was Ignaz Jastrow, de laatste assistent van Ranke, die vanaf 1885 als docent geschiedenis aan de universiteit van Berlijn werkzaam was, maar zich in 1892 liet umhabilitieren tot docent economie en zijn carrière als econoom voortzette. 
onderzoek. Het feit dat de nieuwe cultuurhistorici een belangrijke rol in deze nieuwe organisaties konden spelen heeft er ongetwijfeld mee te maken dat zij hier vaak de steun kregen van de economen. Het berustte bijvoorbeeld ongetwijfeld niet op toeval dat Breysig bestuurslid werd van de Brandenburgse geschiedvereniging op het moment dat Schmoller daarvan tot voorzitter werd benoemd. ${ }^{158}$

Maar de steunverhouding werkte ook in de andere richting: voor zover de nieuwe instellingen te danken waren aan het initiatief van de cultuurhistorici, waren zij minder afhankelijk waren van de instemming van vakgenoten en konden zij zelf hen welgezinde economen in de organisatie betrekken. Zo werden bijvoorbeeld bij de oprichting van de Saksische Kommission für Geschichte - een initiatief van Lamprecht behalve de Leipzigse hoogleraren geschiedenis ook de economen Bücher en Miaskowski, en later nog Stieda lid. ${ }^{159}$ Ook in de Verband Deutscher Historiker en de organisatie van de Historikertage zien we dit verschijnsel optreden. Meteen op de eerste Historikertag nam Lamprecht uitdrukkelijk het initiatief om voortaan ook nietvakhistorici te mogen uitnodigen. ${ }^{160}$ Het resultaat was op de volgende Historikertage direct te merken. Terwijl de economen op de eerste Historikertag nog afwezig waren, doken zij op vanaf de eerste bijeenkomst die onder Lamprechts leiding werd georganiseerd: de namen van de economen Bücher, Miaskowski, Schmoller en Stieda zijn bijvoorbeeld terug te vinden op de aanwezigheidslijst van 1894 en die van Knapp, Inama-Sternegg, Schmoller en Meitzen op de lijst van $1896 .{ }^{161}$ Ook aan de keuze voor de lezinghouders op de Historikertage was Lamprechts invloed te merken: tijdens de tweede bijeenkomst sprak Schmoller, op de derde Bücher, op de vierde Knapp.

Dit hoofdstuk laat ons derhalve achter met twee vaststellingen die het onderzoek verder leiden. Aan het slot van het hoofdstuk zijn de talloze nauwe en effectieve relaties tussen de nieuwe cultuurhistorici en de economen uit de Historische School naar voren gekomen. Dit spoor wordt in hoofdstuk 6 verder vervolgd en onderzocht. Daar zal blijken dat de nauwe praktische relaties tussen cultuurhistorici en economen een parallel vonden in sterke overeenkomsten in hun opvattingen over geschiedenis. De scholing door de economen uit de Historische School behoorde zonder twijfel tot de krachtigste intellectuele impulsen die de nieuwe cultuurhistorici ontvingen, ook als het gaat om de gedachte van de veranderlijkheid van de menselijke psyche.

Tegelijk is eerder in dit hoofdstuk echter ook de relatief sterke worteling van de nieuwe cultuurhistorici in de historische discipline duidelijk geworden. Op grond van hun onderwijscarrière en vroegste vakhistorische publicaties behoorden de nieuwe cultuurhistorici aanvankelijk tot de meest veelbelovende jonge historici van hun generatie, die het vertrouwen en de bescherming genoten van hun oud-docenten geschiedenis. Het breekpunt in de carrière van de meeste nieuwe cultuurhistorici volgde pas nadat zij zich expliciet hadden uitgesproken tegen het primaat van de politieke geschiedenis en dus niet op grond van de overige kwaliteiten van hun werk. Op het moment dat zij afstand namen van de heersende vaknormen, werden de nieuwe

${ }^{158}$ Zie de appendix van Schultze (1923).

${ }^{159}$ Zie Wiemers (1996).

${ }^{160}$ Zie Bericht (1893), 24 (Lamprecht noemde hier overigens niet met zoveel woorden de economen...)

${ }^{161}$ Ook in de eerste gepubliceerde lijst van leden van de Verband deutscher Historiker (1896) vinden we de namen van economen: Knapp, Schmoller en Stieda. 
cultuurhistorici vooral onder vuur genomen door nog niet gevestigde jonge historici, die zich daarmee uitdrukkelijk en publiekelijk conformeerden aan de op dat moment dominante disciplinaire normen. De strijd tussen voor- en tegenstanders van de cultuurgeschiedenis was derhalve maar in beperkte mate een conflict tussen twee generaties. Evenmin onderscheidden de nieuwe cultuurhistorici zich van de meerderheid van de hoogleraren geschiedenis van hun generatie door hun 'goed-burgerlijke', academische, urbane en protestantse sociaal-culturele achtergrond.

Deze vaststelling roept de vraag op, wat de nieuwe cultuurhistorici opstaken uit hun historische opleiding en van welke aspecten zij bij nader inzien afstand namen. En welke rol speelden de opvattingen over de veranderlijkheid van de mens daarin? Aan die vragen is het volgende hoofdstuk gewijd. 


\section{Verlicht historisme}

' $\mathrm{O}$ vereenkomstig haar oorsprong treffen we de psychologische geschiedschrijving voornamelijk aan bij mannen en tijden van zwak geloof, waarin de kennis van de menselijke kracht gering is en het onderscheid tussen de verschillende waarden en tussen waarde en waardeloosheid vervaagt. Zo was het [ook] in het tijdperk [...] waarin het positivisme en het industrialisme overheersten [...]. Het waren nutteloze mensen die zulk een psychologische geschiedenis fabriceerden, ze speelden met de dingen, draaiden er in een cirkel omheen, zetten ze bij elkaar in niet steekhoudende, absurde verbanden. Maar dat hadden ze niet gedaan als het filosofische en dichterlijke geesten waren geweest, mensen die mannelijk dachten en functioneerden.'

Dit citaat van de in het Duitse idealisme geschoolde Italiaanse geschiedfilosoof Croce is om meer dan één reden belangwekkend. ${ }^{1}$ Het illustreert goed de weerzin die de psychologische oriëntatie van de geschiedschrijving bij idealistische tijdgenoten kon oproepen. Vooral het gebrek aan inzicht in de 'waarde' van dingen, de tekortschietende 'mannelijkheid' en de 'absurde verbanden' die Croce associeerde met de psychologische geschiedenis, springen in het oog. Opvallend is ook het verband dat hij suggereerde tussen de 'psychologische geschiedschrijving' en het tijdperk van 'industrialisme' en 'positivisme'. Het is niet onwaarschijnlijk dat hij bij deze terugblik uit 1938 daadwerkelijk terugdacht aan de Duitse cultuurhistorici van de jaren negentig. Als generatiegenoot van de cultuurhistorici die in dit boek centraal staan, had hij zich indertijd, in 1895, al negatief uitgelaten over de pleidooien ten gunste van de cultuurgeschiedenis van Gothein en Steinhausen. ${ }^{2}$ En zijn oordeel strookte, zoals we zullen zien, met dat van veel Duitse tegenstanders van de cultuurgeschiedenis, die hun kritiek meestal echter op een meer academische wijze formuleerden.

In dit hoofdstuk wordt de relatie onderzocht tussen de nieuwe cultuurgeschiedenis en de dominante richting in de negentiende-eeuwse Duitse geschiedwetenschap, die sinds Meineckes studie Die Entstehung des Historismus (1936) meestal wordt aangeduid als 'historisme'. ${ }^{3}$ Dit historisme werd getypeerd door een overwegend filosofisch-idealistische oriëntatie en een sterke preoccupatie met de staat. Meinecke verklaarde nog aan de vooravond van de Lamprechtstrijd, als nieuwe redacteur van de Historische Zeitschrift: 'Wij, die menen dat de idealistische levensovertuiging en het intensieve staatsgevoel van de oudere generatie nog geenszins afgedaan hebben,

\footnotetext{
${ }^{1}$ Citaat vertaald uit het Duits: Croce (1944), 191 (oorspronkelijk 1938). Zie voor een genuanceerde analyse van Croce's verhouding tot het Duitse idealisme: Roberts (1987).

${ }^{2}$ Croce noemde in 1938 geen namen. Vgl. voor de kritiek uit 1895: Steinhausen en Bernheim (1896)

${ }^{3}$ Zie voor de betekenisverandering die Meinecke in het bestaande historisme-begrip teweegbracht: Wittkau (1994), 190-191.
} 
willen deze nalatenschap trouw hoeden'. ${ }^{4}$ In dit hoofdstuk zal in de eerste plaats de aard van de meningsverschillen tussen de nieuwe cultuurgeschiedschrijving en het politiek-historisch georiënteerde historisme precieser worden bepaald.

Daarbij zal blijken dat veel meningsverschillen uiteindelijk zijn terug te voeren tot verschillende opvattingen over de aard van de menselijke geest en de verhouding van het individu tot zijn (sociale) omgeving. De historisten verzetten zich tegen historischpsychologische redeneringen en de daaraan ten grondslag liggende idee van de plooibare psyche en de onwillekeurig door de omstandigheden gevormde mens. De ideeën van mensen veranderden in de loop van de geschiedenis, niet hun psychische uitrusting. Het fundamentele historische inzicht dat mensen in het verleden 'anders' waren, werd daarom met recht door de nieuwe cultuurhistorici herleid tot Verlichte geschiedopvattingen en niet tot de in Romantiek en idealisme gewortelde geschiedtheoretici van het historisme.

Dit hoofdstuk heeft evenwel - in het verlengde van het voorgaande hoofdstuk nog een tweede pointe: het legt ook continuïteiten tussen historisme en nieuwe cultuurgeschiedenis bloot. Bij alle verschillen en conflicten tussen cultuurhistorici en hun tegenstanders binnen de historische discipline dienen we niet te vergeten dat de cultuurhistorici ook zelf in de eerste plaats als historici waren opgeleid, en gevormd waren door een academische beroepsgroep met duidelijke vaknormen en met instituties om die normen over te brengen en te handhaven. Tot hun belangrijkste en door hen zelf niet zelden ook gewaardeerde docenten behoorden oudere vakhistorici (geboren tussen 1833 en 1841) als Heinrich von Treitschke (leermeester van Breysig), ${ }^{5}$ Bernhard Erdmannsdörffer (Gothein), ${ }^{6}$ Wilhelm Maurenbrecher (Goetz), ${ }^{7}$ Heinrich Ulmann (Steinhausen) ${ }^{8}$ en Carl von Noorden (Lamprecht): ${ }^{9}$ veelal politiek gemotiveerde historici uit de zogenaamde Pruisische School, die zelf waren opgeleid in de jaren ' 50 en ' 60 .

Ook Ranke, de grootmeester van de Duitse geschiedschrijving, hoewel sinds 1871 met emeritaat, was tijdens de studiejaren van de cultuurhistorici nog altijd (en vanaf de jaren tachtig zelfs weer in toenemende mate) een invloedrijke figuur in de geschiedwetenschap, aan wiens gezag ook de nieuwe cultuurhistorici zich maar moeizaam konden onttrekken. Typerend was het dat Kurt Breysig een belangrijk deel van zijn Tübingse studietijd doorbracht met het bestuderen van Ranke's verzameld werk. ${ }^{10}$ Typerend voor Ranke's gezag was ook de aarzeling die Gothein bij zichzelf bespeurde, toen hij bij het onderzoek voor zijn dissertatie moest constateren dat hij het niet eens was met voorstelling van zaken die Ranke had gegeven. ${ }^{11}$ Desondanks bleef hij overigens zijn hele leven een verklaard Ranke-bewonderaar. ${ }^{12}$ Dat gold zonder meer ook voor Goetz, die 'Ranke' uitdrukkelijk met de nieuwe inzichten wilde verenigen. Hetzelfde kon niet gezegd worden van Lamprecht, die de controverse rond

\footnotetext{
${ }^{4}$ Meinecke in HZ 75 (1895) 390-395, geciteerd door Lamprecht (1896a), 1; het citaat vervolgt overigens: 'zonder dat wij het [die nalatenschap dus] daarom epigonenhaft tot onveranderlijk dogma hoeven te laten verstarren'.

${ }^{5}$ Zie Breysig (1962), 74-78.

${ }^{6}$ Zie Gothein (1901).

${ }^{7}$ Zie Goetz (1957a), m.n. 11.

${ }^{8}$ Steinhausen had overigens weinig waardering voor Ulmann, o.a. vanwege diens eenzijdige politiek-historische belangstelling, maar volgde wel al diens hoor- en werkcolleges, zie Steinhausen (1925), m.n. 238

${ }^{9}$ Over de wederzijdse waardering van Lamprecht en Von Noorden zie Schönebaum (1962).

${ }^{10}$ Brocke (1971), 21.

${ }^{11}$ Gothein (1931), 23

${ }^{12}$ Zie Gothein (1931), 24.
} 
zijn werk begon met een kritiek op de Rankeaanse geschiedschrijving. Toch hoopte ook hij de stokoude historicus tijdens een persoonlijk bezoek kort voor diens overlijden nog te winnen voor zijn plan om een Deutsche Geschichte te schrijven. Een latere criticus zou met een zekere voldoening vaststellen dat passages in dit magnum opus van de bestrijder van de 'oude richtingen' in de geschiedwetenschap uiteindelijk teruggingen op teksten van Ranke. ${ }^{13}$ En, wat meer zegt, Lamprecht merkte in een brief aan Treitschke uit 1895 ook zelf zijn schatplichtigheid aan Ranke op: 'het blijkt dat wij jongeren aanmerkelijk veel verder zijn gevormd [präformiert] door Ranke, dan door de zuiver politieke geschiedschrijving van Sybel', schreef hij daar. ${ }^{14}$

De nieuwe cultuurhistorici zetten zich af tegen de politieke historici, maar tegelijk ontwikkelden zij onderdelen van het historistische gedachtengoed verder. De vraag is derhalve: welke invloed had de historische opleiding op de opvattingen van de nieuwe cultuurhistorici? Welke gevestigde opvattingen wezen zij af en in welke opzichten zetten zij de ideeën van hun voormalige docenten voort?

\section{Het primaat van de politiek}

Voor de beantwoording van deze vragen vormen de kritieken die door de tegenstanders van de cultuurgeschiedenis werden geformuleerd een rijke bron: hier werd immers met zoveel woorden tot uitdrukking gebracht aan welke heersende vaknormen de cultuurhistorici niet voldeden (of verondersteld werden niet te voldoen). De kritieken - de belangrijkste werden geschreven door Dietrich Schäfer, Georg von Below, Felix Rachfahl, Max Lenz en Hermann Oncken - bieden ons derhalve zowel zicht op de geldende vaknormen als op de (veronderstelde) afwijkingen van die norm door de cultuurhistorici. Met name de meest principiële en uitvoerige van deze kritieken - geschreven door Von Below en Rachfahl - geven een goede indruk van de vooronderstellingen die ten grondslag lagen aan het laat negentiende-eeuwse Duitse historisme. $^{15}$

Zowel Below als Rachfahl formuleerden op enig moment in hun uitvoerige kritieken expliciet drie criteria voor de beoordeling van historische werken in het algemeen, waaraan naar hun mening ook de cultuurgeschiedschrijving moest worden getoetst. Tot deze algemene historische vakeisen behoorden volgens Below allereerst 'smaak en zin voor schoonheid' wat de schrijfstijl betrof, verder 'grondigheid, precisie en helderheid' in het gebruik van de bronnen, en tenslotte 'een zekere kennis van staat en recht'. ${ }^{16}$ Rachfahl formuleerde bijna dezelfde trits aan algemene vakeisen: beoordeeld moest worden of de schrijfstijl in overeenstemming was met Größe und Würde van het onderwerp, of de wetenschappelijke literatuur goed was verwerkt, en

${ }^{13}$ Zie Chickering (1993), 237.

${ }^{14}$ Afgedrukt in Schieder (1959), 100.

${ }^{15}$ Below (1892), (1893), (1898); Rachfahl (1895), (1896a, b, c), (1897). Andere critici van de cultuurgeschiedenis op wier kritieken ik mij in het navolgende baseer zijn Alfred Dove, Heinrich Finke, Otto Hintze, Max Lehmann, Max Lenz, Friedrich Meinecke, Hermann Oncken, Dietrich Schäfer en Gustav Schnürer. Bovendien zal ik waar nodig ingaan op de belangrijkste oudere autoriteiten van de historistische geschiedbeschouwing, naar wie zowel voor- als tegenstanders verwezen: Ranke en Wilhelm von Humboldt, als respectievelijk de meest gezaghebbende vroege historicus en theoreticus van het Duitse historisme, en Droysen, wiens Historik (1857/1882) de meest uitgewerkte geschiedtheorie van het historisme bevat.

${ }^{16}$ Zie Below (1893), 466. 
tenslotte of de interpretatie werd 'gedragen door een diepe en zelfstandige opvatting van de staatkundige en historische ontwikkeling in het algemeen'. ${ }^{17}$

Opvallend is allereerst dat als enige inhoudelijke eis 'een zekere kennis van de staat' en van de 'staatkundige ontwikkeling' werd gevraagd. Niet alleen Below en Rachfahl, maar ook andere critici van de cultuurgeschiedenis hielden vol dat geschiedenis in de eerste plaats een geschiedenis van de staat en van staten was. 'Voor mijn historisch denken', schreef Dietrich Schäfer in zijn reactie op Gothein, 'zijn de geschriften van Ranke, Häusser, Dahlmann, en de colleges van Ad. Schmidt en Treitschke bepalend geweest. Wat ik daaruit begreep, was dat niets beslissender ingrijpt in de ontwikkeling van de menselijke lotgevallen dan de staat [...]'. Net als Below en Rachfahl stelde hij als 'onvoorwaardelijke eis' aan de bekwaamheid van een historicus 'dat hij in alles wat de binnenlandse en buitenlandse politiek van de staat betreft, volledig competent is'. ${ }^{18}$ Het was naar zijn mening de voornaamste taak van de historicus om 'ontstaan, groei en voorwaarden van de politieke macht' duidelijk te maken. ${ }^{19}$ De historicus, zo besloot hij zijn antwoord aan Gothein, zou er tegenover populaire opvattingen op dienen te wijzen 'waar de rijkste en eeuwig onuitputtelijke bronnen van de historische kennis vloeien en [derhalve] de staat, de belangrijkste cultuurfactor, weer zoveel mogelijk in het middelpunt van het historische denken dienen te plaatsen'. ${ }^{20}$ Ook Below had al tegenover Gotheins pleidooi voor de cultuurgeschiedenis benadrukt dat er 'geen twijfel' over kon bestaan 'dat de politieke geschiedenis het meest omvattend is' en dat 'de historicus dikwijls voortdurend over staatkundige zaken te vertellen zal hebben'. 21

Dit staatkundig criterium moest onvermijdelijk tot een afwijzing van de cultuurgeschiedschrijving leiden. Het was dan ook weinig verrassend dat Below in zijn bespreking van Lamprechts Deutsche Geschichte bijvoorbeeld vaststelde dat hij het met 'met de verdeling van de stof niet eens' was: 'de politieke geschiedenis is niet genoeg in acht genomen'. 22 Ook Rachfahl bekritiseerde herhaald de 'geringere aandacht en zorgvuldigheid' als het ging om de politieke wederwaardigheden van het Duitse volk. $^{23}$

Toch wordt de tegenstelling tussen cultuurhistorici en politieke historici verkeerd opgevat als we zouden menen dat de cultuurhistorici niet aan politieke geschiedenis deden of er onvoldoende kennis van hadden en, omgekeerd, de politieke historici uitsluitend politieke geschiedenis bedreven.

De cultuurhistorici zelf hielden zich vrijwel allemaal met de geschiedenis van de interne politiek bezig. Gothein promoveerde op de totstandkoming van de rijksbelastingen op de Rijksdag van Spiers (maar week daarbij al wel af van de naar zijn mening al te politieke behandeling van Ranke). In veel van zijn economische studies gaf hij juist relatief veel aandacht aan de invloed van bestuurlijke en politieke verhoudingen. Goetz' promotie en habilitatie waren gebaseerd op twee studies op het terrein van de zestiende-eeuwse regionale en Duitse politiek en hij legde in zijn verklaringen ten gunste van de cultuurgeschiedenis later sterk de nadruk op de samenhang van culturele en politieke geschiedenis. Breysig dankte zijn buitengewone

\footnotetext{
${ }^{17}$ Rachfahl (1896a), 49.

${ }^{18}$ Schäfer (1891), 18 (mijn cursivering, MS).

${ }^{19}$ Schäfer (1888), 33.

${ }^{20}$ Schäfer (1891), 69-70.

${ }^{21}$ Below (1892), 287, 291.

${ }^{22}$ Below (1893), 467. Zo ook Schnürer (1897), 94.

${ }^{23}$ Rachfahl (1896a), 87. Vgl. Rachfahl (1896b), 554: 'Nu moet ik evenwel toegeven, dat ik op het "verouderde" standpunt sta, dat een "Deutsche Geschichte" voornamelijk als een geschiedenis van het staatkundige leven van de Duitse natie opgevat dient te worden'.
} 
leerstoel in Berlijn aan zijn dissertatie en andere vroege publicaties op het terrein van de Pruisische bestuursgeschiedenis. Het minst vinden we de politiek-historische oriëntatie terug in de (vroege) publicaties van Lamprecht en Steinhausen. Steinhausen schreef zelf zelden over politieke geschiedenis en verdedigde bovendien een taakscheiding tussen politieke en cultuurgeschiedenis (al deed hij dit, zoals we hebben gezien, eerder uit strategische dan principiële overwegingen). ${ }^{24} \mathrm{Bij}$ Lamprecht ging de politieke geschiedenis pas in zijn Deutsche Geschichte (1891-) een rol van betekenis spelen; vervolgens was zij echter niet meer weg te denken uit zijn geschiedschrijving. Van de drie delen eigentijdse geschiedenis in zijn hoofdwerk, bijvoorbeeld, was er één volledig aan de (interne en externe) politieke geschiedenis gewijd. Nog in 1912 schreef hij voor Labands Handbuch der Politik een bijdrage die uitsluitend deze thematiek behandelde: 'Staatsform und Politik im Lichte der Geschichte'. ${ }^{25}$

Omgekeerd was de Duitse geschiedschrijving van vóór de jaren negentig niet uitsluitend beperkt gebleven tot de politiek. Dat verkondigden de tegenstanders van de nieuwe cultuurgeschiedenis ook met klem. Tegenover Steinhausen en zijn pleidooi voor cultuurhistorische leerstoelen merkte de Historische Zeitschrift bijvoorbeeld op dat 'elke docent in de algemene geschiedenis [...] vanzelf de nodige aandacht aan cultuurhistorische problemen geeft'. ${ }^{26}$ Zoals met name Below niet moe werd te beweren, was al het zogenaamd 'nieuwe' van de nieuwe cultuurgeschiedenis, voor zover het waardevol was, in feite een verworvenheid van de oudere Duitse geschiedschrijving. ${ }^{27}$ Hij meende dat vooral Lamprecht wat dat betreft een groot gebrek aan kennis van de bestaande vakliteratuur verweten kon worden. Hadden niet al Niebuhr en Ranke economische kwesties in hun geschiedschrijving opgenomen en kon niet datzelfde zelfs van een politiek historicus bij uitstek als Sybel worden beweerd? $\mathrm{Na}$ 1878 nam, aldus Below, de vakhistorische belangstelling voor economische onderwerpen studies verder toe en het was opnieuw te danken aan een eminente politiek historicus, Treitschke, dat deze studies voor het eerst in een synthetisch overzicht van de Duitse geschiedenis werden verwerkt. Dat laatste werd overigens door de cultuurhistorici tot op zekere hoogte erkend en verklaart voor een deel de waardering van bijvoorbeeld Gothein, Lamprecht en Breysig voor Treitschke. ${ }^{28}$ Zij waren het ook met Below erover eens dat de Berlijnse hoogleraar Nitzsch (1818-1880) op dit terrein al inspanningen van betekenis had geleverd; hij was bijvoorbeeld een van de drie wetenschappers, naast Schmoller en Burckhardt, aan wie Breysig een deel van zijn Kulturgeschichte der Neuzeit opdroeg. ${ }^{29}$ Gotheins meest gewaardeerde historische docent, Bernhard Erdmannsdörffer, hoewel vooral actief als politiek historicus, behoorde niet alleen tot de vroege vakhistorische bewonderaars van Burckhardt, maar

${ }^{24}$ Zie hoofdstuk 3, paragraaf 2.1.

${ }^{25}$ Afgedrukt in Lamprecht (1974), 747-760.

${ }^{26}$ Geciteerd in Steinhausen (1895b), 192 (mijn cursivering, MS)

${ }^{27}$ Zie bijv. Below (1898), 217.

${ }^{28}$ Zie bijv. Gothein (1889), 25. Zie voor Breysig en Treitschke: Brocke (1971), 133-141.

${ }^{29}$ Vgl. Brocke (1971), 141-144. Zie over Nitzsch' staatsopvatting, Simon (1988), 61. Van Nitzsch werd in de jaren tachtig posthuum op grond van collegedictaten een Duitse geschiedenis gepubliceerd, waarin niet de staat maar 'het volk' de eenheid van onderzoek vormde en de economische factor aandacht kreeg. Dat Nitzsch ondertussen door sommige vakgenoten werd beschouwd als een vreemde eend in de bijt - geen echte econoom, maar ook geen echte historicus - blijkt uit een brief uit 1890 van Alfred Dove (aan de econoom Knapp): sprekend over Lamprecht merkt hij op dat 'sein Geist [mir] nicht wahrhaft - unkonstruktiv - historisch erscheinen will; womit ich nicht sagen will, daß er Nationalökonom von Geburt sei'. En hij vervolgt dan: 'Diese Wirtschaftshistoriker von der Linie Nitzsch sind eben wie die Dragoner des 17. Jahrhunderts, die auch weder zur Reiterei noch zum Fußvolk zählten und doch sehr merkwürdig waren'. Geciteerd naar Schorn-Schütte (1984), 73, uit Dove (1925), 130. 
publiceerde ook zelf een opmerkelijke cultuurhistorische analyse over de populariteit van de novelle als literair genre in de verschillende tijdvakken. ${ }^{30}$ En last but not least waardeerden de cultuurhistorici ook Ranke als een politiek historicus die universeler, meer cultuurhistorisch georiënteerd was geweest dan veel van zijn latere collega's. ${ }^{31}$ Zijn werk vormde, zoals Gothein het in 1889 formuleerde, een Mittelglied tussen politieke en cultuurgeschiedenis, omdat het staatsleven weliswaar ook bij hem in het middelpunt stond, maar hij dat staatsleven vervolgens weer als een uitdrukking van heersende 'ideeën' opvatte. Ook al had hij onvoldoende inzicht in de betekenis van economische en sociale ontwikkelingen, zijn 'psychologisch-cultuurhistorische interpretatie' was te prefereren boven de eenzijdige politieke verklaringen van veel latere politieke historici. ${ }^{32}$

Toch schreef Steinhausen in 1892 niet ten onrechte: 'Van dat wat wij verlangen, heeft de huidige geschiedschrijving bijna niets vervuld'. ${ }^{33}$ Ten eerste stamden de niet politiek georiënteerde historische studies - zowel algemeen cultuurhistorische als meer speciaal economisch-historische - feitelijk voor het overgrote deel niet uit de pen van universitaire historici. ${ }^{34}$ En ten tweede lag het accent van de politieke historici bij de behandeling van niet-politieke zaken heel anders dan bij de cultuurhistorici, zoals al eerder duidelijk is geworden: terwijl beide groepen uitdrukkelijk pretendeerden 'algemene geschiedenis' te schrijven lag voor de cultuurhistorici het primaat inderdaad anders dan bij de politieke historici bij de culturele en sociaal-psychische factoren.

De politiek historici twijfelden er niet aan dat de geschiedenis werd bepaald door de machtigste staten, hun onderlinge conflicten en verhoudingen? ${ }^{35}$ De geschiedenis was volgens hen een 'complex' van verschillende 'ideeën' of 'tendenzen' die in de gedaante van de individuele nationale staten met elkaar om de voorrang streden. Staten werden in expliciete tegenstelling tot de Verlichte contracttheorie dus niet opgevat als een vereniging van burgers tot welzijn van allen, maar als 'geestelijke essenties, oorspronkelijke creaties van de menselijke geest - men mag zeggen Gedanken Gottes' (Ranke). ${ }^{36}$ Volkeren zonder staat werden beschouwd als volkeren zonder geschiedenis. ${ }^{37}$

Het analytische primaat dat aan de staat als beslissende historische factor werd toegekend had mede een politiek-morele achtergrond: door in de geschiedschrijving voorrang te verlenen aan de staat tegenover de krachten van de samenleving, kon het algemene, nationale belang - en zijn behoeder: de landsheer - alle nadruk krijgen en de anarchie van het groeps- en eigenbelang in geschrifte worden bestreden. ${ }^{38}$

${ }^{30}$ Zie Erdmannsdörffer (1911a). Dilthey (1960), 195, beschreef zijn vriend Erdmannsdörffer in 1865 als 'ganz einer tieferen Grundlegung der Geschichte durch Studium der Kultur zugewandt.' Vergelijk over Erdmannsdörffer als politiek historicus de bijdrage van Werner Giesselmann in Miethke (1992), m.n. 85-90.

${ }^{31}$ Het mag typerend heten dat Goetz, bepaald niet de meest radicale onder de cultuurhistorici, de 'epigonen van Ranke' verweet dat zij het 'universalhistorische Prinzip' van diens geschiedopvatting, dat hem volgens Goetz verbond met de Verlichting (!), niet onderkenden, zie Goetz (1934), 274.

${ }^{32}$ Gothein (1889), 50 en 57, zie ook 20-21 en 26.

${ }^{33}$ Steinhausen (1892), 56.

${ }^{34} \mathrm{Vgl}$. Simon (1988), 16.

${ }^{35}$ Vgl. Ranke (1925), 31, en het citaat van Lenz uit 1914 bij Bruch (1988), 128.

${ }^{36}$ Ranke (1925), 25 [Politisches Gespräch, 1836].

${ }^{37}$ Zie bijvoorbeeld de afwijzing door de Berlijnse historici (1909) van Breysigs voorstel om ook de geschiedenis van primitieve volkeren te doceren: 'eine Geschichte haben die nordamerikanischen und die australischen Stämme [...] eben nicht', zie Blanke (1994b), 242.

${ }^{38}$ Daartegen betoogde Gothein (1889), 54: 'Die Geschichte zeigt uns aber mindestens ebenso oft, daß der Staat seinen sittlichen Aufgaben nicht gerecht wurde, wie daß er es wurde'. 
Gothein en Goetz toonden zich van de cultuurhistorici het meest verwant aan de politieke historici door hun uitdrukkelijke erkenning van het belang van de staat, ook voor de cultuurgeschiedenis. Ook bij Steinhausen en Breysig kunnen we de invloed bespeuren van het heersende politiek-historische denken in hun beider nadruk op de internationale verhoudingen - zij het dan in de zin van culturele wisselwerkingen. Maar uiteindelijk lag voor alle cultuurhistorici het primaat bij cultuur en samenleving. De abstractie Gesellschaft, meende Gothein in 1892, is 'onontbeerlijk' gebleken: als we dit woord gebruiken, geven we aan dat een geïsoleerde interpretatie van een historisch fenomeen niet mogelijk is en

'dat we het in relatie tot andere uitingen van het geistige leven moeten beschouwen. Om deze samenhang te kunnen denken, moeten wij een gemeenschappelijke drager daarvan denken, en deze noemen we Gesellschaft ${ }^{39}$

Ook de staatswetenschappen behoefden daarom een 'sociale behandeling'. Of zoals Breysig het formuleerde: de geschiedenis van de staatkundige ontwikkeling is een deel van de sociale geschiedenis (die hij zelf weer als een onderdeel van de cultuurgeschiedenis beschouwde) en de staat was in de eerste plaats een 'soziales Gebilde'. ${ }^{40}$ 'Het valt niet in te zien', schreef hij, 'waarom de sterkste en machtigste sociale institutie die er is, de staat, niet in dit bereik [van een sociale geschiedenis van klassen, standen en familie] opgenomen zou moeten worden. . . ${ }^{41}$ Ook in Lamprechts woorden was de staat een 'sociale organisatie' en wel 'de hoogste sociale vereniging vanwege de cultuur'. En de cultuur zelf was dan weer 'een product van de menselijke socialisering überhaupt, vooral van de natuurlijkste vorm daarvan, de nationale'. ${ }^{42}$ En net als Lamprecht verklaarde ten slotte ook Steinhausen: 'Niet het staatkundige, maar het nationale perspectief, het begrip van de nationaliteit [Volkstum], maakt het ons mogelijk de dingen in hun samenhang te begrijpen'. ${ }^{43}$ De enige historische ordinarius op wiens uitgesproken opvattingen de cultuurhistorici in dit opzicht konden terugvallen was, en dat kan nauwelijks toeval zijn, docent geweest van twee van hen: het was Ernst Bernheim die in 1889 in zijn leerboek ook al had verkondigd dat de geschiedenis een Gesellschaftswissenschaft was. ${ }^{44}$

\section{De stille zuiverheid van de historische zin}

De twee andere beoordelingscriteria die Below en Rachfahl in hun recensies formuleerden, naast de vereiste van grondige politieke kennis, lijken in eerste instantie nauwelijks specifieke vakeisen: van historici eisten zij een fraaie, gepaste en heldere schrijfstijl en een nauwkeurige verwerking van de informatiebronnen. Het negatieve oordeel dat zij velden over deze elementaire wetenschappelijke kwaliteiten moest de bekritiseerde cultuurhistorici natuurlijk des te sterker treffen. Vooral Lamprecht werd door verschillende critici met zoveel woorden neergezet als een niet-wetenschapper, als een ignorant en charlatan. Toch werden ook met behulp van deze twee nauw samenhangende eisen vooral disciplinaire grenzen geformuleerd, zoals een nadere beschouwing leert.

\footnotetext{
${ }^{39}$ Gothein (1892b), 843.

${ }^{40}$ Breysig (1896a), 1093.

${ }^{41}$ Breysig (1896b), 167 en Breysig (1896a), 3.

${ }^{42}$ Lamprecht (1896/97), 99.

${ }^{43}$ Steinhausen (1892), 54.

${ }^{44}$ Bernheim (1889), 11. Vgl. Hoofdstuk 2, paragraaf 1.
} 
Over de gepaste schrijfstijl maakten de critici vooral bij Lamprecht een punt: zij waren het er over eens dat de veel gelezen historicus weliswaar over een 'gladde en vlotte presentatie' beschikte, maar zich daarbij teveel door de 'moderne journalistenstijl' had laten leiden en er een Hetzjagdstil op na hield. ${ }^{45}$ Below stelde met een zekere tevredenheid vast dat Lamprechts Deutsche Geschichte, als het 'veelgeroemde boek der "Moderne" in de geschiedwetenschap', optrad 'in volmaakte lelijkheid'. ${ }^{46}$ Hij en andere critici spraken over Lamprechts Evolutionsstil, waarvan zij de overmaat aan Fremdwörter veroordeelden en waarvan naar de mening van enkele critici behalve de helderheid ook de gepastheid soms ver te zoeken was. ${ }^{47}$ Daarbij dachten zij waarschijnlijk aan woorden als 'diapason', 'osmose' en 'diosmose' die Lamprecht gebruikte in zijn Deutsche Geschichte. ${ }^{48}$

Achter deze stilistische kritiek gingen andere waardeoordelen schuil. Niet alleen probeerden de critici Lamprecht te associëren met laakbare darwinistische opvattingen en 'moderne' (in dit geval 'naturalistische') opvattingen in het algemeen, maar bovendien kwam hier een specifieke houding tot uiting over de wijze waarop het verleden beschreven en geanalyseerd moest worden. De taal en de termen van de historicus dienden alledaags noch al te modern te zijn; bovendien moesten 'universeel-cultuurhistorische typische categorieën', zoals de historicus Dove zich uitdrukte, worden vermeden. ${ }^{49}$ Daartegenover kenmerkte de schrijfstijl van de ware historicus zich behalve door 'goede smaak' en 'waardigheid', vooral door hingebende Anschauung, dit wil zeggen door een 'zich voegen naar' en 'zich overgeven aan' de historische stof. Het is natuurlijk nog maar de vraag of de critici zelf bij machte waren zich 'naar het verleden te voegen' en tegelijk tot het heden te spreken, maar zij raakten hier wel aan een wezenlijk verschil van mening met de cultuurhistorici.

Die erkenden dit verschilpunt ook zelf. Niet dat zij het belang van de artistieke representatie voor de geschiedschrijving ontkenden - zelfs Lamprecht en Breysig, de twee meest sciëntistische cultuurhistorici, deden dat niet. ${ }^{50}$ Zoals Breysig in zijn herinneringen optekende, had hij de maxime van zijn docent Treitschke ter harte genomen dat 'de historicus niet slechts een geleerde, maar ook een kunstenaar' diende te zijn. ${ }^{51}$ Maar het valt niet te ontkennen dat de cultuurhistorici meer dan hun tegenstrevers waarde hechtten aan 'begripsmatige geschiedschrijving' (zoals dezelfde Breysig zijn Kulturgeschichte der Neuzeit typeerde). Het was voor hen geen probleem om het verleden in eigentijdse en algemene begrippen te vatten, integendeel: zij beschouwden dat als een voorwaarde om het verleden in zijn oorzakelijke samenhangen te kunnen analyseren. De tijd van de beschrijvende geschiedwetenschap is voorbij, schreef Lamprecht in een geruchtmakende recensie uit 1895: er moest voortaan daadwerkelijk verklaard worden. En de voortgang van de wetenschap kwam juist daarin tot uitdrukking dat zij haar begrippenapparaat op een wetenschappelijke wijze verder ontwikkelde. En in eenzelfde trant keerde Gothein zich al in 1889 tegen

${ }^{45}$ Zie Rachfahl (1895), 841; Below (1893), 466-467 en Below (1898), 253. Over Breysig oordeelden de Berlijnse historici later dat hij teveel door 'literarische Modeströmungen' werd beïnvloed, zie Brocke (1971), 110-111. Overigens heeft Metz (1979), 585, erop gewezen dat in de nietvakpers Lamprechts stijl van schrijven uitdrukkelijk werd geprezen.

${ }^{46}$ Below (1898), 253.; vgl. Schnürer (1897), 114.

${ }^{47}$ Lenz (1896), 399: 'seine evolutionshistorisch erhitzte Phantasie'; Schnürer (1897), 114.

${ }^{48}$ Vgl. Mergel (2003).

${ }^{49}$ Dove (1925), 144.

${ }^{50}$ Zie Hfdst. 3, par. 6.3; vgl. ook Metz (1979), 584-585.

${ }^{51}$ Breysig (1962), 77. Breysig zette zelfs uitgesproken literaire middelen in: zie bijv. de 'beelden' van de vroegste geschiedenis van de mensheid die hij vooraf liet gaan aan zijn Geschichte der Menschheit, Breysig (1907), 1-28. 
het 'vertellen van gebeurtenissen' en de 'synthetische' beschrijving waartoe de politieke geschiedenis naar zijn mening veroordeeld was: 'de gebeurtenis als zodanig is voor haar [de cultuurgeschiedschrijving] niets, de kracht, de idee die erin tot uitdrukking komt, alles'. Was de politieke geschiedenis vergelijkbaar met eenvoudige natuurbeschrijving, dan had de cultuurgeschiedenis eerder het karakter van scheikunde of fysica, aldus Gothein. ${ }^{52}$

Dit verschil van opvatting over de gepaste historische schrijfstijl hield ten nauwste verband met de derde expliciete vakeis van Below en Rachfahl: grondigheid en precisie in de verwerking van literatuur en bronnen. ${ }^{53}$ Opnieuw werd met name Lamprecht op dit punt onder vuur genomen. Nogal wat besprekingen van Lamprechts Deutsche Geschichte bestonden voor een groot deel uit een opsomming van lees-, schrijf- en interpretatiefouten die hij zou hebben gemaakt. Eén kritiek was zelfs in haar geheel gewijd aan de 'bronnenanalyse van de modernste Duitse geschiedschrijving' - let op de spottende superlatief. ${ }^{54}$ En het werk van Lamprechts studenten werd op dezelfde wijze tegen het licht gehouden. Ook Gothein ontkwam niet aan het verwijt van gebrekkige nauwkeurigheid. Zo meende Schäfer dat zich bij zijn tegenstander 'een gebrek aan precisie en exactheid [openbaarde], dat gelukkig bij historici althans tot de uitzonderingen behoort'. ${ }^{55}$ Dat was een opmerking die onderhuids gericht was tegen Gotheins gefnuikte historische carrière en zijn professionele status als hoogleraar economie. In dezelfde reactie had Schäfer er al op gewezen dat "niet weinig jongere economisch-historici overhaaste werken op de markt brengen, werken die tot stand zijn gekomen ten koste van de grofste overtredingen van de eenvoudigste principes van het historisch onderzoek, [en die] soms gewoonweg wemelen van de kleine en grote fouten en scheve oordelen' ${ }^{56}$ En ten slotte werd ook Breysig 'gebrekkig onderzoek en oppervlakkige constructies' verweten. ${ }^{57}$

Het is bijzonder lastig om een kundig en afgewogen oordeel te vellen over de juistheid van de verwijten die in dit opzicht aan het adres van de cultuurhistorici werden gemaakt; daarvoor is een grondige kennis nodig van zowel de historische onderwerpen als de vakliteratuur die door de diverse historici werden besproken. ${ }^{58}$ Zeker is dat elke kritische lezing van een historisch werk, zeker van omvangrijke en synthetische studies als Lamprechts Deutsche Geschichte, onvolkomenheden in de verwerking van de informatiebronnen aan het licht zal brengen. Het is veelzeggend

${ }^{52}$ Gothein (1889), 11-13.

${ }^{53}$ Zo ook bij Schäfer (1891), 18.

${ }^{54}$ Oncken (1897). Overigens was het typerend dat Oncken zich in zijn recensie weer hoofdzakelijk 'auf die politische Abschnitte' van een deel van Lamprechts DG concentreerde.

${ }^{55}$ Schäfer (1891), 49.

${ }^{56}$ Schäfer (1891), 21. Een echo daarvan klonk in Belows bespreking van het Gothein-Schäfer debat Below (1892), 295: 'auf das niedrige Niveau auf dem sich diese [ganz wertlose wirtschaftsgeschichtliche Arbeiten] befinden, [ist] ein politischer Historiker nie herabgesunken'.

${ }^{57}$ Zie de kritieken van o.a. Below, besproken in Brocke (1971), 79-84, m.n. 83, en het oordeel van de Berlijnse historici in 1922, geciteerd in Brocke (1971), 111.

${ }^{58}$ Typerend voor de moeilijkheid om een eenduidig oordeel te vellen, zijn twee gevallen uit Lamprechts 'school'. Een ervan betrof Ernst Schaumkell (1905), die volgens een eigentijdse recensent geplagieerd zou hebben - een oordeel dat grif door tegenstanders van Lamprecht werd overgenomen en uitgebuit. Maar volgens een huidige commentator is de beschuldiging van plagiaat niet terecht: het werk van Schaumkell was veel breder in opzet en uitwerking dan de overigens inderdaad soms te slordig door hem geciteerde studies van Dilthey en Julius Goldstein, zie Schleier (1982), 52. Schaumkells omvangrijke studie naar de ontwikkeling van de Duitse cultuurgeschiedschrijving bleef dan ook tot in 1971 de belangrijkste overzichtstudie op haar terrein. Een ander voorbeeld is de dissertatie van Lamprechts promovendus Felix Günther; zij wordt door de ene huidige beoordelaar 'überdurchschnittlich' genoemd, en door een ander als 'ein trauriges Beispiel epigonenhaften Schülertums’ beoordeeld; zie Schleier (1982), 51 en Blanke (1994a), 137. 
dat Lamprecht en sommige van zijn medestanders enkele critici met gelijke munt konden betalen en ook hen met kracht van argumenten konden verwijten dat zij onnauwkeurig lazen, slordig citeerden en onverantwoord interpreteerden. ${ }^{59}$ Bovendien zijn er de nodige kanttekeningen te plaatsen bij de aanvallen van de tegenstanders. Vooral zijn er goede redenen om aan te nemen dat de vakcritici met hun 'bronnenkritiek' niet zozeer zuiver wetenschappelijke kritiek leverden als wel disciplinaire grenzen probeerden te trekken.

Allereerst dient er op gewezen te worden dat de nadruk op verantwoord bronnengebruik een 'identiteitsconstituerend' kenmerk van de historistische geschiedwetenschap was. Veel Duitse geschiedschrijvers beschouwden de exacte en kritische bronnenstudie als een specifieke verworvenheid van de professionele Duitse geschiedschrijving sinds Ranke. De nadruk die Ranke en andere vroege historisten hadden gelegd op de bronnenstudie was gericht tegen een vorm van geschiedbeschouwing die 'geschiedfilosofie' werd genoemd. Voor veel historisten waren dergelijk algemene beschouwingen over het verloop van de wereldgeschiedenis te weinig op bronnenonderzoek en feitelijkheden gebaseerd en teveel op theorieën en speculaties. Hier speelde de wens tot disciplinaire differentiatie een rol: bij het 'zoeken naar een principe dat geschiedenis een eigen leven kan geven', zoals Ranke het in 1831 zelf formuleerde, ging het er vooral om 'onze wetenschap tegen de claims van de filosofie te rechtvaardigen'. ${ }^{60}$ Maar fundamenteler was de historistische overweging dat het afstand nemen van de bronnen dat in elke geschiedfilosofie besloten lag, het verleden geweld aan deed. Dit standpunt had overigens zeker bij Ranke ook een politieke connotatie: in de geschiedfilosofie heerste hetzelfde gevaarlijke, eigenmachtige en systematische denken van de wijsgeer, dat ook het onhistorische natuurrechtsdenken met zijn revolutionaire potenties kenmerkte. De mate waarin geschiedfilosofen hun eigen gedachten aan het verleden wilde opleggen, was in strijd met de uitgangspunten van de historisten, die meenden dat het verleden als zodanig gerespecteerd diende te worden, door de historicus niet minder dan door de staatsman.

$\mathrm{Nu}$ kan onmogelijk beweerd worden dat de cultuurhistorici van de jaren negentig onberoerd waren gebleven door het ethos van de geschichtliche Quellenforschung, zoals nota bene de ondertitel van Lamprechts Habilitationsschrift luidde. In allerlei publicaties gaven zij van dat ethos blijk. Dat treft juist bij Lamprecht. Zijn dissertatie werd door zijn historische promotor Von Noorden uitdrukkelijk geprezen vanwege het nauwkeurige bronnenonderzoek; de bladspiegel van het zonder meer indrukwekkende proefschrift toonde de karakteristieke horizontale tweedeling van voetnoten met bronverwijzingen aan de onderzijde en hoofdtekst daarboven, waarbij de voetnoten door de hele studie heen meer dan de helft van de bladzijde besloegen. ${ }^{61}$ Lamprecht verzorgde ook verschillende bronnenedities en hij publiceerde zelfs een vergelijkende bronnenstudie. $^{62}$ Zijn vierdelige Deutsches Wirtschaftsleben im Mittelalter, waarmee hij zich van een extraordinariaat verzekerde, bestond voor tweederde uit bronnenmateriaal, dat hij uit verspreide archieven in het hele Rijngebied had verzameld. Ook de andere cultuurhistorici verzorgden elk verschillende bronnenuitgaven alsmede op

\footnotetext{
${ }^{59}$ Zie bijv. Lamprecht (1897) en Günther (1909).

${ }^{60}$ Ranke (1975), 74 [Idee der Universalhistorie, 1831/32].

${ }^{61}$ Lamprecht (1878); zie voor het oordeel van co-promotor Von Noorden: Chickering (1993), 51.

${ }^{62}$ Zie Schönebaum (1955/56), Nrs. 53, 62, 63.
} 
archiefonderzoek gefundeerde studies. ${ }^{63}$ Zowel Lamprecht als Goetz en Steinhausen namen bovendien ook verschillende initiatieven om het onderzoek van specifiek cultuurhistorische bronnen te stimuleren.

Aan bronnenethos ontbrak het de cultuurhistorici dus duidelijk niet. ${ }^{64} \mathrm{Zij}$ opteerden niet voor een terugkeer naar een geschiedbeschouwing die minder gefundeerd was op historische bronnen dan in het historisme gebruikelijk was; zij pleitten integendeel voor een uitbreiding van de soorten bronnen die historici dienden te bestuderen, zoals we eerder hebben gezien. ${ }^{65}$ Bovendien kan opgemerkt worden dat de 'enormiteiten' met betrekking tot het bronnengebruik die critici ontwaarden, blijkbaar toch niet van dien aard waren dat wetenschappers van verwante disciplines daaraan aanstoot namen. Een man als Lamprecht, die de meeste kritiek te verduren had, werd door veel (historisch georiënteerde) economen aanmerkelijk positiever beoordeeld dan door vakhistorici, terwijl hen noch de kennis van zaken noch het kritisch vermogen ontzegd kan worden om eventuele elementaire gebreken in het werk van de cultuurhistorici te zien. Ook de waardering van andere vooraanstaande wetenschappers, zoals Hermann Grimm, Ratzel, Wundt en Ostwald voor Lamprecht zou bevreemden als hij zich zo overduidelijk aan algemene wetenschappelijke principes zou hebben vergrepen. ${ }^{66}$

${ }^{63}$ Zie voor Breysig: Schilling (1928), 179-215, nrs. 30-32. Voor de overige cultuurhistorici zie: Goetz (1898), Goetz (1904), Goetz en Theobald (1913); vgl. Weigand (1992), 33-35. Steinhausen (1895a), Steinhausen (1899-1907); Gothein (1893).

${ }^{64}$ Overigens typerend voor Lamprechts eigen bewustzijn van dit disciplinaire bronnenethos is dat hij in zijn beschrijving van de plannen voor het IKU op het internationaal congres van historici in 1908 uitdrukkelijk wijst op de 'Spezialforschung' en de 'emsige Arbeit am Detail' die in het cultuurhistorische seminar door studenten geleverd zou moeten worden, zie Lamprecht (1988), 369370. Op hetzelfde congres bepleitte Breysig een empirische, vergelijkende wereldgeschiedenis die 'nie und nimmer' de 'schöne Gedankenspiele' van de Hegelse of Fichteaanse geschiedfilosofie zou proberen te laten herleven, zie Breysig (1994), 217. Bepaald inconsequent verweet Below Lamprecht overigens in eenzelfde kritiek zowel zijn 'geschiedfilosofische constructies' als zijn overwegend 'antiquarische' belangstelling voor 'historische Kleinheiten': 'Er geht - soweit es ihm seine Flüchtigkeit gestattet - in den kleinen Einzelheiten auf’. Vgl. Below (1898), 234, 257 met 269.

${ }^{65}$ Zie hoofdstuk 3, paragraaf 6.3. Overigens merkte Lamprecht in verband hiermee nog op dat de historisch-kritische methode die door Niebuhr was ontwikkeld, geschikt was voor het onderzoek van een evenementiële geschiedenis; voor een vergelijkende geschiedwetenschap zou de historische methode - bijv. m.b.v. de statistiek - verder moeten worden ontwikkeld. Zie Lamprecht (1974), 408 [1898/99].

${ }^{66}$ Ik moet hier bekennen dat het uitzonderlijk harde oordeel van Max Weber, die in zijn correspondentie Lamprecht in 1905 een 'Schwindler und Scharlatan schlimmster Sorte' noemde, voor mij onbegrijpelijk is gebleven (geciteerd naar Schorn-Schütte (1984), 93). Niet dat de specifieke meningsverschillen tussen beide wetenschappers onbegrijpelijk zijn. Een belangrijk verschilpunt betrof Lamprechts gebruik van de wetenschappelijke psychologie van zijn dagen. Volgens Weber probeerde de historicus hiermee vooral zijn geschiedfilosofische positie te verhullen en 'einen falschen Schein von Exaktheit' voor te wenden. Zie Weber (2001), 4187. Dezelfde argumentatie komt ook in de Protestantische Ethik voor, waar Weber het gebruik van de vakwetenschappelijke psychologie onder verwijzing naar Lamprecht afwijst, overigens met het niet erg dwingende argument dat anders 'die Unbefangenheit des historischen Urteils' vertroebeld zou worden. Zie Weber (2001), 5643, en voor een overzicht van kritiekpunten en bewijsplaatsen: Dassen (1999), 520. Maar deze meningsverschillen rechtvaardigen nog niet Webers oordeel 'zwendelaar'. Bovendien waren er bij alle zakelijke verschillen tussen beiden zeker ook overeenkomsten, zie bijv. Schorn-Schütte (t.a.p.) en Dassen (1999), 537. Hahn (1988) wijst er op dat Weber ook zelf een vorm van historische psychologie 'tegen wil en dank' bedreef. Misschien hebben derhalve Whimster (1988), 398, en Hübinger (1989), 32-34, gelijk als ze veronderstellen dat Weber vooral zijn eigen wetenschappelijke positie en zijn eigen opvatting van 'cultuurgeschiedenis' wilde afschermen tegenover de al te verwante opvattingen van Lamprecht. In een debat met Gothein over de mogelijkheid van een psychologische fundering van de moraal, liet Weber zijn 'minachting' voor de psychologie merken. 'Ich vermute: er versteht unter Psychologie nur Trübungen der Leidenschaft', was het commentaar van Gothein, die daarin eveneens met Weber van 
Het lijkt er derhalve op dat wat de critici presenteerden als een gebrekkige kwaliteit van de cultuurgeschiedschrijving, in feite een bepaalde houding ten opzichte van het verleden betrof, waarvan zij de kenmerken ook al in de schrijfstijl van sommige cultuurhistorici hadden bespeurd. ' $[\mathrm{H}]$ et ontbreekt vooral aan dié overgave aan de stof', schreef Rachfahl in een kritiek op Lamprecht, 'die de Duitse geschiedwetenschap nu al sinds langere tijd met recht als haar voornaamste postulaat opstelt'. ${ }^{67}$ De 'precisie van onderzoek en presentatie' werden in het historistische vertoog verbonden met 'de stille zuiverheid van de historische zin', zoals Dove het formuleerde. Hij miste bij Lamprecht 'het naïeve, de hingebende Anschauung' en bespeurde in plaats daarvan de 'souvereine willekeur van sociologische abstractie en combinatie'. Lamprechts geest was naar zijn smaak 'niet werkelijk on-constructief, historisch' ${ }^{68}$ Een ware historicus zag het immers als zijn hoogste opdracht, in Rachfahls woorden, 'een zo getrouw mogelijk Abbild van de werkelijkheid te geven'. ${ }^{69}$ Om een dergelijke objectiviteit te bereiken moest de historicus liefst zo weinig mogelijk zelf aanwezig zijn in zijn geschiedverhaal. De historist verlangde ernaar, zoals Ranke het in een bekende ontboezeming uitdrukte, zijn eigen persoon 'als het ware uit te wissen en slechts de dingen te laten spreken en de machtige krachten te laten verschijnen, ${ }^{70}$

De fundamentele tegenstelling die zich hier openbaarde werd door historisten graag gepresenteerd als een nieuwe variant van de erfvijandschap tussen geschiedenis en filosofie. ${ }^{71}$ Deze tegenstelling deed zich nu voor in de gedaante van geschiedwetenschap versus natuurwetenschap. ${ }^{72}$ Een cultuurhistoricus als Lamprecht zou een natuurwetenschappelijke benadering van de geschiedenis voorstaan en daarmee de ware aard van verleden èn geschiedwetenschap miskennen. 'Juist daarom', meende Below, 'wordt men ertoe gebracht de vraag op te werpen of Lamprecht werkelijk tot de historici in strikte, wetenschappelijke zin gerekend kan worden'. ${ }^{73}$ De geschiedwetenschap zou volgens hem altijd de algemene geldigheid van systemen en begrippen moeten bestrijden en duidelijk maken dat niets 'stabiel' is en dat de menselijke ontwikkeling niet volgens vaste natuurwetten verliep. ${ }^{74}$ Vanwege de vooropgestelde uniciteit van de historische gebeurtenissen kon de statistiek en de vergelijking of de analogie en ook het door de cultuurhistorici zo gewaardeerde 'typische geval' geen plaats krijgen in de geschiedwetenschap, zoals hij en andere historisten meenden. ${ }^{75} \mathrm{Zij}$ voelden zich daarbij gesteund door idealistische neokantiaanse methodologen als Windelband en Rickert (en in mindere mate Dilthey), die in dezelfde jaren hun stellingen tegen de snel expanderende natuurwetenschappen oprichtten. $^{76}$

mening verschilde. Hij noemde diens Protestantische Ethik elders een 'meesterlijk voorbeeld' van de 'historische psychologie' die hij zelf altijd had voorgestaan, zie Maurer e.a. (2006), 457-458 en 379.

${ }^{67}$ Rachfahl (1895), 851.

${ }^{68}$ Dove (1925), 143 en citaat bij Schorn-Schütte (1984), 73, uit Dove (1925), 130.

${ }^{69}$ Rachfahl (1897), 672.

${ }^{70}$ Geciteerd in: Jaeger en Rüsen (1992), 83

${ }^{71}$ Lamprecht kreeg herhaald te horen dat hij slechts 'slechte geschiedfilosofische constructies' presenteerde, zie bijv. Below (1898), 257, 234.

${ }_{72}$ Zie als een van de eerste historistische critici, die deze tegenstelling opwerpt: Lehmann (1894).

${ }^{73}$ Below (1898), 234, vgl. 238; vgl. Rachfahl (1897), 688.

${ }^{74}$ Below (1898), 241-242.

${ }^{75}$ Zie behalve Below (1898), 250, bijv. ook de oratie van Max Lehmann (gericht tegen o.a. Lamprecht en de historische economen), getiteld 'Geschichte und Naturwissenschaft' (1893); alsmede Meinecke (1896), 264 (contra statistiek).

${ }^{76}$ Zie voor de verwijzing naar Dilthey: Rachfahl (1896a), 91 (overigens baseerden ook de cultuurhistorici zich op Dilthey, zie hoofdstuk 6, paragraaf 6.3); voor verwijzingen naar Rickert en 
Het is van belang op te merken dat deze kritiek op het zoeken naar patronen en regelmatigheden in de geschiedenis weliswaar sinds Ranke een vast ingrediënt van het historisme vormde (dat met name door Droysen nog eens stevig werd aangezet) maar de Duitse geschiedwetenschap toch nooit volledig domineerde: er waren in de tweede helft van de negentiende eeuw talloze universitaire historici die wel degelijk geloofden in zogenaamde 'historische wetten'. ${ }^{77}$ Zoals de Jenaer professor Ottokar Lorenz (1832-1904), die een wetenschappelijke fundering van de geschiedbeoefening zocht in historisch erfelijkheidsonderzoek. Daarmee, zo meende hij, kon 'een natuurlijk systeem van historische perioden' worden ontwikkeld en derhalve ook een wetmatige periodisering van de geschiedenis tot stand worden gebracht. ${ }^{78}$ Ook Bernhard Erdmannsdörffer (1833-1901), de meest geliefde historische docent van Gothein, had er in een studie over 'de novelle' geen enkele moeite mee om de bloei van dit literaire genre in de verschillende historische tijdperken met behulp van een vergelijkende methode te verklaren uit een 'consequent analoge reeks verschijnselen'. ${ }^{79}$ Hetzelfde gold voor de Berlijnse hoogleraar en Ranke-leerling Nitzsch (18181880 ), wiens werk door Lamprecht, maar vooral door Breysig werd gewaardeerd. ${ }^{80}$ En Steinhausens Doktorvater, de oudhistoricus Otto Seeck (1850-1921), stelde zich in zijn geschiedschrijving uitdrukkelijk tot doel bepaalde, biologisch geïnspireerde 'wetten van historische wording en verval' te demonstreren. ${ }^{81}$

De historicus Fuchs heeft enkele jaren geleden de stelling verdedigd dat de radicale afwijzing van het historische wetsbegrip en de daarmee gepaard gaande 'hermeneutische wending' binnen de Duitse geschiedwetenschap geleidelijk plaats-

Windelband, zie Below (1925), 30; Rachfahl (1924), m.n. 67n1; en Brands (1965), 123, waar een uitspraak van Meinecke wordt geciteerd waarin hij Rickerts opvattingen typeert als 'das festeste philosophische Bollwerk für das Eigenleben des schöpferischen Geistes'.

${ }^{77}$ Zelfs een man als Sybel koesterde althans in 1864 nog het ideaal van een 'volledig exacte [historische] kennis', dat hij haalbaar achtte op grond van de vooronderstelling van de wetmatigheid van de menselijke ontwikkeling. Zie Fuchs (1997), 410-411. In 1889, het aanvangsjaar van mijn onderzoeksperiode, verscheen in de Historische Zeitschrift een artikel waarin het gebruik van het wetsbegrip in de geesteswetenschappen uitdrukkelijk werd verdedigd: Hinneberg (1888). Hinneberg enige tijd assistent van Ranke - was in meer opzichten verwant aan de nieuwe cultuurgeschiedenis. Hij had zowel bij historici (Delbrück, Mommsen, Koser, Jastrow, Treitschke, Weizsäcker) als bij filosofen (Völkerpsycholog Lazarus, Dilthey, Paulsen), filologen (Herm. Grimm, Scherer) en economen (Schmoller en Wagner) colleges gevolgd. In 1890 zou hij in de HZ een verzoenende houding innemen in het Schäfer-Gothein debat, zie Hinneberg (1890). Volgens Chickering (1993), 220, raakte hij bevriend met Lamprecht. Vgl. ook Fuchs (1997), 411-412.

${ }^{78}$ Zie bijv. Lorenz (1886-1891), I, 195, 275-276. Meer over Lorenz en zijn connecties met de cultuurhistorici, hieronder Paragraaf 6.

${ }^{79}$ Erdmannsdörffer (1911a), 5-6, bovendien 26, waar hij over de 'allgemeingiltige und immer wiederkehrende Grundzüge und Grundbestimmungen' spreekt, die 'aus der Natur gleichartiger gesellschaftlicher Gliederungen, Gegensätze und Interessen mit Notwendigkeit [...] sich ergeben und zum Teil gerade die wichtigsten Sphären menschlicher Lebensbeziehungen berühren'.

${ }^{80}$ Zie Brocke (1971), 141-144.

${ }^{81}$ Zie Leppin (1998), 476, 485-490; Leppin noemt Darwin als inspiratiebron van Seeck, die er volgens zijn eigen studie echter eerder lamarckiaanse ideeën op na lijkt te hebben gehouden. Steinhausen, die door Leppin de 'bekendste promovendus' van Seeck wordt genoemd, vond zijn Doktorvater weliswaar een 'sehr lebhafter und anregender' docent, 'aber mein kritisches Gemüt widerstrebte entschieden seinem höchst ausgeprägten Subjektivismus, seiner Hypothesensucht und Vorliebe für überkühne Auffassungen', zie Steinhausen (1925), 238. Toch moet ter onderstreping van de betekenis van Seeck voor Steinhausen opgemerkt worden dat Steinhausen niet alleen promoveerde op een door Seeck geïnitieerde bronnenkritische en rechtsvergelijkende studie over de relatie tussen de Griekse en Romeinse wetgeving, maar bovendien in zijn allervroegste publicaties soms opmerkelijke biologistische argumentaties tentoonspreidde. Zie m.n. zijn (o.a. m.b.v. Spencer onderbouwde) studie over de betekenis van de groet in Steinhausen (1893), 2: 'Nicht symbolisch, sondern genetisch müssen wir unsere Sitten erklären. Jede Sitte hat ihren natürlichen Ursprung'. 
vond en dat de strijd rond de nieuwe cultuurgeschiedenis rond 1900 daarin een katalyserende rol heeft gespeeld. ${ }^{82}$ Daar lijkt het inderdaad sterk op. Typerend voor de omslag lijkt de verandering van opvattingen die bij de oudhistoricus Eduard Meyer in de loop van de strijd rond de nieuwe cultuurgeschiedenis plaatsvond: ná 1900 een van de critici van Lamprecht en Breysig met uitgesproken historistische opvattingen, had hij in de jaren tachtig nog zelf verkondigd dat de geschiedwetenschap ook 'de algemene wetten en vormen van het historische leven' en de 'samenhang van oorzaak en effect' moest naspeuren. ${ }^{83}$ In de strijd tegen de nieuwe cultuurgeschiedenis reikten het oude filosofisch idealisme en de revolte van een deel van de jongere generatie tegen het positivisme elkaar de hand. Deze constatering versterkt de al in het vorige hoofdstuk gemaakte vaststelling dat de strijd tussen politieke en cultuurhistorici niet zonder meer een strijd tussen 'oude' en 'jonge' historici was.

De nieuwe cultuurhistorici hechtten minder dan de historisten aan een formele scheiding van natuur- en geesteswetenschappen en meenden dat zij zich op een meer algemene wijze rekenschap dienden te geven van de resultaten van hun historisch onderzoek. Meer dan hun historistische tegenstanders waren de nieuwe cultuurhistorici, en onder hen vooral Lamprecht en Breysig, geneigd algemenere historische theorieën op te stellen, de historische werkelijkheid met behulp van 'onhistorische' typen en vergelijkingen te analyseren, en grote historische ontwikkelingslijnen te schetsen. Op dit punt namen de meeste cultuurhistorici afstand van de historistische vaknormen, zonder de noodzaak van een empirische onderbouwing door middel van bronnenonderzoek te miskennen.

\section{De oorsprong van de moderne geschiedwetenschap}

De verschillende houdingen ten opzichte van het verleden - de cultuurhistorici meer begripsmatig construerend en analyserend, de critici meer verhalend en beschrijvend werden weerspiegeld in hun meningsverschil over de oorsprong van de moderne geschiedwetenschap.

Volgens Meinecke, de criticus van de cultuurgeschiedschrijving die zijn eigen idealistische geschiedbeschouwing de naam 'historisme' gaf, betekende dat historisme niets minder dan de ontdekking van de 'historische Sinn', waardoor een echte wetenschap van het verleden pas mogelijk was geworden. Deze ontdekking van het historisch besef was volgens Meinecke een daad van wereldhistorische betekenis die op het conto van Duitse geleerden kon worden geschreven, een van de 'Großtaten des deutschen Geistes'. ${ }^{84}$ Meinecke drukte daarmee het zelfbeeld van veel Duitse geschiedwetenschappers uit. Al rond het midden van de negentiende eeuw stond het voor leidende Duitse historici als Sybel en Giesebrecht vast dat de geschiedenis als vakwetenschap in hun eigen land was ontstaan, en wel voornamelijk als reactie op de Franse Revolutie en de daar op volgende oorlogen. ${ }^{85}$ De Franse revolutionaire overheersing, die gelegitimeerd werd met natuurrechtelijk gefundeerde claims over rechtvaardig bestuur op grond van vrijheid, gelijkheid en broederschap, had als reactie een heroriëntatie meegebracht op de eigen Duitse rechten en vrijheden, de eigen aard en geschiedenis. Die speurtocht naar de Duitse eigenheid in het verleden was ten tijde van en direct na de Franse overheersing des te urgenter, omdat in de actuele situatie

\footnotetext{
${ }^{82}$ Zie Fuchs (1997).

${ }^{83}$ Zie over Meyers Wende: Brocke (1971), 303.

${ }^{84}$ Geciteerd door Wittkau (1994), 194.

${ }^{85}$ Zie Sybel (1880); Giesebrecht (1859).
} 
het gebrek aan eenheid en nationale identiteit juist zo pijnlijk was gebleken. Uit deze heroriëntatie op het nationale verleden ontstond nu het ware historische denken en de daarop gebaseerde moderne geschiedwetenschap. Daarom was de geschiedwetenschap ook bij uitstek een Duitse wetenschap en nam zij in de Duitse landen als academische vakdiscipline eerder vaste vormen aan dan in Engeland, dat geen Franse overheersing had gekend, of in Frankrijk, het land van de revolutie zelf. Dit beeld bleef tot ver in de twintigste eeuw onder Duitse en andere historici bestaan. Niet voor niets behandelde Georg von Below in zijn historiografisch overzichtswerk uit 1916 de Duitse geschiedschrijving 'von den Befreiungskriegen bis zu unseren Tagen': het 'deutsche Nationalgefühl' dat tegen de Fransen in het geweer kwam, bracht een 'Erhebung der deutschen Wissenschaft' en vooral van de historische studies met zich, die een einde maakte aan de voor die tijd overheersende Franse cultuur op het continent. ${ }^{86}$

Volgens veel Duitse historici hadden Niebuhr en Ranke de geschiedwetenschap niet alleen als zodanig gesticht, maar ook meteen tot volmaakte hoogten gevoerd: ná Ranke was er zodoende geen verdere ontwikkeling van de geschiedwetenschap meer mogelijk en vóór hem was er nauwelijks sprake van een wetenschap van het verleden. Voor een historische benadering van de geschiedwetenschap zelf was in deze optiek derhalve weinig plaats, zoals een oud-promovendus van Lamprecht al in 1911 scherp vaststelde. ${ }^{87}$ Bijgevolg kon Ernst Bernheim, de bekendste Duitse geschiedmethodoloog van zijn tijd, in 1908 niet anders dan vaststellen dat de geschiedenis van de geschiedwetenschap op dat moment nog 'zeer ontoereikend' was onderzocht. ${ }^{88}$ Dat gold met name voor de ontwikkeling van de geschiedwetenschap na 1500. Men teerde daarvoor gedeeltelijk nog op artikelen van Giesebrecht en Sybel uit de jaren vijftig of zelfs op de nog oudere studie van Wachler uit 1812-1820. ${ }^{89}$ Het eerste omvangrijke overzicht van de moderne Duitse geschiedschrijving sinds de Renaissance verscheen pas in 1885 toen de Würzburgse hoogleraar Wegele zijn omvangrijke Geschichte der deutschen Historiographie publiceerde. Geheel volgens de traditionele voorstelling van zaken liet Wegele de zegetocht en de ware grondlegging van de Duitse geschiedwetenschap beginnen met Niebuhr en Ranke. Ze vormden voor hem het welgekozen besluit van zijn overzicht van de moderne geschiedschrijving: na deze historici was er geen werkelijke vooruitgang meer mogelijk.

Wat er bestond aan geschiedschrijving van de moderne historiografie rond 1900 kwam voor een buitenproportioneel deel op het conto van de nieuwe cultuurhistorici. Zij namen rond 1900 het initiatief tot een uitgebreid onderzoek naar de geschiedenis van de moderne geschiedwetenschap. In dit verband is door Hans Schleier en anderen gewezen op de rol van Lamprecht als initiator van een intensievere studie van de historiografiegeschiedenis. ${ }^{90}$ Maar ook de andere woordvoerders van de nieuwe

${ }^{86}$ Below (1924), [1e dr. 1916], inhoudsopgave en blz. 9-10.

${ }^{87}$ Günther (1911), 1-2. De verschillende houding kwam tot uiting in het meningsverschil van Lamprecht en Rachfahl over de betekenis van de sage. Voor Lamprecht ging het hier om een oudere vorm van geschiedschrijving; volgens Rachfahl ging het bij de sage echter niet om de waarheid, maar slechts om 'aangenaam vertellen', zie o.a. Rachfahl (1896b), 544.

${ }^{88}$ Bernheim (1908), 41.

${ }^{89}$ Wachler (1812-1820); Sybel (1880); Giesebrecht (1859). Zie voor een overzicht van de beschikbare hoofdwerken het naslagwerk van Wolf (1910), 131-136.

${ }^{90}$ Zie Schleier (1982), Haas (1994), 202n; Blanke (1990, (1994a); en eerder al Günther (1911), 24. De 'schaarse' studies op het terrein van de geschiedenis van de historische methode en geschiedfilosofie waarnaar Bernheim in 1908 in zijn Lehrbuch kon verwijzen (zie blz. 206-250 en 686735), bestonden voor een groot deel uit dissertaties uit de school van Lamprecht. En ook na 1908 initieerde Lamprecht nog een groot aantal historiografisch of geschiedtheoretisch relevante studies. Een aantal van deze studies ontleent een extra belang aan het feit dat daarin bepaalde personen en thema's voor het eerst uitgebreider worden onderzocht. Dat geldt bijvoorbeeld voor het onderzoek van Pflaum 
cultuurgeschiedenis begaven zich op dit terrein met boeken, artikelen en colleges. ${ }^{91}$ De cultuurhistorici presenteerden daarin in het algemeen een ander beeld van de oorsprong van de moderne geschiedwetenschap dan de politiek historici en werden door hun pogingen dit alternatieve beeld te onderbouwen tot pioniers van de historiografiegeschiedenis in het algemeen en van de Verlichtingshistoriografie in het bijzonder. $^{92}$

De nieuwe cultuurhistorici modificeerden de opvatting van de Duitse Romantiek en het Duitse negentiende-eeuwse nationalisme als de bakermat van de moderne geschiedwetenschap. ${ }^{93}$ Gothein verkondigde in zijn Aufgaben bijvoorbeeld al de stelling dat 'onze Duitse geschiedschrijving' niet aan de negentiende-eeuwse nationale beweging was ontsproten, maar uit de achttiende eeuw dateerde en voortkwam uit het 'particularistische Kleinleben enerzijds, uit de kosmopolitische gedachte anderzijds'. ${ }^{4}$ Lamprecht presenteerde Niebuhr en Ranke - de helden van de historisten - zonder terughouding juist niet als grondleggers van de moderne geschiedwetenschap, maar als historici die eerder de definitieve afsluiting vormde van een historiografische ontwikkeling die van de zestiende tot de achttiende eeuw gericht was geweest op de staat, op staatkundige bronnen en individuele staatslieden. Ranke en Niebuhr behoorden volgens Lamprecht tot een voorbij tijdperk, het tijdperk van Staatengeschichte en Heldengeschichte; zij waren geen pioniers, maar Vollender. ${ }^{95}$ De hele Rankeaanse ideeënleer - waarin de werkzame ideeën als 'manifestaties van God'

uit 1907 naar Droysens Historik of van Menke-Glückert uit hetzelfde jaar naar de geschiedbeschouwing van Goethe. In een aantal gevallen zijn deze historiografische studies niet alleen de eerste, maar ook lange tijd de enige monografieën op hun terrein geweest. Dat is bijvoorbeeld het geval bij de dissertatie van Georg Schridde over Gustav Freytags Kultur- und Geschichtspsychologie (1910), de studie van Johannes Goldfriedrich over Die historische Ideenlehre in Deutschland (1902) en de verhandeling van Ernst Schaumkell, Geschichte der deutschen Kulturgeschichtsschreibung von der Mitte des 18.

Jahrhunderts bis zur Romantik (1905). Van het onwaarschijnlijke aantal van 140 dissertaties dat Lamprecht tussen 1891 en 1914 als eerste promotor begeleidde, was ruim een vijfde (nl. tweeëndertig) gewijd aan de geschiedenis van de geschiedwetenschap; een hoog percentage, gelet op de grote diversiteit van de onderwerpen die door Lamprecht's promovendi werden onderzocht. Lamprecht publiceerde ook zelf verschillende historiografische studies.

${ }^{91}$ Goetz is in dit opzicht eerder atypisch voor de nieuwe cultuurhistorici: hoewel hij al sinds 1897 over dit thema doceerde, volgde zijn eerste historiografische publicatie, over de Duitse negentiendeeeuwse historiografie, pas in 1919. Met een lezing over dit thema trad Goetz in 1916 ook aan als opvolger van Lamprecht. Kenmerkend voor Goetz' aanleunen tegen de traditionelere vakgenoten is zijn herhaald verwijzen naar de historiografische werken van Below en Ritter.

92 Blanke (1990). Zelfs compromissenman Goetz, die Ranke en Niebuhr wèl een uitzonderlijke plaats in de ontwikkeling van de wetenschap der geschiedenis toekende, onderstreepte dat de betekenis van de romantiek (overigens te onderscheiden van de nationale beweging) voor de 19de-eeuwse geschiedwetenschap niet overschat moest worden en trok de ontwikkelingslijnen van de moderne geschiedwetenschap terug tot in de achttiende eeuw: zowel het historische als het kritische denken dateerde volgens hem uit die tijd. 'De moderne Europese historische wetenschap begint met de periode van de Verlichting', begon hij een historiografisch overzicht. Zie Goetz (1957b), 90 [1916/19] en Goetz (1932), 374-376.

${ }^{93}$ Vgl. ook het opstel over 'Ursprung und Wesen der modernen Geschichtsauffassung' uit 1889 van Gustav Buchholz, een beschermeling van Lamprecht en later historisch (extra)ordinarius in Leipzig (1896) en Posen (1906). 'Het is gebruikelijk', schreef Buchholz 'om de Aufschwung van de Duitse geschiedwetenschap in onze eeuw terug te voeren op de wedergeboorte van de nationale gedachte, die na een tijd van ongeëvenaarde nood en druk op gewelddadige wijze tot uiting kwam in de machtige beweging van de Vrijheidsoorlogen'. Dat is zeker niet geheel ten onrechte, ging hij verder, maar de wortels van het verschijnsel lagen dieper. Het 'ontwaken van het historisch denken' waar het hier om ging, moest gedateerd worden decennia vóórdat de Franse Revolutie zelfs maar was uitgebroken. Zie Buchholz (1889), 17-18.

${ }^{94}$ Gothein (1889), 33.

${ }^{95}$ Zie Lamprecht (1974), 480, 484, 491 [1898]. 
werden opgevat - getuigde naar zijn oordeel van een 'mystieke overtuiging' die niet van de moderne tijd was. ${ }^{96}$ Ook Breysig merkte in zijn artikelen over de Verlichtingshistoriografie op dat bepaalde achttiende-eeuwse historici 'de ware moderne historicus' oneindig veel meer te bieden hadden dan Ranke. ${ }^{97}$ Het was de periode rond het midden van de achttiende eeuw die de nieuwe cultuurhistorici beschouwden als het begin van een ungeheure Umwälzung in het culturele leven, het begin van 'de tijd waarin wij tegenwoordig nog leven', waarin ook de oorsprongen van de moderne geschiedbeschouwing moesten worden gezocht. ${ }^{98}$

Niet de negentiende-eeuwse, nationalistisch geïnspireerde politieke historici, maar achttiende-eeuwse, eerder kosmopolitisch georiënteerde geschiedschrijvers hadden naar de mening van de nieuwe cultuurhistorici de fundamenten van de moderne geschiedwetenschap gelegd. Er bestond onder hen een vergaande eensgezindheid over wie de hoofdfiguren waren. De nieuwe canon, zoals die door onder andere Breysig werd opgesteld, liep van de Italiaan Vico over de Fransen Montesquieu, Voltaire, Turgot en Condorcet, en de Schotse Verlichters (met name Ferguson en Robertson), naar de Duitsers Herder, Justus Möser en Winckelmann. ${ }^{99}$ Voor de Duitse ontwikkeling werd bovendien nog gewezen op de betekenis van de zogenaamde Göttingse school van Universalhistoriker, waartoe Gatterer, Schlözer, Meiners en Spittler werden gerekend. ${ }^{100}$

De nieuwe cultuurhistorici waardeerden in de eerste plaats de uitbreiding van het domein van de geschiedwetenschap van de politieke en staatkundige geschiedenis tot een geschiedenis van de gehele cultuur die hun achttiende-eeuwse collega's teweegbrachten. ${ }^{101}$ De geschiedschrijving van Voltaire werd in dit opzicht door veel nieuwe cultuurhistorici als exemplarisch beschouwd, niet alleen omdat hij een van de eersten was, maar ook omdat hij zijn keuze expliciet aan de orde had gesteld. ${ }^{102}$ Voltaire's uitspraak in Le siècle de Louis XIV dat hij in dat werk niet de handelingen van een enkel individu (Lodewijk XIV), maar de 'geest van het tijdperk' wilde schilderen, luidde, zoals Kurt Breysig opmerkte, een nieuw tijdperk van geschiedschrijving in. ${ }^{103}$

De waardering voor de achttiende-eeuwse geschiedschrijving ging echter dieper. De Verlichte geschiedbeschouwing introduceerde namelijk twee nieuwe, naar de toekomst wijzende concepten, zoals Lamprecht het formuleerde: Umwelt en Abfolge! ${ }^{104}$ De achttiende-eeuwse historici waren naar de overtuiging van de cultuur-

${ }^{96}$ Lamprecht (1896a), 34. In het kader van zijn polemiek met Rachfahl publiceerde Lamprecht ook een kritische uiteenzetting over Von Humboldts geschiedtheorie, waarin hij dezelfde strategie toepast, zie Lamprecht (1974), 340-348. Voor Wegele tien jaar eerder nog 'wellicht het geniaalste en treffendste' dat over de geschiedschrijving was gezegd, worden Humboldts opvattingen door

Lamprecht gehistoriseerd tot een uiting van romantisch individualisme dat 'unserer Zeit völlig fremd geworden ist' (a.w. 348).

${ }^{97}$ Zie Breysig (1897), 347.

${ }^{98}$ Lamprecht (1974), 482-483 [1898].

${ }^{99}$ Zie Breysig (1897); Lamprecht (1974), 420 e.v.; Steinhausen (1896), 5-6; Gothein (1889); Schaumkell (1905); Goldfriedrich (1902); Menke-Glückert (1907); Schneider (1905).

${ }^{100}$ Gothein (1889), 33; Schaumkell (1905), 49-113, Breysig (1898), 103 e.v., Lamprecht (1974), 428 en 481; Goetz (1932), 375; Steinhausen (1896), 6.

${ }^{101}$ Zie Goetz (1932), 375 ('aiming to bring within their orbit all phases of social life they [the French historians of the Enlightenment] laid the foundations for a general history of human culture'); Steinhausen (1896), 5 .

${ }^{102}$ Bijv. Steinhausen (1896), 5: 'wir Modernen dürfen nie vergessen, was wir diesem oft geschmähten Führer der Aufklärung verdanken'; Lamprecht (1974), 421 [1898/99].

${ }^{103}$ Breysig (1897), 346.

${ }^{104}$ Zie Lamprecht (1974), 419-420 en 485 [1898/99]. Zo ook Breysig. Opgemerkt moet worden dat Goetz (1932), 375 kritisch was over het Verlichte concept van ontwikkeling - sterker: hij meende dat dat begrip ontbrak in het 'oppervlakkige' Verlichte vooruitgangsdenken. 
historici de eerste wetenschappers die zich in hun geschiedwerken rekenschap gaven van de gebondenheid van historische individuen aan hun (sociale en natuurlijke) omgeving (Umwelt) en die samenlevingen wilden beschouwen als deel van een procesmatig voortgaande historische ontwikkeling (Abfolge). Zoals we in de volgende paragrafen zullen zien, betrof het hier fundamenteel andere dan historistische opvattingen over sociale gebondenheid en historische ontwikkeling.

Met hun waardering voor de Verlichtingshistoriografie liepen de cultuurhistorici vooruit op de herontdekking van de Verlichte geschiedbeschouwing aan het eind van de twintigste eeuw, die overigens zelf ook weer samenhangt met een streven naar vernieuwing van de geschiedwetenschap. ${ }^{105}$ Dat de nieuwe cultuurhistorici de Verlichte pogingen tot cultuurgeschiedschrijving waardeerden, was natuurlijk op zichzelf weinig verwonderlijk. Door deze voorgangers te bestuderen probeerden de vernieuwers van de Duitse geschiedwetenschap duidelijk te maken dat zij in een traditie stonden waaraan zij autoriteit konden ontlenen. Typerend is het voorwoord van Lamprecht bij een studie van een van zijn studenten over Goethe's geschiedbeschouwing, waarin hij opgelucht concludeert: 'hij was een van ons'! ${ }^{106}$ Het historiografisch onderzoek vervulde een legitimerende functie ten aanzien van de nieuwe onderzoeksrichting die de cultuurhistorici wilden inslaan: door middel van een historische argumentatie werd het eigen onderzoek gerechtvaardigd en tegelijk het politiek georiënteerde historisme bekritiseerd. ${ }^{107}$

Het streven hun onderzoeksrichting door middel van een historische argumentatie te legitimeren verklaart het feit dat de vernieuwers zich aanvankelijk veel meer met de geschiedenis van de geschiedschrijving bezighielden dan hun tegenstanders. In tegenstelling tot de historisten moesten zij zich een positie verwerven en deze positie zien te rechtvaardigen. Pas nadat historisten op deze wijze waren uitgedaagd, voelden ook zij de noodzaak door middel van historiografisch onderzoek hun wetenschappelijke positie te versterken: de historiografische overzichtswerken van Georg von Below (1916) en Moriz Ritter (1919) werden pas gepubliceerd na de dood van Lamprecht. De grote, klassiek geworden studies van Meinecke en Troeltsch over de ontwikkeling van het historisme dateren van nog weer later en stammen uit de jaren twintig en dertig.

\section{Engagement en het belang van de levensbeschouwing}

Een beoordelingscriterium voor historisch onderzoek dat niet in de algemene rijtjes van vakeisen van Below en Rachfahl was opgenomen, maar dat desondanks een grote plaats kreeg in de recensies over de nieuwe cultuurgeschiedenis, was het criterium 'levensbeschouwing': de expliciete eisen die gesteld werden aan de filosofische, politieke en morele opvattingen van de historicus.

Kwesties van Weltanschauung speelden vanaf het begin en met zoveel woorden een belangrijke rol in de beoordeling van de cultuurgeschiedenis. Zoals in hoofdstuk 2 al is gememoreerd, associeerde Dietrich Schäfer de cultuurgeschiedenis al met een bedenkelijke verwaarlozing van de betekenis van buitengewone individuen en van hoogstaande morele motivaties in de geschiedenis. ${ }^{108}$ Enkele jaren later, ten tijde van de Lamprechtstrijd, waren het opnieuw de critici die vanaf het begin verkondigden dat

\footnotetext{
${ }^{105}$ Zie Blanke (1990), m.n. 111.

${ }^{106}$ Zie Menke-Glückert (1907), voorwoord door Lamprecht.

${ }^{107} \mathrm{Vgl}$. Haas (1994), 143-148.

${ }^{108}$ Schäfer (1888), 6, 8, 28 en Schäfer (1891), 54-55. Zie hoofdstuk 2, paragraaf 1.
} 
het hier uiteindelijk om een levensbeschouwelijk conflict ging. Terwijl Lamprecht zelf bij hoog en bij laag volhield niets anders dan wetenschappelijke standpunten te verkondigen, ${ }^{109}$ schreef Meinecke bijvoorbeeld:

'Het verschil in methode [...] berust in feite op een tegenstelling van de metafysische vooronderstellingen, aangezien de jongere richting blijkbaar een biologische [!] verklaring van het individuele leven nastreeft, de oudere echter op grond van haar idealistische levensovertuiging aan de onoplosbare, einheitlichen, apriorische kern van het individu vasthoudt'. ${ }^{110}$

En Rachfahl dacht er niet anders over: 'Want om een andere Weltanschauung, niet om een andere methode gaat het bij de "nieuwe richting". 111 De meest gehoorde opvatting was dat Lamprecht een 'materialist' was. ${ }^{112}$ Ook het etiket 'evolutionist' dat Lamprecht door verschillende historici (Below, Schnürer, Lenz, Rachfahl) kreeg opgeplakt, droeg levensbeschouwelijke connotaties. Waar men bij deze kwalificaties in concreto aan dacht, werd in een opstel over het oprukkende materialisme in historische wetenschappen in de Preußische Jahrbücher kort samengevat: het ging om een ieder die 'de wisselwerking tussen de individuen en de tijdgeest geheel eenzijdig opvat en zelfs in het genie niets meer ziet dan een door overerving en aanpassing beïnvloed product van de tijdgeest'. ${ }^{113}$ Het waren juist de Verlichte opvattingen over het belang van Umwelt en Abfolge, die door de cultuurhistorici werden gewaardeerd, die de stenen des aanstoots vormden voor hun historistische critici.

Met het aanwenden van deze levensbeschouwelijke kritiek traden de historisten geenszins buiten het geaccepteerde kader van de historische vakdiscipline. Sinds 1848 waren de banden tussen geschiedwetenschap, politiek en levensbeschouwing in Duitsland bewust aangehaald. Historici uit de zogenaamde Pruisische School, zoals Sybel, Droysen en Treitschke, waren voorstanders van een politiek correcte geschiedschrijving, die zou moeten bijdragen aan de realisering van een politiek ideaal: de vorming van een Duitse eenheidsstaat onder leiding van Pruisen. Het ideaal van strikte onpartijdigheid dat Ranke zijn studenten nog had voorgehouden, werd door historici uit de Pruisische School aan studenten gepresenteerd als 'Keinseitigkeit' (Dove) of 'eunuchische Objektivität' (Droysen). ${ }^{114}$ De 'objectieve, onpartijdige, zenuwzwakke en bloedeloze historici' zijn verdwenen, schreef Sybel tevreden in 1856, 'een zeer aanmerkelijke vooruitgang!'. ${ }^{115}$ In zijn redactionele toelichting bij de oprichting van de Historische Zeitschrift maakte hij enkele jaren later duidelijk dat de $\mathrm{HZ}$ weliswaar 'vooral een wetenschappelijk' tijdschrift wilde zijn, maar zich tegelijk door een 'politiek oordeel' liet leiden, volgens welk elk volk een 'natuurlijke en individuele

${ }^{109}$ Zie Lamprecht (1896b).

${ }^{110}$ Meinecke in HZ 76 (1896), 531; zo ook Meinecke (1896), 264-265.

${ }^{111}$ Rachfahl (1896b), 555.

${ }^{112}$ De uitdrukking valt bijv. bij Rachfahl, Below, Meinecke, Aly. De Zwitserse katholieke historicus Gustav Schnürer, hoogleraar in Fribourg $(\mathrm{CH})$, legde eveneens de nadruk op de 'Weltanschauung': 'Lamprechts Stellung wird so vielleicht Späteren bemerkenswerter sein in der Geschichte unserer Weltanschauungen als in der Entwicklung der Geschichtswissenschaft'; zie Schnürer (1900), 785. Hij stelde vast dat 'tussen hem [Lamprecht] en degenen, die het christendom als een op goddelijke openbaring berustende geloofs- en zedenleer beschouwen, een kloof gaapt waarover geen brug meer bestaat', Schnürer (1897), 112.

113 Aly (1895), 206. Aly verwees daarbij o.a. naar de opkomst van de cultuurgeschiedenis, d.w.z. naar Lamprecht en de eerdere strijd (tussen Gothein en Schäfer) over cultuurgeschiedenis vs. politieke geschiedenis.

${ }^{114}$ Alfred Dove over Moriz Ritter, zie Meinecke (1941), 107.

${ }^{115}$ Geciteerd in: Jaeger en Rüsen (1992), 88. 
ontwikkeling' doormaakte, 'die niet willekeurig vertraagd en versneld, en niet onder vreemde regel gedwongen mag worden'. Daarmee was de koers van het blad, aldus Sybel, onverenigbaar met 'feodalisme' (lees: reactionaire politiek), 'radicalisme' (lees: revolutionaire politiek) of 'ultramontanisme' (lees: katholieke politiek). ${ }^{116}$

Maar ook buiten kringen van de Pruisische School was er sprake van een intieme relatie tussen historisme en politiek. Het historistische uitgangspunt dat het (nationale) verleden als zodanig recht gedaan moest worden, was immers ontstaan als een politiek credo. Het werd voor het eerst geformuleerd door de Duitse rechtswetenschapper Savigny, die zich in 1814 tegen degenen keerde die naar Frans voorbeeld een algemeen burgerlijk wetboek in de Duitse landen wilden invoeren. Als het uit Frankrijk afkomstig recht met haar universele, natuurrechtelijke pretenties zou worden ingevoerd zou dat een radicale inbreuk op de van oudsher gegroeide nationale rechtsvormen betekenen, meende Savigny. Elk natie had volgens hem een eigen rechtsstelsel, dat uit het wezen van die natie en uit haar geschiedenis was voortgekomen. ${ }^{117}$ Ranke en andere Duitse historici namen deze stellingname van Savigny over: de inrichting van het staatsbestel diende uit de nationale aard en geschiedenis voort te komen en kon niet worden overgenomen van andere landen, noch gefundeerd worden in de 'leer van de aangeboren mensenrechten', waartegen Droysen nog in 1882 - let wel: in het kader van zijn colleges over de studie van de geschiedenis - polemiseerde. ${ }^{118}$ Zoals Ranke het formuleerde:

'De vormen [nl. van constituties] zouden nog overgeplant kunnen worden, maar dàt waaruit zij voortkomen, niet slechts hun historische wortels maar de geest die verleden en heden verbindt en die ook de toekomst moet bezielen - hoe zou je dat willen kopiëren?'119

Duitse historici beschouwden het derhalve zowel voor als na 1848 als hun voornaamste taak om kennis en inzicht te verschaffen inzake de nationale ontwikkeling en een eigen besef van nationaliteit te ontwikkelen dat ook voor de politiek in heden en toekomst richtingwijzend kon zijn. Dat was de rechtvaardiging van hun professionele bestaan. Niet pas Sybels Historische Zeitschrift concentreerde zich daarom bij voorkeur op moderne en met de actualiteit verbonden vaderlandse onderwerpen, ook de door Ranke veel eerder opgerichte en geredigeerde HistorischPolitische Zeitschrift (1832-1834) was voornamelijk gewijd aan de meest recente politieke geschiedenis. ${ }^{120}$ 'Echte politiek moet gebaseerd zijn op de geschiedenis', meende Ranke - en met hem veel andere historici. ${ }^{121}$ Dat betekende dat de politiek de historici nodig had; en inderdaad waren onder de meest zelfbewuste Duitse historici in de negentiende eeuw velen in de politiek of althans in de publieke politieke discussie actief. 'Er kan geen twijfel over bestaan', schreef Dietrich Schäfer, zelf een politiek actief historicus, in zijn diatribe tegen de cultuurgeschiedenis uit 1888, 'dat het historisch werk in woord en geschrift een diepgaande invloed uitoefent op de ontwikkeling van staten, op het politieke leven. Hier ligt haar recht en tegelijk haar

\footnotetext{
${ }^{116}$ Sybel (1859), [III]-IV.

${ }^{117}$ Jaeger en Rüsen (1992), 29; zie ook Wieland (1979), m.n. 213-214.

${ }^{118}$ Zie Droysen (1977), 438r8-11.

${ }^{119}$ Ranke (1925), 18 [Politisches Gespräch, 1836]. Zo ook Droysen (1977), 273r5-28.

${ }^{120}$ Ranke (1925), 3-4 [redactionele inleiding, 1832]; zie ook Stieg (1986), 22-23. De HPZ werd overigens ondersteund door de Pruisische minister van buitenlandse zaken.

${ }^{121}$ Ranke (1925), 21 [Politisches Gespräch, 1836].
} 
plicht'. ${ }^{122}$ Op deze manier diende de geschiedwetenschap uitdrukkelijk 'scholae et vitae'.

Het uitgesproken politieke engagement van de Pruisische school betekende volgens deze historici geen aantasting van de wetenschappelijkheid van hun geschiedschrijving. Allereerst bleef het methodische ideaal van kritisch bronnenonderzoek, dat Ranke had benadrukt, te allen tijde gehandhaafd. Daarnaast hadden deze historici meer aandacht voor de verschillende mogelijke interpretaties van het bronnenmateriaal. Dat betekende echter nog niet dat in de geschiedschrijving met persoonlijke willekeur genoegen moest worden genomen. Er waren goede en slechte interpretaties van dezelfde feiten. Een goede interpretatie kenmerkte zich door een verheven standpunt, dat uitdrukking gaf aan een hogere zedelijke macht of ideaal. Zoals Droysen zijn Historik-studenten voorhield:

'als ik vanuit het perspectief, de gedachte van mijn staat, mijn volk, mijn godsdienst de lotgevallen van de wereld beschouw, ben ik al hoog verheven boven mijn eigen ik, ik denk als het ware vanuit een hoger ik, doordat de slakken van mijn eigen kleine persoon weggesmolten zijn. ${ }^{123}$

Ook door de historici uit de Pruisische School werd met andere woorden het rankeaanse 'uitwissen' van het ego van de historicus als een ideaal gekoesterd, maar dan geformuleerd als het 'wegsmelten van de slakken van de eigen persoon' door het innemen van een hoger 'zedelijk' standpunt, het standpunt van het eigen volk, de eigen staat of het eigen geloof. Men geloofde in 'objektive Parteilichkeit', zoals deze positie wordt genoemd. ${ }^{124}$

In de praktijk fungeerde deze redenering als een rechtvaardiging om de deugdelijkheid van een historische interpretatie te beoordelen op grond van de erin tot uiting komende politieke of religieuze tendens. Niet alleen het bronnenethos, maar ook de expliciete normativiteit was derhalve een standaard ingrediënt van de Duitse historistische geschiedwetenschap. Dat blijkt niet alleen uit de historische essayistiek van politiek actieve historici als Droysen of Treitschke, maar misschien nog wel pregnanter uit verschillende handboeken van de historische discipline. Zoals bijvoorbeeld de al eerder genoemde Geschichte der deutschen Historiographie (1885) van Wegele. ${ }^{125}$ Dit handboek, geschreven in opdracht van de Beierse Historische Kommission, droeg een encyclopedisch karakter en was nauwelijks als een doorlopende geschiedenis van de geschiedschrijving te lezen. Achtereenvolgens werden de verschillende afzonderlijke historici van belang besproken, waarbij de auteur telkens afsloot met een oordeel over de kwaliteit van hun historisch werk. Het typeert de onverhulde normativiteit in de Duitse geschiedwetenschap van dat moment dat tot de kwaliteitscriteria die Wegele expliciet hanteerde ook de politieke en religieuze oriëntatie van de historici behoren. Ook de aard van de heersende normen wordt duidelijk bij Wegele: zonder reserve werd een naar radicaal liberalisme of katholicisme neigende oriëntatie of een van het 'nationale' perspectief afwijkend standpunt door de Würzburgse ordinarius als een minpunt aangetekend bij de beoordeling van geschiedwerken. Zo beoordeelde Wegele bijvoorbeeld Friedrich von Schlossers lof voor Napoleon negatief als een achterhaalde uiting van kosmopo-

122 Schäfer (1888), 34.

${ }^{123}$ Droysen (1977), 236-238.

${ }^{124}$ Jaeger en Rüsen (1992), 90.

${ }^{125}$ Wegele (1823-1897), een leerling van Häusser en Schlosser, was historisch ordinarius in Würzburg van 1857 tot 1897 . 
litisme, terwijl hij de anti-Franse gezindheid van zijn leerling Häusser juist als national prees. Historici als de katholiek Görres of de democraat Karl Hagen rekende hij hun Roomse respectievelijk 'vulgair-liberale' gezindheid aan, terwijl de 'ehrenhaften, patriotisch-nationalen Motiven' van een historicus als Löbell Wegele's lof oogstten. ${ }^{126}$ Niet minder karakteristiek voor de acceptatie van het politiekideologische engagement in de Duitse geschiedwetenschap was het eerste uitgebreide Duitse Lehrbuch der historischen Methode (1889/1908) van Ernst Bernheim, als gezegd een voormalig docent van Steinhausen en Lamprecht. In het voorwoord rechtvaardigde Bernheim zijn boek zonder omwegen met de verwijzing naar het gevaar dat de oprukkende darwinistische en 'sociaal-democratische materialistische geschiedopvatting' betekende voor 'onze vakwetenschap'. ${ }^{127}$

De generatie historici die tussen 1880 en 1890 aantrad en waartoe ook de nieuwe cultuurhistorici behoorden, was deels opgeleid door historici die in de traditie van de Pruisische School stonden. De verhouding tot de politiek was voor hen echter minder eenduidig en ongecompliceerd dan voor de Pruisische historici. Het politieke ideaal waarvoor de Pruisische School zijn geschiedschrijving in de eerste plaats had ingezet, was in 1871 gerealiseerd. Zowel de nieuwe cultuurhistorici als de zogenaamde neorankeanen die nu op de voorgrond traden, gingen zich in sterkere mate dan hun voorgangers expliciet beroepen op de wetenschappelijkheid, onpartijdigheid en objectiviteit van hun geschiedschrijving. Gothein memoreerde bijvoorbeeld dat zijn leermeester Erdmannsdörffer in 1874 bij zijn aantreden als ordinarius in Heidelberg zijn teleurgestelde studenten voorhield dat de tijd voorbij was waarin historici nog, net als Treitschke en Gervinus, 'leiders van de publike opinie' wilden zijn. ${ }^{128}$ Iets van de veranderde stemming bleek uit de reactie op de al eerder genoemde onderwijsplannen van Wilhelm II voor het middelbaar onderwijs in 1890, waarin een meer expliciet antisocialistische inhoud van het historisch onderwijs werd voorgeschreven. ${ }^{129}$ Uit verontrusting over deze inhoudelijke druk van staatswege werd in 1893 op initiatief van een aantal Zuidduitse historici de eerste Duitse Historikertag georganiseerd. ${ }^{130} \mathrm{Op}$ de bijeenkomst, waar overigens nauwelijks Pruisische historici aanwezig waren, werd de stelling dat het geschiedenisonderwijs expliciet tot vaderlandsliefde en staatsbewustzijn moest opvoeden uiteindelijk verworpen.

Toch is ook na 1890 de band tussen geschiedenis, politiek en levensbeschouwing nog bijzonder sterk. ${ }^{131}$ Opvallend is bijvoorbeeld dat bij de genoemde stemming op de eerste Historikertag het aantal voor- en tegenstemmen elkaar niet veel ontliep en dat alle aanwezigen het bovendien eens waren met de uitspraak dat de vaderlandsliefde hoe dan ook het resultaat van het geschiedonderwijs diende te zijn. ${ }^{132}$ In zijn aanval op de cultuurgeschiedenis uit 1888 schreef Dietrich Schäfer weliswaar dat het een vooruitgang was dat de geschiedschrijving niet langer tendentieus was, maar tegelijk verwierp hij een door hem gesignaleerde 'ziekelijke [...] onpartijdigheid' en benadrukte hij dat de bezieling van de geschiedwetenschap aan het politieke of

${ }^{126}$ Wegele (1885), 1029.

${ }^{127}$ Bernheim (1908), III.

${ }^{128}$ Gothein (1901), 20; vgl. Erdmannsdörffer (1911b), I, XX: ‘die Strenge und Kühle Ranke'scher Objektivität, welche ich für meinen Teil allerdings als das Höchste und Reinste verehre, was die deutsche Wissenschaft auf dem Gebiet historischer Leistung zur Anschauung gebracht hat'.

${ }^{129}$ Zie Hoofdstuk 2, paragraaf 2.

${ }^{130}$ Schumann (1975), 13-35.

${ }^{131}$ Zie Bruch (1988).

${ }^{132}$ Zie Bericht (1893), m.n. blz. 3-14, 20 en 25; de these 'dat het geschiedonderwijs in het bijzonder tot vaderlandsliefde en een strenge plichtsbesef tegenover de staat dient op te wekken' werd met 38 tegen 29 stemmen verworpen. 
nationale leven ontleend diende te worden. ${ }^{133}$ Even kenmerkend voor de ideologische lading van de 'wetenschappelijke' geschiedschrijving van de jaren negentig was dat in de kritiek op de nieuwe cultuurhistorici, ook van de zijde van 'onpartijdige' neorankeanen als Lenz, zonder voorbehoud levensbeschouwelijke oordelen en ideologische uitspraken naar voren werden gebracht. ${ }^{134}$ Lamprechts benoeming aan de universiteit van Leipzig in 1891 vond plaats op grond van het uitgesproken vertrouwen van de benoemingscommissie dat hij niet alleen 'het wetenschappelijke handwerk ten volle beheerst' (sic!), maar ook 'in staat en gewend is de studenten het ethische en politieke gehalte van historische gebeurtenissen te tonen'. ${ }^{135}$

En de cultuurhistorici zelf? Enerzijds hechtten zij zonder meer aan wetenschappelijke objectiviteit. Breysig pleitte in zijn Kulturgeschichte der Neuzeit bijvoorbeeld voor een 'principiële onpartijdigheid' van de historicus en een 'volkomen ontbreken van vooroordelen en vooronderstellingen'. ${ }^{136}$ Steinhausen legde voortdurend de nadruk op de 'specialistische wetenschappelijkheid' van de cultuurgeschiedenis en meende dat de cultuurgeschiedschrijving in de praktijk vaak 'minder vooringenomen' was dan de politiek geschiedenis. ${ }^{137}$ Lamprecht verdedigde weliswaar het standpunt dat de geschiedschrijving altijd een product van haar tijd was, maar bestreed, niet helemaal consequent, de gedachte dat zijn eigen geschiedopvattingen een levensbeschouwelijke achtergrond hadden. Ook hij meende dat de cultuurgeschiedenis door haar bewuste begripsvorming wetenschappelijker beter gefundeerd was dan de politieke geschiedenis. En alle cultuurhistorici keerden zich tegen de in hun eigen tijd opkomende esthetiserende neoromantische geschiedschrijving, juist omdat zij die als een ontoelaatbare aantasting van de wetenschappelijkheid van de geschiedschrijving beschouwden. ${ }^{138}$

Toch had het engagement van de politieke historici klaarblijkelijk ook op hen indruk gemaakt. Net als de historici van de Pruisische School waren de cultuurhistorici stuk voor stuk ervan overtuigd dat de geschiedschrijver een belangrijke taak had in het bepalen of begeleiden van de koers van mens, natie en wereld in de eigen tijd. Zo noemde Goetz de geschiedwetenschap in zijn eerste publieke verdediging van de cultuurgeschiedenis de 'leermeesterin van de natie' en sprak hij na de Wereldoorlog van een 'falen [van de Duitse geschiedschrijving] tegenover de natie', omdat zij 'de natie' niet de juiste weg had gewezen. ${ }^{139}$ Ook bij de andere cultuurhistorici leefde sterk de gedachte van de geschiedschrijver als gids voor de eigen tijd. Volgens Nietzscheaan Breysig moest 'elke geschiedenis [...] het leven dienen en daarom moet elke geschiedenis uit de bron van het verleden slechts díe kennis scheppen, die voor het huidige leven nog van waarde kan zijn'. ${ }^{140}$ En hij verdedigde

${ }^{133}$ Schäfer (1888), 31 en 11.

${ }^{134}$ Zo ook Simon (1988).

${ }^{135}$ Citaat bij Czok (1984), 5.

${ }^{136}$ Breysig (1900), 43-44. Daarentegen schreef hij in zijn herinneringen: 'Moet de geschiedschrijver echter überhaupt [...] partij kiezen? Ik geloof van wel, als hij niet in een zouteloze onpartijdigheid vervallen wil.' Breysig memoreerde ook dat hij aan zijn docent en beschermheer Treitschke onder andere de leidende gedachte dankte dat de historicus 'oordelen moet'. Zie Breysig (1962), 27 en 77.

${ }^{137}$ Steinhausen (1925), 252.

${ }^{138}$ Zie Hoofdstuk 3, paragraaf 6.

${ }^{139}$ Goetz (1910), 9 (daar ook de opvatting dat 'historische kennis het fundament van alle ware politiek' is) en Goetz (1957b), 414-416 [1924].

${ }^{140} \mathrm{Vgl}$. de opmerking aan het begin van een geschiedtheoretisch werk: 'Dies Buch will zweien Herren dienen: dem Leben und der Wissenschaft' (Breysig (1925)). Breysig formuleerde het doel van de geschiedwetenschap elders eens als als volgt: 'het leven houdt zich de spiegel van zijn verleden voor 
zijn plannen voor een seminarium voor vergelijkende wereldgeschiedenis (1907) onder meer door te wijzen op het belang voor 'onze politieke en koloniale praktijk'. ${ }^{141}$ Hetzelfde uitgesproken hodiecentrisme vinden we ook terug bij Lamprecht, die de geschiedwetenschap een Vorbereitungswissenschaft voor het handelen van tijdgenoten noemde, 'een zonder meer noodzakelijke inleiding in de stand van de huidige mensheid'. ${ }^{142}$ En bij Gothein, die geschiedwetenschap kortweg typeerde als 'het onderzoek van het verleden met het doel het heden te begrijpen'. ${ }^{143}$ Steinhausen, die het minst expliciet was over de functie van de geschiedschrijving, was tegelijk degene onder de nieuwe cultuurhistorici die de meest directe morele en politieke oordelen velde in zijn werk en zich zeker na de Wereldoorlog opwierp als een diagnosticus van het nationale falen. ${ }^{144}$

De 'aufgeregte Gegenwartsnähe' van de nieuwe cultuurhistorici, die hen nog veel later soms door critici is verweten, leek al met al veel op de 'gegenwartsbezogene Geschichtsforschung' van de Pruisische School. ${ }^{145}$ Alleen was de inhoud van hun eigentijdse engagement anders, zoals nog zal blijken. ${ }^{146}$ Verschillen in levensbeschouwing speelden daarbij een belangrijke rol: over de verhouding van individu en collectief, over vrijheid en gedetermineerdheid van de mens en over de betekenis die aan de historische ontwikkeling moest worden toegekend, verschilden historisten en cultuurhistorici vèrgaand van mening.

\section{Individu en collectief}

In de historistische kritieken op de cultuurgeschiedenis doken twee samenhangende levensbeschouwelijke thema's bij voortduring op: de verhouding van het (al dan niet 'grote') individu tot de massa en de verhouding tussen vrije wil en gedetermineerdheid van de menselijke geest. Het verwijt van 'materialisme' dat cultuurhistorici werd gemaakt, kwam er op neer dat zij het individu te zeer presenteerden als een product van de massa en te weinig als een vrije persoonlijkheid: een waardevolle, onafhankelijke en invloedrijke historische factor. Zoals we hebben geconstateerd, bestonden er over deze kwestie ook tussen de cultuurhistorici onderling aanmerkelijke meningsverschillen. De heftigheid waarmee zelfs op onderlinge meningsverschillen op dit punt werd gereageerd, kan gezien worden als een indicatie van het cruciale belang dat Duitse intellectuelen rond 1900 aan dit thema hechtten. Maar bij alle onderlinge

het aangezicht om zich zelf ook nog in deze verminderde gestalte te genieten, door deze verdubbeling zich zelf bevestigd te voelen, er nieuwe kracht uit te zuigen'. Zie Breysig (1932), [1].

${ }^{141}$ Geciteerd in Brocke (1971), 306-307.

${ }^{142}$ Lamprecht (1974), 728 [1910]. De historica Luise Schorn-Schütte heeft in dit verband gesproken van een 'Funktionalisierung historischer Bildung' door Lamprecht: Schorn-Schütte (1994), 72 .

${ }^{143}$ Gothein (1889), 28 en 2 (mijn cursivering, MS). Zie ook de het voorwoord van Gothein en Neuhaus (1915-1916), iii, waarin hij de bedoeling van dit historisch werk aldus omschrijft: 'nicht nur zu weiterer Forschung anregen, sondern auch dem praktischen Leben dadurch dienen, daß es der Gegenwart die Voraussetzungen ihrer eigenen Aufgaben in der Vergangenheit ins Bewußtsein ruft'.

${ }^{144}$ Zie het meest expliciet zijn boek over Der politische Niedergang Deutschlands in seinen tieferen Ursachen, Steinhausen (1927). Hier bijv. VI-VII: 'Das Buch ist durchaus überparteilich gehalten: sein Standpunkt ist der der Gerechtigkeit [...] Es läßt sich ein eigener Standpunkt [...] durchaus mit der Gerechtigkeit verbinden. Sie geziemt vor allem dem Historiker.'

145 'Aufgeregte Gegenwartsnähe' is een kwalificatie van de historicus Ernst Schulin voor Lamprecht, geciteerd door Schorn-Schütte (1984), 202. 'Gegenwartsbezogene Geschichtsforschung' is de typering van Metz (1979), 237 e.v., voor het werk van Treitschke.

${ }^{146}$ Zie Hoofdstuk 7. 
meningsverschillen, erkenden de nieuwe cultuurhistorici stuk voor stuk meer dan de historisten de betekenis van de massa en het collectief. ${ }^{147}$

De historistische opvatting van het individu als vrije persoonlijkheid werd onder andere verwoord door Dietrich Schäfer in zijn reactie op Gothein, waarbij hij deze opvatting zonder meer als 'des historicus' karakteriseerde:

'De historicus begrijpt de mens in eerste linie als persoonlijkheid, niet als vertegenwoordiger van zijn soort [Gattung], hij houdt voor alles de vrije handelingen in het oog, die het individu boven zijn omgeving uittillen, hem tot een leider of tot diens tegenstander maken. [...] de historische daad ontstaat in het algemeen pas daar, waar de individuele handeling zich verheft boven de gelijkvormigheid van de massa. ${ }^{, 148}$

Zonder aandacht voor de betekenis van de persoonlijkheid zou, zo vreesden de historisten de moraliteit, het heldendom en de waarheid uit de geschiedschrijving verdwijnen, zoals Max Lehmann het in een reactie op Lamprecht uitdrukte:

\begin{abstract}
'verdwijnen zou het morele element en de relatie tot het eeuwige, bovenzinnelijke, waaruit toch juist de grootste staatsmannen aller tijden hun beste kracht hebben geput. Verdwijnen zou het heldendom [...]. Verdwijnen zou tenslotte [...] de historische waarheid. Want de sociale en politieke instituties uit het verleden zijn toch immers allemaal creaties van persoonlijkheden en krijgen hierdoor hun individuele karakter. Zo is en blijft de geschiedenis van de mensheid de geschiedenis van persoonlijkheden'. ${ }^{149}$
\end{abstract}

Historistische critici van de cultuurgeschiedenis beschouwden de persoonlijkheid als 'het innerlijke heiligdom van de geschiedenis': ze vormde niet alleen een belangrijke morele en historische factor, maar was bovendien einheitlich, ondoorgrondelijk en niet te ontleden. Herhaald weerklonk in de reacties op de cultuurgeschiedenis het woord van Goethe individuum est ineffabile, waaraan dan de conclusie werd verbonden dat de historicus moest rekenen met het individu als een 'unzerlegbare Tatsache'. ${ }^{150}$ Historisten gruwden van Breysigs stelling dat een moderne historicus slechts een determinist kon zijn en dat 'de wilsvrijheid derhalve uit de beschouwing van het mensenleven en de geschiedenis geëlimineerd' diende te worden. ${ }^{151}$ 'Zo ongeveer elke normale Duitse historicus', schreef Below unverfroren, benadrukte immers 'het moment van de vrijheid' tegenover de gebondenheid van de mens, terwijl iemand als Lamprecht de vrijheid klaarblijkelijk uit de menselijke aangelegenheden wilde verbannen. ${ }^{152}$ Een individu was echter weliswaar mede door allerlei externe krachten gevormd, maar dàt en hoe deze krachten in een persoon met elkaar verbonden werden,

${ }^{147}$ Zie Hoofdstuk 3, Paragraaf 6.3

${ }^{148}$ Schäfer (1891), 60; vergl. ook Below (1898), 245-247: 'in de ogen van de historicus tellen het individuele en het individu mee, niet slechts de soort [Gattung]. [...] Hij ziet zich overal genoodzaakt, empirisch het individualisme van de menselijke handelingen te constateren'.

${ }^{149}$ Zie Lehmann (1894), 246-247; vgl. Meinecke (1896), 265.

${ }^{150}$ O.a. Below (1898), 247. De uitdrukking betekent dat 'het individu(ele) niet in woorden gevat kan (of mag!) worden'.

${ }^{151}$ Breysig (1896b), 200; vgl. bijv. Schnürer (1897), 99-100.

${ }^{152}$ Below (1898), 220 (mijn cursivering, MS) en Rachfahl (1897), 663. Zo ook Lehmann (1894), 247: 'So ist und bleibt denn die Geschichte der Menschheit die Geschichte der Persönlichkeiten. Herrscht im Reiche der Natur Notdwendigkeit, so waltet im Reich der geschichtlichen Entwickelung Freiheit'. Vgl. bijv. Lamprecht (1896/97), 88-89. 
was voor een goed deel 'de spontane daad van de apriorische $\mathrm{x}$ in de mens' (Meinecke). ${ }^{153}$

Deze opmerking van Meinecke over de 'apriorische $\mathrm{x}$ ' van de mens borg een verwijzing in zich naar de belangrijkste theoreticus van het historisme, van wiens geschiedtheoretische colleges hij tijdens zijn studie naar eigen zeggen bijzonder onder de indruk was geraakt: Johann Gustav Droysen. ${ }^{154}$ Het was de tekst van dezelfde colleges waaraan Lamprecht zich als student had geërgerd. ${ }^{155}$ Droysen had al in 1863 in zijn polemiek met de Engelse cultuurhistoricus Buckle volgehouden dat het individu een creatieve en mysterieuze kern bezat, die niet uit de omstandigheden verklaard kon worden: ${ }^{156}$

\begin{abstract}
'Wanneer men alles wat een afzonderlijke mens is en heeft en presteert A noemt, dan bestaat deze A uit a $+x$, waarbij a alles omvat wat hij aan de uiterlijke omstandigheden van zijn land, volk, tijd etc. dankt, en de uiterst kleine $\mathrm{x}$ zijn eigen toedoen, het werk van zijn vrije wil is. Hoe uiterst klein deze $\mathrm{x}$ ook altijd zijn mag, het is van oneindige waarde, moreel en menselijk beschouwd het enige van waarde.'
\end{abstract}

Juist deze 'kleine $\mathrm{x}$ ' - de kern van de persoonlijkheid - was de eigenlijk bewegende factor in de geschiedenis, zoals Droysen in zijn Historik-colleges opmerkte, en verdiende derhalve de meeste aandacht van de historicus. Historici denken niet aan de duizenden gevallenen in een veldslag, hield hij zijn studenten voor, zij denken niet aan de arbeiders die de pyramiden bouwden. Het historisch onderzoek 'richt zich slechts op de leiders en de maatgevenden, op de boven alles uitstekende toppen; slechts dezen komen naar voren in het voorliggende materiaal; hun geest en hun hand leidde de dingen en deze dragen daarom hun stempel. ${ }^{157}$ De historisten uit de jaren negentig veroordeelden derhalve in de cultuurgeschiedschrijving het gebrek aan inzicht in de betekenis van buitengewone individuen en de verwaarlozing van de 'grote mannen'. ${ }^{158}$ 'Zijn het niet ook op het oneindig brede veld van de cultuurgeschiedenis de afzonderlijke handelingen van grote mannen, die alle voortgang bepalen?', vroeg Rachfahl retorisch. ${ }^{159}$ 'Waar blijven de grote juristen? Waar de grote mannen [...]?'160

Toch waren ook volgens historisten niet uitsluitend individuen van belang in de geschiedenis. Verschillende critici van de nieuwe cultuurgeschiedenis, zoals Below en

\footnotetext{
${ }^{153}$ Meinecke (1896), 265. Zo ook Below (1898), 244-247.

${ }^{154}$ Meinecke memoreert dat juist deze passage uit Droysens Historik-college (dat hij als het waardevolste van zijn hele studietijd kenmerkt) grote indruk op hem maakte: 'Das ist es, jubelte es damals in mir, dies Geheimnis der Persönlichkeit liegt allem geschichtlichem Tun und Treiben zugrunde', zie Meinecke (1941), 87, vgl. ook 91, 132. Vgl. ook de waardering van Meinecke voor Humboldts Aufgabe (176) en zijn afkeer van de positivistisch georiënteerde germanist Scherer uit de kring van Dilthey (118) - die door verschillende cultuurhistorici juist gewaardeerd werd (zie Hoofdstuk 6 , noot 109). Meinecke beschrijft zichzelf in zijn herinneringen uit 1941 als van huis uit 'romantisch disponiert' (44), met een vanzelfsprekende Deutschgesinnung (77), indertijd nog niet van de juistheid (!) van het antisemitisme doordrongen (80-81), tot aan 1895 met de Konservatieve Partei verbonden (206) en daarna in de ban van Friedrich Naumann.

${ }^{155}$ Lamprecht bekritiseerde als student in 1876 het voluntarisme in Droysens Historik, zie Chickering (1993), 40.

${ }^{156}$ Droysen (1977), ['Geschichte als Wissenschaft', oorspr. 1863], 462; ook in zijn college blz. 266: 'in dem noch so kleinen x liegt die Bewegung der Geschichte und die Bedeutung des sittlichen Lebens $[\ldots]$ '.

${ }^{157}$ Droysen (1977), 195.

${ }^{158}$ Zie Schäfer (1888), 6, 8, 28 en Schäfer (1891), 54-55.

${ }^{159}$ Rachfahl (1896a), 92.

${ }^{160}$ Rachfahl (1897), 664.
} 
Rachfahl, hielden vol dat ook binnen de gevestigde Duitse geschiedwetenschap al lang voldoende aandacht werd gegeven aan de invloed van bovenindividuele verschijnselen, met name aan de tijds- en volksgeest. Lamprechts opvatting dat historisten, Ranke voorop, eigenlijk individualisten waren, werd door hen schamper afgedaan als een schrijnend gebrek aan kennis en inzicht. En inderdaad, de typering 'individualist' was voor historisten alles behalve als een eretitel. Bij herhaling prentte bijvoorbeeld Droysen zijn studenten in dat de gedachte van het atomistisch individu als een ernstige misvatting moest worden beschouwd, een product van 'het moderne radicalisme' met zijn 'mensenrechten' en het 'moderne materialisme en nihilisme' met zijn 'sociologie'. Elk individu had immers vanaf het moment van zijn geboorte deel aan 'sittliche Gemeinsamkeiten' zoals familie, volk, staat, religie en 'ontving' daardoor pas wat hij was. ${ }^{161}$

Het meest typerend kwam deze historistische vorm van 'collectivisme' tot uitdrukking in het concept van de 'volksgeest'. ${ }^{162}$ Voor historisten was de staat weliswaar het eigenlijk object van de historicus, maar, zoals Ranke het uitdrukte, elke staat werd bezield door een eigen nationale aard: 'Dit geheimzinnige iets, dat de geringste [burger] evengoed vervult als de voornaamste, deze geistige lucht, die we uit- en inademen - gaat vooraf aan elke constitutie, geeft leven en inhoud aan al haar vormen.' 163 'Verleden en heden verbindend, verhief zich de opvatting van de nationaliteit, als één grote, de afzonderlijke mensen omvattende, in de loop van de tijdperken groeiende persoonlijkheid,' zo karakteriseerde Sybel in 1856 het begin van de 'moderne geschiedschrijving' in de voorafgaande decennia. '[O]veral bespeurde men nu de polsslag van het eigen bloed, overal voelde men het waaien van de heimatlichen lucht'. ${ }^{164}$

Nationale staten werden derhalve beschouwd 'individualiteiten' met een eigen karakter, 'de een analoog aan de ander - maar wezenlijk onafhankelijk van elkaar', zoals Ranke schreef, 'noodzakelijkerwijs en naar idee van elkaar verschillend'. ${ }^{165}$ Deze nationale idee bepaalde alle vormen van leven in de staat, niet alleen de staatsvorm zelf, maar ook het privé-leven van haar burgers. Want zelfs het individuele karakter werd mede door de nationaliteit gevormd: een Italiaan bewoog immers als een Italiaan, hij gedroeg zich als een Italiaan als hem iets onverwachts overkwam, hij voelde en dacht als een Italiaan. De nationale aard drukte, kortom, een onuitwisbaar stempel op elke burger: ${ }^{166}$

'Ons vaderland [...] is bíj ons, ín ons. Duitsland leeft in ons, wij vertegenwoordigen het, of we willen of niet, in elk land waar we naar toe gaan, in elke [klimaat]zone. Wij zijn er vanaf het begin in geworteld en we kunnen ons er niet van emanciperen.'

$\mathrm{Nu}$ bestond er al in de Verlichtingshistoriografie een levendige belangstelling voor het vraagstuk van de national characters (Hume), l'esprit des nations (Montesquieu), le genie d'un peuple (Voltaire), en last but not least de Geist der Zeiten en de Geist des Volkes (Herder). Er valt in het algemeen echter een aanmerkelijk verschil te

${ }^{161}$ Droysen (1977), 478, ook 438.

${ }^{162}$ Bijv. Rachfahl (1897), 675: 'Denn je nach ihrem Gesamtcharakter werden sich die Völker zu den einzelnen Gebieten des Kulturlebens verschieden verhalten und dies mit ihrem eigenen, unter einander verschiedenen Geiste durchdringen'.

${ }^{163}$ Ranke (1925) [Politisches Gespräch, 1836], 22.

${ }^{164}$ Sybel (1880), 352-353.

${ }^{165}$ Ranke (1925) [Politisches Gespräch, 1836], 25, 35.

${ }^{166}$ Ranke (1925) [Politisches Gespräch, 1836], 22. 
constateren tussen de eerdere Verlichte en de latere historistische opvattingen over het nationale karakter.

Kort gezegd werd het nationale karakter van een Verlichte vraag een romantisch gegeven. Terwijl bij Verlichte historiografen de aandacht uitging naar het nationale karakter als een te verklaren fenomeen, waarbij de vraag centraal stond waar de opvallende verschillen tussen mensen uit verschillende regio's nu eigenlijk vandaan kwamen, ${ }^{167}$ werd de volksaard in het historisme veel meer een fait accompli, dat niet zozeer verklaard moet worden, als wel zelf beschouwd werd als een verklarende factor. Historisten beschouwden het individuele karakter van naties met andere woorden op dezelfde wijze als de individualiteit van persoonlijkheden: zij was een uiterst belangrijke historische factor, maar tegelijk niet historisch of anderszins verklaarbaar. Waarom, bijvoorbeeld, de stedenbouwende Azteken en de nomadische Noordamerikaanse Indianen zo van elkaar verschilden, was een vraag die een historicus volgens Droysen niet kon beantwoorden en dus ook niet moest stellen: de historicus beperkte zich tot het vaststellen van dergelijke verschillen. ${ }^{168}$ Evenmin als het individuele karakter was het nationale karakter een product of resultaat van een aantal uiterlijke factoren, maar eerder een productief fenomeen dat zelf bepalend was voor het verloop van de geschiedenis. Het waren derhalve niet de omstandigheden die de individuele mens en de individuele natie dwongen een bepaalde richting in te slaan of een bepaald karakter aan te nemen, maar omgekeerd: de individuen en de naties zelf bepaalden uiteindelijk de loop van de geschiedenis. Oftewel, met een vervolg op het indianenvoorbeeld uit Droysens geschiedtheoretische college: 'Het is niet het Amerikaanse oerwoud dat de indiaan tot jager heeft gemaakt, maar omdat hij het liefste een jager was, heeft hij het bos niet gerooid en de akker niet leren bewerken. ${ }^{, 169}$ De vrije wil van de mens, die bij uitstek tot uiting kwam in zijn mysterieuze en spontane creativiteit, was voor historisten als Droysen doorslaggevend.

Net als bij de historisten speelde bij de nieuwe cultuurhistorici de gedachte van collectieve geestesgesteldheden een belangrijke rol, zoals eerder is gebleken. ${ }^{170}$ En net als de historisten schonken zij de meeste aandacht aan nationale collectieven. Maar anders dan de meeste historisten (en net als de Verlichte denkers waardoor zij geïnspireerd waren), maakten zij dit thema expliciet tot onderwerp van historisch onderzoek. Veel meer dan de historisten legden zij de nadruk op het historische karakter en dus op de veranderlijkheid van de nationale aard; alleen bij Steinhausen overwoog uiteindelijk de gedachte van een beharrend, niet-meer-veranderend Volkstum. Bovendien beschouwden de nieuwe cultuurhistorici de nationale aard in principe als de belangrijkste onder verschillende sociaal-psychologische eenheden die zij onderscheidden: ook van afzonderlijke sociale of culturele groepen binnen een natie probeerden zij de collectieve geestesgesteldheid te bepalen. En terwijl, tenslotte, de nieuwe cultuurhistorici voornamelijk sociaal-psychologische verklaringen aanvoerden om het bestaan van nationale karakters te begrijpen - en daarmee inderdaad de vrije wil van het individu aan banden legden - moesten historisten een andere weg inslaan om de verhouding tussen individu en collectief te duiden.

\footnotetext{
${ }^{167}$ Zie bijv. Jahoda (1992), 17-18, 32-33.

${ }^{168}$ Droysen (1977), 292-293.

${ }^{169}$ Droysen (1977), 292.

170 Zie Hoofdstuk 3.
} 


\section{Idealisme, Verstehen en psychologie}

De gebondenheid van het individu aan het collectief werd door historisten niet psychologisch, sociologisch en doorgaans evenmin biologisch verklaard. Expliciet keerde Droysen zich bijvoorbeeld in zijn colleges over de historische studie tegen de psychologische aanname die ten grondslag had gelegen aan de Verlichte cultuur- en mensheidsgeschiedenis: namelijk dat de ziel als onbeschreven blad pas door de invloeden van buiten inhoud kreeg. De prikkels van buiten maakten volgens Droysen hooguit wakker wat al aanwezig was. ${ }^{171}$ Of zelfs sterker, het innerlijk vormde het uiterlijk, en niet andersom. 'Tot in het uiterste is het waar dat de geest zich een lichaam bouwt', schreef Droysen met een stilzwijgende verwijzing naar een klassiek motto van het Duitse idealisme. ${ }^{172}$ De omgekeerde opvatting, de Verlichte gedachte dat de invloeden van buitenaf, de Reize, de mens wezenlijk vormden tot wat hij is, gold binnen het historisme als 'materialistisch'.

Elke menselijke individualiteit, zowel individu als natie, werd door historisten beschouwd als 'een in de verschijning gewortelde idee' ${ }^{173}$ In historische verschijnselen kwamen ideeën tot uitdrukking,

'die naar hun aard buiten het bereik van de eindigheid liggen, maar de wereldgeschiedenis in al haar delen besturen en beheersen [...] de hele geschiedenis is slechts de verwerkelijking van een idee en in de idee ligt tegelijk de kracht en het doel'. ${ }^{174}$

Ideeën waren de bewegende krachten in de geschiedenis; het doel van de geschiedenis en van de afzonderlijke historische verschijnselen was de realisering van een idee. En dat was niet alleen de opvatting van historisten uit het begin van de negentiende eeuw, zoals de hierboven geciteerde Humboldt, maar het werd ook volgehouden door de tegenstanders van de cultuurhistorici aan het eind van de negentiende eeuw, toen met name Lamprecht zijn pijlen tegen deze historistische ideeënleer richtte.

De discussie richtte zich toen vooral op de herkomst van 'de idee'. Lamprecht legde er de nadruk op dat voor Ranke 'ideeën' uiteindelijk niet voortkwamen uit de geschiedenis zelf, maar een mystiek karakter droegen. 'De idee is van goddelijke oorsprong', schreef Ranke zelf daarover onder andere. ${ }^{175}$ De historisten van de jaren negentig ontkenden dat Ranke's religieuze inspiratie in de praktijk diens geschiedschrijving had beïnvloed en verkondigden dat de ideeënleer op zichzelf een strikt empirisch karakter droeg. ${ }^{176}$ 'Ideeën' waren niet 'mystiek', maar moesten eenvoudig beschouwd worden als 'de telkens bestaande algemene opvattingen over de verhouding van de mensen tot de hoogste vragen van het leven, van hele sociale kringen, hele volkeren en hele generaties'. ${ }^{177}$ Maar duidelijk was wel dat dergelijke

${ }^{171}$ Zie bijv. Droysen (1977), 292 of 27.

${ }^{172}$ Droysen (1977), 27; naar Schiller (Wallensteins Tod III/13): 'Es ist der Geist, der sich den Körper baut'.

${ }^{173}$ Aldus Wilhelm von Humboldt in zijn onder historisten tot in de twintigste eeuw gezaghebbende opstel over de taak van de geschiedschrijver (1821): Humboldt (1980)

${ }^{174}$ Humboldt (1980), 601. Opnieuw kan Meinecke dienen als illustratie van de invloed van dit vroege historisme op de critici van de nieuwe culturgeschiedenis, zie Meinecke (1941), 176.

${ }^{175}$ Ranke (1925), 25 [Politisches Gespräch, 1836]. De Ranke-leerling Ottokar Lorenz (18861891), I, 270-271, wees er kort voor de strijd om de cultuurgeschiedenis eveneens op dat via de ideeënleer 'der Gott in der Geschichte [...] in stiller Voraussetzung' nog vaak de eigentijdse geschiedschrijving bepaalde.

${ }^{176}$ Below (1898), 207-208; Rachfahl (1897), 676.

${ }^{177}$ Rachfahl (1896b), 547. 
'grote ideeën' volgens de historistische tegenstanders van de cultuurgeschiedenis in ieder geval niet herleid mochten worden tot maatschappelijke verschijnselen en uiteindelijk inderdaad iets onverklaarbaars behielden. ${ }^{178}$ En sommige historisten voerden ze anno 1890 nog steeds uitdrukkelijk terug tot een hogere, buitenmenselijke macht. Zo typeerde Dietrich Schäfer in zijn verhandeling tegen de cultuurgeschiedenis de 'politieke en religieuze overtuigingen en passies van de volkeren' als 'dié geestelijke en zedelijke aspiraties die als goddelijk erfdeel in de mensen leven'. Hoe dan ook, historisten waren het erover eens dat het de 'grote ideeën' waren die staat, kerk en maatschappij beheersten - en niet andersom.

Het filosofisch idealisme dat in deze opvattingen tot uitdrukking komt, levert ons het antwoord op de vraag hoe de historisten de innige samenhang tussen individu en natie konden denken en desalniettemin konden vasthouden aan de vrijheid van het individu. Die samenhang was kortgezegd niet immanent maar transcendent. Het leidinggevende individu was niet een product van zijn volk en daardoor zijn representant, nee, de grote persoonlijkheden representeerden dezelfde idee als hun natie en konden dáárdoor als nationale leiders optreden. Via deze idealistische omweg om de samenhang van individu en natie te denken, kon de vrijheid van het individu behouden blijven: hij was een representant van zijn natie door zijn keuze voor de nationale idee. Op grond van deze redenering konden 'grote persoonlijkheden' onbekommerd als representatief voor 'het volk' worden beschouwd. Zoals Droysen het formuleerde: 'over hen sprekend, spreekt men tegelijk over honderden en duizenden, spreekt men over het gehele tijdperk, het hele volk'. ${ }^{179}$

De belangrijkste taak van de historicus was volgens deze theorie om te achterhalen welke ideeën tot uiting kwamen in een bepaalde historische situatie. 'Het werk van de historicus bestaat er in zijn laatste, maar eenvoudigste Auflösung in', schreef Humboldt, 'het streven van een idee weer te geven om in de werkelijkheid gerealiseerd te worden'. ${ }^{180}$ De geëigende methode daartoe, nadat het kritisch bronnenonderzoek had plaatsgevonden, behelsde 'nicht genetisch zu erklären, sondern forschend zu verstehen', zoals de al in de jaren negentig klassieke formulering van Droysen luidde. ${ }^{181}$

Om deze tegenstelling tussen genetisch erklären en forschend verstehen te begrijpen is het van belang om onderscheid te maken tussen de Verlichte milieutheorie en de historistische opvatting van context. In de milieutheorie werd het individu 'verklaard' door de geschiedenis en de omstandigheden, als het ware buiten zijn wil om. In de idealistische contexttheorie ging het erom door de analyse van de context duidelijk te maken voor welke keuzen de historische persoonlijkheid stond. Het historistische Verstehen was teleologisch van aard: het was gericht op het begrijpen van de doelen en doelstellingen waardoor mensen zich lieten leiden, zoals met name door Rachfahl in zijn discussie met Lamprecht werd beklemtoond. ${ }^{182}$ Volgens hem kon het bij 'causale verbanden' in de geschiedwetenschap uitsluitend gaan om dergelijke Zweckzusammenhänge: de samenhang die tussen historische verschijnselen bestond op grond van doelen waardoor mensen, groepen en staten

${ }^{178}$ Zie bijv. Rachfahl (1896a), 78; Rachfahl (1897), 678.

${ }^{179}$ Droysen (1977), 391.

${ }^{180}$ Humboldt (1980), 602-605. Zo ook Droysen (1977) [oorspronkelijk 1857], 17r15-23.

${ }^{181}$ Droysen (1977), 311; Lehmann (1894), 247, verwees in zijn discussie met de nieuwe opvattingen naar deze uitspraak.

${ }^{182}$ Rachfahl (1897), 667, ook 685, 681. 
geleid werden, hun idealen, wensen, overtuigingen, en de middelen die ze inzetten om die doelstellingen te realiseren. ${ }^{183}$

De ultieme 'ideeën' waarnaar de historist op zoek was, waren niets anders dan díe Zweckzusammenhänge 'die hele volkeren en tijdperken beheersen'. ${ }^{184}$ Op een minder veelomvattend niveau moest de historicus onderzoeken welke ideeën met elkaar wedijverden in een bepaalde historische situatie en proberen te begrijpen door welke ideeën en idealen de handelende historische persoonlijkheden werden geleid. Om dit goed te kunnen beoordelen was de kennis van de context essentieel, maar tegelijk leverde de context geen verklaring voor het gedrag van de historische persoonlijkheden. Die werden immers als vrije persoonlijkheden beschouwd. De historische wereld was in de terminologie van de historisten, zoals Treitschke het nog in 1895 in een reactie op Lamprecht formuleerde, de 'wereld van de morele vrijheid', 'de wereld van wil en daad', of ook een 'zedelijke wereld' - een uitdrukking die in Droysens colleges voortdurend terugkomt. ${ }^{185}$ In een dergelijke wereld paste begrijpen, niet verklaren.

Het voluntaristisch idealisme dat historisten kenmerkte, maakt duidelijk waarom zij ondanks hun nadruk op het Verstehen, het begrijpen van historische persoonlijkheden, weinig moesten hebben van de psychologie. ${ }^{186}$ Weliswaar waardeerden zij de 'psychologische' kwaliteiten van een historicus als Ranke, dit wil zeggen zijn inlevingsvermogen en het vermogen om een fijngevoelige schildering van het karakter van historische persoonlijkheden te geven. ${ }^{187}$ Maar een psychologische deconstructie werd niet gewaardeerd. Zij dachten daarbij overigens niet zozeer aan een analyse van zowel willen, denken, voelen en waarnemen (zoals de nieuwe cultuurhistorici), maar in samenhang met het hun eigen voluntarisme - vooral aan Motivenforschung, het onderzoek naar de diepste motieven of beweegredenen van individuen. ${ }^{188}$

Niet alleen de critici van de nieuwe cultuurgeschiedenis, maar ook al vroegere autoriteiten van het historisme als Humboldt en Droysen hadden zich uitdrukkelijk tegen een dergelijke psychologische Motivenforschung gekeerd. ${ }^{189}$ Op de eerste plaats werd daardoor naar hun mening al te gemakkelijk 'de tragedie van de wereldgeschiedenis [verlaagt] tot het drama van het alledaagse leven [...] en in plaats van het wereldlot een kleingeestig mechanisme van persoonlijke motieven' geplaatst, zoals Humboldt al in 1821 had geschreven. ${ }^{190}$ Een moreel argument dat een echo vond in Schäfers bezwaar tegen cultuurhistorici, namelijk dat zij in tegenstelling tot de politieke historici slechts geïnteresseerd zouden zijn in de 'alledaagse gewoonten en

${ }^{183}$ Rachfahl (1897), 667.

${ }^{184}$ Rachfahl (1896b), 547n.

${ }^{185}$ Zie Chickering (1993), 180; het gaat bij de citaten van Treitschke om zijn programmatische uitspraken als kersverse hoofdredacteur van de $H Z$ na de mislukte overnamepoging door Lamprecht.

${ }^{186}$ In dit opzicht waren de historisten erfgenamen van de idealistische filosofie van Fichte, Schelling en Hegel, met haar antipsychologische houding en haar nadruk op het actieve ego. Zie Leary (1980), 302

${ }^{187}$ Zie bijv. Below (1898), 224.

${ }^{188}$ Zie bijv. Rachfahl (1897), 667-669 en 682: 'Ueberall können wir also Motive, Zwecke und Zwecksammmenhänge, Abhängigkeit von Bedingungen und äußeren Einflüssen, die wieder als Motive durch den Geist hindurchgehen müssen, konstatieren'; en Below (1898), 247: 'Er [der Historiker] sucht, soweit es geht, die Motive des Individuums zu erforschen; ganz es zu erklären vermag er nicht. Das Urtheil des Philosophen, das Individuum sei nur eine Resultante der Wirkung von Ursachen, interessirt ihn als Historiker nicht.'

${ }^{189}$ Humboldt (1980); Droysen (1977), m.n. 187-200, ook 29: 'unmöglich oder wenigstens ungeschichtlich wäre es, wenn man das Geschehene nur psychologisch erklären, d.h. nur aus dem Willen oder der Willkür der Menschen ableiten wollte'.

${ }^{190}$ Humboldt (1980), 599. 
gebruiken', 'de vormen van bevrediging van de lagere behoeften, die in de dierlijke delen van het menselijke bestaan hun oorsprong hebben'. ${ }^{191}$

Verder werd de geschiedenis volgens historisten niet zozeer door de individuele motieven van mensen bepaald, als wel door ideeën. De psychologische Motivenforschung schoot tekort omdat zij 'een gat' liet vallen tussen het afzonderlijke individu en het historisch geheel. ${ }^{192}$ De 'ideeën' overbrugden voor de historisten de kloof tussen individu en collectief, tussen de strikt persoonlijke motivaties en de beweegredenen van 'historische betekenis'. 'De interpretatie van de ideeën vult het gat dat de psychologische [interpretatie] laat bestaan', zoals Droysen concludeerde. ${ }^{193}$

Ten slotte achtten historisten de wetenschappelijke psychologie helemaal niet in staat zóver in de psyche van een historische persoonlijkheid door te dringen dat men werkelijk de gebeurtenissen uit de motieven van mensen kon verklaren. De mening van Droysen: 'In dit heiligdom van de persoonlijkheid dringt de blik van de aardse wetenschap niet' - werd door de tegenstanders van de cultuurgeschiedenis gedeeld en tegen de nieuwe richting aangevoerd. ${ }^{194}$ Daarbij voelden zij zich gesteund door een argument van de neokantiaans georiënteerde epistemologen Dilthey, Windelband en Rickert, die juist in de jaren negentig hun stellingen tegen de natuurwetenschappelijke psychologie hadden opgetrokken. Volgens hen was de psychologie, althans voor zover zij een generaliserende natuurwetenschap was, zo radicaal verschillend van de individualiserende geschiedwetenschap dat zij nauwelijks een bijdrage kon leveren aan het historisch denken of het historisch inzicht, laat staan een fundament daarvoor kon bieden. ${ }^{195}$ Dat het de cultuurhistorici, Lamprecht incluis, helemaal niet om een natuurwetenschappelijke psychologie te doen was, maar eerder om een historisering van de psychologie, leek hen te ontgaan en paste in ieder geval niet in de poging de cultuurhistorici als historici het recht van spreken te ontnemen. Opvallend was overigens dat met name Windelband en Rickert dezelfde opvattingen over geschiedenis - bijvoorbeeld over de grote rol van het individu en de individuele vrijheid daarin - er op na bleken te houden als de historisten, in wier oren hun opvattingen dan ook als Poesie des Lebens klonken. ${ }^{196}$

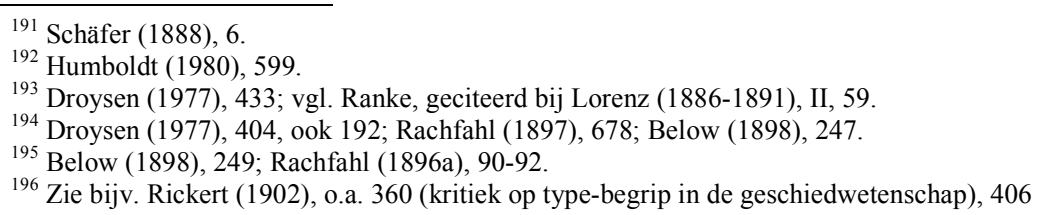
(kritiek op het Verlichte 'atomiserende' individualisme), 426 (kritiek op milieubegrip), 496 e.v. (kritiek op dominantie collectieve factoren: 'Sollen aber darum nur diese Gruppen und Massen massgebend sein? In unserem demokratischen Zeitalter wünscht man vielleicht, die Masse soll immer den Einzelnen gewissermassen erdrücken. Logisch wird es sich jedoch nicht wahrscheinlich machen lassen, dass dieser Wunsch Aussicht auf Erfüllung hat. [...] es ist umgekehrt viel eher möglich, dass eine einzelne Persönlichkeit das Gepräge ihrer individuellen Eigenart ihrer Umgebung oder ihrer Zeit aufdrückt'). Het verrast niet dat Rickert, zoals hij zelf opmerkt (Rickert (1926), XIV), onder historici meer weerklank vond dan onder zijn vakgenoten. Zowel in zijn Kulturwissenschaft als in Grenzen kiest hij in de controverses over de cultuurgeschiedenis impliciet en expliciet de zijde van de tegenstanders (zie voor een overzicht van plaatsen in Rickerts Grenzen: Spranger (1905), 41n). Het meest theoretische artikel van Below (1898) over Lamprecht - een stuk vol schimpscheuten - werd door Rickert 'ganz ausgezeichnet' genoemd: Rickert (1926), 9n2). Below (1925), 30, schreef op zijn beurt over Rickert: 'Ich hatte bei der Lektüre der Rickertschen Schriften das Glücksgefühl, befreit zu werden von der Bedrohung durch Vorurteile, die ich als verkehrt durchaus empfand, deren Verkehrtheit ich indessen nicht bis zum lezten Grund zu deduzieren vermochte. In diesem Sinne waren mir Rickerts "Grenzen" mit ihren Darlegungen gegen Positivismus und Naturalismus Erhebung, Erbauung, Poesie des Lebens.' Vgl. overigens ook de vergelijkbare opvattingen over geschiedenis en psychologie van de nauw met Rickert bevriende psycholoog Hugo Münsterberg: Stoffers (2003), m.n. 174-175. 
$\mathrm{Al}$ met al is het geen wonder dat Gothein zijn kansen op een historische leerstoel niet verbeterde toen hij in zijn Habilitationsschrift niet zozeer de nadruk legde op de idealen die de prereformatorische hervomingsbewegingen bezielden, maar daarentegen aandacht gaf aan massapsychologische verschijnselen die in deze bewegingen een rol speelden en daarvoor terloops het psychologische begrip geistige Epidemie in de Duitse geschiedwetenschap introduceerde. En geen wonder dat historistische critici, die mèt Droysen meenden dat het wezen van een volk gelegen was in het bewuste ideaal van de eenheid, das Wollen der Einheit, dat pas onder leiding van een 'grote persoonlijkheid' als Bismarck gestalte kon krijgen, schande spraken van Lamprechts 'ungeheuerliche opvatting', dat de recente eenwording van de Duitse natie te maken zou hebben gehad met economische ontwikkelingen en de 'psychologie van de vrije onderneming'. ${ }^{197}$

Toch was de tegenstelling tussen de cultuurhistorici en hun vakgenoten ook waar het de verbintenis van geschiedenis en psychologie betrof minder absoluut dan de geschetste meningsverschillen suggereren. Zelfs onder de critici van de nieuwe cultuurgeschiedenis vinden we op dit punt niet uitsluitend afwijzende geluiden. Zo is al een keer aangehaald dat een gematigd criticus van Lamprecht als Otto Hintze zich wel kon vinden in diens nadruk op een sociaal-psychologische aanpak. ${ }^{198}$

Opmerkelijk was eveneens de stellingname op dit punt van de al eerder genoemde historicus Ottokar Lorenz. ${ }^{199}$ Lorenz hield uitdrukkelijk vast aan de politieke geschiedenis als de kern van de geschiedwetenschap en had tegen eerdere vormen van cultuurgeschiedenis zijn stem verheven. Desalniettemin kwam deze Jenaer hoogleraar met zijn voorstellen voor een 'wetenschappelijke genealogie' dicht in de buurt van de nieuwe cultuurhistorische opvattingen over de noodzaak van een historische psychologie. Lorenz nam het Verlichte (Kantiaanse) standpunt in dat er in de loop van de geschiedenis sprake was van een 'verdere ontwikkeling van de menselijke vermogens'. Er kon 'historisch-genealogisch' volgens hem bijvoorbeeld nauwelijks twijfel over bestaan dat de middeleeuwse voorvaderen 'muzikaal anders georganiseerd' waren dan de eigentijdse Wagner-liefhebbers en ook op het terrein van de kleurwaarneming achtte hij een 'generatiegewijze variabiliteit van de overerving' zeer waarschijnlijk. ${ }^{200}$ De studie van dergelijke 'genealogische' veranderingen vormde naar zijn mening weliswaar niet het eigenlijke object van de geschiedwetenschap, maar wel het fundament ervan. ${ }^{201}$ Alleen een dergelijke wetenschappelijke studie van de generatiegewijze veranderingen in de mens kon een veel voorkomende tekortkoming in de historistische geschiedschrijving verhelpen, namelijk dat de ideeën in historische werken rondwaarden 'als spoken door de geschiedenis'.

De verwantschap van deze opvattingen met opvattingen van de nieuwe cultuurhistorici wordt bevestigd door het feit dat 'genealogie' en Familienforschung een onderdeel zou worden van het onderwijs aan Lamprechts Institut für Kultur- und Universalgeschichte, waarbij een oud-promovendus en medewerker van Lorenz betrokken was. $^{202}$ Dat Lorenz ondanks zijn traditionele voorkeur voor politieke

${ }^{197}$ Droysen (1977), 305; Rachfahl (1896b), 554.

${ }^{198}$ Hintze (1982), 320-321 [1897]; zie eerder Hoofdstuk 2, paragraaf 3. Hier kan ook nog eens opgemerkt worden dat Rachfahl (1896a), 91 een zekere waardering uitte voor Diltheys Ideen waarin een toenadering tussen geschiedenis en psychologie werd voorgestaan.

${ }^{199}$ Zie hierboven paragraaf 2.

${ }^{200}$ Zie Lorenz (1898), 38-73, m.n. 47-49, 68-72.

${ }^{201}$ zie Lorenz (1886-1891), I, 272-278.

${ }^{202}$ Het gaat om Ernst Devrient; vgl. het leerprogramma van het IKU in Hoofdstuk 3, Tabel 3.4 (onder nr. 15). Daarnaast zou een van Lamprechts eigen studenten, Armin Tille, zich expliciet inzetten voor deze richting in het historisch onderzoek (zie Bernheim (1908), 309-310). Lorenz was na Wundt 
geschiedenis niet geheel afwijzend stond tegenover de nieuwe cultuurgeschiedenis blijkt ook uit het feit dat hij Steinhausens poging ondersteunde om zich als docent voor cultuurgeschiedenis te habiliteren aan de Universiteit van Jena. ${ }^{203}$

Verder was er ook onder verschillende historische docenten van de cultuurhistorici sprake van een opvallende psychologische belangstelling. Zo deelde de politiek historicus Erdmannsdörffer, een favoriete docent van Gothein, het streven van zijn goede vriend Dilthey naar een 'psychologische fundering' van de geschiedwetenschap. ${ }^{204}$ Maar vooral de geschiedtheoreticus Ernst Bernheim, docent van Lamprecht en Steinhausen, moet in dit verband opnieuw - en iets langer - ter sprake worden gebracht. ${ }^{205}$

Bernheim wilde de cultuurgeschiedenis geen alles overheersende plaats toekennen in de geschiedwetenschap en vond met name Lamprechts collectivisme veel te ver gaan. ${ }^{206} \mathrm{Hij}$ onderscheidde zich evenwel van veel van zijn collega-historici door zijn studie van de binnen- en vooral buitenlandse positivistische wetenschapstheoretische literatuur. Al in zijn eerste geschiedtheoretische publikatie uit 1880 gaf hij te kennen dat hij de verdienste van de 'socialistisch-natuurwetenschappelijke' richting (zoals hij het positivisme aanduidde) vooral zag in de ontwikkeling van de Völkerpsychologie. ${ }^{207}$ In een voorwoord uit 1903 bij zijn Lehrbuch noemde Bernheim de völkerpsychologische opvatting 'een ongemeen vruchtbaar element in het historisch onderzoek, dat men zich eigen zou moeten maken'. ${ }^{208}$ Zoals hij op dezelfde plek aangaf, was een dergelijke Aneignung vanaf het begin een doelstelling van zijn grote Lehrbuch geweest. Niet alleen wijdde hij in het belangrijke hoofdstuk over de historische interpretatie een aparte paragraaf aan de 'sociaal-psychische factoren' in de geschiedenis (die in de loop van de verschillende drukken in omvang zou verdubbelen), maar ook elders in zijn boek had hij naar eigen zeggen voortdurend rekening gehouden met het sociaal-psychologische perpectief.

verder de meest geciteerd auteur in Lamprechts belangrijkste vroege geschiedtheoretische studie, Lamprecht (1896/97).

${ }^{203}$ Zie Steinhausen (1925), 256-257. Overigens onderhield ook Breysig met Lorenz persoonlijk een inspirerend contact, zie Brocke (1971), 41n.

${ }^{204}$ Zie Erdmannsdörffer (1911b), I, XXIII. Over de waardering van de cultuurhistorici voor Dilthey, zie Hoofdstuk 6, Paragraaf 3.

${ }^{205} \mathrm{Zie}$ over Bernheims geschiedopvatting, en zijn receptie door de nieuwe cultuurhistorici, eerder al Hoofdstuk 2, paragraaf 1. Bernheim was als jonge docent in Göttingen en later als extraordinarius voor historische hulpwetenschappen in Greifswald degene die Lamprecht en Steinhausen introduceerde in de theorie der geschiedenis en in beiden enthousiaste studenten trof. Met Lamprecht bleef Bernheim bovendien vanaf zijn studietijd lange tijd in vrienschappelijk en collegiaal contact, waarbij geschiedtheoretische kwesties soms uitgebreid werden besproken. Zie Steinhausen (1925), 236, 238; en voor Lamprecht: Schorn-Schütte (1984), 31-33 en Schönebaum (1961). Over Bernheim bestaat nauwelijks literatuur, zie Weber (1987), 41 en Schorn-Schütte (1984), 31n. De enige recentere studie betreft Bernheim als geschieddidacticus: Buszello (1978), waarin op blz. 224-233 een analyse van zijn geschiedopvattingen. De dissertatie van Baudet (1948) heeft geen biografische waarde; het is een kritiek op Bernheims interpretatie van de middeleeuwse geschiedbeschouwing. De correspondentie tussen Lamprecht en Bernheim, onder redactie van Luise Schorn-Schütte, staat al enige jaren op het punt van verschijnen.

${ }^{206}$ Zie bijv. Bernheim (1899), 18-19, 33-35.

${ }^{207}$ Bernheim (1880), 76. Hij spreekt dan ook van de 'ungemein anregenden tiefdringenden Forschungen ihrer Vertreter' (124-125). Zie over de Völkerpsychologie meer in Hoofdstuk 6, Paragraaf 3.

${ }^{208}$ Bernheim (1903), VII. In het voorwoord uit 1908 van zijn Lehrbuch benoemt Bernheim opnieuw het völkerpsychologische, resp. sociaalpsychologische element van het positivisme als het 'bruikbare' element van deze richting. Bernheim voerde de uitgangspunten van Völkerpsychologie, onder uitgesproken waardering en erkenning van de Völkerpsychologen Lazarus en Steinthal, uiteindelijk via John Stuart Mill terug tot Comte. 
Het völker- of sociaal-psychologisch perspectief betekende voor Bernheim vooral dat hij zich rekenschap gaf van de wisselwerking tussen individuen, van de 'veelvuldige sociale relaties' waarin elke individu 'stak', die elk individu 'intellectueel en qua gemoed' beïnvloedden en door hem werden beïnvloed. Tegen deze achtergrond krijgt ook Bernheims definitie van de geschiedenis in het begin van zijn werk meer reliëf: 'De geschiedenis', schreef hij daar, 'is de wetenschap van de ontwikkeling van mensen in hun activiteit als sociale wezens'. ${ }^{209}$ Met deze algemene omschrijving keerde Bernheim zich niet alleen expliciet tegen een beperking van de geschiedwetenschap tot politieke geschiedenis, maar bovendien legde hij daarmee willens en wetens de nadruk op alle vormen van menselijke Vergesellschaftung als centraal object van de historicus. ${ }^{210}$ Anders dan de Völkerpsychologen Lazarus, Steinthal en later Wundt prefereerde Bernheim voor de analyse van deze socialiseringsprocessen de uitdrukking 'sociaal-psychologisch': de 'volksgeest' kreeg bij hem geen speciale plaats onder de sociale relaties van mensen. Bernheim ging het uitdrukkelijk om 'alle psychische relaties' tussen individuen en groepen en hij erkende expliciet de grote verscheidenheid in Vorstellungs- und Empfindungskreise van individuen binnen een tijdvak of in een bepaald volk 'al naar gelang hun sociale relaties en posities'. ${ }^{211}$

Waar het volgens Bernheim bij de erkenning van de sociaal-psychische factoren vooral om ging, was dat de historicus zich bewust diende te worden van de naïeve vooronderstelling dat mensen in het verleden dezelfde voorstellingen en gevoelens koesterden die hijzelf normaal achtte. ${ }^{212}$ Hij moest zich er rekenschap van geven dat en hoe de voorstellingen en gevoelens van mensen en tijden veranderd waren en steeds veranderden. Het doel van de sociaal-psychologische analyse was om de Differenz der Zeiten in dit opzicht te onderzoeken en anachronismen te voorkomen. De betreffende psychische Disposition van een tijd mocht niet zonder meer vanuit de eigen dispositie en de eigen gewoonten van de historicus worden beoordeeld: ${ }^{213}$

'Dat de mensen in vroegere tijden andere kleren hebben gedragen dan wij, dat
begrijpt iedereen, maar dat de mensen vroeger andere opvattingen en gevoelens
gehad hebben, realiseert men zich niet altijd in dezelfde mate als nodig is om de
handelingen en de toestanden correct te begrijpen.'

In zijn Lehrbuch gaf Bernheim een hele reeks van vooral middeleeuwse voorbeelden waaruit het onderscheid tussen denken en voelen vroeger en nu duidelijk moest worden. Op het terrein van de gevoelens wees hij bijvoorbeeld op de grotere emotionaliteit, of althans de sterkere uitdrukking van emoties van middeleeuwse gezagsdragers vergeleken met mensen uit zijn eigen tijd, en op de specifieke aard van de (sociaal-)psychische stoornissen in elke historische periode.

Wat spreekt voor de invloed van Bernheim op Lamprecht en Steinhausen is niet alleen het feit dat juist hij hen als docent wegwijs maakte op geschiedtheoretisch

${ }^{209}$ Bernheim (1889), 4 (mijn cursivering, MS). Deze definitie werd in latere drukken weliswaar nader gespecificeerd, maar niet wezenlijk veranderd.

${ }^{210}$ Zie eerder Hoofdstuk 2, paragraaf 1. Vgl. zijn uitleg van dit deel van zijn omschrijving, Bernheim (1889), 10-11. Een en ander maakt de bijzonder negatieve recensie van Bernheims Lehrbuch door Below, in het bredere kader van een bespreking van het Gothein-Schäfer debat (!), begrijpelijk, Below (1892).

${ }^{211}$ Bernheim (1889), 452, 454-455. Bernheim volgde in zijn keuze voor de term 'sociaalpsychologisch' de Nationalökonom Albert Schäffle, die deze uitdrukking volgens hem had bedacht. Vgl. ook Bernheim (1905), 135, waar Bernheim nog eens de diversiteit binnen een volk beklemtoont.

${ }^{212}$ Zie Bernheim (1889), 454.

${ }^{213}$ Bernheim (1920), 163. 
terrein, maar bovendien dat zij net als Bernheim de voorkeur gaven aan het begrip 'sociaal-psychologisch' boven völkerpsychologisch ter karakterisering van hun benadering, in het geval van Steinhausen net als bij Bernheim met uitgesproken erkenning van de verscheidenheid binnen een volk. ${ }^{214}$ Bij Lamprecht is bovendien opvallend hoe hij zelf in 1896/97 het ontstaan van zijn eigen geschiedtheorie beschreef. ${ }^{215}$ Aan de oorsprong van zijn psychologische opvatting van de geschiedenis stond volgens zijn eigen zeggen een ervaring die hij als student maakte bij de studie van middeleeuwse bronnen. Wat hem trof, was de afwijkende psychische Disposition die hij in deze bronnen ontwaarde. Het was door deze ervaring, en dus 'op zuiver empirische wijze' zoals hijzelf schrijft, dat hij op de gedachte kwam om een geschiedenis van psychisch differenten Zeitalter te schrijven. Lamprecht formuleerde hier dezelfde gedachte als Bernheim in (vrijwel) dezelfde bewoordingen als Bernheim en net als Bernheim naar aanleiding van middeleeuwse bronnen. ${ }^{216}$ Als we ons realiseren dat Lamprecht als student zijn bronnenstudie uitgebreid besprak met Bernheim en dat hij bovendien bij zijn docent uitdrukkelijk de aandacht voor de 'psychologische kant' van de bronnen waardeerde, dan wordt het aannemelijk dat zijn 'zuiver empirische' ervaring met de middeleeuwse bronnen werd voorgestructureerd door de concepten en theoretische inzichten van Bernheim. ${ }^{217}$

De voorbeelden van Hintze, Lorenz, Erdmannsdörffer en Bernheim maken duidelijk dat er op het punt van de verbintenis van geschiedenis en psychologie allerlei tussenposities mogelijk waren tussen de meest extreme historisten en de cultuurhistorici. Dat was ook niet vreemd, aangezien beide groepen een belangrijke invalshoek deelden: zowel historisten als cultuurhistorici bekeken het verleden bij

${ }^{214}$ Zie Lamprecht (1896/97), waar hij voor het eerst spreekt over 'sozialpsychischen Faktoren' (111) èn Bernheim (ondanks allerlei meningsverschillen) noemt als representant van de jongere generatie historici die de waarde van het 'sociaaltypische' erkent (83). Zie verder Steinhausen (1905), 236, waar Steinhausen zijn zojuist verschenen Geschichte der deutschen Kultur als 'ein neues praktisches Beispiel der Durchführung sozialpsychologischer Geschichtschreibung' presenteert, waarin behalve aan de 'grote gemeenschappen' als het volk, ook veel aandacht wordt gegeven aan de verschillende kleinere sociale groepen. Eerder (zie Steinhausen (1894), 350) had hij al de ontwikkeling van de sociaalpsychische factoren niets anders dan cultuurgeschiedenis genoemd. Overigens bekritiseert Steinhausen Bernheim omdat die een dergelijke descriptieve sociale psychologie niet als 'cultuurgeschiedenis' identificeerde en teveel zou verwachten van een aparte Völker- of Sozialpsychologische discipline.

${ }^{215}$ Zie Lamprecht (1896/97), 127. De betreffende passage is in zijn geheel geciteerd in Hoofdstuk 3, Paragraaf 3.4. Lamprecht geeft geen exacte datering van zijn ervaring, zij moet echter uit zijn Göttingse tijd (herfst 1874 - voorjaar 1877) stammen: in zijn relaas plaatst hij haar immers vóór zijn economische studie bij Roscher en zijn kennismaking met Burckhardt, die hij aan Voigt te danken had, beide tijdens zijn studie in Leipzig (1877/78). Bernheim was als gezegd een van Lamprechts docenten in Göttingen.

${ }^{216}$ Bernheim: Differenz der Zeiten, psychische Disposition; Lamprecht: psychisch differenten Zeitalter, psychische Disposition.

${ }^{217}$ In een biografisch opstel dat gebaseerd was op persoonlijke mededelingen van Lamprecht zelf, wordt Bernheim als docent van Lamprecht van betekenis genoemd vanwege 'seine Art, auf die litterargeschichtliche, überhaupt auf die psychologische Seite der mittelalterlichen Quellenkunde einzugehen [...]', Winter (1898), 309 (mijn cursivering MS). Zie verder Schönebaum (1961), 218. In principe zou de invloed ook wederzijds kunnen zijn geweest - ook Bernheim was immers nog maar een jonge docent van 25/26 jaar toen hij zijn eerste geschiedtheoretische hoorcollege in het WS van 1875/76 gaf, dat Lamprecht (toen 19/20 jaar) bijwoonde (Schorn-Schütte (1984), 31 heeft het overigens over Bernheims eerste geschiedtheoretische werkcollege in WS 1874/75 dat Lamprecht zou hebben gevolgd; Chickering (1993), 40, plaatst dit werkcollege een jaar later). Daar staat tegenover dat dit relatief geringe leeftijdsverschil juist in deze leeftijdsfase een groot verschil in intellectuele vorming uitmaakte. Voor Bernheim is bovendien zijn conceptuele vorming op dit terrein door zijn kennisname van de Völkerpsychologie vanaf 1880 aantoonbaar - het is waarschijnlijk dat hij juist ten behoeve van zijn geschiedtheoretische colleges zich in de relevante vakliteratuur verdiepte. 
voorkeur vanuit de 'collectieve geest' van de historische actoren. Bij de historisten vormden de 'ideeën' de inhoud van deze collectieve geest, bij de cultuurhistorici waren het de gemeenschappelijke 'psychische disposities' - maar onoverbrugbaar was dit verschil niet. De 'ideeën' die door historisten werden beschouwd als de belangrijkste sturende krachten in de geschiedenis, konden immers worden opgevat als 'hoogst reële sociaal-psychische elementen' - ook Bernheim interpreteerde ze zo. $^{218}$ Hier lag de meest fundamentele overeenkomst tussen de opvattingen van historisten en cultuurhistorici. Zoals al door sommige critici werd opgemerkt, was Lamprechts opvatting van de 'collectieve psychische disposities' niets anders dan een (in hun ogen) gemaltraiteerde ideeënleer. ${ }^{219}$ En opvallend genoeg werd ook door medestanders van de nieuwe cultuurgeschiedenis, onder andere door Johannes Goldfriedrich in zijn grote studie over Die historische Ideenlehre in Deutschland (1902), deze zelfde relatie gelegd, zij het dat zij Lamprechts sociaal-psychologische geschiedtheorie als een logisch vervolg en vervolmaking van de historistische ideeënleer beschouwden. ${ }^{220}$ Ook Lamprecht zelf beschouwde de ideeënleer op deze wijze. $^{221}$ Hij kwam met zijn suggestie dat het 'geestelijke leven' wellicht als de eigenlijke 'schepper' van 'de psychische organisatie' beschouwd kon worden, zelfs opmerkelijk dicht in de buurt van de idealistische aanname dat 'der Geist sich den Körper baut'.22 Dat er op dit punt ondanks alle verschillen sprake was van verwantschap blijkt ook uit het feit dat na 1910, met name door toedoen van Walter Goetz, onder de noemer Geistesgeschichte een zekere toenadering plaatsvond tussen cultuurhistorici en historisten. ${ }^{223}$

Toch bleven ook toen de fundamentele breuklijnen tussen beide oriëntaties zichtbaar. Typerend was bijvoorbeeld het verschil in interpretatie van historische portretten door Lamprecht en Goetz enerzijds en de Heidelbergse historicus Percy Schramm anderzijds: terwijl voor Lamprecht en Goetz de geschiedenis van het portret een geschiedenis was van het (psychische) vermogen tot individualiseren - en dus de onwillekeurige weerslag van een bepaalde psychische gesteldheid - verwierp Schramm deze directe koppeling van de kunst en de zintuigen en interpreteerde hij de middeleeuwse koningsportretten die hij bestudeerde als de uiting van een bewuste politieke ideologie. ${ }^{224}$ Nota bene in een Festschrift voor Goetz uit 1927 bracht de kersverse Erlanger hoogleraar Bernhard Schmeidler dit verschil tussen de ideeënhistorische variant van de Geistesgeschichte en de meer psychologisch georiënteerde cultuurgeschiedenis nog eens expliciet tot uitdrukking:

'Volgens geistesgeschichtlicher standpunt onderscheiden de tijden zich nauwelijks van elkaar door de psychische substantie [...] en de innerlijke constitutie van de mensen en hun generatie. [...] Als maatstaf voor het onderscheid der tijden kunnen voorlopig slechts dienen de gedachteninhouden

${ }^{218}$ Bernheim (1908), 671-672.

${ }^{219}$ Rachfahl (1897), 676 (naar Buchholz); Below (1898), 208.

${ }^{220}$ Zie Pflaum (1907); 64; Goldfriedrich (1902), 456.

${ }^{221}$ Zie Lamprecht (1896/97), 109: 'Die Ideen [..] sind nichts, als die Richtungen des psychischen Gesamtorganismus einer Zeit'. Vgl. ook Lamprecht (1974), 497 waar hij ten overstaan van de verzamelde historici op de Historikertag van 1898 Droysens 'idealistische voluntarisme' 'veel interessanter' noemt dan het 'realistische voluntarisme' van Marx en de Darwinisten.

${ }^{222}$ Zie Lamprecht (1896/97), 119.

${ }^{223}$ Zie Hoofdstuk 2, paragraaf 3 en Hoofdstuk 3, paragraaf 5.3.

${ }^{224}$ Zie Schramm (1928) en voor Goetz en Lamprecht, Hoofdstuk 3, paragraaf 5. 
(ideeën), waaraan de mensen zich in de opeenvolging van generaties en tijdperken achtereenvolgens hebben overgegeven. ${ }^{225}$

In zijn polemiek met Lamprecht haalde Rachfahl met instemming een gesprek met Ranke aan, waarin deze mensen als door ideeën 'bezeten' typeerde. Tot een diepere laag in de geschiedenis doordringen dan het niveau van de ideeën was voor de historicus onmogelijk, meende Ranke: 'Dat is het enige wat men kan vaststellen, verder gaat het niet'. En dat herhaalde hij nog verschillende keren: 'Verder gaat het niet..., verder gaat het niet'. ${ }^{226}$

\section{De menselijke natuur, cultuur en ontwikkeling}

De genoemde meningsverschillen over individu en collectief, ideeënleer en psychologie weerspiegelden au fond een verschil van mening over de aard van de menselijke natuur, cultuur en ontwikkeling.

De moreel en methodisch gemotiveerde weigering van historisten om 'verder' dan de ideeën te vorsen, hing samen met de aanname van een overal en altijd gelijkblijvende menselijke natuur. 'Tegenover de mens, menselijke uitingen en scheppingen staan wij en voelen wij ons in wezenlijke gelijkaardigheid en wederkerigheid', zoals Droysen benadrukte. ${ }^{227}$ De historicus had derhalve aan zijn mensenkennis genoeg om zich in een historische actor te verplaatsen en hem of haar, mits voorzien van kennis van de historische omstandigheden en de heersende ideeën, te begrijpen. Daarvoor was helemaal geen (historisch-)psychologische analyse nodig. Daarop doelde waarschijnlijk ook Rachfahl toen hij in een van zijn kritieken ietwat cryptisch opmerkte dat de historicus 'met de menselijke psyche moet rekenen in de vorm zoals zij hem al bij het begin van alle geschiedenis tegemoet komt'. ${ }^{228}$ Weder Seele noch Gehirn van de mensen waren in de loop van de geschiedenis toegenomen, zoals Burckhardt, in dit opzicht een trouwe leerling van Ranke, zijn studenten voorhield. De Fähigkeiten waren al lang complett; voor de historicus was het uitgangspunt de mens 'zoals hij is en altijd was en zijn zal'. ${ }^{229}$ De Rankeaanse afwijzing van de vooruitgangsgedachte, zoals zijn leerling Lorenz opmerkte, was juist gericht geweest tegen de (Verlichte) aanname van 'veranderende eigenschappen van de historische mens'. 230

Van 'psychisch differente tijdperken' kon bij zo'n opvatting natuurlijk geen sprake zijn. Dat hing samen met de opvatting van historische ontwikkeling binnen het historisme. Historisten verhielden zich ambivalent ten opzichte van een van de parolen

${ }^{225}$ Schmeidler (1927), 35. Enkele jaren eerder had Schmeidler (1925), 311-312, zich overigens minder stellig over deze kwestie uitgelaten; hij sprak daar lovend over Ranke en bekritiseerde Lamprechts opvattingen (222), maar meende tegelijk dat historici zich in ieder geval moesten afvragen 'Ob es eine in historischen Zeiten wahrnehmbare Entwicklung geistiger Eigenschaften und psychischer Fähigkeiten, eine Steigerung des menschlichen Geschlechts über seine frühere geistige Beschaffenheit hinaus, gebe, [...] ob dann überhaupt in bzw. hinter dem bunten einzelnen Spiel in der Geschichte ein großes allgemein Geistiges von bestimmbarer Haltung, von innerer Wandlungsfähigkeit und zeitlich fixierbarer Verschiedenheit gefunden werden könne?'

${ }^{226}$ Rachfahl (1897), 679n1; oorspronkelijk te vinden bij Lorenz (1886-1891), II, 59-60n2.

${ }^{227}$ Droysen (1977), 423. Vgl. het commentaar van de econoom en Schmoller-leerling Werner Sombart dat het juist 'de vakhistorici' waren die zich verzetten tegen zijn these dat de 'geest' (bij Sombart is dat 'alles Seelische') die het economisch leven beheerste in de verschillende tijden fundamenteel anders geaard was, zie Sombart (1913), 3.

${ }^{228}$ Rachfahl (1897), 680.

${ }^{229}$ Burckhardt (1982), 282 en 226 [1868].

${ }^{230}$ Lorenz (1898), 47. 
van de cultuurhistorici, de roep om een 'genetische' of 'ontwikkelende geschiedwetenschap'. De cultuurhistorici verstonden hieronder een geschiedwetenschap waarin de veranderingen van tijdperk naar tijdperk en de verklaring daarvan centraal stonden. Historisten legden daarentegen de nadruk op de betekenis van de historische continuiteit. ${ }^{231}$ Natuurlijk, iemand als Below werd niet moe om te beweren dat de Duitse geschiedwetenschap altijd al 'ontwikkelend' was geweest en dat de cultuurhistorici dus ook op dit punt, voor zover ze althans iets zinnigs beweerden, helemaal niets nieuws deden. Maar hij zelf gaf al aan dat het ontwikkelingsbegrip in principe naar twee verschillende kanten kon worden uitgelegd, zoals hij aan de hand van Darwin en Savigny demonstreerde: terwijl in Darwins ontwikkelingsbegrip het element van de 'metamorfose', de verandering, overwoog, domineerde bij Savigny het element van de continuïteit. ${ }^{232}$ In tegenstelling tot de cultuurhistorici, gaf Below - en met hem de meeste historisten - de voorkeur aan de interpretatie van Savigny. Als zij de uitdrukking 'historische ontwikkeling' gebruikten dan lag daarbij de nadruk op de historische continuïteit - een begrip dat niet voor niets bij voortduring opdook in Droysens Historik. ${ }^{233}$ Hooguit als contrastbegrip van 'revolutie' kon het ontwikkelingsbegrip op waardering van de historisten rekenen. Natuurlijk erkende de historicus wel het 'principe van beweging', hield Ranke zijn studenten in de jaren dertig voor, maar: 'als evolutie, niet als revolutie'. Immers: 'De geschiedenis verzet zich tegen een verandering die het bestaande verwerpt' - uitspraken die als een feitelijke constatering konden gelden, maar voor zijn studenten ongetwijfeld ook de lading van een voorschrift hadden. ${ }^{234}$ Een visie op het verleden waarin de aandacht uitging naar 'de voortgang, de ontwikkeling, de totaliteit', kwalificeerde Ranke als een filosofische manier van kijken - en dat was uit zijn mond geen aanbeveling. ${ }^{235}$

De geschiedenis was in het historisme een ontwikkeling van zichzelf in wezen gelijkblijvende individualiteiten. Weliswaar waren de ideeën (en de toestanden) veranderlijk in de loop van de tijd, verschillend per tijdvak en per historische individualiteit. Maar veranderlijk - of althans veranderlijk als gevolg van sociale invloeden - was niet wat daar 'achter' lag, de menselijke natuur, de menselijke psyche. De menselijke natuur was een gegeven, geen studieobject voor de historisten. Dat kwam tot uiting in de manier waarop zij cultuur begrepen.

Anders dan de cultuurhistorici met hun panoramische blik, ${ }^{236}$ neigden historisten ernaar 'cultuur' te beperken tot de 'waardevolle' uitingen van de mens, tot de

${ }^{231}$ Behalve de waardering voor de historische continuïteit, speelde hierbij ook de afwijzing van het historisch determinisme een rol. Zie bijv. Droysen (1977), 431, waar hij zijn afwijzing van het 'genetische erklären' uitlegt: 'Die historische Forschung will nicht erklären, d.h. aus dem Früheren das Spätere, aus Gesetzen die Erscheinungen als notwendig, als bloße Wirkungen und Entwicklungen ableiten.' Dit was uitdrukkelijk wel wat de cultuurhistorici probeerden te doen.

${ }^{232}$ Zie Below (1898), 200-201. In de achttiende eeuw had het ontwikkelingsbegrip aanvankelijk opgang gemaakt onder 'preformistische' biologen, geleerden die geloofden dat alle leven vanuit geheel voorgevormde kiemen uitgroeide tot volwassenheid. Maar al gauw namen ook de zogenaamde 'epigenisten' het ontwikkelingsbegrip over, al waren zij anders dan de preformisten van mening dat ontwikkeling van levensvormen plaatsvond door latere vormingen als gevolg van invloeden en toevoegingen van buiten af. De preformisten legden zodoende grotere nadruk op de continuïteit, de epigenisten meer op de verandering binnen de ontwikkeling. Dit laatste ontwikkelingsconcept was ook kenmerkend voor de achttiende-eeuwse cultuur- en mensheidsgeschiedenis. De geschiedenis werd daarin beschouwd als een reeks opeenvolgende, kwalitatief onderscheiden stadia of Kulturstufen. Zie: Wieland (1979), m.n. 200.

${ }^{233}$ Vgl. Blaas (1988), 65-68.

${ }^{234}$ Ranke (1975), 77 en 82 [Idee der Universalhistorie, 1831/32].

${ }^{235}$ Ranke (1975), 77 [Idee der Universalhistorie, 1831/32].

${ }^{236}$ Zie Hoofdstuk 3, Paragraaf 6.1. 
verfijnde en hogere cultuur: van alle menselijke dingen het beste. Dat werd het duidelijkst onder woorden gebracht door de methodoloog die de tegenstanders van de nieuwe cultuurgeschiedenis als hun huisfilosoof leken te waarderen: Heinrich Rickert. ${ }^{237}$ Rickert definieerde 'cultuur' uitdrukkelijk als de dingen waaraan mensen waarde hechtten - zij het met twee cruciale inperkingen. Het kon daarbij ten eerste uitsluitend gaan om zaken die een maatschappelijk algemeen aanvaarde waarde vertegenwoordigden, om zaken die men zich in een zekere samenleving verplicht voelde te waarderen, niet om voorwerpen van individuele preoccupaties en obsessies. En het kon bij 'cultuur' verder evenmin gaan om 'voorwerpen van puur begeren'. ${ }^{238}$ Die laatste behoorden tot het domein van de natuur, niet van de cultuur, meende Rickert - twee domeinen die in zijn filosofie als antipolen fungeerden. 'Cultuur' was geladen met betekenis, zinvol, begrijpelijk - 'natuur' daarentegen het 'slechts waarneembare', het zinloze, dat niet 'verstaan' kon worden.

Voor ons thema van belang is vooral dat het 'psychische' door Rickert werd uitgesloten van het cultuurbegrip en opgevat werd als een deel van het 'waardevrije' domein van de (menselijke) natuur; het verdiende derhalve geen plaats onder de objecten van de historische cultuurwetenschappen. ${ }^{239}$ Rickert pleitte voor een strikte onderscheiding van de begrippen Geist en Psyche: terwijl de cultuurhistorici de begrippen Psyche, Seele en Geist zonder veel onderscheid door elkaar gebruikten, ${ }^{240}$ wilde Rickert wat hij een 'oudere', beperkte opvatting van Geist noemde in ere herstellen, namelijk Geist als het 'hoger ontwikkelde seelisches leven'. Geist zou dan samenvallen met hetgeen hij onder 'cultuur' verstond: het 'betekenisvolle, verstehbare zijn'. In concreto mogen we daarbij misschien vooral denken aan wat Burckhardt eens de 'spontane' en 'vrije' uitingen van 'de geest' noemde: de sociabiliteit (Geselligkeit), techniek, kunst, taal, literatuur en wetenschap. ${ }^{241}$ Zo opgevat was de Geist het object van de historische cultuurwetenschappen, terwijl de psyche een deel was van de menselijke natuur en derhalve geen object van de historische cultuurwetenschappen.

Het is verhelderend om er op te wijzen hoezeer dit historistische cultuurbegrip zich verwijderde van eerdere, Verlichte cultuuropvattingen. Dat was overigens niet in alle opzichten het geval: ook de historisten waren erfgenamen van het nieuwe, achttiende-eeuwse begrip van 'cultuur' als een min of meer zelfstandig fenomeen, dat kenmerkend geacht werd voor een collectief. ${ }^{242}$ Maar de invulling van dit begrip was

${ }^{237}$ Zie de al eerder (in noten 75, 193 en 194) genoemde waardering van Below, Rachfahl en Meinecke voor Rickert. In Rachfahl (1924), neemt Rachfahl het beperkte Geist-begrip van Rickert over en legt ook hij de nadruk op 'cultuur' als algemene waarde (zie m.n. 67n1 en 75). Vgl. daarentegen de negatieve uitspraken van zelfs Gothein over het werk van Windelband en Rickert, in zijn briefwisseling: Maurer (2006), 340.

${ }^{238}$ Zie Rickert (1926), 20-21.

${ }^{239}$ Rickert (1926), 22-26, 60-71 en 98-101.

${ }^{240}$ Zie Hoofdstuk 3, paragraaf 6.3.

${ }^{241}$ Zie Burckhardt (1982), 254, 276 [1868]. Bij Burckhardt stond 'cultuur' voor 'de gehele som van al die ontwikkelingen van de Geist die spontaan gebeuren'. Het spontane was in deze omschrijving een belangrijk element: cultuur was het niet-dwingende, niet-noodzakelijke, het was 'de wereld van het beweeglijke, vrije'. Voor de receptie van Burckhardt door de nieuwe cultuurhistorici zie Hoofdstuk 6, Paragraaf 1. We kunnen hier overigens ook wijzen op Bernheim, die anders dan de cultuurhistorici culturele en sociaal-psychische factoren van elkaar onderscheidde: terwijl voor de cultuurhistorici 'cultuur' stond voor het geheel van menselijke vaardigheden en vermogens, verstond Bernheim er eerder de producten van die vaardigheden onder, zie Bernheim (1908), 655, 677.

${ }^{242}$ Het begrip 'cultuur' had vóór de negentiende eeuw de algemene betekenis van cultivering en kon eigenlijk uitsluitend in samenstellingen voorkomen die duidelijk maakten over welk specifiek terrein van cultivering men sprak. In de traditionele, aan het klassiek Latijn ontleende betekenis werd (en wordt) 'cultuur' vooral gebruikt als agrarische vakterm (de bewerking van de akker, cultura agri), daarnaast ook wel, in overdrachtelijke zin, om opvoeding, vorming, scholing (cultura animi) mee aan te 
voor Verlichtingsdenkers in cruciale opzichten radicaal anders dan voor historisten. Allereerst klonk in het Verlichte spraakgebruik het oorspronkelijke dynamische karakter van het woord veel sterker door: 'cultuur' betekende meer het proces van cultivering dan de cultuurproducten zelf, de waardevolle zaken waar Rickert over sprak. ${ }^{243}$ 'Cultuur' was daarmee op zichzelf al een uitdrukking van Verlicht vooruitgangsgeloof. Om te preciseren: het was het concept waarmee in de Verlichting de maakbaarheid of perfectibiliteit van de menselijk aard werd uitgedrukt. 'Cultuur' werd niet als contrast tot 'natuur' opgevat, zoals bij Rickert en andere historisten, maar als een voortzetting en vervolmaking daarvan, als een 'tweede natuur' van de mens. De Verlichte cultuurgeschiedenis werd niet voor niets ook Menschheitsgeschichte of een 'natural history of man' genoemd: de geschiedenis van de menselijke soort. ${ }^{244} \mathrm{De}$ mens die eerder door zijn ratio en zijn onsterflijke ziel verbonden werd geacht met het eeuwige en bovennatuurlijke, werd in de Verlichting steeds meer als een onlosmakelijk deel van een veranderende natuur en samenleving gezien. Of zoals Lamprecht de Verlichte opvattingen typeerde: het individu werd beschouwd als een product van Umfeld en Abfolge. ${ }^{245}$

Het fundament van deze visie - en daarmee de basis van het Verlichte cultuurbegrip - werd gevormd door nieuwe psychologische opvattingen, die in de tweede helft van de achttiende eeuw in heel Europa terrein wonnen. In de eerste helft van de achttiende eeuw domineerde in wetenschappelijke kringen nog de zogenaamde rationele psychologie, in Duitsland geassocieerd met Christian Wolff, in Frankrijk met Descartes, die zich vooral bezighield met de intellectuele vermogens van de mens. $\mathrm{Na}$

duiden. Wanneer het gebruikt werd in de zin van cultura animi - een klassieke betekenis die pas in de zeventiende eeuw en vooral onder invloed van Bacon opnieuw gebruikelijk werd - kon dat tot het midden van de achttiende eeuw alleen op de vorming van individuen betrekking hebben. De Verlichte Menschheits- en cultuurhistorici waren in hoge mate verantwoordelijk geweest voor de introductie en internationale verbreiding van een nieuw cultuurbegrip na 1760 . Kenmerkend voor dit nieuwe cultuurbegrip was dat het, ten eerste, niet op individuen maar op groepen van toepassing was en, ten tweede, als zelfstandig begrip betrekking had op het geheel van alle menselijke bezigheden en vaardigheden. Zie voor de geschiedenis van het cultuurbegrip: Fisch (1992).

${ }^{243}$ Fisch (1992), 706, spreekt treffend over het cultuurbegrip van de Verlichte mensheids- en cultuurhistorici als een geschiedfilosofisch Bewegungsbegriff. Het dynamisch karakter ervan lag overigens besloten in de klassieke betekenis van cultura als 'cultivering'. De Verlichte cultuurhistorici beschouwden de geschiedenis van de mens als een reeks van kwalitatief onderscheiden en op elkaar voortbouwende stadia van cultuur. 'Cultuur' kon in dit perspectief als synoniem met 'ontwikkeling' worden opgevat, zoals bijv. door Daniel Jenisch in de inleiding tot zijn Philosophie der Culturgeschichte (1801), geciteerd bij Fisch (1992), 712-713. De nadruk lag daarbij dan minder op de continuïteit dan op de veranderingen - preciezer gezegd: verbeteringen - in dit loop van de culturele ontwikkeling: vandaar de veel gebruikte uitdrukkingen 'gradatie' of 'stadium' van cultuur.

${ }^{244}$ In 1782 verscheen de eerste Duitse monografie die in de titel van een 'geschiedenis van de cultuur' spreekt: Versuch einer Geschichte der Cultur des menschlichen Geslechts van de hand van Adelung; zie Hartmann (1971), 20. Hartmann signaleert na het verschijnen van Adelungs Versuch nog vijf achttiende-eeuwse Duitstalige werken die zich expliciet als Kulturgeschichte afficheren.

${ }^{245}$ De 'keten van bestaan' die vanaf de oudheid de voorstelling van de natuurlijke orde had gedomineerd, werd in de achttiende eeuw 'getemporaliseerd', zoals Arthur Lovejoy (1964) het in zijn bekende studie over The great chain of being uitdrukte: in plaats van de statische orde en indeling van de kosmos ontstond de dynamische voorstelling van een ontwikkeling of evolutie van de natuur. Een statische beschouwing van de natuur werd niet langer toereikend geacht om de diversiteit van de soorten te verklaren, zoals Kant bijvoorbeeld in 1777 opmerkte: 'Die Naturbeschreibung (Zustand der Natur in der jetzigen Zeit) ist lange nicht zureichend, von der Mannigfaltigkeit der Abartungen Grund anzugeben. Man muß [....] eine Geschichte der Natur wagen [....], zie Kant (1983), 30. In lijn met de hoofdstelling van dit hoofdstuk is overigens Gotheins grote waardering van Kants antropologische werken: 'Alles was ich von Psychologie erwarte und hoffe, alles was Dilthey postuliert hat, steckt drin, abgesehen von der historische Begründung, obgleich auch darüber sehr Feines gesagt ist'. Brief van 264-1914, in Maurer (2006), 440. 
1750 won een empirische en sensualistische psychologie terrein, waarin de menselijke geest in navolging van de opvattingen van Locke werd omschreven als een onbeschreven blad, dat in de loop van het leven gevuld wordt met 'ideeën', dit wil zeggen met afbeeldingen van onze zintuigelijke gewaarwordingen (sensations) in de geest, en de associaties daartussen. De menselijke geest had in deze opvatting een sterk receptief karakter; zij kende geen aangeboren ideeën, maar werd gevormd door de indrukken en prikkels van buitenaf. Niet de autonome en actieve cartesiaanse ratio, maar de ontvankelijke sens(e) of Empfindung vormde het belangrijkste psychologische vermogen.

Opvallend is nu dat de geleerden die in de achttiende eeuw het nieuwe cultuurbegrip introduceerden en pleitten voor een geschiedenis van de menselijke cultuur, tegelijk aanhangers waren van deze nieuwe, sensualistische psychologie. De 'natural history of man' die populair was bij Schotse Verlichters en bijvoorbeeld tot uiting kwam in Fergusons Essay on the history of civil society, was gebaseerd op de sensualistische opvattingen van onder andere Locke en Bacon. ${ }^{246}$ Condorcet, met zijn Esquisse d'un tableau historique des progrès de l'esprit humain (1794) volgens Breysig een van de ersten Vollender van de moderne geschiedopvatting, was eveneens een aanhanger van het sensualisme. ${ }^{247}$ En ook in het Duitse taalgebied zijn de nauwe banden tussen de sensualistische psychologie en de Verlichte cultuurgeschiedenis onmiskenbaar. Karl Franz von Irwing, bijvoorbeeld, was niet alleen een van de eerste geleerden die een moderne omschrijving van het cultuurbegrip gaf en en passant opriep tot het schrijven van een Geschichte der Kultur (1779); hij was ook een van de radicalere vertegenwoordigers van de sensualistische psychologie. ${ }^{248}$ En in de meest invloedrijke, laat-achttiende-eeuwse Duitse psychologie, Tetens' Philosophische Versuche über die menschliche Natur und ihre Entwickelung (1777), mondden sensualistische uitgangspunten over de plooibaarheid van de menselijke aard uit in talrijke historische verwijzingen en een lange historische beschouwing over de 'perfectibiliteit en ontwikkeling van de mens', waaruit het volgende typerende citaat stamt: ${ }^{249}$

${ }^{246}$ Zie Wood (1990). Peter Bowler (1989), 82, een bekend historicus van het evolutionaire denken, merkt op dat Erasmus Darwin (de grootvader van) zijn 'Lamarckiaanse' opvattingen over de overerving van verworven eigenschappen 'curiously' baseerde op de psychologie van David Hartley in zijn Observations on Man (1749). Zo ‘curious' was dat echter niet: Hartley kwam immers (op grond van Lockeaanse ideeën) tot een invloedrijke associatiepsychologie, volgens welke de mens wezenlijk gevormd wordt door de omstandigheden.

${ }^{247}$ Zie Jahoda (1992), 36.

${ }^{248}$ Zie Fisch (1992), 708 en 712, en voor gedetailleerde besprekingen van de Duitse psychologie aan het eind van de achttiende eeuw (incl. Irwing) nog altijd: Sommer (1892); Günther (1907); Dessoir (1897-1901).

${ }^{249}$ Zie Tetens (1777), II, 600. Volgens Tetens werd de mens, het meest 'plooibare' en 'meest perfectibele wezen', gevormd door opvoeding, maar vooral door wat hij 'toeval' noemde: de constant werkende invloeden die een individu onwillekeurig en vaak onbewust onderging als gevolg van klimaat, voeding en contacten met medemensen. Door 'toevallige' dagelijkse Übung werden bepaalde psychische vermogens het meest versterkt, terwijl andere psychische vermogens ongetraind bleven of verzwakten. (II, 405) Pas door oefening werden psychische eigenschappen die in aanleg en potentieel aanwezig waren ook daadwerkelijk tot 'Disposition, Fähigkeit, Trieb, Fertigkeit' (II, 427). In dezelfde context als het citaat van Tetens moeten we ook de bekende verzuchting van Herder uit diens Journal meiner Reise im Jahr 1769 plaatsen: 'Wenn ich ein Philosoph sein dörfte und könnte; ein Buch über die Menschliche Seele, voll Bemerkungen und Erfahrungen, das sollte mein Buch sein! [...] und eine Geschichte der Menschlichen Seele überhaupt, in Zeiten und Völkern! Welch ein Buch!' Zie Herder (1984-), I, 378. Vgl. Jahoda (1992), 75 e.v. 


\begin{abstract}
'Wat een project zou het zijn, de innerlijke mensheid in al haar contrasterende uiterlijke toestanden na te gaan en de gewaarwordingen, geestesverheffingen, gevoelsvermogens en wilskrachten op te speuren, die in elk van deze zelfde toestanden bij uitstek tot ontwikkeling komen; en dan bij elke toestand het verschil in intensiteit, uitbreiding en duur van de vermogens [...] en in hun daaruit voortkomende relaties tot elkaar te observeren. De toekomst kan wellicht een zo aantrekkelijke, volledige geschiedenis van de mensheid verwachten' .
\end{abstract}

Dat was inderdaad het project van de op dat moment opkomende cultuurgeschiedschrijving en geheel in overeenstemming met deze gedachten hadden de Verlichte cultuurdefinities niet alleen een sterk dynamisch, maar ook een uitgesproken psychofysiologisch karakter. 'Cultuur' werd gedefinieerd als 'het geheel van alle verbeteringen en versterkingen waartoe de menselijke vaardigheden en krachten in staat zijn' (Irwing), als de 'veredeling of verfijning van de gezamenlijke geestelijke en lichamelijke krachten van een mens of een volk' (Adelung), of om nog een andere formulering te geven, als 'ontwikkelde aanleg, verhoogde kracht, gewonnen vaardigheid' (Carus). ${ }^{250}$

De in het Verlichte cultuurbegrip besloten historisering van de menselijke natuur werd uit een hybride mengsel van morele en methodische overwegingen afgewezen door de latere historisten. De nieuwe cultuurhistorici uit de periode 1889-1915 mogen daarentegen juist gerekend worden tot de erfgenamen van de Verlichte cultuurhistorici, die zij ook uitdrukkelijk een vooraanstaande plaats in de geschiedenis van de geschiedwetenschap toekenden. In tegenstelling tot de historisten scheidden zij cultuur niet van de menselijke natuur, maar beschouwden zij cultuur net als de Verlichters als een uitdrukking van de psychische veranderingen die de mens in de loop van de geschiedenis onderging. Zij hielden ook, anders dan de historisten, vast aan het ontwikkelingsperspectief en de nadruk op kwalitatieve veranderingen tussen tijdperken die de Verlichte cultuurgeschiedschrijving kenmerkten. De psychische distantie ten opzichte van het verleden die zowel Verlichte als nieuwe cultuurhistorici ervoeren, was het historisme wezensvreemd.

In de loop van dit hoofdstuk zijn nog andere verschillen geanalyseerd. Het belangrijkste was het verschil in opvatting over de gewenste aard van de geschiedbeschouwing: tegenover de hingebende Anschauung van de historisten verdedigden de cultuurhistorici de analytische blik die, gewapend door een ontwikkeld begripsmatig instrumentarium, speurde naar regelmatigheden en lijnen in de geschiedenis, en die patroon en incident van elkaar probeerde te onderscheiden. Dit verschil van mening had een levensbeschouwelijke achtergrond: de historistische opvatting was gegrond in de gedachte dat het optreden van (grote) individuen in de geschiedenis van cruciaal belang was en de loop van de gebeurtenissen beslissend beïnvloedde. De vrije, creatieve persoonlijkheid was volgens historisten bovendien een onaantastbaar heiligdom, dat niet in algemene lijnen en patronen gevangen kon of mocht worden. Omgekeerd was de cultuurhistorische opvatting gegrond in de overtuiging van het 'typische', collectieve karakter van de belangrijkste historische verschijnselen.

Résumerend mogen we gerust stellen dat de nieuwe cultuurhistorici geen trouwe zonen van hun historistische vaders waren. Maar het waren desalniettemin - we kunnen nu zeggen: Verlichte - zonen van het historisme. Terwijl in het publieke debat

${ }^{250}$ Mijn cursiveringen MS. Alle citaten bij Fisch (1992), 708, 713, 733. 
de conflicten overwogen, bestonden er behalve meningsverschillen ook opmerkelijke overeenkomsten. Afzonderlijke cultuurhistorici stonden allereerst zelf in sommige opzichten meer of minder dicht bij de genoemde historistische uitgangspunten. Het meest radicaal en op de meeste punten daarvan afwijkend was Lamprecht. Maar bij alle andere cultuurhistorici vinden we belangrijke onderdelen van de historistische uitgangspunten terug: de nadruk op de rol van leidersfiguren bij Breysig en Goetz, de aandacht voor de staat en de ideeëngeschiedenis bij Gothein en Goetz, de grote betekenis van een nauwelijks veranderend Volkstum bij Steinhausen.

Bovendien deelden alle cultuurhistorici het bronnenethos, de nadruk op wetenschappelijkheid en vooral de aandacht voor 'de collectieve geest' van de historische actoren die de Rankeaanse geschiedschrijving kenmerkte. Vandaar ook de meer of minder vergaande erkenning van de betekenis van Ranke, waarvan zij bij alle meningsverschillen getuigden. Daarnaast deelden zij ook de hodiecentrische taakopvatting van de historici uit de Pruisische school door wie zij waren opgeleid.

Ten slotte is ook duidelijk geworden dat het verschil in opvatting tussen de meest idealistische politieke historici en de meest collectivistische cultuurhistorici weliswaar groot was, maar dat er tussen deze uiterste posities een heel scala aan tussenposities bestond, waardoor deze tegenstelling in de praktijk meer of minder werd overbrugd. Niet alleen stonden sommige cultuurhistorici dichter bij de historistische opvattingen dan anderen, voor politieke historici gold hetzelfde. Vastgesteld kan worden dat in ieder geval verschillende van de vakhistorische docenten die als Doktorvater of anderszins een speciale betekenis voor de cultuurhistorici hadden, vaak dergelijke tussenposities innamen: historici als Erdmannsdörffer (docent van Gothein), Seeck (docent van Steinhausen) en Bernheim (docent Lamprecht en Steinhausen) waren in een of meer cruciale opzichten anders georiënteerd - en stonden dichter bij de nieuwe cultuurgeschiedenis - dan historistische hardliners als Schäfer, Below, Rachfahl of Meinecke.

De vraag die resteert, is hoe de nieuwe cultuurhistorici in aanraking waren gekomen met de Verlichte opvatting van cultuur voor zover zij die niet van hun docenten geschiedenis hadden meegekregen. Die vraag is aan de orde in het volgende hoofdstuk. 


\section{hoofdstuk 6}

\section{De plooibare psyche in de Duitse geesteswetenschappen}

I

n 1889 presenteerde Eberhard Gothein de opkomst van de cultuurgeschiedenis als 'een noodzakelijk gevolg van de ontwikkeling van de moderne geest überhaupt'. Ook Steinhausen noemde de cultuurgeschiedenis 'een product van de nieuwere tijdgeest'. ${ }^{2}$ En bij Lamprecht, Breysig en Goetz vinden we dezelfde gedachte: hun geschiedopvatting was welbeschouwd 'niets nieuws' en evenmin een geheel individuele schepping, maar diende gezien te worden als een uitvloeisel van de moderne tijd, waarvan zij het begin in het midden van de achttiende eeuw zochten. 'Ik loop eenvoudig in de pas met de ontwikkeling van moderne ideeën', verklaarde Lamprecht parmantig in 1897.

De historici die in Duitsland na 1889 op de voorgrond traden met hun psychologisch georiënteerde cultuurgeschiedenis waren, zoals uit het voorgaande hoofdstuk duidelijk is geworden, zowel erfgenamen van de achttiende-eeuwse Verlichting als gevormd door het historisme dat de negentiende-eeuwse Duitse geschiedwetenschap domineerde. Dat zij rond 1890 uitdrukkelijk teruggrepen op Verlichtingstradities is opvallend, aangezien het gebruikelijk is om te veronderstellen dat de historische opleiding in de Duitse landen in het algemeen door een anti-Verlichtingsdiscours werd beheerst. In het voorgaande hoofdstuk hebben we echter vastgesteld dat er naast tegenstellingen en discongruenties wel degelijk continuïteiten zijn aan te wijzen tussen de geschiedenisopleiding van de nieuwe cultuurhistorici en de geschiedopvattingen die zij als volwassen vertegenwoordigers van de historische discipline verkondigden. Onder andere is duidelijk geworden dat enkele van de belangrijkste historische docenten van de nieuwe cultuurhistorici niet beantwoordden aan het stereotype van de anti-Verlichte historist en hun studenten mogelijk op het spoor hebben gezet van alternatieve benaderingen van het verleden.

Deze individuele disciplinaire invloeden vormen echter maar een deel van het verhaal achter de ontstaansgeschiedenis van de nieuwe cultuurgeschiedenis; zij was zeker niet alleen een product van de interne ontwikkeling van de historische discipline. In hoeverre werden de nieuwe cultuurhistorici bijvoorbeeld beïnvloed door oudere, negentiende-eeuwse vormen van cultuurgeschiedenis, die vaak buiten de historische discipline gestalte hadden gekregen? En welke rol speelde het vooral buiten de geschiedwetenschap wijd verspreid Positivisme in de totstandkoming van hun werk? Dat zijn de vragen die in dit hoofdstuk centraal staan.

\footnotetext{
${ }^{1}$ Gothein (1889), 6.

${ }^{2}$ Steinhausen (1892b), 54

${ }^{3}$ Citaat uit een brief aan Harden, vertaald naar Chickering (1993), 226.
} 


\section{In het spoor van Burckhardt, Freytag en Riehl}

De van oorsprong Verlichte traditie van cultuurgeschiedschrijving onderging in de loop van de negentiende eeuw in de Duitse landen aanmerkelijke veranderingen. ${ }^{4}$ Eén kenmerk bleef gedurende deze periode evenwel hetzelfde: de cultuurgeschiedschrijving behield in de gehele negentiende eeuw grotendeels het karakter van een Oppositionswissenschaft, waarvan de beoefenaren zich afzetten tegen de binnen de historische discipline meer gebruikelijke geschiedenis van staatsmannen en veldheren. Het merendeel van de Duitse cultuurgeschiedenissen die in de loop van de negentiende eeuw werden gepubliceerd, was niet geschreven door universitaire historici. ${ }^{5}$ Dat gold zowel voor de patriottisch en bildungsbürgerlich georiënteerde cultuurgeschiedenissen uit de eerste helft van de eeuw, ${ }^{6}$ als voor de sociaaldarwinistische cultuurgeschiedenissen die in de jaren zeventig en tachtig populair werden. Er waren niet alleen weinig vakhistorici die cultuurgeschiedenissen schreven, het vak werd ook nauwelijks gedoceerd aan de universiteiten. $^{7}$

Alleen rond het midden van de negentiende eeuw was er sprake van een grotere betrokkenheid van universitaire wetenschappers en vakhistorici bij de cultuurgeschiedenis: (buitengewone) hoogleraren als Wachsmuth, Drumann, Biedermann, Riehl, Burckhardt en Scherr verbonden hun naam toen met de cultuurgeschiedenis (waarbij overigens moet worden opgemerkt dat Biedermann en Riehl geen historische leerstoel bezetten). ${ }^{8}$ 'Men begon nu de aard van de gehele cultuurtoestand van een volk tot uitgangspunt en doel van de beschouwing te nemen', signaleerde zelfs politiek historicus Heinrich von Sybel in 1856 met instemming. Daarbij moest dan naar zijn mening wel de staat uiteindelijk als de 'hoogste aardse vrucht' van het 'gezamenlijke leven van de natie' worden gepresenteerd. ' Typerend voor het momentum dat de cultuurgeschiedenis in de jaren vijftig kreeg, was de oprichting in 1856 van de eerste Zeitschrift für deutsche Kulturgeschichte en een jaar later op initiatief van Biedermann de Verein für deutsche Kulturgeschichte. ${ }^{10}$ Ook de stichting in 1852 van het Neurenbergse Germanische Museum (later: Germanisches Nationalmuseum), gewijd aan de geschiedenis van de 'Germaanse' volkeren, was een vrucht van de toegenomen cultuurhistorische interesse en werd gedragen door dezelfde personen die ook bij de Verein en Zeitschrift für deutsche Kulturgeschichte betrokken waren. ${ }^{11}$ Met uitzondering van het nog altijd bestaande GNM was deze initiatieven slechts een kort leven beschoren. Wel zou vanaf deze jaren de roep om een versterking van de cultuurgeschiedenis in het lager

\footnotetext{
${ }^{4}$ Zie hiervoor: Jodl (1878); Hartmann (1971); Dilly en Ryding (1975); Haas (1994), 32-39 en 57-69; Schleier (1997a); Schleier (1997b) en Schleier (2003-).

${ }^{5}$ Vgl. Hartmann (1971), 71.

${ }^{6}$ Zie Hartmann (1971), 72-91.

${ }^{7}$ Zie voor de eerste helft van de negentiende eeuw: Hartmann (1971), 64-67, en voor de jaren 18881891: Steinhausen (1892c), 256-259.

${ }^{8}$ Drumann was sinds 1821 historisch ordinarius in Königsberg, Wachsmuth sinds 1825 in Leipzig, Burckhardt sinds 1858 in Bazel, Scherr vanaf 1860 in Zürich. Biedermann was 1838-1853 en opnieuw vanaf 1865 (extra-)ordinarius voor staatswetenschappen in Leipzig, Riehl sinds 1854 ordinarius staatswetenschappen in München. Overigens kunnen nog Vehse, Kolb en Freytag worden genoemd als cultuurhistorici uit deze periode.

${ }^{9}$ Sybel (1880), 354.

${ }^{10}$ Tijdschrift en vereniging bestonden tot 1859 . De geschiedenis van de vereniging is te vervolgen in de verslagen in de Zeitschrift für deutsche Kulturgeschichte van 1857 en 1858, zie Hartmann (1971), 96n3. Het tijdschrift werd in het leven geroepen door Müller en Falke, medewerkers van het enkele jaren eerder opgerichte Germanische Museum in Neurenberg. Zie Müller en Rieke-Müller (2000).

${ }^{11}$ Zie Deneke (1977) en Müller en Rieke-Müller (2000). En verder: Deneke en Kahnsnitz (1978).
} 
en middelbaar historisch onderwijs, waarvoor onder anderen Biedermann zich sterk maakte, in de loop van de volgende decennia alleen maar luider worden. ${ }^{12}$

Het toegenomen belang van de cultuurgeschiedenis in deze periode kan grotendeels op het conto worden geschreven van de steeds krachtiger wordende nationalisme in de Duitse landen. Kenmerkend voor de toenmalige cultuurgeschiedschrijving was de gedachte dat 'het Volkstum op grond van zijn van nature gegeven, eigenwillige en driftmatige karakter de eigenlijke basis voor de opbouw van de cultuur vormt', zoals de Leipzigse historicus Wachsmuth het in 1850 formuleerde. ${ }^{13}$ Cultuurgeschiedenis werd opgevat als 'de weergave van het geheel van levensuitingen van de volksgeest' (Falke), die derhalve in een 'historische ethnografie' (Wachsmuth) haar fundament kon vinden. ${ }^{14}$ Zowel bij een democratisch gezinde cultuurhistoricus als Scherr, als bij zijn gematigder liberale collega Freytag, als bij de conservatief Riehl, speelde dit concept van (ethnische) nationaliteit een dominante rol. De nationaliteit gold als de belangrijkste verklarende factor voor de culturele verschillen tussen de diverse volkeren.

Het was de cultuurgeschiedschrijving uit deze periode die voor de nieuwe cultuurhistorici uit de jaren negentig van betekenis werd - veel meer dan de latere, sociaal-darwinistische cultuurgeschiedenissen die tijdens of kort voor hun eigen studietijd verschenen. Met name drie cultuurhistorici uit het midden van de eeuw werden door de cultuurhistorici uit de jaren negentig gewaardeerd: Riehl, Freytag en vooral Burckhardt. ${ }^{15}$ Met het werk van deze generatiegenoten van Spencer, Buckle en Taine raakten zij al vroeg bekend, soms al tijdens hun middelbare schooltijd, maar in ieder geval aan de universiteit. Verschillende van de nieuwe cultuurhistorici maakten bovendien persoonlijk kennis met een van deze voorgangers: Goetz volgde colleges bij Riehl in München, Gothein en Breysig correspondeerden met Burckhardt en brachten hem elk een bezoek. En zowel Steinhausen, Gothein als Breysig publiceerden naar aanleiding van het overlijden van deze drie cultuurhistorici in de jaren negentig Freytag overleed in 1895, Burckhardt en Riehl in 1897 - een of meer intellectuele Würdigungen.

De waardering van de nieuwe cultuurhistorici gold daarmee díe oudere cultuurhistorici die ook onder historistisch georiënteerde politieke historici relatief vaak op waardering konden rekenen; in een aantal gevallen hadden ze hun kennismaking met deze wetenschappers direct aan een van hun docenten geschiedenis te danken gehad een bewijs te meer dat zij minstens ten dele ook een product van hun eigen disciplinaire vorming waren. ${ }^{16}$ In ons verband is interessant om vast te stellen wat de nieuwe cultuurhistorici in de cultuurgeschiedschrijving uit het midden van de eeuw

${ }^{12}$ Zie Erdmann (1982).

${ }^{13}$ Citaat bij Hartmann (1971), 104-105.

${ }^{14}$ Zie Hartmann (1971), 117 e.v. (Riehl), 135 (Freytag), 136 (Müller \& Falke).

${ }^{15}$ Bij Lamprecht (1974), 432 en 460 is een zekere waardering te bespeuren voor andere historici uit deze periode, met name Wachsmuth en Kolb, die hij in ieder geval prefereerde boven de uiterlijke stofverzamelingen van Klemm e.a. Steinhausen uitte zich ook positief over Wachsmuth: Steinhausen (1892b), 54; later met een kritische noot: Steinhausen (1910), 131. Verder kennen we (zie Steinhausen (1892a)) zijn kritisch oordeel over de cultuurgeschiedenissen van Scherr (die hij overigens al sinds het gymnasium kende): verouderd, subjectief, teveel compilatie, te weinig aandacht voor economie, zie Steinhausen (1900); over een van populaire werken van Biedermann was hij ook kritisch: Steinhausen (1891b), 80.

${ }^{16}$ Dat gold in ieder geval voor Erdmannsdörffer en Voigt, docenten van resp. Gothein en Lamprecht die hun studenten lieten kennismaken met het werk van Burckhardt. Erdmannsdörffer noemde in de HZ 6 (1861) 520-522, Burckhardts Kultur der Renaissance een 'Muster für die Behandlung der Kulturgeschichte ueberhaupt'. Verder werd Freytag o.a. in de Jahresberichte der Geschichtwissenschaft (1879) door Von Zwiedineck-Südenhorst geprezen en later ook gewaardeerd door Below en Schäfer, felle tegenstanders van de nieuwe cultuurgeschiedenis. 
waardeerden (en wat niet). In het algemeen beschouwden zij als de gezamenlijke verdienste van het genoemde drietal de opvatting van cultuurgeschiedenis als 'het onderzoek van een psychisch collectief leven in een nationaal kader', zoals Steinhausen het formuleerde. ${ }^{17}$ Of zoals Breysig in zijn Geschichte der Seele zijn waardering voor Burckhardt en Freytag omschreef: zij waren de eerste historici die een geschiedenis van de mens in een bepaalde tijd en plaats schreven - in plaats van een geschiedenis van individuele mensen. ${ }^{18}$

Van de drie gewaardeerde voorgangers kreeg de conservatieve Münchense hoogleraar Staatswissenschaft (ook journalist, dirigent en literator) Wilhelm Heinrich Riehl (1823-1897) duidelijk de minste credits. ${ }^{19}$ Riehls vierdelige hoofdwerk, Die Naturgeschichte des Volkes als Grundlage einer deutschen Social-Politik (1851-1869) werd door Gothein net als door veel latere commentatoren meer als een 'conservatief pamflet' beschouwd, dan als een serieuze historische studie. ${ }^{20}$ Lamprecht, die in zijn middelbare schooltijd nog overwoog om bij Riehl te gaan studeren en zijn werk als student bestudeerde, associeerde diens boeken in zijn Deutsche Geschichte met folkloristisch geneuzel. ${ }^{21}$ Goetz noemde zijn voormalige docent in een zuinige terugblik eerder een volkskundige dan een groot cultuurhistoricus en hij leek in dit verband ook diens geloof in een onveranderlijke volksgeest te kritiseren. ${ }^{22}$ En ook Steinhausen, die Riehl uitdrukkelijk opnam in zijn trits van gewaardeerde voorgangers, oordeelde dat de Münchense professor bij al zijn prijzenswaardige aandacht voor Volkspersönlichkeit,

${ }^{17}$ Steinhausen (1898), 454, zie ook: Steinhausen (1896b) en (over Burckhardt) Steinhausen (1898), 452-454. Lamprecht mat ook de latere cultuurgeschiedenissen uit de jaren '70 en ' 80 expliciet aan dat criterium af en beoordeelde ze als psychologisch te eenzijdig, zie Lamprecht (1974), 461-468 en 496-498. Gothein (1889), 58-62, beoordeelde Buckle ook al als 'eenzijdig intellectualistisch': aan diens 'historische logica' van de wetenschapsgeschiedenis moet een 'historische psychologie' van kunst en religie worden toegevoegd en een 'historische ethiek' van het recht. Breysig stemde althans in 1886 in met Lorenz' negatieve oordeel over cultuurgeschiedenis à la Riehl en Du Bois-Reymond, zie Brocke (1971), 41n. Steinhausen, die overigens het werk van Buckle al op de middelbare school las, toonde zich kritisch over werk van Hellwald (Steinhausen (1891b), nr. 14) en Henne am Rhyn; de laatste gaf naar zijn mening zowel aan Zeitgeist als volkskarakter te weinig aandacht, zie Steinhausen (1892d), nr. 10, zie ook Steinhausen (1892a), nr. 9, 370.

${ }^{18}$ Breysig (1931), 9-10. Bij de hierna volgende receptiegeschiedenis van Riehl, Freytag en Burckhardt door de nieuwe cultuurhistorici kan het er uiteraard niet om gaan het werk van deze drie voorgangers op zichzelf te presenteren; het gaat hier uitsluitend om de betekenis die zij voor de nieuwe cultuurhistorici kregen.

${ }^{19}$ In Zinnecker's ideologiekritische receptiestudie over Riehl ontbreken de nieuwe cultuurhistorici; alleen Gotheins verhouding tot Riehl wordt kort (en eenzijdig) genoemd: Zinnecker (1996), 265. Zie over Riehl verder: Steinbach (1980); Altenbockum (1994). Opvallend is dat Riehl ook door politieke historici meer werd bekritiseerd dan de beide andere cultuurhistorische voorgangers Freytag en Burckhardt, zie bijv. Treitschke (1859), o.a. 77 e.v. en Lorenz (1886).

${ }^{20}$ Gothein (1898), 9.

${ }^{21}$ Lamprecht (1891-1909), XI (3de dr. 1914), 180: 'beide [Riehl en Freytag]... im Grunde antiquarisch ... die großen Perspektiven verschwanden ... so verkriecht sich die kulturgeschichtliche Forschung überhaupt unter dem Vorgeben von Exaktheit ins Kleine, in Folklore und Quellenedition'. Zie ook Chickering (1993), 22, 39. Goetz (1957e), 258, heeft het over Lamprechts collegelopen bij Riehl en de persoonlijke invloed van zijn 'leermeester'. Daarvan lijkt geen sprake: in een biografische schets over Lamprecht die de met hem bevriende archivaris Georg Winter op grond van diens eigen mededelingen schreef, wordt Riehl weliswaar een 'in mancher Hinsicht geistesverwandten Kulturhistoriker' genoemd, maar ook vermeld dat Lamprecht hem niet persoonlijk leerde kennen, zie Winter (1898), 310. Volgens zijn biograaf Chickering (1993), 22, 39, 93 had Lamprecht als scholier weliswaar overwogen bij Riehl te gaan studeren, maar veranderde hij als student zijn plannen.

${ }^{22}$ Goetz (1957e). 
Volksseele en Volksgeist de concrete historische werkelijkheid te zeer verwaarloosde en het verleden al te schematisch en collectivistisch behandelde. ${ }^{23}$

De reden om Riehl hier desalniettemin als gewaardeerde voorloper van de nieuwe cultuurhistorici te bespreken is vooral de positief gestemde necrologie die Gothein over Riehl publiceerde, al moet meteen worden opgemerkt dat Gothein zich bij deze gelegenheid positiever uitte dan hij eigenlijk over Riehls werk oordeelde (zoals hij later onthulde), waarschijnlijk in de hoop om Riehls opvolger in München te worden. ${ }^{24}$ Ook hij bekritiseerde de snelle generalisaties van Riehl en het feit dat hij nauwelijks inging op het vraagstuk van de historische ontwikkeling van de Volksindividualität. ${ }^{25}$ Prijzenswaardig achtte hij wel Riehls vermogen tot microstorie: de kunst om aan de hand van een schijnbaar detail een betekenisvolle historische analyse van bredere reikwijdte te geven. ${ }^{26}$ Zo verwees Gothein naar Riehls sociale analyse van de stadsplattegrond van Augsburg, die hem als student tot enthousiaste vergelijkbare ondernemingen aanzette. Maar vooral roemde Gothein twee opstellen van Riehl waarin deze 'de belangrijke poging heeft gedaan, de beide zintuigen oog en oor, die onze esthetische gewaarwordingen tot stand brengen, historisch te analyseren'. ${ }^{27}$ Gothein refereerde hier aan twee essays, getiteld Das landschaftliche Auge (1850) en Das musikalische Ohr (1852), waarin Riehl aan de hand van de ontwikkeling van landschapsschilderijen en de veranderende 'stemming' van muzikale composities wilde laten zien dat onze zintuigen, of althans onze wijzen van waarnemen, in de loop van de geschiedenis waren veranderd. Riehl schreef daar in het algemeen over de cultuurgeschiedenis: ${ }^{28}$

'Het is een van de aantrekkelijkste, maar ook moeilijkste opgaven van de cultuurgeschiedenis om de als het ware persoonlijke Empfindungsweise, die elk tijdperk specifiek kenmerkt, de toon waarin het is gestemd, te beluisteren, ter onderscheiding van de kennis van zijn uitgesproken daden en gedachten.'

Dát was inderdaad een taakstelling waar de nieuwe cultuurhistorici het zonder uitzondering mee eens konden zijn, maar het was iets anders dan Riehl in zijn sociaalpolitiek georiënteerde Naturgeschichte des Volkes hoofdzakelijk presenteerde.

Veel enthousiaster waren de meeste nieuwe cultuurhistorici over het werk van Gustav Freytag (1816-1895). Met uitzondering van Lamprecht was elke nieuwe cultuurhistoricus buitengewoon te spreken over het werk van deze universitair docent germanistiek, later schrijver en hoofdredacteur van het nationaal-liberale weekblad Die Grenzboten. ${ }^{29}$ Vooral Steinhausen had een sterke voorkeur voor de cultuurgeschiedschrijving van Freytag, wiens Bilder aus der deutschen Vergangenheit (1859-1867) hij

\footnotetext{
${ }^{23}$ Zie Steinhausen (1898), 457-458; overigens citeerde Steinhausen in zijn eerste pleidooi voor de cultuurgeschiedenis nog met instemming Riehls omschrijving van de cultuurgeschiedenis, Steinhausen (1892c), 256.

${ }^{24}$ Gothein (1898); en Gothein (1931), 108-109.

${ }^{25}$ Gothein (1898), 18 bekritiseerde om deze reden ook in het algemeen de Völkerpsychologie, waarin te gemakkelijk veralgemeniseerd wordt en die 'veelal verworven, historisch ontwikkelde eigenschappen verwisselt met oorspronkelijke aanleg'.

${ }^{26}$ Gothein (1898), 8; verwijzing naar 'Der Stadtplan als Grundriß der Gesellschaft' [1857], in: Riehl (1862), 271-284. Vgl. Steinhausen (1896b), 13.

${ }^{27}$ Gothein (1898), 8.

${ }^{28}$ Riehl (1862), 81 (mijn cursivering, MS).

${ }^{29}$ Lamprecht noemde het werk van zowel Freytag als Riehl antiquarisch en verouderd, zie Lamprecht (1891-1909), XI (3e dr. 1914), 180. Een dissertatie onder Lamprechts begeleiding, die gewijd was aan Freytags 'Geschichtspsychologie', oordeelde eveneens negatief, o.a. omdat Freytags volkszielconcept naar het oordeel van de schrijver minder historisch dan naturalistisch-racistisch gedacht was, zie Schridde (1910), m.n. 91-92.
} 
al op school las. ${ }^{30}$ Maar ook Gothein, Breysig en Goetz lieten zich opvallend lovend uit over deze historicus. ${ }^{31}$ Gewaardeerd werd vooral de manier waarop Freytag in zijn Bilder aan de hand van concrete historische individuen het naar tijd en plaats variërende type van de Duitse doorsneemens had weten te schilderen. ${ }^{32}$ In zijn inleiding bij deze 'berichten van mensen uit het verleden over hun eigen lot' benadrukte Freytag net als de nieuwe cultuurhistorici het fremdartige van het denken en voelen in het verleden. 'Tevergeefs zoekt de Duitser de goede oude tijd', zo begon hij zijn Bilder: ${ }^{33}$

'Zeer veel harder en armer dan nu is het leven in elke periode van het Duitse verleden. Het zijn echter niet de afzonderlijke onverdraaglijke dingen die de oude tijd voor ons zo unheimisch maken; in de hele methode om te leven, in het hele denken en voelen is iets Grundverschiedenes. En ziet men nauwkeuriger toe, dan ligt dit onderscheid tussen toen en nu meestal daarin, dat in elke generatie van onze voorouders de ziel van het individu veel onvrijer en gebondener was, meer ondergeschikt aan de ziel van het volk.'

Met zijn concrete schildering van deze verschillen was Freytag de eerste grote geschiedschrijver van het Duitse gemoedsleven, meende Steinhausen. In dit verband prezen zowel hij als Gothein Freytag speciaal als een van de eerste historici die het belang hadden erkend van egodocumenten - autobiografieën, brieven - een verdienste waarvan Steinhausen zelf in de praktijk van zijn historisch onderzoek de vruchten had geplukt: dat hij op het idee was gekomen om een geschiedenis van de brief als een cultuurgeschiedenis van het Duitse volk te concipiëren, verklaarde hij achteraf met een verwijzing naar zijn kennisname van Freytags veelvuldige gebruik van deze categorie bronnen. ${ }^{34}$

Unaniem waren de nieuwe cultuurhistorici evenwel uitsluitend over de derde van de drie directe cultuurhistorische voorlopers: Jacob Burckhardt (1818-1897). De blijken van hun waardering voor de Bazelse historicus en van de grote indruk die zijn werk op hen maakte, zijn talrijk. Allemaal werden zij gedurende hun studie enthousiaste Burckhardt-lezers. ${ }^{35}$ Zowel bij Goetz als bij Gothein resulteerde dat enthousiasme in een blijvende belangstelling voor de (Italiaanse) Renaissancecultuur. Zowel Gothein als Breysig correspondeerden met Burckhardt, brachten hem elk een vererend bezoek en schreven na zijn dood een necrologie. ${ }^{36}$ Het dankwoord dat Burckhardt naar Gothein stuurde voor de ontvangst van diens Culturentwickelung Süd-Italiens (waarin Gothein zichzelf als 'verehrenden Jünger Burckhardts' kenschetste), beschouwde de jonge hoog-

\footnotetext{
${ }^{30}$ Zie vooral Steinhausen (1925, (1898, (1896b), en verder Steinhausen (1925), 236, 241 en Steinhausen (1892d), nr. 17-19.

${ }^{31}$ Bij Gothein (1889), 5 en 14 ('unsere durchgeführteste Kulturgeschichte') is een positief oordeel te vinden, evenals bij Goetz (1957c), 296 en bij Breysig, die 'Freytags unübertreffliche, an Gründlichkeit wie an Weite des Blicks gleich vorzügliche Bilder' tot de voorbeelden voor zijn eigen Kulturgeschichte der Neuzeit rekende, zie Breysig (1901), 727;

${ }^{32}$ Vgl. Steinhausen (1896a), 765-766; zo ook Gothein (1898), 23, en Breysig (1931), 10: 'Freytag als Begründer einer neuen hohen Form von Kulturgeschichte hat die Geschichte des Menschendurchschnitts $[\ldots]$ geschrieben.'

${ }^{33}$ Freytag (1920), 1 en 13.

${ }^{34}$ Steinhausen (1925), 241.

${ }^{35}$ In het geval van Gothein en Lamprecht gebeurde dat (mede) onder invloed van hun vakhistorische docenten, respectievelijk Erdmannsdörffer en Voigt. Verder beschrijft Goetz in zijn herinneringen hoe tijdens zijn studie in München (1886) Burckhardts boek over de Italiaanse renaissancekunst tot een lijfboek van hem wordt (Goetz (1957a), 9). In dit verband kan er op gewezen worden dat de manieren waarop de nieuwe cultuurhistorici het contrast tussen middeleeuwers en 'moderne mensen' schetsten (zie Hoofdstuk 3) sterk herinnerde aan Burckhardt.

${ }^{36}$ Dagboekaantekeningen n.a.v. het bezoek aan Burckhardt en de necrologie opnieuw afgedrukt in Breysig (1962), 78-82.
} 
leraar als zijn Meisterbrief. ${ }^{37}$ Breysig op zijn beurt droeg aan Burckhardt een deel van zijn Kulturgeschichte der Neuzeit op en beschouwde hem, naast de econoom Schmoller en de historicus Nitzsch, als degene die hem als student en jonge docent het meest had beïnvloed. ${ }^{38}$ Ook Steinhausen nam hem op in zijn persoonlijke trits van meest gewaardeerde voorgangers (in zijn geval: Freytag, Burckhardt, Riehl). Voor de student Lamprecht, ten slotte, werd het lezen van Burckhardts Cultur der Renaissance een sleutelervaring, waarbij hij naar eigen zeggen voor het eerst getroffen werd door de gedachte dat 'een hele cultuurperiode is afgeleid uit haar psychische kern'. 39

Niet alleen voor Lamprecht, maar voor vrijwel alle nieuwe cultuurhistorici was Burckhardt een cultuurhistoricus bij wie, zoals Steinhausen het in 1898 formuleerde, 'de ontwikkeling van de psyche op de voorgrond staat'. ${ }^{40}$ Ook Breysig bewonderde met zoveel woorden de 'seelenkündender Tiefe' van Burckhardts 'sociologische' analyse van het geestelijke en sociale leven. ${ }^{41}$ Burckhardt beperkte zich bij zijn analyse van het 'totale karakter van een tijd' namelijk niet tot de 'geestelijke' activiteiten van een volk, maar zocht 'in de diepte', daar 'waar geestelijke en politieke en materiële geschiedenis in één wortel met elkaar verbonden zijn'. ${ }^{42}$ Gothein prees de Cultur der Renaissance op vergelijkbare wijze als zijnde

'de analyse van een tijdperk in haar veelvoudige verschijnselen, die tot fundamentele eigenschappen worden herleid, de analyse van een bijzonder mensentype en wel van de moderne mens als zodanig, in zijn eerste en meest volledige, of in ieder geval rücksichtslosesten manifestatie. ${ }^{43}$

Gothein doelde hiermee op Burckhardt's analyse van het moderne individualisme in de Italiaanse renaissancecultuur, een intellectuele krachttoer die op alle nieuwe cultuurhistorici veel indruk maakte. Zoals Lamprecht de verzamelde historici op de vijfde Historikertag (1898) voorhield, had Burckhardt daarmee gedemonstreerd dat eenzijdig natuurwetenschappelijk of materialistisch georiënteerde cultuurgeschiedenissen de plank missloegen: niet slechts verstand of behoeften waren aan een historische ontwikkeling onderhevig, maar 'het hele psychische leven'. 'A4 'Als wij ergens van een

${ }^{37} \mathrm{Zie}$ daarover Hoofdstuk 3, noot 16. Gotheins vrouw en biografe noemde de invloed van Burckhardt op haar man groter dan van welke directe docent ook, Gothein (1931), 21.

${ }^{38}$ Het vroegst in een dagboekaantekening van 1898, zie Brocke (1971), 47n65, vgl. ook ib. 52 (1901) en 309 (1920) en een dagboekaantekening van 1904 in Breysig (1962), 107.

${ }^{39}$ Geciteerd door Guilland (1916), 86; deze baseert zich op aantekeningen van Lamprecht meegedeeld door Eduard Spranger in zijn necrologie: 'Karl Lamprechts Geschichtsauffassung', in: Vossische Zeitung 23 (1915), nr. 284 (6 juni), blz. 173-176, dat ik helaas niet zelf heb kunnen inzien. Vgl. overigens ook Lamprecht (1896/97), 127.

${ }^{40}$ Steinhausen (1898), 454. Steinhausen werd overigens in zijn habilitatiepoging aan de universiteit van Jena gesteund door de Burckhardt-leerling Heinrich Gelzer, die later ook zijn herinneringen aan Burckhardt in Steinhausens Zeitschrift für Kulturgeschichte publiceerde. Alleen bij Goetz is de waardering voor het psychologisch perspectief minder evident. Hij prees Burckhardt's Cultur der Renaissance in een Engelstalige publicatie als 'de eerste wetenschappelijke uiting van een cultuurgeschiedenis in de zin van intellectual history' - een begrip dat ongetwijfeld een vertaling is van het Duitse Geistesgeschichte, dat bij hem zowel psychische als meer intellectuele connotaties had. Zie Goetz (1932), 379-380. Vgl. bovendien Goetz (1916), 274, Goetz (1957b), 98 [1919] en Goetz (1930), 471.

${ }^{41}$ In een van zijn laatste werken, gereedgekomen in zijn sterfjaar, wijdt Breysig nog een uitvoerig hoofdstuk aan Burckhardt dat echter uitsluitend diens kunsthistorisch werk betreft. Ook daar prijst hetzij laakt Breysig vooral de aan- resp. afwezigheid van aandacht voor de 'seelische Grundlagen' van de kunst, zie Breysig (1944), bijv. 8, 13, 41.

${ }^{42}$ Vgl. Breysig (1896), 2.

${ }^{43}$ Gothein (1897), 10-11.

${ }^{44}$ Lamprecht (1974), 498; vgl. ook Lamprecht (1905), 14. 
historische psychologie kunnen spreken', schreef op zijn beurt Gothein in 1897, 'dan is hier haar eerste Probestück gegeven. Hier wordt getoond hoe men tot een dergelijke [historische psychologie] kan komen'. ${ }^{45}$ Zowel hij als Lamprecht gingen het als 'de eigenlijke opgave van de cultuurgeschiedschrijving' (Gothein) beschouwen om Burckhardts analyse van het moderne menstype van een voorgeschiedenis en van een vervolg te voorzien. ${ }^{46}$

Een aantal dingen valt op in de waardering van de nieuwe cultuurhistorici voor Riehl, Freytag en Burckhardt. Allereerst blijken zij deze onderling toch zeer verschillende cultuurhistorici op vergelijkbare wijze te hebben gerecipieerd en voornamelijk om een en dezelfde reden te hebben gewaardeerd: namelijk vanwege het historisch-psychologisch perspectief dat zij in hun werk ontwaarden. Opvallend is verder dat de nieuwe cultuurhistorici veel minder waardering toonden voor het in de cultuurgeschiedschrijving uit de decennia rond 1850 vaak dominante statische Volkstum-concept. Integendeel: de in deze jaren gebruikelijke opvatting van een van nature gegeven en onveranderlijke volksgeest werd door hen, zelfs door Steinhausen (die het dichtst bij deze opvatting stond), expliciet gekritiseerd. In dit verband was het niet zonder betekenis dat juist Burckhardt, bij wie het nationaliteitsconcept geen grote rol speelde, zonder uitzondering werd gewaardeerd door de nieuwe cultuurhistorici. Burckhardt had aan de hand van het voorbeeld Italië 'het grote psychische verschil tussen de zogenaamde middeleeuwen en tijden van hogere cultuur' belicht, zoals Lamprecht zich uitdrukte, maar datzelfde kon naar zijn mening evengoed bij 'analoge tijdperken' van andere volkeren gebeuren. ${ }^{47}$ Lamprechts Deutsche Geschichte was niets anders dan een demonstratie van die overtuiging.

Nog iets anders valt op: de nieuwe cultuurhistorici hadden meer affiniteit met de cultuurgeschiedschrijving uit de decennia rond 1850 dan met de jongere, sociaaldarwinistisch getinte cultuurgeschiedenissen uit de jaren zeventig en tachtig. ${ }^{48}$ Betekende dat ook dat zij in het algemeen niet gecharmeerd waren van de positivistische opvattingen die in deze natuurwetenschappelijk geïnspireerde cultuurgeschiedschrijving tot uitdrukking kwam?

\section{De nieuwe cultuurhistorici en het West-Europese positivisme}

Als de nieuwe cultuurhistorici (of althans Lamprecht en Breysig) met een specifieke intellectuele traditie worden geassocieerd, dan toch meestal met 'het Positivisme met

\footnotetext{
${ }^{45}$ Gothein (1897), 12; nog eens Gothein (1918), 290.

${ }^{46}$ Lamprecht (1905), 14. Vgl. Gothein in Maurer e.a. (2006), 211 (brief 11.1.1906).

${ }^{47}$ Lamprecht (1905), 14 en Lamprecht (1896/97), 309.

${ }^{48}$ Gustav Klemm kan met zijn uit 1843-1852 daterende, tiendelige Allgemeine Cultur-Geschichte der Menschheit als voorbode van deze antropologische variant van cultuurgeschiedschrijving worden gezien, die vanaf de jaren zeventig door schrijvers als Friedrich Heller von Hellwald, Otto Henne am Rhyn, Julius Lippert en J. Honegger wordt uitgedragen. Zij waren niet sterk vertegenwoordigd aan de universiteit: Klemm was bibliothecaris, Hellwald privé-geleerde, Henne archivaris en Lippert leraar; alleen Honegger werkte als hoogleraar in Zürich. In hun visie was cultuurgeschiedenis net als in de Verlichting mensheidsgeschiedenis, maar dan met een sterke nadruk op de cultuurproducten en op de natuurlijke of materiële invloeden op de beschaving. Zie Haas (1994), 57-69 en Schleier (1997a), 83- 87. Voor de kritiek van nieuwe cultuurhistorici op deze schrijvers zie bijv. Lamprecht (1974), 467 en 497 (over Hellwald en Lippert, 1898/1899). Ook Steinhausen uitte zich kritisch over verschillende van deze schrijvers, zie Steinhausen (1891b), nr. 14 (Hellwald) en Steinhausen (1892d), nr. 10 (Henne), verder Steinhausen (1892a), nr. 10 (Henne).
} 
een hoofdletter': ${ }^{49}$ de sterke negentiende-eeuwse intellectuele traditie die de wetenschappelijke, wettenstellende en oorzakelijke verklaring van menselijke verschijnselen hoog in het vaandel had geschreven. Wij denken dan aan intellectuelen als Comte (1798-1857), Mill (1806-1873), Buckle (1821-1862) en Taine (1828-1893), of aan Darwin (1809-1882), Marx (1818-1883) en Spencer (1820-1903) - om slechts de bekendste vertegenwoordigers te noemen.

En inderdaad: er kan weinig twijfel over bestaan dat de genoemde denkers en de verbreiding van hun ideeën vanaf het midden van de negentiende eeuw hebben bijgedragen aan een intellectueel klimaat waarin de nieuwe cultuurgeschiedenis kon opkomen. Zij stimuleerden het zoeken naar regelmatigheden en patronen in de ontwikkeling van mens en samenleving en zij verbreidden het vertrouwen in de kracht van de wetenschap om in deze kwesties een weg te vinden - zaken die, in het algemeen, door de nieuwe cultuurhistorici op waarde werden geschat.

Voor ons thema speciaal van betekenis is bovendien dat veel aanhangers van het positivisme in zijn verschillende varianten zonder meer overtuigd waren van het directe verband tussen de historische ontwikkeling van de mensheid en de veranderingen van de psychische constitutie en geestesgesteldheid die in de loop van deze ontwikkeling zouden hebben plaatsgevonden. ${ }^{50}$ Dat ging dan van het terloopse adagium van Marx dat 'de Bildung van de vijf zintuigen het werk is van de hele wereldgeschiedenis tot nu toe', ${ }^{51}$ tot John Stuart Mills uitgewerkte voorstel in zijn System of Logic uit 1843 voor een nieuwe psychologische wetenschap die ten grondslag moest liggen aan de geschiedwetenschap en andere moral sciences. Deze 'ethologie' zou tot taak hebben om inzicht te bieden in de wijzen waarop individuele en collectieve karakters werden gevormd en hervormd. ${ }^{52}$ Immers, zoals Mill opmerkte:

\footnotetext{
${ }^{49}$ De uitdrukking is van Eric Hobsbawm, ik ontleen haar aan Blaas (1988), 27, 63. Zie voor overzichten van de hier relevante theorieën: Jüttemann (1988), Peeters (1978), (1994), en Jahoda (1992).

${ }^{50}$ Meer in het algemeen bestond er onder positivisten al vroeg belangstelling voor de betekenis die geschiedwetenschap en psychologie voor elkaar konden hebben. Al in 1838 publiceerde de Parijse arts L.-F. Lélut (*1804) een verhandeling waarin hij belang en reikwijdte van wat hij 'psychologie historique' of 'psychologie de l'Histoire' noemde, uiteenzette: 'il est une espèce d'histoire, la plus intime dans ces sources, la plus élevée dans ces résultats qui, loin de se borner à rassembler les faits de la vie des peuples et à les enchaîner dans les rapports extérieurs, recherche dans les profondeurs de l'âme leurs plus secrètes origines. Elle saisit à leur naissance, et dès les temps les plus reculés, les instincts et la raison de l'homme; elle en suite le développement à travers le cours de nations et le mélange des races qui les constituent, elle en signale, enfin, les variations, les écarts, les folies.' Zie Lélut (1838), geciteerd in: Cabanès (z.j [1921]), 275. Twee jaar eerder had Lélut al een geruchtmakende psychopathologische analyse van Socrates gepubliceerd, die hij betitelde als een Specimen d'une application de la science psychologique à celle de l'histoire (Parijs: Trinquart, 1836).

${ }^{51}$ Geciteerd door Brockmeier (1988), 390; hier ook meer over Marx' historisch-psychologische opvattingen (blz. 387-394). Marxistische psychologische opvattingen zouden pas in de twintigste eeuw uitgewerkt worden in een baaierd van marxistisch geïnspireerde psychologische onderzoeksprogramma's, zie hiervoor verschillende bijdragen in Jüttemann (1988) en bovendien Peeters (1978, (1994). Tot de interessantse varianten behoort de sovjet cultuurpsychologie van Leont'ev, Vygotskij en Lurija, die ook van invloed was op de Russische mentaliteitshistoricus Gurevic, zie Métraux (1993), 113 e.v.

${ }^{52}$ Mill (1981), 869. Mill wijdde een heel hoofdstuk aan deze 'ethology' in het deel van zijn System of Logic dat de moral sciences behandelde. Daarmee doelde Mill op wat wij geesteswetenschappen, sociale wetenschappen of cultuurwetenschappen zouden noemen: 'those which relate to man himself' voor zover het niet om zijn fysieke aard ging. Mill gebruikte hiervoor ook de uitdrukking 'science of human nature' en omschreef haar objectdomein als 'the thoughts, feelings and actions of human beings'. (a.w., 833-834). De 'ethology' was een soort van toegepaste psychologie: 'we employ the name Psychology for the science of the elementary laws of mind, Ethology will serve for the ulterior [ed. 1843/46: subordinate] science which determines the kind of character produced in conformity to those general laws, by any set of circumstances, physical and moral. [.|.] The one ascertains the simple laws of
} 
'onze geestesgesteldheid [mental state] en onze mentale capaciteiten en gevoeligheden worden gemodificeerd door alles wat ons overkomt in het leven, hetzij voor enige tijd, hetzij blijvend. [...] er zijn nauwelijks gevoelens of gedragingen die, in absolute zin, door de hele mensheid worden gedeeld. [...] Met andere woorden, de mensheid heeft niet één, universeel karakter, maar er bestaan wel universele wetten van karaktervorming, ${ }^{53}$

Eén conclusie die positivisten uit deze constatering trokken, was dat de geschiedenis in belangrijke mate 'een psychologisch probleem' was. Dat beweerde bijvoorbeeld Hippolyte Taine in zijn geruchtmakende Histoire de la littérature anglaise (1863). ${ }^{54}$ Volgens Taine was het een van de belangrijkste taken van de historicus om zich af te vragen tot wat voor geestesgesteldheid bepaalde historische en sociale verschijnselen aanleiding gaven en te analyseren op welke manier 'ras, milieu en geschiedenis' daarin een rol speelden. Ook geestelijke verschijnselen als 'deugd en ondeugd' moesten immers als producten worden beschouwd, niet anders dan 'suiker en vitriool', zoals het beruchte mauvaise parole uit de inleiding luidde. De 'onderwereld' van de 'vermogens en gevoelens' van de ziel, de 'onzichtbare mens', zoals Taine zich uitdrukte, vormde derhalve een nieuw en fundamenteel terrein voor de historicus.

Veel positivisten deelden de overtuiging dat er in de loop van de tijd vooral sprake was van toegenomen cognitieve vaardigheden en capaciteiten van de mens en dat deze cognitieve progressie bovendien de belangrijkste historische factor van verandering vormde. Comtes 'wet van de geestelijke evolutie van de mensheid', onder andere geformuleerd in zijn Discours sur l'esprit positif (1844), was het invloedrijke prototype van deze opvatting. Volgens deze 'wet' zou in de loop van drie opeenvolgende historische stadia de heerschappij van fictie en verbeelding uiteindelijk gebroken worden door de steeds sterker wordende vermogens van de rede en de waarneming. Al doende zou de mensheid zich ontwikkelen van haar 'kinderjaren' tot 'geestelijke volwassenheid'.55 Ook Mill meende in zijn System of Logic dat de menselijke vooruitgang vooral afhankelijk was van de 'wet van de successieve transformaties van de menselijke opvattingen' en dan met name van de staat van de 'speculatieve faculteiten' van de mensheid. ${ }^{56}$ In de (cultuur-)geschiedschrijving kwamen dergelijke opvattingen op exemplarische wijze tot uiting in de History of Civilization in England (1857-1861) van Henry Thomas Buckle, waarin deze Engelse privé-geleerde probeerde aan te tonen dat 'de vooruitgang die Europa heeft doorlopen van barbarij tot beschaving geheel te danken is aan haar intellectuele activiteit.' De 'dynamiek van de samenleving' was volgens Buckle uiteindelijk te herleiden tot de 'wetten van de geest [mind]'. 57

Een direct verband tussen de ontwikkeling van de mensheid en haar mentale uitrusting werd eveneens gelegd in de biologische evolutietheorieën die in de tweede helft van de negentiende eeuw opgang makkten. Tot circa 1900 domineerden in dergelijke theorieën vaak lamarckiaanse opvattingen: de herhaalde oefening van specifieke vermogens, die door bepaalde omstandigheden werd afgedwongen, zou

Mind in general, the other traces their operation in complex combinations of circumstances'. (a.w., 869870). 'Political ethology' was dan de 'science of national character': 'the theory of the causes which determine the type of character belonging to a people or to an age.' (a.w., 905). Zie Leary (1982) voor de reacties op dit voorstel.

${ }^{53}$ Mill (1981), 863-864.

${ }^{54}$ Taine (1877/78), xlv. Vgl. ook Taine (1870), 8: 'En d'autres termes, l'historien étudie la psychologie appliquée, et le psychologue étudie l'histoire générale.'

${ }^{55}$ Zie Comte (1979).

${ }^{56}$ Mill (1981), II, 926-927.

${ }^{57}$ Buckle (1903-1904), I, 177 en 180. 
leiden tot een erfelijke aanpassing van de psychische (en fysieke) eigenschappen van de mens en dus tot psychische veranderingen in de opeenvolging van de generaties - met alle gevaren (degeneratie!) en mogelijkheden (vooruitgang!) van dien. ${ }^{58}$ Voor lamarckianen, zoals bijvoorbeeld Spencer, stond het vast dat 'de vroege menselijke natuur verschilde van de latere menselijke natuur, 59

De vraag is nu: in hoeverre en op welke wijze waren deze positivistische opvattingen over de plooibare psyche van invloed op het gedachtegoed van de nieuwe cultuurhistorici?

Wie ernaar op zoek gaat, vindt in het werk van de nieuwe cultuurhistorici allerlei referenties naar de genoemde vertegenwoordigers van het West-Europese positivisme. ${ }^{60}$ Zo presenteerde Lamprecht in zijn eerste pleidooi voor de cultuurgeschiedenis Comte, Taine en Buckle als verdienstelijke voorgangers. ${ }^{61}$ In 1914 merkte hij ook nog de verdiensten van Marx in dit opzicht op: 'Toen [...] Marx het economische leven en het sociale proces verantwoordelijk maakte voor het nieuwe psychische leven, had hij zo ongelijk nog niet'; Marx was alleen te eenzijdig en te 'logisch-mystisch' in zijn interpretatie van het verband tussen beide. ${ }^{62}$ Zowel bij Lamprecht als bij Steinhausen vinden we in de jaren negentig bovendien enkele literatuurreferenties naar werk van Spencer, bij Lamprecht later ook (zij het indirect) naar Haeckel. ${ }^{63}$ In diezelfde tijd verdiepte Breysig zich in de opvattingen van Taine en Comte en noemde Gothein het werk van Taine een voorbeeld van een 'historische analyse' à la Burckhardt, die hij in het algemeen prefereerde boven de gebruikelijke beschrijvende en 'synthetiserende' geschiedschrijving. ${ }^{64}$ Ook voor Comte vond hij lovende woorden: hij noemde diens werk in zijn beste onderdelen meisterhaft en in andere gevallen op zijn minst äußerst anregend. ${ }^{65}$ Goetz, tenslotte, erkende aan het eind van zijn carrière dat de opvattingen van Comte en zijn volgelingen 'een vruchtbare stimulans' hadden betekend voor de geschiedschrijving: 'sinds zijn tijd is het sociologische perspectief een deel van elke diepgravende geschiedschrijving', meende hij in $1932 .^{66}$

Er kunnen nog andere connecties genoemd worden. Van Steinhausen weten we dat hij Buckle al las op het gymnasium en Taine en Comte bestudeerde in zijn studietijd. ${ }^{67}$ Ook weten we dat zijn Doktorvater Seeck biologistische opvattingen over de geschiedenis koesterde, al verkondigde Steinhausen later dat hij nooit erg gecharmeerd

${ }^{58}$ Zie Bowler (1989), 246-270, 296-306; zelfs Darwin (en Darwinianen als Haeckel) gingen in de loop van hun leven een rol toekennen aan de 'overerving door gebruik', zie a.w., 258. Pas na 1900 raakte het Lamarckiaanse denken langzaam in diskrediet en wonnen darwinistische opvattingen terrein.

${ }^{59}$ Citaat bij Jahoda (1992), 112.

${ }^{60} \mathrm{Al}$ door tijdgenoten werd opgemerkt dat vooral Lamprechts geschiedopvattingen in essentie teruggingen op het gedachtengoed van Comte en andere vertegenwoordigers van het West-Europese positivisme. Zie bijv. Bernheim (1905); Goetz (1957d), 311.

${ }^{61}$ Lamprecht (1896/97), 111. Ook elders erkende hij de betekenis van met name Comte, zie Lamprecht (1900), 33.

${ }^{62}$ Lamprecht (1914), 35.

${ }^{63}$ Zie Steinhausen (1893) 4, 14n; Lamprecht (1896/97), 144 (Spencer), en Lamprecht (1896/97), 114; Lamprechts 'Anhang' in Levinstein (1905), V en Lamprecht (1913), 136 (biogenetische grondwet / Haeckel).

${ }^{64}$ Zie verschillende boekrecensies van Breysig, Schilling (1928), nr. 197, 205; vgl. ook Breysig (1898), 117 (slotzin). Gothein (1897), 9; Gothein (1889), 11-12, 17. Vgl. Gothein (1931), 24, 320.

${ }^{65} \mathrm{Zie}$ Gothein (1892a), 842-843. Opvallend is overigens dat Gothein Comte's benadering als 'idealistisch' typeert. In een brief van 24.7.1920 memoreert hij dat Dilthey hem bij gelegenheid van zijn habilitatie aanspoorde 'het werk van Comte te voltooien', zie Maurer e.a. (2006), 541. Ook elders in zijn briefwisseling suggereert Gothein een verband tussen Comte's 'historische' benadering van de sociologie en zijn eigen 'historische psychologie', zie Maurer e.a. (2006), 332 (brief 11-8-1909).

${ }^{66}$ Goetz (1932), 379.

${ }^{67}$ Zie Steinhausen (1925), 236. 
was geweest van diens speculaties. ${ }^{68}$ Niet alleen Steinhausen maar ook Lamprecht had verder in Ernst Bernheim een docent geschiedtheorie getroffen die zijn studenten behalve op de 'gevaren' van het Positivisme, ook wees op de 'eminente betekenis' voor de geschiedwetenschap van iemand als Comte. ${ }^{69}$

Toch zijn de verwijzingen naar klassieke West-Europese positivisten die her en der in het oeuvre van de nieuwe cultuurhistorici zijn aan te treffen tamelijk oppervlakkige indicaties als het erom gaat hun betekenis voor de nieuwe cultuurgeschiedenis te bepalen. Geen van de nieuwe cultuurhistorici getuigde uitdrukkelijk van de betekenis van het West-Europese positivisme voor de persoonlijke ontwikkeling. Integendeel. Lamprecht ontkende weliswaar niet dat er overeenkomsten bestonden tussen zijn eigen opvattingen en die van bijvoorbeeld Comte, maar wel dat hij zijn ideeën op een of andere manier ontleend zou hebben aan Comte. ${ }^{70}$ En op een vergelijkbare wijze verklaarde Breysig in 1902 dat Comte en 'misschien' Darwin tot de 'stamvaders' van de nieuwe riching in de geschiedwetenschap gerekend mocht worden, maar merkte hij tegelijk op dat hij ze geen van beiden ooit gelezen had. ${ }^{71}$

Vergeleken met de aandacht van vooral Lamprecht en Breysig voor Verlichte voorgangers vallen de verwijzingen naar negentiende-eeuwse positivisten van deze beide meest sciëntistische nieuwe cultuurhistorici eerder zuinig uit. 'Noch de theorie van Comte en Buckle, noch de praktijk van Guizot en Thierry, Nietzsche en Burckhardt, Tocqueville en Taine', schreef Breysig uitdrukkelijk aan het eind van een van zijn opstellen over de Verlichtingshistoriografie, 'zijn denkbaar zonder de rijke vruchten die hen door de grote inspiratoren en plannenmakers van de achttiende eeuw ten deel zijn gevallen'. ${ }^{2}$

Bovendien valt op dat de lovende woorden van de nieuwe cultuurhistorici voor de West-Europese positivisten in het algemeen vergezeld gingen van aanmerkelijke kritische kanttekeningen. Zo meende Gothein bijvoorbeeld dat Buckle met zijn Brandgescho $\beta$ de cultuurgeschiedenis weliswaar terecht opnieuw onder de aandacht had gebracht, maar dat zijn blijvende betekenis toch gering was. ${ }^{73}$ Niet alleen hij maar ook Lamprecht bekritiseerden uitdrukkelijk het eenzijdige intellectualisme van Comte, Buckle en de door hen geïnspireerde Duitse fysioloog Du Bois Reymond, die in een geruchtmakende academische rede met de titel Culturgeschichte und Naturwissenschaft (1877) de hele historische voortgang had herleid tot de ontwikkeling van de natuurwetenschap. $^{74}$

En als niet minder eenzijdig werd door Lamprecht het 'voluntarisme' van met name Marx en Darwin veroordeeld, waarmee hij hun eenzijdige nadruk bedoelde op de natuurlijke driften en de begeerte als de motor van de historische ontwikkeling. ${ }^{75}$ In

\footnotetext{
${ }^{68}$ Steinhausen (1925), 238. Zie ook: Hoofdstuk 5, Paragraaf 2, noot 81.

${ }^{69}$ Dat was althans de boodschap van zijn Lehrbuch: Bernheim (1903), VII. Zie verder de bespreking van Bernheim in Hoofdstuk 5, paragraaf 6.

${ }^{70}$ Lamprecht (1905), 89n.

${ }^{71}$ Citaat in Brocke (1971), 144. Breysig leerde de opvattingen van Comte kennen door bestudering van een monografie over hem in de zomer van 1895, ibidem $47 \mathrm{n} 65$.

${ }^{72}$ Breysig (1898), 117.

${ }^{73}$ Gothein (1889), 58-61; vgl. ook Gothein (1892a), 843.

${ }^{74}$ Lamprecht (1974), 461-463 en 496-497 [1898/1899]; vgl. bovendien Lamprecht (1913), 124 e.v. Du Bois-Reymond verkondigde dat 'Naturwissenschaft das absolute Organ der Cultur [ist], und die Geschichte der Naturwissenschaft somit die eigentliche Geschichte der Menschheit', zie Du BoisReymond (1877), 232.

${ }^{75}$ Lamprecht (1974), 464-468 en 497-498 [1898/1899]. Het is overigens de vraag of Lamprecht een helder zicht had op de opvattingen van Darwin: hij typeerde ze met de trefwoorden Anpassung en Vererbung, die beide eerder binnen het lamarckiaanse denken over de evolutie van betekenis zijn, zie Lamprecht (1913), 149 e.v. Overigens veroordeelde Lamprecht ook wat hij Darwin's 'mechanistische
} 
datzelfde verband past ook de kritiek van Lamprecht en andere nieuwe cultuurhistorici op de verschillende, in de jaren zeventig en tachtig in Duitsland populaire cultuurgeschiedenissen met sociaaldarwinistische inslag. ${ }^{76}$

Dat betekent allemaal geenszins dat het negentiende-eeuwse positivisme niet van betekenis is geweest voor het denken van de nieuwe cultuurhistorici. Alleen volstaat het niet om te wijzen op algemene overeenkomsten met het positivisme als het er om gaat de herkomst van de opvattingen van de nieuwe cultuurhistorici te bepalen. Er zal nauwkeuriger gekeken moeten worden: naar de 'lokale' wegen waarop het positivistische gedachtengoed, en speciaal de door dit gedachtegoed geïnspireerde historischpsychologische ideeën, de nieuwe cultuurhistorici bereikte.

In het navolgende zal duidelijk worden dat twee van dergelijke lokale, Duitse exponenten van het positivisme van belang moeten worden geacht voor de nieuwe cultuurhistorici: de herbartiaanse traditie (en haar critici) in de Duitse psychologie en de Historische School in de Duitse Nationalökonomie.

\section{De herbartiaanse psychologie en haar critici}

John Stuart Mills gedachte dat de geschiedwetenschap gediend zou zijn met een nieuwe wetenschap die zich bezig hield met het collectieve 'karakter van een volk of een tijdperk', kreeg in het Duitse taalgebied een endogene variant: daar werd deze 'wetenschap die als zodanig nog niet bestaat' in 1851 geïntroduceerd onder de naam Völkerpsychologie. ${ }^{77}$ Haar bedenker was de Berlijnse filosoof Moritz Lazarus (18241903). In een tijd waarin het begrip 'volksgeest' steeds vaker opdook, zoals Lazarus vaststelde, was het wenselijk 'het wezen van de volksgeest en zijn daden psychologisch te begrijpen' en zodoende van een wetenschappelijke basis te voorzien. ${ }^{78}$ Eén van de voornaamste taken van de Völkerpsychologie zou het moeten zijn om het voor historici mogelijk te maken het historische leven van de volkeren tot psychologische principes te kunnen 'herleiden'. 79 Gezien de nauwe relatie tussen geschiedenis en psychologie binnen de Völkerpsychologie kunnen we ons afvragen of en in hoeverre zij van invloed is geweest op het denken van de nieuwe cultuurhistorici.

\footnotetext{
verklaringspoging' noemde: 'op historisch gebied kan de ontwikkeling al helemaal niet door de pure werking en tegenwerking van enkele te allen tijde als permanent veronderstelde psychologische wetten aangenomen worden'. Lamprecht (1903), 270, vgl. Lamprecht (1913), 151 e.v.

${ }^{76}$ Het hoeft niet te verbazen dat deze cultuurhistorici ook konden rekenen op kritiek van historistisch georiënteerde, politieke historici. Droysen besprak het werk van Thomas Buckle bijzonder negatief in de Historische Zeitschrift, zie Droysen (1863). Later uitte hij zich ook negatief over o.a. Hellwald en Du Bois: Droysen (1878). Ook Ottokar Lorenz keerde zich tegen Du Bois-Reymond: zie Lorenz (18861891). En de verhandeling die de aanleiding vormde voor Gotheins Aufgaben der Kulturgeschichte, Schäfers Das eigentliche Arbeitsgebiet der Geschichte (1888), was met name gericht tegen de materialistische cultuurgeschiedenissen uit de jaren zeventig en tachtig (zoals blijkt uit de als antwoord op Gothein geconcipieerde repliek van Schäfer (1891), m.n. 50-61).

${ }^{77}$ Lazarus (1851), 112. Lazarus' medestander Steinthal (1864), 76n, wees zelf op de gelijkenis tussen Mills ethology en de Völkerpsychologie; Bernheim (1908), 652, legt dezelfde relatie. In Leary's studie over de receptie van Mill's ethology, waarin de nadruk ligt op de Angelsaksische receptie, wordt de Völkerpsychologie niet genoemd, zie Leary (1982).

${ }^{78}$ Mijn cursivering, MS. In een later artikel uit 1860 en opnieuw in 1865 wees Lazarus op de connectie met de toegenomen belangstelling voor de cultuurgeschiedenis. Opvallend is dat ook hij Burckhardt, Freytag en, wat minder, Riehl als beste en meest verwante cultuurhistorici noemt, zie Lazarus (1865), 4n, vgl. 78n; en Lazarus en Steinthal (1860), 23.

${ }^{79}$ Lazarus en Steinthal (1860), 1, zie ook 19 en 21.
} 
Net als Mill baseerde Lazarus zijn voorstel in belangrijke mate op Verlichte empirische psychologische tradities. Bepalend voor zijn denken waren wetenschappers die zich uitdrukkelijk afzetten tegen het in de eerste helft van de negentiende eeuw wijd verspreide idealisme, zoals zijn docent, de kritische empirist en psycholoog Beneke (1798-1854) en vooral Kants opvolger in Königsberg, J.F. Herbart (1776-1841) ${ }^{80}$ Deze invloedrijke pedagoog, psycholoog en filosoof, met wiens werk Lazarus al op het gymnasium vertrouwd was geraakt, geldt als de aartsvader van de sociale psychologie in Duitsland. ${ }^{81}$ In zijn Psychologie als Wissenschaft (1824) had Herbart een natuurwetenschappelijk-exacte benadering van het psychisch leven bepleit. In zijn psychologische en pedagogische opvattingen stond, net als in de Verlichte sensualistische psychologie, het begrip Bildsamkeit centraal. ${ }^{82}$ Het menselijke individu was geen afgesloten leibniziaanse monade, maar een bij uitstek 'open' wezen dat gevormd werd door de 'voorstellingen' die het van buiten ontving. Een dergelijk 'open' individu kon niet los worden gezien van zijn omgeving, zijn samenleving en geschiedenis. Dat werd volgens Herbart vooral duidelijk uit de kennismaking met mensen uit primitievere culturen, zoals de Maori in Nieuw-Zeeland: ${ }^{83}$

'De mens is niets buiten de samenleving. Het volstrekte individu kennen we helemaal niet. [...] Sterker nog, we kennen eigenlijk slechts mensen in een beschaafde [gebildete] samenleving. [...] Hoevelen onder ons, die zich met psychologie bezighouden, zijn in Nieuw-Zeeland geweest? Hoevelen hebben de gelegenheid de wilden in hun eigen woonomgeving te observeren? Wij moeten ons ermee tevreden stellen de tegenwoordige beschaafde mens tot direct onderwerp van onze beschouwing te maken. [...] Hij is een product van wat wij de wereldgeschiedenis noemen. We mogen hem niet uit de geschiedenis losrukken.'

Aan de uitwerking van deze herbartiaanse ideeën wijdden Lazarus en zijn naaste intellectuele medestander, de Berlijnse taalwetenschapper Hajim Steinthal (1823-1899), talrijke studies, die zij onder ander publiceerden in hun eigen Zeitschrift für Völkerpsychologie und Sprachwissenschaft, dat van 1860 tot 1890 bestond.

Lazarus en Steinthal beschouwden het individu tot op grote hoogte als een sociaal product - hoe waardevol de individuele persoonlijkheid op zichzelf ook zijn mocht. ${ }^{84}$ Verwijzend naar Droysens gepassioneerde pleidooi voor de vrije wil merkte Steinthal bijvoorbeeld op dat ook diens ' $\mathrm{x}$ ' in de vergelijking $\mathrm{A}=\mathrm{a}+\mathrm{x}$, dat 'wat wij het ego, de vrijheid noemen', door psychologen geanalyseerd en zelfs berekend kon worden. ${ }^{85}$ En dat was bij uitstek de taak van de Völkerpsychologie die behalve als een 'psychologie van de menselijke samenleving' ook als een 'psychologie van de sociale mens' diende

\footnotetext{
${ }^{80}$ Belke (1971), XIX, XLV. F. E. Beneke (1798-1854), auteur van o.a. een Lehrbuch der Psychologie als Naturwissenschaft (1833), beschouwde de ontvankelijkheid voor prikkels als een oervermogen van de mens en zette daarmee een psychologische traditie voort die in de Verlichting opgang maakte. Zie over Beneke en Herbart als critici van het idealisme en voorlopers van de moderne experimentele psychologie: Leary (1978); een algemeen overzicht van hun beider filosofie is te vinden in Vorländer (1919), II, 328-344. Flint (1874), 578-580 bespreekt Herbarts opvatting over geschiedenis; Boyd en King (1969), 338-349 geven een bondig overzicht van zijn pedagogische opvattingen.

${ }^{81}$ Zie Geck (1928) en Jahoda (2006). Allesch (2001) biedt een genuanceerde studie over de relatie van de Völkerpsychologie tot Herbart.

${ }^{82}$ Zie hiervoor Kühne (1976), m.n. hfdst. 2.

${ }^{83}$ Herbart (1968), II, 20-21.

${ }^{84}$ Lazarus (1851), 119, idem, Lazarus en Steinthal (1860), 3. Vgl. ook Lazarus (1865), 16-21, m.n. 19.

${ }^{85}$ Steinthal (1864), 56-58.
} 
te worden opgevat. ${ }^{86}$ De vrijheid van individuen was slechts relatief. Zoals zelfs de briljantste schaker voortdurend gebonden was aan de regels van het spel, zo was het ook gesteld met de individuele vrijheid: zij 'wordt gevormd door opvoeding, onderwijs, sociaal verkeer en levenswijze en wordt daardoor tegelijk beperkt. ${ }^{87}$ Weliswaar wisten sommige uitzonderlijke individuen zich in enkele opzichten aan de invloed van de samenleving te onttrekken, voor alledaagse handelingen en voor de 'doorsnee massa' gold dat zeker niet. ${ }^{88}$

Onder individuen die met elkaar waren verbonden, bijvoorbeeld door middel van taal en economie, ontstond volgens de Völkerpsychologen als vanzelf, door de 'Combination en Collocation' van individuen en de daaropvolgende uitwisseling en Ausgleich van eigenschappen, een soort gemeenschappelijke noemer. Op nationaal niveau kon deze gemeenschappelijke noemer als de 'volksgeest' betiteld worden. ${ }^{89}$ Het ging daarbij expliciet niet om de uitdrukking van een collectieve fysiologische gesteldheid, noch om de uitdrukking van een of andere freischwebende nationale 'idee'. ${ }^{90}$ Conform Herbarts mechanistische uitgangspunten beschouwden de Völkerpsychologen individuen die op enige manier met elkaar in contact stonden in feite als communicerende vaten die hun respectievelijke psychische kwaliteiten onvermijdelijk met elkaar vermengden. Dat betekende niet dat alle individuen die tot een volk behoorden in alle opzichten op elkaar leken: de uitwisseling van eigenschappen vond plaats in alle van de vele sociale kringen waarvan het individu deel uitmaakte, van het gezin tot de natie. Omdat (en voor zover) verschillende individuen deel waren van verschillende sociale kringen, ontstond er een grote variatie aan persoonlijkheden. De volkgeest vormde slechts de grootste gemene deler onder de individuen die samen een natie uitmaakten.

In principe waren op deze wijze geconcipieerde collectieve geesten niet onveranderlijk of eeuwig, 'zij veranderen in de loop van de geschiedenis', zoals Lazarus opmerkte. 'Al 'Alle momenten van de geest worden door de historische beweging gegrepen', schreef op zijn beurt Steinthal: ${ }^{92}$

'de psychologie dient net als de fysica het feitelijk worden van haar objecten in het oog te houden, zij wordt dus historisch en de Völkerpsychologie is niet slechts de psychologie van de volkerengeschiedenis, maar tegelijk de geschiedenis van de psyche'.

De Völkerpsychologen waren niet de enige Duitse wetenschappers die zich in de tweede helft van de negentiende eeuw door Herbart lieten inspireren. Min of meer vergelijkbare opvattingen vonden ook buiten de Duitse psychologie en taalwetenschap weerklank. In de antropologie bijvoorbeeld, waar de herbartiaan Theodor Waitz met zijn zesdelige

${ }^{86}$ Lazarus (1851), 119, ook in Lazarus en Steinthal (1860).

${ }^{87}$ Steinthal (1864), 54-62, m.n. 61. Vgl. ook Lazarus en Steinthal (1860), 22-23.

${ }^{88}$ Lazarus (1865), 63.

${ }^{89}$ Steinthal (1864), 37-38; Lazarus Lazarus (1865), 21 ev.

${ }^{90}$ De invloed van de natuurlijke factoren (afstamming, geografie, klimaat) op de vorming van de volksgeest ontkenden Lazarus en Steinthal niet volledig, maar voor hen was deze invloed niet beslissend. 'Kein Volksgeist ist Erzeugniß der Natur', schreven ze (al was er omgekeerd ook geen een die niet beïnvloed was door de natuur). Belangrijker dan de natuurlijke factoren waren de gedeelde lotgevallen. Lazarus en Steinthal (1860), 39, vgl. ook 34-35 en 16, waar de materialistische opvatting van de geest als 'appendix van de fysiologie' wordt afgewezen. Verder noemde Steinthal de gedachte dat ideeën een soort organismen met een zelfstandig leven en eigen ontwikkeling zijn, 'eine ungeschichtliche [sic!] Hypostasirung der ganz von der Seele abhängigen Gedankenwelt', zie Steinthal (1864), 67-70, citaat 69, vgl. ook Lazarus (1851) 114 en Lazarus en Steinthal (1860), 19-21.

${ }^{91}$ Lazarus en Steinthal (1860), 63.

${ }^{92}$ Steinthal (1864), 34-35 en Steinthal (1875), 185. 
Anthropologie der Naturvölker (1859-1872) de verschillen in de geestesgesteldheid tussen de volkeren verklaarde uit de invloed van de omstandigheden. ${ }^{93}$ Of bij de Staatswissenschaftler Albert Schäffle die in de jaren zeventig en tachtig, eveneens geïnspireerd door Herbart, een 'encyclopedisch ontwerp' voor een Gesellschaftswissenschaft presenteerde, waarin de plooibare volksgeest een belangrijke rol speelde. ${ }^{94}$ Of, ten slotte, in de 'wetenschappelijke pedagogie' die door de Herbart-volgelingen Tuiskon Ziller (1817-1882) en Wilhelm Rein (1847-1929) in de tweede helft van de negentiende eeuw werd gepropageerd. ${ }^{95}$ Zij verkondigden onder meer (net als Haeckel) dat een kind dezelfde geestelijke ontwikkelingsfasen doormaakte als de mensheid en dat derhalve het leercurriculum van de lagere school geordend moest worden naar Kulturstufen, cultuurhistorisch-psychologische stadia. Zo diende bijvoorbeeld in het eerste schooljaar, waarin het kind 'net als de primitieve mens' nog sterk in een fantasiewereld leefde, de sprookjes van Grimm een belangrijke plaats te krijgen, later, in het derde jaar de nomadencultuur van de Bijbelse patriarchentijd, weer een jaar later de Nibelungensage als representatie van het 'heroïsche cultuurstadium', etc. ${ }^{96}$ De herbartiaanse pedagogen ondersteunden vanuit deze gedachte de cultuurhistorische oriëntatie van het geschiedenisonderwijs die onder andere door Karl Biedermann vanaf de jaren zestig werd bepleit en die in de loop van de decennia na 1870 ook steeds meer haar weg vond naar de schoolverordeningen. ${ }^{97}$ In dit verband was het zeker niet toevallig dat Georg Steinhausen regelmatig door Rein werd uitgenodigd om leraren bij te scholen, ongetwijfeld in de cultuurgeschiedenis. ${ }^{98}$ Het verklaart mede waarom een boek als Lamprechts Deutsche Geschichte zich juist bij leraren in een zekere populariteit kon verheugen.

Daarmee is overigens niet gezegd dat de nieuwe cultuurhistorici zelf regelrechte volgelingen waren van de herbartianen. Integendeel. Typerend was de spottende verwijzing van Steinhausen in een van zijn vroegste artikelen naar een studie over gebarentaal uit de Zeitschrift für Völkerpsychologie, waarin door een 'professor in de filosofie' allerlei geestrijke symbolische duidingen werden gepresenteerd, maar naar zijn mening zinvollere historische verklaringen achterwege bleven. ${ }^{99}$ Een dergelijke terloopse kritiek op het onhistorische karakter van de Völkerpsychologie vinden we eveneens bij Gothein als hij in 1898 in zijn necrologie voor Riehl terzijde opmerkt dat de Völkerpsychologie te gemakkelijk generaliseerde en 'veelal verworven, historisch ontwikkelde eigenschappen aanziet voor oorspronkelijke aanleg' ${ }^{100}$ En ook Lamprecht merkte in zijn Deutsche Geschichte op dat de herbartianen te weinig historisch georiënteerd waren om, buiten de volkskunde, in de geesteswetenschappen werkelijk vrucht te dragen. ${ }^{101} \mathrm{Er}$ is in deze kritiek een duidelijke parallel te vinden met de houding van de nieuwe cultuurhistorici tegenover díe cultuurhistorische voorgangers die naar

\footnotetext{
${ }^{93}$ Zie Jahoda (1992), 112.

${ }^{94} \mathrm{Zie}$ voor een referaat over de opvattingen van de tegenwoordig weinig bekende Schäffle: Goldfriedrich (1902), 309-325.

${ }^{95} \mathrm{Zie}$ Coriand en Winkler (1998).

${ }^{96}$ Zie Jaeger (1986), m.n. 175-178 en Bernheim (1899), 46-50.

${ }^{97}$ Zie Erdmann (1982), 94 en Schneider (1982), 159-162.

${ }^{98}$ Steinhausen (1925), 257.

${ }^{99}$ Zie Steinhausen (1893), 2 en Steinhausen (1894), 350-351.

${ }^{100}$ Zie Gothein (1898), 18; vgl. ook afwijzing van Savigny's 'schaffender Volksgeist' in Gothein (1918), 285.

${ }^{101}$ Lamprecht (1891-1909), X, (ed. 1913), 325.
} 
hun mening de samenhang van de cultuurgeschiedenis te zeer in een onveranderlijke volksziel zochten. ${ }^{102}$

We mogen desalniettemin aannemen dat de nieuwe cultuurhistorici goed op de hoogte waren van het herbartiaanse gedachtegoed. ${ }^{103}$ Dat blijkt uit hun literatuur-

${ }^{102}$ Overigens was de kritiek van de nieuwe cultuurhistorici in menig opzicht gerechtvaardigd. Ondanks de nadruk van Lazarus en Steinthal op de betekenis van de Völkerpsychologie voor de geschiedwetenschap en op het historische karakter van de Völkerpsychologie verschenen er zelfs in hun eigen tijdschrift feitelijk nauwelijks historische studies. Dat er volgens Jahoda en Krewer (1990) toch nog in eenzesde van de bijdragen 'historische' veranderingen ter sprake komen, komt waarschijnlijk vooral op rekening van de vele taalkundige studies. Daarnaast waren er nog enkele wetenschapshistorische bijdragen.

${ }^{103}$ Hier is een excurs op zijn plaats over de betekenis van Wundt en zijn variant van de Völkerpsychologie voor de nieuwe cultuurhistorici en dan m.n. Lamprecht. De Völkerpsychologie van Wilhelm Wundt was niet alleen in de praktijk, maar ook theoretisch nog minder historisch georiënteerd dan de Völkerpsychologie van Lazarus en Steinthal. Op grond van Wundts goede persoonlijke en collegiale relaties met Lamprecht in Leipzig - waar zij samen met Ratzel, Ostwald en Bücher een intellectueel discussieclubje vormden - en hun op het eerste gezicht verwante psychologische opvatting van de geschiedenis heeft men Wundt in het verleden wel een beslissende invloed op Lamprechts psychologische opvatting van cultuurgeschiedenis toegekend. Pas onder invloed van Wundt zou Lamprecht in de jaren negentig van een economisch-materialistische fase zijn overgegaan in een psychologisch-cultuurhistorische fase. Deze opvatting was m.n. gebruikelijk sinds Spieß (1921), zie m.n. 45 e.v. Schorn-Schütte (1984) heeft deze voorstelling van zaken bestreden en er op gewezen dat de psychologische en cultuurhistorische oriëntatie bij Lamprecht al in zijn studietijd is aan te wijzen; ook Lamprecht zelf heeft overigens altijd de nadruk gelegd op de continuïteit van zijn psychologische belangstelling sinds zijn studietijd.

Daaraan kan nog worden toegevoegd dat Wundt zijn variant van de Völkerpsychologie gelijktijdig ontwikkelde met de nieuwe cultuurgeschiedenis en vooral dat die veel minder dan de Völkerpsychologie van Lazarus en Steinthal geschikt was om historici te inspireren (zie voor het volgende: Oelze (1991) en Stoffers (2003), 170-171). Expliciet in tegenstelling tot zijn voorgangers beperkte Wundt zich namelijk uitdrukkelijk tot de analyse van 'Sprache, Mythus und Sitte'. Belangrijker was nog dat hij de Völkerpsychologie uitsluitend tot een zaak van de pre- en protogeschiedenis maakte. In zijn 'psychologische Entwicklungsgeschichte der Menschheit' (zoals hij zijn Völkerpsychologie typeerde) ging het uitsluitend om de vroegste fasen van de mensheidsgeschiedenis, die hij verdeelde in drie perioden: de tijd van de primitieve mens, het totemistische tijdperk en de tijd van helden en goden. Het daaropvolgende vierde tijdvak, dat de hele Europese historische ontwikkeling in engere zin besloeg, was geen onderwerp van zijn Völkerpsychologie. In deze historische fase ging naar Wundts overtuiging de politieke geschiedenis een grote rol spelen, en werden de staat en de grote persoonlijkheden belangrijk. Dit tijdvak was derhalve het terrein van de geschiedwetenschap. Wundt verkondigde vanaf het begin de opvatting dat de geschiedwetenschap zich met het singuliere bezighield, terwijl het in de Völkerpsychologie om de algemene en typische verschijnselen van het volksbewustzijn zou moeten gaan. In verband daarmee was de psychologie volgens Wundt wel grundlegend voor de geschiedenis maar niet andersom. Daarmee was de Völkerpsychologie in de variant van Wundt in feite nog minder historisch georiënteerd en daardoor voor historici minder aantrekkelijk dan die van zijn voorgangers. Vergl. in dit verband Lamprechts kritiek op Wundt in de correspondentie met Spranger, waarbij hij Spranger verwijt te zeer in 'einer Welt absoluter Begriffe [te leven], welche eine eigentliche psychogenetische Auffassung ausschließt. Sie treffen sich darin mit Wundt' (geciteerd in: Spranger (1965), 350n). Vgl. ook de kritiek op Wundt die wordt verwoord in de verhandeling die Lamprecht liet opnemen in de door hem geredigeerde reeks Beiträge zur Kultur- und Universalgeschichte en die onmiskenbaar door Lamprechts eigen opvattingen is geïnspireerd: Petersen (1908), m.n. 89-108. Vgl. ten slotte ook de weerlegging van de kritiek van Wundt op Lazarus en Steinthal door Bernheim (1908), 654.

Overigens moet de betekenis van Wundts psychologische opvattingen voor Lamprecht en de overige nieuwe cultuurhistorici niet helemaal weggecijferd worden. Ook al paste het specifieke karakter van Wundts Völkerpsychologie minder goed bij de opvattingen van de nieuwe cultuurhistorici, desalniettemin vormde de psycholoog met zijn aandacht voor deze thematiek een belangrijke autoriteit ten gunste van vergelijkbare pogingen. We treffen ook bij Wundt de opvatting aan dat de 'individuele psyche' een abstractie is en hij legde, vaak onder verwijzing naar Taine, voortdurend de nadruk op de invloed van de 'geistige Umgebung' of het sociale milieu. Wundt beschouwde het inzicht in het bestaan van dergelijke 'geistige Gemeinschaften' als een van de algemene uitgangspunten van zijn psychologie. Dergelijke 
referenties, waarin we bijvoorbeeld verwijzingen naar het werk van herbartianen als Waitz en Schäffle tegenkomen. ${ }^{104}$ Ook Georg Simmel, wiens (vroege) sociaalpsychologische werk in belangrijke opzichten een voortzetting was van de Völkerpsychologie van zijn leermeester Lazarus, ${ }^{105}$ werd zowel door Gothein, Lamprecht, als Breysig bestudeerd en gewaardeerd. ${ }^{106}$ In algemene bewoordingen erkenden met name Steinhausen en Lamprecht bovendien wel de waarde van de Völkerpsychologie en haar rol in de ontwikkeling van het cultuurhistorisch denken. ${ }^{107}$ Een historisch opgevatte Völkerpsychologie die zich bezighield met het onderzoek en de ontwikkeling van de 'sociaalpsychische voorwaarden' in een tijd, was feitelijk niets anders dan Kulturgeschichte, meende Steinhausen. ${ }^{108}$

Beslissend voor de betekenis die we moeten toekennen aan de herbartiaanse traditie voor de nieuwe cultuurgeschiedenis is echter dat verschillende gewaardeerde docenten van de nieuwe cultuurhistorici zelf overduidelijk beïnvloed waren door de herbartiaanse tradities - zelfs als ze daar uiteindelijk een kritisch alternatief tegenover plaatsten. Zowel de waardering van de nieuwe cultuurhistorici voor, als hun gelijktijdige kritiek op het onhistorische karakter van de herbartianen lijken hier hun oorsprong te vinden. De docenten waar het om gaat waren Ernst Bernheim, de al meer dan eens ter sprake gekomen docent in de geschiedtheorie van Steinhausen en Lamprecht, en daarnaast een groep van bevriende wetenschappers rond de filosoof Wilhelm Dilthey. Behalve Dilthey zelf, docent van Gothein en Breysig, behoorden daartoe de taal- en literatuurwetenschapper Wilhelm Scherer (docent van Steinhausen), ${ }^{109}$ de historicus Bernhard Erdmannsdörffer ${ }^{10}$ (docent van Gothein) en de kunst- en literatuurhistoricus Herman Grimm. ${ }^{111}$ Samen vormden deze geleerden een belangrijke schakel in het doorgeven van

algemene psychologische en filosofische opvattingen werden wel degelijk door de nieuwe cultuurhistorici - in ieder geval Lamprecht - gebruikt bij de formulering van hun eigen opvattingen. Een aanwijzing daarvoor is dat Lamprecht in zijn theoretische geschriften vaker verwijst naar Wundts algemene psychologische en filosofische geschriften dan naar diens Völkerpsychologie. Zo behoren Wundts Grundriss der Psychologie (1896) met vijf citaties èn zeker zijn wetenschapsleer met vijftien citaties tot de meest geciteerde werken in Lamprechts belangrijkste vroege theoretische verhandeling Was ist Kulturgeschichte?

${ }^{104}$ Bijv. Steinhausen (1891a), passim, Steinhausen (1892b), 56; Lamprecht (1896/97), 111n, 123n, 124n; Breysig (1907) toont uitdrukkelijk waardering voor Waitz.

${ }^{105}$ Zie Köhnke (1990), ook verwerkt in Köhnke (1996).

${ }^{106}$ Lamprecht (1896/97), 110n1, 144n (Simmel); Lamprecht (1891-1909), Erg. Bd. II (1903), 250, 255 (Hellpach); voor Breysig zie: Schilling (1928)nr. 295, 302 (rec. Durkheim).

${ }^{107}$ Zie bijv. Lamprecht (1900), 32, Lamprecht (1913), 134 en Lamprecht (1896), 7 en 21.

${ }^{108}$ Zie Steinhausen (1905), 236.

${ }^{109}$ Scherer behoorde tot de meest geliefde docenten van Georg Steinhausen. In de tijd dat Steinhausen in Berlijn studeerde, volgde hij niet alleen alle hoorcolleges van Scherer, maar kwam hij ook incidenteel bij hem aan huis. Zie Steinhausen (1925), 238. Overigens kan nog opgemerkt worden dat de Berlijnse hoogleraar Duitse taal- en letterkunde Richard M. Meyer (1860-1914) die algemeen beschouwd wordt als een van de trouwste Scherer-leerlingen, geregeld bijdragen leverde aan Steinhausens Zeitschrift en Archiv für Kulturgeschichte (in 1895, 1898, 1902, 1904 en 1905). Verder steunde een goede vriend van Scherer, de historicus Ottokar Lorenz, Steinhausens habilitatiepoging aan de Universiteit van Jena. Scherer stond ook in contact met Lamprecht, zie Kindt en Müller (1999), 188n47: citaat uit brief van Lamprecht aan Scherer uit september 1884 waarin Lamprecht zichzelf typeert als 'Historiker, der Ihnen aus der Lecture ihrer Litteraturgeschichte viel verdankt'. Rothacker (1930), 252, suggereerde in verband met een aantal parallellen tussen Scherers opvattingen en die van Lamprecht dat er sprake was van een mogelijke beïnvloeding door Scherer. Lamprecht en Scherer werden overigens al in een opstel voor de $\mathrm{PJb}$ uit 1895 samen met nog enkele anderen op één hoop gegooid en veroordeeld vanwege hun 'materialisme in de historische wetenschappen', zie Aly (1895).

${ }^{110}$ Zie over Erdmannsdörffer: Hoofdstuk 5, paragraaf 2 en 5.

${ }^{111}$ Zowel Breysig als Lamprecht onderhielden in de jaren negentig een goed persoonlijk contact met Grimm. Zie Breysig (1962), 53-57. Hier merkt Breysig op dat Grimm op gespannen voet stond zowel met 'de filologen' als met de historici uit de Mommsen-school; hoewel hij het in verschillende opzichten niet 
het herbartiaanse gedachtengoed aan de nieuwe generatie cultuurhistorici. Dat gebeurde niet zonder kritiek en aanpassingen, integendeel, maar voor ons thema is het van belang dat de herbartiaanse gedachte van een historisch georiënteerde sociale psychologie ook bij de critici overeind bleef.

Aan Bernheims belangstelling voor de Völkerpsychologie en aan zijn betekenis voor de nieuwe cultuurhistorici zijn al verschillende alinea's gewijd. ${ }^{112}$ Van belang is vooral om te memoreren dat Bernheim al vanaf zijn eerste geschiedtheoretische publikaties de ontwikkeling van de Völkerpsychologie als de belangrijkste verdienste van het positivisme verdedigde. ${ }^{113}$ Het was de uitgesproken bedoeling van zijn grote Lehrbuch der historischen Methode om de völkerpsychologische opvatting als 'een ongemeen vruchtbaar element in het historisch onderzoek' ingang te doen vinden onder historici. ${ }^{114}$ Hij wilde echter niet zover gaan de Völkerpsychologie als het fundament van de geschiedwetenschap aan te duiden: het was niet meer dan een hulpwetenschap, de geschiedenis bleef voor hem fundamenteel. Bovendien verkoos hij in navolging van de herbartiaan Schäffle de uitdrukking 'sozialpsychologisch' boven 'völkerpsychologisch' als algemene term.

Meer aandacht dient hier uit te gaan naar docenten van buiten de historische discipline: de groep wetenschappers rond Wilhelm Dilthey. Dilthey cum suis vormden enige tijd een intellectuele vriendenclub die in de jaren zestig de mogelijkheden overwoog van een nieuwsoortige, interdisciplinaire Wissenschaft des Geistes. ${ }^{115}$ Het doel van deze nieuwe wetenschap zou moeten zijn om 'de voorwaarden, de elementaire krachten [en] de wetmatige samenhang te onderzoeken die ten grondslag liggen aan de afzonderlijke groepen van intellectuele, morele, sociale, politieke verschijnselen en uiteindelijk ook aan het geheel'. Op grond van deze 'voorwaarden, krachten en wetten' voltrok zich immers 'de voortgang van de menselijke cultuur'. ${ }^{116}$ Hoewel het uitdrukkelijk niet de bedoeling was van Dilthey en de zijnen om alle sociale verschijnselen 'meteen' tot 'de zogenaamde psychologische wetten' te herleiden, ${ }^{117}$ speelde de psychologie een belangrijke rol in de pogingen van de vriendenclub om tot een betere wetenschappelijke fundering van de geesteswetenschappen te komen. ${ }^{118}$

De belangrijkste inspirator van deze groep was zonder twijfel Wilhelm Dilthey, die op zijn beurt zelf een belangrijk deel van zijn inspiratie ontleende aan de ideeën van

eens was met Grimm, waardeerde Breysig wel diens brede blik, die o.a. leidde tot plannen om een 'geschiedenis van de Duitse fantasie' te schrijven. Zie voor Lamprecht: Chickering (1993), o.a. 181. Van Grimm verscheen een opmerkelijk positieve bespreking van Lamprechts Deutsche Geschichte: Grimm (1894)

112 Zie Hoofdstuk 5, paragraaf 5 en Hoofdstuk 2, paragraaf 1.

${ }^{113}$ Bernheim (1880), 76. Hij spreekt dan ook van de 'ungemein anregenden tiefdringenden Forschungen ihrer Vertreter' (124-125).

${ }^{114}$ Bernheim (1903), VII. In het voorwoord uit 1908 van zijn Lehrbuch benoemt Bernheim opnieuw het völkerpsychologische, resp. sociaalpsychologische element van het positivisme als het 'bruikbare' element van deze richting. Bernheim voerde de uitgangspunten van Völkerpsychologie, onder uitgesproken waardering en erkenning van de Völkerpsychologen Lazarus en Steinthal, uiteindelijk via John Stuart Mill terug tot Comte.

${ }^{115} \mathrm{Zie}$ over dit project, dat gestalte moest krijgen in een nieuw op te richten tijdschrift: Kindt en Müller (1999) en Diltheys briefwisseling uit de jaren 1867/68 in Dilthey (1960), m.n. 228, 239, 241-242, 256.

${ }^{116}$ Geciteerd in Kindt en Müller (1999), 184.

${ }^{117}$ Zie Dilthey (1960), 241.

${ }^{118}$ Voor Erdmannsdörffer, zie Erdmannsdörffer (1911), I, XXIII. Ook volgens Scherer zou de causale analyse van de geschiedenis uiteindelijk terugvoeren naar de psychologie, zoals onder andere economen als Roscher hadden beargumenteerd, zie Scherer (1893), 171 en Rothacker (1930), 230. Scherer (1995), VIII sprak van de 'historisch-fysiologische Methode' van de Nationalökonomen. Rothacker (1930), 223, citeert dit als 'historisch-psychologische Methode'. 
Lazarus en Steinthal. ${ }^{119}$ Als tweeëntwintigjarige student had hij in 1855 de bijna tien jaar oudere Lazarus in Berlijn leren kennen, die in de Pruisische hoofdstad het middelpunt vormde van een actieve discussiekring. Dilthey raakte in dat jaar onder de indruk van diens psychologische studie Das Leben der Seele en zou tot aan Lazarus' vertrek als hoogleraar naar Bern in 1859 in intensief vriendschappelijk en intellectueel contact met hem verkeren

Dilthey had in deze periode veel waardering voor Lazarus' opvattingen. Zo schreef hij naar aanleiding van Lazarus' plannen voor een Völkerpsychologisch tijdschrift in een brief aan zijn ouders uit de herfst van 1858: '[Lazarus] is zeer geïnspireerd door veel nieuwe ideeën, die erg nauw raken aan mijn eigen wijze om de historische dingen te bekijken. Hij deelt met mij de overtuiging dat de bewegingen van de geschiedenis beheerst worden door wetten die net zo kenbaar zijn als de wetten van de natuur.' En in dezelfde maanden aan zijn broer: '[Lazarus] is op een zeer met mijn ideeën verwante weg met een wetenschap die hij Völkerpsychologie noemt'. ${ }^{120}$ En toen de 26-jarige Dilthey naar aanleiding van het afscheid van Lazarus uit Berlijn terugblikte op de betekenis van de Völkerpsycholog voor zijn eigen intellectuele ontwikkeling, merkte hij op hoezeer zijn eigen vorming schatplichtig was aan de joodse filosoof: 'Wat ik mogelijkerwijs intellectueel worden zal, daarvan dank ik hem het grootste deel van de inspiratie'. 121

Bij alle erkenning van de 'ongetwijfeld juiste bedoeling' van de Völkerpsychologen, koesterde Dilthey echter vanaf het begin ook 'wetenschappelijke twijfels', zoals hij in zijn brieven liet doorschemeren. ${ }^{122} \mathrm{Al}$ in 1858 vinden we sporen van kritiek, om te beginnen op de door Lazarus voorgestelde naam en afbakening van de nieuwe wetenschap. ${ }^{123}$ En na het vertrek van Lazarus naar Bern werd de intellectuele afstand van Dilthey tot zijn voormalige intellectuele mentor alleen maar groter. Toen Lazarus zes jaar later terugkeerde naar Berlijn, had Dilthey het ontwerp gereed van een verhandeling Über das Studium des Menschen und der Geschichte, die naar eigen zeggen gericht was 'contra Lazarum et Lazaristas, Millium etc.' ${ }^{124}$ Aan de uitwerking van de in dit manuscript vervatte gedachten wijdde Diltheys een groot deel van zijn hoogleraarschap in Breslau (1871-1882), de tijd waarin Eberhard Gothein bij hem studeerde. ${ }^{125}$ Deze gedachten zouden uitmonden, eerst in de in 1875 gepubliceerde verhandeling Über das Studium der Geschichte der Wissenschaften vom Menschen, der Gesellschaft und dem Staat, ${ }^{126}$ vervolgens in de Einleitung in die Geisteswissenschaften van 1883 en tenslotte in de beroemde akademieverhandeling Ideen über eine beschreibende und zergliedernde Psychologie (1895) en de daaropvolgende Beiträge zum Studium der Individualität (1896). ${ }^{127}$

${ }^{119}$ Zie voor de jonge Dilthey: Dilthey (1960) en Lessing (1985). Lessing geeft overigens geen vergelijking van de psychologische opvattingen van Dilthey en de Völkerpsychologen. Vandaar dat onderstaande uiteenzetting uitvoeriger moet zijn.

${ }^{120}$ Dilthey (1960), 50 en 51 (mijn cursivering, MS)

${ }^{121}$ Dilthey (1960), 112.

${ }^{122}$ Dilthey (1960), 69 (brief aan zijn zus Marie, 1859).

${ }^{123}$ Dilthey (1960), 51.

${ }^{124}$ Dilthey (1960), 218; dit ontwerp is afgedrukt in Dilthey (1914-2006), XVIII, 1-16 en 213-214; het bevat overigens evenmin als andere verhandelingen van Dilthey directe verwijzingen naar Lazarus of de Völkerpsychologie. Vgl. voor de betekenis van dit ms. de redactionele inleiding van deel XVIII, a.w. blz. xix.

${ }^{125}$ Alle voorstudies vanaf 1865 zijn verzameld in Dilthey (1914-2006), XVIII.

${ }^{126}$ Zie Dilthey (1914-2006), V, 31-74.

${ }^{127}$ Daarna zou Dilthey tot op zekere hoogte een nieuwe (sterkere hermeneutische) wending geven aan zijn visie op de geesteswetenschappen. Zie De Mul (1993), voor een afgewogen visie op Diltheys Kehre $(239-242,284)$ en voor een analyse van Diltheys descriptieve psychologie (205-238). 
Net als de Völkerpsychologen (en West-Europese positivisten als Buckle) geloofde Dilthey in de noodzaak van een verwetenschappelijking van de geschiedschrijving: hij bepleitte een wetenschappelijke revolutie die, net als de wetenschappelijke revolutie van de zeventiende eeuw dat voor de natuurwetenschappen had gedaan, nu de geschiedenis (en algemener de 'geesteswetenschappen') van een deugdelijk kentheoretisch fundament kon voorzien. ${ }^{128}$ Daarbij was hij net als de Völkerpsychologen ervan overtuigd dat ook in de geschiedenis wetten of althans regelmatigheden een belangrijke rol speelden: het onderscheid tussen nomothetische en idiografische wetenschappen dat veel later door Windelband werd voorgesteld, wees hij uitdrukkelijk van de hand. ${ }^{129}$ Het ging ook in de geschiedwetenschap (en de geesteswetenschappen in het algemeen) om het vaststellen van oorzakelijke relaties tussen het individuele en het algemene en niet uitsluitend om het individuele en idiosyncratische. ${ }^{130}$ Terwijl aan de vaststelling van afzonderlijke feiten in de geschiedwetenschap gewoonlijk de strengste methodische eisen werden gesteld, werd de fundering van de oorzakelijke relaties tussen de gegevens doorgaans door historici veel te nonchalant behandeld, meende Dilthey. 'Hier behoeft de geschiedenis zeer dringend een verscherping van haar logisch geweten', schreef hij in $1875 .^{131}$ En net als de Völkerpsychologen dacht hij in ieder geval tot in de jaren negentig dat de psychologie in een of andere vorm voor een dergelijke fundering van de geschiedwetenschap de beste diensten kon bewijzen. ${ }^{132}$

Maar uiteindelijk kwam Dilthey bij alle overeenstemming met de Völkerpsychologen over de fundamentele betekenis van de psychologie voor de historische analyse, tot een radicaal andere opvatting over de aard van de psychologie. Deze afwijkende opvatting kwam al naar voren in het tegen Lazarus gerichte manuscript uit 1866 en zou uiteindelijk in de Ideen über eine beschreibende und zergliedernde Psychologie haar meest uitgewerkte gedaante krijgen.

In het manuscript uit 1866 stelde Dilthey onomwonden: 'psychologie [...] als verklarende wetenschap is onmogelijk vanwege de cumulatie van hypothesen, tot welke zij leiden moet'. ${ }^{133}$ Daarmee was echter geenszins de hele psychologie failliet verklaard. Dilthey attaqueerde uitsluitend wat hij 'verklarende psychologie' noemde. Ook Herbart en zijn school - en dus ook de Völkerpsychologie van de herbartianen Lazarus en Steinthal - rekende Dilthey tot de vertegenwoordigers van deze verklarende psychologie. ${ }^{134}$ Onder 'verklarende psychologie' verstond Dilthey een psychologie naar natuurwetenschappelijk model, waarbij complexe psychische verschijnselen herleid werden tot mechanische wisselwerkingen tussen afzonderlijke elementen. Naar Diltheys oordeel was de verklarende psychologie een fiasco: zij gaf niet de 'volle werkelijkheid van het zielsleven', maar reduceerde de gecompliceerde psychische werkelijkeid tot een samenspel van enkele elementaire factoren. Het gevolg was, zoals Dilthey het psychologisch deficiet formuleerde, dat een beetje roman meer psychologisch inzicht leek te verschaffen dan een moderne psychologische verhandeling. Door haar reductionisme was de verklarende psychologie onbruikbaar of zelfs schadelijk voor het werk van de historicus. Dilthey noemde als voorbeeld de opvattingen van Hippolyte Taine, die op

${ }^{128}$ Zie Dilthey (1914-2006), XVIII, 1 en 206; en V, 48.

${ }^{129}$ Zie Dilthey (1914-2006), V, 241-258.

${ }^{130}$ Zie bijv. Dilthey (1914-2006), V, 48 (1875) en V, 258 (1895): '[die systematischen

Geisteswissenschaften] suchen die ursachlichen Relationen, welche diese Individuation, die Abstufungen,

Verwandtschaften und Typen des menschlich-geschichtlichen Lebens bedingen.'

${ }^{131}$ Zie Dilthey (1914-2006), V, 48.

132 Zie De Mul (1993), 174; zie bijv. Dilthey, Dilthey (1914-2006), I, 33 (1883, Einleitung) en V, 273 (1895, Beiträge), V, 148n1.

${ }^{133}$ Dilthey (1914-2006), XVIII, 3 (mijn cursivering).

${ }^{134}$ Dilthey (1914-2006), XVIII, 16, 5. 
grond van een verklarende psychologie de Franse Revolutie reduceerde tot 'een soort massahysterie'. ${ }^{135}$ En ook de door Dilthey overigens hoger gewaardeerde Buckle bleef in zijn beschavingsgeschiedenis van Engeland op vergelijkbare manier eenzijdig intellectualistisch.

Dilthey pleitte zelf voor een psychologie, waarin dergelijke reducties niet zouden plaatsvinden. Zijn methodologische motto luidde 'empirie zonder empirisme!' Vanuit een strikt empirisch uitgangspunt zouden psychische verschijnselen beschreven en geanalyseerd moeten worden, zonder daarbij de aannames van de 'empiristische', natuurwetenschappelijke psychologie over te nemen. ${ }^{136}$ Van een dergelijke beschrijvende en analyserende psychologie verwachtte Dilthey drie correcties die de gereduceerde psychische werkelijkheid van de verklarende psychologie weer in haar oorspronkelijke rijkdom zouden herstellen.

In de eerste plaats moest er behalve voor waarnemings- en kenprocessen (die in de verklarende psychologie centraal stonden) ook aandacht komen voor gevoel, emotie en wil. Verder diende de studie van psychische processen en mechanismen, waartoe de verklarende psychologie zich veelal beperkte, aangevuld te worden met een Realpsychologie, die de inhoud van denken, voelen en willen onderwerp van onderzoek maakte en bovendien oog had voor de wisselwerking tussen psychische inhouden en processen. En ten slotte diende het 'falsche Individualismus' van de verklarende psychologie, dat het individu uit zijn sociale context isoleerde en veel psychische kenmerken ten onrechte als aangeboren beschouwde, vermeden te worden. ${ }^{137}$

Wat opvalt, is dat Dilthey met deze correcties maar ten dele iets anders formuleerde dan wat Lazarus en Steinthal zich van hun eigen Völkerpsychologie voorstelden. Inderdaad hadden de Völkerpsychologen vaak minder oog voor psychische inhouden dan voor psychische processen en structuren. En inderdaad beschouwden zij, met Herbart, de psyche in de eerste plaats als een 'voorstellingsmechanisme' - ook al gaven zij in theorie wel degelijk aandacht aan wil en gemoed. Maar natuurlijk stond ook bij hen de mens als sociaal wezen in het middelpunt van de belangstelling. Toen Dilthey er op wees dat 'de mens als een gegeven dat voorafgaat aan [en dus losstaat van] geschiedenis en maatschappij een fictie is', formuleerde hij in feite een van de uitgangspunten van Herbart en van de Völkerpsychologie. ${ }^{138}$ Zowel voor Lazarus en Steinthal als voor Dilthey diende het individu altijd als een deel van de maatschappij te worden beschouwd, dat in wisselwerking daarmee werd gevormd. Ook de motivaties van het handelen werden in belangrijke mate bepaald door de verhouding tot de maatschappij en, aangezien deze verhouding weer historisch bepaald was, door de geschiedenis.

Volgens Diltheys eigen analyse werd elk individu behalve door algemene menselijke eigenschappen en strikt individuele kenmerken gekarakteriseerd door een hele reeks van psychische Besonderungen of differentiaties die hij deelde met de verschillende groepen waarvan hij of zij deel uitmaakte - ongeveer zoals de Völkerpsychologen het individu opvatten als de deelverzameling van de verschillende sociale kringen waarin het verkeerde. Het ging bij deze psychische Besonderungen volgens

${ }^{135}$ Dilthey (1914-2006), V, 163.

${ }^{136}$ Dilthey (1914-2006), XVIII, 16.

${ }^{137}$ Dilthey (1914-2006), V, 60 (1875).

${ }^{138}$ Dilthey (1914-2006), I, 31. Terwijl Dilthey zich in zijn Ideen geen rekenschap gaf van zijn schatplichtigheid aan Lazarus en Steinthal, gaf hij daar wel aan dat de herbartiaan Theodor Waitz ook al op de gedachte van een 'beschrijvende psychologie' was gekomen, waarin de 'vergelijkende studie' van o.a. 'de psychische veranderingen in het voortschrijden van de cultuur' en de 'ontwikkelingsgeschiedenis van de individuen en de samenleving' een plaats zouden moeten krijgen. Zie Dilthey (1914-2006), V, 154-156. 
Dilthey uitsluitend om kwantitatieve verschillen: verschillen in kracht, intensiteit en duur van de 'innerlijke toestanden', verschillen in de opnamesnelheid en de dieptewerking van indrukken, tenslotte verschillen in de 'maatverhouding' tussen gevoel, wil en cognitie, en tussen de diverse driften. ${ }^{139}$ De principiële, 'kwalitatieve' gelijkvormigheid van de menselijke natuur bleef in zijn theorie zodoende behouden, zodat ook de mogelijkheid van het begrijpen van andere mensen uitdrukkelijk behouden bleef. De verklaring voor de kwantitatieve verschillen zocht Dilthey in de invloeden van het lichaam, het fysisch milieu en vooral de omringende 'geestelijke wereld'. ${ }^{140}$

Diltheys Besonderungen waren niets anders dan sociaal gedifferentieerde psychische kenmerken. Zij kwamen tot uiting in 'collectieve geestesgesteldheden' (de Gesamtgeist): de psychische eigenschappen die een collectief kenmerkten en het onderscheidden van andere collectieven. Dilthey verwierp echter het gebruik van naar omvang onbepaalde begrippen als volksziel of volksgeest: met de daarmee gepaard gaande beschouwing van de samenleving als organisme zou de fout van de asociale en ahistorische individuele psychologie feitelijk alleen maar verplaatst worden naar een hoger, collectief niveau. ${ }^{141}$ Alleen concreet afgebakende groepen individuen 'sowie sie in der gesellschaftlichen Wechselwirkung uns anschaulich gegeben sind' kwamen in aanmerking voor een analyse. ${ }^{142}$

Diltheys beschrijvende psychologie kende een uitgesproken historisch karakter. Het proces van Individuation was immers in hoge mate historisch bepaald. ${ }^{143}$ 'Historische stadia' vormden een van de meest algemene Besonderungen die hij onderscheidde. De geestesgesteldheden van mensen in het verleden konden niet uit 'de tegenwoordige toestand van de psychologie' 'gededuceerd' worden, maar dienden 'inductief' en vergelijkenderwijs onderzocht te worden. ${ }^{144}$ Alle 'hogere' psychische verschijnselen, gemoedstoestanden incluis, moesten uitdrukkelijk als 'historische produkten' te worden beschouwd. ${ }^{145}$ Het was voor Dilthey maar de vraag 'of de mensen in verschillende tijden voor wat betreft de sterkte van de motivaties als binnen zekere grenzen gelijk konden worden beschouwd'. ${ }^{146}$ In ieder geval was er in de loop van de geschiedenis sprake van steeds verder toegenomen 'kwantitatieve verschillen in de eigenschappen' van mensen en derhalve van een toenemende individualisering. ${ }^{147}$ Deze toegenomen kwantitatieve psychische verschillen schreef hij toe aan de voortschrijdende arbeidsdeling en 'sociaalpolitieke differentiëring' en aan de 'toename van cultuur'.

Diltheys beschrijvende en analyserende psychologie kende eigen methoden. De analyse van de psychische Besonderungen zou niet in de eerste plaats door experiment

${ }^{139}$ Dilthey (1914-2006), V, 229-235.

${ }^{140}$ Dilthey (1914-2006), V, 214.

${ }^{141}$ Dilthey (1914-2006), V, 62-62n.

${ }^{142}$ Dilthey (1914-2006), V, 60.

${ }^{143}$ Typerend was de grote betekenis die Dilthey hechtte aan het generatie-begrip. Zie bijv. zijn verhandeling Über das Studium der Geschichte der Wissenschaften uit 1875, waarin hij ingaat op het generatie-begrip en zijn betekenis voor de (intellectuele) geschiedenis. Hij noemde daar een generatie het 'natürliche innere Zeitmaß geistiger Bewegungen' (Dilthey (1914-2006), V, 42). Het gaat dan om mensen die 'in den Jahren der Empfänglichkeit dieselben leitenden Einwirkungen erfahren', 'einen engen Kreis von Individuen, welche durch Abhängigkeit von denselben großen Tatsachen und Veränderungen [...] trotz der Verschiedenheit hinzutretender anderer Faktoren zu einem homogenen Ganzen verbunden sind.' (Dilthey (1914-2006), V, 37) De invloeden op een generatie verdeelde Dilthey in twee categorieën: 'der Besitzstand der intellektuellen Kultur' en de invloed 'des umgebenden Lebens, gesellschaftlicher, politischer, mannigfach unterschiedener Kulturzustände’ (ib.).

${ }^{144}$ Dilthey (1914-2006), XVIII, 6.

${ }^{145}$ Dilthey (1914-2006), XVIII, 218; Dilthey (1914-2006), V, 35.

${ }^{146}$ Dilthey (1914-2006), V, 62.

${ }^{147}$ Dilthey (1914-2006), V, 236-237. 
of introspectie moeten gebeuren. Voor zover het ging om de historische differentiaties van het psychische leven was dat zelfs onmogelijk. Een belangrijke aanvulling vormde daarom de analyse en vergelijking van cultuuruitingen, door Dilthey net als door de Völkerpsychologen samengevat onder de hegeliaanse noemer 'objectieve geest': 'In de taal, de mythen, de literatuur en de kunst, überhaupt in alle historische prestaties hebben we als het ware tot voorwerpen geworden psychisch leven voor ons [...]'. ${ }^{148}$

$\mathrm{Al}$ in 1866 had Dilthey gepleit voor een dergelijke studie van 'psychische feiten' op grond van verzamelde historische gegevens. ${ }^{149}$ 'Wat de mens is', zo luidden misschien wel de beroemdste woorden van Dilthey uit de Ideen, 'dat leert hij immers toch niet door gepieker over zichzelf, ook niet door psychologische experimenten, maar door de geschiedenis.' En aan het eind van deze verhandeling riep hij uit: 'Wat een opgave, om de brug te slaan tussen de psychologie zoals die tot nu toe was en de manier van kijken van de historische wereld! ${ }^{150}$

Welke aanwijzingen zijn er dat de nieuwe cultuurhistorici inderdaad onder de indruk raakten van Diltheys opvattingen over psychologie en geschiedenis? Allereerst kan worden vastgesteld dat Dilthey op verschillende manieren persoonlijk betrokken was bij de nieuwe cultuurgeschiedenis: hij was niet alleen een geliefd docent van Breysig en Gothein, ${ }^{151}$ maar raakte ook geïnvolveerd in Steinhausens Archiv für Kulturgeschichte. Zijn naam verscheen in 1910 op het titelblad als een van de nieuwe hooggeleerde medewerkers aan het tijdschrift, dat op initiatief van Goetz nieuw leven was ingeblazen. Bovendien werd in het blad de samenwerking met Diltheys voormalige studenten Spranger en Misch aangekondigd; de laatste zou, en dat mag typerend heten voor het historisch-psychologisch programma van Dilthey èn de nieuwe cultuurgeschiedenis, literatuurberichten moeten gaan verzorgen over 'de geschiedenis van de persoonlijkheidsontwikkeling'.

Zelfs Lamprecht, die verder geen persoonlijke relatie tot Dilthey onderhield, beschouwde diens 'beschrijvende psychologie' als een welkome stap in de ontwikkeling van een door hem gewenste nieuwe psychologie. ${ }^{152}$ Toen Rachfahl in 1896 Diltheys studie over beschrijvende psychologie tegen Lamprechts opvattingen in stelling probeerde te brengen, wees Lamprecht terecht op een fundamentele overeenkomst tussen hun beider opvatting, namelijk dat de psychologie, in welke vorm dan ook, als fundament van de geschiedwetenschap zou moeten worden beschouwd. ${ }^{153}$ En hij citeerde meer dan eens met instemming Diltheys uitspraak dat we uit de geschiedenis

${ }^{148}$ Dilthey (1914-2006), V, 199.

${ }^{149}$ Dilthey (1914-2006), XVIII, 16

${ }^{150}$ Dilthey (1914-2006), V, 180, 237.

${ }^{151}$ Breysig deelde de waardering voor Dilthey met zijn belangrijkste leermeester, de Nationalökonom Gustav Schmoller. Hij bedankte Dilthey in zijn dissertatie van 1889. Hij kende in ieder geval vanaf 1900 Diltheys verhandeling over beschrijvende psychologie uit 1894, die hij waardeerde als 'ein Meisterwerk eines großen Bauplanes', zie Breysig (1962), 125 (brief aan Hans Driesch van 23.11.1916). Dilthey zelf noemde zijn verhouding tegenover Breysig daarentegen sauer-süß: hij waardeerde bijvoorbeeld Breysigs Stufenbau, maar wilde tot Breysigs eigen verbazing niets weten van de 'historische Gesellschafts-Seelenkunde' in zijn Kulturgeschichte der Neuzeit, zie Breysig (1962), 107 (gesprek met Dilthey 1904), 143 (brief aan Driesch 1926). Vgl. Brocke (1971), 268 en 294, ook 90, 93 94. In de Berlijnse faculteitsstrijd over de oprichting van een seminarium voor vergelijkende geschiedwetenschap onder leiding van Breysig nam Dilthey een tussenpositie in tussen de fel tegen Breysig gekante historici en de voorstanders onder leiding van Schmoller.

152 Zie Lamprecht (1974), 842 [1913].

${ }^{153}$ Zie Lamprecht (1896), 19. Dilthey van zijn kant uitte weinig waardering voor Lamprecht. In een gesprek met Breysig liet hij zich bijzonder negatief uit over Lamprecht ('hat sehr auf ihn gescholten') en verweet Breysig zelfs zijn contact met de Leipzigse historicus, zie Breysig (1962), 107. Opvallend is overigens dat Dilthey zelf wel veel werk van Lamprecht las en exerpeerde, zie Thielen (1999), 227-228. 
kunnen leren dat de mens 'auch in seinen tiefsten Bezügen' ongemerkt door de historische omstandigheden 'als door muren' omsloten is. ${ }^{154}$ Uit erkenning van hun intellectuele verwantschap bracht Dilthey-leerling Eduard Spranger de projecten van beide wetenschappers meer dan eens direct met elkaar in verband: naar zijn mening had alleen Dilthey rond 1900 een psychologie ontwikkeld die verenigbaar was met Lamprechts conceptie van geschiedenis als Seelengeschichte. ${ }^{155}$ Ook een andere bekende Dilthey-volgeling, Erich Rothacker, liet zich (althans aanvankelijk) ook inspireren door Lamprechts ideeën. ${ }^{156}$

Geen van de nieuwe cultuurhistorici bewoog zich echter zozeer in de invloedsfeer van Dilthey als Eberhard Gothein. Voor Gothein was Dilthey in ieder geval gedurende zijn Breslause studietijd (1872-1874, 1875-1877) zijn belangrijkste docent. Al in zijn tweede semester werd hij door Dilthey opgenomen in diens seminarium en verwierf daar meteen, althans volgens het getuigenis van Gotheins vrouw en biografe, een leidende rol. ${ }^{157}$ Terugblikkend op de eerste studiejaren in Breslau, schreef Gothein zijn methodische vorming voor een belangrijk deel toe aan Dilthey, wiens Einleitung in die Geisteswissenschaften hij als 'het belangrijkste filosofische werk van zijn tijd' beschouwde. ${ }^{158}$ Gotheins eerste grote cultuurhistorische werk, Die Culturentwicklung Süd-Italiens (1886) was volgens het voorwoord niet alleen beïnvloed door Burckhardt, maar ook schatplichtig aan Dilthey. Op de eerste Duitse sociologendag in 1910 maakte Gothein duidelijk waarin die schatplichtigheid tegenover zijn leermeester 'zu dem ich mich in meinen grundlegende historischen und philosophischen Ansichten bekenne', lag. ${ }^{159} \mathrm{Hij}$ verklaarde zichzelf daar tot een groot bewonderaar van Diltheys 'baanbrekende' verhandeling over beschrijvende psychologie, die ook al door Breysig als 'meesterwerk' was gekwalificeerd. ${ }^{160}$ Zijn parafrase van de kerngedachte van Diltheys Ideen, besloot hij met de meest poëtische verantwoording voor het psychologische karakter van de nieuwe cultuurgeschiedenis die uit de pen van een van de nieuwe cultuurhistorici vloeide: ${ }^{161}$

'Afgeleide psychologie, dat is in wezen elke cultururwetenschap. Dan is het van belang de psychologische fundamenten zo breed mogelijk op te vatten. Dat lukt echter alleen, wanneer wij de historische werkelijkheid in het oog houden, evenwel niet om daaraan voorbeelden te ontlenen, maar om de ontwikkeling van de psychische eigenschappen, zowel van de

${ }^{154}$ Zie Lamprecht (1988), 210 [1896]; ook opgenomen in Lamprechts aforismenbundel uit 1910: Lamprecht (1974), 724.

${ }^{155}$ Spranger (die met Lamprecht correspondeerde) brengt Lamprecht en Dilthey meer dan eens onder één noemer, zie Spranger (1969-1980), IV, 57, 372, en VII, 10.

${ }^{156}$ Zowel Spranger (1905) als Rothacker (1912) wijdden hun dissertatie geheel of gedeeltelijk aan Lamprechts opvattingen, die zij bovendien minstens ten dele aanvaardden.

${ }^{157}$ Gothein (1931), 10. Volgens Salin zag Dilthey in de jonge student Gothein zelfs 'den geborenen Vollender seines Werkes', Salin (1924), XII. Het was Dilthey die Gothein wist over te halen om naar Breslau terug te keren in zijn filosofisch seminarium en niet bij Burckhardt in Bazel te gaan studeren of in Heidelberg economische colleges te blijven volgen, zie Gothein (1931), 22. Dilthey liet zich in 1881 tegenover Treitschke lovend uit over de 'sehr begabte junge Historiker' die op dat moment als docent op zoek was naar een vaste universitaire positie, zie Thielen (1999), 227n66 (brief aan Treitschke

27.10.1881). En in 1882 schijnt het Dilthey te zijn geweest die zich inzette om Gothein op een kunsthistorische leerstoel in Breslau geplaatst te krijgen; zie Gothein (1931), 42.

${ }^{158}$ Gothein (1889), 20. Als diens grootste verdienste roemt hij het een einde te hebben gemaakt aan de verkeerde toepassing van natuurwetenschappelijke methoden à la Buckle, Comte en Spencer (60). Ook in zijn encyclopedielemma over Gesellschaft (1892) wordt Dilthey in deze zin aangevoerd (Gothein (1892a), 843). Zie ook Gothein (1889), 5.

${ }^{159}$ Gothein (1911), 247.

${ }^{160}$ Vgl. ook Gothein (1931), 216.

${ }^{161}$ Gothein (1911), 247. 
afzonderlijke individuen als van de massa's juist te beoordelen. Want deze [psychische] eigenschappen verschijnen in telkens nieuwe samenstellingen, en zij bepalen niet alleen het historische leven, maar worden zelf daardoor bepaald. De psyche, dat tere ding met zijn vleugelpaar, is zelf het veranderlijkste in de loop der tijden. ${ }^{, 162}$

\section{De Historische School in de Nationalökonomie}

Tot nog toe hebben we in dit hoofdstuk gewezen op individuele wetenschappers die van invloed zijn geweest op de opvattingen over de plooibare psyche onder de nieuwe cultuurhistorici. Zij waren onder de indruk geraakt van de (historisch-)psychologische analyses in het werk van Burckhardt, Freytag en Riehl en verschillende schrijvers uit de herbartiaanse traditie. Zij waren bovendien in hun opvattingen over het belang van een (historisch-)psychologische analyse voor de geschiedwetenschap persoonlijk beïnvloed door verschillende docenten, van wie de historicus Ernst Bernheim en de filosoof Wilhelm Dilthey de belangrijkste moeten worden geacht. Toch is het de vraag of de nieuwe cultuurhistorici uitsluitend op grond van deze individuele invloeden zo radicaal en publiekelijk voor een hervorming van hun vak zouden hebben gepleit als zij deden, indien het bij deze intellectuele 'achterban' zou zijn gebleven.

Zij hadden echter daadwerkelijk een steviger en uitgebreider back up dan dat. De nieuwe cultuurhistorici wisten zich zowel theoretisch en praktisch gesteund door een dominante stroming binnen een geesteswetenschappelijke discipline waarvoor de psychologie als fundament gold. Die discipline was niet de geschiedwetenschap, maar de Nationalökonomie, meer speciaal de Historische School binnen de Nationalökonomie.

De intensieve betrekkingen tussen de nieuwe cultuurhistorici en de economen uit de Historische School waren gebaseerd op een Wahlverwandtschaft. ${ }^{163}$ Er was sprake van een wederzijdse waardering en herkenning van standpunten en benaderingen. De Nationalökonomen komt daarbij de prioriteit toe, zowel in tijd als in schoolvorming: de nieuwe cultuurhistorici gingen bij hen in de leer en niet omgekeerd. Wanneer we het programma van de Historische School bezien dan valt op hoezeer veel van de standpunten die de nieuwe cultuurhistorici binnen de historische discipline uitzonderlijk en tot mikpunt van kritiek maakten, een volstrekt geaccepteerd onderdeel vormden van de uitgangspunten van de Historische School. En tot die uitgangspunten behoorde ook de overtuiging van de fundamentele betekenis voor hun vak van een vorm van (historische) psychologie.

De Historische School in de Nationalökonomie kwam in Duitsland op in de loop van de jaren veertig als een kritiek op de klassieke Engelse economische theorie, zoals die was geformuleerd door onder anderen Adam Smith, Malthus en Ricardo. Deze economen hadden ook in Duitse landen in de eerste helft van de negentiende eeuw veel aanhang verworven. ${ }^{164}$ Het was Wilhelm Roscher, Lamprechts promotor, die in het begin van de jaren veertig als een van de eerste Duitse economen principieel afstand nam van de klassieke benadering met het argument dat de economie niet deductiefwiskundig, maar nach geschichtlicher Methode bestudeerd diende te worden - een standpunt dat kort daarna door zijn collega's Karl Knies en Bruno Hildebrand

\footnotetext{
${ }^{162}$ Gothein (1911), 247 (mijn cursivering MS)

${ }^{163}$ Zie over die betrekkingen Hoofdstuk 4, paragraaf 5.

${ }^{164}$ Zie Winkel (1977).
} 
overgenomen en verdedigd zou worden. ${ }^{165}$ Een volgende lichting historische economen, die de economische discipline in de jaren 1870-1914 zou gaan domineren, maakte van dit programma dagelijkse praktijk en stortte zich op de gedetailleerde bestudering van de economische geschiedenis volgens de regels van de historische kritiek. Toen Eberhard Gothein in 1893 in een state-of-the-art-artikel moest aangeven wat de positie was van de economische geschiedenis binnen de Staatswissenschaften, merkte hij zonder aarzeling op dat zij werd beschouwd als het fundament van de gehele Nationalökonomie. ${ }^{166}$ Studenten in de Nationalökonomie volgden in de hoogtijdagen van de Historische School niet alleen colleges economie en financiën, maar ook 'Gesellschaftslehre, Kulturgeschichte, Politik' en een grote hoeveelheid 'Wirtschafts- und Verwaltungsgeschichte'. ${ }^{167}$

Schmoller, een leerling van Roscher, leverde met zijn studie over Die Straßburger Tucher- und Weberzunft [...] vom 13. bis 17. Jahrhundert (1879) het bekendste voorbeeld van de nauwgezette bronnenstudie van de jongere historisch-economische richting. ${ }^{168}$ Van de andere docenten en vrienden van de cultuurhistorici stonden Hanssen en Meitzen bekend als specialisten op het terrein van de agrarische geschiedenis. ${ }^{169}$ Brentano schreef een geschiedenis van de Engelse arbeidersverenigingen (1871) als onderdeel van zijn Arbeitergilden der Gegenwart. Knapp publiceerde in 1887 een geschiedenis van de boerenbevrijding en de opkomst van landarbeiders in Pruisen. ${ }^{170}$

De kritiek van de economen uit Historische School op hun Engelse collega's kan kort samengevat worden. ${ }^{171}$ Het was naar hun mening onmogelijk om algemene economische wetten te formuleren die voor elke tijd, elke plaats en elke situatie golden. Derhalve leverde de deductieve methode van theorievorming binnen de economie weinig op: zij deed te weinig recht aan de gecompliceerdheid van de feitelijke economische ontwikkelingen. Het was opnieuw Gothein die dit standpunt van de Duitse economen in een Festschrift voor Karl Knies treffend verwoordde: ${ }^{172}$

'[De Duitse economische leer] verwerpt het [...], om algemene theorieën uit schijnbaar vaststaande psychologische feiten af te leiden en de bonte veelvormigheid van de werkelijkheid in het daaruit afgeleide schema onder te brengen...'

In het kader van dit boek is speciaal de kritiek van de historische economen op de 'schijnbaar vaststaande psychologische feiten' van belang. Maar eerst moet worden vastgesteld dat de historisch economen het op een belangrijk punt volkomen eens waren met de vooronderstellingen van de klassieke economen: zij deelden de klassieke aanname dat de psychologie van fundamentele betekenis was voor de studie van de

${ }^{165}$ Zie Eisermann (1956), 124-129.

${ }^{166}$ Gothein (1893), 584.

${ }^{167}$ Zie de opsommig van collegethema's in: Lexis (1893), 614-616.

${ }^{168}$ Het werk bestaat voor meer dan de helft uit een bronneneditie, gevolgd door een samenvattende studie.

${ }^{169}$ Zie: Georg Hanssen (1880-1884), Agrarhistorische Abhandlungen. Leipzig; Georg Hanssen (1875), Zur Geschichte norddeutscher Gutswirthschaft seit Ende des 16. Jahrhunderts. Göttingen; Georg Hanssen (1832), Historisch-statistische Darstellung der Insel Fehmarn: ein Beitrag zur genauern Kunde des Herzogthums Schleswig. Altona: Hammerich. August Meitzen (1868-1871). Der Boden und die landwirtschaftlichen Verhaeltnisse des Preussischen Staates nach dem Gebietsumfange vor 1866 unter Benutzung der amtlichen Quellen dargestellt. Berlin: Wiegandt \& Hempel; August Meitzen (1895). Siedelung und Agrarwesen der Westgermanen und Ostgermanen, der Kelten, Römer, Finnen und Slawen. Berlijn.

${ }^{170}$ Lovend besproken door Lamprecht (1888).

${ }^{171}$ Zie Schäfer (1971), 32 e.v., vgl. ook Winkel (1977), 99.

${ }^{172}$ Gothein (1896), m.n. 234. 
economie. De onbetwiste voorman van de jongere Historische School, Schmoller, wijdde een belangrijk deel van de inleiding van zijn grote theoretische werk Grundri $\beta$ der allgemeinen Volkswirtschaftslehre (1901) aan de algemene omschrijving van het psychologische fundament van de economie. De 'geestelijke krachten' van de mens moesten beschouwd worden als de laatste oorzaken van de economische (en andere sociale) verschijnselen, schreef hij daar: ${ }^{173}$

'De binnen de wereld van de natuur tot stand gebrachte wereld van de economische cultuur, dankt haar ontstaan toch in eerste instantie aan de geestelijke krachten van mensen, die zich in de eerste plaats aan ons voordoen als gevoelens en driften, als voorstellingen en doelen, en verder als handelingen en routinematige wilsrichtingen [habituelle Richtungen des Willens].'

Uit dit citaat blijkt overigens dat Schmoller, net als de nieuwe cultuurhistorici, tot degenen behoorde, voor wie de termen Geist en Psyche in hoge mate synoniem waren. ${ }^{174}$ Onder 'geistige Kräften' verstond hij niet alleen of zelfs in de eerste plaats intellectuele krachten; het ging daarbij allereerst om gevoelens en driften, en verder ook om denkbeelden en doelstellingen, handelingen en gewoonten.

In het register bij zijn theoretische hoofdwerk noteerde Schmoller achter de woorden Psychologie, psychologisch: 'sleutel tot alle geesteswetenschappen' (waartoe hij ook de economie rekende). ${ }^{175}$ Het onderstreept de overeenkomst met de Britse economen op dit punt dat Schmoller elders met kennelijke instemming John Stuart Mills definitie van de economische studie citeerde; het ging daarbij volgens Mill om de wetenschap 'relating to the moral and psychological laws of the production and distribution of wealth'. ${ }^{176}$ En dit was niet een opvatting die Mill alleen met Schmoller deelde: een groot deel van de Duitstalige economische literatuur rond 1900 werd gekenmerkt door 'een psychologisch-zedelijke visie, die realistisch uitgaat van de driften en gevoelens', zoals Schmoller het formuleerde. ${ }^{177}$

In deze formulering valt echter tegelijk de kritiek van de Duitse economen op de klassieke economen te beluisteren. Belangrijk was hier het woord 'realistisch': het betekende dat economen niet dienden uit te gaan van algemene aannames over de driften en gevoelens van de economische actoren, zoals dat in het klassieke economische model gebeurde. Dat model was gebaseerd op de voorstelling van de homo economicus, dit wil zeggen van een universeel geldige psychologische analyse van het individu waarin de Erwerbstrieb, het egoïstische streven naar vermeerdering van goederen, de belangrijkste plaats innam. Schmoller daarentegen meende dat de aard en kracht van de driften en gevoelens per situatie vastgesteld moesten worden. Hij pleitte met andere woorden voor 'massa-' of 'historisch-psychologische' benaderingen zoals die eerder al door Schäffle, Knies en Hildebrand waren verdedigd. ${ }^{178}$

${ }^{173}$ Schmoller (1894), 559.

${ }^{174}$ Vgl. Hoofdstuk 5, Paragraaf 7.

${ }^{175}$ Zie Schmoller (1901), 477.

${ }^{176}$ Schmoller (1894), 550. In het register bij zijn theoretische hoofdwerk noteerde Schmoller achter 'Psychologie': 'Schlüssel zu allen Geisteswissenschaften', zie Schmoller (1901), 477.

${ }^{177}$ Schmoller (1901), I, 122. Zo ook Schäfer (1971), 103 en 77-88. 'Zedelijk' (vertaling van 'sittlich') is hier equivalent met het contemporaine Engelse 'moral'.

${ }^{178}$ Schmoller (1888) over zijn voorgangers Schäffle (222), Hildebrand (298) en Knies (207): 'Er verlangt das konkrete Erfassen der Wirklichkeit. Er hat die entsprechende Fühlung für die psychischen Massenzusammenhänge, er begreift die Tiefen des Volksgeistes, aus denen heraus alles historische Werden entsteht. [...] der theoretische Begründer der historisch-psychologischen modernen deutschen Nationalökonomie'). Vgl. Eisermann (1956), 136, 142 e.v. (over Roscher); 202 (over Knies). Eisermann, die in het algemeen negatief over de Historische School oordeelt, interpreteert het Volksgeist-begrip van de economen overigens ten onrechte als romantisch organologisch gedachtengoed. 
De economen uit de Historische School deelden dus weliswaar de klassieke opvatting over de fundamentele betekenis van psychologische factoren voor de studie van de economie. Maar volgens hen kon alleen een sociale, collectieve psychologie of leer van de volksgeest het fundament van de economie vormen. Het individu mocht niet als 'geïsoleerde, zelfstandige kracht' beschouwd kon worden, zoals de klassieke economische modellen veronderstelden. Een 'collectieve geest' 'beheerst het doen en handelen van alle individuen, ook wat de economische kant betreft'. ${ }^{179}$ 'Natuurlijk ontstaat elk gevoel, elke voorstelling, elke wilsdaad in de afzonderlijke mens', schreef Schmoller bijvoorbeeld. Maar tegelijk moest worden ingezien

'dat elk mens beheerst en bepaald wordt door zijn milieu, d.w.z. door de hem omringende mensen en bestaansvoorwaarden, waarvan de geestelijke elementen de belangrijkste zijn. ${ }^{180}$

Collectieve psychische eigenschappen ontstonden volgens Schmoller onder invloed van het materiële en psychische milieu, als mensen van hetzelfde ras bij elkaar onder dezelfde omstandigheden leefden. De verklaring die hij voor deze 'collectieve geestelijke fenomenen en psychische massaverschijnselen' aanvoerde, was, in overeenstemming met herbartiaanse opvattingen, de onderlinge communicatie tussen individuen. De historische ontwikkeling van de communicatiemiddelen bepaalde derhalve in belangrijke mate de veranderingen in de aard en omvang van de collectieve geestesgesteldheden:

'Terwijl er vroeger slechts een sterke innerlijke psychische samenhang bestond tussen leden van een gezin, gemeente of stam, zo is deze tegenwoordig ontstaan tussen de leden van het volk' ${ }^{181}$

Dit verschijnsel was uitdrukkelijk een historisch product, een gevolg van de sterk tot ontwikkeling gekomen scholing, pers en publieke opinie, en verder van de moderne verkeersmiddelen en de daardoor mogelijk geworden nationale arbeidsdeling die de onderlinge nationale verbindingen sterk hadden bevorderd, en ten slotte van de talloze nationale instituties, van het recht tot leger en bestuur. De volksgeest was echter niet de enige collectieve psychische gesteldheid: er waren kleinere van dergelijke collectiva, zoals gezin en familie, maar ook grotere, zoals de mensheid als geheel. De natie nam in zoverre een speciale plaats in, als tussen de leden van een volk nu eenmaal meer en nauwere banden bestonden dan tussen leden van verschillende volkeren. Schmollers (enigszins overhaaste) conclusie daaruit was dat binnen een natie de Volkswirtschaft beheerst werd door 'uniforme psychische en materiële oorzaken'. ${ }^{182}$

Verhelderend voor het begrip van Schmollers idee van de collectieve geestesesteldheid, is de manier waarop hij zijn standpunt onderscheidde van de opvattingen van de historicus Treitschke. Ook Treitschke geloofde in de betekenis van de 'volksgeest': 'men gaat uit van de geest van een volk en laat zien hoe deze genius zich in de staat, in het geestelijke, economische leven enz. openbaart', had Treitschke bijvoorbeeld geschreven. ${ }^{183}$ Maar, zoals Schmoller opmerkte, voor Treitschke was de ongelijkheid tussen zowel groepen mensen als individuen een natuurlijk en onverandelijk gegeven, en sociale instituties als het privé-eigendom en het huwelijk belichaamden voor hem onverandelijke zedelijke idealen. Voor Schmoller zelf daarentegen waren culturele

\footnotetext{
${ }^{179}$ Schmoller (1998), 220; Schmoller (1894), 529.

${ }^{180}$ Schmoller (1901), I, 15

${ }^{181}$ Schmoller (1894), 529.

182 Ibidem.

${ }^{183}$ Treitschke (1859), 71.
} 
invloeden fundamenteel in de vormgeving van zowel zedelijke idealen als verschillen tussen (groepen) mensen. Slechts bepaalde elementaire fysische natuurprocessen waren historisch gezien onveranderlijk; 'verder zie ik overal slechts een voortschrijden [Fortschritt]'. Overeenkomsten in zedelijke idealen tussen de verschillende cultuurvolkeren werden naar zijn mening dan ook niet veroorzaakt door de universele en onveranderlijke overtuigingskracht van dergelijke idealen, maar door de gelijke uiterlijke levensvoorwaarden en de daardoor veroorzaakte noodzakelijk analoge historische ontwikkeling. Andere omstandigheden zouden leiden tot andere mensen: 'Zelfs bij de krachtigste stammen, bijvoorbeeld bij de negers, brengt een bepaalde behandeling na weinige generaties totaal andere mensen voort'. ${ }^{184}$

De opvatting over de fundamentele plooibaarheid, zelfs maakbaarheid van de menselijke psyche die hier tot uitdrukking werd gebracht, was onverenigbaar met romantische of idealistische opvattingen over de volksgeest. Schmoller beschouwde het dan ook als een verdienste van zijn leermeester Roscher, de promotor van Lamprecht, dat hij 'deze mystieke voorstellingen van de romantische school' niet tot uitgangspunt had gekozen. Hij verweet in een publiek debat in 1883 zijn collega Menger (die niet tot de Historische School behoorde) juist diens 'levendige sympathie voor de mystiek van Savigny's volksgeest'. ${ }^{185}$ In zijn theoretische hoofdwerk wees hij het romantisch volksgeestconcept opnieuw met zoveel woorden af:

'Er bestaat geen objectieve volksgeest, die onafhankelijk is van de individuen, ze bestuurt en op mystieke wijze beheerst, zoals de historische rechtsschool leerde; evenmin een algemene wil, die in alles overeenstemt, zoals Rousseau droomde.'

De historische economen beriepen zich voor hun collectieve psychologie niet op de romantische, statische volksgeest-gedachte. Veeleer sloten zij aan bij wetenschappers uit de herbartiaanse traditie. In zijn psychologische grondlegging van de economische studie verwees Schmoller bijvoorbeeld herhaald naar werk van Herbart en de herbartianen. ${ }^{186}$ Het was ook niet toevallig dat een van de oudere economen uit de Historische School, Bruno Hildebrand, als toenmalig rector van de universiteit van Bern persoonlijk betrokken raakte bij de aanstelling van Moritz Lazarus als (honorair) hoogleraar Völkerpsychologie, de eerste psychologische leerstoel aan een Duitstalige universiteit überhaupt. ${ }^{187}$ Evenmin toevallig was het dat een leerling van Schmoller, Franz Eulenburg, bijdragen leverde aan de theorievorming over de sociale psychologie en daarbij uitdrukkelijk de gedachte van de veranderlijkheid van de collectieve psyche omarmde. $^{188}$

In het eerder genoemde debat met Treitschke verwees Schmoller naar de elders door hem bekritiseerde klassieke econoom Adam Smith om zijn gelijk te halen: ook Smith zou er al op gewezen hebben dat de ongelijkheid tussen mensen grotendeels een maatschappelijk product was. ${ }^{189}$ Deze verwijzing naar Smith was geen slip of the pen, zoals we mogen concluderen uit de onovertroffen scherpe en grondige analyse van de methodenstrijd tussen Schmoller en de 'abstracte' econoom Menger, die Reginald

\footnotetext{
${ }^{184}$ Schmoller (1875), 9, 18-30.

${ }^{185}$ Schmoller (1888), 292.

${ }^{186}$ Zie Schmoller (1901), literatuuropgaven op blz. 6 (Schäffle), 10 (Steinthal), 15 (Herbart, Lazarus, Steinthal, Lindner), 41 (Herbart, Steinthal, Simmel), 48 (Lazarus).

${ }^{187}$ Zie Belke (1971), XXVI-XXVII.

${ }^{188}$ Zie Eulenburg (1907), 336 en Eulenburg (1900). Eulenburg was gepromoveerd bij Schmoller op een historisch onderwerp.

${ }^{189}$ Schmoller (1875), 23.
} 
Hansen jaren geleden heeft gepubliceerd. ${ }^{190}$ De conclusie van deze analyse luidt dat, terwijl Schmoller's tegenstander sterk door romantische denkers en historistische theorievorming - met name Droysen - werd beïnvloed, Schmoller's wetenschapstheorie juist sterk door het Engelse empirisme en positivisme was gevormd. Schmoller bewonderde met name de wetenschapsleer van John Stuart Mill, zoals neergelegd in diens beroemde Logic. Hij was ook bekend met Mills variant van de Völkerpsychologie, de ethology. Hij bezorgde Mill in 1867 zelfs het eredoctoraat van de universiteit van Halle. ${ }^{191}$ En zoals Schmoller Mill waardeerde, zo spraken ook vertegenwoordigers van de oudere Historische School in de Nationalökonomie bij alle kritiek toch hun fundamentele waardering uit voor representanten van de klassieke school. Zo verwonderde Max Weber zich al over het feit dat ook Roscher verschillende malen Smith en Malthus had geprezen, nota bene als voorlopers van een historische benadering in de economie! ${ }^{192}$

Bij alle kritiek die de vertegenwoordigers van de Historische School hadden op de klassieke economen, deelden zij derhalve uiteindelijk hun wetenschapstheoretische uitgangspunten. Dat verklaart ook waarom zij zo tweeslachtig stonden tegenover Duitsnationale economen die meer in de romantiek waren geworteld, met name Adam Müller en Friedrich List: zij deelden weliswaar hun historische en nationale oriëntatie, maar de kentheoretische fundering daarvan was verschillend en bij de historische economen geworteld in het Engelse empirisme. ${ }^{193}$ De 'historische' benadering van de Historische School stond niet in een historistische, idealistische of romantische traditie, maar ging terug op empiristische, Verlichte standpunten.

De uitingen van deze wetenschapstheoretische oriëntatie komen niet alleen naar voren in hun ideeën over de aard van de 'collectieve geest', maar ook in de opvattingen die binnen de jongere Historische School bestonden over hun eigen, uitdrukkelijk 'empirisch-realistische' genoemde onderzoeksmethoden. ${ }^{194}$ Inderdaad behoorde daartoe ook de 'historische methode'. Maar de economen verstonden daaronder niet uitsluitend de kritische methode van bronnenonderzoek, die voor geharnaste historisten het alfa en omega was. Het doel van historisch detailonderzoek was voor de economen niet om de uniciteit van een historisch fenomeen vast te stellen, maar om 'typische Reihen und Formen' (Schmoller) op het spoor te komen. Zowel in bepaalde (synchrone) toestanden als in de (diachrone) opeenvolging van toestanden probeerden zij een patroon of regelmaat te ontdekken; het een leidde tot het beschrijven van typische vormen (bijvoorbeeld van economische organisatie), het andere tot het opstellen van typische reeksen (bijvoorbeeld van achtereenvolgende ontwikkelingsfasen).

De oriëntatie op het algemene of typische bleek bijvoorbeeld in Schmoller's historische onderzoek naar de Straatsburgse textielgildes. Kurt Breysig prees deze

${ }^{190}$ Hansen (1968).

${ }^{191}$ Hansen (1968), 144. De waardering voor Mill gold ook het psychologische aspect van diens denken. Schmoller kende Mills voorstel in diens Logic voor de formulering van een ethology (sociale karakterkunde) als fundament van de sociale wetenschappen: Schmoller (1894), 550.

${ }_{192}$ Weber stelde ook al vast dat het volksgeest-concept van economen van de oudere Historische School in de Nationalökonomie uiteindelijk niet van romantische huize was: de idealistische opvatting van de Volksgeist als oerelement, per volk uniek en als eenheid samenhangend, werd bij deze economen gemengd met een 'biologistische' opvatting over volkeren als aparte soort, die enerzijds individuele verschillen vertonen, maar anderzijds juist vergelijkbare, typische ontwikkelingen met typische fasen (Kulturstufen) doorlopen. Zie Weber (1988), 10-25, 138-145.

${ }^{193}$ Zie Eisermann (1956), 98-118. Dat Eisermann de economen uit de Historische School deze tweeslachtigheid aanrekent, hangt ermee samen dat hijzelf het romantisch gehalte van de Historische School (naar mijn oordeel te) hoog inschat en daardoor een inconsequentie meent vast te stellen die er niet is. Vergelijk ook Pearson (1999).

${ }^{194}$ Aldus Schäfer (1971). 
studie later juist vanwege Schmoller's vermogen om nauwgezet bronnenonderzoek te combineren met een oog voor algemene ontwikkelingslijnen. En representatief voor de waardering van de nieuwe cultuurhistorici voor dit vermogen was het ook dat Breysig in dit verband sprak van de 'forscherliche Überlegenheit' van Schmoller ten opzichte van de historici Sybel en Treitschke. ${ }^{195}$ Om dezelfde reden moest de Historische School in het algemeen en Schmoller in het bijzonder het overigens juist ontgelden bij sterker historistisch georiënteerde historici zoals Von Below. ${ }^{196}$

De typische vormen en reeksen in het verleden waren voor de historische economen enerzijds een 'heuristisch hulpmiddel', anderzijds verwezen zij wel degelijk naar feitelijke oorzakelijke verbanden. In de diachrone beschouwing uitte de belangstelling voor het algemene en voor de oorzakelijke verklaring zich in de speurtocht naar ontwikkelingswetten. Veel economen van de oudere en jongere Historische School onder andere Hildebrand, Schmoller en Bücher - ontwierpen (economische) ontwikkelingsschema's, waarbij telkens verschillende Stufen werden onderscheiden, benoemd naar de economisch 'typische' vorm van het betreffende tijdperk. Hoe voorzichtig de economen vaak ook waren en opmerkten dat dergelijke faseringen geen aanspraak konden maken op absolute zekerheid en algemene geldigheid, desondanks meenden zij dat het zinvol was om tot een omschrijving van dergelijke opeenvolgende fasen te komen en de ontwikkelingswetten ervan te doorgronden. Ook dat verstonden zij onder een historische benadering - terwijl deze aanpak bij veel vakhistorici - de nieuwe cultuurhistorici daarbij niet inbegrepen - op verzet stuitte.

Typerend voor de empiristische wetenschapstheoretische oriëntatie van de economen uit de Historische School en hun wetenschappelijke belangstelling voor generalisaties was ook hun relatief onproblematische verhouding tot de statistiek. Om tot de vaststelling van het normale en typische, het gemiddelde van bepaalde toestanden en ontwikkelingen te komen, was de statistiek in hun ogen een onontbeerlijk hulpmiddel. Verschillende van de economische docenten en vrienden van de nieuwe cultuurhistorici droegen bij aan de ontwikkeling van de statistiek tot zelfstandige wetenschap. ${ }^{197} \mathrm{Zij}$ werd ook aangewend bij de bestudering van het verleden, zoals bijvoorbeeld in Büchers grote studie over de bevolkingsgeschiedenis van Frankfurt in de middeleeuwen (1886) - in 1888 zeer uitgebreid en lovend geanalyseerd door de toenmalige extraordinarius Lamprecht. Lamprecht zelf was van de nieuwe cultuurhistorici degene die de economen het meest zou volgen in hun gebruik van de statistiek als middel om collectieve verschijnselen te analyseren. Zijn Deutsches Wirtschaftsleben bevatte een compleet deel met statistisch materiaal, maar ook in latere werken gebruikte Lamprecht vaak cijfers en statistieken. In zijn belangrijkste en vroegste geschiedtheoretische werk verwees hij bij herhaling naar de statistiektheoretische verhandeling Zur Theorie der Massenerscheinungen in der menschlichen Gesellschaft (1877) van de Nationalökonom Lexis. Lamprecht mocht dan in 1894 door Winter de grondlegger van de sociaal-statistische methode in de Duitse geschiedwetenschap worden genoemd, de economen hadden al veel eerder statistische en historische benaderingen gecombineerd.

Gezien de methodische voorkeuren van de historisch georiënteerde economen is het een vergissing de Historische School in de Nationalökonomie te beschouwen als een product van de Romantiek of het Duitse idealisme. Zelfs is het niet juist deze richting in de Nationalökonomie zonder meer voor te stellen als een 'zusterstudie van de geschied-

\footnotetext{
${ }^{195}$ Breysig (1944), 80-81.

196 Zie vooral Below (1904).

${ }^{197}$ M.n. Knies, Knapp, Schmoller, Meitzen en Lexis.
} 
wetenschap', zoals wel is gebeurd. ${ }^{198}$ Maar de omgekeerde stelling die onlangs werd verdedigd, namelijk dat de 'Historische School', gezien haar voorkeur voor 'generalisaties' het epitheton 'historisch' helemaal niet verdient, is even aanvechtbaar. ${ }^{199}$ Dat standpunt gaat alleen op als de nadruk op de uniciteit van historische verschijnselen als onderscheidend kenmerk van de geschiedwetenschap wordt beschouwd. En duidelijk is dat in ieder geval de nieuwe cultuurhistorici net als de historisch economen geïnteresseerd waren in historische 'typen' en 'fasen', in algemene lijnen en patronen in het verleden. Wat binnen de geschiedwetenschap not done was, was onder economen algemeen aanvaard. Dat gold ook voor een onderwerp, dat historisch georiënteerde economen en politieke historici op het eerste gezicht verbond: hun erkenning van de belangrijke rol van de staat.

Anders dan de klassieke vrijhandelseconomen geloofden de meeste economen van de Historische School dat de staat niet alleen in de praktijk een invloedrijke factor in economische verschijnselen was - en derhalve in economische analyses de nodige aandacht moest krijgen - maar velen onder hen beoordeelden enig staatsingrijpen bovendien als economisch nuttig en uit sociaal en ethisch oogpunt gewenst. Schmoller was een van de meest uitgesproken bewonderaars van de Pruisische staat onder de historisch georiënteerde economen. Hij bracht niet alleen grootschalige bronnenpublikaties en talloze historische studies op het gebied van de Pruisische binnenlandse politiek tot stand, maar werd ook een van de invloedrijkste representanten van de zogenaamde 'Hohenzollern-legende', waarin het sociale karakter van het Pruisische koningschap werd benadrukt. ${ }^{200}$

Met dit 'Borussentum' stond Schmoller dicht bij de verheerlijking van de Pruisische staat door de historici uit de 'Pruisische' school, zoals in het algemeen de aandacht van de economen voor de staatkundige en politieke context op waardering kon rekenen van de politieke historici. Toch komen juist op dit raakvlak van geschiedwetenschap en economie belangrijke verschillen tussen de historische economen en het gros van de politieke historici naar voren. Terwijl onder vakhistorici de aandacht voornamelijk gericht was op de internationale verhoudingen en de buitenlandse politiek van staten, richtten de economen zich immers vooral op de interne staatkundige aangelegenheden. Zo voegde Schmoller aan de oorspronkelijk door Droysen in 1864 opgezette reeks edities van Pruisische Urkunden und Aktenstücke - die vrijwel geheel aan de buitenlandse politiek was gewijd - een nieuwe afdeling toe met bronnenuitgaven op het terrein van het binnenlands bestuur. Ook een door Schmoller nieuw opgezette bronnenreeks, de Acta borussica, was geheel aan dit thema gewijd. In deze nieuwe bronnenreeksen verschenen bronnen met betrekking tot de geschiedenis van de ambtenarenorganisatie, de economische politiek, het financieel beheer en diverse nijverheidstakken in Pruisen. Deze gerichtheid op de interne verhoudingen komt ook tot uiting in de sterke betrokkenheid van de historische economen bij de academisering en institutionalisering van de regionale geschiedschrijving aan het eind van de negentiende eeuw.

Daarmee deden de economen iets, wat de vakhistorici grotendeels hadden nagelaten: zij waren in hoge mate verantwoordelijk voor de thematische domeinuitbreiding van het archivalisch gefundeerde historisch onderzoek naar het terrein van de binnenlandse en de economische politiek. ${ }^{201}$ En het was deze domeinuitbreiding van

\footnotetext{
${ }^{198}$ Het laatste punt o.a. door Raphael (1990), 356-7.

${ }^{199}$ Pearson (1999).

${ }^{200}$ Zie Bruch (1988), 222, en Hartung (1938), m.n. 681.

${ }^{201}$ Vgl. Gothein (1893), 583-584. Tot de vakhistorische uitzonderingen behoorde de Gießense ordinarius H. Schäfer, die al in 1845 de behandeling van de 'innere Zustände' als nieuwe opgave van de
} 
het historisch onderzoek die bijzonder tot de verbeelding sprak van de latere cultuurhistorici toen zij bij de economen gingen studeren, zoals onder andere blijkt uit het feit dat verschillende onder hen hun dissertaties in economische richting aanpasten. Tekenend is in dit verband ook de uitspraak van de drieëntwintigjarige Breysig in 1889 dat hij door Schmollers college over de interne Pruisische geschiedenis tot de overtuiging was gekomen dat de grenzen van het historisch onderzoek verruimd moesten worden. Schmollers nadruk op de samenhang van materiële, politieke en geestelijke ontwikkelingen had hem afgebracht van 'het oude, platgetreden pad van de traditionele politieke geschiedenis', die beperkt bleef tot de internationale verhoudingen. $^{202}$

Behalve in hun aandacht voor de binnenlandse in plaats van de internationale politiek weken de economen bovendien in een ander, fundamenteler opzicht af van de behandeling van de staat door de politieke historici. Voor de politieke historici was de onderlinge strijd van staten de dynamische factor in de wereldgeschiedenis, waarbij elke staat beschouwd werd als de drager van bepaalde nationale ideeën. Voor de economen lag dat anders. Zij achtten de staat weliswaar van grote historische betekenis, maar zij beschouwden haar geenszins als het alfa en omega van het historisch proces. Een uitspraak van Breysig over zijn leermeester Schmoller kan wat dit betreft veralgemeniseerd worden: 'Schmoller sah die geschichtlichen Dinge aufsteigend von ihren wirtschaftlichen Fundamenten'. ${ }^{203}$ Weliswaar besteedden de historische economen meer aandacht aan de staat dan de klassieke vrijhandelseconomen, maar vergeleken met de politieke historici benadrukten zij juist de economie als historische factor. Te veel, naar de smaak van politieke historici als Below of Treitschke. De laatste, nota bene een promovendus van Roscher, bekritiseerde al vroeg deze neiging onder de historische economen: 'Hand in Hand mit der Ueberschätzung der Wirthschaft geht die Unterschätzung des Staates. ${ }^{204}$

historiografie had bepleit tegenover de aloude geschiedenis van de internationale politiek, zie Hartmann (1971), 87-88.

${ }^{202}$ Zie de brief van Breysig aan Schmoller van 9.8.1889, geciteerd in Brocke (1971), 38-39. Elders naar aanleiding van de thematische uitbreiding van de belangrijkste bronnenreeks voor de Pruisische geschiedenis onder Schmollers leiding: 'Es war Schmollers geistesgeschichtliche Sendung, daß er hier in diesem Einzelfalle wie in seiner Gesamtwirkung auf die deutsche Geschichtsforschung für die Erweiterung des wissenschaftlichen Programms eintrat', Breysig (1962), 34, vgl. ook 31-32. Ook Gothein beschouwde de uitbreiding van het historisch domein tot de economische geschiedenis als de verdienste van de Nationalökonomen.

${ }^{203}$ Breysig (1962), 15.

${ }^{204}$ Treitschke (1859), 38-39. Een discussie waaraan de verschillende evaluatie van de betekenis van de staat door economen en historici gedemonstreerd kan worden, was het debat over de Hofrechtstheorie, een debat dat vanaf de jaren tachtig enkele decennia woedde. Deze discussie betrof de oorsprong van de middeleeuwse stad, maar raakte ook aan de vraag naar de oorsprong van de moderne staat. Veel historici beschouwden de middeleeuwse steden als een product van marktontwikkelingen en koninklijk gezag, uitsluitend onderworpen aan koninklijk recht en vrij van de jurisdictie van de grondheren. In de tijd van vervallend centraal gezag na de Karolingen bleven de steden bestaan als kernen van het koninklijk, publiek gezag, waaruit uiteindelijk de moderne staat voortkwam. Er was zodoende sprake van continuïteit van staatsgezag sinds de vroege middeleeuwen. Volgens veel economen daarentegen was het staatsgezag na de Karolingen geheel te gronde gegaan en waren zowel de steden als de moderne staat uit het middeleeuwse particuliere Hofrecht en de Grundherrschaft en dus uit een privaatrechtelijk en economisch verband opnieuw verrezen. Hoewel in deze kwestie genuanceerde standpunten en afgewogen feitelijke oordelen mogelijk waren, speelden de waardeoordelen van de wetenschappers over de verhouding staateconomie een grote rol. Voor veel historici was het ondenkbaar om de moderne staat uiteindelijk op economische en privaatrechtelijke verhoudingen terug te voeren; er moest sprake zijn van een ongebroken continuïteit van publiekrechtelijk staatsgezag. Below - niet alleen een van de heftigste tegenstanders van Lamprecht, maar ook van de historisch georiënteerde economen - was een van de felste verdedigers van de politieke theorie onder de historici en lanceerde in 1887 in de HZ met steun van Lehmann, Sybel e.a. 
De economen onderscheidden naast economie en staat nog andere aspecten van het volksleven - met name taal, wetenschap, kunst, recht, godsdienst - die zij elk van invloed achten op de nationale ontwikkeling. ${ }^{205}$ Veel minder dan onder de politieke historici was er onder de economen sprake van een een causale (of morele) hiërarchie van deze aspecten - en zó die er al was, neigden zij er eerder toe aan sociale toestanden de belangrijkste plaats toe te kennen dan aan de staatkundige verhoudingen. Het is in dit verband typerend dat Schmoller expliciet de voorkeur gaf aan de uitdrukking 'Volkswirtschaft' boven het oudere 'Staatswirtschaft' ter aanduiding van het terrein van de economische studie. ${ }^{206}$ Als de alomvattende eenheid van onderzoek gold voor hem niet de staat, maar de Gesellschaft. 'Der Ausgangspunkt [der neuen Systematik der politischen Oekonomie] ist die Gesellschaft nach ihren materiellen und ihren psychische Zusammenhängen', schreef Schmoller in 1882; en: 'die Nationalökonomie ist heute nur Wissenschaft, sofern sie sich zur Gesellschaftslehre erweitert und in dem Maße, als sie dies thut'. ${ }^{207}$ Niet verrassend, behoorden tot de eerste leden van de 'Deutsche Gesellschaft für Soziologie', naast cultuurhistorici als Breysig en Lamprecht, ook veel Nationalökonomen, zoals Bücher, Eulenburg, Oppenheimer en Sombart.

Ook op een ander raakvlak tussen politieke historici en historische economen kwamen juist belangrijke onderlinge verschillen in oriëntatie naar voren: hun gedeelde eigentijds engagement en ethisch-politieke oriëntatie. Historici van de Pruisische School hadden zich expliciet, onder luidkeelse afwijzing van het ideaal van 'eunuchenobjectiviteit', ingezet voor de Duitse nationale staatsvorming, overigens zonder daarbij hun claim op wetenschappelijkheid op te geven. ${ }^{208}$ Op dezelfde wijze verdedigden de meeste economen van de Historische School een wetenschappelijk activisme ter verwezenlijking van bepaalde actuele doelen. Zoals Gothein het voor Brentano omschreef: zijn bedoeling was 'praktisch resultaat te boeken door het wetenschappelijke onderzoek van sociale toestanden'. ${ }^{209}$ Toen Schmoller in 1880 de leiding overnam van het economisch Jahrbuch dat later zijn naam zou gaan dragen, sprak hij zich in een redactionele verklaring expliciet uit voor het eigentijdse engagement van de wetenschap, die niet alleen om de kennis zelf bedreven moest worden, maar ook 'als een lamp' het praktische leven moest dienen. ${ }^{210}$

De verbinding tussen heden en verleden die de economen maakten, sprak de cultuurhistorici bijzonder aan. 'Uitermate gelukkig was de verbinding van Nationalökonomie en geschiedenis die Schmoller [...] tot stand bracht', schreef Breysig bijvoorbeeld. 'Er tat dem Zustand der Gegenwart ein volles Genügen, und er lehrte doch nicht nur Gegenwart, sondern auch alle nähere Vergangenheit historisch, das heißt in einem vollen Fließen, zu begreifen. ${ }^{, 211}$ En Goetz schreef over zijn voorbeeld Brentano: 'Zijn wetenschap vertrok vanuit het heden en voerde terug naar het heden $[\ldots][\mathrm{V}]$ oor

een felle aanval op de vertegenwoordigers van de Hofrechtstheorie. Daaronder bevonden zich behalve verschillende economen ook Karl Lamprecht, aan wie een weerwoord in het historisch vakblad werd geweigerd... Zie Chickering (1993), 148-150. Overigens vormde Gothein op dit punt een uitzondering onder de economen en cultuurhistorici: hij was geen aanhanger van de Hofrechtstheorie, zie Gothein (1892b), VII.

${ }^{205}$ Zie Schäfer (1971), 33.

${ }^{206}$ Schmoller (1894), 528.

${ }^{207}$ Zie Schmollers recensie van Schönbergs Handbuch der Politischen Oekonomie (1882) in: Schmoller (1998), 156-157.

${ }^{208}$ Zie Hoofdstuk 5, paragraaf 4.

${ }^{209}$ Gothein (1915), 561 (mijn cursivering, MS).

${ }^{210}$ Schmoller (1998), 98.

${ }^{211}$ Breysig (1962), 15. 
de vorming tot een historicus, [...] die uit het ervaren van het heden, het onervaarbare van het verleden probeert te begrijpen, gaf hij mij oneindig veel'. ${ }^{212}$

Er bestond echter een belangrijk verschil tussen het engagement van de politiek historici en dat van de historisch economen: terwijl voor de historici van de Pruisische School de nationale staatsvorming de inzet van hun geschiedschrijving was, ging het de economen in hun engagement zogezegd om de nationale eenwording: om de overbrugging van de sociale en economische tegenstellingen die mede als gevolg van de rap doorzettende industrialisatie in het Keizerrijk snel leken toe te nemen. Schmoller bracht deze richting van het engagement van de Historische School expliciet tot uitdrukking in de al eerder genoemde redactionele verklaring in zijn Jahrbuch: ${ }^{213}$

'[D]e kant waarachter wij ons scharen, is die partijrichting, die terwijl zij vasthoudt aan de grote verworvenheden van een bijna honderdjarige strijd voor persoonlijke vrijheid, vrije constitutionele vormen en parlementair leven, nu echter gelooft dat het ogenblik voor de Duitse actualiteit is gekomen, waarin het overwegend negatieve ageren voor individualistische vrijheid, kortom het negatieve liberale principe, naar de achtergrond moet treden of zich dient te verzoenen met staatkundige en sociale hervormingsopgaven, die de staat als geheel, de corporaties, de sociale verbanden en verenigingen betreffen en willen versterken.'

Op het individualistische tijdperk van Verlichting en liberalisme - aldus Schmoller - zou nu 'een socialistisch [tijdperk] in de beste zin van het woord volgen, een tijd van hervorming, van wetgeving op sociaal gebied'. Dergelijke idealen hadden al eerder geleid tot de oprichting van de Verein für Socialpolitik (1872), door onder anderen Brentano, Knapp en Schmoller (die ook gedurende vele jaren haar voorzitter was). ${ }^{214}$ Deze Vereniging, die bijna als een vakvereniging voor economen ging fungeren, had als uitgangspunt dat de staat, om een revolutie te voorkomen, diende in te grijpen in het sociale en economische leven van de natie. ${ }^{215}$

Terwijl weinig politieke historici waardering konden opbrengen voor dit 'kathedersocialisme' - Treitschke bijvoorbeeld trad ook op dit punt met de economen in debat - raakte het sociaal-politieke engagement van de Historische School een gevoelige snaar bij de meeste cultuurhistorici. Met uitzondering van Steinhausen kan bij hen allemaal een wending naar het kathedersocialisme worden geconstateerd, die zonder twijfel met hun nabijheid tot de Nationalökonomen uit de Historische School in verband moet worden gebracht. Het is een thema, dat in het volgende hoofdstuk zal worden uitgediept. ${ }^{216}$

Dit hoofdstuk kunnen wij afsluiten met de constatering dat aan de kennismaking van de nieuwe cultuurhistorici met de Historische School van de Nationalökonomie een beslissende invloed op hun conceptie van cultuurgeschiedenis moet worden toegekend. De economen verklaarden, net als de nieuwe cultuurhistorici later, de psychologische basis als fundamenteel voor hun wetenschap en verdedigden de betekenis van een

${ }^{212}$ Goetz (1957a), 13.

${ }^{213}$ Zie Schmoller, 'Ueber Zweck und Ziele des Jahrbuchs' [1880], in: Schmoller (1998), 105.

${ }^{214}$ Tot de oprichters behoorden o.a. Schmoller, Brentano, Knapp, Lexis, en Bücher (overigens ook Delbrück); tot de tweede generatie leden worden o.a. gerekend: Friedrich Naumann, Eberhard Gothein, Eulenburg, Stieda, Sombart en de beide Webers. Zie Lindenlaub (1967), 12-13.

${ }^{215}$ Zie Schmoller, '[Eröffnungsrede auf der ersten Tagung des Vereins für Socialpolitik am 8. Oktober 1872 in Eisenach]', in Schmoller (1998), 67-74.

${ }^{216}$ Zie hierna Hoofdstuk 7, paragraaf 7. 
sociale en historisch georiënteerde psychologie. Zij deelden bovendien hun wetenschapstheoretische oriëntatie: ook zij waren geïnteresseerd in historische type-vorming en het opstellen van ontwikkelingswetten, in statistiek en in de alomvattende bestudering van het 'volksleven', waarin de staat weliswaar belangrijk was, maar haar toch geen primaat toekwam. Tenslotte raakten de nieuwe cultuurhistorici ook onder de indruk van het sociale engagement van de economen.

De economen uit de Historische School vormden de best georganiseerde en meest historisch georiënteerde representanten van het 'Positivisme met een hoofdletter P' binnen de Duitse geesteswetenschappen. Zij vormden de nieuwe cultuurhistorici niet alleen in hun opleiding aan de universiteit, maar steunden hen ook in hun carrière (zoals in hoofdstuk 4 aan de orde is gekomen). Zonder de Historische School is de opkomst van de nieuwe cultuurgeschiedenis binnen de Duitse geschiedwetenschap niet goed te begrijpen.

Maar de historische economen vormden niet de enige inspiratiebronnen voor de nieuwe cultuurhistorici. De economen maakten zelf deel uit van de anti-idealistische, sociaal-psychologische traditie die in Duitsland vrijwel altijd is terug te voeren tot Herbart en die in de variant van Lazarus' en Steinthal's Völkerpsychologie het meest bekend is geworden. Hoewel in de Völkerpsychologie concepten werden gebruikt als Volksgeist en 'objectieve geest' die aan de idealistische, met name hegeliaanse filosofie waren ontleend, was de kritische en empiristische filosofie van fundamentele invloed in deze sociaal-psychologische traditie. Daarin werd de individuele mens als een 'open' wezen beschouwd, dat in zijn karakter en psychische eigenschappen gevormd werd door de invloeden van buitenaf. Door de verschillende omstandigheden en sociale kringen waarin de mensen verkeerden, ontstonden zo psychische eigenschappen die individuen met sommige kringen deelden en met andere niet.

Behalve door de economen, kwamen de nieuwe cultuurhistorici ook door een reeks andere docenten met deze traditie in aanraking. Vooral de historicus Ernst Bernheim en de kring van geesteswetenschappers rond Wilhelm Dilthey moeten voor de nieuwe cultuurhistorici in dit opzicht van belang worden geacht. Direct gevormd door deze docenten en door de historische economen, waardeerden de nieuwe cultuurhistorici tenslotte ook een oudere generatie cultuurhistorici uit het midden van de eeuw, met name Riehl, Freytag en Burckhardt. Voor deze voorgangers stond, zoals Steinhausen het formuleerde, net als voor hen zelf, 'de ontwikkeling van de psyche op de voorgrond'. ${ }^{217}$

${ }^{217}$ Zie Steinhausen (1898), 454. 



\section{Cultuurhistorici van 'het nerveuze tijdperk'}

‘...meine Gesamtauffasung [erfließt] aus dem inneren Kern dessen [...], was in unserem historischen Milieu, in dem Europa um 1900, eine historische Auffassung sein kann'. ${ }^{1}$

Karl Lamprecht (1909)

\section{1 'De ademende werkelijkheid van de natie'}

$\mathrm{I}$

$\mathrm{n}$ zijn postuum gepubliceerde jeugdherinneringen geeft Lamprecht een beeld van de tijd rond 1860. Het zijn de jaren dat hij in het landelijke Saksische stadje Jessen wordt geboren en opgroeit, voor hij in Wittenberg op kamers gaat om daar het gymnasium te bezoeken. ${ }^{2}$

Meteen in de eerste zin valt iets te bespeuren van de verkeers- en communicatierevolutie die zich in Duitsland in de loop van Lamprechts leven zal voltrekken. Jessen, schrijft Lamprecht daar, ligt aan de doorgaande spoorlijn tussen Hamburg en Silezië; en, in dezelfde zin: het bevindt zich op ongeveer vijf uren van Wittenberg. Nu kunnen die uren geen spooruren zijn, Wittenberg lag per trein hooguit een uur van Jessen; gezien de afstand van vijfentwintig kilometer tussen beide plaatsen is de vanzelfsprekende maatvoering voor de terugblikkende Lamprecht blijkbaar nog in uren gaans.

Ook in de rest van zijn jeugdherinneringen schetst Lamprecht een uitgesproken traag beeld van het leven in zijn jeugd. Hij stelt zijn geboorteplaats voor als een gemoedelijke, patriarchale boerengemeenschap die hij - specialist in de middeleeuwse geschiedenis - meer dan eens als 'middeleeuws' typeert. Zijn vader, een lutherse predikant, wordt nog grotendeels in natura betaald. Er is geen krant, maar een stadsomroeper. De aanvoer van de post per postkoets is voor de lokale jeugd volgens Lamprechts getuigenis elke keer weer een gebeurtenis van de eerste orde. De plaatselijke boeren en de marktlieden die het stadje aandoen, vervoeren hun goederen met paard en wagen. Lamprecht herinnert zich dat hij als kind, op rupsenjacht in het bos, wegdroomt bij het geratel van de karrenwielen over de slechte wegen in de verte. En hij vermeldt de herhaalde bezoeken aan zijn grootvader in Calau, waarvoor een afstand van tachtig kilometer overbrugd moest worden; in de afgedankte postkoets van zijn ouders nam deze reis twee, soms drie dagen in beslag.

Als de moderne tijd in deze plattelandsidylle doordringt, dan is het in de gedaante van nieuwe, moderne vormen van verkeer. Pas aan het eind van Lamprechts jeugd komt er een spoorweg en een station in Jessen, dat zo wordt opgenomen in het snel groeiende Duitse spoorwegnet. De postkoets verdwijnt van het plaatselijke toneel als de post per spoor wordt aangevoerd. De eerste confrontatie met de moderne verkeerstechniek overrompelt de jonge Karl: ${ }^{3}$

\footnotetext{
${ }^{1}$ Lamprecht (1974), 641.

${ }^{2}$ Delen van dit hoofdstuk zijn in gewijzigde vorm eerder gepubliceerd in Stoffers (1997).

${ }^{3}$ Lamprecht (1918), 36.
} 
'Ik stond niet ver van de locomotief, die ik in al haar onderdelen aangaapte, toen opeens deze fluit weerklonk. Het overweldigde mij zo, dat ik achterover van het spoorwegtaluud viel.'

En als Lamprecht in 1913, een halve eeuw later, opnieuw zijn geboorteplaats bezoekt, zijn het niet meer paard en wagen of trein die hem naar Jessen brengen, maar dat nieuwe symbool van de moderne tijd, de auto. Lamprechts ervaring is verrassend: de van oudsher vertrouwde omgeving wordt vanuit de auto door hem beleefd als een totaal ander landschap. Zelden, schrijft Lamprecht, had hij zo direct ervaren hoe waarneming en denken veranderen door het tempo waarin de indrukken elkaar afwisselen.

De idyllische herinneringen aan Jessen vormen een schril contrast met de ervaringen die Lamprecht tijdens zijn Amerikaanse reis in 1904 optekent. De moderne verkeers- en communicatiemiddelen die in de jeugdherinneringen de oude harmonie af en toe verstoren, bepalen op deze reis volledig het beeld. Hier beschrijft Lamprecht niet het lokale verleden, maar eigentijdse ontwikkelingen met een internationaal karakter, waarin Amerika weliswaar vooropliep, maar geenszins uitzonderlijk was. In het centrum van Seattle ziet hij nog de voorouderpaal staan van het Indianenopperhoofd 'dat hier, naar moderne maatstaven, eenzaam huisde'. De totempaal vormde inmiddels het anachronistische middelpunt van een moderne industrie- en handelsstad waar de elektrische verlichting ' $\mathrm{s}$ avonds met moeite de industriële rookkwalmen en dampen kon doordringen. In twee decennia was hier uit een gehucht een stad van 80.000 inwoners gegroeid. Elders in zijn reisverslag merkt Lamprecht de verwoestende effecten op van de moderne natuurexploitatie, met name de ontbossing, de water- en luchtverontreiniging, de onttakeling van de natuur. De indruk die de moderniteit, in de gedaante van de miljoenenstad Chicago op hem makt, is minstens zo overweldigend als zijn eerste confrontatie met de trein: ${ }^{4}$

'In de zakenwijk van Chicago een vreselijke drukte; ook op heldere dagen al 's ochtends rond een uur of acht, negen alles gehuld in een dichte nevel van rook en stofdeeltjes, die door het verkeer van Elevated Railroad, trams en zwaar vrachttransport, dat overal mag rijden, in de lucht gewerveld worden en tot in de late avond blijven rondzweven. Later ziet men nauwelijks nog vier tot vijf huizen ver. Daarbij een hels kabaal, en, opdat geen enkel zintuig ongekrenkt blijft, een uit het slecht onderhouden en smerige wegdek opstijgende geur, die het ademen ondraaglijk maakt. Wie gewend is aan zuivere lucht en een landelijk verblijf, voelt zich ontmenselijkt en beledigd - als hij tenminste niet om deze razende drukte moet lachen, waarin de enkeling niet eens meer tandrad, maar hoogstens een tand aan het rad is. Hij zal zich voelen als een slijkdeeltje in het diepst van een stilstaand water, dat door een onbarmhartige storm omhooggewoeld wordt.'

Wanneer Lamprecht per stoomschip in zes dagen van de Nieuwe Wereld terugkeert naar de Oude - hij heeft inmiddels opgemerkt hoe dit moderne vervoermiddel hem het directe contact met de zee ontneemt en hem zo 'van de natuur verwijdert' - is het contrast met het kind dat het nieuws nog uit de mond van de stadsomroeper moest vernemen groot: door de nog geen decennium eerder uitgevonden draadloze telegrafie kan hij op volle zee op de hoogte worden gebracht van de herverkiezing van Theodore Roosevelt en de geruchten over de val van Port Arthur in de Russisch-Japanse oorlog.

Deze persoonlijke ervaringen van Lamprecht waren in zijn tijd niet uitzonderlijk. Uitzonderlijk was wel dat hij als specialist in de middeleeuwse geschiedenis deze zelfde ervaringen tot onderwerp maakte van een uitvoerige historische analyse: hij publiceerde

${ }^{4}$ Gepubliceerd in: Lamprecht (1906), 23. 
een driedelige cultuurgeschiedenis van de eigen tijd, die meer dan 1700 bladzijden besloeg. ${ }^{5}$ En opvallend is eveneens dat ook de belangrijkste andere Duitse voorstanders van de cultuurgeschiedenis zich bezighielden met de geschiedschrijving van de eigen tijd, terwijl ook hun oorspronkelijke specialisatie een andere periode betrof. Steinhausen wijdde aan de eigentijdse geschiedenis net als Lamprecht een omvangrijk boek en ook Breysig, Gothein en Goetz besteedden in hun historisch werk substantiële aandacht aan het recentste verleden. ${ }^{6}$

Het lijdt geen twijfel dat contemporaine maatschappelijke ontwikkelingen van eminent belang waren voor de nieuwe cultuurhistorici. Zij waren niet alleen geïnteresseerde en betrokken tijdgenoten, maar beschouwden bovendien een zekere vorm van engagement als een essentieel aspect van hun functie als professionele historici. Zoals in voorgaande hoofdstukken duidelijk is geworden waren zij in dit opzicht goede leerlingen van zowel hun historische als van hun economische leermeesters. ${ }^{7}$ Volgens hun hodiecentristische visie diende de geschiedwetenschap te worden beschouwd als een Vorbereitungswissenschaft voor het handelen van tijdgenoten. ${ }^{8}$

Het wordt derhalve tijd om nà de analyse van het werk van de nieuwe cultuurhistorici, van hun professionele positie en van de intellectuele tradities waarin ze werden opgeleid, de blik te richten op hun wereld buiten universiteit en academie. Zoals zij zelf uitdrukkelijk bepleitten:

'De tijdgenoot moet [...] zelf zijn mannetje staan en om zich heen kijken. En kunnen we in dit opzicht niet van een plicht voor hem spreken? Hoeveel hoog opgeleiden zijn er, die nooit intensief, grondig, een fabriek [van binnen] hebben gezien, ruimte na ruimte, onder het inwinnen van informatie van economische en sociale aard, die nooit uitgebreid een grote verkeersorganisatie, bijvoorbeeld een rangeerstation of een expeditiebedrijf hebben bekeken, en die desondanks menen over de eigen tijd een alomvattend oordeel te kunnen geven. [...] en hoeveel geleerden behoren tot deze categorie! [...] Nee, men moet naar buiten gaan in de ademende werkelijkheid van de natie, men moet de blik vullen met beelden van haar activiteiten op allerlei gebied en onder druk van hun grootsheid ervaringen opdoen. ${ }^{9}$

De vraag van dit hoofdstuk luidt hoe de betrokkenheid van de nieuwe cultuurhistorici bij de eigen tijd tot uiting kwam in hun historische analyses. Deze vraag snijdt aan twee kanten. Het is in de eerste plaats de bedoeling aan te tonen dat er een direct verband bestaat tussen de geschiedtheorie van de nieuwe cultuurhistorici en de manier waarop zijn hun eigen tijd ervoeren: zij percipieerden de actualiteit via hun geschiedtheoretische concepten. Of anders gezegd: hun visie op de eigen tijd (en op het verleden) was 'theoretisch geïnformeerd'. Tegelijk gaat het erom vast te stellen welk verband er

\footnotetext{
${ }^{5}$ Lamprecht (1891-1909), ErgBd. I, II.1 en II.2; in 1912-1913 verscheen een onvoltooid gebleven herziene uitgave van deze Ergänzungsbände onder de titel: Deutsche Geschichte der jüngsten Vergangenheit. Daarnaast is van Lamprecht vooral geraadpleegd Lamprecht (1914), Lamprecht (1905), hfdst. III: 'Der Übergang zum seelischen Charakter der deutschen Gegenwart', 51-76.

${ }^{6}$ De belangrijkste hier geraadpleegde werken van Steinhausen zijn: Steinhausen (1895), Steinhausen (1898), Steinhausen (1927), Steinhausen (1929), hfdst. XI 'Wandel der Menschheit' (ook eerdere edities), en Steinhausen (1931). Van Breysig is vooral geraadpleegd: Breysig (1931), m.n. 183311: 'Die jüngste Vergangenheit (1871 bis 1930)', Breysig (1912) en Breysig (1927). Van Goetz is bestudeerd: Goetz (1916), Goetz (1918a), Goetz (1929), Goetz (1930a), Goetz (1930b), Goetz (1933a), Goetz (1933b). Van Gothein: Gothein (1903) en Gothein en Neuhaus (1915-1916).

${ }^{7}$ Zie hoofdstuk 5, paragraaf 4 en hoofdstuk 6, paragraaf 4.2 .

${ }^{8}$ Lamprecht (1974), 728 [1910]. De historica Luise Schorn-Schütte heeft in dit verband gesproken van een 'Funktionalisierung historischer Bildung' door Lamprecht: Schorn-Schütte (1994), 72.

${ }^{9}$ Lamprecht (1891-1909), ErgBd. II.1, 156.
} 
gelegd kan worden tussen deze geschiedtheoretisch geïnformeerde perceptiewijze en hun (politieke) oordeel over contemporaine ontwikkelingen. Tot welke probleemdefinities en oplossingen met betrekking tot eigentijdse verschijnselen leidde hun specifieke benadering van het verleden?

De relevante contemporaine context van de nieuwe cultuurgeschiedenis zal ik in dit hoofdstuk in eerste instantie opsporen via de vakpublicaties van de nieuwe cultuurhistorici over hun eigen tijd. Zoals uit de paragraaftitels naar voren komt, laat ik me leiden door hun eigen perceptie van de actualiteit. Op die manier sla ik twee of eigenlijk zelfs drie vliegen in één klap. Zowel de eigentijdse context die van belang is voor hun werk, als hun eigen perceptie en hun (politieke) beoordeling daarvan kunnen belicht worden. Om hun (politieke) oordeel scherp te krijgen zal ik behalve hun vakhistorische publicaties over de eigen tijd ook andere, niet-vakwetenschappelijke teksten in het onderzoek betrekken en ingaan op de politieke activiteiten en connecties van de nieuwe cultuurhistorici.

Al met al bevinden wij ons aan het eind van dit boek op een beslissend kruispunt van context en tradities, van (toenmalig) heden en verleden: het hoofdstuk onderzoekt het contemporain-historisch werk van de nieuwe cultuurhistorici met het doel zicht te krijgen op de wisselwerking tussen de intellectuele tradities waarin zij waren opgeleid en de eigentijdse maatschappelijke, politieke en culturele context waarbinnen zij hun functie als professionele historici uitoefenden en waarover zij tegelijk als burgers hun (politieke) oordelen velden.

\section{2 'Wij zijn kinderen van een andere tijd'}

De nieuwe cultuurhistorici waren het in grote lijnen met elkaar eens over de belangrijkste kenmerken van de eigentijdse geschiedenis. Dat gold overigens niet altijd voor hun waardering van diezelfde eigentijdse fenomenen, zoals we nog zullen zien. Maar in hun beschrijvingen van de eigen tijd komen we voortdurend dezelfde trekken tegen.

In wezen was de analyse en beschrijving van de eigen tijd door de nieuwe cultuurhistorici een uitwerking van de ervaringsbreuk zoals die in Lamprechts autobiografische geschriften is aan te wijzen. Fundamenteel voor hun voorstelling van het heden was de gedachte dat zij in een tijd leefden van zowel snelle als fundamentele veranderingen, een tijd die radicaal anders was dan het verleden of die in hoog tempo op weg was radicaal anders te worden. Het begin van deze nieuwe tijd voerden zij veelal terug tot het midden van de achttiende eeuw, maar allemaal meenden zij dat pas in de tweede helft van de negentiende eeuw, dit wil zeggen in de loop van hun eigen leven, de nieuwe tijd echt was doorgebroken.

Net als in hun door stadiadenken gekenmerkte geschiedopvattingen, bepaalden historische breuken hun perceptie van de eigen tijd, de ervaring van discontinuïteit won het van de continuïteit. Typerend genoeg contrasteerden zowel Steinhausen als Lamprecht en Goetz de eigen tijd met een idyllische Goethe-tijd. 'Wij zijn kinderen van een andere tijd', schreef Lamprecht in 1903, 'in stille uren blikken wij terug in het verleden van de laatste anderhalve eeuw als in een verloren paradijs'. ${ }^{10}$

Kenmerkend voor de ervaring van snelle verandering was de typering van de eigen tijd als een overgangstijd die bij vrijwel alle cultuurhistorici is aan te treffen. ${ }^{11} \mathrm{Zij}$ ervoeren hun eigen wereld als een wereld in flux. Lamprecht gebruikte in de

\footnotetext{
${ }^{10}$ Lamprecht (1891-1909), ErgBd. II.1, 242. Vgl. Goetz (1930a), 536; Steinhausen (1898), 1.

${ }^{11}$ Steinhausen (1931), bijv. 1, 11 etc.; Breysig (1931), 364; Lamprecht (1905), hfdst. III.
} 
contemporaine gedeelten van zijn Deutsche Geschichte geen enkel adjectief zo vaak ter aanduiding van eigentijdse veranderingen als 'reißend', contemporaine ontwikkelingen gingen in zijn perceptie 'razend snel'. Niet alleen hij maar ook de andere cultuurhistorici onderbouwden dit oordeel over de snelheid van de veranderingen met cijfers: zij constateerden in de korte tijd van nog geen twee generaties verdubbelingen (bijvoorbeeld van de boekproduktie, 1850-1890), verdrie- (bijvoorbeeld van het spoorwegnet, 1870-1917) of vervijfvoudigingen (bijvoorbeeld van het wegennet tussen 1857 en 1900).

Dat wat zij als 'tegenwoordige tijd' ervoeren, duurde als gevolg van deze snelle veranderingen slechts zeer kort. Dit 'oplossen van het heden' was een ervaring die de historici zelf met zoveel woorden beschouwden als een stimulans voor hun contemporain-historisch werk: 'wij ervaren de tegenwoordige tijd zo intensief, dat wij haar al in elke minuut die komt en gaat, historisch zouden willen bekijken', schreef bijvoorbeeld Lamprecht. ${ }^{12}$ De oorzaak lag in het 'tempo van het moderne leven, de snelle verandering van de dingen, die gisteren al tot geschiedenis maakt'. ${ }^{13}$ De veranderingen waren sinds het midden van de achttiende eeuw zo snel gegaan dat de eigen generatie zich, als we Steinhausen mogen geloven, 'niet thuis' voelde in de nieuwe tijd. ${ }^{14}$

Ervaren werd niet alleen een snelle, maar ook een bijzonder diepgravende verandering. Het ging daarbij naar het oordeel van de cultuurhistorici niet slechts om een wisseling van generaties, maar om niets minder dan de overgang naar een nieuw tijdperk in de wereldgeschiedenis. Steinhausen sprak over een maatschappelijke omwenteling zoals die in duizend jaar niet was beleefd, de definitieve breuk met de oude tijd, in sommige opzichten pas het einde van de middeleeuwen. ${ }^{15}$ Breysig ontdekte in de laatste honderd jaar van de ontwikkelingsgeschiedenis van de ziel zelfs een radicaal afwijkend patroon ten opzichte van alle voorgaande perioden. ${ }^{16}$ De geest van de eigen tijd stond bijna 'in volledig contrast' tot het verleden, meende ook Lamprecht. $^{17}$

Wat waren de belangrijkste kenmerken van deze snelle en fundamentele veranderingen? De cultuurhistorici waren het daarover verregaand eens; in drie trefwoorden uitgedrukt, onderscheidde de eigen tijd zich van voorgaande perioden door een toenemende globalisering (al werd dat woord niet gebruikt), versnelling en 'nervositeit'.

\section{3 'Een nieuw kosmopolitisme'}

Voor veel tijdgenoten stond de periode rond 1900 in het teken van de toenemende, wereldwijde communicatie en de tendens naar internationale uniformering. Ook de nieuwe cultuurhistorici beschouwden het internationale, ja globale karakter van veel eigentijdse verschijnselen als een onderscheidend kenmerk van de eigen tijd. Zoals Goetz in de door hem opgezette Propyläen Weltgeschichte schreef, had de geschiedenis in zijn tijd voor het eerst daadwerkelijk een wereldformaat gekregen:

\footnotetext{
${ }^{12}$ Lamprecht (1891-1909), ErgBd. II.1,. 159.

${ }^{13}$ Steinhausen (1931), 15: het feit dat zijn tijd zichzelf zo snel historisch beschouwde, lag volgens Steinhausen 'vor allem an dem Tempo des modernen Lebens, an den schnellen Wechsel der Dinge, der eben schon das Gestern zur Geschichte macht'.

${ }^{14}$ Steinhausen (1898), 1.

${ }^{15}$ Steinhausen (1913), II, 476; Steinhausen (1929), 8; ook Steinhausen (1931), 641.

${ }^{16}$ Breysig (1931), 494 e.v., 501-503.

${ }^{17}$ Lamprecht (1891-1909), ErgBd. II.1, 242.
} 
'Nog nooit in de historische tijd hebben alle volkeren van de aarde een zo sterke gemeenschappelijke beleving gekend als tegenwoordig. Dat geeft het tijdvak zijn karakter: de mensheid staat op het punt tot een grote eenheid samen te groeien. ${ }^{18}$

Het was het eigentijdse naar elkaar toe groeien van naties en culturen 'tot een telkens sterkere economische, politieke en culturele eenheid', dat de aanleiding vormde en de rechtvaardiging voor het schrijven van een wereldgeschiedenis als de Propyläen Weltgeschichte. ${ }^{19}$ En met die overweging stond Goetz niet alleen, zoals hij zelf constateerde: hij signaleerde een sterke toename van het aantal gepubliceerde 'wereldgeschiedenissen' vanaf $1900 .^{20}$ Ook volgens Steinhausen was er als gevolg van de 'sterke assimilatie [Angleichung] van de culturele verhoudingen' tussen de 'cultuurvolkeren' voor het eerst sprake van een 'Weltkultur'. ${ }^{21}$ Toen hij in zijn grote overzicht van de Duitse cultuurgeschiedenis bij de eigen tijd was aangekomen, gaf hij het betreffende hoofdstuk de titel mee: 'Wandel der Menschheit' ${ }^{22}$ En hij stelde vast dat de 'moderne Zivilisationsmensch' eigenlijk al een internationaal verschijnsel was'. ${ }^{23}$

In dit proces van internationalisering en schaalvergroting speelden volgens de cultuurhistorici zowel politieke als economische factoren een grote rol: alle soorten grenzen werden in dit tijdvak van politiek imperialisme en economisch 'Riesenunternehmertums' overschreden, meende bijvoorbeeld Breysig. ${ }^{24}$ Hij verdedigde zijn plannen uit 1907 voor een Seminar voor wereldgeschiedenis uitdrukkelijk door te wijzen op de recente uitbreiding van de Europese politiek 'over alle werelddelen en de hele aardbol'. ${ }^{25}$ En ook Lamprecht legitimeerde de studie van de Universalgeschichte met een verwijzing naar deze 'tijd van wereldpolitiek'. ${ }^{26}$ De Duitse geschiedschrijving van de negentiende eeuw had veel voor de nationale eenwording betekend, meende hij, het zou mooi zijn als zij in de twintigste eeuw haar deel zou leveren aan de 'eenwording van de mensheid'. 27 Naar zijn oordeel was er rond 1900 een 'nieuw kosmopolitisme' ontstaan, een nieuw 'wereldgevoel': niet gekenmerkt door de gedachte dat iedereen op aarde eender was, maar wel door het besef dat elke natie haar eigen bijdrage leverde aan de wereldwijde arbeidsverdeling. ${ }^{28}$

De technische voorwaarde voor deze globaliserende tendensen was de ongekend sterke verbetering van de transport- en communicatiemiddelen. Lamprecht wees er bijvoorbeeld op dat de (stoom)schepen die tussen Europa en Amerika voeren in 1830 nog 730 vaaruren nodig hadden voor de overvaart, in 1858 nog maar 300 en in 1895 hooguit 130 uren. $^{29}$ Zoals hij in zijn Deutsche Geschichte opmerkte was Verne's fantasie van een Reis om de wereld in tachtig dagen (1873) binnen de kortste keren achterhaald; rond de eeuwwisseling kon een wereldrondreis al in vierenzestig dagen volbracht

\footnotetext{
${ }^{18}$ Goetz (1933b), XIX.

${ }^{19}$ Goetz (1929-1933), I, [xvii]. Zie eerder Hoofdstuk 3, paragraaf 5.

${ }^{20}$ Zie voor een overzicht: Goetz (1934).

${ }^{21}$ Zie Steinhausen (1913), II, 487.

${ }^{22}$ Steinhausen (1929), hfdst. XI, 637-672.

${ }^{23}$ Steinhausen (1931), 140.

${ }^{24}$ Breysig (1931), 241.

${ }^{25}$ Geciteerd in Brocke (1971), 306.

${ }^{26}$ Lamprecht (1974), 634.

${ }^{27}$ Lamprecht (1974), 820 [1912].

${ }^{28}$ Lamprecht (1906), 7-8; zie ook Lamprecht (1974), 614 [1906], 621-622 [1907/8], 819-820

[1912]. Vergelijkbaar is de opvatting van Breysig (1912), 82.

${ }^{29}$ Lamprecht (1891-1909), ErgBd. II.1, 128.
} 
worden. ${ }^{30}$ Steinhausen wist te melden dat het aantal in Hamburg gelegen zeeschepen tussen 1880 en 1914 bijna verdrievoudigde, terwijl het gezamenlijke Duitse stoomtonnage in de twintig jaar tussen 1892 en 1912 zelfs vervijfvoudigde. ${ }^{31}$ Ook werd de 'razendsnelle uitbreiding van de grote kabels' gesignaleerd: terwijl de eerste intercontinentale telegraafkabel tussen Europa en Amerika in 1858 werd aangelegd, verbonden tegen het einde van de negentiende eeuw al meer dan 1000 kabels 'het ouder wordende Europa met de andere werelddelen'. ${ }^{32}$

De wereldhandel nam in overeenstemming met de toegenomen communicatiemogelijkheden toe: haar gezamenlijke waarde bedroeg volgens Lamprechts schattingen in 1890 meer dan vijf keer zoveel als in het midden van de eeuw. ${ }^{33}$ Het 'wereldeconomische karakter' van de eigentijdse economische ontwikkelingen werd door Steinhausen gedemonstreerd met cijfers over de verdrie - en verviervoudiging van de Duitse in- en uitvoerwaarde tussen 1871 en $1913 .^{34}$

Een van de gevolgen van de toegenomen internationale communicatie was, zoals Lamprecht opmerkte 'het gevoel alsof men alomtegenwoordig is op aarde', een 'uitzonderlijke wijdte van de opvatting van ruimte', die paradoxaal genoeg ook een sterker besef van de begrensdheid en daarmee van de schaarsheid en kostbaarheid van de ruimte met zich mee bracht. De ruimte op aarde 'kromp' en werd onderwerp van zowel verhevigde politieke strijd als economische wedijver. Lamprecht achtte het in dit verband veelzeggend dat de waarde van de grond in de Duitse grote steden tussen 1870 en 1898 was verzesvoudigd. ${ }^{35}$

\section{4 'Voorwaarts zonder rust!'}

De verbeteringen van verkeer en communicatie vormden ook een belangrijk aspect van het tweede algemene kenmerk van de eigen tijd, dat zeer direct de contemporaine ervaring van de historici bepaalde: de maatschappelijke versnelling. Volgens de cultuurhistorici was er sprake van een significante Beschleunigung van het hele maatschappelijke en culturele leven. Het ging daarbij in hun perceptie niet alleen om een overgangsfenomeen op het breukvlak van twee perioden, maar om een blijvend kenmerk van het 'moderne leven'.

Zij spraken bij voortduring over de opkomst van een 'nieuw tempo', over de Schnelligkeitssucht van de moderne mens en ze stelden en masse vast dat het leven sneller ging dan dat van hun voorouders. 'De rust en de behaaglijkheid van vroegere tijden zijn voorbij', meende Steinhausen bijvoorbeeld. ${ }^{36}$ 'Snel en sneller werd het tempo en door dit tempo wordt de huidige mens beïnvloed. Hij leeft sneller dan zijn voorouders, hij werkt rustelozer dan zij'. ${ }^{37}$ Maar er was geen weg terug: wij zouden ons

\footnotetext{
${ }^{30}$ Zie Lamprecht (1891-1909), ErgBd. II.1, 160; in de herziene uitgave uit 1912 schrijft Lamprecht dat de reis in minder dan 60 dagen volbracht kan worden (Lamprecht (1912-1913), I, 173). Stephen Kern, die in zijn bekende boek Culture of time and space, veel van dezelfde thema's aansnijdt als de Duitse cultuurhistorici noemt overigens al een aardomronding in 60 dagen uit 1892 en een claim uit 1902 dat de aarde in 40 dagen was te bereizen, zie Kern (1983), 213.

${ }^{31}$ Steinhausen (1931), 72.

${ }^{32}$ Lamprecht (1891-1909), ErgBd II.1, 133-134.

${ }^{33}$ Lamprecht (1891-1909), ErgBd II.1, 152.

${ }^{34}$ Steinhausen (1931), 65, 70 .

${ }^{35}$ Lamprecht (1891-1909), ErgBd II.1, 159-161.

${ }^{36}$ Steinhausen (1929), 667.

${ }^{37}$ Steinhausen (1898), 7. Zie ook Steinhausen (1895), 41.
} 
in de tijd van onze voorouders niet meer thuisvoelen, merkte Lamprecht op, 'want voorwaarts zonder rust, luidt de slagzin van de huidige tijd, ${ }^{38}$

De cultuurhistorici lieten het echter niet bij dergelijke algemene uitspraken, die tot de gemeenplaatsen onder de geletterden van hun tijd behoorden. ${ }^{39}$ De gesignaleerde versnelling werd uitgebreid beschreven en geanalyseerd. De opmerkelijke aanpak van de cultuurhistorici daarbij legt connecties bloot met zowel artistieke als filosofische en psychologische ontwikkelingen in hun tijd. Hun aanpak zou zonder forceren 'fenomenalistisch' of 'impressionistisch' (in technische zin) genoemd kunnen worden. Wat zij in de eigen tijd constateerden en analyseerden, was een Beschleunigung der Erlebniszeitmaße, zoals een voormalige student van Lamprecht het later zou aanduiden: de versnelling van het tempo waarin de verschillende ervaringen elkaar opvolgden. ${ }^{40}$ En deze versnelling werd in hun ogen weer bepaald door de toegenomen afwisseling van prikkels, Reize in het Duits, zowel zintuiglijke als intellectuele prikkels.

Wat waren de oorzaken van de toegenomen afwisseling van prikkels? Lamprecht vatte een aantal factoren als volgt samen:

'het eeuwige haasten, het fluitsignaal van de lokomotief, het rinkelen van de tram, de voortdurende vloed van post, de opdringerige verslaggeving van de kranten, het toenemend aantal persoonlijke contacten bij een voortdurend verhoogd gemak van het personenvervoer'. ${ }^{41}$

De hoeveelheid dagelijkse indrukken was zeker voor de stedeling zo groot geworden dat ze, aldus Steinhausen, eenvoudig niet meer goed verwerkt konden worden. ${ }^{42}$ 'Hoe rustig had de Duitse burger rond 1830 zijn dagelijks werk verricht en van zijn vrije uren genoten', meende ook Goetz: vijftig jaar later werd zijn rust verstoord door het alom aanwezige lawaai van machines en het dagelijks groeiend verkeer. ${ }^{43}$

De cultuurhistorici presenteerden zowel meer of minder persoonlijke impressies als harde cijfers om deze uitspraken over het toegenomen aantal prikkels te onderbouwen. Uitspraken over het overvol raken van de woningen - geen arbeider uit 1898 zou nog genoegen nemen met de sobere inrichting van Goethe's kamer, meende Steinhausen ${ }^{44}$ vonden een bevestiging in mededelingen over de sterke groei van de Duitse nijverheidsproduktie in de laatste decennia van de negentiende eeuw. ${ }^{45}$ Gesignaleerd werd ook de toegenomen vleesconsumptie en de opkomst van delicatessenwinkels. ${ }^{46}$ De cultuurhistorici wezen verder op de snel stijgende bevolkingsomvang waardoor meer mensen dichter dan ooit bij elkaar woonden: van iets meer dan 40 miljoen in 1871 groeide de Duitse bevolking naar bijna 70 miljoen in $1914 .^{47}$ De bevolkingsdichtheid was natuurlijk het hoogst in de stad, die in deze zelfde periode, zoals de cultuurhistorici met de cijfers bij de hand vaststelden, tot biotoop werd van de meeste Duitsers: terwijl in 1871 nagenoeg tweederde van het Duitse bevolking nog in gemeenten van minder dan 2000 zielen woonde, waren de verhoudingen in 1910 omgekeerd: bijna tweederde van

\footnotetext{
${ }^{38}$ Lamprecht (1891-1909), ErgBd. II.1, 242.

${ }^{39}$ Zie Radkau (1998), 190-215.

${ }^{40}$ Hellpach (1940). Hellpach verwijst hier (op blz. 71) ook naar Lamprecht (en Beard).

${ }^{41}$ Lamprecht (1891-1909), ErgBd. I, 184.

${ }^{42}$ Steinhausen (1931), 335, vgl. ook 450: 'die viele auf seinen [des Großstadtkindes] Geist und seine Sinne einstürmenden Eindrücke'.

${ }^{43}$ Goetz (1930a), 536.

${ }^{44}$ Steinhausen (1898), 17-28.

${ }^{45}$ Lamprecht (1891-1909), ErgBd II.1, 199.

${ }^{46}$ Zie Steinhausen (1898), 40.

${ }^{47}$ Steinhausen (1931), 64; Lamprecht (1912-1913), I, 490.
} 
de Duitsers leefde in steden; vier keer zoveel als in 1871 woonde inmiddels in een Großstadt. ${ }^{48}$ De cultuurhistorici - zelf overigens allemaal geboren of getogen in de stad - concludeerden dat er sprake was van een Verstadtlichung des deutschen Menschen. ${ }^{49}$ Lamprecht: 'Zo ging de Großstadt steeds meer en uiteindelijk overwegend het typisch moderne leven sociaal en psychisch bepalen. In haar zette de onrust van het hele bestaan zich op de duidelijkste wijze door'. ${ }^{50}$

De toename van prikkels en indrukken werd behalve door het groeiend aantal mensen en dingen vooral teweeggebracht door de toename van het verkeer en de communicatie. ${ }^{51}$ Dat was een inzicht dat de nieuwe cultuurhistorici wellicht al eens van Schmoller hadden vernomen: al in 1873 had deze Nationalökonom geschreven over de grote maatschappelijke gevolgen van spoorwegen, stoomscheepvaart, telegraaf - onder andere voor de ervaring van de mensen: 'wij zien, wij beleven het honderdvoudige en meer van dat wat onze grootvaders gezien hebben'. 52 'De omwenteling in de verkeersmiddelen veroorzaakt tegelijk een verandering van het hele leven', schreef Steinhausen in zijn eerste boek uit 1891 op een vergelijkbare wijze, 'de spoorwegen, de stoomschepen, de telegraaf, zij verhonderdvoudigen en verduizendvoudigen ons bestaan, vergeleken met vroegere eeuwen'. ${ }^{53}$ Niet alleen internationaal, maar nog veel sterker op lokaal, regionaal en nationaal niveau signaleerden de nieuwe cultuurhistorici een indrukwekkende groei van het aantal bewegingen, verplaatsingen en contacten.

Op lokaal niveau was deze ontwikkeling zeer direct te beleven, met name in de steden ontging niemand de komst van elektrische tram en metro, van auto en autobus, van fiets en motorfiets. ${ }^{54}$ Goetz raakte in 1908 enthousiast over de ontwikkeling van het luchtschip en liet een foto van een zeppelin opnemen in het eigentijdse deel van zijn Propyläen Weltgeschichte. ${ }^{55}$ Met cijfers demonstreerden de cultuurhistorici de snelle groei van de tram en de vroege automobielproductie in Duitsland. ${ }^{56}$ In 1913 kon Steinhausen al de snelle groei van de Duitse automobielproductie in het eerste decennium van de twintigste eeuw noteren: van 1809 voertuigen in 1901, naar meer dan 30.000 in $1910 .{ }^{57}$ Het verkeersleven 'vult onze stations en onze beurzen en stroomt als eb en vloed in onze straten en over onze pleinen', schreef Lamprecht plastisch. ${ }^{58}$ Niet alleen het voortdurende geluid van motoren en claxons, maar ook het schudden van de huizen en straten als gevolg van zwaar vrachtverkeer behoorden tot de opgemerkte zintuiglijke prikkels van het nieuwe, gemotoriseerde verkeer. ${ }^{59}$ De toegenomen

${ }^{48}$ Steinhausen (1913), II, 483; vgl.Lamprecht (1912-1913), 502. Uit het lemma 'Stadt' van het Politisches Handwörterbuch uitgegeven door Paul Herre (2 dln., Leipzig 1923) blijkt dat sinds 1871 gemeenten van meer dan 2000 inwoners in de bevolkingsstatistieken als 'stad' werden aangeduid. Groß $\beta$ städte waren steden met meer dan 100.000 inwoners. De statistische gegevens over de toename van de verstedelijking uit dit naslagwerk komen overeen met de cijfers van Lamprecht en Steinhausen.

${ }^{49}$ Aldus Steinhausen (1931), 64. Lamprecht (1912-1913), I, 504, spreekt over de 'Verstadtlichung [...] unserer gesamten Kultur'.

${ }^{50}$ Lamprecht (1912-1913), I, 502.

${ }^{51}$ Steinhausen (1929), 646; hetzelfde merkt Steinhausen al in 1898 op: 'Insbesondere [...] hat dieser ungeahnte technische und wirtschaftliche Aufschwung einen Wandel der Verkehrsverhältnisse zur Folge gehabt, wie ihn die ganzen Jahrtausende der bisherigen menschlichen Entwickelung nicht erlebt haben.'

Zie Steinhausen (1898), 1.

${ }_{52}$ Zie Schmoller (1873), 424, geciteerd in Radkau (1998), 58.

${ }^{53}$ Steinhausen, 1889-1891 \#284\}, II, 408-409.

${ }^{54}$ Steinhausen (1931), 70-72.

${ }^{55}$ Goetz (1929-1933), X, 25; zie Weigand (1992), 125.

${ }^{56}$ Over de tram, zie Lamprecht (1891-1909), ErgBd II.1, 124-125.

${ }^{57}$ Steinhausen (1913), II, 479.

${ }^{58}$ Lamprecht (1891-1909), ErgBd. II.1, 157.

${ }^{59}$ Steinhausen (1929), 657; Steinhausen (1931), 127. 
beweeglijkheid van het leven in de grote stad demonstreerden zowel Steinhausen als Lamprecht ook door te wijzen op het grote aantal verhuizingen. Als voorbeeld noemde de laatste Breslau, een stad van 400.000 inwoners, waarvan bijna de helft volgens zijn gegevens in één jaar (1899) van woning wisselde. ${ }^{60}$

Niet alleen het lokale, maar ook het interlokale en nationale verkeer en transport nam reißend snel toe. In de vijfentwintig jaar na 1870, aldus Lamprecht, verdrievoudigde in Duitsland het personenverkeer en nam het goederenverkeer met een factor viereneenhalf toe. ${ }^{61}$ Steinhausen signaleerde de ruime verdrievoudiging van de lengte van het Duitse spoorwegnet tussen 1870 en 1917, de aanleg van een groot aantal kanalen en het 'stark gesteigerte' verkeer over deze en andere waterwegen; bij Lamprecht kon de lezer terecht voor preciesere cijfers over het binnenlandse goederentransport: in het laatste kwart van de negentiende eeuw was het aantal Tonnenkilometern verviervoudigd. ${ }^{62}$ Lamprecht vermeldde ook dat de totale lengte aan verharde wegen in het Duitse Rijk vervijfvoudigde tussen 1857 en 1900; hij vertelde hoe de snelpost in 1824 opzien baarde door in slechts vijftien uur de afstand BerlijnMagdeburg te overbruggen, terwijl die afstand in zijn eigen tijd door de sneltrein in twee uur werd afgelegd; ${ }^{63}$ en hij stelde vast dat Duitsers in 1868 per jaar gemiddeld tachtig km per spoor aflegden, maar dertig jaar later al $300 \mathrm{~km} .{ }^{64}$ Hijzelf had overigens aan die groei zijn deel geleverd: enigszins chargerend zou je kunnen zeggen dat hij zijn eerste hoogleraarspost te danken had aan de spoorwegen. Alleen dankzij het veelvuldig gebruik van het spoor had hij in relatief korte tijd de enorme hoeveelheid archivalia uit het Rijn-Moezel-gebied weten te verzamelen die zijn Deutsches Wirtschaftsleben im Mittelalter zo indrukwekkend maakte. ${ }^{65} \mathrm{Je}$ kunt je ook afvragen of de dertien Historikertage tussen 1893 en 1913 van de grond zouden zijn gekomen zonder de ontwikkeling van het Duitse spoorwegnet.

Naast de toename van zintuiglijke prikkels door het groter aantal dingen en de toename van mensen en beweging signaleerden de cultuurhistorici bovendien een sterke groei van de informatieoverdracht en daardoor van het aantal intellectuele prikkels. Alleen al door de toenemende concentratie van mensen in de grote stad was het aantal wisselende menselijke contacten en de uitwisseling van informatie groter dan ooit. Zoals Goetz het omschreef: 'de Großstadt zelf deed de gedachtenomzet stijgen' ${ }^{66}$

Verder constateerden zij een toenemende 'verschriftelijking' van de cultuur, technisch mogelijk gemaakt door de uitvinding van de rotatiepers in de jaren zestig, maatschappelijk verbonden met de hoge alfabetiseringsgraad in Duitsland en bestuurlijk samenhangend met de toenemende wet- en regelgeving door de overheid. ${ }^{67}$ Het tijdschriftwezen (met name op wetenschappelijk en literair terrein) breidde zich sterk uit en veroorzaakte een toenemende circulatiesnelheid van informatie. Steinhausen signaleert verder de toenemende invloed van de dagbladen, 'die Presse, wie man so

\footnotetext{
${ }^{60}$ Lamprecht (1891-1909), ErgBd. II.1, 465. Vgl. Steinhausen (1931), 140 en Steinhausen (1898), $35-36$.

${ }^{61}$ Lamprecht (1891-1909), ErgBd. II.1, 153. Steinhausen (1931), 70, signaleerde een 'außerordentliche Zunahme des Verkehrs'.

${ }^{62}$ Lamprecht geeft cijfers: in het laatste kwart van de negentiende eeuw is het aantal ‘Tonnenkilometern' verviervoudigd. Lamprecht (1891-1909), ErgBd. II.1, 131.

${ }^{63}$ Lamprecht (1891-1909), ErgBd. II.1, 120; Lamprecht meldt ook dat de eerste elektrische trein (tram) ter wereld in Duitsland reed (1879) (a.w. 124).

${ }^{64}$ Lamprecht (1891-1909), ErgBd. II.1, 160.

${ }^{65}$ Chickering (1993), 79.

${ }^{66}$ Goetz (1930a), 531.

${ }^{67}$ Steinhausen (1931), 371.
} 
häßlich sagt'. ${ }^{68}$ De 'zogenaamde publieke opinie' werd een begrip: meer mensen dan ooit werden op de hoogte gehouden van eigentijdse ontwikkelingen elders in hun regio, land of wereld. ${ }^{69}$ Ook de boekproduktie was in Duitsland groter dan waar ook, zoals de cultuurhistorici vaststelden. ${ }^{70}$ In 1890 lag het aantal jaarlijks geproduceerde boeken tweemaal zo hoog als in 1850 , constateerde Goetz. ${ }^{71}$

Behalve de toename van het gedrukte woord, signaleerden de cultuurhistorici ook de explosieve groei van andere communicatiemedia. De opkomst van de envelop, de brievenbus en de postbode na 1850 werden door Lamprecht gepresenteerd als de stille getuigen van de groei van het briefverkeer: daarvóór was het systeem van poste restante meer dan adequaat bij een jaarlijks gemiddelde van drie brieven per hoofd van de Pruisische bevolking. ${ }^{72}$ Tegelijk werd de bekorting van de schriftelijke communicatie door de introductie van de briefkaart en het telegram typerend gevonden voor de moderne tijd. ${ }^{73}$ Niet voor niets nam Goetz een afbeelding van de allereerste briefkaart op in zijn Propyläen Weltgeschichte. Steinhausens Geschichte des deutschen Briefes kwam mede voort uit de verwachting dat het tijdperk van de briefcultuur ten einde liep. ${ }^{74}$ Lamprecht vermeldde dat het aantal telegrammen dat in Pruisen werd verstuurd alleen al in de beperkte tijdsspanne tussen 1850 en 1865 groeide van 35.000 naar anderhalf miljoen! $!^{75}$ Vanaf de jaren zeventig werd ook nog de telefoon met veel succes in Duitsland geïntroduceerd (waarvan meteen de grote gevolgen voor het beurswezen werd gesignaleerd), ${ }^{76}$ en vlak voor 1900 de draadloze telegrafie, waardoor Lamprecht tijdens zijn overtocht uit Amerika op de hoogte kon worden gehouden van het wereldnieuws.

Ook de toegenomen verspreiding van beeldmateriaal als communicatiemiddel wordt opgemerkt - een verschijnsel dat door Lamprecht geduid werd als een groeiende behoefte aan een 'verhoogde Verflüssigung van informatie': door het gebruik van beelden kon informatie sneller, makkelijker en soms zelfs indringender opgenomen worden. ${ }^{77}$ Exponenten van het toenemend beeldgebruik waren de groeiende toepassing van lithografie en fotografie, onder andere ten behoeve van eenvoudiger reproductietechnieken. ${ }^{78}$ Steinhausen wees verder op de snelle opkomst van de bioscoop - de nieuwe, aan de omstandigheden adequate kunstvorm die deze wereld in beweging kon vatten: terwijl in 1900, vijf jaar na de eerste openbare filmvertoning ooit, van de grotere Duitse steden alleen Hamburg en Würzburg een vast 'Lichtspieltheater' bezaten, had in 1910 Berlijn er alleen al $139 .^{79}$

${ }^{68}$ Steinhausen (1931), 331.

${ }^{69}$ Goetz (1930a), 466.

${ }^{70}$ Steinhausen (1931), 458-459.

${ }^{71}$ Goetz (1930a), 463.

72 Steinhausen (1913), II, 480.

${ }^{73}$ Aldus Steinhausen (1889-1891), II, 409. Goetz nam een afbeelding van de eerste (Oostenrijkse) briefkaart op in deel VIII van zijn Propyläen Weltgeschichte (blz. 221).

${ }^{74}$ Steinhausen (1889-1891), II, 409.

${ }^{75}$ Lamprecht (1891-1909), ErgBd. II.1, 133.

${ }^{76}$ Zie Lamprecht (1891-1909), ErgBd. II.1, 134; ook Steinhausen (1913), II, 480, signaleert de 'außerordentliche Entwicklung' van de telefoon aan het eind van de negentiende eeuw.

${ }^{77}$ Lamprecht (1891-1909), ErgBd. II.1, 136-137.

${ }^{78}$ Overigens waren voor Breysig de nieuwe technische mogelijkheden voor artistieke reproducties (inclusief de grammofoon) vooral een teken van massale vervlakking: 'de meest onvolkomen tekening zou levensvoller zijn', zie Breysig (1912), 190. Het is in dit verband interessant te bedenken dat Breysig de enige Berlijnse docent schijnt te zijn geweest die door de latere auteur van Das Kunstwerk im Zeitalter seiner technischen Reproduzierbarkeit werd gewaardeerd, zie: www.bautz.de/bbkl/b/benjamin_wa.shtml.

${ }^{79}$ Steinhausen (1931), 462-463. 
Zowel Lamprecht als Goetz maakten overigens zelf een opvallend gebruik van de nieuwe mogelijkheden om beeldmateriaal te reproduceren. Zo rustte Lamprecht het IKU ten behoeve van het onderwijs uit met een 'epidiaskop' waarmee afbeeldingen geprojecteerd konden worden en stelde hij ten behoeve van het historisch onderzoek de fotografische reproductie en verspreiding van belangrijke archivalia voor. ${ }^{80}$ Typerend was ook de uitzonderlijk rijke uitrusting van Goetz' Propyläen Weltgeschichte met reproducties, foto's en zelfs facsimiles, een onderscheidend kenmerk van deze historische encyclopedie dat Goetz zelf verdedigde met een verwijzing naar Lamprechts vroegere onderwijsmethoden. ${ }^{81}$

Al met al waren de cultuurhistorici het erover eens dat er in hun tijd, in de woorden van Lamprecht, sprake was van een 'ungeheure Andrang neuen Stoffes' en van een 'ungeheure Summe neuer Erfahrungen'. ${ }^{82}$ Over de maatschappelijke processen die verbonden waren met deze vloed van nieuwe indrukken bestond eveneens overeenstemming. Het ging om bevolkingsgroei, verstedelijking, algemene welvaartsstijging (Steinhausen signaleerde in verband hiermee onder andere het toegenomen aantal dikke mensen), de toename van technologische en wetenschappelijke kennis, de industrialisatie (mechanisering en motorisering van verkeer en produktie), de toenemende verschriftelijking, Verschulung en bureaucratisering, en de toenemende staatsinvloed op het leven. Als een van de belangrijkste factoren, ten slotte, werd het kapitalisme, of precieser, de ontwikkeling van de moderne kapitalistische onderneming als de heersende bedrijfsvorm genoemd. ${ }^{83}$ Het is dit fenomeen dat door alle auteurs in verband wordt gebracht met een toegenomen bedrijvigheid, haast, verhoging van het tempo en druk van de arbeid en de toegenomen 'strijd om het bestaan'.

\section{5 'Zenuwen in onze zin hebben onze voorouders niet gehad'}

Het gevolg van de toenemende internationalisering en de moderne versnelling van het leven was een algemene 'nervositeit': het derde algemene kenmerk van de eigentijdse cultuur volgens de cultuurhistorici. 'Zenuwen in onze zin hebben onze voorouders niet gehad', meende Steinhausen. 'Zij zijn een product van een sterk verfijnde cultuur enerzijds en de totale omwenteling van de uiterlijke leefomstandigheden anderzijds' ${ }^{84}$ Voor de cultuurhistorici, die geneigd waren 'cultuur' te beschouwden als het uitvloeisel van 'een collectieve psychische gesteldheid', bereiken we hiermee de kern van hun analyse van de eigen tijd. ${ }^{85}$

Het was Lamprecht die het meest bekend is geworden met zijn typering uit 1902 van de eigen tijd als een 'Periode der Reizsamkeit'. ${ }^{86}$ Maar Lamprecht was niet de enige en ook niet de eerste onder de nieuwe cultuurhistorici die de eigentijdse cultuur als 'nerveus' typeerde. Alle cultuurhistorici spraken over de Nervosität, Reizbarkeit of Erregbarkeit als kenmerk van de eigen tijd. Nog vóór Lamprecht had Steinhausen in 1895 een studie over de historische veranderingen in het Duitse gevoelsleven afgesloten

${ }^{80}$ Zie Lamprecht (1910), 10, en Bericht (1907), 44.
${ }^{81}$ Goetz (1957a), 68.
${ }^{82}$ Lamprecht (1891-1909), 281-282.
${ }^{83}$ Zie Lamprecht (1891-1909), ErgBd. II.1, 241-520.
${ }^{84}$ Steinhausen (1895), 41.
${ }^{85}$ Vgl. hoofdstuk 2, paragraaf 6, hoofdstuk 5, paragraaf 7 en hoofdstuk 6.
${ }^{86}$ Het woord 'Reizsamkeit' wordt voor zover ik weet door Lamprecht voor het eerst gebruikt in Lamprecht (1891-1909), ErgBd. I, VIII, 41, 59 etc. Volgens Chickering gaat het om een neologisme ontleend aan Nietzsche. Dat schreef ook de sociaal/cultuur-psycholoog en oud-student van Lamprecht, Hellpach, die de aanduiding overnam, zie Hellpach (1902), 4. 
met een deel over de 'neue nervöse Periode'. ${ }^{87}$ En ook Steinhausen was geenszins origineel met deze kwalificatie.

De historicus Joachim Radkau heeft in 1998 overtuigend laten zien dat de diagnose èn de ervaring van de eigentijdse nervositeit in het wilhelminische Duitsland wijd verbreid waren. ${ }^{88}$ Steinhausen zelf verantwoordde zijn typering van de eigen tijd door te verwijzen naar het algemene gebruik van 'nervositeit' om het eigentijdse gevoelsleven mee te karakteriseren. ${ }^{89}$ Meer speciaal verwees hij bovendien naar de vooraanstaande Duitse neuroloog Wilhelm Erb (1840-1921), die in 1893 een redevoering 'over de groeiende nervositeit van onze tijd' had gehouden: ${ }^{90}$

'[Erb] heeft zeer juist uiteengezet, hoe de buitengewone verworvenheden van onze cultuur, de onmetelijke versterking en snelheid van het verkeer, de kolossaal toegenomen eisen aan het prestatievermogen van het individu, de politieke en sociale strijd, de scherpte van de huidige genotsmiddelen, het moderne Großstadttreiben, de economische strijd om het bestaan, en nog veel meer de toename van de nervositeit in onze dagen wel begrijpelijk maken.'

Erb op zijn beurt stond in contact met de man die in het algemeen beschouwd wordt als de 'ontdekker' van de moderne nervositeit als ziekteverschijnsel - en als zodanig ook door Lamprecht als autoriteit werd aangehaald: de Amerikaanse arts George M. Beard (1839-1883). ${ }^{91}$ Beard's boek over neurasthenia (letterlijk: 'zenuwzwakte') uit 1880 werd vrijwel meteen in het Duits vertaald en beleefde in die vorm alleen al in de jaren tachtig drie drukken. Erb was een van de sleutelfiguren in de vroege receptie van Beard's boek in Duitsland. ${ }^{92}$ Diens ideeën over neurasthenie sloten naadloos aan bij de

\footnotetext{
${ }^{87}$ Steinhausen (1895), 41: “"Nerven” in unserem Sinne haben unsere Vorfahren nicht gehabt. Sie sind ein Erzeugnis stark verfeinerter Kultur einerseits, des totalen Wandels der äußeren Lebensverhältnisse andererseits: wir leben rascher als unsere Vorfahren. [...]'. In een bespreking van Lamprechts Ergänzungbände I en II.1 wijst Steinhausen erop dat hij hiermee Lamprechts interpretatie voor was, zonder dat dat erkend werd, zie Steinhausen (1903), 362.

${ }^{88}$ Radkau (1998). De afgelopen jaren is er veel aandacht geweest voor deze thematiek, zie behalve Radkau ook Lentz (1994), Eckhart (1997), Gijswijt-Hofstra en Porter (2001).

${ }^{89}$ Steinhausen (1895), 40-41: een woord 'das man so vielfach hört und das man heute mit besonderer Vorliebe auf das Fühlen und Empfinden der Zeitgenossen anwendet'. Later ook: Zie bijv. Steinhausen (1929), 667-668 (idem al Steinhausen (1913), II, 493-4): 'Jene Hast des ganzen Lebens aber, [...] hat, verbunden mit dem Verkehrs- und Maschinenlärm, mit der Schnelligkeit und dem vermehrten Gebrauch der Verkehrsmittel, mit der häufigen Änderung der Wohnung und auch des Wohnsitzes, mit jenen Kampf ums Dasein, endlich mit der starken Genußsucht und der ewigen Jagd nach Neuem, seit langem auch das Nervenleben, vor allem bei der großstädtischen | Bevölkerung, außerordentlich beeinflußt, zum Teil sicher schädlich [...], zum Hauptteil aber in der Richtung einer steigenden Anpassung der Nerven. Man kommt, wie man treffend bemerkt hat, von der Neurasthenie allmählich zur Neurosthenie (von der Nervenschwäche zur Nervenstärke). Immerhin ergibt sich eine starke Reizbarkeit und Empfindlichkeit, anderseits ein Bedürfnis nach ständigen Anreiz der Nerven, das auch das geistige und künstlerische Schaffen und Genießen beeinflußt. Das Musikalische Ohr z. B. liebt nicht mehr das Schlichte, Ruhige, Getragene, sondern das Verwickelte, technisch raffinierte, dabei den äußersten Lärm der Instrumente sowie eine das Innere gewaltsam erregende Stimmung.'

${ }^{90}$ Zie Erb (1893); citaat van Steinhausen (1895), 41.

${ }^{91}$ G.M. Beard, A practical treatise on nervous exhaustion (Neurasthenia). New York, 1880. Het boek werd vrijwel meteen in het Duits vertaald (Die Nervenschwäche, 1881, 2e dr. 1883, 3e dr. 1889). Vgl. Lamprecht (1891-1909), ErgBd. II.1, 250. Zie over Beard: Gijswijt-Hofstra en Porter (2001), en Radkau (1998), 49-55.

${ }_{92}$ Vergl. Roelcke (2001), 181 e.v. over de fasering van de Duitse receptie van het neurasthenieconcept: in de vroege receptie (waarin Erb de centrale figuur was) stonden net als bij Beard de externe oorzaken centraal. Pas later werden erfelijkheid en degeneratie belangrijke aspecten van het neurasthenieconcept. Erb had al vóór of in 1881 contact gehad met Beard over de kwestie van de toenemende nervositeit in hun tijd, zie Beard (1881), 342-343. Zie ook Radkau (1998), 54-62.
} 
opvattingen van de nieuwe cultuurhistorici over de historische aard van collectieve psychische gesteldheden: hij beschouwde de moderne zenuwzwakte als een historisch en collectief verschijnsel, dat hoofdzakelijk veroorzaakt werd door moderniseringsprocessen: $:^{93}$

'The chief and primary cause of this development and very rapid increase of nervousness is modern civilization, which is distinguished from the ancient by these five characteristics: steampower, the periodical press, the telegraph, the sciences, and the mental activity of women.'

Vergelijkbare opvattingen werden verkondigd door andere eigentijdse, medisch en psychologisch geschoolde auteurs waarnaar de cultuurhistorici verwezen, zoals de nog jonge sociaal-psycholoog Willy Hellpach (1877-1955, hij had overigens zelf bij Lamprecht gestudeerd en schreef ook over hem $)^{94}$ en generatie-genoot en Lazarusleerling Georg Simmel. ${ }^{95}$ In een bekende psychologische beschouwing over het leven in de grote stad uit 1903, schreef de laatste bijvoorbeeld dat het typische grootsteedse individu ontstond door 'de verheviging van het zenuwleven, die voortkomt uit de snelle en ononderbroken afwisseling van uiterlijke en innerlijke indrukken' ${ }^{96}$

Bij deze psychologisch georiënteerde auteurs vonden de nieuwe cultuurhistorici een bevestiging van de historisch-psychologische opvattingen die zij al gedurende hun opleiding hadden leren koesteren. Mogen we de cultuurhistorici zelf geloven, dan is dat nog veel te zwak uitgedrukt: overal om zich heen, in wetenschap, kunst, muziek en literatuur bespeurden zij 'een nieuwe onthulling van de ziel', een wending naar het 'intieme' en naar het 'psychische leven'. ${ }^{97}$ Dit verschijnsel moest volgens de cultuurhistorici uitgelegd worden als een eerste kenmerk van de eigentijdse 'nervositeit'.

Op een fundamenteel terrein als de kenleer bijvoorbeeld, kreeg de Kantiaanse analyse concurrentie van een 'steeds sterker wordende fenomenalistische verklaring van het kennen', 'die steeds nauwer bij de psychologische ervaring aansloot'. ${ }^{98}$ We kunnen daarbij bijvoorbeeld denken aan Ernst Mach's Beiträge zur Analyse der Empfindungen (1886), maar natuurlijk ook aan Diltheys pogingen tot een psychologische fundering van de geesteswetenschappen. In de geesteswetenschappen in het algemeen signaleerden de cultuurhistorici een 'wending naar psychologische studies, waarin ook de zogenaamde lagere gebieden van het zielsleven worden onderzocht [...]. ${ }^{, 99}$ Zowel Lamprecht als Steinhausen en Gothein verwezen onder andere naar het gelijktijdige werk van hun generatiegenoot, de econoom en Schmoller-promovendus Werner Sombart, waarin eveneens sprake was van een historisch-psychologische analyse van de

\footnotetext{
${ }^{93}$ Zie Beard (1881), vi, dat gewijd is aan de culturele oorzaken van de neurasthenie. Vgl. Hellpach (1906), 45-46.

${ }_{94}$ Over Hellpach zie: Engstrom (1997), Lück (1988), Stallmeister en Lück (1991). Hij stichtte in 1921 het eerste Duitse instituut voor sociale psychologie.

${ }^{95}$ Lamprecht (1891-1909), ErgBd. II.1, 250. Lamprecht citeert een artikel van zijn oud-student Willy Hellpach uit 1902 over 'Soziale Ursachen und Wirkungen der Nervosität', een thema waar Hellpach nog in hetzelfde jaar en later in 1906 nog eens omvangrijke verhandelingen aan zou wijden. Hellpach signaleerde al in 1902 de populariteit van Lamprechts Reizsamkeit-begrip (dat hijzelf overneemt). Hellpach recipieerde zelf ook Breysigs historisch-psychologische opvattingen. Zie Hellpach (1902), 2-5.

${ }^{96}$ Simmel (1903), 18. Gothein werd door het contact met Simmel in Heidelberg gestimuleerd om het thema van de historische psychologie weer op te pakken, zie Gothein (1931), 211 e.v.

${ }^{97}$ Lamprecht (1891-1909), ErgBd. I, 224, noemt 'intim' een lievelingswoord van de eigen tijd. Verder a.w. I, 428. Voor Goetz, zie: Goetz (1930a), 520.

${ }^{98}$ Lamprecht (1891-1909), ErgBd. I, 447.

${ }^{99}$ Lamprecht (1891-1909), ErgBd. I, 465.
} 
eigentijdse geestesgesteldheid. ${ }^{100}$ Naar aanleiding van een recente publicatie van Sombart in 1911, merkte Gothein op: 'Alles richt zich nu op de sociologische en psychologische behandeling van historische problemen.Het is de weg die ik altijd voor de juiste heb gehouden en zelf ook vaak ben gegaan [....] Het is goed wanneer wij deze 'historische psychologie' zoals ik haar noem, met kracht ondersteunen'. ${ }^{101}$

Tegelijk signaleerden de cultuurhistorici overal 'een nieuwe psychologische kunst', waarin zoals Lamprecht het formuleerde 'tot nu toe nooit tot bewustzijn gebrachte natuurlijke processen' tot uitdrukking kwamen: ${ }^{102}$ de muziek van Wagner en Strauß, het impressionisme in de schilderkunst, de letterkunde van het naturalisme tot het symbolisme - allemaal werden ze door Lamprecht geïnterpreteerd als uitdrukkingen van een steeds gevoeligere psychische gesteldheid en steeds verfijndere psychische vermogens. De nieuwe harmonieën in Wagners muziek waren voor Lamprecht (maar bijvoorbeeld ook voor Goetz) vooral uitdrukking van een diepe 'nerveuze laag' die voordien niet in de muziek aangeboord werd. ${ }^{103}$ De opkomst van het impressionisme werd door zowel Lamprecht als Steinhausen en Breysig beschouwd als een eerste wending naar het innerlijk, die vervolgens in het expressionisme werd voortgezet: al in het impressionisme werd immers, zoals Lamprecht zich uitdrukte 'de harde uiterlijkheid van de dingen [...] als een totaliteit ondergeschikt gemaakt aan de innerlijke impressie [Gesichtseindruck]'. ${ }^{104}$ Van eigentijdse dichters als Hofmannsthal of George lijfdichter van Breysig en huisvriend van de Gotheins - meende Lamprecht dat ze quasi met 'psychologen en psychiaters' gingen wedijveren: ook zij drongen door 'tot het rijk van de primitieve gevoelens [Empfindungen], van de eerste Reizvorgänge'. ${ }^{105}$ Een nieuw bereik van het zielsleven werd in de moderne literatuur blootgelegd, meende ook Steinhausen: 'conform de psychologiserende richting van het hele culturele leven, boorde men zich dieper in de ziel, ontleedde, ontrafelde haar'. ${ }^{106}$ Het psychologisch georiënteerde historisch werk van de nieuwe cultuurhistorici liep in dit opzicht in de pas met eigentijdse ontwikkelingen in kunst en literatuur. Dat vonden niet alleen zijzelf, maar ook hun tegenstanders: meer dan één criticus associeerde in ieder geval Lamprechts werk met 'die Moderne', een begrip dat in de jaren negentig vooral met naturalistische literatuur in verband werd gebracht. ${ }^{107}$ Ook Breysigs werk stond volgens critici al te zeer onder invloed van 'literaire modestromingen'. ${ }^{108}$ Omgekeerd kon bijvoorbeeld Lamprechts typering van Gerhardt Hauptmanns naturalistische drama over

${ }^{100}$ Sombarts werk Der Bourgeois bijvoorbeeld beoogde de 'Untermauerung der seelischen Analyse [der Geist unserer Zeit] mit historischem Material', zie Sombart (1913), [III]. In de Erg.Bde van zijn DG verwijst Lamprecht regelmatig naar Sombart's Moderner Kapitalismus. Zie ook Lamprecht (1974), 600601 (1904). Zie over de relatie Sombart-Lamprecht: Hartmann (1904), Appel (1992), 45-47 en Lenger (1994), 123-127. Steinhausen baseerde zijn opmerkingen over de geschiedenis van het kapitalisme ook sterk op het werk van Sombart, zie Steinhausen (1931), 98n1. Voor Gothein en Sombart, zie Gothein (1931), 234. Ook Breysig was bevriend met Sombart, zie Gertrud Breysig (1967), 83 ev. en Breysig (1962), 149-154.

${ }^{101}$ Brief van 28-2-1911, in: Maurer (2006), 378-379.

${ }^{102}$ Lamprecht (1905), 58.

${ }^{103}$ Lamprecht (1891-1909), ErgBd. I, 31;Goetz (1930a), 520; ook Steinhausen (1931), 249-250 en Breysig (1931), 205.

${ }^{104}$ Lamprecht (1891-1909), ErgBd. I, 111; zo ook Steinhausen (1931), 241. Breysig (1931), 201-

202; ook Breysig (1927), 160-163: 'Der Impressionismus ist eine Phänomenologie der Malerei'.

${ }^{105}$ Lamprecht (1891-1909), ErgBd. I, 257.

${ }^{106}$ Steinhausen (1931), 226.

${ }^{107}$ Vgl. Gumbrecht (1978), 120-121.

${ }^{108}$ Aldus het oordeel van de Berlijnse filosofische faculteit bij monde van Meinecke in 1922, zie Brocke (1971), 111. 
de zestiende-eeuwse boerenleider Florian Geyer (1896) mutatis mutandis doorgaan voor een karakteristiek van zijn eigen geschiedschrijving:

'zelfs buiten de taal wordt de cultuurhistorische psychische toestand van de zestiende eeuw in alle opzichten opgezocht [...] En pas binnen deze grote tijd-psychische grondstemming [diapason] ontvouwt zich de bijzondere dramatische handeling,. ${ }^{109}$

Het psychologiserende karakter van de eigentijdse kunst en wetenschap werden beschouwd als een uiting van de algemene nervositeit. 'Nerveus' betekende dan niet een ziekelijke zenuwzwakte, maar een verhoogde gevoeligheid voor indrukken, 'een grotere ontvankelijkheid van het zenuwsysteem voor prikkels als een habitueller eigenschap'. ${ }^{110}$ De nervositeit was een noodzakelijke mentale aanpassing aan de maatschappelijke versnelling. De grote eigentijdse aandacht van wetenschappers en kunstenaars voor de psyche, waarvan ook hun eigen werk getuigde, werd door de cultuurhistorici uitgelegd als teken van een versterkte waarneming en van een voortgeschreden bewustwording van de werkelijkheid. De nerveuze mens moest entwicklungsgeschichtlich als een hoger en verfijnder menstype worden beschouwd.

Deze positieve beoordeling was de reden dat Lamprecht het woord Reizsamkeit boven 'nervositeit' verkoos als aanduiding van de eigentijdse cultuur, omdat aan het laatste begrip morbide associaties kleefden. En hij was niet de enige die de eigentijdse nervositeit op deze positieve wijze duidde: zowel andere aanhangers van het neurasthenie-discours in het algemeen, als andere cultuurhistorici deelden deze opvatting. Zelfs Steinhausen, die van de cultuurhistorici misschien het meest neigde naar cultuurpessimisme, stelde vast dat de versnelling van het leven, zeker in de grote steden,

'het zenuwleven buitengewoon sterk heeft beïnvloed, ten dele zeker schadelijk, maar hoofdzakelijk toch in de richting van een toenemende aanpassing van de zenuwen. Men komt, zoals men treffend opgemerkt heeft, van de neurasthenie geleidelijk tot neurosthenie (van zenuwzwakte naar sterke zenuwen)'. ${ }^{11}$

Kenmerkend voor de 'nerveuze' mentale gesteldheid achtten verschillende cultuurhistorici de significant verscherpte waarneming van ruimte en tijd. Zo duidden zij de impressionistische schilderkunst met haar nadruk op kleur ten koste van de contour als een uiting van een verscherpte ruimtewaarneming. De behoefte aan exactere tijdwaarneming werd door Lamprecht geïllustreerd met gegevens over de miljoenen in Duitsland ingevoerde zakhorloges gedurende het decennium voor 1903. Hij beschreef hoe, gestimuleerd door het verkeer, de toegenomen snelheid van het leven en een economisch systeem waarin tijd geld was, korte tijdsperiodes in praktisch belang toenamen en stiptheid een nieuw ideaal werd: 'Fünfminutenaudienzen, Minutengespräche am Telephon, Sekundenproduktion der Rotationsdruckmaschine, Fünftelsekundenmessung beim Fahrrad: moralisch ausgedrückt Pünktlichkeit'. ${ }^{112}$

De meeste cultuurhistorici wezen verder op een versterking van de rationele en berekenende vermogens van de mens in de eigen tijd. Speciaal de moderne ondernemers werden door de moderne productietechnologieën, de moderne grootschalige bedrijfsvoering en het functioneren in een vrije markt onderworpen aan een voortdurende

\footnotetext{
${ }^{109}$ Lamprecht (1891-1909), ErgBd. I, 331.

${ }^{110}$ Lamprecht (1891-1909), ErgBd. II.1, 263.

${ }^{111}$ Steinhausen (1929), 667-668. Ook al in Steinhausen (1913), II, 494.

${ }^{112}$ Lamprecht (1891-1909), ErgBd. II.1, 159.
} 
'praktische oefening van intellectuele fijngevoeligheid'. ${ }^{113}$ De moderne ondernemer en zijn adminstratief personeel waren in feite de belangrijkste klasse van 'hoofdarbeiders' geworden, zoals Lamprecht opmerkte. ${ }^{114}$

Maar ook los van de invloed van de vrije onderneming, werd het 'oordeelsvermogen' sterk gestimuleerd door de 'enorme hoeveelheid nieuwe ervaringen' en de daarmee toegenomen 'oordeelsmogelijkheid'. Het rationele aspect werd daarbij nog eens extra gestimuleerd doordat een belangrijk deel van de nieuwe ervaringen van cognitieve aard was: door de sterk toegenomen verschriftelijking, de toename van scholing en onderwijs, van lectuur van allerhande soort, waaronder de dagelijkse krant, van wetenschap en de popularisering daarvan. Zowel Lamprecht als Steinhausen maakten in verband hiermee melding van blijkbaar in brede kring levende klachten over intellectuele overbelasting, bijvoorbeeld van scholieren, die het geheugen zou aantasten en ten koste zou gaan van wilskracht en gevoelsleven. ${ }^{115}$

Toch ontkenden verschillende cultuurhistorici met zoveel woorden dat de moderne tijd alleen maar een verdere rationalisering, een versterking van de rationele vermogens van de mens betekende. Voor Breysig was de moderne Erregbarkeit zelfs vooral een zaak van sterke en heftige gepassioneerdheid waarin gevoel en wil de eveneens versterkte ratio slechts als middel gebruikten. ${ }^{116}$ Duidelijk was voor de meeste cultuurhistorici dat niet alleen de intellectuele kanten van de psyche werden gestimuleerd in de eigentijdse cultuur. Integendeel: het systeem van de vrije onderneming, waarin de onzekerheid en wisselvalligheid van de markt domineerde, leidde voor alle betrokkenen tot een grote psychische druk en spanning; zeker de ondernemer zelf werd voortdurend door wisselende affecten geplaagd. ${ }^{117}$ Ook het gemoedsleven werd in het nerveuze tijdperk zodoende sterk geprikkeld. Het 'driftleven' was, zowel volgens Steinhausen als Breysig, 'sterker dan ooit'. Met name in de grote steden was er sprake van een zich steeds verder uitbreidende 'erotische atmosfeer' en een 'steigende geschlechtliche Gier'. ${ }^{118}$ De toegenomen psychische spanningen dwongen tot extreme zelfbeheersing en dat leidde van de weeromstuit tot een nieuwe ontspanningscultuur waarin opwinding en sensaties, Erregungsgenu $\beta$, zoals Lamprecht zich uitdrukte, centraal stonden. ${ }^{119}$

${ }^{113}$ Lamprecht (1891-1909), ErgBd. II.1, 140-141: 'hier ist klar, daß die kausalen Elemente, die in dem Fabrikationsvorgang beschlossen liegen [i.t.t.de teleologische elementen van het ambacht], daß das rechnerische und rationalistisch-ökonomische Verhalten der wissenschaftlichen Technik, das sich in jeder Maschine, jedem Arbeitsverfahren der Fabrik ausprägt, schließlich auch die Seele des Unternehmers ergreift.' Ook Steinhausen legt grote nadruk op de rationalistische geest en de 'Rechenhaftigkeit' die in de jaren '70 en ' 80 heersend wordt: 'Die Betätigung der Verstandeskräfte ist insbesondere eine

Haupttriebkraft der technisch-kapitalistisch-materiellen Zivilisation, in der wir leben'. Zie Steinhausen (1931), 384-402, aldaar 384.

${ }_{114}$ Lamprecht (1891-1909), ErgBd. II.1, 235-236.

${ }^{115}$ Lamprecht (1891-1909), ErgBd. II.1, 243: 'und tausend klagen erschollen von allen Enden über diese Überbürdung, von den Bureaus und Kontoren hinab bis zu den höheren und mittleren Schulen'. Volgens Lamprecht was er een algemeen klagen over de afname van het geheugenvermogen en over de overbelasting van het geheugen met name bij de jeugd: Lamprecht (1905), 59. Dit wordt bevestigd door Steinhausen; hij heeft het over de grote Bildungslast die de andere psychische vermogens aantast, zie Steinhausen (1931), 331, 447.

${ }^{116}$ Breysig (1931), 394.

${ }^{117}$ Zie Lamprecht (1891-1909), ErgBd. II.1, 241-262, aldaar 244: 'Woher kamen nun diese neuen Stimmungen, diese Gefühlsmomente, welche die neue Kultur mit beherrschten [...]? Sie traten [...] auf als Begleiterscheinungen der Entwicklung der Unternehmung.' Vgl. ook Steinhausen (1931), 335: 'das nervenverzehrende, im Grunde leeren Geschäftstreiben'.

${ }^{118}$ Steinhausen (1931), 433, 489; Breysig (1931), 378, heeft het over een 'neue Verstärkung und Erregung des Liebesgefühls zwischen den beiden Geslechtern'.

${ }^{119}$ Lamprecht (1891-1909), ErgBd. II.1, 249-254. Vergl. idem Breysig (1912), 190. 


\section{6 'Wij zijn geen eenheid meer'}

So far, so good, zou je kunnen denken. De nieuwe cultuurhistorici beleefden hun eigen tijd als een dynamische wereld, die steeds internationaler van karakter werd en steeds sneller veranderde. Een wereld waarin de mensen bovendien een aanmerkelijke verandering, ja verfijning en versterking van hun 'mentale uitrusting' beleefden. Het Verlicht historisme van de nieuwe cultuurhistorici, met de kenmerkende koppeling van opeenvolgende historische stadia en mentale veranderingen, bevestigde hun ervaring van de eigen tijd. En andersom: hun ervaring van de eigen tijd bevestigde hun geschiedtheorie waarin historische breuken en psychische veranderingen centraal stonden.

Het is niet moeilijk om in deze visie het geloof van de nieuwe cultuurhistorici te bespeuren in de vooruitgang van de mensheid. Terwijl alom, zoals zij zelf signaleerden, gesproken werd over 'decadentie' en 'verval', ontkenden Lamprecht en Breysig met zoveel woorden dat daarvan sprake was. ${ }^{120}$ Lamprecht verafschuwde de 'orgiën van het huidige pessimisme'. ${ }^{121}$ En ook Goetz meende: 'De wereldgeschiedenis leert ons een dergelijk pessimisme niet'. Ook na de verschrikkingen van de Wereldoorlog bleef hij geloven in de kracht van 'de geest van de Verlichting' die in de voorbije twee eeuwen Europa tot zijn 'rijkste ontwikkeling' had gebracht. ${ }^{122}$ Zelfs de somber gestemde Steinhausen bleef vertrouwen in een goede afloop. Toen hij na de oorlog een uitvoerig artikel wijdde aan de 'vervalsstemming in keizerlijk Duitsland', eindigde hij met de vaststelling dat de 'aanwezige gezonde, innerlijk waardevolle en voorwaarts wijzende verschijnselen meer waarde moet worden toegekend dan in de besproken opinies meestal is gebeurd [...]. Symptomen van neergang, lijden horen bij een tijd van ungeheur Vowärtsgehen'.

Toch is het duidelijk dat zowel Steinhausen als de andere nieuwe cultuurhistorici zich serieus zorgen maakten over hun eigen tijd. Alle verzekeringen ten spijt dat de eigentijdse Reizsamkeit geen ziekelijk verschijnsel was, vinden we in hun werk talloze uitspraken die erop duiden dat zij de eigentijdse nervositeit niet alleen opvatten als een uiting van een toegenomen gevoeligheid voor indrukken. Het was ook een uiting van onzekerheid, van de 'unsicher-problematische Beschaffenheit' (Breysig), die de eigen tijd sterk van het verleden onderscheidde. ${ }^{124}$

De eigentijdse onzekerheid was een gevolg van verschillende problemen. Allereerst betekende het vrije ondernemerschap zowel voor ondernemers als arbeiders een 'eeuwige angst voor de toekomst', ${ }^{125}$ een gevolg van de onvoorspelbaarheid en ondoorzichtigheid van de markt en de conjunctuurbeweging. De zekerheden van het verleden boden tegen deze angst voor de toekomst geen soelaas. Des te minder omdat zij zelf hun traditionele zeggingskracht razendsnel verloren. Even snel als de steden groeiden, met hun bont geschakeerde bevolkingssamenstelling, verloren oude tradities er aan invloed, stelde Goetz bijvoorbeeld vast. ${ }^{126}$ Alle cultuurhistorici wezen op de rol van de toegenomen rationalisering en verwetenschappelijking als ondergravers van oude zeker-

${ }^{120}$ Breysig (1931), 321-325; Breysig (1912), 70: de kwalijke eigentijdse verschijnselen zijn deel van een 'natuurlijk groeiproces' van de natie. Lamprecht (1891-1909), ErgBd. I, 466-471.

${ }^{121}$ Citaat uit een brief aan Th. Lipps uit 1899, bij Schorn-Schütte (1984), 211.

122 Goetz (1929-1933), X, 524 en xxiv.

${ }^{123}$ Steinhausen (1923), 185. Zie ook bijv. Steinhausen (1913), II, 27: 'door de verbreiding van een fijner cultureel gevoel kunnen de ergste uitwassen uit de weg geruimd worden. Uiteindelijk behoudt het creatieve leven altijd de bovenhand'.

${ }^{124}$ Breysig (1931), 503; vgl. Steinhausen (1931), 228, over de 'Problematik des Daseins' als kenmerk van de tijd voor de Eerste Wereldoorlog.

${ }^{125}$ Goetz (1930a), 536; hierover ook Lamprecht (1891-1909), ErgBd. II.1, 241-262.

${ }^{126}$ Goetz (1930a), 498. 
heden. 'Het rationalisme, het intellectualisme tast de traditie aan', meende Steinhausen. ${ }^{127}$ 'Het besef dat alle vaste, absolute waarden erschüttert zijn, is nu eenmaal beknellend geworden'. ${ }^{128}$ En Steinhausen stond met die vaststelling niet alleen. Ook Lamprecht meende dat als gevolg van de toegenomen kennis 'bijna alles, wat tot nog toe een vast element van het leven leek, in zijn oude vorm althans onhoudbaar werd: het werd vloeibaar'. Het gevolg was 'een ongelooflijke wirwar, een chaos in de begripsvorming'. ${ }^{29}$ De toenemende lectuur van krant en boek droeg bij tot het algemeen worden van de geestelijke 'onzekerheid en verwarring' en rukte 'de mensen van geloof en overlevering los', constateerde ook Goetz: 'de nerveuze geest aan het einde van de [negentiende] eeuw ontwikkelde zich voor een niet gering deel uit de moderne krant en haar methoden van kennisoverdracht'. ${ }^{130}$

Ook de toegenomen mobiliteit zorgde voor onzekerheid: de cultuurhistorici spraken van een wijdverspreide Entwurzelung en een verlies van Heimat. Dat was opnieuw niet alleen de opvatting van Steinhausen, maar werd ook door Breysig en, zij het met kenmerkende afstandelijkheid, door Lamprecht opgemerkt: 'Het stoomschip, de spoorweg, de telegraaf zijn als het ware heimatlos. Daarom maken ze ook heimatlos, maken los van de grond, verlenen binnen de aardse verhoudingen een oneindige horizon'. 131

De industrialisering en mechanisering leidden verder tot wat Steinhausen de toenemende 'kunstmatigheid' van het bestaan noemde, zeker in de stad. Hij ervoer die als een aantasting van het 'eigenlijke wezen' van de mensen: ${ }^{132}$

'Wij leven in een alsmaar kunstmatiger uiterlijke omgeving en zijn in ons doen en laten, op straat, in het professionele leven in een gecompliceerde machinerie ingespannen'.

Het moderne stadsleven deed veel tijdgenoten verlangen naar de natuur of het 'onbedorven' landleven, stelden de cultuurhistorici vast. ${ }^{133}$ Breysig geloofde in 1912 dat de waarlijk creatieve en geistige mensen steeds vaker tot een trek naar het platteland zouden besluiten, waar de 'eigenheid' van de mens nu eenmaal beter in stand bleef dan in de stad. ${ }^{134}$ Hij zelf voegde een jaar later de daad bij het woord en liet in Rehbrücke bij Berlijn een villa in het groen bouwen. ${ }^{135}$

Maar ook natuur en platteland bleken alles behalve onaantastbaar. Breysig moest zelf al constateren dat de boeren vaak 'verstedelijkt' waren en ook Lamprecht beschreef de verpreiding van de cultuur van de vrije onderneming over het platteland. ${ }^{136}$ En terwijl Lamprecht of Gothein bij gelegenheid hun bewondering en fascinatie konden uiten over grote industriële werken, ${ }^{137}$ sprak Steinhausen voortdurend schande over de alom aan te

${ }^{127}$ Steinhausen (1931), 54, 57, 237, 390 e.v.

${ }^{128}$ Steinhausen (1929), 670; Steinhausen (1931), 237.

${ }^{129}$ Lamprecht (1891-1909), ErgBd. I, 283.

${ }^{130}$ Goetz (1930a), 463-464.

${ }^{131}$ Lamprecht (1891-1909), ErgBd. II.1, 159-160. Breysig (1912), 126 (ook 150): 'Wir Städter sind dem Boden Enfremdete, Entwurzelte, können nicht mehr mit noch in der Natur leben'.

${ }^{132}$ Steinhausen (1931), blz. 140.

${ }^{133}$ Zie bijv. Steinhausen (1929), II, 496-497. Steinhausen (1931), 178 e.v., 406, 473 e.v.: opkomst van sport- en lichaamscultuur, natuurgeneeskunde, tuinieren, buitenhuizen, natuurbaden, opkomst jeugdcultuur in vorm van Wandervogel (1897) en freideutsche Lebensreformbewegung (1913) en algemene trek naar de natuur.

${ }^{134}$ Breysig (1912), 153 en 160.

${ }^{135}$ Zie Gertrud Breysig (1967), 116-124.

${ }^{136}$ Breysig (1912), 151; Lamprecht (1891-1909), ErgBd. II.1, 340-419.

${ }^{137}$ Typerend is dat zelfs de moderne, industriële wereld een esthetische fascinatie kon uitoefenen. De eigentijdse industrieën kon Lamprecht appreciëren om hun 'malerische Eindrücke von 
wijzen industriële 'aantasting van de natuur'. ${ }^{138}$ Zijn zorgen daarover speelden ongetwijfeld een belangrijke rol in de aandacht die hij in zijn cultuurhistorisch werk gaf aan de geschiedenis van het landschap. ${ }^{139}$ Ook bij Lamprecht, Breysig en Goetz is overigens de belangstelling voor de geschiedenis van de natuur(beleving) vast te stellen. $^{140}$

Het meest verontrustende aspect van de eigen tijd was ongetwijfeld de aantasting van de sociale orde. Van de natie, de meest omvattende sociale categorie, tot het individu signaleerden de cultuurhistorici een hele reeks van wat niet anders dan identiteitsproblemen genoemd kunnen worden. Op alle niveaus van de samenleving was de eenheid en eigenheid zoek.

Dat de nationale cultuur volgens de cultuurhistorici steeds meer opging in een internationale cultuur, werd al in een eerdere paragraaf opgemerkt. Dat was vooral voor Steinhausen een probleem. Hij signaleerde net als Breysig ook het verdwijnen van de traditionele regionale en lokale verschillen waardoor de 'individuele rijkdom van de Duitse cultuur' steeds verder afnam 'ten gunste van een oppervlakkig type beschaving'. ${ }^{141}$

Maar er werd tegelijk zowel door Steinhausen als de andere cultuurhistorici alom een nieuwe verdeeldheid gesignaleerd. Zij maakten zich zorgen over de 'diepe innerlijke verscheurdheid' op intellectueel, sociaal en politiek terrein. ${ }^{142}$ Volgens Breysig ging de eigentijdse verdeeldheid zelfs dieper dan ooit eerder in de geschiedenis: tot op het psychische niveau was de samenleving verdeeld tussen sociale en elitaire tendensen die om de voorrang streden. 'De burgerlijke samenleving van de negentiende eeuw was ondanks haar snelle opkomst zonder zeker innerlijk houvast', schreef Goetz:

hoe sterker zij in getal en welstand werd, des te groter werd de innerlijke ontbinding, de economische tegenstelling tussen de afzonderlijke lagen, de afwending van gemeenschappelijke doelen, de onbarmhartige strijd om het bestaan'. ${ }^{143}$

Sociaal gesproken leidde de opkomst van de vrije onderneming niet alleen tot de opkomst van een arbeidersklasse en een ondernemersklasse, maar feitelijk tot de Beseitigung en Umschichtung van de gehele bestaande sociale stratificatie, meende Lamprecht. ${ }^{144}$ Dat had onder andere te maken met de steeds verder voortschrijdende arbeidsdeling, die op zichzelf, zoals Steinhausen meende, een belangrijke factor in de diepgaande 'sociale versplintering' was. ${ }^{145}$ De fabrieksarbeid betekende bovendien dat het gezinsleven zijn integriteit verloor. Vrouwen- en kinderarbeid in de steden verstoorden de oude huiselijkheid [Familienhaftigkeit], 'dit stevigste houvast voor de Duitse mens en de sterkste wortel van zijn innerlijk leven' (Steinhausen). ${ }^{146}$

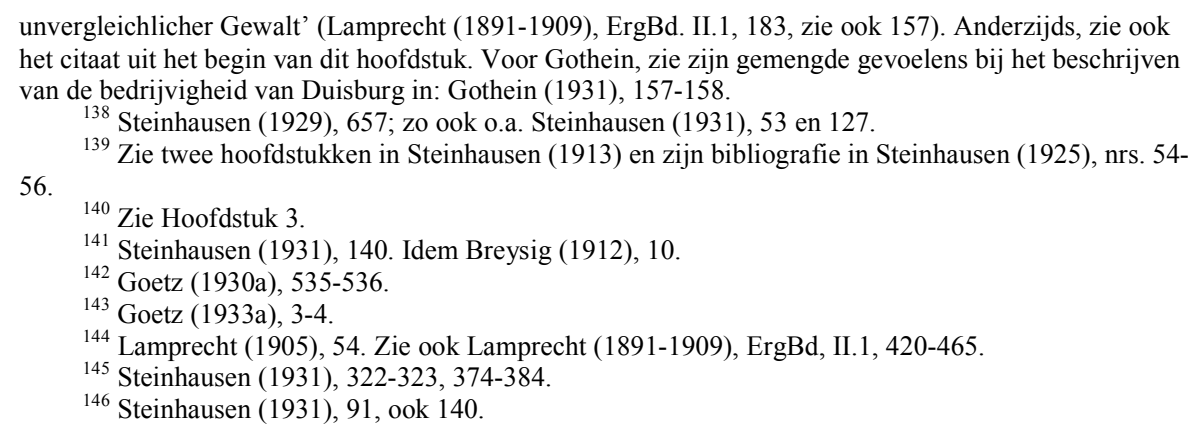


Steinhausen signaleerde ook een Ehekrise die tot uiting kwam in toenemend buitenechtelijk geslachtsverkeer en het stijgend aantal scheidingen. ${ }^{147}$ Zowel Steinhausen als Breysig (die zelf tweemaal van zijn echtgenote scheidde), wezen er bovendien op dat zelfs de vrouw niet meer was wat zij ooit was geweest: zij was 'gedeformeerd' of althans gemiddeld genomen 'mannelijker' geworden. ${ }^{148}$ Breysig en Steinhausen leken zich te scharen achter een in brede kring levende opinie, die de vrouwenemancipatie vooral als een deel van de maatschappelijke 'ontbinding' beschouwden. In dat geval stonden zij in ieder geval niet alleen, zoals Goetz (die zelf de vrouwenemancipatie actief steunde) opmerkte: veel (mannelijke) tijdgenoten beschouwden de vrouwen van hun tijd die naar een betere opleiding en meer rechten streefden slechts als lastige concurrenten van de man. ${ }^{149}$ In ieder geval één van de nieuwe cultuurhistorici was overigens getrouwd met een dergelijke onafhankelijke en ontwikkelde vrouw: Marie Luise Gothein verwierf dankzij haar pioniers- en standaardwerk Geschichte der Gartenkunst (1914) niet alleen een eredoctoraat van de universiteit Heidelberg, maar bovendien een blijvende academische reputatie als tuinhistorica. ${ }^{150}$

De vrouw, het gezin, de sociale lagen, de regio's, de natie: zij waren geen van alle meer de oude. Dat gold ten slotte ook voor het individu. Het individu werd volgens de cultuurhistorici geweld aangedaan door de 'buitengewone toename van de betrekkingen met de hele wereld'. ${ }^{151} \mathrm{Er}$ was geen sprake meer van de 'inhoudelijke eenheid van het bewustzijn', die vroeger vanzelfsprekend in de loop van het leven tot stand kwam. ${ }^{152}$ 'Meer dan ooit sinds de late oudheid [...] worden de individuele mensen van hun persoonlijke eenheid beroofd', meende Goetz. ${ }^{153}$ Ook Breysig stelde vast dat het voor het individu steeds moeilijker werd 'zich tot een geheel in zichzelf rustende cirkel te sluiten'. Hij signaleerde een wijdverspreide 'gespletenheid van het ik' en sprak over het Spaltdasein en het Splittermenschentum van zijn tijd. ${ }^{154}$ Noch in het dagelijkse leven, noch op 'de snijtafel van de wetenschap' vertoonde de mens nog langer innerlijke samenhang en viel hij als het ware in onderdelen en aspecten uiteen. ${ }^{155}$

De gevolgen van deze ontwikkeling waren ernstig: de cultuurhistorici signaleerden het verdwijnen van 'persoonlijkheden' en van 'creatieve kracht' in de samenleving, het oprukken van 'leegheid' en massale 'vervlakking' van het individuele psychisch leven. ${ }^{156} \mathrm{Zij}$ leefden volgens hun eigen perceptie in een tijd die de individualiteit van mensen teniet deed, een tijd van mechanisering en massalisering van het psychisch leven. En zij signaleerden een algemeen verbreid 'egoïsme'. Deze thema's werden niet alleen breed uitgemeten door Steinhausen en Breysig, maar vinden we ook bij Lamprecht. De laatste typeerde zijn tijdgenoten bijvoorbeeld als 'geestelijk en lichamelijk hard en straf gebouwd [...] met soms van louter zakelijkheid inhoudsloze

\footnotetext{
${ }^{147}$ Steinhausen (1931), 491-492.
}

${ }^{148}$ Zie Steinhausen (1931). 471; Breysig (1931), 312-313. Ook Breysig (1912), 126: de vrouwen werden 'gedeformeerd' door intellectualisering en politisering. Ook Beard (1881) noemde de veranderde positie van de vrouw al als reden voor de toegenomen nervositeit; bij hem gaat het dan om de nerveuze belasting van vrouwen zelf, m.n. als gevolg van hun toegenomen scholing.

${ }^{149}$ Goetz (1933a), 4. Zie verder Weigand (1992), 95-96, 113.

${ }^{150}$ Zie over haar: Göttler (1994), incl. bibliografie, Maurer (1999) en Maurer e.a. (2006). Gothein zelf toont zich in zijn briefwisseling een tegenstander van 'reactionaire' critici van de vrouwenemancipatie, zie bijv. Maurer e.a. (2006), 187 (brief 3.7.1904).

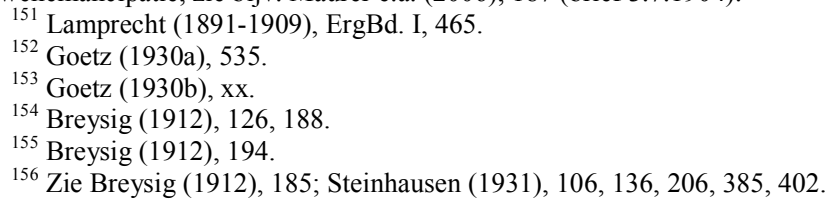


trekken'. ${ }^{157}$ Volgens hem dreigde de mens in het systeem van de vrije onderneming verloren te gaan, de persoonlijkheid werd 'geknecht' en 'verzakelijkt'. ${ }^{158}$ Onder het mom van 'vrije concurrentie' leidde het eigentijdse 'kale egoïsme' tot 'vreselijke gevolgen' in de economie en tot een 'systeem van machtspolitiek' dat onder andere in de 'Expansionstendenzen der Völker' tot uiting kwam. ${ }^{159}$

Lamprecht leverde een sociologische verklaring voor de verspreiding van het egoïsme in zijn tijd: het was een teken van 'sociaal-psychische dissociatie', van het uiteenvallen van de oude sociale orde en het verdwijnen van de oude innerlijke 'directieven' die houvast boden bij de Durchschnittsbetätigung van het individu. ${ }^{160}$ Dàt was de nieuwe 'sociale kwestie' van 1900, aldus Lamprecht. Het ging al lang niet meer alleen om het integreren van de nieuwe arbeidersklasse in de samenleving. ${ }^{161} \mathrm{De}$ verhouding van het individu tot de samenleving moest voor alle individuen opnieuw bepaald worden in deze overgangsperiode naar een nieuwe tijd.

De cultuurhistorici lokaliseerden de eigentijdse problemen met andere woorden op het terrein dat zij ook in hun geschiedopvatting centraal hadden gesteld: op het terrein van de cultuur, van de collectieve geestesgesteldheid, van de collectieve psychische kenmerken. Geheel in overeenstemming met hun geschiedopvattingen geloofden zij dat de sterk veranderde historische omstandigheden belangrijke gevolgen hadden voor de psychische habitus, de geestesgesteldheid van mensen in hun tijd. Die gevolgen gaven aanleiding tot zorgen. De voornaamste problemen waren de wijdverspreide onzekerheid, het gebrek aan 'persoonlijkheid' en het verdwijnen van (nationaal en sociaal) samenbindende waarden en normen. 'Wij zijn geen eenheid meer', constateerde Steinhausen en die vaststelling leek op alle niveaus van het maatschappelijk leven van toepassing. ${ }^{162}$ Er was een verandering nodig en in de ogen van de cultuurhistorici kon dat alleen maar een mentaliteitsverandering zijn, een verandering van de geest van het tijdperk.

\section{7 'Sociaal idealisme' versus 'persoonlijkheidspolitiek'}

Als het om oplossingen voor de eigentijdse problemen ging, zagen de cultuurhistorici in het algemeen weinig in een terugkeer naar het verleden of een herstel van 'oude' zekerheden. Breysig tendeerde er nog het meest naar, zoals al bleek uit de door hem gesuggereerde trek van intellectuelen naar het platteland. Hij durfde te dromen van een onthaaste toekomst waarin 'men voor feesten en vieren de tijd neemt; men zal de rust hebben om daarvoor bijeen te komen en kunst en schouwpel niet verlagen tot een zenuwprikkel van het ogenblik'. ${ }^{163}$ Maar in het algemeen konden de door hen zelf gesignaleerde anti-moderne tendenties als 'kerkelijk en politiek feodalisme', 'intolerant chauvinisme' en 'neoromantiek' op weinig steun van de cultuurhistorici rekenen. ${ }^{164}$

${ }^{157}$ Steinhausen (1931), blz. 53, 444, 504; Lamprecht (1891-1909), ErgBd. II.1, 242; vgl. Lamprecht (1891-1909), ErgBd. II.1, 282.

${ }^{158}$ Lamprecht (1891-1909), ErgBd. II.1, 256.

${ }^{159}$ Lamprecht (1905), 61.

${ }^{160}$ Lamprecht (1891-1909), ErgBd. I, 470.

161 Ook Breysig (1912), 115-120 herdefinieerde het sociale vraagstuk in psychologische zin.

162 Steinhausen (1931), 323, zie ook 257, 444.

${ }^{163}$ Breysig (1912), 163.

${ }^{164}$ Lamprecht (1905), 60. Vgl. ook Goetz (1919), 37 e.v. waar hij kritiek uit op de door sommigen bepleite terugkeer naar de 'gotische mens'. Goetz schrijft o.a. (40): 'Unsere geistige Zukunft liegt nicht in irgendwelcher neuen Romantik, nicht im Trauern um Vergangenes und Verlorenes, sondern im frohen Gestalten der Zukunft'. Vergl. ook Steinhausen (1931), hfdst. en Steinhausen (1927), 202: tegen de irrationele wending. 
De cultuurhistorici worstelden met een welbekend sociologisch dilemma: zij geloofden in het algemeen in de voortgaande en ook vooruitgaande ontwikkeling van de mens, een proces dat zij als een autonoom en collectief beschavingsproces typeerden, buiten het bereik van het individu. 'De enkeling mag voor niets zo weinig verantwoordelijk worden gehouden als voor de geest van zijn tijd', merkte Breysig op in een bundel cultuurkritische opstellen. ${ }^{165}$ Betekende dat dat de cultuurhistorici als burgers slechts konden berusten in de loop van het historisch proces, ondanks de serieuze problemen die zij constateerden? Of kon het beschavingsproces worden bijgestuurd, bijvoorbeeld door politiek ingrijpen?

Op dit punt blijken eerder geanalyseerde verschillen in de geschiedopvattingen van de historici terug te keren in hun houding tegenover de eigentijdse ontwikkelingen. In hun oordeel over de oorzaken en oplossingen van de problemen van de eigen tijd kunnen we een spectrum constateren dat van Lamprecht via Goetz en Gothein naar Steinhausen en Breysig loopt. Onderscheidend in dat spectrum was de mate waarin de afzonderlijke cultuurhistorici oplossingen zagen voortkomen uit een sterkere sociale binding in de samenleving dan wel uit een grotere vrijheid voor het individu. Bovendien verschilden zij van mening over de rol die de politiek (en individuele staatslieden) konden spelen tegenover de heersende cultuur. Tegelijk was het laveren tussen, of combineren van, sociaal en liberaal beleid het gemeenschappelijk kenmerk van de cultuurhistorici als het ging om de aanpak van de door hen gesignaleerde problemen.

Om zowel de overeenkomsten als de variatie van standpunten duidelijk te maken, is het nodig de individuele historici kort de revue te laten passeren.

Veel sterker dan de overige cultuurhistorici beschouwde Lamprecht politieke krachten èn individuele politici 'slechts als exponenten van de onder hen verlopende cultuurhistorische ontwikkeling'. ${ }^{166}$ Oplossingen voor de eigentijdse problemen konden derhalve slechts uit de cultuurontwikkeling zelf voortkomen en niet worden geforceerd door de politiek. Misschien is die opvatting wel een reden waarom Lamprecht zelf geen blijvende politieke allianties aanging en interpretatoren moeite hebben zijn politieke positie eenduidig te bepalen. Zo raakte Lamprecht in de jaren negentig betrokken bij de agressief nationalistische Alldeutscher Verband, om vervolgens na 1900 actief lid van verschillende vredesbewegingen te worden. ${ }^{167}$ Zijn biograaf Chickering schrijft dat hij geen lid was van een van de gevestigde partijen, maar dat zijn opvattingen het 'meest' aansloten bij die van de nationaal-liberalen. ${ }^{168}$ Tegelijk merken zowel hij als SchornSchütte zijn nabijheid tot Naumann's nationaal-sociale vereniging op, een groepering die zich ter linkerzijde van de nationaalliberalen bevond en een versterkt sociaal en democratisch beleid voorstond. ${ }^{169} \mathrm{Al}$ eerder, in een hoorcollege uit 1889/90 verkoos hij uitdrukkelijk het beleid van de 'kathedersocialistische of sociaalhervormingsgezinde richting' boven een strikt liberale of socialistische politiek en toonde hij zich enthousiast over het ideaal van een 'sociaal koningschap' dat, zoals hij zijn toehoorders voorhield, in 'de moderne Duitse Nationalökonomie' werd bepleit. ${ }^{170}$ Zijn opvattingen over sociale politiek stonden volgens Schorn-Schütte tussen de liberale opvattingen van Brentano -

\footnotetext{
${ }^{165}$ Breysig (1912), 185

${ }^{166}$ Lamprecht (1974), 759. De binnen- en de buitenlandse politiek waren 'in de eerste plaats Folgeerscheinungen van zogenaamde specifieke cultuurhistorische machten', Lamprecht (1891-1909), ErgBd. II.2, 44 en ErgBd. II.1, 517: 'gering und unbedeutend nur ist, was Menschen und selbst große Staatsmänner bewußt vermögen gegenüber jenem elementaren und unbewußten Handeln der Massen'.

${ }^{167}$ Aldus Chickering (1993), 400, 409-412.

${ }^{168}$ Chickering (1993), 397.

${ }^{169}$ Chickering (1993), 404-405; Schorn-Schütte (1984), 200, 206, 220-221, 272, 275.

${ }^{170}$ Zie Schorn-Schütte (1984), 66-70.
} 
waarin de (arbeiders-) organisatie van onderop belangrijker was dan de politiek van bovenaf - en de meer dirigistische 'staatssocialistische' ideeën van Schmoller. ${ }^{171}$

Hoe Lamprecht positie ook precies is te bepalen, een oplossing voor de (naar zijn mening) losgeslagen eigentijdse economische en machtspolitieke competitiedrift kon volgens hem uitsluitend komen van een sterk en doorleefd idealisme, een 'sociaal idealisme' of 'idealisme van de daad', zoals hij het zelf noemde. ${ }^{172}$ Lamprechts vertrouwen in het historisch proces bleek er vervolgens uit dat hij een dergelijke cultuuromslag op alle niveaus om zich heen zag plaatsvinden. Op economisch niveau maakte de vrije onderneming steeds meer plaats voor de 'gebonden onderneming', gekarakteriseerd door bedrijfs- en kredietverenigingen, vakverenigingen, kartelvorming. Op maatschappelijk terrein signaleerde Lamprecht de opkomst van 'ethische bewegingen met grote altruïstische doelen'. ${ }^{173}$ En op politiek gebied prees Lamprecht 'kathedersocialistische' maatregelen die tot doel hadden de sociale ellende en de negatieve effecten van de vrije concurrentie tegen te gaan. ${ }^{174} \mathrm{Na}$ het aantreden van Wilhelm II was er aanvankelijk weliswaar sprake van een terugtreden van de sociale politiek (door Lamprecht geduid als een tijdelijke overwinning van de vrije ondernemers), maar onder invloed van onder andere Naumann's nationaal-sociale beweging (1896) ontstond er volgens hem al snel een hernieuwde 'onbaatzuchtige' sociaal-politieke stemming. ${ }^{175}$ Lamprecht prees het toenemende ingrijpen van de overheden in de economie en de zorg voor gemeenschappelijke voorzieningen, onder andere op stedelijk niveau: infrastructuur, bibliotheken, sportvelden, straatverlichting enzovoort. ${ }^{176}$ Op de voorgrond traden

'de grote sociaal bindende elementen staat en samenleving. Zij gingen voor tegen de excessen van de economische concurrentie; zij schiepen een nieuwe wetgeving volgens pas recent tot ontwikkeling gekomen sociaal-zedelijke idealen'. ${ }^{177}$

'Famos!' noteerde een aangedane tijdgenoot in de kantlijn van zijn exemplaar van de Deutsche Geschichte bij de woorden van Lamprecht over de idealistische wending in zijn tijd. ${ }^{178}$ Het 'sociale idealisme', schreef Lamprecht zelf in zijn Deutsche Geschichte, is 'de levensadem van hen die in 1890 jong of nog jong waren' - Lamprecht werd toen vierendertig - 'en zij zullen het moeilijk op hun levensweg nog kwijt raken'. ${ }^{179}$

In 1890 werd Walter Goetz drieëntwintig jaar en hij behoorde tot degenen die door een vergelijkbaar idealisme als Lamprecht waren aangeraakt. Opvallend is dat Goetz ook op dit punt dichter bij Lamprecht stond dan zijn eigen uitspraken meestal laten blijken. Goetz was alleen eenduidiger betrokken bij de partijpolitiek van zijn dagen dan zijn voorganger in Leipzig. Conform zijn (van Lamprecht afwijkende) geschiedfilosofische maxime dat de 'massa pas levend wordt, als haar de weg getoond wordt', ${ }^{180}$ werd hij een politiek bijzonder actief historicus. Goetz sloot zich na de oprichting in 1896 van de 'nationaalsociale vereniging' direct aan bij deze beweging rond Friedrich Naumann, ondanks waarschuwingen van academische zijde dat een dergelijk stap zijn

\footnotetext{
${ }^{171}$ Schorn-Schütte (1984), 180.

${ }^{172}$ Lamprecht (1891-1909), ErgBd. II.2, 405.

${ }^{173}$ Lamprecht (1905), 64-65.

${ }_{175}^{174}$ Lamprecht (1891-1909), ErgBd. II.1, 516-517.

${ }^{175}$ Lamprecht (1891-1909), ErgBd. II.2, 397-399.

${ }^{176}$ Lamprecht (1891-1909), ErgBd. II.1, 514 e.v.

${ }^{177}$ Lamprecht (1905), 65.

${ }^{178}$ Exemplaar in mijn bezit, MS.

${ }^{179}$ Lamprecht (1891-1909), ErgBd. II.2, 405.

${ }^{180}$ Goetz (1918b), 20. Geciteerd in Weigand (1992), 197.
} 
carrière niet ten goede zou komen. ${ }^{181}$ En hij bleef bij deze politieke keuze: hij steunde de aansluiting van de nationaal-socialen bij de linkse liberalen na $1903^{182}$ en werd in 1920 Rijksdaglid voor Naumann's Deutsche Demokratische Partei.

Goetz' betrokkenheid bij Naumann kwam in zijn geschiedschrijving duidelijk naar voren. In een studie over de cultuurgeschiedenis van de periode rond 1900 beschreef hij Naumann in termen waarin zijn identificatie met de opvattingen van deze 'unieke persoonlijkheid' onmiskenbaar naar voren komt. Naumann was, aldus Goetz, een gepassioneerde Duitse patriot, die

'de sociale kwestie als de culturele crisis van het tijdperk beschouwt, hij zet het hele Duitse idealisme in voor het werk aan een hernieuwde vereniging van de verscheurde natie in sociaal en nationaal opzicht, hij vat dit alles in de grote samenhang van de Duitse cultuur'. ${ }^{183}$

Met name de opvatting van de sociale kwestie als een culturele crisis was een gedachte die niet alleen door Naumann en Goetz, maar door alle cultuurhistorici werd gekoesterd. Naumann kreeg volgens Goetz langzaam meer intellectuele invloed toen vooral de jonge generatie uit de liberale partijen aansluiting bij zijn beweging ging zoeken. Zijn beweging streefde naar een verbetering van de positie van de 'Duitse arbeid' tegen de 'overmacht van de bestaande eigendomsrechten'. ${ }^{184}$ Daartoe richtten de nationaalsocialen zich uitdrukkelijk tot de Gebildeten met het verzoek dat zij zich 'in dienst van het algemeen welzijn' voor deze strijd zouden gaan inzetten. 'Het begin van een grote wending' volgens Goetz, die helaas door het uitbreken van de Wereldoorlog teniet werd gedaan. $^{185}$

Dat Goetz zelf overtuigd was geraakt van de noodzaak van het voeren van een sociaal beleid was vooral te danken geweest aan zijn docent economie Lujo Brentano. Brentano's colleges over kwesties als de belangenstrijd tussen ondernemers en arbeiders, de eenzijdige stellingname van de staat en de gebreken van de Duitse sociale wetgeving, oefenden naar eigen zeggen een beslissende invloed uit op zijn politieke opvattingen:

'Een nieuwe wereld ging voor ons open: het Bismarck-tijdperk verloor een deel van zijn glans, wij zagen zijn bedenkelijk keerzijde en zagen de diepe noden van ons volk. Het was de sterkste opwekking die men zich kan vorstellen, de sterkste ontnuchtering van een stemming, die altijd maar van Duitse triomfen, Duitse grootheid en Duitse Selbstgerechtigkeit droomde. Wij leerden de werkelijkheid zien en meevoelen'. ${ }^{186}$

In Goetz' ogen was het vervolgens Naumann's betekenis geweest dat hij dergelijke ideeën in praktische politiek had vertaald. ${ }^{187}$

Ook Eberhard Gothein was tijdens zijn studie onder de indruk geraakt van de politieke standpunten van zijn docent en latere vriend Brentano; hij werd lid van de mede door Brentano opgerichte Verein für Socialpolitik en ging net als Goetz na de Wereldoorlog een actieve rol spelen in de Deutsche Demokratische Partei: tussen 1919 en 1921 was hij afgevaardigde van de DDP in de (grondwetgevende) landdag van

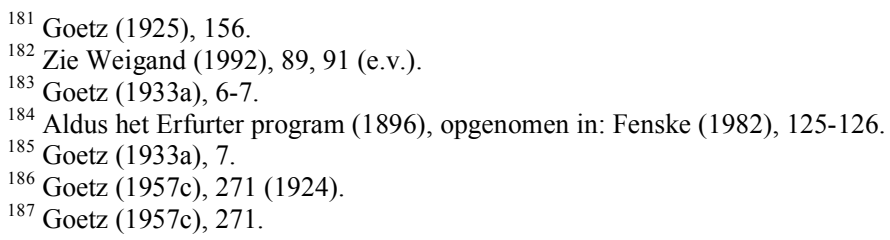


Baden. ${ }^{188}$ Toch bevond Gothein zich politiek duidelijk ter rechter zijde van Goetz. Hij bleef anders dan Goetz trouw aan de Nationalliberalen en werd door sommigen zelfs beschouwd als behorend bij de rechtervleugel van die partij. ${ }^{189}$ Het was vooral zijn sociale betrokkenheid die Gothein onderscheidde van liberalen van de oude stempel en hem in potentie verbond met de linkse liberalen rond Naumann waartoe ook Brentano behoorde. ${ }^{190}$

Net als bij Goetz speelde de invloed van Brentano een rol in de ontwikkeling van Gotheins sociale rechtvaardigheidsgevoel. Hij kon zich althans in 1915 nog het eerste door hem gevolgde college van Brentano in Breslau herinneren, veertig jaar eerder, waarin deze 'de nieuwe boodschap van de arbeidersbonden en arbeidersbewegingen' verkondigde. ${ }^{191}$ En hij herinnerde zich ook het 'hoofdschudden' dat deze boodschap teweegbracht bij 'alle oude pruiken', vooral bij de liberalen voor wie het liberalisme niet meer betekende dan das freie Geschäft. Gothein daarentegen waardeerde bijvoorbeeld de sociale verzekeringswetgeving van Bismarck. ${ }^{192}$ Omgekeerd veroordeelde hij als liberaal diens 'socialistenwet' van 1878 als 'de gewelddadige onderdrukking van al wat niet in het schema van staatsbehoudende partijen viel'. 'Bij alle individualisme ook in sociaal-economische zaken', memoreerde Gothein in 1911, 'was ik toentertijd verontwaardigd over de onderdrukking van het socialisme'. ${ }^{193}$ Het bracht hem ertoe 'te helpen waar ik kon', namelijk door te gaan optreden als Volksbildner voor de 'Humboldtverein' in Breslau. Het onderscheid met de meer elitaire opvattingen van zijn vrouw typeerde hij in 1898 door de opmerking dat zij anders dan hijzelf géén 'demokratische Empfindungen' koesterde en het streven naar beïnvloeding van 'grotere massa's' minderwaardig vond. ${ }^{194}$ In Gotheins opvatting was naast de economische en sociale benadeling van de lagere sociale klassen juist hun gebrek aan aansluiting bij de nationale Bildung een belangrijk aspect van de sociale kwestie. ${ }^{195}$

Toch waren er duidelijke grenzen aan Gotheins steun voor staatsingrijpen in maatschappij en economie. Binnen de Verein für Socialpolitik trad hij nauwelijks op de voorgrond. Zijn belangrijkste activiteiten bestonden uit het organiseren van sociaaleconomische (bij)scholing voor ambtenaren en ondernemers. ${ }^{196}$ Typerend was zijn gemengde waardering voor de zeventiende-eeuwse 'christelijk-sociale' jezuïetenstaat in Paraguay. In een historische studie uit 1883 naar dit specifieke 'type van staatsvorming' toonde hij onmiskenbaar sympathieën voor het sociaal beleid van de paters. Tegelijk

${ }^{188}$ Zie over zijn politieke opvattingen: Alter (1982), 51-52 en Gothein (1931), m.n. 27-28, 285-317. Zijn oud-leerling Uhde-Bernays (1948) noemt Gothein behalve 'liberaal', verschillende keren 'democraat', zonder dat nader toe te lichten. Gotheins jongere broer Georg was overigens 1893-1903 afgevaardigde voor de 'Freisinnige Vereinigung' in de Pruisische landdag, in 1910 lid van de Fortschrittspartei, in 1918 een van de medeoprichters van de DDP en in 1919 Minister van financiën in het kabinet Scheidemann.

${ }^{189}$ Zijn echtgenote kenschetste zijn politieke positie als volgt: 'Gothein rekende zichzelf altijd tot de Nationalliberalen en in veel kwesties was hij werkelijk zeer rechts; anderzijds had zijn hele sociale activiteit hem innerlijk sinds lange tijd sterk van het liberalisme van de oude observantie weggevoerd.' Zie Gothein (1931), 286-287. Als iemand hem in 1908 verwart met zijn linksliberale broer Georg, zegt Gothein: 'Ik ben echter nationalliberal', zie Maurer e.a (2006), 228.

${ }^{190}$ Aldus Gothein (1931), 288-289.

${ }^{191}$ Gothein (1915), 562.

192 Gothein (1931), 288.

${ }^{193}$ Geciteerd in Gothein (1931), 27-28.

${ }^{194}$ Zie de brief van 10-5-1898 in Maurer e.a. (2006), 132. Gothein typeerde zich persoonlijk ook als 'Plebejer-Natur ohne alle aristokratischen Neigungen' (ib., 277).

195 Aldus Gothein (1931), 51.

${ }^{196}$ Lindenlaub (1967), 12,77. Gothein speelt verder geen rol in Lindenlaubs uitvoerige studie over de richtingenstrijd tussen liberale en conservatieve sociale politiek binnen de Verein. 
maakte hij echter duidelijk dat de geringschatting van de individuele vrijheid in dit 'historisch experiment' onherroepelijk tot zijn ondergang moest leiden. ${ }^{197}$ Andere, populair bedoelde historische artikelen van Gothein hadden de uitgesproken doelstelling om te laten zien dat het de ambachtslieden echt niet beter was vergaan in het beschermende gildesysteem, zoals sommige commentatoren in zijn tijd meenden. ${ }^{198}$ Het gematigd liberale gezichtspunt bleek ook in Gotheins historische studie van de negentiende-eeuwse Rijnvaart: daar eindigde Gothein met een lofzang op de overheid die principiëel gekozen had voor opheffing van de Rijntollen, maar tegelijk geïnvesteerd had in de bevaarbaarheid van de rivier, hetgeen samen tot een ongekende bloei van de welvaart had geleid. ${ }^{199}$

De liberale grondtoon gematigd door idealisme en beperkt staatsingrijpen komt eveneens naar voren in Gotheins grote geschiedenis van negentiende-eeuws Keulen. In deze studie, waarmee Gothein uitdrukkelijk de eigen tijd een spiegel wilde voorhouden, ${ }^{200}$ vervulden grote Keulse kapitalisten uit de tweede helft van de negentiende eeuw een heldenrol. Karakteristiek voor deze ondernemers achtte Gothein dat zij niet zo afkerig waren van staatsingrijpen als hun moderne Engelse, 'uitsluitend individualistisch gerichte' collega's. Hun 'idealistisch kapitalisme' werd gekenmerkt door 'aandacht voor het algemeen belang en patriotisme'. Zij verwachtten van de staat meer dan wetgeving, namelijk 'positieve economische politieke activiteiten', bijvoorbeeld bij de zorg voor scholing en goede infrastructuur. Het was de 'verzoening en wederzijdse bevruchting van publieke en ondernemersbelangen', die Gothein hoogste lof wegdroeg. ${ }^{201}$ Het evenwicht mocht daarbij echter niet te zeer in de richting van de bureaucratie en de staat verschuiven, zoals in de opvattingen van iemand als Schmoller. $^{202}$

Dezelfde spanning tussen liberale politiek en sociaal idealisme is ook aan te treffen in de opvattingen van Kurt Breysig. In 1898 droomde hij, ondanks een uitdrukkelijke afkeer van socialistische Gleichheitsschwärmerei, 'van een staatssocialisme als volgend stadium van de ontwikkeling':

'Ik wil gelijkheid van de randvoorwaarden, gelijke lucht- en lichthoeveelheden voor iedereen, daarom grote sociale hervormingen, maar geen gelijkheid achteraf. [...] Derhalve uit de weg ruimen van alle huidige klassenverschillen, derhalve grotere centralisering van de arbeid; maar [ook] alle denkbare maatregelen ten gunste van de individualiteit. [...] Tegen de adel (ondanks veel verlies) en tegen erfrecht. Geen boeren-, geen handwerkers-, geen Duits-Rijk-romantiek. Grote bedrijven in industrie en kleinhandel moeten gestimuleerd worden'. ${ }^{203}$

Dergelijke opvattingen dankte de aanvankelijk mede onder Treitschke's invloed tot 'enthousiast monarchist, nationaal, conservatief' gevormde Breysig volgens eigen zeggen aan de nadere bestudering van geschriften van sociaaldemocraten en, opnieuw, van publicaties uit de kring van Naumann's nationaal-sociale vereniging. ${ }^{204}$

${ }^{197}$ Zie Gothein (1883) en Gothein (1931), 30-31.

${ }^{198}$ Aldus Gothein (1931), 57. Gothein had hiermee een opdracht aanvaard van de Badense regering om tegenover politieke tegenstanders een historische argumentatie ten gunste van de Gewerbefreiheit te leveren, zie Maurer e.a. (2006), 57.

${ }^{199}$ Gothein (1903), 306.

${ }^{200}$ Gothein en Neuhaus (1915-1916), I.1, iii.

${ }^{201}$ Gothein en Neuhaus (1915-1916), I.1, 679-680.

202 Gothein (1915), 560.

${ }^{203}$ Breysig (1962), 99.

${ }^{204}$ Breysig (1962), 98. 
Breysigs sociaal-politieke idealen stonden echter op gespannen voet met diepere opvattingen die hij zelf 'individueel-aristocratisch' en 'fundamenteel liberaal' noemde. ${ }^{205}$ Voor Breysig was het grootste probleem van zijn tijd 'de mechanisering van de ziel' en het daarmee corresponderende gebrek aan 'persoonlijkheid' en 'persoonlijkheden', zoals hij onder anderen aan zijn studenten in een hoorcollegereeks uit 1906/7 probeerde duidelijk te maken. Dit probleem was een probleem van de heersende cultuur: ${ }^{206}$

'Nog nooit in de geschiedenis van de mensheid heeft dril en tucht en een dressuurachtig africhten van de mensen zich uitgestrekt tot zulke verfijnde en vertakte activiteiten en tot zulke hoge rangen van de persoonlijkheid als tegenwoordig.'

Verantwoordelijk voor deze situatie waren 'de grote ambtelijke, overheids- en bedrijfsmachinerieën, waarin de mens zelf tot een radertje wordt gemaakt en waardoor hij gedraaid, afgeslepen, plat en eenvormig gewalst wordt'. ${ }^{207}$ 'Het rijkere goed van de hogere mens' werd bedreigd door de 'massa-economie en massa-heerschappij' en moest verdedigd worden tegen de 'massa en de massageest'. ${ }^{208}$ Elders hield hij Bismarcks bewind verantwoordelijk voor het 'breken van de ruggegraat' van de burgerij, doordat hij haar zowel de macht als het Selbstgefühl had ontnomen. ${ }^{209}$

Eén van de tegenmaatregelen die Breysig in 1912 bepleitte was een terugkeren of althans halthouden op het eerder ingeslagen pad van sociale politiek. De erfenis van het kathedersocialisme mocht hooguit in zoverre behouden blijven als zij diende om economische uitbuiting tegen te gaan. ${ }^{210}$ Het oude 'ruwe' individualisme van de Manchester-liberalen was onhoudbaar geweest en het staatssocialisme van de kathedersocialisten was daarop een noodzakelijke reactie. Maar inmiddels, aldus Breysig, waren de nadelen van dit beleid naar voren getreden en realiseerden 'wij' ons de 'veel juistere kern van de oude ich-mäßigen maatschappijopvatting'. ${ }^{211}$ Decennia van systematisch georganiseerde Fürsorge en fürsorgende wetgeving hadden volgens hem mede geleid tot wijdverspreide 'zielloosheid' en een massa van 'makkelijk levende proletariërs'. 212

Anders dan Lamprecht, Goetz of Brentano, die juist een belangrijke plaats toekenden aan (belangen)verenigingen en vormen van coöperatie, meende Breysig dat staat en maatschappij niet langer op een Genossenschaftsanschauung gebaseerd mochten worden. De sociale binding diende op een andere manier tot stand te komen. Breysig stelde zich daarbij in 1912 idealiter een pyramidale maatschappijopbouw voor, waarin Geistesaristokraten een leidende rol zouden spelen en zelfs de erfelijke landadel tot op zekere hoogte weer in oude ere hersteld zou worden. ${ }^{213}$ Sociale politiek in deze samenleving betekende dat 'de leider voor zijn volgelingen moet zorgen': 'nicht Genossenschaft sondern Gefolgschaft'. ${ }^{214}$

${ }^{205}$ Breysig (1912), 56.
${ }^{206}$ Breysig (1912), 186-187.
${ }^{207}$ Breysig (1912), 187. Vgl. Gothein in Maurer e.a. (2006), 217, over de onderwerping van het

Breysig (1912), 187. Vgl. Gothein in Maurer

${ }^{208}$ Breysig (1912), 227.

${ }^{209}$ Zie Brocke (1972), 110.

${ }^{210}$ Breysig (1912), 56. Breysig is (zelfs in één publicatie van 1912) niet helemaal eenduidig over het behoud of afbraak van de bestaande sociaalpolitieke maatregelen.

${ }^{211}$ Breysig (1912), 129.

${ }^{212}$ Breysig (1912), 92-93, 226.

${ }^{213}$ Breysig (1912), 183.

${ }^{214}$ Breysig (1912), 96-97. 
Net als in zijn geschiedbeschouwing dreef Breysig met andere woorden in zijn maatschappijvisioen de dichotomie persoonlijkheid-massa op de spits: voor de sterke persoonlijkheid, de actieve en creatieve leider, golden andere regels en rechten dan voor de grote massa van lijdzame volgelingen. De politiek moest zo ingericht worden dat het krachtige individu meer vrijheid van de staat zou krijgen en meer macht in de staat. ${ }^{215}$ Heilung (om zijn termen te blijven) van de eigentijdse 'mechanisering van de ziel' kon alleen voortkomen uit een 'sterkere gelding van de persoonlijkheid'. De politiek diende zich derhalve niet langer op de massa te richten, maar op het scheppen van de juiste voorwaarden waarin persoonlijkheden optimaal tot ontwikkeling kon komen en een leidende rol konden gaan vervullen: na het tijdperk van 'sociale politiek' diende nu een periode van 'persoonlijkheidspolitiek' te volgen. ${ }^{216}$ Tegelijk moest de geest en de instelling van de mensen veranderen: zij moesten het leven meer eren, actiever werken aan het eigen Ik en aan de persoonlijkheid van anderen. ${ }^{217}$ Dit gepolitiseerde Bildungsdenken bood volgens Breysig de beste oplossing van de 'sociale kwestie' van zijn tijd.

Net als Breysig meende Steinhausen dat er sprake was van een overmaat aan sociale politiek en van staatsingrijpen in het algemeen. ${ }^{218}$ Volgens hem was het grootste eigentijdse probleem 'het gebrek aan een gemeenschappelijk innerlijk leven'. ${ }^{219}$ Dat wilde echter niet zeggen dat er geen collectief gedrag was - integendeel, dat was nu net het probleem: het algemene zielloze egoïsme, het collectief navolgen van materieel gewin en individuele of groepsbelangen leverde nog geen maatschappelijke samenhang op. Dat was ook de kritiek van Steinhausen op het socialisme, met zijn nadruk op klassenbelangen en klassenstrijd. ${ }^{220}$ Net als de meeste andere cultuurhistorici meende Steinhausen dat er een geestelijke herbezinning nodig was, een diepe geestelijke en morele wending, waardoor creatieve krachten weer de ruimte zouden krijgen. En net als Breysig en Goetz meende hij dat daarbij de leiding van creatieve persoonlijkheden noodzakelijk was. $^{221}$

Net als Breysig meende Steinhausen tenslotte ook dat het gebrek aan leidende persoonlijkheden een van de fundamentele problemen van de eigen tijd was: de eigen tijd was er een van 'bindingen, die de ontplooiing van individualiteiten belemmeren'. ${ }^{22}$ De 'grote persoonlijkheid' kon zich niet meer vrij ontwikkelen. ${ }^{223}$ Steinhausen oefende in dit verband kritiek uit op de groeiende hoeveelheid wetgeving en de bureaucratisering. ${ }^{224}$ Specifieker veroordeelde hij ook de sociale voorzieningen en de 'sociale politiek': zij was een uiting van een 'gemechaniseerde tijd', zij was nadelig voor het individu, doodde initiatief en creativiteit. ${ }^{225}$ Opvallend was dat Steinhausen niet alleen kritiek uitoefende op de sociale politiek van voor en na de Wereldoorlog, maar ook op Pruisische tradities en het regime van Wilhelm II. Het was volgens hem de dominantie van de Pruisische militaristische en bureaucratische geest die in het Keizerrijk had bijgedragen aan het terugdringen van een individuele geesteshouding en aan de

\footnotetext{
${ }^{215}$ Breysig (1912), 191-192.

${ }^{216}$ Breysig (1912), 59.

${ }^{217}$ Breysig (1912), 226-227.

${ }^{218}$ Steinhausen verwees in deze kwestie herhaalde malen naar opvattingen van Breysig, zie bijv.
} Steinhausen (1923). Over de politieke opvattingen van Steinhausen bestaat geen secundaire literatuur. Ik baseer me voor het navolgende vooral op Steinhausen (1927).

${ }^{219}$ Steinhausen (1931), 257; ook al Steinhausen (1913), II, 498.

${ }^{220}$ Zie bijv. Steinhausen (1927), 143.

${ }^{221}$ Bijv.: Steinhausen (1927), 206.

${ }^{222}$ Steinhausen (1931), 319.

${ }^{223}$ Steinhausen (1931), 333.

${ }^{224}$ Steinhausen (1931), 192-193, 336, 110.

${ }^{225}$ Steinhausen (1927), 178-179, 191. 
onzelfstandigheid van het denken. ${ }^{226}$ Wilhelms II 'onduitse' autocratische opvattingen en 'schijnconstitutionele' bewind hadden dit effect alleen maar versterkt. ${ }^{227}$ De grote fout van de Duitse politiek was geweest, dat na 1879 het pad van het liberalisme was verlaten en daarmee de hoogstaande liberale idealen, 'zorg voor geestelijke vrijheid en persoonlijke vrijheid, zorg voor de persoonlijkheid', waren verwaarloosd. ${ }^{228}$ 'De vrije mens is de [...] grote verworvenheid van de negentiende eeuw, die niemand meer mag opgeven', schreef Steinhausen.

Het lijkt er al met al veel op dat het liberalisme in verschillende varianten en gradaties en meer of minder gematigd door een vorm van sociaal idealisme een politiek hoofdmotief van de cultuurhistorici vormde. Het minst gericht op 'het vrije individu' was nog Lamprecht. Dat wordt bevestigd als we de opvattingen analyseren van de cultuurhistorici over liberalisme of democratie als basis voor het Duitse politieke bestel in de toekomst.

\section{De Duitse toekomst: liberalisme of toch 'democratisme'?}

In ieder geval vier van de vijf cultuurhistorici gingen uit van een principieel onderscheid tussen een liberaal en een democratisch politiek bestel. Het helderst werd dat onderscheid tot uitdrukking gebracht door Steinhausen in een historisch-politieke beschouwing uit 1927 waarin hij zijn visie gaf op de zwakke punten in de voorbije halve eeuw Duitse geschiedenis. ${ }^{229}$ Steinhausens karakteristiek van het liberalisme maakt bovendien goed duidelijk wat we in deze specifieke context onder dit cruciale maar diffuse begrip moeten verstaan.

Voordat hij de verschillen tussen liberalisme en democratie duidelijk maakte, stelde Steinhausen eerst hun gemeenschappelijke wortels in de Verlichting vast. Daaraan ontleenden beide ideologieën, aldus de cultuurhistoricus, 'de vooruitgangsgedachte, verbonden met de cultuurgedachte': het geloof in de verbetering van de wereld en de 'Höherentwicklung der Menschheit' naar meer cultuur en vrijheid, met name door het gebruik van de rede. Dit geloof creëerde een bestendige bron van 'onrust': gevestigde waarden werden onder invloed van beide ideologieën voortdurend 'in Frage gestellt'. ${ }^{230}$

Desalniettemin was het volgens Steinhausen fundamenteel onjuist om het 'democratisme' slechts als een radicale variant van het liberalisme te zien. Er bestonden naar zijn mening zwaarwegende verschillen tussen beide ideologieën. In het liberalisme stond zowel de vrijheid als de 'natuurlijke ongelijkheid' van het individu voorop en lag de meeste nadruk op de waarde van de persoonlijkheid. In een democratie daarentegen was de binding van het individu aan de meerderheid bepalend en was de principiële gelijkheid van alle burgers het uitgangspunt. De meest geëigende staatsvorm voor een liberaal bestel was volgens hem de constitutionele monarchie: hier kon een zuivere machtendeling tussen wetgevende en uitvoerende macht gehandhaafd blijven, die in een democratie vervangen werd door een totaal overwicht van de wetgevende macht. Het liberalisme onderscheidde zich volgens Steinhausen tenslotte ook nog van democratische politiek doordat naast de staat, als een pure machtsfactor, ook immateriële zaken als cultuur, Bildung en humaniteit van grote waarde werden geacht, tegenover een vrijwel uitsluitende dominantie van het politieke in het democratisch denken. ${ }^{231}$

\footnotetext{
${ }^{226}$ Steinhausen (1927), 154-155.

${ }^{227}$ Steinhausen (1927), 95

${ }^{228}$ Steinhausen (1927), 44

${ }^{229}$ Steinhausen (1927), 16-18.

${ }^{230}$ Steinhausen (1927), 16-17.

${ }^{231}$ Steinhausen (1927), 24.
} 
Steinhausens eigen voorkeur ging uit naar een liberaal stelsel, zoals hij schreef, vooral vanwege de waarde die hij toekende aan de vrijheid van het individu en de kracht van de persoonlijkheid. ${ }^{232}$ Hij behoorde overigens uitdrukkelijk niet tot degenen die meenden dat de democratie een 'on-Duits' verschijnsel was of dat 'westerse ideeën' in het algemeen de oorzaak waren geweest voor Duitslands neergang. De tegenstelling tussen Duitse en West-Europese opvattingen moest überhaupt niet worden overdreven en de gemeenschappelijkheden niet over het hoofd gezien. ${ }^{233}$ Een 'goede' democratie was ook in Duitsland mogelijk, indien zij vervuld zou zijn van een sterk moreel en zedelijk karakter. ${ }^{234}$ Maar de democratische realiteit was dat belangen domineerden. De partijdemocratie bracht niet de grote leiders voort die het land nodig had, maar stimuleerde uitsluitend carrièrepolitici, Macher en Streber. ${ }^{235}$

Zowel Breysig als Gothein formuleerden politieke opvattingen die dicht bij die van Steinhausen lagen. Breysig noemde de door hem voorgestelde oplossingen voor de eigentijdse problemen 'fundamenteel liberaal en fundamenteel ondemocratisch'. ${ }^{236}$ Het vertrouwen in de heerschappij van de meerderheid en de massa was volgens hem een waan van zijn tijd. ${ }^{237}$ Politieke partijen veroordeelde hij als een geestdodende 'automaten'. ${ }^{238}$ Hij keerde zich (althans tot 1918) tegen het algemeen kiesrecht en geloofde in de waarde van een 'geheel ondemocratisch' Herrenhaus. ${ }^{239}$ De sterke enkeling moest meer vrijheid van de staat krijgen en meer macht in de staat. ${ }^{240}$ In een vergelijking van de Franse en de Duitse cultuur moest Breysig (in 1932) erkennen dat de Fransen in één staatkundig opzicht duidelijk beter scoorden dan de Duitsers: namelijk in de verheffing van de 'vrijheidsidee' 'en alle daarvan afgeleide staatsplannen en staatsvormen' door de Franse Revolutie en Rousseau. ${ }^{241}$ Maar ware vrijheid kon alleen voor het individu zijn, niet voor de massa. Anderzijds verklaarde hij zich in de Weimarrepubliek niet alleen tegenstander van zowel 'radikal-kommunistische Sozalismus' als 'Cäsarismus und Imperialismus', maar ook voorstander van een 'gemäßigt-sozialistischen Demokratismus'. 242

Ook Gothein was een uitgesproken liberaal die na de Eerste Wereldoorlog slechts schoorvoetend meewerkte aan het nieuwe democratische stelsel. 'Gering was [...] zijn sympathie [Neigung] voor de democratie', schreef zijn echtgenote in een terugblik op zijn politieke opvattingen. ${ }^{243}$ In 1908 keerde Gothein zich op een partijbijeenkomst van de nationaal-liberalen niet alleen tegen de belangenpolitiek van partijen, maar ook tegen een parlementarisering van de constitutie en een systeem van ministeriële verantwoordelijkheid. Hij verwees daarbij met instemming naar Bismarck, die was aangebleven, ook toen hij tweederde van de Rijksdag tegenover zich vond. ${ }^{244}$ Ook na de

${ }^{232}$ Steinhausen (1927), VI-VII.

${ }^{233}$ Steinhausen (1927), 12.

${ }^{234}$ Steinhausen (1927), 102.

${ }^{235}$ Steinhausen (1927), 200-206.

${ }^{236}$ Breysig (1912), 56.

${ }^{237}$ Breysig (1912), 126.

${ }^{238}$ Breysig (1912), 116.

${ }^{239}$ Breysig (1912), 34 en 41. In het Pruisische Herrenhaus waren behalve adel ook universiteiten en steden vertegenwoordigd. Pas in februari 1918 accepteerde Breysig de invoering van het algemeen kiesrecht in Pruisen. In de Weimarrepubliek noemde hij zich ook nog een 'radicaler Liberal', geciteerd bij Brocke (1972), 111.

${ }^{240}$ Breysig (1912), 191-192.

${ }^{241}$ Breysig (1932), 284.

${ }^{242}$ Geciteerd bij Brocke (1972), 111.

${ }^{243}$ Gothein (1931), 289. Zijzelf had volgens haar man nog minder 'demokratische Empfindungen', althans begrepen als zorg voor de massa, zie hierboven bij noot 194 .

${ }^{244}$ Gebaseerd op Mommsen (1974), 160. 
oorlog bleef hij het partijensysteem bekritiseren, omdat het volgens hem teveel tot versplintering van de politiek zou leiden: een partij kon geen staatsman vervangen. ${ }^{245}$ Dat Gothein desondanks in 1918 actief werd voor de Deutsche Demokratische Partei motiveerde hij uitdrukkelijk met de hoop zo mee te kunnen werken aan een nationale vereniging van alle liberale partijen en van het Bürgertum, dat anders zijn invloed zou verliezen. $^{246}$ Tegelijk koesterde hij in deze periode een onmiskenbare afkeer van deutschnational en alldeutsch georiënteerde politieke partijen en bewegingen. ${ }^{247}$

Net als Gothein, Breysig en Steinhausen ging Lamprecht uit van een onderscheid tussen liberalisme en democratie. Maar zijn eigen voorkeur lag anders dan bij deze drie collega's en ging niet uit naar het liberalisme: het liberale bestel kenmerkte hij als atomistisch en 'individualistisch' en daarmee als iets van een voorbij tijdperk. ${ }^{248}$ Het was minder helder wat het 'democratisme' behelsde waaraan hijzelf de toekomst beloofde. Die lastige plaatsbepaling heeft opnieuw ermee te maken dat Lamprecht zijn politieke voorkeuren niet direct uitsprak en uitwerkte, maar verpakte in uitspraken over het 'onvermijdelijke' verloop van de cultuurhistorische ontwikkeling.

Onderscheidend voor het moderne 'democratisme' was volgens Lamprecht de grote rol van collectieven in het staatsbestel. Het individu voelde zich binnen het 'sociale democratisme' niet 'op zichzelf' (zoals in het liberalisme), maar als een actief en lijdend subject, door talloze economische betrekkingen met anderen en met het geheel verbonden. ${ }^{249}$ Het ging in een dergelijke democratie om een bestel

\begin{abstract}
'waarin en volgens welke het volk daadwerkelijk heerst, maar niet het volk als optelsom van alle individuen, maar als organisch opgebouwde menigte [Menge], en waarin het individu niet als gelijkgeaarde contribuent en gerechtigde, maar als zeer verschillend uitgeruste drager van plichten en rechten verschijnt, al naar gelang de algemeen menselijke, professionele, sociale positie die hij inneemt.'
\end{abstract}

Volgens Lamprechts voorstelling van zaken werd in het liberalisme het individu als principieel gelijkberechtigd gezien, terwijl er binnen het democratisme een differentiatie van rechten en plichten bestond. Ook het kiesrecht was binnen het democratisme afhankelijk van de positie binnen het sociale en politieke 'organisme' - een opvatting die overigens te verenigen was met het bestaande Dreiklassenwahlrecht in Pruisen (dat toentertijd juist ter discussie werd gesteld in linksliberale kringen). Het feit dat de wetgevende en uitvoerende macht in het democratisme volgens Lamprecht niet, zoals in een liberaal stelsel, strikt tegenover elkaar stonden, maar met elkaar waren verbonden, achtte hij een goede zaak. ${ }^{250}$ Elders sprak hij over de zich voltrekkende democratische ontwikkeling als het van jaar tot jaar 'inniger samengroeien van de natie met de staatsidee'. ${ }^{251}$ De toekomstige samenleving zou (en moest) steeds meer 'gepolitiseerd' betrokken bij de politiek - worden. ${ }^{252}$ In die zin verwelkomde hij ook de steunbetuiging van de sociaaldemocraten aan het Duitse staatsbestel na het uitbreken van de Eerste Wereldoorlog.

Lamprecht gaf voorbeelden van het moderne 'democratisme' die zijn abstracte omschrijvingen enigszins verduidelijken. Typerend ervoor vond hij de opkomst van het

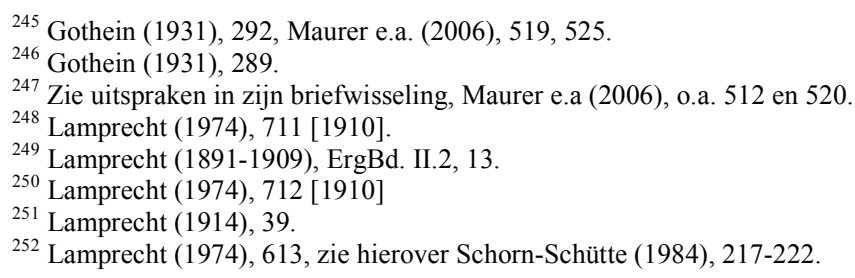


partijstelsel in de loop van de negentiende eeuw, en vervolgens in zijn eigen tijd het toekennen van het recht op initiatief en referendum in verschillende landen. Klaarblijkelijk dacht hij bij 'democratisme' echter ook aan het geheel van buitenparlementaire 'corporaties' die invloed op de staat konden uitoefenen. ${ }^{253}$

Een dergelijk democratisch stelsel zag Lamprecht ook voor Duitsland in het verschiet. Als eerste had zich - 'natuurlijk', schreef Lamprecht - in England een democratisch systeem ontwikkeld, maar daar zou het niet bij blijven:

'alle leidende Europese staten zijn op weg het te scheppen, want het is de natuurlijke politieke uitdrukking van hun economische ontwikkeling, van hun sociale verandering en van het geestesleven van de moderne psyche' ${ }^{254}$

In de meeste recente fase van de historische ontwikkeling paste nu eenmaal een democratisch staatsbestel, legde hij in een overzicht van de Europese staatsontwikkeling uit. ${ }^{255}$ Voor Duitsland voorzag hij in dit opzicht wel problemen. In 1907 formuleerde hij al de stelling dat het Keizerrijk gekenmerkt werd door een tegenstelling tussen het politieke systeem en het maatschappelijke leven: 'De Duitse staatsinstellingen zijn monarchaal-conservatief, maar het leven is democratisch-progressief' ${ }^{256} \mathrm{Bij}$ Lamprechts visie op de relatie tussen staat en cultuur was dat geen constatering die zonder gevolgen kon blijven. De monarchie paste vanuit een historisch ontwikkelingsperspectief in het algemeen minder goed in dit moderne staatsleven. Zij vormde derhalve een zwakke plek van de Duitse staat, zoals hij in 1912 in een historische beschouwing over staatsvormingsprocessen opmerkte: $:^{257}$

'Principieel kan er geen twijfel over bestaan dat de diepste ontwikkelingsmotieven op zijn minst niet direct op de noodzakelijkheid van de monarchie wijzen, en dat daarin voor de Duitse ontwikkeling [volgens het karakter van haar verloop tot nu toe] ongetwijfeld een zwakte van dit moment berust.'

Ook Walter Goetz beschouwde een vorm van democratisering al vóór de Duitse capitulatie van 1918 als een historische onomkoombaarheid voor Duitsland. Dat werd duidelijk uit zijn analyse van de richting die de Duitse binnenlandse politiek na het einde van de oorlog zou moeten inslaan, daterend uit de zomer van $1918 .^{258}$ In een publicatie, waarmee hij wilde bijdragen aan de nationale eensgezindheid over de inrichting van het na-oorlogse Duitsland, noemde hij de 'democratische beweging geen Duitse partijkwestie, maar een ontwikkeling van de hele huidige mensheid. De dwang tot democratisering vloeit voort uit de stand van de algemene cultuur 259

Onder 'democratie' moest volgens Goetz uitdrukkelijk niet de 'heerschappij van de volksmassa's over de staat' worden verstaan. Waar het om ging was - en de formulering is significant voor de gevoelde vrees voor de massa: 'het door gerijpte leiders meewerken van alle klassen van een volk aan de opgaven van de staat'. ${ }^{260}$ Net als Lamprecht meende Goetz dat de oorlog een betrokkenheid van de arbeidersklasse bij de staat had teweeggebracht (in de vorm van de mobilisatie), die in vredestijd niet meer

\footnotetext{
${ }^{253}$ Lamprecht (1974), 755 e.v. (1912).

${ }^{254}$ Lamprecht (1974), 712 [1910].

${ }^{255}$ Lamprecht (1974), 711 [1910].

${ }^{256}$ Lamprecht (1974), 617 [1907/08].

${ }^{257}$ Lamprecht (1974), 760, [1912].

${ }^{258}$ Goetz (1918a), [III]-IV.

${ }^{259}$ Goetz (1918a), 613.

${ }^{260}$ Goetz (1918a), 614.
} 
teruggedraaid kon worden. Het Duitsland van na de oorlog zou een 'monarchistische volksstaat' moeten zijn, waarin het parlement niet zou overheersen, maar wel substantieel versterkt zou worden. Vorst en parlement zouden moeten 'samenwerken', elk met gelijke rechten over de ministerbenoeming. ${ }^{261}$ Naast de door de monarch benoemde kanselier zou een door de Rijksdag benoemde vice-kanselier moeten komen te staan. ${ }^{262}$ Het nieuwe stelsel zou op deze wijze zowel waarborgen moeten bieden tegen de heerschappij van de massa, als tegen de dominantie van het grootkapitaal en het grootgrondbezit. ${ }^{263}$ Zo zou de Duitse staat zich in overeenstemming met haar historische gewordenheid op haar eigen Duitse wijze kunnen verbinden met de democratische beweging. ${ }^{264}$

$\mathrm{Na}$ afloop van de oorlog werd Goetz' pleidooi voor de democratie radicaler. Net als Steinhausen, zag ook hij in Bismarck's breuk met de liberalen in 1879 een fataal breekpunt dat Duitsland 'noodlottig' was geworden en tot 'zware schade' had geleid. ${ }^{265}$ In 1924 schreef hij:

'Een overal elders achterhaald constitutioneel systeem, met een onverdraaglijk overgewicht van de Kroon, was een wezenlijk deel van ons noodlot [...] het oprukken van de democratie is een niet tegen te houden deelaspect van de Europese culturele ontwikkeling [...] Een geschiedschrijving die de onophoudelijke en noodzakelijke ontwikkeling van de nieuwere geschiedenis naar een steeds grotere democratie niet vermag te begrijpen, zal ook niet begrijpen kunnen dat alle staten ter wereld naar alle waarschijnheid vroeger of later halve (naar Engels model) of hele republieken zullen zijn'. ${ }^{266}$

Volgens Goetz betekende 1879 niet slechts een onderbreking van een liberale ontwikkeling, maar ook het halt houden op de weg van 'gematigde democratisering'. Het was tekenend voor de linksliberale opvattingen die hij deelde met Naumann dat hij deze twee begrippen (anders dan de overige cultuurhistorici) in elkaars verlengde zag. ${ }^{267}$

Goetz keerde zich na de oorlog net als Steinhausen uitdrukkelijk tegen degenen die meenden dat er sprake was van een onverenigbaarheid van de Duitse en de 'WestEuropese' (politieke) cultuur. ${ }^{268}$ Hij wees er op dat er nooit een onveranderlijke of 'zuiver Duitse' cultuur was geweest. In de afgelopen twee eeuwen had 'het wezen van de Duitse cultuur' juist gelegen in de idealistische gerichtheid op het 'algemeen menselijke', het 'universele', de 'mensheidscultuur', kortom juist in die eigenschappen die Steinhausen als kenmerken van het liberale gedachtengoed had getypeerd. ${ }^{269}$

Al met al, kunnen we in de opvattingen van de cultuurhistorici over de politieke toekomst van Duitsland (net als in hun opvattingen over sociale politiek versus persoonlijkheidspolitiek) een klassieke liberale tendens constateren: vier van de vijf cultuur-

${ }^{261}$ Goetz (1918a), 617.

${ }^{262}$ Goetz (1918a), 618.

${ }^{263}$ Goetz (1918a), 621.

${ }^{264}$ Goetz (1918a), 613-614, en 624.

${ }^{265}$ Goetz (1957b), 101n (1919). In zijn autobiografie schrijft Goetz: ‘Als historicus moest ik erkennen, dat het Duitse noodlot voor een niet gering deel berustte op de geringschatting van die democratie, die sinds de zeventiende eeuw de cultuur veroverd had', Goetz (1925), 167.

${ }^{266}$ Goetz (1957b), 422 (1924)

${ }^{267}$ Naumann streefde rond 1900 naar een versterking van de rol van het parlement en opheffing van het Dreiklassenwahlrecht. Anderzijds merkt Fenske (1982), 12, op dat zelfs door links-liberale partijen in het Keizerrijk nauwelijks een eenduidige keuze werd gemaakt voor een parlamentaristisch systeem met overwicht van de Rijksdag

${ }^{268}$ Goetz (1919), 29.

${ }^{269}$ Goetz (1919), 45. 
historici pleitten voor een 'liberale' toekomst, waarin vooral de vrijheid van het individu, de waarde van de persoonlijkheid en humanitaire idealen gewaarborgd waren - niet alleen tegen een autoritaire en dirigistische staat, maar ook tegen de heerschappeij van de massa. Drie van deze liberale cultuurhistorici (Gothein, Breysig, Steinhausen) keerden zich uitdrukkelijk tegen de democratie als massa-heerschappij, en meenden dat een elitair burgerlijk leiderschap op een of andere manier in de samenleving gewaarborgd moest worden. Lamprecht, de ene cultuurhistoricus die zich afzette tegen het liberalisme, zag meer toekomst in een vorm van 'democratisme', waarbij de hele natie op een of andere manier bij de politiek betrokken was. Maar ook hij vond klaarblijkelijk niet dat dit voor alle lagen van de bevolking een gelijk kiesrecht inhield. Goetz, tenslotte, kwam van een linksliberale overtuiging na de Wereldoorlog tot de meest hartgrondige omarming van de liberale democratie.

\section{De politiek van de nieuwe cultuurgeschiedenis}

De politieke beoordeling van de nieuwe cultuurgeschiedenis is vanaf het begin omstreden geweest. Dat gold ten tijde van de strijd om de nieuwe cultuurgeschiedenis zelf en werd opnieuw na (en als gevolg van) de Tweede Wereldoorlog duidelijk. Al in de jaren vijftig onderwierp de West-Duitse promovendus Kay Hoffmeister de politieke opvattingen van Lamprecht aan een onderzoek, op zoek naar een 'goede' Duitse historiografische traditie. Hoffmeister hoopte in Lamprecht een 'kritisch geweten' of op zijn minst een tegenstem te vinden tegen het nationalisme en 'machtsegoïsme' dat in de Duitse geschiedenis en de geschiedschrijving domineerde en dat uiteindelijk, aldus Hoffmeister, 'op verschrikkelijke wijze' in het nationaalsocialisme zou culmineren. Maar de onderzoeker eindigde 'teleurgesteld' in zijn onderzoeksobject: Lamprecht was volgens hem uiteindelijk een vertegenwoordiger van 'grootburgerlijke industriële belangen', een 'wilhelminische illusionist' die even gevoelig bleek als zijn wetenschappelijke tegenstanders voor 'irrationele', nationalistische en imperialistische dwaalleren. $^{270}$

Vanuit post-nazistisch standpunt valt het te begrijpen dat dit oordeel werd geveld. Ik vermoed dat Hoffmeister hetzelfde oordeel in meer of mindere mate op alle nieuwe cultuurhistorici van toepassing zou hebben geacht. Zonder uitzondering droegen de woordvoerders van de nieuwe cultuurgeschiedenis 'de Duitse natie' met zoveel woorden een warm hart toe en streefden zij naar een verbetering van haar positie in de wereld.

Nationalisme is echter nauwelijks een onderscheidend criterium als het gaat om de plaatsbepaling van de cultuurhistorici in het politieke landschap van hun tijd: alle politieke stromingen die zich rechts van de sociaaldemocraten bevonden, koesterden uitdrukkelijk nationalistische waarden. Het is echter van belang om op te merken dat de cultuurhistorici binnen dit spectrum tot de minst extreme nationalisten behoorden. Terwijl zij allen meenden dat de Duitse ontwikkeling eigen nationale kenmerken en karakteristieken vertoonde, namen zij geen van allen het standpunt in dat Duitsland zich fundamenteel onderscheidde van de westerse naties en een geheel eigen Sonderweg 'van vreemde smetten vrij' diende te volgen. De wijze waarop zij de 'globalisering' in hun eigen tijd waardeerden, is daarvan een even duidelijke indicatie als de manier waarop zij de nationale geschiedenis behandelden. ${ }^{271}$ Zoals historiograaf Lutz Raphael in 1997 heeft betoogd, was er onder de geschiedwetenschappelijke vernieuwers rond

\footnotetext{
${ }^{270}$ Hoffmeister (1956), IV.

${ }^{271}$ Zie hierboven, paragraaf 3 en hoofdstuk 3, paragraaf 6.1 .
} 
1890 er minder sprake van een nationalistische ideologie, als van een vanzelfsprekend nationaal kader waarbinnen zij dachten en (als deel van de nationale elite) invloed wilden uitoefenen. $^{272}$

Zoals in de Inleiding al is opgemerkt, bekritiseerde Raphael echter tegelijk de historiografische tendens om de vernieuwingsbewegingen in de geschiedwetenschap rond 1900 als politiek vooruitstrevend te duiden, als de vakwetenschappelijke representanten van 'liberale of democratische, of minstens gematigde posities'. ${ }^{273}$ Eén van de argumenten die Raphaels kritiek lijken te ondersteunen is dat een scherpe politieke scheidslijn tussen voor- en tegenstanders van historiografische vernieuwing lastig te trekken valt. Ook Meinecke bijvoorbeeld ging sympathie koesteren voor de ideeën van Friedrich Naumann en werd na de Wereldoorlog lid van de Deutsche Demokratische Partei, waarin ook Goetz en Gothein actief waren; een andere tegenstander van Lamprecht, Delbrück, had net als de cultuurhistorici sympathieën voor de doelstellingen van de Verein für Socialpolitik.

Daar kunnen we tegenover stellen dat Meinecke tot aan 1895 verbonden was met de Konservatieve Partei en dat Delbrück lang actief was voor de Freikonservative Partei. $^{274}$ En belangrijke andere critici van de nieuwe cultuurgeschiedenis, zoals Dietrich Schäfer, Below, Rachfahl, Finke, Seeliger en Eduard Meyer bleven ook na de Wereldoorlog kiezen voor partijen die rechts stonden van de linksliberale DDP, vooral voor de Deutschnationale Volkspartei. ${ }^{275}$

Maar een belangrijker kanttekening bij de depolitiseringsthese is dat we voor de cultuurhistorici zelf aan het eind van dit hoofdstuk daadwerkelijk een nauwe samenhang kunnen vaststellen tussen hun politieke standpunten, hun historische analyse van de eigen tijd en hun opvattingen over geschiedenis in het algemeen.

In eerdere hoofdstukken is duidelijk geworden dat de kennismaking met de Historische School in de Nationalökonomie van doorslaggevend belang moet worden geacht voor vier van de vijf nieuwe cultuurhistorici. ${ }^{276} \mathrm{Zij}$ namen niet alleen belangrijke wetenschappelijke uitgangspunten van deze School over, maar deelden ook het eigentijdse engagement dat veel van de economen uit de Historische School kenmerkte: zij stonden op het standpunt dat het industriële kapitalisme en Manchester-liberalisme de sociale samenhang niet ten goede was gekomen, dat het moment gekomen was om daar verandering in te brengen en dat de wetenschap daaraan een bijdrage diende te leveren.

De cultuurhistorici vatten de geschiedwetenschap op als een Vorbereitungswissenschaft voor het heden. Zij leverden met hun geschiedschrijving een historische probleemanalyse: enerzijds traceerden zij de onontkoombare sociaal-historische ontwikkeling van het moderne individu en zijn vermogens, anderzijds gaf hun werk inzicht in vormen van massagedrag en in processen van 'sociaal-psychologische dissociatie' of culturele verandering in het verleden.

Onderscheidend voor hun opvattingen was daarbij dat de nieuwe cultuurhistorici 'de sociale kwestie' van hun tijd niet in de eerste plaats definieerden als een strijd om economische belangen en politieke rechten, maar als een culturele crisis, en dat betekende in hun termen, als een sociaal-psychologisch fenomeen. Het kernprobleem van de eigen tijd was voor hen allemaal immers dat op alle sociale niveaus de 'eenheid'

${ }^{272}$ Raphael (1997), 75-76.

${ }^{273}$ Raphael (1997), 75.

${ }^{274}$ Meinecke (1941) 206.

${ }^{275}$ Gegevens over Delbrück, Schäfer, Below, Rachfahl, Finke, Seeliger en Meyer te vinden bij Weber (1987).

${ }^{276}$ Zie hoofdstuk 4, paragraaf 5 en hoofdstuk 6 , paragraaf 4. 
en identiteit verloren was gegaan. Daarnaast bespeurden sommigen ook het gebrek aan 'leiderschap' en 'creativiteit'. In beide gevallen lagen de problemen voor de nieuwe cultuurhistorici hoofdzakelijk op het mentale vlak. Zij werden grotendeels veroorzaakt door praktische omstandigheden - van de communicatierevolutie en de industriële omwenteling, tot de groeiende wet- en regelgeving en de gevolgen van de vrije markteconomie. Maar zowel de problemen als de oplossingen ervoor werden vooral gezocht op het geestelijke vlak: de cultuurhistorici juichten nieuwe vormen van sociaal idealisme toe, nieuwe bindingen die de maatschappelijke samenhang konden versterken, en soms ook vormen van 'persoonlijkheidspolitiek' waardoor het hoogstaande individu de prominente plaats zou kunnen innemen of behouden die het toekwam.

De liberale achtergrond van hun opvattingen bleek niet alleen uit de waarde die zij op deze manier in de politiek (maar ook in het verleden) hechtten aan immateriële factoren (ten koste van de factoren macht en belang), maar ook uit de spanning tussen individualisme en collectivisme die hun gedachtegoed kenmerkte - opnieuw zowel in historisch als in politiek opzicht. Weliswaar verdedigden zij het belang van de collectieve factor in geschiedenis en politiek - dat was het element waardoor zij zich onderscheidden van veel critici - maar tegelijk deden de meesten onder hen grote moeite om de prominente rol van het (hoogstaande) individu in het verleden en de politiek te waarborgen. De ontwikkeling van het gedifferentieerde en verfijnde, 'nerveuze' individu beschouwden zij niet alleen als een wezenlijk kenmerk van de moderne tijd, maar ook als een hoogtepunt.

De aandacht die de cultuurhistorici (in politiek en geschiedschrijving) vroegen voor collectieven kwam zowel voort uit angst als uit overtuiging. Het collectief was voor de nieuwe cultuurhistorici een historische factor van belang èn een actuele bron van zorg. Zij vreesden enerzijds de massalisering en de vervlakking, het materialisme en de irrationaliteit van brede lagen van de bevolking als een bedreiging voor het gebildete individu. Anderzijds waren zij ervan overtuigd dat het collectief een macht van betekenis was, die voor het hoogstaande individu ook de verantwoordelijkheid van opvoeden en leidinggeven betekende. In de geschiedopvattingen van de cultuurhistorici kregen grote individuen de rol toebedeeld van het (bege)leiden van de massa in zijn ontwikkeling; in de politiek was hun standpunt eigenlijk niet anders, zoals bleek uit hun vrees voor de democratie en hun voorkeur voor een politiek geleid door een elite van Geistesaristokraten en Bildungsbürger. Belangrijk was dat zij aan de samenleving het primaat toekenden boven de staat (zowel in de geschiedschrijving als in de politiek) en dat derhalve staatsingrijpen gematigd moest zijn.

De liberale achtergrond van het denken van de cultuurhistorici kwam ook naar voren uit hun waardering voor de Verlichtingshistoriografie en in hun optimisme over het verloop van de geschiedenis. Zij stelden vertrouwen in de wetenschap, ook als het ging om de ontleding van de menselijk ziel. Hun historische psychologie was in veel opzichten een vorm van Verlicht vooruitgangsdenken: de algemene lijn die zij meer of minder uitgesproken in de geschiedenis ontwaarden was een ontwikkeling naar grotere eenheid van het mensengeslacht, bij een steeds verdere verfijning en differentatie van de vermogens van het individu. Weliswaar makkten zij zich zorgen over de grote veranderingen in hun eigen tijd en waren met name Breysig en Steinhausen daarover somber gestemd, maar zelfs zij ontkenden uitdrukkelijk dat van verval of degeneratie sprake was. Daarvoor was hun basisvertrouwen in een voortgaande opwaartse ontwikkeling van de mensheid te sterk.

De gedeelde professionele perceptiewijze van de nieuwe cultuurhistorici was derhalve wel degelijk nauw verbonden met een gemeenschappelijke politieke oriëntatie. Het belang dat zij als historici hechtten aan de rol van cultuur, in de zin van een 
collectieve 'geestelijke' vorming, hun internationale perspectief, hun vooruitgangsdenken, hun whig interpretation of history, en last but not least hun worsteling met de verhouding individu - collectief, waren de professionele aspecten van een politiek standpunt dat als klassiek liberaal, met sociale accenten, gekenschetst kan worden. 


\section{hoofdstuk 8}

\section{Conclusie}

In Bernhard Groethuysens 'anonieme Geistesgeschichte van het burgerdom' uit 1927, die hij de titel meegaf Die Entstehung der bürgerlichen Welt- und Lebensanschauung in Frankreich, leidde de Duits-Franse auteur zijn onderwerp in met de volgende woorden:

'Er bestaan tijdperken van historisch leven, waarin de mens van zich zelf zegt: ik ben de mens, de mens zonder meer. Wij leven niet in zo'n tijd. Wij weten van onze tijdelijkheid, wij kennen onze vergankelijkheid. Wij zijn ons van onze uniciteit bewust. Er hebben andere mensen bestaan en er zullen andere mensen bestaan. Wij vertegenwoordigen één type mens, niet de hele mens'.

De psychologisch èn (kunst)historisch geschoolde Simmel- en Dilthey-leerling èn democratisch marxist Groethuysen (1880-1946) putte uit dezelfde tradities als de cultuurhistorici van een generatie eerder en zijn uitspraak zou het motto geweest kunnen zijn boven hun levenswerk. ${ }^{2}$ Het onderzoek naar de historische verandering van collectieve psychische disposities, geestesgesteldheden of mentaliteiten kwam niet pas in het Interbellum van de grond, zoals Michael Sonntag in een studie naar de herkomst van het concept 'historische psychologie' heeft gesuggereerd, onder verwijzing naar de Frankfurter Schule, de kennissociologie uit de kring rond Karl Mannheim en de mentaliteitsgeschiedenis van Annales-voorman Febvre. ${ }^{3}$ De thematiek kent een veel langere geschiedenis, waarvan dit boek een episode in kaart heeft proberen te brengen.

De tegenstanders van de nieuwe cultuurhistorici hebben vanaf het begin volgehouden dat het meningsverschil met hun collega's uiteindelijk terug te voeren was tot een verschil in levensbeschouwing. ${ }^{4}$ Historisten als Schäfer en Below verweten de cultuurhistorici 'materialisme' en (meestal impliciet) steun aan de sociaaldemocratie. Dergelijke waardeoordelen, zo is gebleken, waren een vast onderdeel van de Duitse mainstream geschiedwetenschap rond 1890, die gekenmerkt werd door een politiek geëngageerde en hodiecentristische taakopvatting. ${ }^{5}$

Aan het eind van deze studie kunnen we vaststellen dat deze verwijten aan het adres van de nieuwe cultuurhistorici niet gerechtvaardigd waren. Zij waren noch materialisten, noch aanhangers van de sociaaldemocratie; de meesten onder hen koesterden zelfs zwaarwegende reserves tegenover de democratie als politiek systeem. Tegelijk is in dit boek echter beargumenteerd dat levensbeschouwelijke factoren wel degelijk een rol hebben gespeeld in het ontstaan en de receptie van de nieuwe cultuurgeschiedenis. In die zin hadden de critici van de cultuurhistorici dan toch gelijk.

De politieke thuisbasis van de nieuwe cultuurhistorici was niet de sociaaldemocratie maar het liberalisme, opgevat als een politieke ideologie gebaseerd op de vrijheid van het individu, waarin de rol van de staat gematigd was en het primaat van cultuur en samenleving voorop stond. De liberale oriëntatie van de cultuurhistorici werd

\footnotetext{
${ }^{1}$ Groethuysen (1927-1930), I, [vii].

${ }^{2} \mathrm{Zie}$ over Groethuysen en de receptie van zijn werk: Ermath (1993).

${ }^{3} \mathrm{Vgl}$. Sonntag (1990).

${ }^{4}$ Zie Hoofdstuk 2, inleiding en paragraaf 1 en Hoofdstuk 5, paragraaf 4.

${ }^{5}$ Zie Hoofdstuk 5, paragraaf 4.
} 
politiek èn geschiedtheoretisch verzacht door hun aandacht voor het sociale onrecht in hun tijd, voor de negatieve sociale gevolgen van de vrije economische concurrentie, en voor de (overigens niet altijd gewaardeerde) grote rol van collectieven in de samenleving. 6

Politiek gesproken kunnen de nieuwe cultuurhistorici met enig recht als 'idealisten' gekenmerkt worden. Geen van hen accepteerde groepsbelang of machtsdenken als richtlijn voor de politiek en zonder uitzondering riepen zij zelf op tot een nieuw idealisme, tot een mentaliteitsverandering die een oplossing zou brengen voor maatschappelijke verdeeldheid van hun tijd, hetzij door een sterkere sociale samenhang en 'gebondenheid' te creëren, hetzij door betere mogelijkheden te scheppen voor het individu om zich te ontplooien.

Ook geschiedtheoretisch kan nauwelijks serieus van 'materialisme' onder de cultuurhistorici gesproken worden. Net als Ranke en andere historisten onder hun leermeesters legden de nieuwe cultuurhistorici een grote nadruk op de collectieve geestesgesteldheid als historische factor van het eerste belang. Het was deze factor die de eenheid in een tijd en natie uitmaakte, boven alle verdeeldheid uit, een factor bovendien die van doorslaggevend belang was bij de interpretatie van historische gebeurtenissen. ${ }^{7}$ Alleen definieerden en analyseerden de nieuwe cultuurhistorici de collectieve geestesgesteldheid op een heel andere wijze dan in het Duitse historisme gebruikelijk was. ${ }^{8}$ En op dit punt wordt duidelijk waar de redenen voor het materialisme-verwijt van de tegenstanders lagen.

Voor veel historisten was de Gesamtgeist een onveranderlijk gegeven, een idee, dat de basis vormde voor de nationale samenleving, cultuur en politiek. De strijd van de staten (en ideeën) met elkaar en niet de veranderende maatschappelijke omstandigheden vormde de motor achter historische veranderingen. Vandaar het primaat dat de historisten aan de politiek toekenden. ${ }^{9}$ Voor de nieuwe cultuurhistorici daarentegen lag het primaat, in overeenstemming met hun politieke oriëntatie, bij cultuur en samenleving. Voor hen was de collectieve geestesgesteldheid een sociaal en historisch product dat weliswaar een zekere autonomie bezat, maar toch in hoge mate gevormd werd door de veranderende maatschappelijke omstandigheden, met name op het terrein van economie en communicatiemiddelen. Het waren vooral maatschappelijke veranderingen die tot veranderingen in de collectieve geestesgesteldheid leidden en dat betekende in hun termen veranderingen in de collectieve (en individuele) psychische gesteldheid.

De critici van de nieuwe cultuurgeschiedenis raakten een gevoelige snaar bij de cultuurhistorici met het verwijt dat in de nieuwe cultuurgeschiedenis afbreuk werd gedaan aan de betekenis van 'de vrije persoonlijkheid', dit 'innerlijk heiligdom van de geschiedenis'. Het was exact op dit levensbeschouwelijke punt waar de wegen van voor- en tegenstanders van de nieuwe cultuurgeschiedenis uiteindelijk uiteen gingen. Zoals we hebben gezien, was ook voor de meeste cultuurhistorici de betekenis van het individu boven alle twijfel verheven. Dat was een van de redenen waarom de meeste andere cultuurhistorici zich ongemakkelijk voelden bij de opvattingen van Lamprecht, die de zelfstandige betekenis van het individu het sterkst relativeerde.

De overige cultuurhistorici waren weliswaar eveneens hartstochtelijke pleitbezorgers van de waarde van het individu, maar geloofden tegelijkertijd veel meer dan hun historistische tegenstanders in de feitelijke gedetermineerdheid van het individu (of op zijn minst: van de meeste individuen) door de omgeving. Niet voor niets waren niet

\footnotetext{
${ }^{6}$ Zie Hoofdstuk 7, m.n. paragraaf 7-9.

${ }^{7}$ Zie Hoofdstuk 3, paragraaf 6.

${ }^{8}$ Zie Hoofdstuk 5, paragraaf 5-7.

${ }^{9}$ Zie Hoofdstuk 2, paragraaf 1 en Hoofdstuk 5, paragraaf 1.
} 
alleen Lamprecht, maar ook Gothein en Breysig vanaf het begin betrokken bij de Duitse Gesellschaft für Soziologie (1910). Uit de erkenning van de diepgaande invloed van de sociale omgeving op het individu kwam nu juist hun gedachte voort van cultuurgeschiedenis als een vorm van historische psychologie of Gesellschaftsseelenkunde.

Alle nieuwe cultuurhistorici, behalve Lamprecht, probeerden dit standpunt te combineren met de gedachte dat het ontwikkelde individu een grote waarde moest worden toegekend in geschiedenis, samenleving en politiek. Dit hybride standpunt kwam onder andere pregnant tot uitdrukking in Breysigs stelling dat niet de (gebruikelijke) geschiedenis van personen, maar een geschiedenis van de persoonlijkheid geschreven moest worden: de individuele persoonlijkheid was weliswaar van groot belang, maar tegelijkertijd werd zij in belangrijke mate gevormd door de geschiedenis en de cultuur. Meer in het algemeen beschouwden de cultuurhistorici het individu en het individualisme niet als een tijdloos gegeven, maar als een collectief en cumulatief product van de geschiedenis.

In hun cultuurgeschiedschrijving probeerden de nieuwe cultuurhistorici de ontwikkeling van de eigentijdse kenmerken van het moderne individu, zijn Reizsamkeit, nervositeit en onzekerheid, te traceren en te verklaren. Hun verklaringen wezen vooral naar veranderingen in de economie, de sociale organisatie en de communicatie. Hun geschiedschrijving was tegelijk een uiting van vervreemding van het verleden - de mensen in het verleden waren anders - als een poging om de snel groeiende kloof met het verleden te overbruggen en het verleden weer betekenis te geven voor het heden. Deze poging ondernamen de cultuurhistorici door middel van meer of minder uitgewerkte ontwikkelingsmodellen, waarin de nadruk lag op grote kwalitatieve en psychische veranderingen tussen de opeenvolgende tijdperken. De zekerheid die hun geschiedschrijving temidden van de eigentijdse onzekerheden leek te bieden, was dat deze kwalitatieve veranderingen uiteindelijk verbeteringen betroffen.

In politiek opzicht leidde de matiging van het individualistische uitgangspunt gedachte ertoe dat staatsingrijpen door verschillende cultuurhistorici werd verwelkomd om de negatieve maatschappelijke gevolgen voor de meeste individuen van totale individuele vrijheid tegen te gaan. Anderzijds was het juist de erkenning van de (mis)vormende invloed op het individu door druk van buitenaf die maakte dat andere cultuurhistorici waarschuwden tegen de al te grote invloed van de staat, als een rem op de ontplooing en creativiteit van het individu. Zowel politiek als geschiedtheoretisch waren de cultuurhistorici al met al minder etatistisch dan hun historistische tegenstanders, die vasthielden aan het primaat van de politiek boven de maatschappelijke krachten. Aan de andere kant hadden zij meer aandacht voor de gebondenheid van het individu aan zijn omgeving dan klassieke liberalen en derhalve ook meer aandacht voor de sociale rol die de staat kon (en volgens sommigen: diende) te spelen.

We moeten vaststellen dat de levensbeschouwelijke en politieke verschillen tussen de cultuurhistorici en hun critici weliswaar reëel waren, maar vanuit eenentwintigsteeeuws perspectief niet zo groot lijken als voor de tijdgenoten in het heetst van de strijd. Dat verklaart ook dat latere commentatoren hebben kunnen ontkennen dat er van politieke meningsverschillen sprake was.

Dat de posities van voor- en tegenstanders soms dicht bij elkaar lagen is in deze studie ook in andere opzichten duidelijk geworden. Hoewel sciëntistischer van karakter dan de politieke geschiedenis, werd bijvoorbeeld ook de nieuwe cultuurgeschiedenis gekenmerkt door een uitgesproken hodiecentrisme en maatschappelijk engagement. ${ }^{10}$ En weliswaar hadden de cultuurhistorici in het algemeen een afstandelijker houding ten

${ }^{10}$ Zie Hoofdstuk 5, paragraaf 4. 
opzichte van historische bronnen dan hun tegenstanders, onmogelijk kan worden volgehouden dat zij het 'bronnenethos' van hun leermeesters misten. ${ }^{11}$ Verder geloofden de nieuwe cultuurhistorici weliswaar meer dan hun tegenstanders in algemene lijnen en patronen, in de mogelijkheid en het nut van historische generalisaties, en in 'typen' en 'stadia'; maar het is meer dan een misvatting om hun geschiedtheorie op grond daarvan als 'natuurwetenschappelijk' of 'nomothetisch' te kwalificeren. Ook voor de cultuurhistorici - Lamprecht inbegrepen - bleef de geschiedenis de fundamentele geesteswetenschappelijke discipline, waaraan andere disciplines slechts hulpmiddelen konden leveren voor zover die 'gehistoriseerd' konden worden. Dat gold in hun ogen bij uitstek voor de psychologie, die zij als een geesteswetenschappelijke en derhalve als een fundamenteel historische discipline wensten op te vatten. ${ }^{12}$

De overeenkomsten tussen de cultuurhistorici en hun tegenstanders zijn niet verrassend als hun vroege academische carrière in ogenschouw wordt genomen, zoals in hoofdstuk 4 is gebeurd. Als studenten en jonge docenten bleken de nieuwe cultuurhistorici in veel opzichten een exemplarische ontwikkeling te hebben doorlopen vergeleken met de andere hoogleraren geschiedenis van hun generatie. Indien ergens een onderscheid met hun collega's in dit opzicht was vast te stellen, dan lag het verschil eerder in hun voorlijkheid en het aanvankelijke succes van hun carrière dan in een vermeend gebrek daaraan. ${ }^{13}$ Hetzelfde gold voor hun sociale achtergrond: de vijf woordvoerders van de nieuwe cultuurgeschiedenis hadden stuk voort stuk een bildungsbürgerliche sociale achtergrond en onderscheidden zich qua geografische herkomst, beroep van de vader, godsdienst en scholing niet van de meerderheid van de hoogleraren geschiedenis van hun generatie. ${ }^{14}$ Het was juist onder de uitgesproken critici van de nieuwe cultuurgeschiedenis dat een aantal opvallende afwijkingen van het algemene beroepspatroon gevonden werd.

Dat brengt ons bij een andere conclusie, namelijk dat de strijd over de cultuurgeschiedenis geen generatiestrijd was, maar een strijd binnen één (of meer) generatie(s). Enerzijds is gebleken dat ook al onder vakhistorische docenten van de cultuurhistorici, zoals Bernheim, Erdmannsdörffer, Seeck en Lorenz niet uitsluitend gedacht werd in termen van historische singulariteit, maar gezocht werd naar historische regelmatigheden en patronen. Anderzijds werd ook het verzet daartegen gedeeld door leden van zowel de oudere als de nieuwe generatie historici. ${ }^{15}$

Het idee dat de negentiende- (en vroeg-twintigste-)eeuwse Duitse geschiedwetenschap als geheel gedomineerd werd door een idealistisch georiënteerd historisme lijkt derhalve gerelativeerd te moeten worden, al is onduidelijk in welke mate. Duidelijk is wel dat een algeheel oordeel over de aard van de Duitse geschiedwetenschap in de tweede helft van de negentiende eeuw, een vak dat in deze periode gedoceerd werd door zeker meer dan honderdvijftig verschillende historische ordinarii, niet bepaald zou moeten worden door de opvattingen van een zeer beperkt aantal spraakmakende historici als Ranke, Droysen, Below en Meinecke.

Duidelijk is ook dat de publieke strijd over de meningsverschillen binnen de historische discipline toenam aan het eind van de negentiende eeuw, zoals een aantal historici zelf vaststelde. ${ }^{16}$ Er kan een aantal factoren worden genoemd dat daarbij een

\footnotetext{
${ }^{11}$ Zie Hoofdstuk 5, paragraaf 2.

${ }^{12}$ Zie Hoofdstuk 3, paragraaf 6.

${ }^{13}$ Zie Hoofdstuk 4, paragraaf 2 en 3.

${ }^{14}$ Zie Hoofdstuk 4, paragraaf 1.

${ }^{15}$ Zie Hoofdstuk 4, paragraaf 3 en Hoofdstuk 5, paragraaf 2.

${ }^{16}$ Zie Hoofdstuk 2, paragraaf 1 .
} 
rol heeft gespeeld. In de eerste plaats was het verloren gaan van de disciplinaire consensus ongetwijfeld mede het gevolg van de bijzonder snelle toename van het aantal universitaire historici in de decennia voor 1890: de gemiddelde aanwas tussen 1865 en 1885 van meer dan één nieuwe historische leerstoel per jaar maakte het op zichzelf al moeilijker om de eenheid van visie te bewaren. Na 1890 zou bovendien ook het aantal disciplinaire instituties en vaktijdschriften opmerkelijk gaan toenemen, waardoor de historische discipline enerzijds een sterker polycentrisch karakter kreeg, anderzijds meningsverschillen makkelijker publiek en organisatorisch gerepresenteerd konden worden. ${ }^{17}$ En last but not least was het welhaast onvermijdelijk dat de snel groeiende groep universitaire historici verdeeld raakte door de grote technische, economische en maatschappelijke veranderingen in deze periode in het Keizerrijk, vooral door de snel doorzettende industrialisering met alle sociale en culturele gevolgen van dien. Het geloof van de cultuurhistorici in verandering en vooruitgang, in de grote rol van immateriële factoren in politiek en geschiedenis, in de waarde van het individu, èn in de betekenis die nolens volens aan de massa moest worden toegekend, was niet meer dan een overtuiging temidden van vele andere die in het Keizerrijk werden gekoesterd.

De vaststelling dat de nieuwe cultuurhistorici aanvankelijk goed in de historische vakwetenschap geïntegreerde wetenschappers waren, roept de vraag hoe zij tot hun binnen de discipline omstreden opvattingen van geschiedenis als cultuurgeschiedenis en van cultuurgeschiedenis als een geschiedenis van de menselijke natuur en de menselijke vaardigheden kwamen. In deze studie is duidelijk geworden dat de cultuurhistorici ook wat deze opvattingen betreft beïnvloed waren door enkele van hun historische docenten (onder wie Ernst Bernheim de belangrijkste genoemd mag worden), maar dat in dit opzicht invloeden van buiten de historische discipline van doorslaggevend belang moeten worden geacht voor hun intellectuele vorming.

Vastgesteld is dat de nieuwe cultuurhistorici zelf de oorsprong van de moderne geschiedwetenschap, anders dan hun historistische tegenstanders, niet terugvoerden tot de nationalistische heropleving na de bevrijdingsoorlogen tegen de Fransen, maar tot achttiende-eeuwse Verlichtingsdenkers. ${ }^{18}$ Het project van een geschiedenis van de cultuur zoals dat in de Verlichting voor het eerst werd geformuleerd, sloot direct aan bij de opvattingen van de nieuwe cultuurhistorici. De Verlichte Menschheitsgeschichte was immers (net als het historisch denken van de nieuwe cultuurhistorici) gebaseerd op een universeel, collectief, psychologisch en dynamisch cultuurbegrip. ${ }^{19}$ Het ging hier in feite om een psychologische beschavingsgeschiedenis, waarin de nadruk lag op de historische veranderingen in de psychische uitrusting en vermogens van de mens.

Daarmee sloot de Verlichte opvatting van cultuurgeschiedenis beter aan bij de ideeën van de nieuwe cultuurhistorici dan de meeste latere, negentiende-eeuwse varianten van cultuurgeschiedschrijving. Daarvan waardeerden de nieuwe cultuurhistorici nog het meest de cultuurgeschiedschrijving uit het midden van de eeuw en dan vooral het werk van Riehl, Freytag en Burckhardt, dat zij om de collectiefpsychologische interpretaties waardeerden. Voor het overige vonden zij dat in de cultuurgeschiedschrijving van rond 1850 teveel werd uitgegaan van een onveranderlijke volksgeest. $^{20}$

De waardering van de nieuwe cultuurhistorici voor de Verlichtingshistoriografie kwam niet uit de lucht vallen. Via een hele reeks docenten en auteurs waren zij beïnvloed door de empirisch-psychologische traditie van de herbartiaanse sociale en

\footnotetext{
${ }^{17}$ Zie Hoofdstuk 2, paragraaf 2 en 3 en Hoofdstuk 4, paragraaf 4.

${ }^{18}$ Zie Hoofdstuk 5, paragraaf 3.

${ }^{19}$ Zie Hoofdstuk 5, paragraaf 7.

${ }^{20}$ Zie Hoofdstuk 6, paragraaf 1 .
} 
Völkerpsychologie èn de (historiserende) kritiek die deze traditie had opgeroepen. Naast Ernst Bernheim (docent van Steinhausen en Lamprecht) maakte vooral de filosoof Wilhelm Dilthey (docent van Gothein en Breysig) op grond van zijn uiteenzetting met het denken van de herbartianen het fundamentele belang voor historici duidelijk van een historisch georiënteerde, sociale psychologie. ${ }^{21}$ De gedachte van een 'psychische distantie' tussen heden en verleden, van een veranderende geestesgesteldheid in de loop van de geschiedenis, werd door beide wetenschappers van groot belang geacht.

Belangrijker nog dan deze individuele docenten moeten de nauwe relaties van de meeste nieuwe cultuurhistorici met de Historische School in de Nationalökonomie worden geacht. Vier van de vijf nieuwe cultuurhistorici werden mede opgeleid (en vervolgens in hun carrière gesteund) door belangrijke vertegenwoordigers van de Historische School, voor wie net als voor Bernheim en Dilthey (en mede geïnspireerd door de herbartianen), een historiserende, sociale psychologie fundamenteel was in de historische en maatschappelijke analyse. ${ }^{22}$ Het was deze goed georganiseerde beroepsgroep die ook in belangrijke andere opzichten (de historische aandacht voor economie en samenleving, de uitbreiding van het bronnenarsenaal, de overtuiging van het belang van de statistiek, het geloof in 'typen' en 'ontwikkelingsstadia') de belangrijkste vormende invloed op de nieuwe cultuur-historici moet worden toegekend. Dat gold ten slotte ook voor het sociale engagement van veel economen uit de Historische School, waarmee zij indruk maakten op de nieuwe cultuurhistorici die bij hen studeerden.

De cultuurhistorici bleven een rol spelen binnen de historische discipline, ook nadat de kritiek op hun werk van de kant van historisten en politieke historici was losgebarsten: door hun opvallende rol in de fase van institutionele vernieuwing van de Duitse geschiedwetenschap, waarvan na 1890 gesproken kan worden, schiepen zij de organisatorische voorwaarden voor de voortbestaan van het cultuurhistorisch onderzoek binnen de discipline. ${ }^{23}$ Dat van een voortbestaan en zelfs van een doorbraak van de cultuurgeschiedenis in het Interbellum gesproken mag worden is in Hoofdstuk 2 verdedigd. $^{24}$

Dat roept, tot slot, de onvermijdelijke vraag op waarom de Duitse cultuurgeschiedschrijving vergeleken met de Franse mentaliteitsgeschiedenis na de Tweede Wereldoorlog grotendeels uit het zicht en de aandacht is verdwenen en zo lang, tot in de jaren negentig van de twintigste eeuw, op haar herontdekking heeft moeten wachten.

Het antwoord op die vraag moet tentatief blijven, want zij is noch hier noch elders afdoende onderzocht. Allereerst moet worden vastgesteld dat de receptie van de nieuwe cultuurgeschiedenis onder het nationaal-socialisme ambigu was. Volgens Stefan Haas betekende de machtsovername door de nationaal-socialisten niet alleen een personele uitdunning onder de cultuurhistorici - onder meer werd Goetz gedwongen zijn ambt aan het IKU neer te leggen - maar leidde zij ook tot het uiteindelijke doodbloeden van de cultuurhistorische traditie in Duitsland. ${ }^{25}$ Inderdaad vinden we bij historici die met het nationaal-socialisme sympathiseerden, zoals Otto Westphal en Christoph Steding, in de jaren dertig een uitgesproken negatieve beoordeling van de cultuurgeschiedenis. Westphal publiceerde in 1930 een ideologiehistorische studie waarin hij Lamprecht, samen met onder anderen Dilthey en Gothein schaarde onder wat hij de 'Duitse oppositie' en de intellectuele Feinde Bismarcks noemde, met in hun vaandel het devies 'Seele, Gesellschaft, Kultur'. In deze visie was Lamprecht de vertegenwoordiger van een

\footnotetext{
${ }^{21}$ Zie Hoofdstuk 6, paragraaf 3.

${ }^{22}$ Zie Hoofdstuk 6, paragraaf 4.

${ }^{23}$ Zie Hoofdstuk 4, paragraaf 4 en 5.

${ }^{24}$ Zie Hoofdstuk 2, paragraaf 3.

${ }^{25}$ Haas (1994), 355-361.
} 
'onduitse', 'westerse', positivistische en modernistische wereldbeschouwing, die nauw verbonden was met de opkomst van het industriële kapitalisme in Duitsland. ${ }^{26}$ Christoph Steding hield in 1937 een lezing op de Historikertag te Erfurt, waarin hij pleitte voor een hernieuwde concentratie op de politieke geschiedenis en de cultuurgeschiedschrijving diskwalificeerde als een 'Geschichtsschreibung der Geschichtslosen', een produkt van de Verlichting en een teken van verval. ${ }^{27}$

Aan de andere kant hebben Willi Oberkrome en anderen geconstateerd dat op zijn minst deelaspecten van het vernieuwende cultuurhistorische discours een völkische voortzetting vonden na 1933, onder andere in de regionale geschiedschrijving en bij verschillende wetenschappers die mede door de cultuurhistorici waren opgeleid, zoals de rechtsrevolutionaire socioloog Hans Freyer, de regionaal historicus Hermann Aubin, en Lamprechts laatste assistent Herbert Schönebaum. ${ }^{28}$ Hier kan ook gememoreerd worden dat Steinhausens Geschichte der Deutschen Kultur in 1936 in een uitgebreide nationaal-socialistische bewerking werd uitgebracht, ook al had de auteur ervan zich tijdens zijn leven tegen racistische en völkische geschiedinterpretaties uitgesproken. ${ }^{29}$

Dat vervolgens ná de Tweede Wereldoorlog de Duitse cultuurhistorische traditie weinig belangstelling van geschiedwetenschappers heeft getrokken, is dan eigenlijk niet verrassend meer. Allereerst werkte de negatieve beoordeling door die vooral Lamprechts werk van collega-historici voor èn na 1933 had gekregen. Bovendien droegen opvattingen van oudere Duitse wetenschappers over historische vormen van 'collectieve identiteit' en Völkerpsychologie juist door de associatie met völkische opvattingen voortaan de hardnekkige verdenking met zich dat zij op een of andere manier politiek incorrect of 'fout' waren geweest. Het lijkt er sterk op dat na de Tweede Wereldoorlog geschiedwetenschappers buiten Duitsland zich op grond van dergelijke politieke overwegingen lange tijd hebben afgekeerd van de Duitse historiografie, òf die slechts hebben bestudeerd in het teken en omwille van 1933. Dat gebeurde, tenslotte, ook onder Duitse historici zelf die, na twee verloren wereldoorlogen en de ideologisch gemotiveerde misdaden van een extreem politiek regime, zich begrijpelijkerwijs opnieuw hoofdzakelijk met de eigen politieke geschiedenis gingen bezighouden. Op deze wijze is ook de Duitse cultuurhistorische traditie terecht gekomen in de zwarte schaduw van Auschwitz.

\footnotetext{
${ }^{26}$ Westphal (1930), 193; behalve een hoofdstuk aan Lamprecht (blz. 186-201), wijdde Westphal een deel aan de 'Historisierung der Seele und der Gesellschaft. Dilthey' (blz. 148-173). Over Westphal zie Weber (1987), 657 en Hying (1964).

${ }^{27}$ Steding (1941) en Hying (1964), 50-60.

${ }^{28}$ Zie Oberkrome (1993), en over Freyer bovendien: Schorn-Schütte (1988), m.n. 178-179, SchornSchütte (1993), Hoyer (1993), Üner (1993). Over Schönebaum: Middell (2005), 26-28.

${ }^{29}$ Zie Hoofdstuk 3, paragraaf 2.2 (bij noot 175).
} 



\section{Aangehaalde bronnen en literatuur}

Abb, Gustav, red. Aus fünfzig Jahren deutscher Wissenschaft. Die Entwicklung ihrer Fachgebiete in Einzeldarstellungen. Berlin etc.: 1930.

Allesch, Christian, 'Johann Friedrich Herbart als Wegbereiter der Kulturpsychologie.' In: Herbarts Kultursystem. Perspektive der Transdisziplinaritat im 19. Jahrhundert, red. A. Hoeschen en Lothar Schneider. Würzburg: Königshausen \& Neumann, 2001, blz. 51-67.

Altenbockum, Jasper von, Wilhelm Heinrich Riehl 1823-1897. Sozialwissenschaft zwischen Kulturgeschichte und Ethnographie. [Münstersche Historische Forschungen, Bd. 6] Keulen, Weimar, Wenen: Böhlau Verlag, 1994.

Alter, Peter, 'Eberhard Gothein.' In: Deutsche Historiker, VIII, red. H.-U. Wehler. Göttingen: 1982, blz. 40-55.

Aly, Friedrich, 'Der Einbruch des Materialismus in die historischen Wissenschaften', in: Preußische Jahrbücher 81 (1895), blz. 201-214.

Appel, M., Werner Sombart: Historiker und Theoretiker des modernen Kapitalismus. Marburg: 1992.

Arens, Franz, 'Karl Lamprecht. Ein Gedenkblatt zur siebzigsten Wiederkehr seines Geburtstages (25. februar 1926)', in: Preußische Jahrbücher 203 (1926a), blz. 191-213, 306-328.

Arens, Franz, 'Über Karl Lamprechts Geschichtsauffassung und einige dringliche Fragen der Geschichtswissenschaft', in: Archiv für Politik und Geschichte 6 (1926b), blz. 227-244.

Barbu, Zevedei, Problems of historical psychology. [International library of sociology and social reconstruction] Londen: Routledge \& Kegan Paul, 1960.

Baudet, Ernest Henri Philippe, Onderzoekingen over het systeem der middeleeuwsche geschiedbeschouwing: een studie over Ernst Bernheim's 'Mittelalterliche Zeitanschauungen.' [s.1.]: [s.n.], Diss. Leiden 1948.

Beard, George M., American nervousness, its causes and consequences. A supplement to Nervous exhaustion (Neurasthenia). New York: 1881.

Becher, Ursula A.J., 'Die Bedeutung Lamprechts bei der Neuorientierung der französischen Geschichtswissenschaft um die Jahrhundertwende.' In: Transformation des Historismus. Wissenschaftsorganisation und Bildungspolitik vor dem Ersten Weltkrieg. Interpretationen und Dokumente, red. Horst Walter Blanke. Waltrop: Spenner, 1994, blz. 95-111.

Belke, Ingrid, 'Einleitung.' In: Moritz Lazarus und Heymann Steinthal. Die Begründer der Völkerpsychologie in ihren Briefen, red. I. Belke. Tübingen: Mohr/Siebeck, 1971, blz. XIII-CXLII.

Below, Georg von, '[rec. van debat Gothein/Schäfer + Bernheim, Lehrbuch d. hist. Methode]', in: Göttingische gelehrte Anzeigen 1 (1892), blz. 280-296.

Below, Georg von, '[recensie Lamprecht, Deutsche Geschichte I-III]', in: Historische Zeitschrift 71 (1893), blz. 465-498.

Below, Georg von, 'Die neue historische Methode', in: Historische Zeitschrift 81 (1898), blz. 193-273. 
Below, Georg von, 'Zur Würdigung der historischen Schule der Nationalökonomie [IVI]', in: Zeitschrift für Sozialwissenschaft 7 (1904), blz. 145-185, 221-237, 304329, 367-391, 451-466, 654-659, 685-686.

Below, Georg von, Die deutsche Geschichtschreibung von den Befreiungskriegen bis zu unseren Tagen: Geschichtschreibung und Geschichtsauffassung. [Handbuch der mittelalterlichen und neueren Geschichte] 2de dr., München/Berlijn: Oldenbourg, 1924 [1e dr. 1916].

Below, Georg von, '[Selbstdarstellung].' In: Die Geschichtswissenschaft der Gegenwart in Selbstdarstellungen, II, red. Sigfrid Steinberg. Leipzig: Felix Meiner, 1925, blz. 1-49.

Bengel, Johann, Geschichte der Methodik des kulturgeschichtlichen Unterrichts. [Pädagogische Zeit- und Streitfragen, IX:3/4] Wiesbaden: Emil Behrend, 1896.

Bergsträsser, A., 'Eberhard Gothein.' In: Neue deutsche Biographie, Berlijn: 1964, blz. 654-656.

Bericht (1893), Bericht über die erste Versammlung deutscher Historiker in München [1893]. Leipzig: 1893.

Bericht (1894), Bericht über die zweite Versammlung deutscher Historiker [...] 1894 in Leipzig. Leipzig: 1894.

Bericht (1895), Bericht über die dritte Versammlung deutscher Historiker [...] 1895 in Frankfurt a.M. Leipzig: Duncker \& Humblot, 1895.

Bericht (1896), Bericht über die vierte Versammlung deutscher Historiker zu Innsbruck [...] 1896. Leipzig: Duncker \& Humblot, 1897.

Bericht (1898), Bericht über die fünfte Versammlung deutscher Historiker zu Nürnberg [...] 1898. Leipzig: Duncker \& Humblot, 1898.

Bericht (1903), Bericht über die siebente Versammlung deutscher Historiker zu Heidelberg [...] 1903. Leipzig: Duncker \& Humblot, 1903.

Bericht (1907), Bericht über die zehnte Versammlung deutscher Historiker [...] 1907 in Dresden. Leipzig: Duncker \& Humblot, 1907.

Bernert, Helmut, 'Die Murhardsche Bibliothek der Stadt Kassel und ihre wissenschaftlichen Bibliothekaren.' In: 125 Jahre Murhardsche Stiftung der Stadt Kassel und ihrer Bibliothek 1863-1988, red. Hans-Jürgen Kahlfuß. Kassel: 1988, blz. 105-131.

Bernheim, Ernst, Geschichtsforschung und Geschichtsphilosophie. Göttingen: Peppmueller, 1880.

Bernheim, Ernst, Lehrbuch der historischen Methode: mit Nachweis der wichtigsten Quellen und Hülfsmittel zum Studium der Geschichte. 1e dr., Leipzig: Duncker \& Humblot, 1889a.

Bernheim, Ernst, '[rec. van Schäfer, Eigentliche Arbeitsgebiet en Gothein, Aufgaben der Kulturgeschichte]', in: Deutsche Litteraturzeitung (1889b), blz. 1610-1611.

Bernheim, Ernst, Geschichtsunterricht und Geschichtswissenschaft im Verhältnis zur kultur- und sozialgeschichtlichen Bewegung unseres Jahrhunderts. Wiesbaden: 1899.

Bernheim, Ernst, Lehrbuch der historischen Methode und der Geschichtsphilosophie. 3e $+4 \mathrm{e}$, herz. dr., Leipzig: Duncker \& Humblot, 1903.

Bernheim, Ernst, 'La science historique moderne', in: Revue de synthèse historique 10 (1905), blz. 125-139.

Bernheim, Ernst, Lehrbuch der historischen Methode und der Geschichtsphilosophie. 5e $+6 e$, vermeerderde dr., Leipzig: Duncker \& Humblot, 1908.

Bernheim, Ernst, Einleitung in die Geschichtswissenschaft. Berlijn, Leipzig: Goeschen, 1920 [1e dr. 1905]. 
Blaas, P.B.M., 'De prikkelbaarheid van een kleine natie met een groot verleden: Fruins en Bloks nationale geschiedschrijving', in: Theoretische Geschiedenis 9 (1982), blz. 271-303.

Blaas, P.B.M., Anachronisme en historisch besef. Momenten uit de ontwikkeling van het Europees historisch bewustzijn. Rotterdam: Nijgh \& Van Ditmar, 1988.

Blanke, Horst Walter, 'Die Wiederentdeckung der deutschen Aufklärungshistorie und die Begründung der Historischen Sozialwissenschaft.' In: Die sog. Geisteswissenschaften: Innenansichten, red. Wolfgang Prinz en Peter Weingart. Frankfurt a.M.: Suhrkamp, 1990, blz. 105-133.

Blanke, Horst Walter, 'Selbstreflexion der Historie im Umbruch.

Historiographiegeschichte bei Karl Lamprecht und seinen Schülern.' In:

Transformation des Historismus. Wissenschaftsorganisation und Bildungspolitik vor dem Ersten Weltkrieg. Interpretationen und Dokumente, red. Horst Walter Blanke. Waltrop: Spenner, 1994a, blz. 112-153.

Blanke, Horst Walter, red. Transformation des Historismus. Wissenschaftsorganisation und Bildungspolitik vor dem Ersten Weltkrieg. Interpretationen und Dokumente. [Wissen und Kritik, 4]. Waltrop: Spenner, 1994b.

Bloch, Marc, Pleidooi voor de geschiedenis of Geschiedenis als ambacht, vertaald door Marleen Wessel. Nijmegen: SUN, 1989 [1e dr. 1949].

Blok, P.J., De geschiedenis als sociale wetenschap. Groningen: 1894.

Boekhorst, Peter te, Peter Burke en Willem Frijhoff, red. Cultuur en maatschappij in Nederland 1500-1850: een historisch-antropologisch perspectief. Meppel / Heerlen: Boom / Open universiteit, 1992.

Boer, Pim den, 'Existentiële geschiedenis. Enkele Franse studies over dood en angst', in: Tijdschrift voor Geschiedenis 94 (1981), blz. 58-70.

Boer, Pim den, 'Mentaliteitsgeschiedenis: een begripsbepaling', in: Bijdragen en mededelingen voor de geschiedenis der Nederlanden 98 (1983), blz. 318-336.

Böhme, Hartmut, Peter Matussek en Lothar Müller, Orientierung Kulturwissenschaft. Was sie kann, was sie will. Reinbek b. H.: Rowohlt, 2002 [1e dr. 2000].

Bois-Reymond, E. du, 'Culturgeschichte und Naturwissenschaft', in: Deutsche Rundschau 13 (1877), blz. 214-250.

Bowler, Peter J., Evolution. The history of an idea. Herz. dr., Berkeley, Los Angeles: UCP, 1989 [1e dr. 1983].

Boyd, William en Edmund J. King, The history of Western education. 9de, herz. dr., Londen: Black, 1969.

Brands, Maarten, Historisme als ideologie. Het 'onpolitieke' en 'anti-normatieve' element in de Duitse geschiedwetenschap. Assen: Van Gorcum \& Prakke, 1965.

Braubach, Max, 'Aloys Schulte 1857-1941.' In: Bonner Gelehrte: Beiträge zur Geschichte der Wissenschaften in Bonn. Geschichtswissenschaften, Bonn: 1968, blz. 299-310.

Breisach, Ernst, Historiography: ancient, medieval, modern. Chicago, Londen: University of Chicago Press, 1983.

Bresslau, Harry, Geschichte der Monumenta Germaniae Historica. Hannover: Hahnsche Buchhandlung, 1921.

Breysig, Gertrud, Kurt Breysig. Ein Bild des Menschen. Heidelberg: Lothar Stiehm Verlag, 1967.

Breysig, Kurt, '[rec. van Schäfer, Geschichte und Kulturgeschichte]', in: Literarisches Centralblatt (1892), blz. 869.

Breysig, Kurt, '[rec. van Simmel, Probleme der Geschichtsphilosophie]', in: Literarisches Centralblatt (1893), blz. 636-637. 
Breysig, Kurt, '[rec. van Bernheim, Lehrbuch, 2e dr. 1894]', in: Literarisches Centralblatt (1895), blz. 1157-1158.

Breysig, Kurt, 'Die sociale Entwicklung der führenden Völker Europas in der neueren und neuesten Zeit. Ein Versuch [I]', in: Schmollers Jahrbuch für Gesetzgebung, Verwaltung und Volkswirtschaft 20 (1896a), blz. 1091-1162.

Breysig, Kurt, 'Nietzsches ethische und sociologische Anschauungen', in: Schmollers Jahrbuch 20 (1896b), blz. 349-371.

Breysig, Kurt, 'Ueber Entwicklungsgeschichte', in: Deutsche Zeitschrift für Geschichtswissenschaft. Monatsblätter 1 (1896c), blz. 161-174, 193-211.

Breysig, Kurt, 'Die Historiker der Aufklärung', in: Die Zukunft 19 (1897a), blz. 295305 en 343-355.

Breysig, Kurt, 'Die Liebe zum Ich und die Liebe zum Anderen', in: Die Zukunft 21 (1897b), blz. 337-347 en 377-387.

Breysig, Kurt, 'Deutsche Geschichtsschreibung im Zeitalter Herders', in: Die Zukunft 23 (1898), blz. 103-117.

Breysig, Kurt, 'Die Entwickelung der europäischen Völkergesellschaft und die Entstehung des modernen Nationalismus. Ein sozialgeschichtlicher Versuch [I]', in: Zeitschrift für Kulturgeschichte 6 (1899), blz. 329-441.

Breysig, Kurt, Aufgaben und Maßstäbe einer allgemeinen Geschichtsschreibung. Ziele der Forschung. Umrisse einer historischen Staats- und Gesellschafts-, Kunstund Wissenschaftslehre. [Kulturgeschichte der Neuzeit, I] Berlijn: Bondi, 1900a.

Breysig, Kurt, 'Die Entwickelung der europäischen Völkergesellschaft und die Entstehung des modernen Nationalismus. Ein sozialgeschichtlicher Versuch [II]', in: Zeitschrift für Kulturgeschichte 7 (1900b), blz. 81-139.

Breysig, Kurt, 'An Friedrich Nietzsches Bahre', in: Die Zukunft 32 (1900c), blz. 409419.

Breysig, Kurt, 'Territorialgeschichte', in: Deutsche Geschichtsblätter. Monatsschrift zur Förderung der landesgeschichtlichen Forschung 1 (1900d), blz. 1-12.

Breysig, Kurt, Kulturgeschichte der Neuzeit. Vergleichende Entwicklungsgeschichte der führenden Völker Europas und ihren sozialen und geistigen Lebens. Berlijn: 1900-1901.

Breysig, Kurt, 'Ein Versuch begriffsmäßiger Geschichtsschreibung. Eine Selbstanzeige [der Kulturgeschichte der Neuzeit]', in: Schmollers Jahrbuch für Gesetzgebung, Verwaltung und Volkswirtschaft 25 (1901), blz. 719-734.

Breysig, Kurt, 'Die erste Renaissance des germanischen Kunstgeistes', in: Neue deutsche Rundschau 13 (1902a), blz. 1009-1032.

Breysig, Kurt, 'Geschichtliche Gesetzmäßigkeiten', in: Die Zukunft 38 (1902b), blz. 107-122 en 159-170.

Breysig, Kurt, 'Ich und Welt in der Geschichte', in: Schmollers Jahrbuch für Gesetzgebung, Verwaltung und Volkswirtschaft 26 (1902c), blz. 1361-1438.

Breysig, Kurt, 'Maßstäbe der Geschichtswissenschaft', in: Die Zukunft 40 (1902d), blz. $12-26$.

Breysig, Kurt, '[rec. van Lamprecht, Deutsche Geschichte, ErgBd. I]', in: Euphorion 9 (1902e), blz. 500-509.

Breysig, Kurt, '[rec. van Lamprecht, Deutsche Geschichte, ErgBd. II.1]', in: Schmollers Jahrbuch 27 (1903), blz. 1533-1539.

Breysig, Kurt, Der Stufen-Bau und die Gesetze der Welt-Geschichte. Berlin: Bondi, 1905a.

Breysig, Kurt, 'Kulturgeschichte', in: Das litterarische Echo. Halbmonatsschrift für Litteraturfreunde 7 (1905b), blz. 1671-1675. 
Breysig, Kurt, '[rec. van Steinhausen, Geschichte d. deutschen Kultur]', in: Schmollers Jahrbuch 29 (1905c), blz. 1644-1648.

Breysig, Kurt, Die Geschichte der Menschheit I: Die Völker ewiger Urzeit 1: Die Amerikaner des Nordwestens und des Nordens. Berlin: Bondi, 1907.

Breysig, Kurt, 'Geschichtslehre.' In: Grundrisse und Bausteine zur Geschichtslehre zusammengetragen zu den Ehren Gustav Schmollers, red. K Breysig, e.a. Berlijn: Bondi, 1908, blz. 1-40.

Breysig, Kurt, Von Gegenwart und Zukunft des deutschen Menschen. Berlijn: 1912. Breysig, Kurt, Persönlichkeit und Entwicklung. [Vom geschichtlichen Werden, 1] Stuttgart, Berlijn: Cotta, 1925.

Breysig, Kurt, 'Die Kulturgeschichte im Unterricht der höheren Schulen', in: Pädagogisches Zentralblatt (1926), blz. 555-576.

Breysig, Kurt, Eindruckskunst und Ausdruckskunst. Ein Blick auf die Entwicklung des zeitgenössischen Kunstgeistes von Millet bis zu Marc. Berlijn: Bondi, 1927.

Breysig, Kurt, 'Seelenbau, Geschichts- und Gesellschaftslehre', in: Kölner Vierteljahreshefte für Soziologie 8 (1929a), blz. 1-26.

Breysig, Kurt, 'Seelenformen, Gesellschaftslehre und Geschichtswissenschaft', in: Schmollers Jahrbuch 53 (1929b), blz. 1-31.

Breysig, Kurt, 'Seelentypen, Gesellschaftslehre und Geschichte', in: Philosophie und Leben 6 (1930), blz. 91-99.

Breysig, Kurt, Die Geschichte der Seele im Werdegang der Menschheit. Breslau: 1931.

Breysig, Kurt, Vom deutschen Geist und seiner Wesensart. Berlijn: Deutsche BuchGemeinschaft, 1932.

Breysig, Kurt, Das neue Geschichtsbild im Sinne der entwickelnden Geschichtsforschung. Berlijn: 1944.

Breysig, Kurt, Aus meinen Tagen und Träumen. Memoiren, Aufzeichnungen, Briefe, Gespräche, red. Gertrud Breysig en Michael Landmann. Berlijn: De Gruyter, 1962.

Breysig, Kurt, 'Über die Ziele und die Wege einer vergleichenden weltgeschichtlichen Forschung.' In: Transformation des Historismus. Wissenschaftsorganisation und Bildungspolitik vor dem Ersten Weltkrieg. Interpretationen und Dokumente, red. Horst Walter Blanke. Waltrop: Spenner, 1994, blz. 216-226.

Breysig, Kurt, Samson B. Knoll en Michael Landmann, Kurt Breysig - Stefan George. Gespräche, Dokumente, [Castrum Peregrini XLII]. Amsterdam: 1960.

Brinkmann, Karl, 'Eberhard Gothein', in: Zeitschrift für die Geschichte des Oberrheins 79 (1927), blz. 313-329.

Brocke, Bernhard vom, Kurt Breysig. Geschichtswissenschaft zwischen Historismus und Soziologie. [Historische Studien 417] Lübeck/Hamburg: Matthiesen Verlag, 1971.

Brocke, Bernhard vom, 'Kurt Breysig.' In: Deutsche Historiker, V, red. Hans-Ulrich Wehler. Göttingen: 1972, blz. 95-116.

Brocke, Bernhard vom, 'Hochschul- und Wissenschaftspolitik in Preußen und im Deutschen Kaiserreich 1882-1907: das 'System Althoff'.' In: Bildungspolitik in Preußen zur Zeit des Kaiserreichs, red. Peter Baumgart. Stuttgart: Klett-Cotta, 1980, blz. 9-118.

Brockmeier, Jens, 'Der dialektische Ansatz und seine Bedeutung für die Psychologie.' In: Wegbereiter der historischen Psychologie, red. G. Jüttemann. München, Weinheim: Beltz/PVU, 1988, blz. 381-397.

Bruch, Rüdiger vom, Wissenschaft, Politik und öffentliche Meinung. Gelehrtenpolitik im Wilhelminischen Deutschland (1890-1914). Husum: Matthiesen, 1980. 
Bruch, Rüdiger vom, 'Gustav Schmoller.' In: Deutsche Geschichtswissenschaft um 1900, red. Notker Hammerstein. Stuttgart: 1988a, blz. 219-238.

Bruch, Rüdiger vom, 'Historiker und Nationalökonomen im Wilhelminischen Deutschland.' In: Deutsche Hochschullehrer als Elite 1815-1945, red. Klaus Schwabe. Boppard: Matthiesen, 1988b, blz. 105-150.

Bruch, Rüdiger vom, 'Weiterführung der Schmollerschen und Lamprechtschen Traditionen in der Weimarer Republik?' In: Karl Lamprecht weiterdenken. Universal- und Kulturgeschichte heute, red. Gerald Diesener. Leipzig: 1993, blz. 225-241.

Bruguière, A., 'Der Begriff der "Mentalitäten" bei Marc Bloch und Lucien Febvre: zwei Auffassungen, zwei Wege.' In: Mentalitäten-Geschichte, red. U. Raulff. Berlijn: 1989, blz. 33-49.

Brush, Kathryn, 'Der Kulturhistoriker Karl Lamprecht: Wirkungen und Einflüße auf die Entwicklung der Kunstgeschichte', in: Rheinische Vierteljahrsblätter : Mitteilungen des Instituts für Geschichtliche Landeskunde der Rheinlande an der Universität Bonn 60 (1996), blz. 205-232.

Brush, Kathryn, 'Aby Warburg and the Cultural Historian Karl Lamprecht.' In: Art history as cultural history: Warburg's projects, red. Richard Woodfield. Amsterdam [etc.]: G+B Arts International, 2001, blz. 65-92.

Buchholz, G., 'Philosophie und Methodologie der Geschichte [literatuurreferaat]', in: Jahresberichte der Geschichtswissenschaft (1889a), blz. IV, 67-77.

Buchholz, G., 'Philosophie und Methodologie der Geschichte [literatuurreferaat]', in: Jahresberichte der Geschichtswissenschaft (1891), blz. IV, 35-46.

Buchholz, Gustav, 'Ursprung und Wesen der modernen Geschichtsauffassung', in: Deutsche Zeitschrift für Geschichtswissenschaft 2 (1889b), blz. 17-37.

Buckle, Henry Thomas, History of civilization in England. Londen: Grant Richards, 1903-1904 [1e dr. 1857-1861].

Burckhardt, J., Über das Studium der Geschichte. Der Text der 'Weltgeschichtlichen Betrachtungen' [...] nach den Handschriften herausgegeben, red. Peter Ganz. München: C.H. Beck, 1982.

Burckhardt, Jacob, Briefe, 10 dln., red. Max Burckhardt. Bazel, Stuttgart: 1949-1986.

Burke, Peter, The French historical revolution. The Annales School, 1929-89. Cambridge: Polity Press, 1990.

Buszello, Horst, 'Ernst Bernheim (1850-1942).' In: Deutsche Geschichtsdidaktiker des 19. und 20. Jahrhunderts. Wege, Konzeptionen, Wirkungen, red. Siegfried Quandt. Paderborn etc.: Schöningh, 1978, blz. 219-256.

Cabanès, Augustin, L'histoire éclairée par la clinique. Parijs: Michel, z.j [1921].

Caenegem, R. van, 'Psychologische geschiedenis', in: Tijdschrift voor geschiedenis 78 (1965), blz. 129-149.

Chickering, Roger, 'Karl Lamprecht (1856-1915) und die methodische Grundlegung der Landesgeschichte im Rheinland.' In: Landesgeschichte: historische Grundlagen und neue Herausforderungen, red. Freya Stephan-Kühn. Paderborn: Schöningh, 1992, blz. 16-23.

Chickering, Roger, Karl Lamprecht. A German academic life (1856-1915). New Jersey: 1993.

Christ, Karl, Von Gibbon zu Rostovtzeff. Leben und Werk führender Althistoriker der Neuzeit. 2e dr., Darmstadt: WBG, 1979 [1e dr. 1972].

Comte, Auguste, Het positieve denken. Vertaald door H. Plantenga. Meppel, Amsterdam: Boom, 1979 [1e dr. 1844]. 
Coriand, Rotraud en Michael Winkler, red. Der Herbartianismus. Die vergessene Wissenschaftsgeschichte. Weinheim: Deutscher Studienverlag, 1998.

Croce, Benedetto, Die Geschichte als Gedanke und als Tat. Hamburg: Marion von Schröder Verlag, 1944.

Czok, Karl, 'Der Methodenstreit und die Gründung des Seminars für Landesgeschichte und Siedlungskunde 1906 an der Universitat Leipzig', in: Jahrbuch für Regionalgeschichte 2 (1965/7), blz. 11 e.v.

Czok, Karl, Karl Lamprechts Wirken an der Universität Leipzig. [Sitzungsberichte der Sächsischen Akademie der Wissenschaften zu Leipzig, phil.-hist. Klasse 124:6] Berlijn(-O): Akademie Verlag, 1984.

Dassen, Patrick, De onttovering van de wereld. Max Weber en het probleem van de moderniteit in Duitsland, 1890-1920. Amsterdam: Van Oorschot, 1999.

Deneke, Bernward, 'Die Museen und die Entwicklung der Kulturgeschichte.' In: Das kunst- und kulturgeschichtliche Museum im 19. Jahrhundert, red. Bernward Deneke en Rainer Kahnsnitz. München: Prestel, 1977, blz. 118-132.

Deneke, Bernward en Rainer Kahnsnitz, Das Germanische Nationalmuseum Nürnberg 1852-1977. Beiträge zu seiner Geschichte. München, Berlijn: Deutscher Kunstverlag, 1978.

Dessoir, Max, Geschichte der neueren deutschen Psychologie. 2de, geheel herziene dr., Berlijn: 1897-1901 [1e dr. 1894].

Deutsch, Robert en Wolfgang Weber, 'Marginalisierungsprozesse in der deutschen Geschichtswissenschaft im Zeitalter des Historismus', in: Schweizerische Zeitschrift für Geschichte 35 (1985), blz. 174-197.

Devrient, Ernst, Familienforschung. [Aus Natur und Geisteswelt, 350] Leipzig: Teubner, 1911.

Diesener, Gerald, red. Karl Lamprecht weiterdenken. Universal- und Kulturgeschichte heute. Leipzig: Leipziger Universitätsverlag, 1993.

Diesener, Gerald, 'Die schwierige Nachfolge. Hans Freyer als Direktor des Instituts für Universal- und Kulturgeschichte', in: Archiv für Kulturgeschichte 77 (1995), blz. 117 e.v.

Dilly, Heinrich en James Ryding, 'Kulturgeschichtsschreibung vor und nach der bürgerlichen Revolution von 1848', in: Ästhetik und Kommunikation 6 (1975), blz. 15-32.

Dilthey, Wilhelm, Gesammelte Schriften. Leipzig [etc.]/Göttingen: Teubner / Vandenhoeck und Ruprecht, 1914-2006.

Dilthey, Wilhelm, Der junge Dilthey. Ein Lebensbild in Briefen und Tagebüchern, 1852-1870, red. Clara Misch-Dilthey. 2de dr. Stuttgart, Göttingen: Teubner, Vandenhoeck \& Ruprecht, 1960.

Doren, Alfred, 'Karl Lamprechts Geschichtstheorie und die Kunstgeschichte', in: Zeitschrift für Ästhetik und allgemeine Kunstwissenschaft 11 (1916), blz. 353389.

Dosse, F., New history in France. The triumph of the Annales. Urbana/Chicago: 1994.

Dove, Alfred, Ausgewählte Aufsätze, red. Friedrich Meinecke. München: Bruckmann, $1925 \mathrm{a}$.

Dove, Alfred, Ausgewählte Briefe, red. Oswald Dammann. München: Bruckmann, 1925 b.

Droysen, Joh. Gustav, 'Die Erhebung der Geschichte zum Rang einer Wissenschaft', in: Historische Zeitschrift 9 (1863), blz. 1-22.

Droysen, Joh. Gustav, 'Philosophie der Geschichte', in: Jahresberichte der Geschichtswissenschaft 1 (1878), blz. 626-635. 
Droysen, Johann Gustav, Historik. Rekonstruktion der ersten vollständigen Fassung der Vorlesung (1857) Grundriss der Historik in der ersten handschriftlichen (1857/1858) und in der letzten gedruckten Fassung (1882), red. P. Leyh. Stuttgart, Bad Canstatt: Fromann-Holzboog, 1977.

Drüll, Dagmar, Heidelberger Gelehrtenlexikon, 1803-1932. Berlijn: 1986.

Duby, Georges, 'Histoire des mentalités.' In: L’histoire et ses méthodes, red. Charles Samaran. Parijs: 1961, blz. 937-966.

Eckhart, Wolfgang, “"Die wachsende Nervosität unserer Zeit.” Medizin und Kultur um 1900 am Beispiel einer Modekrankheit.' In: Kultur und Kulturwissenschaften um 1900. [II] Idealismus und Positivismus, red. R. vom Bruch, F.W. Graf en G. Hübinger. Stuttgart: Steiner Verlag, 1997, blz. 207-226.

Eisermann, Gottfried, Die Grundlagen des Historismus in der deutschen Nationalökonomie. Stuttgart: Enke, 1956.

Engel, Josef, 'Die deutschen Universitäten und die Geschichtswissenschaft', in: Historische Zeitschrift 189 (1959), blz. 223-378.

Engelberg, Ernst, 'Zum Methodenstreit um Karl Lamprecht.' In: Karl-Marx-Universität Leipzig, 1409-1959. Beiträge zur Universitätsgeschichte, Leipzig: 1959, blz. 2338.

Engstrom, Eric J., 'Kulturelle Dimensionen von Psychiatrie und Sozialpsychologie. Emil Kraepelin und Willy Hellpach.' In: Kultur und Kulturwissenschaften um 1900. [II] Idealismus und Positivismus, red. R. vom Bruch, F.W. Graf en G. Hübinger. Stuttgart:: Steiner Verlag, 1997, blz. 164-189.

Erb, Wilhelm, Über die wachsende Nervosität unserer Zeit. Heidelberg: 1893.

Erdmann, Elisabeth, 'Karl Biedermann (1812-1901).' In: Deutsche Geschichtsdidaktiker des 19. und 20. Jahrhunderts. Wege, Konzeptionen, Wirkungen, red. Siegfried Quandt. Paderborn etc.: Schöningh, 1978, blz. 84-109.

Erdmann, Elisabeth, 'Tendenzen und Neuansätze in Geschichtsdidaktik und Geschichtsunterricht nach 1848 bis in die Mitte der achtziger Jahre des 19. Jahrhunderts.' In: Gesellschaft, Staat, Geschichtsunterricht. Beiträge zu einer Geschichte der Geschichtsdidaktik und des Geschichtsunterichts von 1500-1980, red. K. Bergmann en G. Schneider. Düsseldorf: Schwann, 1982, blz. 77-103.

Erdmann, K.D., 'Geschichte, Politik und Pädagogik - aus den Akten des Deutschen Historikerverbandes', in: Geschichte in Wissenschaft und Unterricht 19 (1968), blz. 2-21.

Erdmann, Karl Dietrich, Die Ökumene der Historiker. Geschichte der Internationalen Historikerkongresse und des Comite International des Sciences Historiques. Göttingen: Vandenhoeck \& Ruprecht, 1987.

Erdmannsdörffer, Bernhard, 'Das Zeitalter der Novelle in Hellas.' In: Kleinere historische Schriften, II, Berlin: Verlag Deutsche Bücherei, 1911a, blz. 3-84.

Erdmannsdörffer, Bernhard, Kleinere historische Schriften, red. Heinrich Lilienfein. 2 dln. Berlin: Verlag Deutsche Bücherei, 1911b.

Ermath, Michael, 'Intellectual history as philosophical anthropology: Bernard Groethuysen's transformation of traditional Geistesgeschichte', in: Journal of modern history 65 (1993), blz. 673-705.

Estermann, Monika, 'Buchhandelsgeschichte in kulturhistorischer Absicht. Johann Goldfriedrich und Karl Lamprecht.' Bewerking van de bijdrage in Monika Estermann, Ernst Fischer en Ute Schneider (red.), Buchkulturen. Festschrift für Reinhard Wittmann. Hrsg. von. Wiesbaden: Harrassowitz 2005. Online geraadpleegd op 27 maart 2007, via iasl.unimuenchen.de/discuss/lisforen/Estermann_Goldfriedrich.pdf 
Eulenburg, F., 'Über die Möglichkeit und die Aufgaben einer Socialpsychologie', in: Schmollers Jahrbuch 24 (1900), blz. 201-237.

Eulenburg, F., 'Neuere Geschichtsphilosophie: kritische Analysen I', in: Archiv für Sozialwissenschaft und Sozialpolitik NF 25 (1907), blz. 283-337.

Faulenbauch, Bernd, 'Die Historische Zeitschrift. Zur Frage geschichtwissenschaftlicher Kontinuität zwischen Kaiserreich und Bundesrepublik.' In: Historische tijdschriften, red. P.B.M. Blaas, et al. . Groningen: Wolters-Noordhoff, 1986, blz. 517-529 [= Tijdschrift voor Geschiedenis 99 (1986) 3/4].

Febvre, Lucien, 'Psychologie et histoire.' In: Encyclopédie Francaise, VIII, red. Henri Wallon. Parijs: 1938, blz. 8*12: 3-7.

Febvre, Lucien, 'Comment reconstituer la vie affective d'autrefois? La sensibilité et l'histoire.' In: Combats pour l'histoire, Parijs: Armand Colin, 1992a, blz. 221238.

Febvre, Lucien, 'Une vue d'ensemble. Histoire et psychologie.' In: Combats pour l'histoire, Parijs: Armand Colin, 1992b, blz. 207-220.

Febvre, Lucien en Henri Berr, 'History.' In: Encyclopaedia of the social sciences, VII, red. E.R.A. Seligman. New York: 1932, blz. 357-368.

Fenske, Hans, red. Unter Wilhelm II., 1890-1918. [Quellen zum politischen Denken der Deutschen im 19. und 20. Jahrhundert , 7]. Darmstadt: Wissenschaftliche Buchgesellschaft, 1982.

Finke, Heinrich, '[Selbstdarstellung].' In: Die Geschichtswissenschaft der Gegenwart in Selbstdarstellungen, I, red. Sigfrid Steinberg. Leipzig: Felix Meiner, 1925, blz. 91-128.

Fisch, Jörgen, 'Zivilisation, Kultur.' In: Geschichtliche Grundbegriffe, 7, red. O. Brunner, e.a. Stuttgart: 1992, blz. 679-714.

Fischer, D., Die deutsche Geschichtswissenschaft von Droysen bis Hintze in ihrem Verhältnis zur Soziologie. Diss. Keulen: 1966.

Flint, Robert, The philosophy of history in France and Germany. Edinburgh, Londen: 1874.

Fortmann, Han, Inleiding tot de cultuurpsychologie. 3de dr., Bilthoven: Ambo, 1979.

Freyer, Hans, 'Geschichte und Soziologie. Anläßlich des 10. Todestages von Karl Lamprecht', in: Vergangenheit und Gegenwart 16 (1926), blz. 201-211.

Freytag, Gustav, Bilder aus der deutschen Vergangenheit, I, Aus dem Mittelalter. 40ste dr., Leipzig: Hirzel, 1920 [1e dr. 1867].

Friedell, Egon, Ecce poeta. Berlijn: 1912.

Friedell, Egon, Kulturgeschichte der Neuzeit. Die Krisis der europäischen Seele von der Schwarzen Pest bis zum Ersten Weltkrieg. München: 1960 [1e dr. 1927-1931].

Frijhoff, Willem, “"The French connection”. Mentaliteitsgeschiedenis als cultuurstrijd.' In: Geschiedenis, psychologie, mentaliteit, red. M. Damen et al. Amsterdam: 1982, blz. 21-44.

Frijhoff, Willem, 'Impasses en beloften van de mentaliteitsgeschiedenis', in: Tijdschrift voor Sociale Geschiedenis 36 (1984), blz. 406-437.

Fuchs, Eckhardt, 'Positivistischer Szientismus in vergleichender Perspektive: Zum nomothetischen Wissenschaftsverständnis in der englischen, amerikanischen und deutschen Geschichtsschreibung.' In: Geschichtsdiskurs, red. Wolfgang Küttler, Jörn Rüsen en Ernst Schulin. Frankfurt a.M.: Fischer, 1997, blz. 396423.

Fürstenberg, August, Georg Hanssen als Professor der Nationalökonomie und praktischer Volkswirt um die Mitte des 19. Jahrhunderts. Quakenbrueck: 1933. 
Geck, L.H. Ad., 'Sozialpsychologie in Deutschland. Eine Einführung in die Literatur', in: Archiv für Rechts- und Wirtschaftsphilosophie 22 (1928), blz. 544-615.

Geiger, Theodor, Die soziale Schichtung des deutschen Volkes. Soziographischer Versuch auf statistischer Grundlage. [Soziologische Gegenwartsfragen, 1] Stuttgart: F. Enke, 1932.

Giesebrecht, W., 'Die Entwicklung der modernen deutschen Geschichtswissenschaft', in: Historische Zeitschrift 1 (1859), blz. 1-17.

Gijswijt-Hofstra, Marijke en Roy Porter, red. Cultures of neurasthenia from Beard to the First World War. Amsterdam [etc.]: Rodopi, 2001.

Goebel, Klaus, 'Des Kaisers neuer Geschichtsunterricht. Änderungen des preußischen Lehrplans 1915 und ihre Vorgeschichte', in: Geschichte in Wissenschaft und Unterricht 25 (1974), blz. 709-717.

Goetz, Walter, red. Beiträge zur Geschichte Herzog Albrechts V. und des Landsberger Bundes, 1556-1598. [Briefe und Akten zur Geschichte des sechszenten Jahrhunderts mit besonderer Rücksicht auf Bayerns Fürstenhaus, Bd. 5]. München: Reiger'sche Universitäts-Buchhandlung (G. Himmer), 1898.

Goetz, Walter, Die Quellen zur Geschichte des hl. Franz von Assisi: eine kritische Untersuchung. Gotha: Perthes, 1904a.

Goetz, Walter, 'Zur geschichte des literarischen Porträts', in: Historische Zeitschrift 92 (1904b), blz. 61-72.

Goetz, Walter, red. Beiträge zur Kulturgeschichte des Mittelalters und der Renaissance. Leipzig, Berlin: 1908-1939.

Goetz, Walter, 'Geschichte und Kulturgeschichte', in: Archiv für Kulturgeschichte 8 (1910a), blz. 4-19.

Goetz, Walter, 'Kulturgeschichte und Geschichte. Schlußwort', in: Archiv für Kulturgeschichte 8 (1910b), blz. 230-232.

Goetz, Walter, 'Das Institut für Kultur- und Universalgeschichte an der Universität Leipzig', in: Archiv für Kulturgeschichte 12 (1916a), blz. 273-284.

Goetz, Walter, Deutschlands geistiges Leben im Weltkrieg. 2e dr., Gotha: 1916b.

Goetz, Walter, red. Deutschland und der Friede. Notwendigkeiten und Möglichkeiten deutscher Zukunft. Berlijn: Teubner, 1918a.

Goetz, Walter, Die Bedeutung von Persönlichkeit und Gemeinschaft in der Geschichte. [Geschichtliche Abende im Zentralinstitut für Erziehung und Unterricht, 1] Berlijn: 1918 b.

Goetz, Walter, Das Wesen der deutschen Kultur. Darmstadt: 1919.

Goetz, Walter, '[Selbstdarstellung].' In: Die Geschichtswissenschaft der Gegenwart in Selbstdarstellungen, I, red. Sigfrid Steinberg. Leipzig: Felix Meiner, 1925, blz. 129-169.

Goetz, Walter, 'Nationale Kultur und Weltkultur', in: Die neueren Sprachen 34 (1926), blz. 1-16.

Goetz, Walter, 'Das menschliche Bildnis.' In: Résumés des communications présentées au [VIe] Congrès internationale des sciences historiques[a Oslo], Oslo: 1928a, blz. 345-346.

Goetz, Walter, 'Das menschliche Bildnis. Zur Einführung.' In: P.E. Schramm, Die deutschen Kaiser und Könige in Bildern ihrer Zeit. Leipzig, Berlin: 1928b, blz. VII-IX.

Goetz, Walter, 'Die geistigen Grundlagen des Zeitalters [1789-1848].' In: Propyläen Weltgeschichte, VII, Berlijn: 1929, blz. xix-xxiv. 
Goetz, Walter, red. Propyläen-Weltgeschichte: der Werdegang der Menschheit in Gesellschaft und Staat, Wirtschaft und Geistesleben. Berlin: Propyläen-Verlag, 1929-1933.

Goetz, Walter, 'Das leipziger Forschungsinstitut für Kultur- und Universalgeschichte.' In: Forschungsinstitute: ihre Geschichte, Organisation und Ziele, red. L. Brauer, A. Mendelssohn Bartholdy en Meyer. A. Hamburg: Paul Hartung Verlag, 1930a, blz. 487-390.

Goetz, Walter, 'Die geistige Bewegung im 19. Jahrhundert.' In: Propyläen Weltgeschichte, VIII, red. Walter Goetz. Berlijn: 1930b, blz. 457-540.

Goetz, Walter, 'Die geistige Struktur des Zeitalters [1848-1890].' In: Propyläen Weltgeschichte, VIII, red. Walter Goetz. Berlijn: 1930c, blz. xix-xxvi.

Goetz, Walter, 'Die Rassenforschung + Nachwort', in: Archiv für Kulturgeschichte 22 (1932), blz. 1-20 en 379-380.

Goetz, Walter, 'Historiography: Modern Europe.' In: Encyclopaedia of the social sciences, VII, red. E.R.A. Seligman. New York: 1932c, blz. 374-381.

Goetz, Walter, 'Die geistige Entwicklung um die Jahrhundertwende.' In: Propyläen Weltgeschichte, X, red. Walter Goetz. Berlijn: 1933a, blz. 3-42.

Goetz, Walter, 'Einleitung [tot 'Das Zeitalter des Imperialismus, 1890-1933'].' In: Propyläen Weltgeschichte, X, red. Walter Goetz. Berlijn: 1933b, blz. XIXXXIV.

Goetz, Walter, 'Georg Steinhausen.' In: Encyclopaedia of the social sciences, XIV, red. E.R.A. Seligman. New York: 1934a, blz. 383-384.

Goetz, Walter, 'Georg Steinhausen †', in: Archiv für Kulturgeschichte 24 (1934b), blz. $1-2$.

Goetz, Walter, 'Weltgeschichte', in: Archiv für Kulturgeschichte 24 (1934c), blz. 273303.

Goetz, Walter, red. Historische Bildkunde. Hamburg: 1934-1937.

Goetz, Walter, Intuition in der Geschichtswissenschaft. [Sitzungsberichte der Bayerischen Akademie der Wissenschaften, 35-5] München: 1935.

Goetz, Walter, 'Literaturbericht: Naturgefühl', in: Archiv für Kulturgeschichte 26 (1936), blz. 345-353.

Goetz, Walter, 'Die Entwicklung des Wirklichkeitssinnes vom 12. zum 14. Jahrhundert.' [ $1^{\mathrm{e}}$ dr. 1937] In: id., Italien im Mittelalter, II, Leipzig: Koehler \& Amelang, 1942, blz. 3-61.

Goetz, Walter, 'Aus dem Leben eines deutschen Historikers.' In: id., Historiker in meiner Zeit. Gesammelte Aufsätze, red. Herbert Grundmann. Keulen/Graz: 1957a, blz. 1-87.

Goetz, Walter, 'Die deutsche Geschichtsschreibung des letzten Jahrhunderts und die Nation.' [1919] In: id., Historiker in meiner Zeit. Gesammelte Aufsätze, red. Herbert Grundmann. Keulen/Graz: 1957b, blz. 88-111.

Goetz, Walter, Historiker in meiner Zeit. Gesammelte Aufsätze, red. Herbert Grundmann. Keulen/Graz: 1957c.

Goetz, Walter, 'Kurt Breysig zum 70. Geburtstag.' [1936] In: id., Historiker in meiner Zeit. Gesammelte Aufsätze, red. Herbert Grundmann. Keulen, Graz: Böhlau, 1957d, blz. 313-315.

Goetz, Walter, 'Lamprechts Deutsche Geschichte.' In: id., Historiker in meiner Zeit. Gesammelte Aufsätze, red. Herbert Grundmann. Keulen, Graz: Böhlau, 1957e, blz. 296-307. 
Goetz, Walter, 'Lamprechts Stellung in der Geschichtswissenschaft.' In: id., Historiker in meiner Zeit. Gesammelte Aufsätze, red. Herbert Grundmann. Keulen, Graz: Böhlau, 1957f, blz. 308-312.

Goetz, Walter, 'Lujo Brentano.' In: id., Historiker in meiner Zeit. Gesammelte Aufsätze, Köln, Graz: Böhlau, 1957g, blz. 270-276.

Goetz, Walter, 'Wilhelm Heinrich Riehl.' In: id., Historiker in meiner Zeit. Gesammelte Aufsätze, red. Herbert Grundmann. Keulen/Graz: 1957h, blz. 256-258.

Goetz, Walter en Leonhard Theobald, red. Beiträge zur Geschichte Herzog Albrechts $V$. und der sog. Adelsverschwörung von 1563. [Briefe und Akten zur Geschichte des sechszehnten Jahrhunderts mit besonderer Rücksicht auf Bayerns Fürstenhaus, Bd. 6.] Leipzig: B.G. Teubner, 1913.

Goldfriedrich, J., Die historische Ideenlehre in Deutschland. Ein Beitrag zur Geschichte der Geisteswissenschaften, vornehmlich der Geschichtswissenschaft und ihrer Methoden im 18. und 19. Jahrhundert. Berlijn: 1902.

Gooch, George Peabody, History and historians in the nineteenth century. 2e dr., Londen, etc.: Longmans, Green and Co., 1952 [1e dr. 1913].

Gothein, Eberhard, Politische und religiöse Volksbewegungen vor der Reformation. Breslau: 1878.

Gothein, Eberhard, Der christlich-sociale Staat der Jesuiten in Paraguay. [Staats- und socialwissenschaftliche Forschungen, IV:4] Leipzig: Duncker \& Humblot, 1883.

Gothein, Eberhard, 'Die Lage des Bauernstandes am Ende des Mittelalters, vornehmlich in Südwestdeutschland', in: Westdeutsche Zeitschrift für Geschichte und Kunst 4 (1885), blz. 1-22.

Gothein, Eberhard, Die Culturentwicklung Süd-Italiens in Einzel-Darstellungen. Breslau: 1886.

Gothein, Eberhard, Die Aufgaben der Kulturgeschichte. Leipzig: Duncker \& Humblot, 1889a.

Gothein, Eberhard, Pforzheims Vergangenheit. Ein Beitrag zur deutschen Städte- und Gewerbegeschichte. [Staats- und socialwissenschaftliche Forschungen, IX.3] Leipzig: Duncker \& Humblot, 1889 b.

Gothein, Eberhard, 'Familie.' In: Handwörterbuch der Staatswissenschaften, III, red. J. Conrad, L. Elster en W. Lexis, [et al.]. Jena: Fischer, 1892a, blz. 349-358.

Gothein, Eberhard, 'Gesellschaft und Gesellschaftswissenschaft.' In: Handwörterbuch der Staatswissenschaften, III, red. J. Conrad, L. Elster en W. Lexis, [et al.]. Jena: Fischer, 1892b, blz. 838-844.

Gothein, Eberhard, Wirtschaftsgeschichte des Schwarzwaldes und der angrenzenden Landschaften, I, Städte- und Gewerbegeschichte. Straatsburg: Trübner, 1892c.

Gothein, Eberhard, 'Die deutschen Kreditverhältnisse und der dreißigjährige Krieg.' In: Ein Neu: Nutzlich- vnd Lustigs Colloquium : von etlichen Reichstags-Puncten. Insonderheit die Reformation der Zöllen Zinszahlung vnd Verbesserung der Matricul antreffend, red. idem. Leipzig: Duncker \& Humblot, 1893a, blz. IXCVII.

Gothein, Eberhard, 'Wirthschaftsgeschichte.' In: Die deutschen Universitäten, I, red. Wilhelm Lexis. Berlijn: A. Asher \& Co., 1893b, blz. 583-598.

Gothein, Eberhard, 'Thomas Campanella. Ein Dichterphilosoph der italienischen Renaissance', in: Zeitschrift für Kulturgeschichte 1 (1894), blz. 50-92.

Gothein, Eberhard, Ignatius von Loyola und die Gegenreformation. Halle: Niemeyer, 1895.

Gothein, Eberhard, 'Agrarpolitische Wanderungen im Rheinland. Vortrag gehalten bei Eröffnung des socialwissenschaftlichen Vereins in Bonn.’ In: 
Staatswissenschaftliche Arbeiten. Festgaben für Karl Knies, red. O. von Boenigk. Berlijn: 1896, blz. 233-338.

Gothein, Eberhard, Beiträge zur Geschichte der Familie im Gebiete des alamannischen und fränkischen Rechts. Festschrift d. Landwirtschaftl. Akademie zu Poppelsdorf zur Feier ihres fünfzigjährigen Bestehens. Bonn: Georgi, 1897a.

Gothein, Eberhard, 'Jakob Burckhardt', in: Preußische Jahrbücher 90 (1897b), blz. 133.

Gothein, Eberhard, 'Wilhelm Heinrich Riehl', in: Preußische Jahrbücher 92 (1898), blz. 1-27.

Gothein, Eberhard, 'Bernhard Erdmannsdörffer', in: Preußische Jahrbücher 104 (1901), blz. 15-22.

Gothein, Eberhard, Die geschichtliche Entwicklung der Rheinschiffahrt im 19. Jahrhundert. [Schriften des Vereins für Socialpolitik, 101] Leipzig: 1903.

Gothein, Eberhard, 'Die Weltanschauung der Renaissance', in: Jahrbuch des Freien deutschen Hochstifts (1904), blz. 95-131.

Gothein, Eberhard, 'Die kulturellen Grundlagen der Gegenreformation', in: Internationale Wochenschrift für Wissenschaft, Kunst und Technik (1907), blz. 583-594.

Gothein, Eberhard, 'Staat und Gesellschaft des Zeitalters der Gegenreformation.' In: Staat und Gesellschaft der neueren Zeit (biz zur Französischen revolution), red. Fr. von Bezold, etc. Berlijn, Leipzig: Teubner, 1908, blz. 137-230.

Gothein, Eberhard, 'Soziologie der Panik.' In: Verhandlungen des Ersten Deutschen Soziologentages vom 19.- 22. Oktober 1910, Tübingen: J. C. B. Mohr, 1911, blz. 216-248.

Gothein, Eberhard, Krieg und Wirtschaft. Heidelberg: 1914.

Gothein, Eberhard, 'An Lujo Brentano bei seinem siebzigsten Geburtstage', in: Schmollers Jahrbuch für Gesetzgebung, Verwaltung und Volkswirthschaft im Deutschen Reiche (1915), blz. 559-564.

Gothein, Eberhard, 'Kultur und Wissenschaft.' In: Deutscher Staat und Deutsche Kultur, red. 'Heeresgruppe Herzog Albrecht'. Straatsburg: Trübner, 1918, blz. 276-293.

Gothein, Eberhard, 'Typen und Stufen', in: Kölner Vierteljahreshefte für Sozialwissenschaften 2 (1922), blz. 5-17.

Gothein, Eberhard, 'Über einige soziologische Grundfragen.' In: Hauptprobleme der Soziologie. Erinnerungsgabe für Max Weber, red. Melchior Palyi. München/Leipzig: 1923, blz. 193-234.

Gothein, Eberhard en G. Neuhaus, Die Stadt Cöln im ersten Jahrhundert unter preußischer Herrschaft, 1815 bis 1915. Keulen: 1915-1916.

Gothein, Marie Luise, Eberhard Gothein. Ein Lebensbild seinen Briefen nacherzählt. Stuttgart: Kohlhammer, 1931.

Gothein, Percy, ‘Aus dem Florentiner Tagebuch', in: Castrum Peregrini 6 (1952), blz. 5-23.

Gothein, Percy, 'Letzte Universitätsjahre - der Tod des Vaters', in: Castrum Peregrini (1956), blz. 7-32.

Göttler, Christine, 'Marie Luise Gothein (1863-1931). 'Weibliche Provinzen' der Kultur.' In: Frauen in den Kulturwissenschaften. Von Lou Andreas-Salome bis Hannah Arendt, red. Barbara Hahn. Müchen: C.H. Beck, 1994, blz. 44-62.

Grimm, Herman, '[rec. van Lamprecht, Deutsche Geschichte, V.1]', in: Deutsche Litteraturzeitung (1894), blz. 811-815. 
Griss, Peter, Das Gedankenbild Karl Lamprechts. Historische Verhalten im Modernisierungsprozeß der "Belle Époque”. Bern etc.: 1987.

Groethuysen, Bernhard, Die Entstehung der bürgerlichen Welt- und Lebensanschauung in Frankreich. 2 dln., Halle: Max Niemeyer, 1927-1930.

Guilland, Antoine, 'Karl Lamprecht', in: Revue historique 121 (1916), blz. 83-108.

Gumbrecht, H. U., 'Modern, Modernität, Moderne.' In: Geschichtliche Grundbegriffe, 4, red. O. Brunner et al. Stuttgart: 1978, blz. 93-131.

Günther, Felix, Die Wissenschaft vom Menschen. Ein Beitrag zum deutschen Geistesleben im Zeitalter des Rationalismus mit besonderer Rücksicht auf die Entwickelung der deutschen Geschichtsphilosophie im 18. jahrhundert. [Geschichtliche Untersuchungen, 5:1] Gotha: Perthes, 1907.

Günther, Felix, Troetsch-Heidelberg und die Lamprechtsche Richtung. Leipzig: Seele, 1909.

Günther, Felix, 'Neuere Beiträge zur Geschichte der Geschichtswissenschaft im XVIII. Jahrhundert', in: Deutsche Geschichtsblätter 13 (1911), blz. 1-19.

Haas, Stefan, Historische Kulturforschung in Deutschland, 1880-1930. Geschichtswissenschaft zwischen Synthese und Pluralität. [Münstersche Historische Forschungen] Keulen etc.: Böhlau Verlag, 1994.

Hahn, Alois, 'Max Weber und die Historische Psychologie.' In: Wegbereiter der historischen Psychologie, red. G. Jüttemann. München, Weinheim: Beltz/PVU, 1988, blz. 115-124.

Hampe, K., 'Eberhard Gothein. Eine Gedächtnisrede', in: Historische Zeitschrift 129 (1924), blz. 476-490.

Hansen, Reginald, 'Der Methodenstreit in den Sozialwissenschaften zwischen Gustav Schmoller und Karl Menger [etc.].' In: Beiträge zur Entwicklung der Wissenschaftstheorie im 19. Jahrhundert, red. A. Diemer. Meisenheim a. G.: 1968, blz. 137-173.

Hartmann, L.M., '[recensie Lamprecht, DG, Erg.Bd. II.1]', in: Vierteljahrschrift für Sozial- und Wirtschaftsgeschichte 2 (1904), blz. 166-176.

Hartmann, Volker, Die deutsche Kulturgeschichtsschreibung von ihren Anfängen bis Wilhelm Heinrich Riehl. Marburg/München: 1971.

Hartung, Fritz, 'Gustav von Schmoller und die preußische Geschichtsschreibung', in: Schmollers Jahrbuch für Gesetzgebung, Verwaltung und Volkswirtschaft 62 (1938), blz. 661-686.

Heimpel, Hermann, 'Über Organisationsformen historischer Forschung in Deutschland', in: Historische Zeitschrift 189 (1959), blz. 139-222.

Heimpel, Hermann, 'Geschichtsvereine einst und jetzt.' In: Geschichtswissenschaft und Vereinswesen im 19. Jahrhundert, red. H. e.a. Boockmann. Göttirngen: 1972, blz. 45-73.

Helbig, Herbert, 'Fünfzig Jahre Institut für Deutsche Landes- und Volksgeschichte (Seminar für Landesgeschichte und Siedlungskunde) an der Universität Leipzig', in: Berichte zur Deutsche Landeskunde 19 (1957), blz. 55-77.

Hellpach, W., 'Geschichtswissenschaften', in: Socialistische Monatshefte 8 (1902a), blz. 829-832.

Hellpach, W., Nervosität und Kultur. [Kulturprobleme der Gegenwart, 5] Berlijn: Räde, $1902 b$.

Hellpach, W., 'Geschichte als Sozialpsychologie. Zugleich eine Epikrise über Karl Lamprecht.' In: Kultur- und Universalgeschichte. [Festschrift] Walter Goetz, Leipzig/Berlijn: Teubner, 1927, blz. 501-517. 
Hellpach, W., 'Die Beschleunigung der Erlebniszeitmaße ('psychophysische Akzeleration') beim Großstadtmenschen.’ In: Biologie der Großstadt, red. E. de Rudder en F. Linke. Dresden: Steinkopf, 1940, blz. 60-74.

Hellpach, Willy, Nervenleben und Weltanschauung. Ihre Wechselbeziehungen im deutschen Leben von heute. [Grenzfragen des Nerven- und Seelenlebens, 41] Wiesbaden: 1906.

Herbart, Johann Friedrich, Psychologie als Wissenschaft, neu gegründet auf Erfahrung, Metaphysik und Mathematik. 1968 [1e dr. 1824].

Herder, Johann Gottfried, Werke. Darmstadt: Wissenschaftliche Buchgesellschaft, $1984 \mathrm{f}$.

Herold, Jürgen, 'Georg Steinhausen und die Kulturgeschichte', in: Archiv für Kulturgeschichte 85 (2003), blz. 29-70.

Hinneberg, Paul. Die philosophischen Grundlagen der Geschichtswissenschaft. Diss. Philosophische Fakultät, Halle, 1888.

Hinneberg, Paul, '[rec. Schäfer, Eigentliches Arbeitsgebiet, en Gothein, Aufgaben]', in: Historische Zeitschrift 65 (1890), blz. 80-83.

Hintze, Otto, 'Über individualistische und kollektivistische Geschichtsauffassung.' In: Soziologie und Geschichte. Gesammelte Abhandlungen zur Soziologie, Politik und Theorie der Geschichte, red. G. Oestreich. 3e, onveranderde dr., Göttingen: Vandenhoeck \& Ruprecht, 1982, blz. 315-322.

Hitz, H. Beiträge zum psychologischen Aspekt der neuern Geschichtsbetrachtung. Diss. Zürich, 1950.

Hoffmeister, Kay, Karl Lamprecht. Seine Geschichtstheorie als Ideologie und seine Stellung zum Imperialismus. Diss. Göttingen: 1956.

Hohorst, Gerd, Jürgen Kocka en Gerhard A. Ritter, red. Sozialgeschichtliches Arbeitsbuch. Materialien zur Statistik des Kaiserreichs 1870-1914. [Statistische Arbeitsbücher zur neuern deutschen Geschichte.] München: Beck, 1975-1978.

Hoppe, Willy en Gerhard Lüdtke, red. Die deutschen Kommissionen und Vereine für Geschichte und Altertumskunde. [Minerva-Handbücher 4-I]. Berlijn: De Gruyter, 1940.

Hoyer, Siegfried, “'Das politische Semester”. Das Institut für Kultur- und Universalgeschichte am Beginn der NS-Zeit.' In: Karl Lamprecht weiterdenken. Universal- und Kulturgeschichte heute, red. Gerald Diesener. Leipzig: Leipziger Universitätsverlag, 1993, blz. 86-98.

Hübinger, Gangolf, 'Kapitalismus und Kulturgeschichte.' In: Kultur und Kulturwissenschaften um 1900. Krise der Moderne und Glaube an die Wissenschaft, red. vom R. Bruch, F.W. Graf en G. Hübinger. Stuttgart: 1989, blz. 25-43.

Hübinger, Gangolf, ‘Konzepte und Typen der Kulturgeschichte.' In: Geschichtsdiskurs, IV, red. Wolfgang Küttler, Jörn Rüsen en Ernst Schulin. Frankfurt a.M.: Fischer, 1997, blz. 136-152.

Hughes, H. Stuart, Consciousness and society. The reorientation of European social thought, 1890-1930. herz. dr., New York: Random House, 1977 [1e dr. 1958].

Humboldt, Wilhelm von, 'Ueber die Aufgabe des Geschichtschreibers.' In: Schriften zur Anthropologie und Geschichte, red. A. Flitner en K. Giel. Darmstadt: Wissenschaftliche Buchgesellschaft, 1980, blz. 585-606.

Hutschemaekers, Giel en Micha de Winter, 'Over Meneer Toekomst en het verwijlen in vroeger tijden. Harry Peeters en de historische psychologie.' In: De veranderlijke moraal. Over moraliteit en psychologie [Festschrift H.F.M. 
Peeters], red. Giel Hutschemaekers en Micha de Winter. Nijmegen: SUN, 1996, blz. 13-33.

Hying, Klemens. Das Geschichtsdenken Otto Westphals und Christoph Stedings. Ein Beitrag zur Analyse der Nationalsozialistischen Geschichtsschreibung. Diss. Philosophische Fakultät, Freie Universität Berlin, 1964.

Iggers, G.G., Deutsche Geschichtswissenschaft. Eine Kritik der traditionellen Geschichtsauffassung von Herder bis zur Gegenwart. Vertaald door C.M. Barth. München: DTV, 1971.

Iggers, G.G., 'Geschichtswissenschaft und Sozialgeschichtsschreibung 1890-1914. Ein internationaler Vergleich.' In: Marxistische Typisierung und idealtypische Methode in der Geschichtswissenschaft, red. W. Küttler. Berlijn: 1986, blz. 234244.

Iggers, Georg G., 'The "Methodenstreit" in international perspective. The reorientation of historical studies at the turn from the nineteenth to the twentieth century', in: Storia della storiografa 6 (1984), blz. 21-32.

Iwand, W.M., Paradigma Politische Kultur. Konzepte, Methoden, Ergebnisse der Political-Culture Forschung in der Bundesrepublik. Ein Forschungsbericht. Opladen: 1985.

Jaeger, Friedrich en Jörn Rüsen, Geschichte des Historismus. Eine Einführung. München: C.H. Beck, 1992.

Jaeger, Siegfried, 'Individuelle und historische Entwicklung. Zur Geschichte pädagogisch-psychologischer Parallelismusvorstellungen.’ In: Die Geschichtlichkeit des Seelischen, red. G. Jüttemann. Weinheim: Beltz/PVU, 1986, blz. 167-184.

Jahoda, Gustav, Crossroads between culture and mind. Continuities and change in theories of human nature. [Theoretical imagination in psychology] New York, etc.: Harvester Wheatsheaf, 1992.

Jahoda, Gustav, 'Johann Friedrich Herbart : Urvater of social psychology', in: History of the human sciences 19 (2006), blz. 19-38.

Jahoda, Gustav en Bernd Krewer, 'On the scope of Lazarus and Steinthal's "Völkerpsychologie" as reflected in the Zeitschrift für Völkerpsychologie und Sprachwissenschaft (1860-1890)', in: The quarterly newsletter of the laboratory of comparative human cognition 12 (1990), blz. 4-12.

Jodl, Friedrich, Die Culturgeschichtschreibung, ihre Entwickelung und ihr Problem. Halle: 1878.

Jüttemann, G., red., Wegbereiter der historischen Psychologie. München, Weinheim: Beltz/PVU, 1988.

Kant, Immanuel, 'Von den verschiedenen Rassen der Menschen.' In: Schriften zur Anthropologie, Geschichtsphilosophie, Politik und Pädagogik, red. Wilhelm Weischedel. Darmstadt: Wissenschaftliche Buchgesellschaft, 1983, blz. 11-30.

Kern, Arthur, red., Deutsche Hofordnungen des 16. und 17. Jahrhunderts. [Denkmäler der deutschen Kulturgeschichte, II, 1-2]. Berlijn: 1905-1907.

Kern, Stephen, The culture of time and space, 1880-1918. Cambridge, Mass.: 1983.

Keyser, Erich, 'Das Bild als Geschichtsquelle.' In: Historische Bildkunde, Heft 2, red. Walter Goetz. Hamburg: 1935, blz. 5-32.

Kindt, Tom en Hans-Harald Müller, 'Dilthey, Scherer, Erdmanndörffer, Grimm - ein 'positivistisches' Zeitschriftenprojekt in den 1860er Jahren', in: Berichte zur Wissenschaftsgeschichte 22 (1999), blz. 180-188.

Köhnke, Klaus Chr., 'Soziologie als Kulturwissenschaft. Georg Simmel und die Völkerpsychologie', in: Archiv für Kulturgeschichte 72 (1990), blz. 223-232. 
Köhnke, Klaus Christian, Der junge Simmel - in Theoriebeziehungen und sozialen Bewegungen. Frankfurt a. M.: Suhrkamp, 1996.

Köllmann, Wolfgang, 'Der Prozeß der Verstädterung in Deutschland in der Hochindustrialierunsgperiode.' In: Gesellschaft in der industriellen Revolution, red. R. e.a. Braun. Keulen: Kiepenheuer \& Witsch, 1973, blz. 243-258.

Krause, Hans-Thomas, 'Karl Lamprecht und der Alldeutsche Verband.' In: Karl Lamprecht weiterdenken. Universal- und Kulturgeschichte heute, red. Gerald Diesener. Leipzig: Leipziger Universitätsverlag, 1993, blz. 182-206.

Kühne, Josef, Der Begriff der Bildsamkeit und die Begründung der Ethik bei Johann Friedrich Herbart. [Zürcher Beiträge zur Pädagogik, 15] Zürich: Juris, 1976.

Kuhnert, Adolf, Der Streit um die geschichtswissenschaftlichen Theorien Karl Lamprechts. Gütersloh: 1906.

Lamprecht, Karl, Beiträge zur Geschichte des französischen Wirthschaftslebens im elften Jahrhundert. [Staats- und socialwissenschaftliche Forschungen, I.3] Leipzig: Duncker \& Humblot, 1878.

Lamprecht, Karl, Initial-Ornamentik des VIII. bis XIII. Jahrhunderts. Vierundvierzig Steindruck-Tafeln meist nach Rheinischen Handschriften nebst erläuterndem Text. Leipzig: 1882.

Lamprecht, Karl, 'Das Schicksal des deutschen Bauernstandes bis zu den agrarischen Unruhen des 15. und 16. Jahrhunderts', in: Preußische Jahrbücher 56 (1885), blz. 173-190.

Lamprecht, Karl, Skizzen zur Rheinischen Geschichte. Leipzig: Dürr, 1887.

Lamprecht, Karl, '[recensie van G.F. Knapp, Die Bauernbefreiung etc. Leipzig, 1887]', in: Deutsche Literaturzeitung für Kritik der internationalen Wissenschaften (1888a), blz. 402-403.

Lamprecht, Karl, 'Über die Prinzipien der neueren wirtschaftsgeschichtlichen Forschung', in: Historische Jahrbücher 9 (1888b), blz. 76-91.

Lamprecht, Karl, '[recensie van Gothein, Wirtschaftsgeschichte des Schwarzwaldes (1891)]', in: Jahrbücher für Nationalökonomie und Statistik 56 (1891), blz. 437440.

Lamprecht, Karl, Deutsche Geschichte. XII + 2 dln. Berlijn: Weidmannsche Buchhandlung, 1891-1909.

Lamprecht, Karl, '[recensie van P.J. Blok, De geschiedenis als sociale wetenschap, 1894]', in: Deutsche Literaturzeitung (1894), blz. kol. 1454-1455.

Lamprecht, Karl, 'Die Herrlichkeit Erpel. Ein wirtschafts-, social und verfassungsgeschichtliches Paradigma.' In: Beiträge zur Geschichte vornehmlich Kölns und der Rheinlande. [Festschrift Gustav Mevissen], Köln: Archiv der Stadt Köln, 1895a, blz. 1-26.

Lamprecht, Karl, '[recensie Inama-Sternegg, Deutsche Wirtschaftsgeschichte des 10. bis 12 Jahrhunderts]', in: Jahrbücher für Nationalökonomie und Statistik 64 (1895b), blz. 294-298.

Lamprecht, Karl, Alte und neue Richtungen in der Geschichtswissenschaft. Berlijn: 1896a.

Lamprecht, Karl, 'Zum Unterschiede der älteren und jüngeren Richtungen der Geschichtswissenschaft', in: Historische Zeitschrift 77 (1896b), blz. 257-261.

Lamprecht, Karl, 'Was ist Kulturgeschichte? Beitrag zu einer empirischen Historik', in: Deutsche Zeitschrift für Geschichtswissenschaft NF 1 (1896/97a), blz. 75-145.

Lamprecht, Karl, '[recensie van M. Ritter, Leopold von Ranke etc. Stuttgart 1896]', in: Deutsche Zeitschrift für Geschichtswissenschaft NF 1 (1896/97b), blz. 48-50. 
Lamprecht, Karl, Zwei Streitschriften den Herren H. Oncken, H. Delbrück, M. Lenz zugeeignet. Berlijn: 1897.

Lamprecht, Karl, 'Das deutsche Porträt bis auf Holbein und Dürer', in: Museum 3 (1898).

Lamprecht, Karl, Die kulturhistorische Methode. Berlijn: 1900a.

Lamprecht, Karl, '[recensie van Breysig, Kulturgeschichte der Neuzeit I + II 1]', in: Literarisches Zentralblatt (1900b), blz. 1971-1974.

Lamprecht, Karl, '[recensie van Breysig, Kulturgeschichte der Neuzeit II 2]', in: Literarisches Zentralblatt (1901a), blz. 2061-2063.

Lamprecht, Karl, 'Relativismus', in: Die Zukunft (1901b), blz. 12-13.

Lamprecht, Karl, ‘Entwicklungsstufen', in: Die Zukunft 39 (1902), blz. 139-143.

Lamprecht, Karl, 'Über den Begriff der Geschichte und über historische und psychologische Gesetze', in: Annalen der Naturphilosophie 2 (1903), blz. 255278.

Lamprecht, Karl, '[Brief aan Georg Steinhausen van 15.9.1903]', in: Archiv für Kulturgeschichte 2 (1904), blz. 107-111.

Lamprecht, Karl, Moderne Geschichtswissenschaft. Fünf Vorträge. Freiburg i.B.: H. Heyfelder, 1905a.

Lamprecht, Karl, '[recensie van Georg Steinhausen, Geschichte der deutschen Kultur, 1e dr. 1904]', in: Göttingische gelehrte Anzeigen (1905b), blz. 322-334.

Lamprecht, Karl, Americana. Reiseeindrücke, Betrachtungen, geschichtliche Gesamtansicht. Freiburg i.B.: Heyfelder, 1906.

Lamprecht, Karl, Historische Methode und historisch-akademischer Unterricht. Berlijn: Weidmannsche Buchhandlung, 1910.

Lamprecht, Karl, Deutsche Geschichte der jüngsten Vergangenheit und Gegenwart. Berlijn: 1912-1913.

Lamprecht, Karl, 'Eine Gefahr für die Geisteswissenschaften', in: Die Zukunft 83 (1913a), blz. 16-24.

Lamprecht, Karl, 'Eine Gefahr für die Geisteswissenschaften (Antwort an Herrn Professor Dr. Georg Simmel)', in: Die Zukunft 83 (1913b), blz. 421-429.

Lamprecht, Karl, Einführung in das historische Denken. 2e, onveranderde dr., Leipzig: Voigtländer, 1913c [1e dr. 1912].

Lamprecht, Karl, 'Einleitung.' In: Handbuch der praktischen Genealogie, red. Eduard Heydenreich, Robert Sommer en Armin Tille. Leipzig: Degener, 1913d, blz. [VII]-VIII.

Lamprecht, Karl, Deutscher Aufstieg 1750-1914. Einführung in das geschichtliche Verständis der Gegenwart zur Selbstbelehrung für jedermann zum Gebrauche bei Vorträgen und zum Schulgebrauch. Gotha: F.A. Perthes, 1914a.

Lamprecht, Karl, 'Die kulturgeschichtliche Abteilung auf der Weltausstellung für Buchgewerbe und Graphik Leipzig 1914. Einleitung: Die Grundausstellung', in: Archiv für Buchgewerbe 51 (1914b), blz. [ongepagineerd, 1-8].

Lamprecht, Karl, Krieg und Kultur. Drei vaterländische Vorträge. [Zwischen Krieg und Frieden, 7] Leipzig: Hirzel, 1914c.

Lamprecht, Karl, Kindheitserinnerungen. Gotha: Perthes, 1918.

Lamprecht, Karl, Ausgewählte Schriften zur Wirtschafts- und Kulturgeschichte und zur Theorie der Geschichtswissenschaft, red. H. Schönebaum. Aalen: ScientiaVerlag, 1974.

Lamprecht, Karl, Alternative zur Ranke. Schriften zur Geschichtstheorie, red. Hans Schleier. Leipzig: Reclam, 1988. 
Lamprecht, Karl, e.a., Internat[ionale] Ausstellung für Buchgewerbe und Graphik Leipzig 1914: Halle der Kultur. Amtlicher Führer. Leipzig: 1914d.

Lazarus, Moritz, 'Über den Begriff und die Möglichkeit einer Völkerpsychologie', in: Deutsches Museum. Zeitschrift für Literatur, Kunst und öffentliches Leben 1 (1851), blz. 112-126.

Lazarus, Moritz, 'Einige synthetische Gedanken zur Völkerpsychologie', in: Zeitschrift für Völkerpsychologie und Sprachwissenschaft 3 (1865), blz. 1-94.

Lazarus, Moritz en Hajim Steinthal, 'Einleitende Gedanken über Völkerpsychologie als Einladung zu einer Zeitschrift für Völkerpsychologie und Sprachwissenschaft', in: Zeitschrift für Völkerpsychologie und Sprachwissenschaft (1860), blz. 1-73.

Leary, David E., 'The philosophical development of the conception of psychology in Germany, 1780-1850', in: Journal of the history of the behaviorial sciences 14 (1978), blz. 113-121.

Leary, David E., 'German idealism and the development of psychology in the nineteenth-century', in: Journal of the history of philosophy 18 (1980), blz. 299317.

Leary, David E., 'The fate and influence of John Stuart Mill's proposed science of ethology', in: Journal of the history of ideas 43 (1982), blz. 153-162.

Lees, Andrew, Revolution and reflection. Intellectual change in Germany during the 1850's. Den Haag: Martinus Nijhoff, 1974.

Lehmann, M., 'Geschichte und Naturwissenschaft', in: Zeitschrift für Kulturgeschichte 1 (1894), blz. 245-248.

Lélut, L-F., 'Sur un des points de vue de la psychologie de l'histoire', in: Gazette médicale de Paris (1838).

Lenger, F., Werner Sombart, 1863-1941: eine Biographie. München: Beck, 1994.

Lentz, Matthias, 'Ruhe ist erste Bürgerpflicht.' Lärm, Großstadt und Nervosität im Spiegel von Theodor Lessings 'Antilärmverein', in: Medizin, Gesellschaft und Geschichte 13 (1994), blz. 81-105.

Lenz, Max, 'Lamprecht's Deutsche Geschichte, 5. Band', in: Historische Zeitschrift 77 (1896), blz. 385-447.

Leppin, Hartmut, 'Ein 'Spätling der Aufklärung'. Otto Seeck und der Untergang der antiken Welt.' In: Imperium Romanum. Studien zu Geschichte und Rezeption. Festschrift für Karl Christ zum 75. Geburtstag, red. V. Losemann en P. Kneißl. Stuttgart: Steiner, 1998, blz. 472-491.

Lessing, Hans-Ulrich, 'Dilthey und Lazarus.' In: Dilthey-Jahrbuch für Philosophie und Geschichte der Geisteswissenschaften, red. F. Rodi. Göttingen: 1985, blz. 57-82.

Levinstein, Siegfried, Kinderzeichnungen bis zum 14. Lebensjahr. Mit Parallelen aus der Urgeschichte, Kulturgeschichte und Völkerkunde. Leipzig: 1905.

Lewald, Ursula, 'Karl Lamprecht 1856-1915.' In: Bonner Gelehrte: Beiträge zur Geschichte der Wissenschaften in Bonn. Geschichtswissenschaften, Bonn: 1968, blz. 231-253.

Lexis, Wilhelm, red. Die deutschen Universitäten, I. Berlijn: A. Asher \& Co., 1893.

Lexis, Wilhelm, red. Die Universitäten im Deutschen Reich. [Das Unterrichtswesen im Deutschen Reich I]. Berlijn: A.Asher \& Co., 1904.

Lindenlaub, Dieter, Richtungskämpfe im Verein für Sozialpolitik. Wissenschaft und Sozialpolitik im Kaiserreich vornehmlich vom Beginnn des "Neuen Kurses" bis zum Ausbruch des Ersten Weltkrieges (1890-1914). [Vierteljahrschrift für Sozial- und Wirtschaftsgeschichte, Beiheft 52-53] Wiesbaden: Steiner, 1967.

Lorenz, Ottokar, 'Die Kulturgeschichte (W.H. Riehl).' In: Die Geschichtswissenschaft in Hauptrichtungen und Aufgaben, I, Berlijn: 1886, blz. 171-196. 
Lorenz, Ottokar, Die Geschichtswissenschaft in Hauptrichtungen und Aufgaben. 2 dln. Berlijn: Hertz, 1886-1891.

Lorenz, Ottokar, Handbuch der gesammten wissenschaftlichen Genealogie. Berlijn: Hertz, 1898.

Lovejoy, A.O., The great chain of being. A study in the history of an idea. The William James lectures delivered at Harvard University, 1933. Cambridge, Mass.: Harvard UP, 1964.

Lück, H.E., 'Willy Hellpach. Geopsyche, Völker- und Sozialpsychologie in historischem Kontext.' In: Wegbereiter der historischen Psychologie, red. Gerd Jüttemann. München, Weinheim: Beltz/PVU, 1988, blz. 263-272.

Lurija, A.R., 'Towards the problem of the historical nature of psychological processes', in: International Journal of psychology 6 (1971), blz. 259-272.

Mandelbaum, Maurice, History, man and reason. A study in nineteenth-century thought. Baltimore: Johns Hopkins UP, 1974 [1e dr. 1971].

Mandrou, Robert, Introduction à la France moderne (1500-1640): essai de psychologie historique. Parijs: Albin Michel, 1961.

Mandrou, Robert, 'L'Histoire des mentalites.' In: Encyclopaedia Universalis, VIII, 1968, blz. 436-438.

Mann, Hans-Dieter, Lucien Febvre: la pensée vivante d'un historien. [Cahiers des Annales, 31] Parijs: 1971.

Manuel, Frank E., 'The use and abuse of psychology in history', in: Daedalus 100 (1971), blz. 187-213.

Maurer, Michael, 'Eberhard Gothein - Marie Schröter. Briefwechsel aus der Privatdozenten- und Brautzeit (1882-1885).' In: Briefkultur im 19. Jahrhundert, red. Rainer Baasner. Tübingen: 1999, blz. 141-168.

Maurer, Michael, et al., Im Schaffen genießen. Der Briefwechsel der Kulturwissenschaftler Eberhard und Maria Luise Gothein (1883-1923). Böhlau, 2006.

Mehring, Franz, 'Deutsche Geschichte', in: Die Neue Zeit 12 (1893/94), blz. 443-448, 475-480.

Meinecke, Friedrich, 'Erwiderung [contra Lamprecht]', in: Historische Zeitschrift 77 (1896), blz. 262-266.

Meinecke, Friedrich, Erlebtes 1862-1901. Leipzig: Koehler \& Amelang, 1941.

Menke-Glückert, Emil, Goethe als Geschichtsphilosoph und die geschichtsphilosophische Bewegung in seiner Zeit. [Beiträge zur Kultur- und Universalgeschichte, 1] Leipzig: Voigtländer, 1907.

Mergel, Thomas, 'Evolution, Entropie und Reizsamkeit. Naturwissenschaftliche Kategorien im Lamprecht-Streit.' In: Historisierung und gesellschaftlicher Wandel in Deutschland im 19. Jahrhundert, red. Ulrich Muhlack. Berlijn: Akademie Verlag, 2003, blz. 211-227.

Métraux, Alexandre, 'Geschichte als Polyphonie: zu Aaron Gurjewitsch.' In: Stimmen des Mittelalters - Fragen von heute. Mentalitäten im Dialog, red. A.J. Gurjewitsch. Frankfurt/New York: 1993, blz. 101-120.

Metz, K.H., Grundformen historiographischen Denkens. Wissenschaftsgeschichte als Methodologie. Dargestellt an Ranke, Treitschke und Lamprecht. Mit einem Anhang über zeitgenössische Geschichtstheorie. München: 1979.

Metz, Karl H., "Historisches "Verstehen" und sozialpsychologie. Karl Lamprecht und seine "Wissenschaft der Geschichte", in: Saeculum 33 (1982), blz. 95-104. 
Metz, Karl H., 'Der Methodenstreit in der deutschen Geschichtswissenschaft (1891-99): Bemerkungen zum sozialen Kontext wissenschaftlicher Auseinandersetzungen', in: Storia della storiografia 6 (1984), blz. 3-20.

Middell, Matthias, Weltgeschichtsschreibung im Zeitalter der Verfachlichung und Professionalisierung. Das Leipziger Institut für Kultur- und Universalgeschichte 1890-1990. Leipzig: Akademische Verlagsanstalt, 2005.

Miethke, J., red. Geschichte in Heidelberg. 100 Jahre Historisches Seminar. 50 Jahre Institut für Fränkisch-Pfälzische Geschichte und Landeskunde. Berlijn [etc.]: 1992.

Mill, John Stuart, A system of logic ratiocinative and inductive. Being a connected view of the principles of evidence and the methods of scientific investigation, red. J.M. Robson. Toronto, etc.: University of Toronto Press, Routledge \& Kegan Paul, 1981 [1e dr.1843].

Miller, P.N., 'Nazis and Neo-Stoics: Otto Brunner and Gerhard Oestreich Before and after the Second World War', in: Past and present 177 (2002), blz. 144-186.

Mommsen, W.J., Max Weber und die deutsche Politik 1890-1920. 2de, herz. dr., Tübingen: Mohr-Siebeck, 1974.

Mucchielli, Alex, Les mentalités. [Que sais-je?] Paris: PUF, 1985.

Mul, Jos de, De tragedie van de eindigheid. Diltheys hermeneutiek van het leven. Kampen: Kok Agora, 1993.

Müller, Siegfried en Annelore Rieke-Müller, 'Konzeptionen der Kulturgeschichte um die Mitte des 19. Jahrhunderts. Das Germanische Nationalmuseum in Nürnberg und die Zeitschrift für deutsche Kulturgeschichte', in: Archiv für Kulturgeschichte 82 (2000), blz. 345-375.

Münsterberg, Hugo, 'Psychology and history', in: The psychological review 6 (1899), blz. 1-31.

Mütter, Bernd, Die Geschichtswissenschaft in Münster zwischen Aufklärung und Historismus. [Geschichtliche Arbeiten zur westfälischen Landesforschung, Geistesgeschichtliche Gruppe, I] Münster: Aschendorffsche Verlagsbuchhandlung, 1980.

Naumann, Friedrich, 'Kulturgeschichte und Kapitalismus', in: Die neue Rundschau 22 (1911), blz. 1337-1348.

Neuhaus, Helmut, 'Hundert Jahre Archiv für Kulturgeschichte', in: Archiv für Kulturgeschichte 85 (2003), blz. 1-28.

Nipperdey, Thomas, 'Kulturgeschichte, Sozialgeschichte, historische Anthropologie', in: Vierteljahrschrift für Sozial- und Wirtschaftsgeschichte 55 (1968), blz. 145164.

Nipperdey, Thomas, Deutsche Geschichte 1866-1918. München: 1990-1992.

Oberkrome, Willi, Volksgeschichte. Methodische Innovation und völkische Ideologisierung in der deutschen Geschichtswissenschaft 1918-1945. Göttingen: 1993.

Oelze, Berthold, Wilhelm Wundt. Die Konzeption der Völkerpsychologie. Münster/New York: 1991.

Oestreich, Gerhard, 'Die Fachhistorie und die Anfänge der sozialgeschichtlichen Forschung in Deutschland', in: Historische Zeitschrift 208 (1969), blz. 320-363.

Oettermann, S., Das Panorama: die Geschichte eines Massenmediums. Frankfurt a.M.: Syndikat, 1980.

Oncken, Hermann, 'Zur Quellenanalyse modernster deutscher Geschichtsschreibung', in: Preußische Jahrbücher 89 (1897), blz. 83-125. 
Oppenheimer, Franz, 'Moderne Geschichtsphilosophie', in: Vierteljahrsschrift fur wissenschaftliche Philosophie und Soziologie 32 (1908), blz. 242, 250-253.

Pandel, Hans-Jürgen, 'Von der Teegesellschaft zum Forschungsinstitut. Die historischen Seminare vom Beginn des 19. Jahrhunderts bis zum Ende des Kaiserreichs.' In: Transformation des Historismus. Wissenschaftsorganisation und Bildungspolitik vor dem Ersten Weltkrieg. Interpretationen und Dokumente, red. Horst Walter Blanke. Waltrop: Spenner, 1994, blz. 1-31.

Passmore, J.A., 'The malleability of man in eighteenth-century thought.' In: Aspects of the eighteenth century, red. E.R. Wasserman. Baltimore: 1965, blz. 21-46.

Pastore, Nicholas, The nature-nurture controversy. New York: King's Crown Press, 1949.

Patzel-Mattern, Katja, Geschichte im Zeichen der Erinnerung : Subjektivität und kulturwissenschaftliche Theoriebildung. [Studien zur Geschichte des Alltags, Bd. 19] Stuttgart: Steiner, 2002.

Pearson, Heath, 'Was there really a German Historical School of Economics?', in: History of political economy 31 (1999), blz. 547-562.

Peeters, Harry F.M, 'Prolegomena van een psychologische geschiedenis', in: Tijdschrift voor Geschiedenis 80 (1967), blz. 23-38.

Peeters, Harry F.M., 'Prolegomena van een psychologische geschiedenis. Een programmatische en bibliografische studie.' In: Enige facetten van opvoeding en onderwijs, red. Anton Monshouwer. Malmberg: Den Bosch, 1975, blz. 135-151.

Peeters, Harry F.M., Historische gedragswetenschap: theorieën, begrippen en methoden. Een bijdrage tot de studie van menselijk gedrag op de lange termijn. Meppel, Amsterdam: Boom, 1978.

Peeters, Harry F.M., 'Pychologie en geschiedenis', in: Tijdschrift voor Geschiedenis 101 (1988), blz. 600-615.

Peeters, Harry F.M., Hoe veranderlijk is de mens? Een inleiding in de historische psychologie. Nijmegen: SUN, 1994.

Peeters, Harry F.M., M. Gielis en Ch. Caspers, Literatuurgids historische gedragswetenschappen. Baarn: Ambo, 1985.

Peeters, Harry F.M. en J. Kruithof, 'Inleiding [speciaalnummer Mentaliteitsgeschiedenis]', in: Tijdschrift voor Geschiedenis 86 (1973), blz. 152-154.

Petersen, Peter, Der Entwicklungsgedanke in der Philosophie Wundts. Zugleich ein Beitrag zur Methode der Kulturgeschichte. [Beiträge zur Kultur- und Universalgeschichte, 9] Leipzig: Voigtländer, 1908.

Pflaum, Chr. D., Die individuelle und die soziale Seite des Seelenlebens. [Grenzfragen des Nerven- und Seelenlebens, 43] Wiesbaden: 1906.

Pflaum, Chr. D., J.G. Droysens Historik in ihre Bedeutung für die moderne Geschichtswissenschaft. [Geschichtliche Untersuchungen 5:2] Gotha: Perthes, 1907.

Quidde, L., 'Zur Einführung', in: Deutsche Zeitschrift für Geschichtswissenschaft 1 (1889), blz. 1-9.

Rachfahl, Felix, '[rec. van Lamprecht, Deutsche Geschichte IV]', in: Deutsche Literaturzeitung für Kritik der internationalen Wissenschaften (1895), kol. 840851.

Rachfahl, Felix, 'Deutsche Geschichte von wirthschaftlichen Standpunkt', in: Preußische Jahrbücher 83 (1896a), blz. 48-96.

Rachfahl, Felix, '[rec. van Lamprecht, Alte und neue Richtungen]', in: Preußische Jahrbücher 84 (1896b), blz. 542-555. 
Rachfahl, Felix, '[rec. van Lamprecht, Deutsche Geschichte V.2]', in: Mitteilungen des Instituts für österreichische Geschichtsforschung 17 (1896c), blz. 468-478.

Rachfahl, Felix, 'Ueber die Theorie einer "kollektivistischen" Geschichtswissenschaft', in: Jahrbücher für Nationalökonomie und Statistik 68 (1897), blz. 659-689.

Rachfahl, Felix, Staat, Gesellschaft, Kultur und Geschichte. Jena: 1924.

Rachfahl, Felix, '[Selbstdarstellung].' In: Die Geschichtswissenschaft der Gegenwart in Selbstdarstellungen, II, red. Sigfrid Steinberg. Leipzig: Felix Meiner, 1926, blz. 199-222.

Radkau, Joachim, Das Zeitalter der Nervosität. Deutschland zwischen Bismarck und Hitler. Darmstadt: WBG, 1998.

Ranke, Leopold von, Das politische Gespräch und andere Schriftchen zur Wissenschaftslehre [1832-1871], red. Erich Rothacker. Halle: Niemeyer, 1925.

Ranke, Leopold von, Vorlesungseinleitungen, red. Volker Dotterweich en Walther Fuchs. [Aus Werk und Nachlass IV]. München, Wenen: Oldenbourg, 1975.

Raphael, Lutz, 'Historikerkontroversen im Spannungsfeld zwischen Berufshabitus, Fächerkonkurrenz und sozialen Deutungsmustern: Lamprecht-Streit und französischer Methodenstreit in vergleichender Perspektive', in: Historische Zeitschrift 251 (1990), blz. 325-363.

Raphael, Lutz, 'The present as challenge for the historian. The contemporary world in the Annales ESC, 1929-1949.', in: Storia della storiografia 21 (1992), blz. $25-$ 44.

Raphael, Lutz, Die Erben von Bloch und Febvre. Annales-Geschichtsschreibung und nouvelle histoire in Frankreich, 1945-1980. Stuttgart: Klett-Cotta, 1994.

Raphael, Lutz, 'Die "Neue geschichte" - Umbrüche und Neue Wege der Geschichtsschreibung in internationaler Perspektive (1880-1940).' In: Geschichtsdiskurs, IV, red. Wolfgang Küttler, Jörn Rüsen en Ernst Schulin. Frankfurt a.M.: Fischer, 1997, blz. 51-89.

Rapp, Adolf, 'Geschichte der politischen Kultur. Neuzeit [Literaturbericht]', in: Archiv für Kulturgeschichte 10 (1912), blz. 118-154.

Rath, Matthias, Der Psychologismusstreit in der deutschen Philosophie. Freiburg i.Br. / München: Karl Alber, 1994.

Raulff, Ulrich, 'Die Geburt eines Begriffs. Reden von 'Mentalitäten' zur Zeit der Affäre Dreyfus.' In: Mentalitäten-Geschichte. Zur historischen Rekonstruktion geistiger Prozesse, red. Ulrich Raulff. Berlin: Wagenbach, 1989, blz. 50-68.

Rickert, Heinrich, Die Grenzen der naturwissenschaftlichen Begriffsbildung. Eine logische Einleitung in die historischen Wissenschaften. Tübingen, Leipzig: Mohr, 1902 [1e dr. 1896-1902].

Rickert, Heinrich, Kulturwissenschaft und Naturwissenschaft. 6de/7de aangevulde dr., Tübingen: Mohr/Siebeck, 1926 [1e dr. 1899].

Riehl, W.H., Culturstudien aus drei Jahrhunderten. Stuttgart: J.G. Cotta, 1862.

Ritter, Moriz, 'Der Streit zwischen politischer und Kulturgeschichte', in: Münchner Allgemeine Zeitung. Beilage (1893), blz.

Roberts, David D., Benedetto Croce and the uses of historicism. Berkeley [etc.]: University of California Press, 1987.

Roelcke, Volker, 'Electrified nerves, degenerated bodies: medical discourses on neurasthenia in Germany, circa 1880-1914.' In: Cultures of neurasthenia from Beard to the First World War, red. Marijke Gijswijt-Hofstra en Roy Porter. Amsterdam [etc.]: Rodopi, 2001, blz. 177-197.

Roethe, G., '[rec. van Steinhausen, Geschichte des deutschen Briefes I]', in: Historische Zeitschrift 66 (1891), blz. 95-100. 
Romein, Jan, Op het breukvlak van twee eeuwen. 2 dln., Leiden / Amsterdam: Brill / Querido, 1967.

Rothacker, Erich, Über die Möglichkeit und den Ertrag einer genetischen Geschichtschreibung im Sinne Karl Lamprechts. [Beiträge zur Kultur- und Universalgeschichte, 20] Leipzig: 1912.

Rothacker, Erich, Einleitung in die Geisteswissenschaften. 2e dr., Tübingen: Mohr, 1930 [1e dr. 1919].

Salin, Edgar, 'Eberhard Gothein.' In: Eberhard Gothein, Schriften zur Kulturgeschichte der Renaissance, Reformation und Gegenreformation. Mit einer biographischen Einleitung, I, München, Leipzig: Duncker \& Humblot, 1924, blz. IX-XXXI.

Sammler, S., "Histoire nouvelle" und deutsche Geschichtswissenschaft. Der Einfluß deutscher Historiker auf die Herausbildung der Geschichtskonzeption von Marc Bloch.' In: Karl Lamprecht weiterdenken. Universal- und Kulturgeschichte heute, red. Gerald Diesener. Leipzig: Leipziger Universitätsverlag, 1993, blz. 258-271.

Schäfer, Dietrich, Das eigentliche Arbeitsgebiet der Geschichte. Jena: 1888.

Schäfer, Dietrich, Geschichte und Kulturgeschichte. Eine Erwiderung. Jena: 1891.

Schäfer, Ulla G., Historische Nationalökonomie und Sozialstatistik als Gesellschaftswissenschaften. Forschungen zur Vorgeschichte der theoretschen Soziologie und der empirischen Sozialforschung in Deutschland in der zweiten Hälfte des 19. Jahrhunderts. [Neue Wirtschaftsgeschichte, 2] Keulen, Wenen: Böhlau, 1971.

Schaumkell, Ernst, Geschichte der deutschen Kulturgeschichtschreibung von der Mitte des 18. Jahrhunderts bis zur Romantik im Zusammenhang mit der algemeinen geistigen Entwicklung. [Preisschriften gekrönt und herausgegeben von der Fürstlich Jablonowski'schen Gesellschaft zu Leipzig] Leipzig: Teubner, 1905.

Scherer, Wilhelm, '[recensie van E. Petzsche, Geschichte und Geschichtschreibung unserer Zeit (1865)].’ In: Kleine Schriften, I, Berlijn: Weidmannsche Buchhandlung, 1893, blz. 169-175.

Scherer, Wilhelm, Zur Geschichte der deutschen Sprache, red. K.R. Jankowsky. Amsterdam, Philadelphia: John Benjamins, 1995 [1e dr.1868].

Schieder, Theodor, 'Die deutsche Geschichtswissenschaft im Spiegel der Historischen Zeitschrift', in: Historische Zeitschrift 189 (1959), blz. 1-104.

Schilling, Friedrich, 'Kurt Breysigs Forschungen und Vorlesungen. Der Werkbericht über seine Jahre 1889-1927.' In: Geist und Gesellschaft. Kurt Breysig zu seinem sechszigsten Geburtstage, Breslau: M.\&H. Marcus, 1928, blz. 179-215.

Schilling, Friedrich, 'Kurt Breysigs Forschungen und Vorlesungen, Teil II. Der Werkbericht über seine Jahre 1928-1939 und die Veröffentlichungen aus dem Nachlass 1940-1961.’ In: Kurt Breysig, Aus meinen Tagen und Träumen. Memoiren, Aufzeichnungen, Briefe, Gespräche, red. Gertrud Breysig en Michael Landmann. Berlijn: De Gruyter, 1962, blz. 179-187.

Schleier, Hans, 'Karl Lamprecht als Initiator einer intensivierten Forschung über die Geschichte der Geschichtsschreibung', in: Storia della storiografia 2 (1982), blz. 28-56.

Schleier, Hans, Geschichte der Geschichtswissenschaft. [Lehrmaterial zur Ausbildung von Diplomlehrern: Geschichte] Potsdam: 1983.

Schleier, Hans, 'Deutsche Kulturhistoriker des 19. Jahrhunderts. Über Gegenstand und Aufgabe der Kulturgeschichte', in: Geschichte und Gesellschaft: Zeitschrift für historische Sozialwissenschaft 23 (1997a), blz. 70-98. 
Schleier, Hans, 'Kulturgeschichte im 19. Jahrhundert: Oppositionswissenschaft, Modernisierungsgeschichte, Geistesgeschichte, spezialisierte Sammlungsbewegung.' In: Geschichtsdiskurs, III, red. Wolfgang Küttler, Jörn Rüsen en Ernst Schulin. Frankfurt a.M.: Fischer, 1997b, blz. 424-446.

Schleier, Hans, Geschichte der deutschen Kulturgeschichtsschreibung. Waltrop: Hartmut Spenner, 2003-.

Schmeidler, B., 'Zur Psychologie des Historikers und zur Lage der Historie in der Gegenwart', in: Preußische Jahrbücher 202 (1925), blz. 219-239; 304-327.

Schmeidler, Bernhard, 'Anti-asketische Äußerungen aus Deutschland im 11. und beginnenden 12. Jahrhundert.' In: Kultur- und Universalgeschichte. [Festschrift] Walter Goetz, Leipzig/Berlijn: Teubner, 1927, blz. 35-52.

Schmoller, Gustav, Ueber einige Grundfragen des Rechts und der Volkswirtschaft. Ein Offenes Sendschreiben an Herrn Professor Dr. Heinrich von Treitschke. Jena: Friedrich Mauke, 1875.

Schmoller, Gustav, Zur Litteraturgeschichte der Staats- und Sozialwissenschaften. Leipzig: Duncker \& Humblot, 1888.

Schmoller, Gustav, 'Volkswirtschaft, Volkswirtschaftslehre und -methode.' In: Handwörterbuch der Staatswissenschaften, VI, red. J. Conrad, L. Elster en W. Lexis, [et al.]. Jena: Fischer, 1894, blz. 527-563.

Schmoller, Gustav, Grundriß der allgemeinen Volkswirtschaftslehre, I. Leipzig: Duncker \& Humblot, 1901 [1e dr. 1900].

Schmoller, Gustav, 'Ueber den Einfluß der heutigen Verkehrsmittel', in: Preußische Jahrbücher 31 (1873), blz. 413-430.

Schmoller, Gustav, Historisch-ethische Nationalökonomie als Kulturwissenschaft, red. H.H. Nau. Marburg: Metropolis, 1998.

Schnabel, Franz, e.a., Die Historische Kommission bei der bayerischen Akademie der Wissenschaften 1858-1958. Götingen: Vandenhoeck \& Ruprecht, 1958.

Schneider, Gerhard, 'Der Geschichtsunterricht in der Ära Wilhelms II. (vornehmlich in Preußen).' In: Gesellschaft, Staat, Geschichtsunterricht. Beiträge zu einer Geschichte der Geschichtsdidaktik und des Geschichtsunterichts von 1500-1980, red. K. Bergmann en G. Schneider. Düsseldorf: Schwann, 1982, blz. 132-189.

Schneider, Hermann, Das kausale Denken in deutschen Quellen zur Geschichte und Literatur des zehnten, elften und zwölften Jahrhunderts. [Geschichtliche Untersuchungen II.4] Gotha: Perthes, 1905.

Schnürer, G., 'Lamprechts Deutsche Geschichte', in: Historisches Jahrbuch 18 (1897), blz. 88-116.

Schnürer, G., 'Zum Streite über Lamprechts Deutsche Geschichte', in: Historisches Jahrbuch 21 (1900), blz. 776-785.

$\mathrm{Sch}[$ önebaum], H[erbert], 'Bericht über das Institut für Kultur- und Universalgeschichte bei der Universität Leipzig', in: Archiv für Kulturgeschichte 16 (1926a), blz. 109-112.

$\mathrm{Sch}[$ önebaum], H[erbert], 'Bericht über das Staatliche Forschungsinstitut für Kulturund Universalgeschichte zu Leipzig', in: Archiv für Kulturgeschichte 16 (1926b), blz. 270272.

Schönebaum, Herbert, 'Vom Werden der Deutschen Geschichte Karl Lamprechts', in: Deutsche Vierteljahrsschrift für Literaturwissenschaft und Geistesgeschichte 25 (1951), blz. 94-111.

Schönebaum, Herbert, 'Lamprechtiana. Verzeichnis der Schriften Karl Lamprechts und der on ihm in Referat und Korreferat betreuten Dissertationen.', in: 
Wissenschaftliche Zeitschrift der Karl-Marx-Universität Leipzig / Gesellschaftsund sprachwissenschaftliche Reihe 5 (1955/56), blz. 7-21.

Schönebaum, Herbert, 'Unausgeführte Vorhaben wissenschaftlicher und kulturpolitischer Art und die Forschungsinsitute Karl Lamprechts.', in: Forschungen und Fortschritte 33 (1959), blz. 117-123.

Schönebaum, Herbert, 'Karl Lamprecht und Ernst Bernheim', in: Archiv für Kulturgeschichte 43 (1961), blz. 217-239.

Schönebaum, Herbert, 'Carl von Noorden und Wilhelm Maurenbrecher im Austausch über die geistige Entwicklung des jungen Karl Lamprechts', in: Archiv für Kulturgeschichte 44 (1962), blz. 379-387.

Schorn-Schütte, Luise, Karl Lamprecht. Kulturgeschichtsschreibung zwischen Wissenschaft und Politik. Göttingen: 1984a.

Schorn-Schütte, Luise, 'Karl Lamprecht. Wegbereiter einer historischen Sozialwissenschaft?' In: Deustche Geschichtswissenschaft um 1900, red. Notker Hammerstein. Göttingen: 1988, blz. 153-191.

Schorn-Schütte, Luise, 'Kulturgeschichte als Aufklärungswissenschaft. Karl Lamprechts Bemühungen zur Reform der historischen Bildung im Kontext dert internationalen Reformbewegung an der Jahrhundertwende.' In: Transformation des Historismus. Wissenschaftsorganisation und Bildungspolitik vor dem Ersten Weltkrieg. Interpretationen und Dokumente, red. Horst Walter Blanke. Waltrop: Spenner, 1994, blz. 64-94.

Schorn-Schütte, Luise, 'Territorialgeschichte - Provinzialgeschichte - Landesgeschichte - Regionalgeschichte. Ein Beitrag zur Wissenschaftsgeschichte der Landesgeschichtsschreibung.' In: Civitatum Communitas. Studien zum europäischen Städtewesen. Festschrift Heinz Stoob zum 65. Geburtstag, red. Helmut Jäger. Köln: 1984b, blz. 390-416.

Schorn-Schütte, Luise, 'Karl Lamprecht und die internationale Geschichtswissenschaft an der Jahrhundertwende', in: Archiv für Kulturgeschichte 67 (1985), blz. 417 e.v.

Schorn-Schütte, Luise, 'Nachwirkungen der Lamprechtschen Geschichtsschreibung. Rezeptionen im Ausland und in der deutschen Geschichtswissenschaft und Soziologie.' In: Karl Lamprecht weiterdenken. Universal- und Kulturgeschichte heute, red. Gerald Diesener. Leipzig: Leipziger Universitätsverlag, 1993, blz. 272-294.

Schramm, Percy Ernst, Die deutschen Kaiser und Könige in Bildern ihrer Zeit, I [7511152]. [Die Entwicklung des menschlichen Bildnisses I] Leipzig, Berlijn: Teubner, 1928.

Schridde, Georg, Gustav Freytags Kultur- und Geschichtspsychologie. Ein Beitrag zur Geschichte der Geschichtsphilosophie. Leipzig: 1910.

Schulin, Ernst, 'Geistesgeschichte, Intellectual History und Histoire des mentalités seit der Jahrhundertwende.' In: id., Traditionskritik und Rekonstruktionsversuch. Studien zur Entwicklung der Geschichtswissenschaft und historischem Denken, Göttingen: 1979, blz. 144-162.

Schultze, Johannes, 'Der Verein für die Geschichte der Mark Brandenburg. Ein Rückblick', in: Forschungen zur brandenburgischen und preußischen Geschichte 35 (1923), blz. 1-20.

Schumann, Peter, Die deutschen Historikertage von 1893 bis 1937. Die Geschichte einer fachhistorischen Institution im Spiegel der Presse. Göttingen: 1975.

Seeliger, Gerhard, 'Ueber die Kulturgeschichtschreibung Karl Lamprechts', in: Preußische Jahrbücher 156 (1914), blz. 539-542. 
Seeliger, Gerhard, 'Karl Lamprecht', in: Historische Vierteljahrschrift 19 (1919), blz. 133-144.

Seifert, F., Der Streit um Karl Lamprechts Geschichtsphilosophie. [Sozialphilosophische Vorträge und Abhandlungen] Augsburg: 1925.

Show, A.B., 'Die Kulturgeschichtschreibung Karl Lamprechts', in: Vergangenheit und Gegenwart 4 (1914), blz. 65-87.

Simmel, Georg, 'Die Großstädte und das Geistesleben.' In: Die Großstadt. Vorträge und Aufsätze zur Städteausstellung, red. K. Bücher, e.a. Dresden: 1903, blz. 185206.

Simmel, Georg, 'Die Probleme der Geschichtsphilosophie.' In: Aufsätze 1887-1890 [etc.], red. H.-J. Dahme. Frankfurt a.M.: Suhrkamp, 1989, blz. 297-423.

Simon, Christian, Staat und Geschichtswissenschaft in Deutschland und Frankreich 1871-1914. 2 dln., Bern etc.: 1988.

Smith, W.D., Politics and the sciences of culture in Germany, 1840-1920. New York/Oxford: OUP, 1991.

Sombart, Werner, Der Bourgeois. Zur Geistesgeschichte des modernen Wirtschaftsmenschen. München/Leipzig: 1913.

Sommer, Robert, Grundzüge einer Geschichte der deutschen Psychologie und Aesthetik von Wolff-Baumgarten bis Kant-Schiller. Wuerzburg: Stahel'scher K. Hof- und Universitaetsbuch- und Kunsthandlung, 1892.

Sonntag, Michael, 'Zur Herkunft des Konzepts einer "historischen Psychologie".' In: Black Box Psyche? Texte zur Historischen Psychologie I, red. Martin Reuter. Pfaffenweiler: Centaurus-Verlagsgesellschaft, 1990, blz. 2-7.

Spieß, E.J., Die Geschichtsphilosophie von Karl Lamprecht. Erlangen: 1921.

Spranger, Eduard, Die Grundlagen der Geschichtswissenschaft: eine erkenntnistheoretisch-psychologische Untersuchung. Berlijn: Reuther \& Reichard, 1905.

Spranger, Eduard, 'Allgemeine Kulturgeschichte und Methodenlehre [Literaturbericht]', in: Archiv für Kulturgeschichte 9 (1911), blz. 363-381.

Spranger, Eduard, Lebensformen. Geisteswissenschaftliche Psychologie und Ethik der Persönlichkeit. München/Hamburg: Siebenstern, 1965 [1e dr. 1925].

Spranger, Eduard, Gesammelte Schriften, red. H.W. Bähr e.a. Tübingen: Max Niemeyer, 1969-1980.

Spranger, Eduard, 'Grundgedanken der geisteswissenschaftlichen Psychologie [1934].' In: Gesammelte Schriften, IV, Psychologie und Menschenbildung, red. W. Eisermann. Tübingen: 1974, blz. 37-64.

Sproll, Heinz, 'Wilhelm Herbst (1825-1882).' In: Deutsche Geschichtsdidaktiker des 19. und 20. Jahrhunderts. Wege, Konzeptionen, Wirkungen, red. Siegfried Quandt. Paderborn etc.: Schöningh, 1978, blz. 110-136.

Stallmeister, W. en H.E. Lück, Willy Hellpach: Beiträge zu Werk und Biographie. Frankfurt, New York: Lang, 1991.

Steding, Christoph, 'Kulturgeschichte und politische Geschichte.' In: Reich und Reichsfeinde, red. Walter Frank. Hamburg: 1941, blz. 61-79.

Steinbach, Peter, 'Wilhelm Heinrich Riehl.' In: Deutsche Historiker, V, red. HansUlrich Wehler. Goettingen: Vandenhoeck und Ruprecht, 1980, blz. 37-54.

Steinberg, Sigfrid H. en Christine Steinberg-Von Pape, Die Bildnisse geistlicher und weltlicher Fürsten und Herren. [Die Entwicklung des menschlichen Bildnisses, III] Leipzig, Berlijn: Teubner, 1931.

Steinhausen, Georg, Geschichte des deutschen Briefes. Zur Kulturgeschichte des deutschen Volkes. Berlijn: 1889-1891. 
Steinhausen, Georg, 'Der Gruß und seine Geschichte', in: Täglicher Rundschau (1891a), ook in: id., Kulturstudien. Berlijn: 1893.

Steinhausen, Georg, 'Kulturgeschichte [literatuurreferaat]', in: Jahresberichte für neuere deutsche Literaturgeschichte 2 (1891b), blz. 79-102.

Steinhausen, Georg, 'Allgemeine Kulturgeschichte [literatuurreferaat]', in: Jahresberichte der Geschichtswissenschaft (1892a), blz. IV, 5-30.

Steinhausen, Georg, 'Der Streit um die Culturgeschichte', in: Die Gegenwart 41 (1892b), blz. 53-56.

Steinhausen, Georg, 'Die Kulturgeschichte und die deutschen Universitäten [1891]', in: Zeitschrift für deutsche Kulturgeschichte NF 2 (1892c), blz. 256-259.

Steinhausen, Georg, 'Kulturgeschichte [literatuurreferaat]', in: Jahresberichte für neuere deutsche Literaturgeschichte 3 (1892d), blz. I 4:1-857.

Steinhausen, Georg, 'Allgemeine Kulturgeschichte [literatuurreferaat]', in: Jahresberichte der Geschichtswissenschaft (1893a), blz. IV, 8-48.

Steinhausen, Georg, Kulturstudien. Berlijn: 1893b.

Steinhausen, Georg, 'Mitteilungen und Notizen', in: Zeitschrift für Kulturgeschichte 1 (1894a), blz. 244-250.

Steinhausen, Georg, '[recensie Bernheim, Lehrbuch, 2e dr.]', in: Zeitschrift für Kulturgeschichte 1 (1894b), blz. 349-351.

Steinhausen, Georg, 'Zur Einführung', in: Zeitschrift für Kulturgeschichte 1 (1894c), blz. 1-4.

Steinhausen, Georg, red. Briefwechsel Balthasar Paumgartners des Jüngeren mit seiner Gattin Magdalena,geb. Behaim (1582-1598). [Bibliothek des Literarischen Vereins in Stuttgart, Bd. 204]. Tübingen: 1895a.

Steinhausen, Georg, Der Wandel deutschen Gefühlslebens seit dem Mittelalter. Eine Jenaer Rosenvorlesung. [Sammlung gemeinverständlicher wissenschaftlicher Vorträge, n.F., 10. Serie, Heft. 22] Hamburg: Verlagsanstalt und Druckerei A.G. (vormals J.F. Richter), 1895b.

Steinhausen, Georg, 'Professoren der Kulturgeschichte?', in: Zeitschrift für Kulturgeschichte 2 (1895c), blz. 192-198.

Steinhausen, Georg, 'Der Streit um die Kulturgeschichte', in: Die Nation 51? (1896a), blz. 763-766.

Steinhausen, Georg, 'Gustav Freytags Bedeutung für die Geschichtswissenschaft', in: Zeitschrift für Kulturgeschichte 3 (1896b), blz. 1-20.

Steinhausen, Georg, 'Freytag, Burckhardt, Riehl und ihre Auffassung der Kulturgeschichte', in: Neue Jahrbücher für das klassische Altertum 1 (1898a), blz. 448-458.

Steinhausen, Georg, Häusliches und gesellschaftliches Leben im neunzehnten Jahrhundert. [Am Ende des Jahrhunderts, 4] Berlijn: Cronbach, 1898b.

Steinhausen, Georg, 'Ueber den Plan einer zusammenfassenden Quellenpublikation für die deutsche Kulturgeschichte', in: Zeitschrift für Kulturgeschichte 5 (1898c), blz. 439-450.

Steinhausen, Georg, Der Kaufmann in der deutschen Vergangenheit. [Monographien zur deutschen Kulturgeschichte, 2] Leipzig: Diederichs, 1899.

Steinhausen, Georg, red. Denkmäler der deutschen Kulturgeschichte [I: Deutsche Privatbriefe. II: Deutsche Hofordnungen]. Berlijn: 1899-1907a.

Steinhausen, Georg, red. Deutsche Privatbriefe des Mittelalters. I: Fürsten und Magnaten, Edle und Ritter. II: Geistliche, Bürger. [Denkmäler der deutschen Kulturgeschichte I, 1-2.] Berlijn: Weidmannsche Buchhandlung, 1899-1907b. 
Steinhausen, Georg, '[rec. van Scherr, Deutsche Kultur- und Sittengeschichte]', in: Zeitschrift für Kulturgeschichte 7 (1900), blz. 292-293.

Steinhausen, Georg, '[rec. van Breysig, Kulturgeschichte der Neuzeit, I-II.1]', in: Zeitschrift für Kulturgeschichte 8 (1901), blz. 359-363.

Steinhausen, Georg, '[rec. van Breysig, Kulturgeschichte der Neuzeit, II.2]', in: Zeitschrift für Kulturgeschichte 9 (1902), blz. 105-107.

Steinhausen, Georg, '[rec. van Lamprecht, Deutsche Geschichte, Erg. Bnde I + II.1]', in: Archiv für Kulturgeschichte 1 (1903), blz. 361-367.

Steinhausen, Georg, Geschichte der deutschen Kultur, 1e dr. Leipzig, Wien: Bibliographisches Institut, 1904.

Steinhausen, Georg, Germanische Kultur in der Urzeit. [Aus Natur und Geisteswelt, 75] Leipzig: 1905a.

Steinhausen, Georg, '[recensie Bernheim, Lehrbuch, 3e/4e dr.]', in: Archiv für Kulturgeschichte 3 (1905b), blz. 235-237.

Steinhausen, Georg, 'Zur Charakteristik des Historikers Karl Lamprecht', in: Archiv für Kulturgeschichte 3 (1905c), blz. 366-371.

Steinhausen, Georg, '[rec. van Breysig, Stufen-Bau und die Gesetze der WeltGeschichte]', in: Archiv für Kulturgeschichte 4 (1906), blz. 87-95.

Steinhausen, Georg, 'Kultur und Volkstum', in: Archiv für Kulturgeschichte 8 (1910), blz. 129-145.

Steinhausen, Georg, 'Das deutsche Volk.' In: Schaffen und Schauen. Ein Führer ins Leben, red. A. Giesecke-Teubner. Leipzig, Berlijn: Teubner, 1911, blz.

Steinhausen, Georg, Geschichte der Deutschen Kultur. 2de, herz. dr., Leipzig, Wenen: Bibliographisches Institut, 1913.

Steinhausen, Georg, Kulturgeschichte der Deutschen im Mittelalter. [Wissenschaft und Bildung, 88] 3de, herz. dr., Leipzig: Quelle \& Meyer, 1921 [1e dr. 1910].

Steinhausen, Georg, 'Die deutsche Kultur.' In: Der Deutsche Genius, red. Rudolf Eucken. 2e dr., Falkenberg /Mark: Deutsche Büchereigesellschaft, 1922, blz. 520.

Steinhausen, Georg, 'Deutscher Nationalcharakter.' In: Politisches Handwörterbuch, red. P. Herre. Leipzig: 1923a, blz. 391-394.

Steinhausen, Georg, 'Verfallsstimmung im kaiserlichen Deutschland', in: Preußische Jahrbücher 194 (1923b), blz. 153-185.

Steinhausen, Georg, '[Selbstdarstellung].' In: Die Geschichtswissenschaft der Gegenwart in Selbstdarstellungen, I, red. Sigfrid Steinberg. Leipzig: Felix Meiner, 1925, blz. 233-274.

Steinhausen, Georg, Der politische Niedergang Deutschlands in seinen tieferen Ursachen. Osterwieck: 1927.

Steinhausen, Georg, Geschichte der Deutschen Kultur. 3de, herz. dr., Leipzig: Bibliographisches Institut, 1929 [1e dr. 1905].

Steinhausen, Georg, Deutsche Geistes- und Kulturgeschichte von 1870 bis zur Gegenwart. Halle a.S.: Max Niemeyer Verlag, 1931.

Steinhausen, Georg en Ernst Bernheim, 'Ein neuer Gegner der Kulturgeschichte. Erwiderung auf Benedetto Croces Schrift: Intorno alla Storia della coltura', in: Zeitschrift für Kulturgeschichte 3 (1896), blz. 318-324.

Steinhausen, Georg en [Goetz?], 'An die Leser des Archivs für Kulturgeschichte', in: Archiv für Kulturgeschichte 8 (1910), blz. 1-3.

Steinle, Juergen, 'Geschichtsmethode und Politik bei Karl Lamprecht', in: Archiv für Kulturgeschichte 77 (1995), blz. 405-428. 
Steinthal, Hajim, Philologie, Geschichte und Psychologie in ihren gegenseitigen Beziehungen. Ein Vortrag gehalten in der Versammlung der Philologen zu Meißen 1863 in erweiternder Überarbeitung. Berlijn: Ferd. Dümmler, 1864.

Steinthal, Hajim, 'Zusatz zum vorstehenden Artikel [Windelband, 'Die Erkenntnislehre unter dem völkerpsychologischen Gesichtspunkte']', in: Zeitschrift für Völkerpsychologie und Sprachgeschichte 8 (1875), blz. 178-189.

Stenzler, R., F. Lindner en H. Landwehr, Lehr- und Lesebuch der Geschichte von der Gegenwart bis auf Kaiser Karl d. Großen für die unteren Klassen höherer Lehranstalten. Berlijn: 1891.

Stieg, Margaret F., The origin and development of scholarly historical periodicals. Alabama: University of Alabama Press, 1986.

Stoffers, Manuel, 'De geschiedenis van de psychologen en de geschiedenis van de psyche', in: Theoretische Geschiedenis 23 (1996a), blz. 231-236.

Stoffers, Manuel, '[rec. van S. Haas, Historische Kulturforschung in Deutschland, 1880-1930 (1994)]', in: Theoretische Geschiedenis 23 (1996b), blz. 111-113.

Stoffers, Manuel, 'Versnelling, nervositeit en geschiedenis. Over de betekenis van de eigen tijd voor de Duitse cultuurgeschiedschrijving tussen 1890 en 1930', in: Kennis en methode. Tijdschrift voor empirische filosofie 21 (1997), blz. 192203.

Stoffers, Manuel, 'Münsterberg's Nightmare: Psychology and History in Fin-de-Siècle Germany and America', in: Journal of the History of the Behavioral Sciences 39 (2003), blz. 163-182.

Sybel, Heinrich von, 'Vorwort', in: Historische Zeitschrift I (1859), blz. [III]-V.

Sybel, Heinrich von, 'Über den Stand der neueren deutschen Geschichtsforschung.' [1856] In: id., Kleine historische Schriften, I, 3de dr., München: Cotta, 1880, blz. 351-364.

Taine, H.A., De l'intelligence. Parijs: Hachette, 1870.

Taine, H.A., Histoire de la littérature anglaise. 4de dr., Parijs: Hachette, 1877/78 [1e dr. 1863].

Tetens, Johann Nicolas, Philosophische Versuche über die menschliche Natur und ihre Entwicklung. Leipzig: Weidmanns Erben \& Reich, 1777.

Thielen, Joachim, Wilhelm Dilthey und die Entwicklung des geschichtlichen Denkens in Deutschland im ausgehenden 19. Jahrhundert. Würzburg: Königshausen und Neumann, 1999.

Tollebeek, Jo, De toga van Fruin. Denken over geschiedenis in Nederland sinds 1860. Amsterdam: Wereldbibliotheek, 1990.

Treiber, Hubert, 'Der 'Eranos'. Das Glanzstück im Heidelberger Mythenkranz.' In: Asketischer Protestantismus und der 'Geist' des modernen Kapitalismus. Max Weber und Ernst Troeltsch, red. Wolfgang Schluchter en F.W. Graf. Tübingen: Mohr Siebeck, 2005, blz. 75-153.

Treitschke, Heinrich von, Die Gesellschaftswissenschaft. Ein kritischer Versuch. Leipzig: Hirzel, 1859.

Uhde-Bernays, Hermann, 'Eberhard Gothein.' In: id., Mittler und Meister. Aufsätze und Studien, München: Leibniz-Verlag, 1948, blz. 111-129.

Üner, Elfriede, 'Leipziger Schule und historische Soziologie.' In: Karl Lamprecht weiterdenken. Universal- und Kulturgeschichte heute, red. Gerald Diesener. Leipzig: Leipziger Universitätsverlag, 1993, blz. 295-312.

Verhandlungen (1910), Verhandlungen des Ersten Deutschen Soziologentages vom 19.22. Oktober 1910. Tübingen: J. C. B. Mohr, 1910. 
Viikari, Matti, Die Krise der 'historistischen' Geschichtsschreibung und die Geschichtsmethodologie Karl Lamprechts. Helsinki: 1977.

Voigt, Friedemann, 'Vorbilder und Gegenbilder. Zur Konzeptualisierung der Kulturbedeutung der Religion bei Eberhard Gothein, Werner Sombart, Georg Simmel, Georg Jellinek, Max Weber und Ernst Troeltsch.' In: Asketischer Protestantismus und der 'Geist' des modernen Kapitalismus. Max Weber und Ernst Troeltsch, red. Wolfgang Schluchter en F.W. Graf. Tübingen: Mohr Siebeck, 2005, blz. 155-184.

Vorländer, Karl, Geschichte der Philosophie. 5e dr., Leipzig: Felix Meiner Verlag, 1919 [1e dr. 1903].

Wachler, Ludwig, Geschichte der historischen Wissenschaften. Göttingen: 1812-1820.

Weber, Max, 'Roscher und Knies und die logischen Probleme der historischen Nationalökonomie.' In: Gesammelte Aufsätze sur Wissenschaftslehre, red. Johannes Winckelmann. Tübingen: Mohr/Siebeck, 1988, blz. 1-145.

Weber, Max, Gesammelte Werke. Mit der Biographie »Max Weber. Ein Lebensbild" von Marianne Weber. [CD Rom Digitale Bibliothek 58] Berlijn: Directmedia Publishing, 2001.

Weber, Wolfgang, 'Wissenschaftssoziologische Aspekte des Strukturwandels der Geschichtsiwwsenschaft von der Aufklärung zum Historismus.' In: Von der Aufklärung zum Historismus. Zum Strukturwandel des historischen Denkens, red. Horst Walter Blanke en Jörn Rüsen. Paderborn, etc.: Schöningh, 1984, blz. 73-90.

Weber, Wolfgang, Biographisches Lexikon zur Geschichtswissenschaft in Deutschland, Österreich und der Schweiz. Die Lehrstuhlinhaber für Geschichte von den Anfängen des Faches bis 1970. 2e dr., Frankfurt a.M. etc.: Peter Lang, 1987a.

Weber, Wolfgang, Priester der Klio. Historisch-sozialwissenschaftliche Studien zur Herkunft und Karriere deutscher Historiker und zur Geschichte der Geschichtswissenschaft 1800-1970. 2e dr., Frankfurt a.M. etc.: Peter Lang, $1987 \mathrm{~b}$.

Wegele, Franz X. von, Geschichte der deutschen Historiographie seit dem Auftreten des Humanismus. [Geschichte der Wissenschaften in Deutschland. Neuerer Zeit, Bd. 20] München, Leipzig: Oldenbourg, 1885.

Weigand, Wolf V., Walter Wilhelm Goetz, 1867-1958. Eine biographische Studie über den Historiker, Politiker und Publizisten. Boppard: 1992.

Werner, Karl Ferdinand, 'Historisches Seminar - Ecole des Annales. Zu den Grundlagen einer europäischen Geschichtsforschung.' In: Geschichte in Heidelberg. 100 Jahre Historisches Seminar. 50 Jahre Institut für Fränkisch-Pfälzische Geschichte und Landeskunde, red. J. Miethke. Berlijn [etc.]: 1992, blz. 1-38.

Wesseling, H.L., 'De Annales en de contemporaine geschiedenis.' In: id., Onder historici. Opstellen over geschiedenis en geschiedschrijving, Amsterdam: Bert Bakker, 1995, blz. 163-176.

Westphal, Otto, Feinde Bismarcks. Geistige Grundlagen der deutschen Opposition, 1848-1918. München/Berlijn: 1930.

Whimster, Sam, 'Die begrenzten Entwicklungsmöglichkeiten der Historischen Soziologie im "Methodenstreit": Karl Lamprecht und Max Weber.' In: Max Weber und seine Zeitgenossen, red. W.J. Mommsen en W. Schwentker. Göttingen/Zürich: 1988, blz. 380-402.

Wieland, W., 'Entwicklung, Evolution.' In: Geschichtliche Grundbegriffe, 2, red. O. Brunner, e.a. Stuttgart: 1979, blz. 199-228. 
Wiemers, Gerald, 'Die Anfänge der Sächsischen Kommission für Geschichte.' In: Geschichtsforschung in Sachsen. Von der Sachsischen Kommission für Geschichte zur Historischen Kommission bei der Sächsischen Akademie der Wissenschaften zu Leipzig 1896-1996, red. R. Groß, e.a. Stuttgart: Franz Steiner Verlag, 1996, blz. 13-43.

Wilhelm II, e.a., Verhandlungen über Fragen des höheren Unterrichts. Berlin, 4. bis 17. Dezember 1890. Berlijn: 1891.

Winkel, Harald, Die deutsche Nationalökonomie im 19. Jahrhundert. Darmstadt: WBG, 1977.

Winter, Georg, 'Karl Lamprecht', in: Die Gesellschaft: realistische Wochenschrift, Litteratur, Kunst und öffentliches Leben 17 (1898), blz. 296-314.

Wittkau, Annette, Historismus. Zur Geschichte des Begriffs und des Problems. 2de dr., Göttingen: Vandenhoeck \& Ruprecht, 1994 [1e dr. 1992].

Wolf, Gustav, Einführung in das Studium der neueren Geschichte. Berlijn: Weidmannsche Buchhandlung, 1910.

Wood, P.B., 'The natural history of man in the Scottish Enlightenment', in: History of science 27 (1990), blz. 89-123.

Zinnecker, Andrea, Romantik, Rock und Kamisol. Volkskunde auf dem Weg ins Dritte Reich - die Riehl-Rezeption. Münster, New York: 1996.

Zorn, Wolfgang, 'Eberhard Gothein 1853-1923.' In: Bonner Gelehrte: Beiträge zur Geschichte der Wissenschaften in Bonn. Geschichtswissenschaften, Bonn: 1968, blz. 260-271.

Zorn, Wolfgang, "Volkswirtschaft und Kulturgeschichte' und 'Sozial- und Wirtschaftsgeschichte' - Zwei Zeitschriften in der Vorgeschichte der VSWG 1863-1900', in: Vierteljahrschrift für Sozial- und Wirtschaftsgeschichte 72 (1985), blz. 457-475.

Zwart, Hub, Boude bewoordingen. De historische fenomenologie ('metabletica') van Jan Hendrik van den Berg. Kampen, Kapellen: Klement \& Pelckmans, 2002. 


\title{
Register
}

\author{
van personen, plaatsen en enkele zaken
}

Verwijzingen naar de hoofdpersonen van deze studie, Kurt Breysig, Eberhard Gothein, Walter Goetz, Karl Lamprecht en Georg Steinhausen, zijn om voor de hand liggende redenen niet volledig in dit register opgenomen. De inhoudsopgave biedt de beste algemene toegang tot de verschillende aspecten van hun werk die in deze studie aan de orde komen. Wel is in het register onder hun naam een selectie van in dit boek besproken publicaties van hun hand terug te vinden en zijn enkele specifiekere subthema's via het register terug te vinden.

Uitsluitend in literatuurreferenties voorkomende secundaire auteurs zijn niet opgenomen in het register. Als een paginanummer voorzien is van de toevoeging ' $n$ ', komt de betreffende naam of zaak uitsluitend in een voetnoot op die pagina voor.

Adelung, J. Chr. 205n, 207

Alldeutscher Verband 85, 269, 278

Almond, Gabriel 111

Althoff, Friedrich 31, 147, 148, 158, 160, 161, 162.

Aly, Friedrich 35, 37, 183n, 226n.

American Psychological Association 14

Amerika 14, 38, 121, 248, 252, 257

Annales (ESC) 4-7, 17, 285

Antisemitisme 47, 138n, 140n, 190

Archiv für Kulturgeschichte (zie ook Zeitschrift für Kulturgeschichte) 19, 39, 40, 4244, 46, 72, 109-111, 125, 153, 154, 158, 226, 232.

Arens, Franz 44

Ariès, Philippe 5, 17

Associatiepsychologie 206

Aubin, Hermann 291

Augsburg 213

Bacon, Francis 205, 206

Badische Historische Kommission 147, 151, 154, 158, 162

Barbu, Zevedei 15

Baron, Hans 43, 111

Barth, Paul 38

Bauer, Stephan 31

Bauer, Wilhelm 40, 132n

Baumgarten, Hermann 47, 51, 146, 147.

Beard, George M. 19, 254, 259, 260, 267.

Beloch, Julius 56n

Below, Georg von, 24, 26, 28, 31, 36-39, 42, $43,56,60,61,110,111,115,135,140$, $145,147-150,152,160,167-169,171-173$, 175-177, 179-183, 189-191, 193, 195, 196, 199, 201, 203, 204, 208, 211, 240, 242, 243, 282, 285, 288.
Benjamin, Walter 257n

Berg, J.H. van den 14, 17

Berlijn (m.n. universiteit van), 32, 37, 38, 49, $60,63,74,95,97,130,135,137,138,142$, $143,144,147,153,158,161,162,169$, $226,228,235,256,257,265$

Bernheim, Ernst 18, 26-35, 45, 63, 74, 94, 97, $124,140,154,165,171,179,186,198-$ 201, 204, 208, 219-221, 224-227, 234, 245, 288, 289, 290.

Berr, Henri 14

Bevrijdingsoorlogen 20, 179

Bezold, Friedrich von 31, 42, 43, 45, 153

Biedermann, Karl 63, 210, 211, 224

Bismarck, Otto von 12, 41, 47, 77, 197, 271, 272, 278, 280.

Bloch, Marc 5, 6, 15, 33n

Blok, P.J. 74, 76

Blondel, Charles 14

Boer, Pim den 4-6

Bonn (m.n. universiteit van) 32, 49, 59, 76, $142,143,144,147,148,149,153,159$, $160,161,162$

Brandenburg 137

Brandi, Karl 36, 59, 118.

Brentano, Lujo 157-159, 161, 235, 243, 244, 270-272, 274

Breslau (m.n. universiteit van) 47, 137, 138, $140,142,143,144,146,157,158,228$, 233, 256, 272.

Bresslau, Harry 36, 140n

Breysig, J.A. 124

Breysig, Kurt

- 'Die sociale Entwicklung der führenden Völker Europas' 96

- 'Ueber Entwicklungsgeschichte' 96, 147 
- Nietzsches ethische und sociologische Anschauungen' 100

- 'Die Historiker der Aufklärung' 181

- Kulturgeschichte der Neuzeit 18, 37, 94103, 106-108, 123, 151, 169, 172, 187, 214, 215, 232

- Der Stufen-Bau und die Gesetze der WeltGeschichte 97

- Die Geschichte der Menschheit 97

- Seminar fur vergleichende Geschichtsforschung 37, 97, 232n, 252

- Von Gegenwart und Zukunft des deutschen Menschen 274

- Geschichte der Seele 99-100, 103-106

- Vom deutschen Geist 105n

Brinkmann, Carl 43, 45, 47n, 49n, 50n, 53n, $55 \mathrm{n}$

Brocke, Bernhard vom 94, 99n

Bronnen (historische, gebruik van), 3, 4, 7, 32, $61,81,85,86,109,115,116,119$ n, 126$128,144,161,167,168,171,173-175$, $180,200,214,235,241,288$

Bruder, A. 160

Brush, K. 19n, 80

Bücher, Karl 150n, 158n, 160, 163, 225n, 240, $243,244 n$

Buchholz, Gustav, 26, 27n, 37n, 142, 146n, $180 \mathrm{n}, 201 \mathrm{n}$

Buckle, Henry Thomas 25n, 79, 190, 211, 212, 217-221, 229, 230, 233

Bugra (1914) 80, 118.

Burckhardt, J. 48n, 52, 53, 55, 56, 60n, 67, 88, 119, 146, 169, 200, 202, 204, 210-212, 214-216, 219-221, 233, 234, 245, 289.

Burke, Peter 5, 6

Busch, Wilhelm 150

Calau 247

Calvinisme 50

Campanella, Thomas 52

Carlyle, Th. 64

Carnegie, Andrew 155n

Caro, J. 31, 42

Carus, F.A. 207

Cassirer, Ernst 44

Chicago 31, 49, 248

Communicatie (als onderwerp van de cultuurgeschiedenis, zie ook Transport) 3 , $66,81,89,91,125,132,237,251,253$, $255,257,287$

Comte, Auguste 15, 79, 198n, 217-220, 227n, $233 n$

Condorcet 181, 206.

Conrady, August 77, 154.

Contrareformatie 48, 52, 54

Corbin, Alain 5

Croce, Benedetto 10, 165

Culture and personality school (antropologie) 14
Cultuurbegrip 27-30, 51-52, 62-64, 66-70, 73$76,96-98,111-112,120-123,124-125$, 128-134, 204-207

Curschmann, Fritz 40

Daenell, Ernst 40

Dahlmann, F.C. 146

Dante 109, 115

Darwin, Erasmus 206n

Darwin, Charles 90n, 177n, 203, 217, 219n, 220

Darwinisme (incl. sociaal-d.) 74, 87, 183, 210 , $211,219,221$.

Decadentie 264

Degeneratie 219

Delbrück, Hans 24, 37, 47, 135, 147, 152, 155 , 177, 244n, 282.

Democratie 12, 25, 102, 211, 269, 276-283, 285

Descartes, René 206

Deutsche Demokratische Partei 271, 278, 282

Deutsche Geschichtsblätter 39, 126, 154

Deutsche Gesellschaft für Soziologie 30, 94, $132,153,243$.

Deutscher Ikonographischer Ausschuß 118

Deutsche Zeitschrift für Geschichtswissenschaft 26, 27, 30, 35, 37, 151, 154.

Deutschnationale Volkspartei 278, 282

Devrient, Ernst 78n, 198n.

'Diapason' (Lamprecht) 86, 172, 262

Dilthey, Wilhelm 10, 11, 19, 40, 51, 93, 128, $132,145,157,162,170,173,176,177$, 190, 196, 198, 205, 219, 226-234, 245, 285, 290, 291.

Dopsch, Alphons 36, 40, 42, 60n.

Dove, Alfred 33, 47, 53, 146-149, 167, 169, $172,176,183$.

Dreiklassenwahlrecht (Pruisen) 278, 280

Driften 66, 69, 88, 89, 104, 127, 220, 231, 236, 263

Droysen, Johann Gustav 25, 47n, 136, 146n, $147 \mathrm{n}, 177,183-185,221 \mathrm{n}, 239,241,288$

- Historik 27-28, 167n, 185, 190-197, 202203

Drumann, W. 210

Du Bois-Reymond, Emil 28, 30, 79, 212, 220, 221.

Duby, Georges 5

Economie (als onderwerp van cultuurgeschiedenis, zie ook Nationalökonomie) 3, 10-11, 24, 27, 29, 31, 33, 34, 39, 40, 41, 47-51, 53, 55n, 62, 67, 68, 73, 75-83, 87, 89-91, 94, 97, 98, 106, 111, 112, 116, 120, 124-125, 127, 133, 148-149, 154, 157-163, $168-170,173,197,219,234,235,242-243$, 249, 251-259, 262-268, 270-274, 279, 283, 286

Egodocumenten (als bron van de historicus) 3, 65, 126, 127, 214.

Elias, Norbert 14, 43, 90 
Engagement (van historici) 185-188, 243-245, 249, 282, 287, 290.

Engelberg, Ernst 11n, 12n.

Epigenisten, 203n

Eranos-kring (Heidelberg) 54, 56.

Erb, Wilhelm 3, 66, 259.

Erdmannsdörffer, Bernhard 46n, 146, 158, 166, 169-170, 177, 186, 198, 201, 208, $211 \mathrm{n}, 214 \mathrm{n}, 226,227 \mathrm{n}, 288$.

Erfurt 137, 291

Ethology (John Stuart Mill), 217, 221, 239n

Eulenburg, Franz 7, 38, 160, 238, 243, 244n

Evolutie (zie ook Darwin) 93, 183, 203, 205, 218,220

Expressionisme 145, 261

Falke, J. 210, 211

Febvre, Lucien 5, 6, 14, 15, 285.

Feminisme 16, 267

Fenomalisme 254, 260

Ferguson, Adam 181

Fichte, J.G. 175n, 195n

Filologie 32n, 143, 145, 155

Finke, Heinrich 37, 38, 42, 43, 60, 135, 140, $145,147,150,152,153,167,282$

Fischer, Wolfram 49

Forschungen zur brandenburgischen und preußischen Geschichte 151

Forschungen zur deutschen Geschichte 151

Foucault, M. 14

Franciscus van Assisi 109

Frankfurt 34, 61, 89, 142, 240

Franse Revolutie 178, 180, 230, 277

Freiburg (m.n. universiteit van) 49, 142, 143, $144,147,150,157,158$

Freikonservatieve Partei 282

Freud, Sigmund 10, 14n

Freyer, Hans 44, 155, 291

Freytag, Gustav 19, 44, 67, 210, 211, 212, 213214, 215, 216, 221n, 234, 245, 289

- Bilder aus der deutschen Vergangenheit 214-215

Friedell, Egon 19, 43

Friedländer, Ludwig 63

Frijhoff, Willem 4, 5, 17

Frobenius, Leo 43

Fuchs, Eckhardt 177, 178

Gatterer, J.C. 181

Geiger, Theodor 15, 21

Geist vs. Seele/Psyche 15-16, 78n, 96, 112115, 195, 201-202, $204,236$.

Geistesgeschichte 6, 40, 51, 112-120, 201, $215 \mathrm{n}, 285$

Geisteswissenschaften 51n, 57, 93, 228-229, 236

Gelzer, Heinrich 36, 42, 43, 146n, 215n

Genealogie (m.n. volgens O. Lorenz) 18, 78, 197

George, Stefan 130, 261

Gergen, Kenneth 14

Germanen 65, 68, 76, 88, 210
Germanisches (National) Museum

(Neurenberg) 210

Gervinus, G.G. 186

Geschichtliche Untersuchungen 39

Gesellschaft für Rheinische Geschichtskunde 148, 153

Gesellschaftswissenschaften 30, 57, 224

Gierke, Otto von 158n

Giesebrecht, W. von 178, 179

Gießen (universiteit van) 142, 144n, 150n

Giotto 120

Goethe, J.W. von 96, 180, 189, 250, 254

Goetz, Walter

- 'Geschichte und Kulturgeschichte' 109112

- Bedeutung von Persönlichkeit und Gemeinschaft 113-114

- Historische Bildkunde (red.) 118

- Die Entwicklung des menschlichen Bildnisses 117

- Propyläen Weltgeschichte 113, 116, 120123, 252, 255, 257, 258

- 'Die Rassenforschung' 115

- 'Die Entwicklung des Wirklichkeitssinnes' 119-120

- Quellen zur Geistesgeschichte des Mittelalters und der Renaissance 115-116

- Beiträge zur Kulturgeschichte des Mittelalters und der Renaissance 116

Goldfriedrich, Johannes 37n, 132n, 180n, $181 n, 201$

Goldstein, Julius 173n

Gooch, G.P. 60

Görres, J. von 186

Gothein, Eberhard

- Der Gemeine Pfennig (diss.) 46

- Politische und religiöse Volksbewegungen 47, 54, 55, 56, 197

- Der christlich-sociale Staat der Jesuiten 52-53, 272

- Die Culturentwicklung Süditaliens 48, 5355, 124 147, 233

- Die Aufgaben der Kulturgeschichte 46, 48, 50-52, 54-56, 66, 133

- Wirtschaftsgeschichte des Schwarzwaldes 48, 49, 50, 59

- Ignatius von Loyola und die Gegenreformation 48, 54, 55

- Die geschichtliche Entwicklung der Rheinschiffahrt 49, 273

- $\quad$ Die Stadt Cöln 49, 273

- $\quad$ Soziologie der Panik, 56-58

Gothein, Marie Luise 267

Gothein, Percy 130

Göttingen (m.n. universiteit van) 138, 142, $143,144,158,159,198,200,235$

Grauert, Hermann 63, 152

Greifswald (m.n. universiteit van) 137, 142144, 198

Grimm, Hermann 63n, 175, 177n, 226 
Groethuysen, Bernhard 43, 285

Grundmann, Herbert 40

Guizot, François 220

Günther, Felix 173n, 174n, 179, 206n

Gurevic, A.J. 15n, 116n, 217n

Gymnasium 136-139

Haas, Stefan 9, 12, 13, 44n, 60n, 124n, 179n, 182n, 210n, 216n, 290

Haeckel, Ernst 219, 224

Hagen, Karl 186

Halle-Wittenberg (universiteit van) 142-144

Hamburg (incl. universiteit van) 43, 142, 155, $247,253,257$

Hampe, Karl 40, 42, 43, 44, 68, 117, 146

Handbuch der mittelalterlichen und neueren Geschichte (Below \& Meinecke, 1903ff.) 39, 149

Handwörterbuch der Staatswissenschaften 160 Hansen, Reginald 239

Hanssen, Georg 157-159, 162, 235

Harden, Maximilian 45, 108, 206

Hartley, David 206n

Hartmann, Ludo M. 31n

Hashagen, Justus 40, 42, 43

Hauptmann, Gerhard 261

Häusser, Ludwig 168, 185n, 186

Haussman, R. 153

Hegel, G.W.F. 58, 175n, 195n

Heidelberg (m.n. universiteit van) 32, 43, 44, $49,60,129,142,143,144,146,157,158$, $159,186,233,260,267$

Hellpach, Willy 38, 44, 226, 254, 258, 260

Hellwald, Friedrich Heller von 25, 212n, 216n, $221 n$

Helmolt, Hans 146n

Henne am Rhyn, Otto 25, 216n, 212n

Herbart, J.F. 222, 223, 229, 230, 238, 245

Herbartianisme 20, 221-234, 237

Herbst, Wilhelm 136

Herder, J.G. 108, 181, 192, 207n

Hildebrand, Bruno 235, 236, 238, 240

Hinneberg, Paul 26, 177n

Hintze, Otto 38, 145, 152, 153, 160n, 167n, 197,201

Historikertage 30, 33-36, 38, 45, 55, 61, 75, $82,88,144,154,156,163,186,201,215$, 256, 291

Historische Jahrbücher 160

Historische Kommission (München / Beierse Akademie van Wetenschappen) 148, 149, $151 n, 153,156,185$

Historische psychologie 4, 5, 9, 13-17, 18, 20, $46,55-59,65,128,131,176 \mathrm{n}, 197,212 \mathrm{n}$, 216, 219n, 236, 260, 261, 283, 285, 287

Historische School (Nationalökonomie) 20, $157,162,163,221,234-245,282,290$

Historisches Taschenbuch $151 \mathrm{n}$

Historische Vierteljahrschrift 27, 37, 154
Historische Zeitschrift 24, 26, 27, 35, 37, 39, $40,41,43,44,63,149,151-153,156,165$, 169, 177, 184, 221

Historisch-Politische Zeitschrift (Ranke) 184

Historisme 10, 20, 30, 165-208, 209, 211, 221, 239, 240, 264, 286, 287, 288, 289

Hodiecentrisme (zie ook Engagement) 7, 13, $188,249,285,287$

Hoffmeister, Kay 8n, 12n, 281

Hofmannsthal, Hugo von 261

Hofrechtstheorie 55, 242

Holst, Hermann von 158

Honegger, J. 216

Hughes, Henry Stuart 9-10

Humboldt, Wilhelm von 167, 193-196

Hume, David 192

Ideeën(leer) 52-54, 193-195, 201-202, 223n

Iggers, Georg 6, 8, 11, 12, 23, 123

Impressionisme 81, 89, 145, 261-262

Inama-Sternegg, K. Th. Von 163

Individu 16, 59, 75, 96, 97, 98, 102, 103, 113, $114,116,119,188,189,190,191,194$, 196, 197, 207, 222, 268, 271, 274, 275, $276,277,281,286,287$

Individualisme (als thema van de cultuurgeschiedenis) 69, 83, 88, 89, 109, 117-119, $128,133,149,215,278,287$

Individualisme (als overtuiging) 25, 59, 74-75, 100, 102-103, 110, 113-116, 120, 130, 181n, 188-190, 196n, 244, 272-274, 283, 287

Industrie 10, 138, 248, 265, 273, 274, 289

Innsbruck 61

Institut für Altertumskunde (Berlijn) 155

Institut für Kultur und Universalgeschichte (IKU, Leipzig) 39, 40, 80n, 85-87, 90, 97, $109,112,113,117 \mathrm{n}, 118,121,123,131$, $154-156,175 \mathrm{n}, 198 \mathrm{n}, 258,290$

Internationaal Congres van Historische Wetenschappen (Oslo 1928) 118

Internationaal Congres van Historische Wetenschappen (Berlijn, 1908) 38, 175n

Internationalisering (als thema en achtergrond van de cultuurgeschiedenis) 251-253

Irwing, Karl Franz von 206, 207

Jahoda, Gustav 16, 192n, 206n, 207n, 217n, 219n, 222n, 224n, 225n

Jahrbücher für Nationalökonomie und Statistik 160

Jahresberichte der Geschichtswissenschaft 26, 27n, 31, 34n, 39, 60-61, 146, 156, 162n

Jastrow, Ignaz 63n, 146n, 162n, 177n

Jenisch, Daniel 205n

Jessen 137, 247, 248

Kant, Immanuel 205n

Kapitalisme (als onderwerp en achtergrond van de cultuurgeschiedenis, incl. Vrije onderneming) $11,50,77,81,197,258$, $261,263,265,266,268,270,273,282$, 291 
Karl Lamprecht Gesellschaft (Leipzig) 8

Karlsruhe (m.n. TH van) 48, 147, 150, 158

Kathedersocialisme 162, 244, 269, 270, 274

Katholicisme 41, 47, 54-55, 138n, 140, 149, $152 \mathrm{n}, 153 \mathrm{n}, 160,183 \mathrm{n}, 184,186$

Kaufmann, G. 33, 36

Kern, Fritz 40, 42, 43, 117n

Kindertekeningen 86, 90, 127, 155

Klemm, Gustav 211n, 216n

Knapp, G.F. 158, 159n, 163, 169n, 235, 240n

Knies, Karl 157, 158, 162, 235, 236, 240n

Kolb, G.F. 210n, 211n

Königsberg (Universiteit van) 142, 143, 144, 210, 222

Konservatieve Partei 190n, 282

Koser, R. 144, 177

Kosmopolitisme 85, 122, 126, 180, 181, 186, 251-253

Kötzschke, Rudolf 37n, 38, 39, 40, 42, 146n

Kraus, F.X. 158

'Kritische Historische Sozialwissenschaft' 1012

Kritische psychologie 14, 17

Krüger, Felix 87, 90n, 154

Kulturkampf 41, 47, 140

Kulturstufen zie Ontwikkelingsstadia

Kulturwissenschaften 57

Kunst (als thema en bron van de cultuurgeschiedenis) 23, 27, 32, 34, 51, 63n, 77, 78-81, 83, 86, 87, 88, 89, 97, 99, 102, 109, $112,118-120,124,126-127,130145 n$, 201, 204, 213, 215n, 232, 260-262, 268

Lamarck, J.B. 206, 219

Lamprecht, Karl

- Beiträge zur Geschichte des französischen Wirthschaftslebens (diss.) 75, 136, 174

- Deutsches Wirtschaftsleben im Mittelalter 75, 84, 174, 256

- $\quad$ Deutsche Geschichte 23, 35, 73n, 75, 76$77,80-85,88,89,97,118,149,167,168$, $169,172,173,212,216,224,249,251$, 252, 270

- $\quad$ Alte und neue Richtungen in der Geschichtswissenschaft 23, 73n

- 'Was ist Kulturgeschichte?' 35, 71, 73n, 77-79, 83, 84, 86, 91, 226n

- Americana 248-249

- $\quad$ Kindheitserinnerungen 247-248

- Beiträge zur Kultur- und Universalgeschichte 39, 225

Landschap \& natuur (als onderwerp van de cultuurgeschiedenis) $62,64,65,67,71,78$, 98, 116-117, 213, 265-266

Lazarus, Moritz , 19, 177n, 198-199, 221-230, 238,245

Le Goff, Jacques 5

Leerstoelen (historische) 32, 38, 63, 141-143, $147-150,152,153,156,169,289$

Lehmann, Max 60n, 160n, 167n, 176n, 189, 194n, 243n
Leipzig (m.n. Universiteit van) 6, 7, 8, 23, 24, $32,34,38,39,40,44,49,55,59,80,87$, $91,107,109,112,117,118,128,137,138$, $140,142,143,144,147,148,149,154$, $155,158,159,161,163,180,187,200$, $210,211,225,233,235,255,270$

Leipziger Studien aus dem Gebiet der Geschichte 39

Lélut, L.-F. $217 \mathrm{n}$

Lenz, Max 24n, 28, 37, 63n, 135, 145, 147, 150n, 152, 167, 170n, 172n, 183, 187

Leontjev, A.N. 17

Lexis, Wilhelm 158, 160n, 162, 235, 244n

Liberalisme 12, 16, 21, 28, 185-186, 211, 213, $244,269-284,285,287$

Lindner, Theodor 31n, 36, 42, 144n, 146n

Linksliberalisme 21, 185, 186, 271, 272n, 278, $280,281,282$

Lippert, Julius 25, 216n

Lipps, Theodor 92, 93, 264n

List, Friedrich 239

Löbell, J.W. 186

Locke, John 16, 206

Lorenz, Ottokar, 18, 25, 28n, 91, 146n, 177, 193n, 197-198, 201, 203, 212n, 221n, 226n, 288

Lurija, A.R. 14, 17, 217n

Luther, Martin 47, 140

Mach, Ernst 260

Malthus, T.R. 234, 239

Manchester-liberalen 274

Mandelbaum, Maurice 16

Mandrou, Robert 5, 10, 17

Mannheim, Karl 1, 285

Marburg 142, 143, 144, 148, 160, 162

Marcks, Erich 36, 38, 44, 110, 149

Martens, Richard 33

Marx, Karl 15, 79, 82, 201n, 217, 219, 220

Marxisme (zie ook Socialisme) 10-11, 12, 16, $17,24,217 \mathrm{n}$

Materialisme 10n, 13, 23, 27, 37, 140, 183, $186,188,191,221,223,225,226,283$, 285,286

Maurenbrecher, Wilhelm 47n, 166, 140n, $147 \mathrm{n}, 148,149,151 \mathrm{n}$

Maximiliaan I, Duits keizer 46, 148

Mehring, Franz 24

Meinecke, Friedrich 10, 11n, 24, 35n, 36-39, $110,113,135,145,147,150 \mathrm{n}, 152,153$, $165-166,167 \mathrm{n}, 176 \mathrm{n}, 177 \mathrm{n}, 178,182,183$, 190, 193n, 204n, 208, 261n, 282, 288

Meiners, Chr. 181

Meitzen, August 157n, 160, 161, 163, 235, $240 \mathrm{n}$

Menger, Carl 238, 239

Menke-Glückert, Emil 37n, 180n, 181n, 182n

Mentalité, Mentalität 6, 14n, 15-16, 64, 85

Menzel, K. 153n

Meyer, Eduard 178, 282

Meyer, Richard M., 226n 
Meyerson, Ignace 14, 15n

Miaskowksi, A. von 163

Middeleeuwen 48, 66, 70, 76, 77, 80-81, 8689 , 91, 97, 98, 101, 109, 115, 117, 119120, 122, 199-200, 214n, 249, 268n

Mill, John Stuart 16-17, 198n, 217-218, 221222, 228, 236, 239

Misch, Georg 128, 232

Mogk, Eugen 155

Mommsen, Theodor 162, 177, 226n, 278

Montesquieu 181, 192

Monumenta Germaniae Historica 61, 148n

Möser, Justus 181

Müller, J. 210n, 211n

Müller, Adam 239

München (m.n. Universiteit van) 32, 33, 49 , $100,140,142,143,144,157,158,210$, $211,213,214$

Münsterberg, Hugo 14, 91, 197n

Murray, A. 91

Natie (volk) 6, 7, 51, 54-55, 66-70, 84-86, 90, 105-106, 122, 191-192, 199, 211, 223, 237-238, 252, 266, 278, 281-282

Nationaal karakter: zie Volksgeest

Nationaal-socialisme 70, 281, 290-291

Nationalisme 20, 46, 67, 97, 102, 180, 211, 269, 281-282, 289

Nationaliteit (ethnisch, zie ook Volkstum) 54, 67, 99, 105, 171, 184, 191, 211

Nationalliberalen 213, 269, 272

Nationalökonomie (als discipline) 20, 49, 135, 145, 157-163, 173 221, 234-245, 269, 282, 290

National-Sociale Vereinigung (Naumann) 140, 269-270, 274

Naturalisme 88, 172, 261

Natuurwetenschappelijke 'methode' 27, 130, 172, 176-178, 196, 198, 220, 229, 230, 233n, 288

Naumann, Friedrich 21, 140, 190n, 244n, 269, 270-272, 274, 280, 282

Naumburg 137

Neorankeanen 186,187

Nervositeit 3, 66, 81, 128, 251, 258-264, 267n, 287

Neue Kurs 33

Neumarkt 137

Neurasthenie 259-260, 262

Neurenberg 61, 210

Niebuhr, B.G. 169, 175, 179, 180

Nietzsche, F. 100-101, 136, 140, 220, 258n

Nipperdey, Th. 11n, 123n

Nitzsch, K.W. 169, 177, 215

Noorden, Carl von 140, 148, 149, 159, 166, 174

Oberkrome, Willi 291

Oestreich, Gerhard 8, 10, 94n, 123, 124

Oncken, Hermann 24n, 37, 38, 135, 145, 150n, $152,167,173 n$
Onderwijs (in geschiedenis, zie ook Volksschule, gymnasium), 33-35, 39, 87, 136, 138-139, 142-144, 154-156, 186, 210211,258

Ontwikkelingsstadia (Kulturstufen) 53, 66, 8283, 86-91, 93, 97 102, 104-106, 113, 117, 121-122, 133, 203, 205, 218, 224, 231, 239, 240-241, 264, 288

Oppenheimer, Franz 38, 160n, 243

Ostwald, Wilhelm 38, 175, 225

Ozment, Steven 4

Paulsen, Friedrich 177

Peeters, Harry 4, 6

Pflaum, Chr. 7n, 38, 180n, 201n

Pöhlmann, R. 26, 63

'Politieke cultuur' (concept) 111

Portret (geschiedenis van) 80, 117-119, 155, 201

Posen 137, 142, 180

Positivisme 10n, 165, 178, 198, 216-221, 227, 239

Preformisten, 203n

Preußische Jahrbücher 24, 37, 44, 47, 55, 59n, $151,152,155,183$

Protestantisme 50, 54, 68, 138, 139, 140, 164

Pruisische School (geschiedschrijving) 166, 183-188, 243, 244

Psychohistory 8, 9, 14n

Psychologie (zie ook Herbartianisme, Historische ps., rationele ps., sensualistische ps. en Völkerps.) 4, 5, 7, 910, 13-20, 37, 46, 50n, 55-59, 65, 72, 74, 77, 79, 87, 90, 91-94, 98-100, 103-107, $109,113,114,116,117,128-131,154$, $155,165-166,175 \mathrm{n}, 193-202,206-207$, 212n, 216-219, 221-234, 236-239, 245, 259-261, 283, 285, 287-290

Rachfahl, Felix 24, 36, 37, 38, 43, 91, 92, 135, $140,145,150,152,167,168,171,172$, $173,176,179,181,182,183,189,190$, 191, 193, 194, 195, 196, 197, 201, 202, $204,208,232,282$

Radkau, Joachim 254, 255, 259

Ranke, Leopold von 20, 23, 45, 46, 52, 55, 63n, 74, 94, 110, 128, 136, 139, 144, 146n, $147 \mathrm{n}, 148 \mathrm{n}, 157,162,166-167,168-170$, $174,176,177 \mathrm{n}, 179,180,183-186,191$, 193, 195, 196, 202, 203, 208, 286, 288

Raphael, Lutz 7, 8, 9, 12, 13, 17, 124, 241, 282

Ras (als historische factor) $78,85,86,105-$ $106,114-115,121 \mathrm{n}, 213 \mathrm{n}, 218,237-238$, 291

Rationele psychologie 206

Ratzel, Friedrich 38, 175, 225

Regionaal-historisch onderzoek 32, 33, 35, 38, $84,125-126,153-154,156,162-163$

Regressieve methode (in historisch onderwijs en onderzoek) $33 \mathrm{n}$

Rein, Adolf 37n, 43, 128

Rein, Wilhelm 224 
Reizsamkeit (Lamprecht) 81, 82, 258, 260, 262, 264, 287

Religie (als thema van cultuurhistorisch onderzoek) $27,29,41,47,50-55,62,73$, $77,78,79,80,83,87,97,101,102,109$, $124,125,128,212 \mathrm{n}, 243$

Religie (van historici) 15, 140, 152, 185, 191, 193, 288

Renaissance 44, 53, 56, 69, 70, 109, 116, 118 , $119,179,211,215$

Ricardo, David 234

Rickert, Heinrich 11n, 176, 196, 204-205

Riehl, W.H. 25n, 55, 56, 60, 63n, 67, 151n, 210-216, 221n, 224, 234, 245, 289

Ritter, Moriz 26, 37, 110, 111, 136n, 149, 150 n, 180n, 182, 183n

Robertson, W. 181

Romantiek 12, 67, 130, 166, 180, 238, 239, 240

Romein, Jan 10n, 11

Roscher, Wilhelm 76n, 157, 159, 200n, 227n, 234-235, 236n, 238, 239, 242

Rostock (Universiteit van)142, 144, 150

Rothacker, Erich 8n, 226n, 227n, 233

Rousseau, J.-J. 98, 238, 277

Sächsische Kommission für Geschichte 32n, 154,163

Savigny, F.C. von 184, 203, 224n, 238

Schäfer, Dietrich 25-26, 27, 28, 30, 31, 36, 37, $45,51,59,60,62,73 \mathrm{n}, 74 \mathrm{n}, 95,111,135$, $140,145,147,152,153,159$ n, 167, 168, $173,177,182-187,189,190$ n, 194, 195 196, 199n, 208, 211n, 221n, 282

Schäfer-Gothein debat 25-26, 30, 31, 45, 62, 73n, 74n, 95, 177n, 199n

Schäfer, H. 242n

Schäffle, Albert 199, 224, 226, 227, 236n, 238

Schaumkell, Ernst 173, 180, 181

Schelling, F.W.J. 195n

Scherer, Wilhelm 146, 177, 190, 226, 227

Scherr, Johannes 210, 211

Schleier, Hans 9, 10n, 11n, 60n, 124n, 173n, 179n, 210n, 216n

Schlözer, A.L. von 181

Schmeidler, Bernhard 40, 201-202

Schmidt, A. 168

Schmitt, J.C. 5

Schmoller, Gustav von 38, 75, 95, 147, 157$163,169,177 \mathrm{n}, 202 \mathrm{n}, 215,232 \mathrm{n}, 235-244$, 255, 260, 270, 273

- $\quad$ Schmollers Jahrbuch 161

- Die Straßburger Tucher- und Weberzunft 235

- $\quad$ Staats- und socialwissenschaftliche Forschungen 158, 159, 161

- Grundriß der allgemeinen Volkswirtschaftslehre 236

Schnürer, Gustav 37, 135, 140, 145, 152, 167n, $168,172 \mathrm{n}, 183,189 \mathrm{n}$

Schönberg, Gustav von 157, 161
Schönebaum, Herbert 291

Schramm, Percy Ernst 40, 201

Schridde, Georg 180, 213

Schrijfstijl (van de cultuurhistorici) 167, 171173,176

Schulpforta 136, 137, 138n, 139

Schulte, Aloys 36, 42, 153n, 158n

Seeck, Otto 177, 208, 219, 288

Seeliger, Gerhard 36, 113n, 150n, 155n, 282

Seminar fur vergleichende Geschichtsforschung (Berlijn, Breysig) 37, 97, 232n, 252

Seminar für Landesgeschichte (Leipzig) 155

Seminare (historische) 37, 97, 143-144, 154155,252

Sensualistische psychologie 206, 222

Silezië 137, 247

Simmel, Georg 91, 92, 129, 226, 238n, 260

Simson, Bernhard 158n

Smith, Adam 234, 238

Sociale politiek 269-276, 281

Socialisme (zie ook Marxisme) 79, 102, 186, $269,272,273,275,285,290$

Socialistenwet (1878-1890) 47, 272

Sociologie, 14, 30, 50n, 56, 57, 58, 98, 100, $121,131,132,156,176,191,215,219$, 261,268

Sombart, Werner 38, 88n, 202n, 243-244n, 261

Sonderweg 11-13, 277, 282

Sonntag, Michael 285

Spencer, Herbert 15, 17, 177n, 211, 217, 219, $233 n$

Spengler, Oswald 43

Spittler, Ludwig 181

Spranger, Eduard 7, 38, 43, 44, 196n, 215n, 225n, 232, 233

Springer, Anton 145, 148

Staats- und socialwissenschaftliche Forschungen (Schmoller) 158, 159, 161

Stadialeer: zie Ontwikkelingsstadia

Statistiek (als historische methode) 90, 116, 126-127, 175n, 176n, 240, 245, 255, 290

Steding, Christoph 290-291

Steinberg, Sigfrid 43, 118

Steindorff, Ernst

Steinhausen, Georg

- Geschichte des deutschen Briefes 31, 60, 62, 65, 146, 151, 257

- Der Wandel deutschen Gefühlslebens seit dem Mittelalter 3, 62, 70, 72

- Briefwechsel Balthasar Paumgartners 4, 65

- Denkmäler der deutschen Kulturgeschichte 3, 61

- Monographien zur deutschen Kulturgeschichte 68

- Geschichte der deutschen Kultur 68, 7071, 180, 200

- $\quad$ Der politische Niedergang Deutschlands 188n, 276-277 
Steinthal, Hajim 19, 198, 199, 221-230, 238n, 245

Stenzel, Gustav 136

Stieda, Wilhelm 163, 244n

Stieve, Felix 36, 153

Strauß, R. 261

Stufen: zie Ontwikkelingsstadia

Sybel, Heinrich von 24, 37, 140, 152, 167, $169,177 \mathrm{n}, 178,179,183,184,191,210$, $240,243 n$

Symbolisme 83, 88, 261

Taal 62, 75, 78, 79, 80n, 83, 204, 232, 243

Taine, Hyppolite 211, 217, 218, 219, 220, $225 \mathrm{n}, 230$

Tetens, J.N. 206-207

Thierry, A. 220

Thoma, Hans $145 \mathrm{n}$

Tille, Armin 37n, 39, 198n

Tocqueville, A. de 220

Transport en verkeer (als onderwerpen van de cultuurgeschiedenis) $3,39,48,62,77,81$, $89,91,106,223,237,247-248,251-259$, 262,287

Treitschke, Heinrich von 25, 37, 147, 148, 152, $161,162,166-169,172,177 \mathrm{n}, 183,185$, 186,187 n, 188n, 195, 212n, 233n, 237238, 240, 242, 244, 273

Troeltsch, Ernst 11n, 182

Tübingen 25, 60, 109, 142, 143, 144, 150, 157, 160

Turgot, A.R.J. 181

Type-begrip 7, 53, 64-65, 84-85, 114, 121, 126, 172, 196n, 214, 239-240, 245, 266, $272,285,288$

Übungen 87, 98, 144

Ulmann, Heinrich 36, 47, 147n, 166

Universalgeschichte (zie ook Wereldgeschiedenis) 6, 8n, 39, 40, 84-87, 96, 98$99,109,112,126,153,154-156,197,252$

Vehse, C.E. 210

Verband deutscher Historiker (VDH) 34-36, $38,118,127$

Verein für deutsche Kulturgeschichte 210

Verein für die Geschichte der Mark Brandenburg 153, 161

Verein für Socialpolitik 244, 271, 272, 282

Verlichting 20, 69, 120n, 170, 180, 204-208, 209, 216n, 222, 244, 264, 276, 289, 291

Verlichtingshistoriografie 180-182, 192, 220, 283, 289, 290

Verschriftelijking (als thema van cultuurgeschiedenis) 256, 258, 263

Versnelling (van het maatschappelijk proces) 250-258, 262

Verstedelijking / steden (als thema en achtergrond van de cultuurhistorici) 53, 62, $71,89,122,137,139,242 n, 253,254-255$, $258,264-265$

Verval 177, 264, 284, 291

Vico, G. 10n, 181
Voigt, Georg 59, 200n, 211n, 214n

Völkerpsychologie 18, 131, 156, 198, 200, 213n, 221-230, 238-239, 245, 290, 291

Volksgeist (ook nationaal karakter) 54-55, 6673, 85, 99, 105-106, 114, 191-192, 199, $211,212-213,216,221-224,231,237-238$, 239n, 245, 289

Volksschule zie onderwijs

Volkskunde 110, 154, 155, 224

Volkstum (zie ook Nationaliteit en Volksgeest) 67-73, 99, 105, 114-115, 122, 171, 191$192,208,211,216$

Voltaire 181, 192

Vooruitgang (van de mens/heid) 59, 66, 89, 104-105, 115, 120, 121-122, 203, 205-207, 218-219, 264, 289

Vorlesungen 144

Vovelle, M. 5

Vrouwenemancipatie 267

Vygotskij, L. 14, 15, 17

Wachler, L. 179

Wachsmuth, W. 36, 210, 211

Wagner, A. $177 \mathrm{n}$

Wagner, R. 81, 127, 197, 261

Waitz, Theodor 223, 226, 230n

Warburg, Aby 19, 43, 80

Wattenbach, W. 153

Weber, Alfred 43

Weber, Max 11n, 19, 50, 54, 158, 175-176n, 239,

Weber, Wolfgang 135n, 137, 145

Weech, Friedrich von 36,158 n

Wegele, Franz X. von 42, 153n, 181n

- Geschichte der deutschen Historiographie 179, 185-186

Wehler, Hans-Ulrich, $11 \mathrm{n}$

Weizsäcker, Julius 148, 177

Wereldgeschiedenis (zie ook Universalgeschichte) 31n, 55, 59, 97, 99, 102, 104, $120,121,125,126,133,146,174,175$, $188,193,195,217,222,242,251,252$, 264

Westdeutsche Zeitschrift für Geschichte und Kunst 84, 148, 159

Westphal, Otto 12n, 44n, 290-291

Wetmatigheden (in de geschiedenis) 66, 91-93, 97, 110-111, 121, 130, 155, 176-178, 217, 218, 221, 227-229, 235, 240-241, 288

Wilhelm II, Duits Keizer 7, 33, 77, 155n, 186, 270,276

Winckelmann, J.J. 181

Winckelmann, Ed. 158

Windelband, Wilhelm 11n, 176-177, 196, 204n, 229

Winter, Georg 26, 32n, 200n, 212n, 240

Wittenberg 137, 247

Wolff, Christian 206

Wundt, Wilhelm 15, 38, 91-92, 175, 198n, $199,225-226 n$ 
Zeitschrift für deutsche Kulturgeschichte 31n, 61,210

Zeitschrift für die Geschichte des Oberrheins 151, 158

Zeitschrift für Kulturgeschichte (zie ook

Archiv für Kulturgeschichte) 3, 7, 18, 27n,

$31,32,39,42,43,45,61,69,93,127,129$, 146, 154, 215n

Zeitschrift für Sozial- $u$ nd Wirtschaftsgeschichte 31n, 39, 154

Zeitschrift für Völkerpsychologie 222, 224, $225 n$

Ziller, Tuiskon 224

Zivilisation (vs. Kultur) 125, 263n

Die Zukunft 45, 108.

Zwiedineck-Südenhorst, H. von 30n, 34, 36, $63 n, 211 n$ 



\section{The 'age of nervousness' and its historians. The rise of the history of mentalities in Germany, 1889-1915*}

This dissertation sets out to demonstrate that in the German Kaiserreich of the 1890s a new, academic form of cultural history developed, which was characterized by an interest in the history of collective psychological dispositions: perceptions, feelings, passions and sensibilities. Living at a time which they described as an 'age of nervousness', the new cultural historians promoted a kind of 'history of mentalities' (as similar historical research became known after World War II), or - in their own words - a form of 'historical psychology', Menschengeschichte or Seelengeschichte. The dissertation answers the questions how and why this variant of cultural history emerged in fin-de-siècle German academic historiography.

The main characters of the dissertation are five German historians who, in the period 1889-1915, fervently committed themselves to changing academic historiography from a predominantly political orientation to an all-encompassing cultural perspective. In order of appearance these historians are: Eberhard Gothein (1853-1923, professor in Karlsruhe, Bonn and Heidelberg), Karl Lamprecht (18561915, professor in Bonn, Marburg and Leipzig), Georg Steinhausen (1866-1933, academic librarian in Jena and Kassel, and professor in Heidelberg), Kurt Breysig (1866-1940, professor in Berlin), and Walter Goetz (1867-1958, professor in Tübingen, Strasburg and Leipzig). The analysis of their intellectual development and careers, their historical work and political ideals forms the substance of this study in intellectual history.

It is argued in the dissertation that there are good reasons to view these five cultural historians as belonging to the same historiographical discourse, despite the fact that they never acted as a group and despite the many differences of opinion between them. First of all, the analysis of their work shows that they were fundamentally in agreement regarding the contents and the necessity of cultural history, and the need for a form of 'historical psychology'. Furthermore, the dissertation demonstrates that the five cultural historians shared both supporters and opponents, and exhibited many commonalities in social background, intellectual development, and political outlook.

Thus, although their differences of opinion are carefully researched in the dissertation, its aim is to show that the new cultural historians were more than just five separate individual intellectuals. Apart from stressing the connections between the new cultural historians, the dissertation also highlights their connections with mainstream historiography in Germany. The usual qualification of 'disciplinary Außenseiter' for the new cultural historians evokes a one-sided image, both of the historical discipline in Germany and of their position within it. The dissertation argues that the new cultural historians were well-rooted in the historical discipline. They received important ideas and incentives from their academic history teachers, and they played an important role in the institutional innovations that characterized the German historical discipline in the 1890 s and after. In sum, this dissertation interprets the

\footnotetext{
* I would like to thank Geert Somsen and Joke Spruyt for their efforts to correct my English.
} 
history of the new cultural history not as the history of a few isolated and idiosyncratic individuals, but as a broader and as more substantial phenomenon in the history of (German) historiography.

The reasons why this perspective is not predominant in the existing research on the new cultural historians, and why both cultural and psychological aspects of their work have received less attention than they deserve, are explained in Chapter 1. It is argued that until the 1990s the study of the new cultural historians was dominated by Marxist historians and 'critical' historians. Both groups of historians tended to look upon the new history of the 1890s first and foremost as a 'symptom' of broader social and political developments. And both groups of historians interpreted the new history predominantly as representing social and economic history.

Marxist historians viewed the appearance of the new history as the symptom of an inevitable 'crisis' of the existing elitist way of looking at history, that was unable to 'cope' with the industrial mass society at the end of the nineteenth century. From their perspective, the new history was a half-baked, bourgeois effort to come to terms with the new social and economic reality. Following Georg Iggers' lead, 'critical' historians emphasized the German Sonderweg in this historiographical respect, as they did in others as well. They tended to play down the importance of the 'modernizing' elements in German historiography in the Kaiserreich. From their perspective the new historians were a failure in Germany, both because the opposition against their work was too strong and because they themselves were only halfway progressive, both politically and methodically. Both Marxist and critical historiographers paid most attention to the social and economic contents of the new history. To them, these aspects represented a step forward from the older political and idealist historiography, whereas they gave little attention to the cultural and socialpsychological aspects of the new history which they considered as a fall-back into reactionary or specifically German 'irrational' patterns of thought.

Arguing against these views, Chapter 2 of the dissertation suggests that the new history had a strong start in the 1890 s and was weakened but not stopped by the opposition against it, while Chapter 3 extensively demonstrates the fundamentally cultural character of the new history and analyzes its social-psychological aspects. While the new cultural historians indeed did pay a lot of attention to economic and social phenomena in the past, their perspective was fundamentally broader than that. It can be called 'panoramic': they aimed to bring into view all aspects of human life, including law, religion, art and politics - on a regional and national, as well as on a global scale. They were convinced that to achieve this aim historians could not stick to the individualistic and singularistic approach that characterized mainstream political history, concentrating on single persons and the chain of events. Instead, (cultural) historians needed to distinguish and elaborate collective 'types' of behavior and more general patterns of development.

Furthermore, the cultural historians believed that the only possible way to connect and explain all different aspects of human history was to develop a socialpsychological perspective, in which episodes or aspects of history were analyzed as indications and expressions of (changing) collective psychological characteristics. Their concept of 'culture' was all-embracing and at the same time fundamentally psychological. It was also profoundly dynamic in character, emphasizing change and progress. They highlighted the 'psychological distance' between different periods of history, they warned historians of the hidden trap of psychological anachronisms, and many of them showed an interest in (or were influenced by) phase-theories of human development. 
The quintessence of this 'historical psychology' was not to apply universal psychological laws to different periods and aspects of history, but instead to elaborate a historical view of the psychological development of groups of people in different circumstances and through different periods of time. Two different but seldom explicitly distinguished theories were fundamental to this historical view of psychology and mankind.

On the one hand 'culture' as a collective psychological disposition was, in a sociological fashion, considered to be a product of 'human socialization', depending on the organization and different means of human interaction, which in themselves depended very much on technological and economical developments. The new cultural historians' most interesting work, from our point of view, was produced when they took this proposition seriously, analyzing connections between works of art or personal documents and economical, technical or social changes.

The differences of opinion among them had much to do with the more or less absolute value they attached to this sociological proposition, i.e. the measure in which they considered individuals to be determined by collective forces. Although all cultural historians recognized the power of collective forces in forming men's psychological dispositions, most of them considered it important to reserve a special place for (outstanding) individuals that were less affected by collective forces and even could be said to lead the masses in some respects. Lamprecht stood out from the other cultural historians in that he was the most radical supporter of the 'collectivist' sociological assumption, consistently stressing the very limited freedom of individual development.

On the other hand, the new cultural historians' idea of changing mental abilities of men was based upon a far more implicit assumption, distinct from the sociological assumption, and not always in agreement with it. As is evident from their acceptance of phase-theories of human development, according to which man progressed from lower to higher Kulturstufen, they were prone to view the development of culture in a quasi-biological fashion as a more or less autogenous process of growth, refinement and differentiation. World history appeared to them as 'the collective effort of the human species towards perfection' (Eberhard Gothein).

The second half of the dissertation (Chapters 4-7) is devoted to explaining how and why the new cultural historians of the 1890s came to their conceptions of historical psychology and history as cultural history. Successively, their social background, education and early careers, the intellectual influences from within and without the historical discipline, and the contemporary social, cultural and political context of their work is analyzed.

In Chapter 4 the social background, education and early careers of the five cultural historians are compared with those of other professional historians of their generation in general (using Wolfgang Weber's data), and with those of their most direct opponents specifically. One of the conclusions is that, unlike several of their opponents, the cultural historians all had a social background that did not distinguish them from the majority of historical professors of their generation. They were all Protestants, mostly from Prussia, most of them grew up in cities, some were educated at elite-schools, and all had academically educated fathers who - as gymnasiumteachers, clergymen or physicians - belonged to the social and cultural elite of Bildungsbürger in the Kaiserreich. Furthermore, compared to other students who later became professors of history, their educational and (early) professional careers were rather successful: supported in their early careers by their history professors, most of them became teachers and professors at the university at a relatively early age. Even 
after the opposition against their ideas had manifested itself, they were able to maintain important activities within the historical discipline. One important thing made the cultural historians different from most of their colleagues: four out of five of them also studied economics, whereas only $16 \%$ of all historical professors between 1851 and 1900 did the same. Significantly, apart from their history teachers, their economy teachers also gave them substantial support in their careers.

In Chapters 5 and 6 the cultural historians' early intellectual influences are analyzed. Chapter 5 evaluates the influences from within the historical discipline. It is shown that the influential criticisms of their historical opponents, who stressed the 'un-historical' and 'un-disciplinary' character of their work, were exaggerated. In important respects the work of the five was not different from mainstream historiography. Besides, even those aspects that appeared to be 'new' or 'different' can be found in the works of some of their history teachers or elsewhere in the field of history. Especially the historian Ernst Bernheim, teacher of both Steinhausen and Lamprecht, stands out as an important influence for their way of looking at history.

There were, of course, real differences of opinion with their historical opponents, but these concerned issues of conviction and ideology rather than historical craftmanship. The main dividing point was the different conception of the relationship between individuals and the groups they belong to. The cultural historians acknowledged the socially determined, collective and passive nature of many 'individual' characteristics, whereas their opponents highlighted the fundamental freedom of choice and the creative incomprehensibility of personalities. Accordingly, the cultural historians espoused the enlightened, psychological conception of culture as 'changing collective abilities and faculties' of men, whereas their opponents conceived of culture in a more restricted way as the 'valuable' and willful products of the human Geist.

How the cultural historians came to their 'enlightened' conceptions of the individual, of culture and of cultural history, is shown in Chapter 6. Four lines of influence and reception are discussed: the earlier specimen of academic cultural history in Germany from the middle of the nineteenth century (especially Burckhardt, Freytag and Riehl); Western European Positivism; the Herbartian tradition in psychology and its critics (especially the Völkerpsychologie and Dilthey); and the Historical School of economics. Especially the last group of scholars should be considered as a crucial force in determining and confirming the intellectual outlook of the cultural historians (including the idea of a 'historical psychology') at an early stage.

Finally, Chapter 7 examines the contemporary political and cultural significance of the new cultural historiography. The cultural historians themselves presented their conception of history explicitly as a necessary and inevitable part of the development of modern times. They intensively studied their own age, which they characterized as an 'age of nervousness', and remarked that their own focus upon the psychological aspects of life was a typical expression of this 'nervousness', which could also be found in contemporary art, literature and science. They did not consider this 'nervousness' to be a symptom of cultural decadence or degeneration, but saw it as a sign of the psychological refinement and improvement of the modern individual, i.e. as the necessary psychological adaptation to a fundamentally new age.

In this sense their view of the present was an expression of their perception of the past - and vice versa. At the same time both views were strongly connected to their political beliefs, of which the dissertation shows the proximity to variants of (social/left) liberalism. It was typical of their political and historical views, that they 
considered the modern, 'nervously' refined individual as the apex of historical development. As the leading social-liberal of the time, Friedrich Naumann, remarked in 1911, the new cultural historiography emerged as part of a 'new system of being man': it could serve as the intellectual 'dress' for the contemporary man, surrounding him with insights about the historical and social differentiation of the human soul. This 'dress' were not politically neutral, however. It was the expression of an ideology, which can be traced back to a (left)liberal confrontation with modernity and which in many ways was rooted in Enlightenment ideas about man and history. As in so many other cases, this historical psychology was connected to the progressive idea of the perfectibility of man. 



\section{Over de auteur}

Manuel Stoffers groeide op in de voormalige Oostelijke Mijnstreek, waar hij aan het Eijkhagencollege in Schaesberg het Atheneum-B-diploma behaalde. Hij studeerde in 1988 af in de vroeg-moderne geschiedenis aan het Instituut voor Geschiedenis van de Rijksuniversiteit Utrecht, en was daarna achtereenvolgens werkzaam bij de Koninklijke Bibliotheek, de Open Universiteit, de Nederlandse Organisatie voor Wetenschappelijk Onderzoek en tenslotte als docent cultuur- en wetenschapsstudies en European Studies aan de Universiteit Maastricht. Hij publiceerde onderzoeksartikelen over uiteenlopende onderwerpen, onder meer in Theoretische Geschiedenis, Kennis \& Methode, het Jaarboek voor Nederlandse Boekgeschiedenis, de Proceedings of the XXIX International Congress of the History of Art, en de Journal of the History of the Behaviorial Sciences. In 1994 verscheen onder zijn redactie De middeleeuwse ideeënwereld 1000-1300 (Open Universiteit / Verloren; tweede oplage 1999). 
